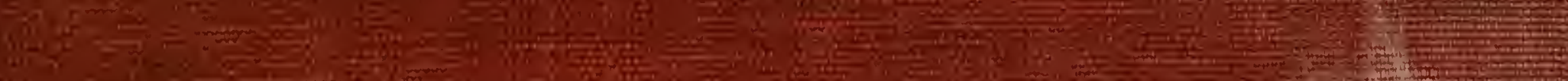

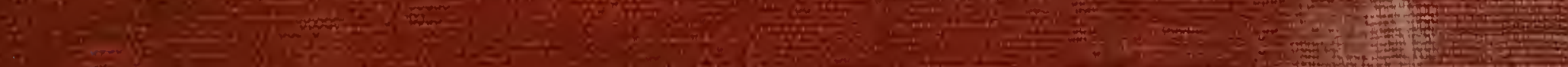

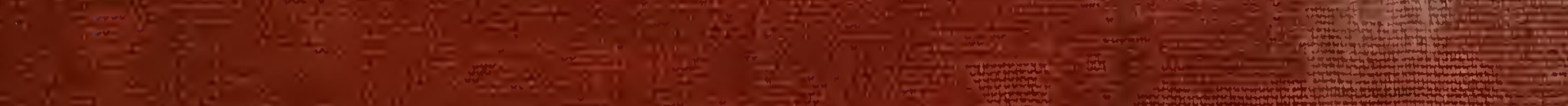

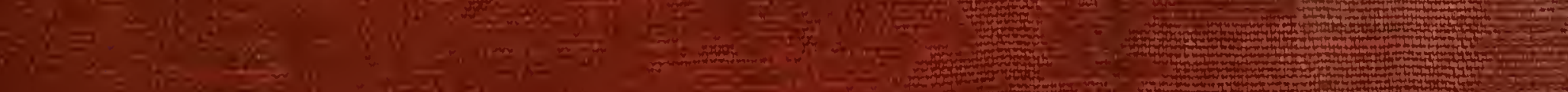

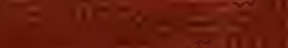

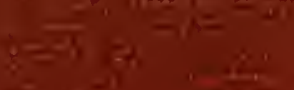
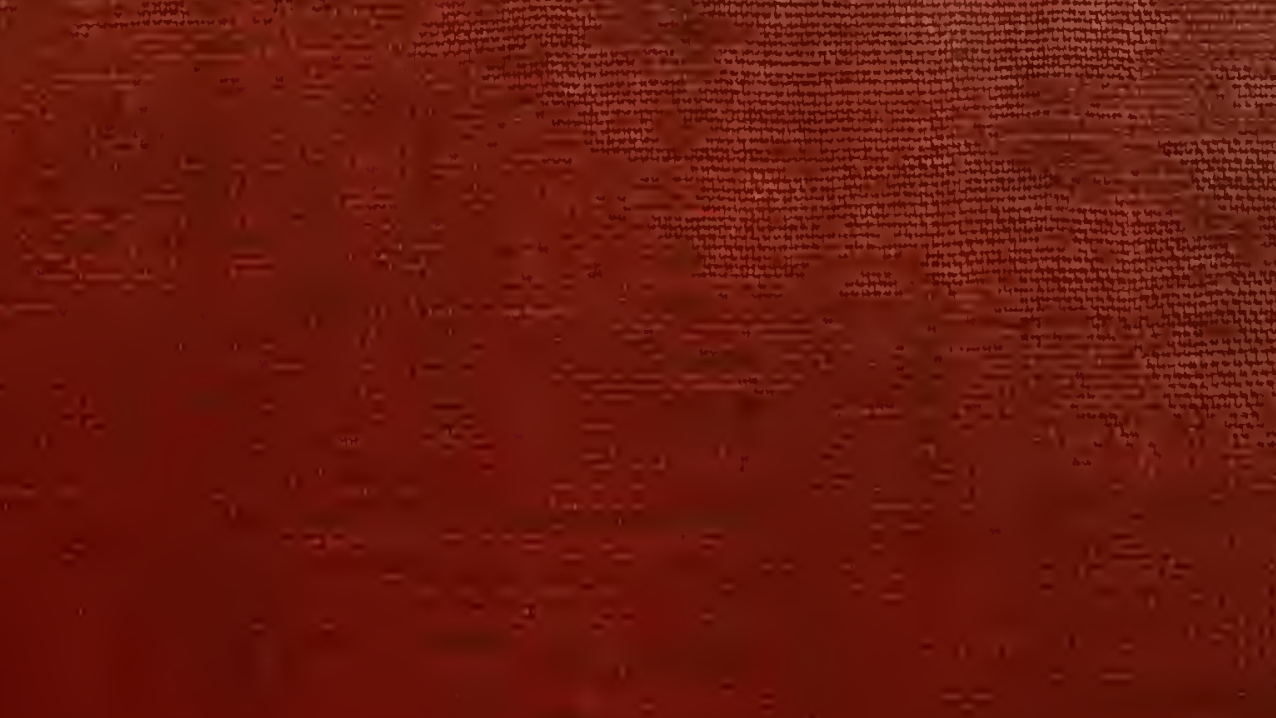


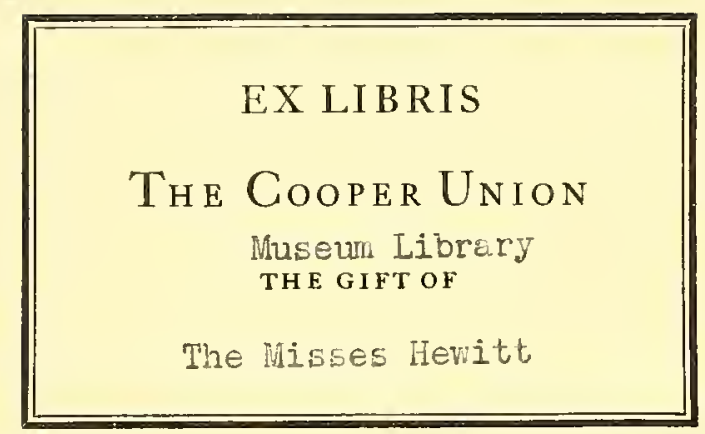







$$
\begin{gathered}
\text { EXPOSICION } \\
\text { HIERROS ANTIGUOS ESPAÑOLES } \\
\text { CATÁlOGO }
\end{gathered}
$$



SOCIEDAD ESPANOLA DE AMIGOS DEL ARTE

$$
\text { EXPOSICIÓN }
$$

DE

\section{HIERROS ANTIGUOS

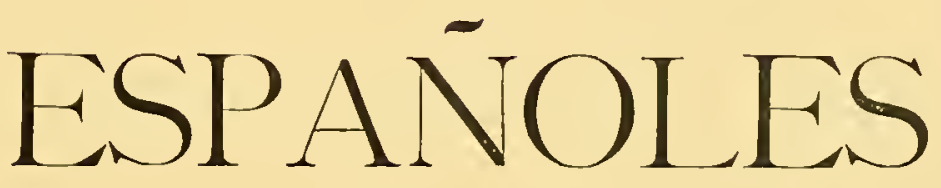

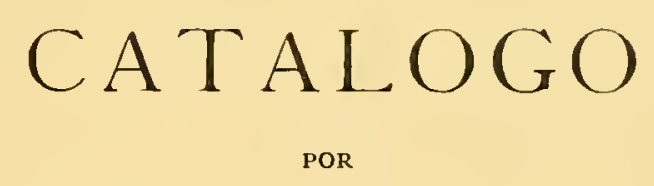

PEDRO MIGUEL DE ARTÍŇANO Y GALDÁCANO

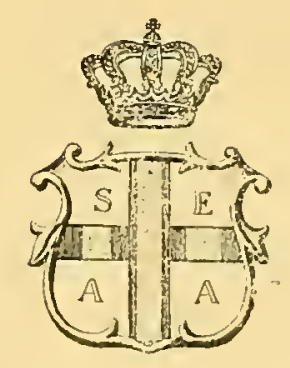

MADRID MCMXIX 



\title{
COMISIÓN ORGANIZADORA
}

\author{
Excmo. Sr. Marqués de Comillas. \\ Excmo. Sr. Conde de Casal. \\ Excmo. Sr. Moreno Carbonero. \\ Sr. D. José María Florit. \\ Sr. D. Pedro M. de Artínano.
}



$E^{\text {ncargado por mis compañeros de Comisión del estudio de los ejemplares }}$ $y$ de la redacción del presente Catálogo, no podía desconocer las dificultades que supone una exposición como la presente, si ha de responder al fin educativo y cultural con que fue iniciada, procurando reunir en lo posible los elementos que de un modo más caracteristico pueden definir una época en la historia nacional del trabajo del hierro, siendo esta la razón de que se hayan incluido las armas de los tiempos prehistóricos, y lamentando que no figurasen en ella, a pesar de nuestros deseos y gestiones, piezas fundamentales, como por ejemplo, el tenebrario de la Catedral de Jaén.

Inspirada la Comisión en este criterio y ante la imposibilidad de transportar obras fundamentales de nuestra industria patria, ha tomado el acuerdo de publicar un estudio de nuestras rejas, púlpitos, balcones y puertas que no pudieron figurar en nuestra exposición, pero cuyo conocimiento es indispensable para llegar a saber algo de lo que fué el arte del hierro entre nosotros. Debe complementar este trabajo una parte documental, no sólo referente a los ejemplares que se reproduzcan, como pueden ser las cuentas de obras de rejería de catedrales, iglesias o palacios, sino las generales a la industria, como disposiciones en Cortes, ordenanzas gremiales, fueros y otros.

Falta decir que si esta labor es debida en gran parte al apoyo desinteresado de corporaciones y cabildos, como la Junta de Museos de Barcelona, museos provinciales, coleccionistas y aficionados cuyos nombres figuran en este Catálogo, para gloria de nuestra cultura patria, y que cooperaron a esta obra, han existido entidades y personas, que sin el carácter de expositores, contribuyeron generosamente con el caudal de sus conocimientos, con su trabajo y con su entusiasmo; es por tanto un grato deber, manifestar mi sincero agradecimiento al Centro de Estudios Históricos, y muy especialmente en él a D. Manuel Gómez Moreno y a D. Juan Cabré, a la Sociedad Bilbaina y muy concretamente a su bibliotecario D. Alvaro de Gortazar, al director del Museo Diocesano de Vich, D. José Gudiol y a personalidades como don Fernando Molina, D. Carmelo Echegaray, D. Serapio Mígica y a tantos otros cuya relación haria interminables estos renglones.

Pedro M. DE ARTIÑNANO 



\section{INTRODUCCION AL ESTUDIO DEL TRABAJO DEL HIERRO EN ESPAÑA}

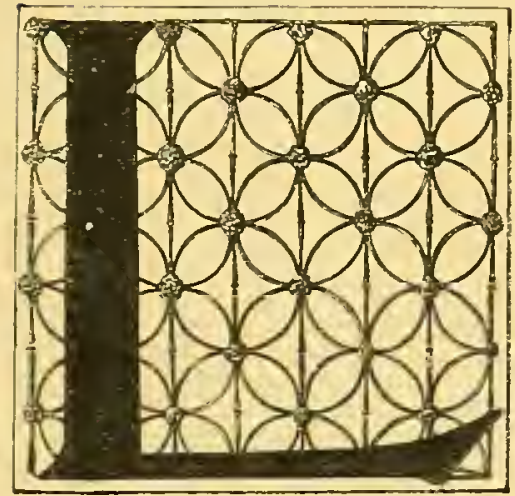

A «SOCIEDAD ESPAÑOLA DE AMIGOS DEL ARTE», al organizar para este año de 1919 una Exposición de "Hierros Españoles antiguos", ha pretendido nada más que dar la sensación de lo mucho y maravilloso que supieron hacer nuestros artífices en este ramo de las artes industriales.

Los extraordinarios descubrimientos del Excelenmo Sr. Marqués de Cerralbo muestran efectivamente el dominio que del hierro tuvieron los iberos en tiempos prehistóricos; y las rejas insuperables de Burgos, Toledo, Granada y Sevilla, realizadas en los principios de la Edad moderna, testifican el alto grado a que llegó entonces su manufactura en España, tal como no fué alcanzado jamás en parte alguna. En cambio, y a pesar de los Altos Hornos de Vizcaya, de las instalaciones de la Felguera, Mieres, Nueva Montaña, Vera, Moreda, Málaga, Araya, etc., y hasta las factorías hoy en construcción en Sagunto, nuestro presente lastimoso demuestra, de un modo evidente, que, en los tres grandes períodos que la historia del hierro abarca, su manufactura y la categoría de su elaboración artística, ha sido constantemente una de las medidas de la cultura y poderío o de la decadencia de nuestra raza. 
Su elaboración industrial ha influído en la humanidad de un modo tan decisivo, que su aparición constituye el prólogo de la variación de los tiempos, y la técnica correspondiente da los orígenes de las épocas mismas, en forma que la aparición del hierro en los días de Hallstatt y la difusión de su manufactura en los de la Tène, determinan un grado que puede llamarse de cultura y civilización, y que por ello marca la separación entre tiempos históricos y prehistóricos. ${ }^{(1)}$

Terminaba asimismo el siglo XIV, cuando grandes avances técnicos se realizaron en todo el norte de España ${ }^{(2)}$, y la industria, al vulgarizarse poco después marchando por nuevos derroteros, proporcionó a los artífices materiales adecuados para construir las rejerías monumentales de nuestros templos, las armas de fuego de sus ejércitos y los usillos que accionaban en sus imprentas: empezaba la Edad moderna.

Muchos años más tarde, cuando la máquina de vapor funcionaba ya en algunas fábricas y talleres, allá en el primer tercio del siglo XIX, al nacer la siderurgia contemporánea, todo se industrializa ${ }^{(3)}$ y la humanidad se lanza a una desenfrenada carrera de evolución y de progreso caracterizando y definiendo la Edad contemporánea.

Cada una de estas grandes épocas presenta un aspecto propio y que podría definirse diciendo, para la más antigua, que el hierro tiene en ella un carácter marcadamente utilitario; en la segunda al carácter utilitario

(1) El hierro se trabajó al principio en hornos toscamente fabricados, donde coincidían un yacimiento de mineral purísimo y grandes bosques que proporcionasen el adecuado combustible; pero lo que define toda la época, por la limitación que impone a sus productos, es que alimentados estos hornos por tiro nótural, o todo lo más por luelles embrionarios, el lobo o bola que se obtiene es necesariamente pequeño y mezclado con abundante cantidad de escoria.

(2) Los franceses y de ellos la Europa Central, tomaron este avance de los catalanes, y de aquí Ia preponderancia del nombre «forja catalana». Consiste en sustituir el fuelle a mano o a pie, por instalaciones hidráulicas, por trom pas, que producian una fuerte $y$ continua corriente de aire, obteniéndose de este modo en el horno una mayor temperatura; el metal, mucho más fluído, expulsa la escoria con mayor facilidad; la cantidad que se trata en una operación es incomparablemente más grande, y mirerales que hasta entonces se consideraban infusibles son reducidos.

(3) Los siderúrgicos entendieron que su potencia podría ser aplicada a máquinas soplantes, que venciendo la resistencia de los regeneradores de calor, inyectasen en un horno mucho más alto, una fortísima corriente de aire caliente, adecuada para dar las más fuertes temperaturas; el funcionamiento del horno pudo hacerse continuo, el metal se obtiene carburado y líquido a un precio baratisimo; con ello la construcción de todo género de maquinaria se facilita extraordinariamente, provocándose el maquinismo, y se acometen las grandes construcciones en hierro, los puentes monumentales, los ferrocarriles, la construcción naval, que al cambiar la madera por el hierro hace posible esos trasatlánticos gigantescos. 
se suma el decorativo y es el período de mayor arte, y en la tercera, el conjunto se industrializa impregnándose de un tinte sociológico y vulgarista.

Tres épocas distintas, pero siempre con un espíritu común, pues, a medida que transcurre el tiempo, las formas ornamentales podrán cambiar, pero las modalidades anteriores en realidad no desaparecen sino que se suman fundiéndose sobre las nuevas.

Cuando deja el hierro de ser considerado como metal precioso y su manufactura se vulgariza entre los pueblos, resulta que es, en efecto, característica de toda aquella época prehistórica, de la romana y hasta de la visigoda, el que la industria del hierro presente ese aspecto principal y casi exclusivamente utilitario. Los pueblos que en tales tiempos supieron hacer de bronce los ejemplares artísticos más perfectos y admirables, no labraron en hierro más que armas, o piezas destinadas a uso doméstico, unas y otras (con curiosas excepciones en algunas espadas prehistóricas), con la menor cantidad posible de decoración, y buscando tan sólo en ellas una recta aplicación a las necesidades de la guerra o de la vida. Las dificultades de una técnica rudimentaria y el aspecto del hierro, menos agradable y ostentoso que el bronce, su rival, explican esta tendencia.

Cuando en la segunda época la técnica permite el empleo de masas más considerables, resultando su forja y su trabajo mucho más cómodo, y se logra atenuar o combatir en absoluto, por la pintura, el dorado, el estañado, etc., los efectos del óxido, cuando la utilidad del hierro se impone, se extiende su uso y se antepone en aprecio al bronce, se emprenden en hierro ejemplares que, sin prescindir de su carácter utilitario, tienen ya una ornamentación agradable. Los ejemplares trabajados en los últimos tiempos del arte gótico y en los años del Renacimiento que les siguieron inmediatamente después, cuando terminaba de vulgarizarse por toda Europa la técnica caracterizada por la llamada forja catalana, presentan unas proporciones armónicas y casi puede decirse que en ellos la finalidad utilitaria del trabajo que se ejecuta es lo menos interesante, y que la decoración, el calado de la plancha o el repujado; y en una palabra todo 
lo que representa el aspecto artístico que encierra el ejemplar, es lo único interesante; el artista se deleita en dominar con su maestría el tenaz metal, en hacerle expresar ideas y sentimientos y promover efectos que nadie sospechara pudieran brotar de la rudeza e insignificancia de la primera materia, y asi va desarrollando y fabricando toda esta labor artística, con la disculpa de establecer una reja, hacer un candelabro o fabricar una pieza cualquiera, cuya finalidad práctica apenas si interesa. En estos momentos casi no cabe hablar de arte industrial, es arte puro.

Ya en la edad contemporánea, cuando la siderurgia dió a la industria del hierro las proporciones de nuestras gigantescas manufacturas actuales, los trabajos en hierro toman un aspecto distinto, la decoración se industrializa, se democratiza y reaparece el aspecto utilitario, pero disfrazado, revestido con tipos de ornamentación amanerada, que no tenían los ejemplares siempre únicos, como los trabajados individualmente, durante la segunda época, impregnados del alma y expresión de la habilidad del artista, que los creaba con un objeto determinado no para un mercado. Las grandes construcciones en hierro de la época moderna, como los ejemplares «artísticos» fabricados por series para su venta al detalle, unos y otros propios de nuestro tiempo, son trabajos donde el aspecto utilitario aparece velado por los más bellos diseños de la época del florecimiento, pero ejecutados de una manera fría, sin espiritualidad, sin personalizarse el artífice, y por eso todas estas piezas transpiran su carácter industrial y democrático, completamente opuesto al espíritu que anima los ejemplares que muchas veces imitan en su aspecto, y a los que siempre o casi siempre superan técnicamente. Este carácter popular y democrático de las piezas construídas para los bazares, de un arte que industrializa el valor decorativo de los ejemplares que moldea, y tan sólo cotiza las dificultades técnicas para la ejecución de las piezas en serie, es lo que define esta última edad del hierro, que naturalmente coincide con la edad de los "Museos», y que suma, a las condiciones utilitarias y decorativas de las dos anteriores, la sociológica, democrática o popular, la mercantil de los tiempos contemporáneos. A pesar de sus pretensiones y forma artística, no son obras de arte; les falta el ser expresión de un sentimiento; son nada más que la explotación de un mercado. 
Conocido el hierro, según se desprende de las investigaciones arqueológicas más dignas de fe, desde tiempos remotísimos, ${ }^{(1)}$ quizás desde los días mismos en que se descubrió el cobre, su empleo no se vulgariza, utilizándose tan sólo en pequeños objetos domésticos o para usos agrícolas; y únicamente mucho más tarde, cuando ya las piezas de bronce habían recorrido los pueblos, empiezan a fabricarse de hierro armas y utensilios ferreros entrando de un modo definitivo en el ramo de manufactura fundamental socialmente considerada.

(1) Afirma Ledebur en su «Metalurgia del Hierro», reconocida universalmente como la obra fundamental de su género, que ningún hombre ni ningún pueblo puede atribuirse la gloria de haber descubierto la siderurgia, encontrándose vestigios indiscutibles de esta industria en parajes muy distanciados entre si y habitados por pueblos que mutuamente se ignoraban.

En oposición a esta teoria, defienden con Dechelette $\left(^{*}\right)$ la casi totalidad de los arqueỏlogos, que parece es en Egipto donde por vez primera son tratados con éxito los minerales ferruginosos, encontrándose trozos de hierro en las juntas interiores de la mampostería de la gran pirámide de Gizeh, en la del rey Ounas de la V. dinastia, en la de Mohammeria cerca de Esnech, y en los descubrimientos de Petrie cerca de Abydos.

Pero el dato más antiguo que se conoce $\left({ }^{*}\right)$ corresponde al descubrimiento de una tumba pre-dinástica hallada en unas excavaciones próximas a El Gizeh por la Escuela Británica de Arqueología de Egipto, conteniendo entre otros objetos, un collar compuesto de cuentas de hierro, de oro, de àgata y de cornalina, habiéndose determinado mediante el análisis correspondiente que se trataba precisamente de hierro obtenido por manufactura.

Pero de todos modos, cualquiera que fuese el instante en que apareció el hierro en Egipto, no puede en realidad hablarse de una civilización y una industria siderúrgica $\left(^{* *}\right)$ hasta fechas poco distantes del siglo xv antes de Jesucristo; y si el hierro en realidad fué conocido antes, su empleo fué limitadísimo y apenas aparecen vestigios que carecen de importancia relativa ante los copiosos y numerosos descubrimientos de objetos de cobre y bronce, cuyo tratamiento y empleo es anterior al hierro.

Esta posible escalonada sucesión de metalurgias, ha sido comprobada en la casi totalidad de las investigaciones arqueológicas metódicamente realizadas, sin que pueda ser aceptada la teoria inversa sostenida por Ledebur, y otros como Alsberg $\left({ }^{* * *}\right)$ citado como autoridad por el mismo Dechelette, quien, apoyándose en el hecho de que los pueblos primitivos debieron emplear herramientas de acero para tallar la piedra, trabajar la madera, y cultivar la tierra antes de que el hierro fuera aplicado a la fabricación de armas ofensivas y defensivas $\left({ }^{* * *}\right)$, sacan la consecuencia de que fué su uso anterior al cobre y al bronce (metales que sustituyeron al hierro, hoy desaparecido por oxidación) por su color y brillo y principalmente por su facilidad de trabajo en estado liquido, es decir, por moldeo, procedimiento que no ha sido aplicado al hierro, como se sabe, hasta época bien reciente.

Tienen en realidad alguna fuerza estos argumentos, porque antes del siglo $\mathrm{x}$ de los tiempos antiguos, aparecen en efecto muchas de las piezas de uso doméstico, y más principalmente las destinadas al trabajo de la tierra, como de hierro y coetảneas a las armas de cobre y bronce, y asi vemos que Aquiles ofrece como premio, en los funerales de Patroclo, una mesa de hierro que pueda proporcionar el necesario material para los instrumentos agricolas durante cinco años mientras que en los combates Homero nos va determinando concretamente el metal de cada una de las armas, siendo de notar que las citas de hierro que empiezan siendo rarisimas en la lliada, no aumentaron hasta que fué redactada la Odisea.

Sin necesidad cie recurrir a los tiempos heróicos podriamos encontrar ejemplos bien interesantes, como el que nos ofrecen las civilizaciones japonesas, donde aún hace medio siglo el bronce era el único material de uso corriente, y las piezas de hierro eran constantemente excepcionales.

P'ero la realidad de los hechos demuestra, como todos conocen, precisamente esta marcha cronológica, sin que

$\left({ }^{*}\right)$ Manuel d'Archeologie prehistorique celtique et gallo-romaine, tomo Il, pảginas 541-551.

$(* *)$ Die Anfadge der Eisenkultur.

$(* * *)$ Dechelette.-En su obra y capitulo ya citado.

(****) Beck-Ges-chichte der Eisens. 
Tal es el criterio generalmente aceptado, aunque parezca muy raro el que una vez conocidas por el hombre las cualidades excepcionales del hierro para usos como los agrícolas, no lo aplicase para confeccionar sus armas; dificultades arqueológicas que para no pocos exigen serias demostraciones, que, por otra parte, tampoco resultan demasiado evidentes.

Las relaciones, documentadas hoy, de aquellos pueblos de Egipto con el Asia Menor, con Creta y hasta con la misma Grecia continental, son la justificación más completa de cómo a partir del siglo xV y mucho antes del $x$ antes de Jesucristo se hallaba vulgarizado el conocimiento del hierro por todos países del Mediterráneo oriental.

Y fué precisamente en este tiempo cuando, al desarrollarse la navegación y el comercio de los fenicios, sucediendo a los marinos del archipiélago del mar Egeo, allá por el año 1100 antes de Jesucristo, atraviesan los colonizadores de Tiro las columnas de Hércules y fundan un poco más allá la estación de Gadir (Cádiz), centro de sus explotaciones mineras y de sus elementales, pero curiosas, instalaciones metalúrgicas.

puedan tener otro valor que el de interpretaciones personales, la significación que ha querido darse a los hallazgos antes citados y otros análogos, como el realizado por Hill en el macizo de mampostería de la pirámide de Cheops en 1335. La sustitución de! cobre y el bronce por el hierro, además de lógica, dadas las condiciones de resistencia del hierro, es por tanto científica y registrada; pero por si ello no fuera bastante, dos razones naturales, aparte de las arqueológicas, apoyan el hecho de la prioridad del cobre como elemento de utilización; es una, que sus minerales, muy repartidos en la Naturaleza, presentan esos colores azules, verdes o dorados significativos y determinantes, en oposición a los de hierro, siempre terrosos, rojizos o negruzcos; y es otra la facilidad de la reducción del mineral correspondiente.

El papel que se ha pretendido dar al hierro meteórico tampoco es aceptable más que como una excepción singularísima, no tan sólo por tratarse de casos muy raros, sino también porque la generalidad de las veces este hierro contiene una parte de níquel que, dándole una dureza marcadísima, debió hacer imposible en aquellos días su trabajo, su talla o su pulimento. 


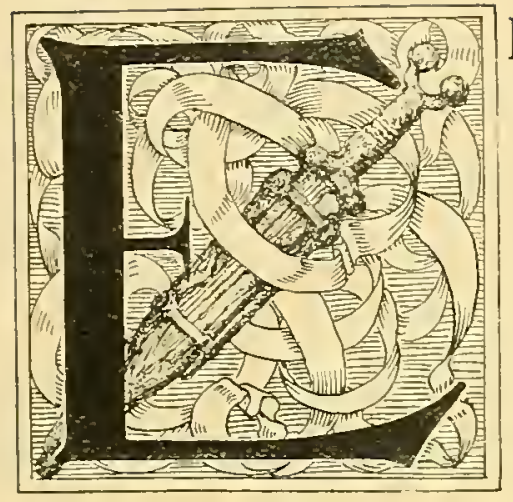

L ESTUDIO METÓDICO DE LA NECRÓPOLIS de Hallstatt, descubierta en el año 1846 en el lugar de Salzkammergurt(Austria), rico en minas de sal explotadas desde los tiempos más remotos, y próximo a una de las vías comerciales del ámbar que definieron los siglos neolíticos, dió nombre a esa época prehistórica que tiene en Europa como característica de su cultura la aparición del hierro, y puede quedar fechada entre los años 1000 y 900 antes de J. C.

El Sr. Marqués de Cerralbo, tan conocedor de aquellas civilizaciones que pasaron; ha buscado las necrópolis españolas de esta época de Hallstatt en las márgenes de los grandes ríos, necesarias vías de comunicación de los pueblos primitivos, y precisamente donde existen o pudieron existir arroyos, fuentes o pozos de aguas saladas; porque a los tiempos del cobre y del bronce, que marcaron sobre la tierra los caminos del ámbar, preciadísimo elemento de decoración, cuya trascendencia social debió ser muy superior a las que hoy corresponde a las pesquerías de perlas o a las minas de brillantes, sucedieron los siglos democráticos y mercantiles de hierro, caracterizados por las explotaciones de salinas en toda Europa y el establecimiento de las correspondientes vías comerciales, que prepararon las grandes emigraciones de los pueblos y concretamente la de los Celtas.

Lo que España representaba en aquellos días y en los siguientes de la Tène, estación prehistórica en una de las extremidades del lago de Neufchatel, descubierta y estudiada desde el año 1856, y que ha servido para dar nombre a la civilización de la segunda época prehistórica del hierro, cuyos últimos períodos tocan en los albores de la historia, lo que entonces era España puede adivinarse recordando que en la estación 
clasificadora de Hallstatt, han sido reconocidas y estudiadas 993 sepulturas, en la célebre italiana de Vilanova, sumando las cercanas de Bolonia, no llegan a 2.000 , las de Suiza se reducen a un millar y a unos centenares las de Francia, mientras que solamente en la necrópolis española de Aguilar de Anguita, explorada por el Sr. Marqués de Cerralbo, se han podido estudiar más de 5.000 sepulturas.

De todos modos, bien porque no hayan sido encontradas hasta el presente necrópolis españolas de los primeros siglos del hierro, bien porque si se encontraron no han sido estudiadas con suficiente detenimiento, es el caso que los primeros ejemplares que se encuentran con importancia ya definida y en número suficiente para que se acuse una escuela con personalidad independiente, pertenecen a la última época de los tiempos de Hallstatt, a los días, por otra parte, en que los procedimientos de trabajo habían llegado a una perfección interesante, lo cual supone por necesidad, y más en aquellos tiempos, una previa evolución de siglos.

Pudo ser, y desde luego resulta como si así hubiera sido, que la llegada de los celtas determinase en toda España la divulgación de los procedimientos siderúrgicos. ${ }^{(1)}$ Ciertamente que algunas necrópolis exploradas por el Sr. Marqués de Cerralbo, como las de Aguilar de Anguita, tienen personalidad propia, sin que ello quiera decir que pueda hacerse independiente por completo de estaciones celtas situadas al otro lado del Pirineo,

(1) La obtención del metal se hizo por el pueblo celta siguiendo dos criterios, evidenciados hoy, gracias a interesantes y curiosos des cubrimientos.

En un principio se disponía el taller con dos hornos desiguales, mejor dicho, dos agujeros, apisonados de arcilla,

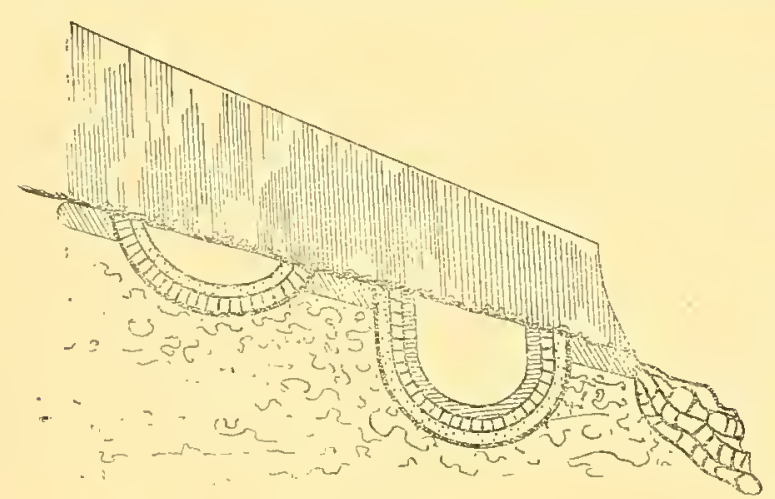
cuyos centros separaba una distancia aproximada de cinco metros; el primero con un diámetro de metro y medio y unos sesenta centímetros de profundidad, y el segundo con un metro treinta centímetros de diámetro y un metro, poco más o menos, de altura.

El mineral parece que se atronaba en el primer horno $\left(^{*}\right)$ para luego ser cribado, y en estas condiciones se mezclaba con el combustible (siempre carbón de madera) y con el fundente o castina y se cargaba el segundo horno, donde se sostenía viva la combustión por fuelles accionados a mano, cuyas hocas se prolongaban en trozos acoplados a tuberías de cerámica, de las que se han encontrado restos y que tenían un diámetro de unos cinco centímetros por once de longitud y uno de espesor aproximadamente. Después de no poco tiempo obtendríase una bola o lobo de hierro y escorias, que a fueza de repetidos

(*) Operación de calentar con energía un mineral para enfriarlo bruscamente y lograr que se cuartée, se agriete, se rompa y se desmenuce. 
como la de Avezac-Prat, quizás prolongación de las nuestras, y en las que hasta los más curiosos detalles, como las joyas de las mujeres, encuentran correspondencia con otras, como las de la necrópolis de Anfidena, en el Norte de Italia.

La industria del hierro que por estos caminos, fenicios o celtas, queda así establecida en nuestros bosques, adquiere un desarrollo extraordinario poco después de la llegada del pueblo celta, por el Norte, y de las expediciones de los griegos instalados en Marsella, por el mar; que si para los unos era conocida y hasta vulgar su metalurgia, para los griegos debió ser bien productiva la explotación de nuestras minas iniciada en el mismo siglo vi antes de J. C. Ello es, que en las necrópolis, desde esta época en adelante, se aprecia el predominio progresivo del hierro sobre el cobre y el bronce, hallándonos ante civilizaciones, como la de Aguilar de Anguita, que conocieron y trabajaron el hierro normalmente, para sus útiles de labranza, para los arreos de sus corceles, para las armas de sus guerreros y para las joyas de sus mujeres.

Que la civilización de los pobladores de España, a partir por lo menos del siglo vi se hallaba relacionada con el resto de los países que dominaban los celtas, se demuestra examinando los ejemplares encontrados

martillazos y caldas iríase haciéndose susceptible de trabajo. (*) En este tipo de horno, que seguramente es el más primitivo, se tienen que hacer las cargas, soplar el fuego y descargar el horno todo por la misma boca, y las escorias, que se encontraron en sus restos, contenian del 50 al 60 por 100 de hierro.

El segundo tipo de horno celta, encontrado por vez primera en el Jura por M. Quiquerez, aparece siempre en terrenos montañosos, y las arcillas con que apisonan sus paredes fueron mucho más seleccionadas y las más refractarias de la cuenca minera donde el horno fué establecido.

Estas curiosas instalaciones destinadas a fundir el hierro, estaban formadas por una cavidad cilindrica, cuyas paredes, cubiertas, como decimos, de tierra refractaria, se apoyaban sobre tierra apisonada que sostenia un muro de piedra.

El mineral fragmentado se debió colocar por la boca en capas alternadas con carbón de leña. Una abertura practicada en la base pudo servir lo mismo para la extracción del lobo o bola de hierro, después de reducido, que para la ventilación del horno, pues no es fácil, como pretende Quiquerez, que los celtas, galos y celtiberos trabajasen con el escaso tiro natural que supone esta instalación rudimentaria. La altura total del horno no debió ser muy distante de unos

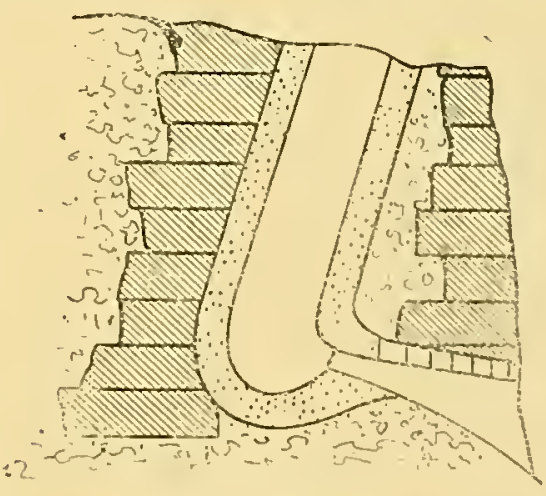

Horno de fuldir hierro empleado por los celtas, encontrado en el monte Jura dos metros; el diámetro interior disponible, de unos 45 centimetros; el espesor de cada una de las paredes, de 30 centímetros y la capacidad disponible, muy escasamente de un décimo de metro cúbico. $\left({ }^{* *}\right)$

(*) L. de Launay.

(**) Quiquerez.-De l'âge du fer, Recherches sur les anciennes forjes du Jura cernois.-Societé Jurasienne d'Emulation.-1866 pl. I. 
en necrópolis, como la de Aguilar de Anguita y otras exploradas por el Sr. Marqués de Cerralbo principalmente, y varios después, entre los que se pueden citar el Sr. Morenas de Tejada, D. Juan Cabré, D. Federico Motos y otros; y comparando sus resultados con los hallazgos de la estación clasificadora de Hallstatt, los del Pirineo francés y en general con todos los de la época, porque la industria del hierro debió ser común o poco menos a aquellos pueblos. Así, por ejemplo, sus armas, elemento que interviene en la vida de los mismos de un modo absolutamente fundamental, coinciden, por completo, en los tipos, y encontramos en España la espada de antenas, definidora de aquella época, análoga en forma, dimensiones y decoración a las mismas de Hallstatt. Es interesante y da idea del desarrollo que la forja del hierro había adquirido en este tiempo, conocer el procedimiento seguido para confeccionarlas; dice Sandars ${ }^{(1)}$ que forjaban la hoja y la espiga en una sola pieza; de otra parte, las antenas; constituyendo una tercera la empuñadura, en forma de tubo cortado "en cuadro" por uno de los extremos, y batida hasta formar la guarda de la hoja por el otro. Las tres se reunían luego, embutiendo primero el tubo en la espiga para después pasar la terminación de ésta por la abertura de la barra de unión de las antenas. Remachando a martillazos la punta de la espiga que sobresalía, sobre la barra que contiene las antenas, reunían las tres piezas y formaban el puño completando el arma. Separadamente fabricaban las bolitas, que generalmente eran de hierro y algunas veces de bronce, o bronceadas, y las remachaban a su antojo en los extremos de las antenas. Dichas bolitas más bien servian de adorno que formaban parte integral de la espada, si bien cabe en lo posible que fueran de utilidad para su equilibrio.

No siempre remachaban el extremo de la espiga; muchas veces formaban de él una bolita céntrica terminal de bronce, la cual posteriormente desarrollándose llegó a adquirir la forma de testa humana que se encuentra en algunos tipos de espada corta.

Es lo más curioso del caso que la misma técnica se ha seguido de un modo riguroso por los pueblos que habitaron las estaciones exploradas

(1) The Weapons of the Iberians. 
en Austria y los que vivieron en las poblaciones descubiertas por el señor Marqués de Cerralbo.

No puede dejarse de mencionar que, correspondiente a esta misma época de Hallstatt, han sido encontradas en las excavaciones de Turmiel y de Atance espadas de antenas, cuyo puño de acero presenta incrustaciones de plata siguiendo dibujos geométricos y rectilíneos, y es dato del mayor interés porque mucho tiempo después, en plena época visigoda, hemos de encontrar ejemplos similares.

Por otra parte, si los descubrimientos del Sr. Marqués de Cerralbo dan una serie interesantísima, completa, de la evolución de la espada en los días de Hallstatt, los del Sr. Marqués de Comillas, en lo que fué núcleo de Cantabria, han dado tipos nuevos y por tanto completamente españoles, cuya vaina también está ricamente incrustada y termina en una especie de cuadrilongo con grandes roeles, más que en los vértices, en las prolongaciones de los dos lados perpendiculares al eje de la espada. Como siempre ocurre, las espadas del Sr. Marqués de Comillas han sido reputadas por los arqueólogos extranjeros como una falsedad burda, hija de la imaginación de un anticuario ignorante, hasta que descubrimientos sucesivos, sin contar con el estudio hecho por el Sr. Cabré de la sepultura de un guerrero en Miraveche ${ }^{(1)}$, han demostrado la autenticidad del tipo, repitiéndose una vez más la triste y gloriosa historia de nuestras cuevas de Altamira.

Pero la espada de antenas, como se sabe, no fué exclusiva entre los iberos, que además tomaron de los griegos la espada "macaira», y modificándola dieron lugar al tipo español conocido por espada "falcata"; arma, como la griega, destinada a herir por golpe, pero que los celtíberos afilaron en su lomo o recazo desde la mitad del largo y terminaron en punta, convirtiendo de este modo en arma punzante la que era sólo una especie de machete.

Las fíbulas que representan, entre los elementos de decoración, una a modo de joya de las mujeres de aquellos días, suelen ofrecer distintas formas, y las más importantes son las que tienen vuelto hacia arriba el ex-

(1) Trabajo publicado por la Sociedad de los Amigos del Arte en su revista Arte Español, en 1916. 
tremo de la muesca, terminado en un botón cónico y provistas de un muelle de alambre, que forma igual número de espirales a cada lado del arco para luego prolongarse en forma de aguja. Este tipo se encuentra con frecuencia en el centro y norte de España y Portugal, y ejemplares análogos, hechos también únicamente de hierro, fueron hallados en el cementerio de Avesac-Prat, allende los Pirineos.

El alambre empleado como muelle, la fabricación de sus armas, cuya superioridad indiscutible ha sido reconocida por los mismos historiadores romanos de la época, demuestran que la elaboración del acero y su temple fué operación conocida y dominada por los celtíberos. Plutarco y Plinio refieren la manera como aquéllos hombres fabricaron sus aceros y los templaron, diciendo el primero que seleccionaban las piezas (seguramente después de carburadas), enterrándolas durante un período largo de años y dedicando únicamente a ser tratados como acero aquellos hierros que no habían sido o habían sido muy poco atacados por el óxido; curiosísimo sistema seguido hasta hace bien poco tiempo por los japoneses; y Sandars en su interesante obra, ${ }^{(1)}$ nos dice que habiendo sido cortado un segmento del lomo de una espada, examinado y fotografiado, permitió comprobar que la parte exterior contenía carbono, pero que éste disminuía paulatinamente hasta desaparecer por completo antes de llegar al núcleo. Esto demuestra que las piezas aceradas habían sufrido un tratamiento de cementación, siempre difícil y mucho más en aquellos días, porque supone un caudal de procedimientos técnicos extraordinarios. Falta para completar la información, añadir que Plinio reconocía como sobresalientes los aceros tratados en Bílbilis, cuyas aguas, según los historiadores de aquellos días, tenían la virtud de dar un temple que fué célebre en todo el Imperio.

Resulta de lo dicho, que antes y durante la época romana, nuestros celtíberos, después de obtener el hierro en sus hornos de carbón de madera y tiro natural o sencillo, supieron cementarlo con carbono; los resultados indecisos de esta operación delicada se aquilataban exponiendo los tochos a una oxidación prolongada e intensa, y tan sólo aquellas piezas

(1) Sandars. Obra mencionada. 
que resistían por estar realmente carburadas eran templadas, lo que explica bien fácilmente la constante seguridad en el éxito.

Uno de los detalles que más demuestran lo mucho que se había extendido el uso del hierro en esta época de Hallstatt es el hallazgo singularísimo de nueve herraduras en Aguilar de Anguita, por el Sr. Marqués de Cerralbo, a profundidades que varían entre metro y medio y medio metro, y próximas a una espada de antenas que determina época.

Como ejemplares de trabajo normal de forja pueden citarse los frenos de caballo que se encontraron en sepulturas de guerreros ibéricos, y que a la par que confirman la noticia proclamada por Estrabón y otros, describiendo la maestría y habilidad con que los iberos dominaron el arte de la equitación y lo notablemente que educaron sus caballos para todos los lances de la guerra, demuestran lo perfecto que fué entre los mismos el arte de forjar, desde las épocas más remotas, pues algunos de los ejemplares, importados probablemente por los celtas desde el Oriente, representan tipos arcáicos, que serían sin el menor género de duda los primeros ejemplares que en España se copiaron; tal es, por ejemplo, el de camas curvas que se ve repetido en las esculturas asirias del Museo Británico y del Louvre. Este freno curvo es ejemplar que no se encuentra sino en Etruria y en España; en aquellos países lo hallamos en representaciones tan espléndidas como el triunfo de Sardanápalo, y en España no tan sólo los vemos en los ejemplares encontrados por el Sr. Marqués de Cerralbo, sino en estatuillas ecuestres interesantes halladas en Despeñaperros en los curiosos descubrimientos de bronces ibéricos allí realizados.

Vemos, pues, que en el instante en que termina la prehistoria, o sea en los años que precedieron a la dominación romana y aun a la cartaginesa, encontramos en nuestra Patria la industria del hierro, no tan sólo vulgarizada, sino habiendo llegado a un grado de esplendor técnico y artístico por lo menos igual al de otros países, como demuestran los procedimientos de cementación y temple de sus armas, las decoraciones incrustadas de los puños y vainas de sus espadas, las fíbulas y los anillos que nos restan. ¿Se llegaría a la exportación, como posiblemente se llegó en la cerámica contemporánea, la llamada de Ciempozuelos, dadas las excelentes condiciones naturales, famosas ya en la antigüedad, de nuestras minas y 
minerales dulces de hierro, sin igual en los países europeos cercanos?

La semejanza de nuestros tipos celtas con los extranjeros de la misma época, la importancia extraordinaria en cantidad y calidad de los descubrimientos españoles hacen más que posible, probable esta teoría.

E la época romana en España apenas queda otra cosa que la docu$30000 \%$ 68 mentación histórica, la que nos ofrecen las lápidas y bien pocos ejemplares, como rejas de arado, llaves, etc., y ello es debido a que habiéndose repetido en este tiempo cuanto se había hecho en las muy avanzadas civilizaciones celtibéricas que la precedieron, hoy se confunden como de una misma época los objetos pertenecientes a los siglos celtibéricos con los romanos, anteriores o posteriores a Jesucristo, incluso los ejemplares producidos en pleno período de dominación, es decir, siendo España una provincia del Imperio romano. Sabemos que los conquistadores continuaron extrayendo el mineral y utilizando los procedimientos y prácticas indígenas para la elaboración y temple; y la importancia que llegaron a adquirir sus manufacturas durante esta época romana nos lo demuestra cierto número de inscripciones relacionadas con el arte del hierro o su comercio.

Entre las que ofrecen mayor interés se pueden recordar la 4.316 y la 4.498 de Hübner, refiriéndose las dos al Colegio de Ferreros, así como la 5.181, encontrada en términos de Portugal, en la que se dice que ciertos productos "se venden según la Ley de los Herrajes" (ex lege ferrariarum).

Hübner menciona otros: así, el núm. 1.199 corresponde a una lápida hallada en Sevilla, cuya inscripción funeraria está dedicada a F. Frutonio Broccio, negociante ferrario y habitante Romulense. Podría citar algunas otras interesantes, como la 2.211 del mismo Hübner, todo lo cual viene a demostrar que este ramo de la industria había llegado a adquirir en la época romana una intensa preponderancia. 
Es lo más interesante de cuanto pudiéramos mencionar en esta época, que en técnica y ornamentación no se hace otra cosa que seguir lo de períodos prehistóricos; aparte de ello, y como justificando el carácter utilitario que habíamos asignado a este período, los ejemplares que se encuentran son en todos los casos artefactos caseros o herramientas de trabajo, principalmente agrícolas, incluso las fíbulas, que cuando son de hierro no suelen tener decoración, predominando las rejas de arado, las azadas, las hachas y picos, las sierras, que aparecen aquí por vez primera quizás, tenazas que pudieron tener un uso corriente, siendo los ejemplares más grandes las de forjador, y por fin una serie de cadenas de eslabones desproporcionadamente grandes, terminadas en anillas, que bien pudieron en la historia atestiguar la misión antipática de grilletes.

No deja también de ser curioso, que ya desde el tiempo de los iberos vienen apareciendo tijeras, siempre del mismo tipo pero de dimensiones variadas, y que por ser de una pieza y estar basadas en la elasticidad del acero que se emplea, demuestran una seguridad y un dominio de la técnica siderúrgica que aun en los momentos actuales exigen poner en juego los procedimientos más adelantados que los conocimientos modernos facilitan.

Termina en España la época romana sin que pueda decirse que el trabajo del hierro saliera de su característica condición utilitaria. En la metrópoli, en los últimos siglos que fueron de refinamiento y suntuosidad, se forjaron y hasta se cincelaron algunos pequeños ejemplares destinados a los usos corrientes de la vida, como, por ejemplo, llaves, que por estar así cinceladas se pueden considerar como manufacturas artísticas, pero en España, donde se construyeron estos mecanismos con la mayor valentía y precisión, no se decoraron los ejemplares o por lo menos así no se han encontrado. $\mathrm{Y}$ en efecto, en las excavaciones de Numancia primero y en otros varios descubrimientos después, fueron apareciendo arados, cadenas, Ilaves y otros objetos que tienen un gran interés y curiosidad, no sólo por su diámetro, algunas veces considerable, sino por su disposición de conjunto y por la perfección que supone el correspondiente ejemplar o mecanismo, mas no por su decoración, pues de ella carecen en absoluto. La industria del hierro, como todas las artes industriales, sigue paso a 
faso la historia política de la nación, y por ello las primorosas labores que produce la civilización de los celtíberos; los trabajos, por ejemplo, de incrustación en plata conque ornamentaron las armas de sus caudillos, desaparecen en la época colonial, cartaginesa y romana, encontrando tan solo en estos tiempos los objetos utilitarios que suponen una fabricación vulgarista y rutinaria. 


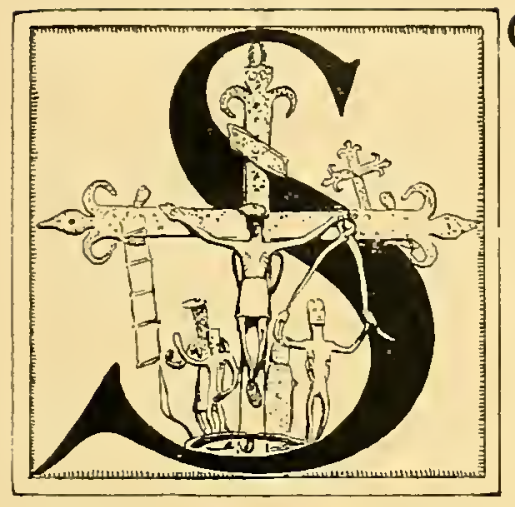

OBREVIENE EN TALES CONDICIONES LA INvasión de los pueblos del Norte, desaparece momentáneamente todo lo que fué arte y por tanto los indicios y comienzos de éste en el hierro, pero se conserva la manufactura como tal industria, y cuando la monarquía visigoda, ya estable y poderosa, inicia un lujo que copia de la Corte bizantina, mezclando a los elementos decorativos romanos, traducidos con toda la rudeza del pueblo godo los propios de su raza y los de la indígena, hace todo lo que requiere decoración y lujo en metales, siempre más dúctiles y maleables que el hierro, en bronce, en plata o en oro, según la riqueza que se pretende.

Tan sólo cuando la primera materia viene impuesta por condiciones de resistencia por una parte, y por otro lado por su intrínseca categoría, es indispensable que la pieza sea rica, se adopta una solución intermedia que es fabricar el ejemplar en hierro con sus proporciones, perímetros y superficies lisas, respondiendo escuetamente o poco menos a su carácter utilitario, y luego con oro y plata que se incrusta en las superficies primitivas se avaloran con una decoración y una riqueza, que no se había sospechado en aquellos días que se pudiera lograr simplemente obrando sobre el hierro por la forja con el martillo, o con el cincel.

$\mathrm{Y}$ tal procedimiento, continuación de la técnica decorativa de los iberos que incrustaron las empuñaduras de las espadas de antenas que guardan las colecciones de los Sres. Marqueses de Cerralbo y Comillas, parece como que lo resucitan o continúan los visigodos en aquellos casos extremos en que no era posible, como decíamos antes, elegir otra materia prima que el hierro.

Es de una curiosidad extraordinaria y resulta una especie de demos- 
tración de lo dicho, el que entre las escasísimas piezas que con alguna seguridad se pueden atribuir a los tiempos visigodos figuran tres bocados de caballo casi exactamente del mismo tipo y los tres, decorados con arreglo a un criterio único, que se ajusta exactamente a lo que venimos diciendo.

Era conocido hasta ahora tan sólo el ejemplar que desde el año 1656 figura en la Real Armería y ejemplar que indudablemente es godo, no tan sólo por los monogramas, ${ }^{(1)}$ sino también por toda la ornamentación de un carácter francamente bizantino.

Y uno de los restantes, con curiosas incrustaciones en oro y plata, ejemplar que por vez primera se presenta al examen de los estudiosos, parece confirmar definitivamente nuestra teoría, porque de su disposición se deduce que no estaba dispuesto para que a él se unieran las riendas, que el caballero no debía llevar; pero sí, unos cordones que arrancando de dos anillas que no pueden tener otra finalidad, pudieron estar destinados a dos pajes encargados de la conducción del caballo. Es decir: que nos encontramos delante de una pieza de ceremonia.

Los árabes que se desparramaron por la península al comenzar el siglo vIII, no aportaron a su llegada ni un sólo elemento decorativo; las piezas incrustadas en oro y plata que nacieron en un período de esplendor en la corte visigoda, desaparecen completamente, adquiriendo la industria del hierro un carácter aún más francamente utilitario, y mientras nuestros más viejos manuscritos cristianos, los de ese tiempo, hablan de trabajos en hierro, como por ejemplo, el códice de Sahagún de 1059, otro de León de 1090, uno más de Vich de 1100, en cambio en las excavaciones de Medina-Azzahra, de Alamiriya y de Elvira, se demuestra bien claramente que entre los árabes, aun en los días de cultura, adelanto y esplendor del Califato, en plenos siglos x y XI, no fué el arte del hierro la ocupación pre-

(1) Efectivamente, cuando las monedas de esta época solo contenían el nombre del rey, éste figuraba en una de las caras y en la otra el de la ceca o población en que se verificaba la acuñación; pero cuando al final de la dominación visigoda se inició la costumbre de poner en las monedas también el nombre del príncipe heredero como asociado al gobierno del reino, se puso el nombre de cada uno de los personajes en cada una de las caras, y fué preciso poner el nombre de la población en un monograma, generalmente en forma de cruz con las letras en los extremos de sus brazos y hasta en el centro.

El freno o bocado de la Real Armería presenta un monograma exactamente en esta forma y donde pueden leerse las letras W, T, l, A, y esto unido como decíamos a su decoración bizantina y a la forma característica del bocado parece que demuestran la razón de la atribución antes dicha. 
dilecta de sus artistas y, no obstante, en el Museo Arqueológico de Granada, se conservan los herrajes completos de una puerta, que procede de Elvira, y que por las circunstancias que rodearon el hallazgo, debido al Sr. Gómez Moreno, parece que puede fecharse entre los siglos x al $\mathrm{XI}$, es decir, precisamente en esos mismos días de Medina-Azzahra, y presentan estos objetos la rara e importante curiosidad de ser los primeros ejemplares decorados en plancha recortada; cierto es que en la época romana, aparecen algunos cofres con trabajos en hierro, cuyos ángulos y cantoneras, y cuyas alguazas y visagras se ornamentaron en plancha, pero ésta fué siempre de cobre, como puede comprobarse en los ejemplares conservados en el Museo de Saint-Germain y otros, mientras que los de Granada no solamente tienen de hierro sus abrazaderas o visagras sino que se hallan bifurcadas en su terminación y recortadas según un contorno floral agradable que encaja dentro del gusto seudo-clásico de la época. Otra interesante particularidad presenta esta puerta, y es la aparición en ella de los grandes clavos o chatones que más adelante han de evolucionar decorando las puertas medievales y perdurando en y después del Renacimiento.

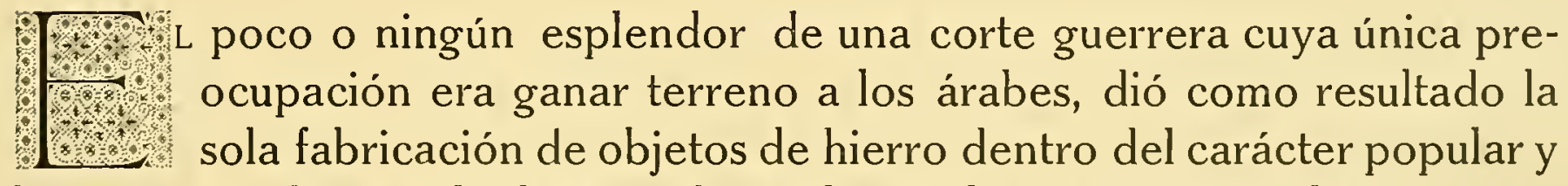
la escasa o tal vez nula de ejemplares decorados o excepcionales; y consecuencia de ello es que por su escasísimo valor decorativo, ni los contemporáneos ni sus sucesores trataron de conservarlos y han desaparecido o poco menos. Pero si por casualidad llegó alguno hasta nosotros, seguramente que no ha sido clasificado en su edad verdadera, porque esas piezas de carácter francamente utilitario perpetuaron sus formas, sus dimensiones y su rudimentaria decoración durante siglos y más siglos, y la mayor parte de los arqueólogos tienden a definirlos como de la época en que se inicia su construcción y su uso; el arado romano, por ejemplo, ha llegado hasta épo- 
ca bien reciente ${ }^{(1)}$, de manera que piezas análogas o quizá las mismas que aquí figuran como de los años últimos del Imperio Romano, es posible sean tal vez visigodas o medievales, no siendo fácil atribuirlas a su verdadera época cuando en ellas la persistencia de una técnica siderúrgica venga unida a la carencia de ornamentación, que es la que hubiera podido en cada caso fijar la época.

Dicen algunos autores ${ }^{(2)}$ que en España para el trabajo del hierro no había estilo fijo hasta que el románico fué introducido de Francia por los Monjes de la Orden del Cluny, que venían en las complejas comitivas de aquellas damas francesas con las que nuestros reyes españoles acostumbraban a casarse (i!); ciertamente que la observación tiene bastante peso, sobre todo si comparamos nuestra arquitectura románica con la francesa; pero de todos modos, en lo que al arte del hierro se refiere, es necesario tener en cuenta tres puntos: es el primero, que España, con mucha más importancia que Francia y que los demás países, ha sido siempre país productor de hierro; es el segundo, que las formas clásicas de las construcciones románicas, como tales formas decorativas, no son importadas, sino que son también para nosotros la continuación tradicional de las usadas en España constantemente desde los tiempos prehistóricos; así, por ejemplo, las volutas en hilo de cobre con que se adornaron las mujeres españolas de los siglos VII al III, antes de J. C., y que muchas de las excavaciones ya citadas del Sr. Marqués de Cerralbo, tales como la de Aguilar de Anguita y otras, han puesto de manifiesto, son, con toda evidencia, un antecedente histórico que pudo determinar la construcción de nuestras rejas de San Isidoro y del Mercado, en León; las de Zamora, Palencia y hasta las catalanas.

Por fin es preciso recordar, y es el tercer punto que la decoración por espirales se acomoda sin la menor violencia a la técnica de aquellos días, que arrollaba cómodamente sobre el extremo del yunque la barra caldeada al rojo.

El forjador en el corazón de la Edad Media trabaja aún con elemen-

(1) No conociéndose intento de modificación hasta el año 1572 y no realizándose ésta formalmente hasta después de 1774, en que Arbuthnot expuso la primera teoria del volteo de la tierra.

(2) A. Byne M. Stapley y otros. 
tos pequeños y sólo por excepción construye un barrote recto y cuadrado que forma el marco o armazón de la reja; pero los tiempos y la técnica habían adelantado bastante para que se considerase como necesario el decorar con volutas esos espacios intermedios formados por los barrotes rectos, aunque su poca separación garantizase quizás siempre la seguridad que se pretendía con la reja.

Además de todo lo dicho, debe hacerse constar y es observación de mucho peso, que contra lo que hasta hoy se entendía, este tipo de rejas es dentro de la rareza que supone su fecha, muy abundante en España, principalmente en la meseta castellana, Asturias y más tarde en Cataluña y Navarra, llegando hasta las Vascongadas, (1) pero con la particularidad de que propuesto el modelo común, quizás en la segunda mitad del siglo $\mathrm{XI}$, cuando ya olvidadas las incursiones de Almanzor, las constantes ampliaciones de dominio en los reyes castellanos, dieron a sus pueblos la sensación de estabilidad que no habían logrado antes, se desarrolla el tipo primitivo que vemos, por ejemplo, en la provincia de Zamora, en Cataluña y en Castilla de modo diferente, tendiendo en los ejemplares de los reinos de León y Castilla a macizar la superficie, mientras que los navarros y catalanes dan antes a los conjuntos mayor variedad y transparencia y en los modelos más tardíos llegan a ejes simétricos oblícuos, como queriendo trazar estilizaciones florales geometrizadas y acomodándose antes que los castellanos a las siluetas del nuevo estilo gótico, hasta el extremo, de que la persona que sin previo estudio contemplase la reja de la Capilla de Santa Cruz en Pamplona o la puerta de la iglesia de San Juan de las Abadesas en la provincia de Gerona, más las juzgaría trazadas dominando ya el arte gótico que en pleno florecimiento del románico.

Este concepto decorativo que ahora se inicia con pujanza, se debió imponer lentamente a todos los órdenes de trabajo, y los candeleros que se conservan de aquellos días, los característicos del siglo XIII, se inspiran en las proporciones de la arquitectura vigente, se forman en ese ambiente y son los primeros elementos después de las rejas en que se inicia una decoración, estando constituídos por un pie de tres patas curvas, de sec-

(1) La puerta de Santa Maria de Galdácano, en Vizcaya, tiene alternados unos interesantísimos herrajes que en su primitiva aplicación indudablemente formaron parte de una reja. 
ción que más que elíptica es circular deformada, terminando en su apoyo por un ensanchamiento a manera de pata de ave; el vástago del candelero suele ser también de sección circular más o menos exacta y presenta, generalmente, como decoración dos o tres anillos o ensanchamientos tronco-cónicos y dobles, unidos en aristas por su sección más grande que puede tener en su parte más ancha un diámetro doble del vástago. Toda la pieza rara vez excede de unos 40 centímetros de altura; el pie puede representar una cuarta parte del conjunto y el largo del eje cilíndrico suele variar de once a diez y seis veces su diámetro; falta decir que estos ejemplares terminaban en pincho, sobre el cual se clavaba el hachón que iluminaba en aquellos templos.

Algunos hechos de excepcional importancia completan la historia de la época; uno es que en el año 1250, son llamados los rejeros catalanes Blay y Suñol, para ejecutar las rejas de Nuestra Señora de París; otros, el que cita Campany en sus Memorias, resultando que en este tiempo, los herreros de Barcelona formaba un gremio muy importante, y así debía de ser, porque ya en 1200 Pedro II cita la corporación de Ferrers en las Constituciones Catalanas; el que en un pergamino del Consulado del Mar, conste que en este tiempo los Ferrers de Barcelona tenian derecho a construir todos los herrajes y piezas necesarias para la marina sin pagar derechos; y por fin, el hecho de que no debía ocurrir mucho menos en el resto de la España cristiana, en cuanto a importancia de su organización gremial, por cuanto Don Alfonso X en los «ordenamientos de posturas» en las Cortes de León y Castilla habidas en el Ayuntamiento de Jerez el año 1268 , tasa las obras de hierro muy detalladamente, especificando la procedencia, la localidad donde se vende y hasta si el transporte fué por mar o por tierra.

La preponderancia que en esta época medioeval llegó a adquirir el gremio de herreros, lo demuestra el hecho de que en el Consejo de Ciento de la ciudad de Barcelona, poco después de comenzar el año de 1316, ya tuvieron asiento varios herreros, como tales representantes del gremio, ${ }^{(1)}$ y el caso de tenerse que derogar la prohibición que imperaba en

(1) Company.-Memorias históricas sobre la marna, comercio y artes de la antigua ciudad de Barcelona.P. III ${ }^{3}$, pág. 135 y Uña y Sarthou. Las Asociaciones obreras en España, pág. 178. 
Valencia desde 1298 para el funcionamiento de la cofradía correspondiente, autorizándola nuevamente el Rey Don Alfonso II, en las memorables Cortes de 1329; siendo todo ello más de notar, cuanto que los herreros en el resto de Europa tenían en estos momentos organizaciones deficientes, y así vemos que en París no llegan a constituirse como tal gremio hasta el año 1411.

Durante el transcurso de este siglo XIV puede decirse que dichas corporaciones organizaron su funcionamiento en toda España de un modo definitivo, desarrollándose y adquiriendo preponderancia social y política muy a pesar, incluso del poder real, que poderosamente trata de combatirlas, como por ejemplo en los famosos "Ordenamientos y posturas otorgadas a las ciudades, villas y lugares..." en las Cortes de Valladolid habidas en 1351 por el rey Don Pedro, donde se tasan detalladamente, series de objetos fabricados, teniendo en cuenta los distintos lugares para donde se legisla y declarando libre su fabricación ${ }^{(1)}$ después de haber disuelto todas las cofradías; porque Don Pedro encabeza aquellas Cortes por esta medida radical contra las de todos los oficios y entre ellas las de los herreros, análogamente a como medio siglo antes había hecho el Monarca aragonés, atacando valientemente a un sindicalismo medioeval que tiene por finalidad "por ffazer poca lavor: e que porque lo vendan más caro," el oficio se declara libre taxativamente... "más que libremente puedan mostrar los dicho officios los quellos sopieren e aprenderlos los quelos quisieren aprender..." y como los objetos fabricados se deben vender a precio de tasa, los intereses del consumidor quedan a cubierto. Claro está que era bien difícil garantizar de igual manera la calidad de la mercancía y precisamente a este detalle habían de acogerse las cofradías o, mejor dicho, los gremios, para lograr su reconstitución y su vida, cada momento más pujante.

Véase como también en aquellos días los problemas sociales marchaban por derroteros poco distintos de los nuestros.

No dieron un resultado tan grande como la Corona se prometía aque-

(1) Nuestra Sociedad Española de Amigos del Arte, se propone publicar, unido al estudio de la evolución de la rejería, un complemento extenso de nuestro catálogo, donde sean tratados con mayor detenimiento estas cuestiones documentales que revisten un interés emocionante. 
llos «ordenamientos de posturas» que prácticamente se anulan cuando en las Cortes de Burgos de 1373 se acuerda, visiblemente retrocediendo, que sean de nuevo los Consejos los que tasen los jornales y precios "porque los Consejos e omes bonos, cada uno en su comarca sabrán ordenar en rrazón... según los prezios de las viandas que valieren...»

Pero mucho antes de que la determinación fuese de Cortes, ya Concejos de cierta categoría se habían lanzado por ese camino, y sirva de ejemplo lo hécho por el de Toledo el año de 1355 (incorporado después a las ordenanzas de 1455), cuando a los señores que componían su Concejo les pareció demasiado remunerativo el precio a como se vendian los objetos ya fabricados y resolvieron verlo y palparlo por sí mismos «labrando un quintal de fierro que solía valer en Toledo cincuenta maravedises"; (1) y de este modo, sumando hasta los más pequeños gastos, llegaron a saber cuanto valía una gruesa de azadas o azadones, etc., de ferraduras e clavos, etcétera, y a los trabajos de la primera categoría les fijaron un precio de once dineros la libra, y de doce a los segundos, mientras la primera materia no cambiase de precio.

Continuaron durante todo el siglo las alternativas de preponderancia o abatimiento de aquellas cofradías que, cubiertas tras una disciplina religiosa, educaban a sus miembros en el criterio corporativo más intransigente, resolviéndose el problema en favor de los gremios, cuyas ordena-

(1) Ordenanzas del Almotacen de Toledo de 1455. - Biblioteca Nacional, Manuscritos. - 13.036. «TíTULO DEL FlERRO.-Otro, si porque solía valer en Toledo el quintal del fierro cincuenta mrs. con el peso e corredor, Toledo mandó labrar un quintal espidiose en labra cinco saxos de carbón que vale dos mrs. e medio é el que suena los pellejos a cada arrova catorze dineros en que moran el quintal cinco mrs. é seis dineros y de Agua de cada arrova tres dineros que monta el quintal, doce dineros la tienda cada uno cuatro dineros en quatro días son dies e seis dineros al maestro tres mrs. al Arrova que monta el quintal que labran en cuatro días doce mrs. tirar de un quintal a quatro ma. ravedises o el arrova que monta dies e seis mrs. suma de la corta noventa e nueve mrs. dieron a el maestro en cada quintal honze mrs. de ganancia e recado a honze dineros la libra e otro si en tomar el fierro para ferraduras e clavos e otras obras menudas menoscaba en cada arrova cinco mrs. e porque esta obra menuda la labran dos Maestros en la fragua no es prenden tanto carbón e porque se vende mucho esta labor menuda e porque fué siempre acostumbrado de dar en Toledo un dinero más en la lavor menuda que a la gruesa a la libra por ende ordenaron é mandaron que los ferreros vendan é den el fierro labrado o bien fecho de lavor gruesa asi como azadas e azadones e rejas e palancos e toda la oira lavor gruesa a honze dineros la libra e de la lavor menuda así como ferraduras e clavos e plegos para plegar a cualquier otra ferra mienta menuda que la den a doce dineros la libra. As mientra el quintal del fierro valiere cinquenta mrs. y si subiere el quintal cinco mrs. que suba un dinero la libra y quando el quintal descendiere cinco mrs. que dixa un dinero en cada libra e así por este quento para siempre esto fué fecho ábenentia de Toledo. Con los ferreros que estan labrando de lavor e qualquier que no la labrare en su tienda como esta acostumbrado e vendiere la libra del ferro a mayor contia desta quedhaes que peche por cada vez setenta e dos mrs. e que a donde en la cibdad de fierro labrado fallandolo a comprar en la manera que dicha es sola dha pena cestas penas sean dos tercias partes para los Almotacenes y la otra tercia parte para el Acusador.» 
ciones se consolidan de un modo definitivo, como ocurre, por ejemplo, en Barcelona cuando Don Pedro IV, el Ceremonioso, el 10 de Mayo de 1380, otorga el decreto de constitutión de la Corporación de Maestros Cerrajeros, documento que confirman el rey Don Martín y después el Emperador Don Carlos, y que al igual que la Entidad, ha llegado hasta nuestros días, ${ }^{(1)}$ como ejemplo viviente que demuestra lo que fueron en otros tiempos.

La constante intervención de los herreros desde entonces en el Concejo de Ciento es la más demostrativa explicación de la preponderancia política de tales corporaciones.

Mientras esto pasa en Castilla, la fabricación, principalmente en las Vascongadas, adquiere cada momento más importancia y estabilidad, consolidándose los derechos y privilegios que garantizan el funcionamiento y régimen de las ferrerías en el fuero concedido a los ferrones de Oyarzun y de Irún en Burgos a 15 de Mayo de 1366 por Don Alfonso XI, documento de excepcional importancia ${ }^{(2)}$ porque demuestra que en aquel momento las ferrerías vascongadas aplicaban la fuerza hidráulica para la obtención del metal, trabajando los minerales como un par de siglos después pudieran hacerlo en las más perfeccionadas instalaciones de Europa.

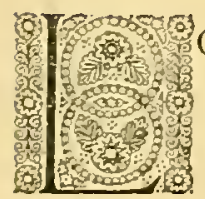
os principios del siglo XIV son una consecuencia directa del estado anterior y de las nuevas modas que se implantan definitivamente en nuestra patria, con la vulgarización del gótico. Es de advertir, no obstante, que el arte del hierro, quizás por las condiciones del trabajo, tal vez por amaneramiento de sus artífices, ha seguido la evolución de los gustos y los estilos con un retraso muy evidente, puede ser que de medio siglo y no debe extrañarnos, por tanto, encontrar ejemplares fabricados

(1) Hoy existente en el Archivo del Ayuntamiento municipal de Barcelona, encomendado a la justodia del archivero Sr. Durán, a quien debemos estos y otros interesantes datos donde se ha recogido al modificar su organización el gremio que hasta hace muy poco subsistia con casa propia, en la calle del Consejo de Ciento, núm. 292.

(2) Cuyo texto literal debo a la mucha amabiliclad de mis respetados amigos D. Serapio de Múgica y D. Carmelo Echegaray. De él se dará noticia exactamente en la obra que preparan los Amigos del Arte, mencionada anteriormente. 
en pleno siglo XIV, inspirados en las volutas o espirales que definieron el románico, como, por ejemplo, los braseros portátiles de algunas catedrales o los herrajes de puertas principales, como la de la iglesia de Castellbó en la provincia de Lérida, en la Seo de Urgel.

Otro ejemplo de la persistencia del románico, son los candelabros, que en la primera mitad del siglo XIV guardan fielmente la tradición, inspirándose en la arquitectura; el eje o vástago, ya no suele ser necesariamente cilíndrico y con mucha más frecuencia es poligonal, de seis, ocho y hasta de mayor número de lados. Cuando aún es en toda su longitud cilíndrico y tosco (las proporciones dadas para el románico) el número de anillos se multiplica, la separación entre ellos se acorta y cuando como ocurre con más frecuencia, es el eje poligonal, la superficie de sus caras se decora, siguiendo la técnica árabe, por líneas incisas que dibujan un motivo geométrico, con trazos monótonos y apretados que repiten el asunto como si fuera una persistencia del románico, o con grecas entrecruzadas que hacen pensar en los motivos de lacerías árabes. Los anillos, en este caso, no son tronco-cónicos, y con mucha más frecuencia son un cubo, cuyos vértices se achaflanaron en ángulo, decorando los rombos a que quedaron reducidas sus caras, por aspas o por puntos, siempre incisos.

Aparece en este momento entre el pie y el vástago de los candelabros, una bandeja de planchas formada por una hoja casi siempre rectangular, sobre todo en los ejemplares arcaicos, muchos más tarde redonda, doblada la cuadrada en sus ángulos y con los vértices en pico, o levantada a martillo y festoneada cuando es circular. Es curioso, muy curioso, que muchos ejemplares de este tipo, claro es que los más antiguos, presenten bajo la plancha de la bandeja rectangular la sustentación en tres patas, declarando de esta manera el como a un candelero del tipo anterior ya descrito, se le añadió más tarde la bandeja, para recoger la cera que antes manchaba el pavimento.

Pero aquellos herreros cuyos maestros se inspiraron en los gustos del románico fueron desapareciendo, y una generación nueva, educada en la imitación del natural, en la ejecución de la flora que decoraba los capiteles de las nuevas catedrales, impuso unas proporciones y un arte nuevo, apoyándose en los elementos mismos del tradicional. 
Es la primera modificación que impone el gótico a los tipos en uso, la de variar fundamentalmente sus proporciones; los candelabros por ejemplo, afinan los trípodes de sustentación para que arranque de ellos un vástago que podrá tener sesenta y más diámetros de altura, adornado todavía con múltiples anillos, espaciados sensiblemente a la misma distancia que en los ejemplares románicos; pero mucho más interesante es la tendencia manifiesta de inspirarse en la flora, dando al conjunto, más que el aspecto de un útil que llena una prevista necesidad, el de una flor, el de una planta, y dentro de ellas, las que por su significación poética y por su facilidad de ejecución fuesen posibles. De esta manera, soldando al último nudo de los vástagos del candelabro láminas lanciformes que se doblaban caprichosamente para dejar lucir el pincho propio del candelabro, que hacía en el conjunto ornamental el oficio de los estambres de la flor, nacieron en este tiempo los "candelabros de lirio", de unas formas y proporciones delicadas y puras, todo armonía y poesía, como producto de unos gremios que buscaron su fuerza en las novísimas arquitecturas de nuestras catedrales góticas.

La exagerada desproporción entre el vástago y su diámetro, justificada por la resistencia del material, no debió de satisfacer a los artífices que aún tenían ante los ojos los tipos del románico y tal vez por iesto, los ejemplares que se conservan de aquellos dias, principios o mediados del siglo XIV, no suelen presentar el vástago con desnudez; unas veces del trípode mismo salen otros tres vástagos menores, haciendo el oficio de retoños que acompañan al principal hasta la mitad de la altura; otra, de los nudos medios salen hojas o brotes; lo que siempre ocurre es que al vástago recto y limpio de largas dimensiones, respetando la sección pequeña que su material necesita, se le refuerza espiritualmente y se da al conjunto una disposición tal, que el perímetro, que la envolvente de todas las decoraciones del ejemplar, resulte como trazada a base de un eje francamente robusto.

En este tiempo dominan los herreros el trabajo de los dos elementos fundamentales para su labor, la barilla y la plancha; la primera desarrollándose como se ha dicho al tratar de los ejes de los candelabros podría decirse que al apurar en el siglo xv los motivos del arte gótico, inicia un 
principio de barroquismo porque decoradas, como se recordará, con nudos escalonados, empiezan a trabajarse en sección cuadrada y retorcida, tan exageradamente retorcida, que en no pocos casos, más que una decoración, da la sensación del fileteado moderno de un tornillo, muy defectuosamente hecho, aunque en realidad lo que se trataba de imitar debió de ser el arrollado de una cuerda.

Las patas de apoyo adquieren también una mayor importancia en las proporciones del conjunto, y no pocas veces suelen ser rectas y entonces de varilla retorcida, en mayor número de tres y como trazando las generatrices de un cono unidas cerca del suelo, esto es, en el punto de apoyo por rectas o por arcos.

Corresponde lo dicho a ese momento antes recordado, en que los artífices impresionados por las proporciones exageradamente alargadas de los conjuntos, cuando en ellos se utilizaba toda la potencia resistente del material, dibujan composiciones compuestas que simulan perímetros más resistentes.

El segundo elemento fundamental en las decoraciones góticas, es la plancha, trabajada como veremos en varios grados, dentro de los diferentes órdenes de decoración.

Es característico del empleo de la plancha como elemento constructivo el dar a los conjuntos un valor corpóreo y arquitectural de que carecía casi en absoluto en los primeros tiempos del gótico; la plancha puede ser utilizada como complemento de un sistema y entonces el conjunto, aunque más corpóreo y más arquitectural, lo es mucho menos que cuando esta misma plancha entra a formar parte integrante de la construcción del ejemplar. Las arandelas de los candelabros románicos de tres pies son un ejemplo de lo primero; la plancha recortada de las obras posteriores lo son del resto.

En el trabajo de la plancha como en toda evolución del arte industrial, se comienza por el empleo de los conjuntos, dando de un modo progresivo mayor importancia a los detalles, hasta llegar en los últimos tiempos de su empleo a la minuciosidad y perfección en los mismos, que en nuestro caso crearon los tan labrados y curiosos ejemplares de los días de los reyes Católicos. 
Así vemos que en los ejemplares más arcaicos, la plancha es una superficie lisa, plana o curvilínea, recortada en perímetros ya decorados sencillos, generalmente repetidos, por ejemplo un coronamiento almenado en una barandilla de arandela de candelabro.

Pero muy pronto esos conjuntos se debieron examinar de cerca y entonces aparecen encargados de quitar a la superficie lisa la correspondiente monotonía, dos modas o sistemas; son estos el realzado de la plancha y las siluetas perforadas.

Es el primero en realidad un repujado, elemental si se quiere, pero repujado. Apenas si el relieve alcanza un par de milímetros sobre el plano general de la plancha; pero lo más propio de la escuela, es que los motivos que se tratan son elementalísimos, repetidos y casi pudiéramos decir que más antiguos cuanto más pequeños y geométricos sean, no pudiendo entrar en la clasificación el punteado, por ser detalle repetido constantemente o poco menos en todos los ejemplares de este tipo. La línea, la cruz, los radios, diminutos rosetones, etc., son motivos que se repiten y entrelazan decorando las superficies.

Debemos recordar que este sistema de ornamentación llega rápidamente a un apogeo, cuando mediaba el siglo xv, estacionándose después por largo tiempo para desaparecer en el XVI o si se quiere evolucionar a los tipos industrializados de los últimos años del Emperador. La plancha recortada en perímetros adecuados se realza de esta manera y luego plana o graciosamente curvada en ejemplares más recientes integra los conjuntos; pero el relieve de repujado en ella no progresa y el que merece este nombre en los días del renacimiento, llega por un camino diferente.

Falta decir que la plancha recortada, unas veces realzada con diminutos motivos geométricos, las más de las veces lisas, en pequeños rosetones lobulados que se enlazan entre sí por una barilla que se les une por soldadura, forma los aros, que suponen, más que dan, seguridad y robustez a los arcones, cofres o cajas que forradas en cuero con mucha frecuencia decorado, son el inmediato precedente de los llamados de cuatro conchas, con decoración en plancha calada y usados con predilección especial en los días de los reyes Católicos. 
Paralelamente a lo dicho, y durante todo el siglo $\mathrm{xv}$, la plancha se trabaja por recortes o calados que empiezan por dejar como fondo o hueco espacios, con frecuencia repetidos, de poca superficie, pero que desde los primeros días presentan su cierta complicación; arquerías de más de medio punto, son motivo ornamental muy socorrido. Estos huecos son cada vez más importantes y pronto la decoración no es consecuencia de su perímetro sino todo lo contrario, de la faja de plancha que resulta separando dos huecos; entonces aparecen las decoraciones góticas en rosetones que se inspiran en la arquitectura flamígera, pero como en aquéllas los nervios arqueados que se destacan sobre el fondo de la vidriera, tienen una sección compleja, en la que se quiebra la luz en múltiples líneas de iluminación y de sombra, el herrero buscó en sus trabajos un efecto parecido, que logra con las composiciones de doble plancha.

Consiste esta técnica de doble plancha, empleada de un modo corriente desde mediados del siglo $\mathrm{xV}$, en superponer dos y hasta tres planchas caladas, que dando el mismo trazado y a igual escala, se realiza en cada una con anchos progresivamente menores, de modo que al superponer las dos o tres planchas coincidan los motivos o parte de éstos, de tal manera, que una lámina sirva de fondo exactamente centrado a la siguiente, dando al conjunto un aspecto escultural o de relieve y desarrollándose el dibujo no por un siluetado monótono, sino por líneas múltiples, casi en su totalidad paralelas, no trazadas sino realizadas por las aristas mismas, produciendo los efectos obligados de luz y sombra.

Esta tendencia a componer ejemplares esculturales, y cuando se trata de piezas que se completan en sí mismas a darlas un sentido marcadamente arquitectónico, dentro de los límites de la técnica, sin imitaciones ni servilismos, es quizás la nota dominante que ha de presidir al arte gótico del hierro durante el siglo $\mathrm{xv}$.

Si en los herrajes de muchos de nuestros viejos arcones no aparecieran sobre la cenefa de hierro, minuciosamente calada, las torres de Castilla y sobre los cuatro ángulos de las cerraduras las conchas del Apóstol, tal vez, si en España muchos de los trabajos en doble plancha no presentasen una tan marcada influencia árabe, seguramente que a estas horas, dada nuestra propensión nacional a considerar invariablemente como ex- 
tranjero todo lo bueno, hubieran sido clasificados como extranjeros la totalidad de los herrajes del siglo xv.

Definen este género de trabajos en doble plancha tres características curiosas e independientes. Es siempre labor complementaria, rica, minuciosa, precisa y pequeña; aparece invariablemente en ella una gran tendencia, al relieve, al modelado arquitectónico y escultural; sus motivos se desarrollan sobre conjuntos sobre parcelas geométricamente sencillísimas, rectángulos o círculos.

Como se ha dicho, es labor más que propia, aislada o fundamental, complementaria de un conjunto que se pretende enriquecer; es la cerradura de un arcón forrado de terciopelo, es el marco de un aldabón de la puerta principal de un palacio; es una pequeña cenefa rectangular que limita los barrotes de una rejería; y cuando por excepción el ejemplar va todo él trabajado en esta forma, como por ejemplo, las pequeñas cajas rectangulares de joyas o dinero, todas ellas en plancha calada, tampoco el trabajo forma un conjunto, y cada una de las superficies rectangulares está formada por un cierto número de cenefas, como independientes entre sí, siendo los pestillos de la cerradura, también rectangular, barras esculpidas siempre con pináculos góticos.

Paralelamente al empleo de la plancha calada, en su último grado de desarrollo, se inicia un curioso procedimiento que pudiéramos llamar industrial. Consiste el sistema en hacer el trazado con plancha recortada que se desarrolla en forma de cinta, en sinusoide, recordando casi siempre un tallo, del que arrancan otros secundarios cuya terminación queda libre. Todo ello se curva ligeramente, y repetidas veces, completándose el decorado por dos o tres líneas incisas que siguen todo el motivo y que tienen por finalidad distraer la superficie lisa de la cinta que desarrolla la decoración. El efecto es bueno, el relieve admirable y delicado, el conjunto agradable y el trabajo y la dificultad relativamente pequeños.

No es posible confundir el curvado de la plancha, es decir sus alternativos y variables desplazamientos sobre el plano general de la obra, con el repujado propiamente dicho, porque este, es un relieve que tiene por finalidad trazar un asunto, realzando el perímetro de un motivo, que se produce de esta manera, y además con profundidades distintas que co- 
rresponden a las modulaciones del asunto que desarrolla, mientras que en la técnica que nos ocupa, el motivo está producido por la plancha recortada y únicamente se trata de dar al conjunto, que es tan sólo una silueta, un efecto de luz y sombra, una sensación de relieve, que por la doble plancha se obtenía de un modo más penoso.

Este procedimiento se extiende rápidamente y durante toda la segunda mitad del siglo xv, alterna en la decoración con el de doble plancha, utilizándose en todas aquellas producciones que se necesitaban contemplar a distancia. Es mucho más, en los últimos tiempos del gótico, y cuando se emprenden obras arquitecturales de gigantescas proporciones o de esquisita composición, sobre frisos de plancha reaizada tal como se viene describiendo, se colocan en intervalos definidos, motivos esculturales de plancha calada, torres, medallones, pináculos, etc., que completan el dibujo y dan una extraordinaria vida al conjunto de la obra.

Complementarias a estas dos técnicas fundamentales, la varilla y la plancha, se desarrollan otras dos de menor importancia, pero tal vez no menos interesantes; el trabajo de figuras macizas hechas a martillo, y el de las decoraciones lineales incisas geométricas y repetidas, hechas a cincel.

Con lo dicho, es suficiente para definir el origen de cada una de estas técnicas complementarias; cristiana una, la de figuras corpóreas, y árabe o morisca la otra, la de trazados en cenefas de composiciones yustapuestas.

La costumbre de decorar las cruces y en general los distintos ejemplares, con figuras también de hierro, empieza en los finales del románico y se desarrolla durante todo el siglo XIV, invadiendo buena parte del XV, hasta llegar a una especie de barroquismo, cuando multiplica las representaciones y los atributos, sólo con la finalidad de hacer un ejemplar más vistoso. Las cruces que el Museo de Barcelona y D. Santiago Rusiñol presentan en esta Exposición, son quizás los más bellos y característicos ejemplares de esta manera de hacer; las figuras suelen ser generalmente pequeñas, en algunos casos trazadas con ingenio y gracia, utilizando un recorte de plancha, nunca precisos y detallados, hasta el punto de que más suponen un boceto de figura que un trabajo definitivo. Por otra par- 
te, las proporciones de las figuras se apartan de las usadas en el románico, aunque los detalles y los conjuntos no siempre disuenen de aquella época. Resulta de lo dicho que con no poca frecuencia existe dificultad para armonizar figuras, detalles y conjuntos, así, por ejemplo, la posición relativa de la Virgen y el Niño, no guarda casi nunca relación cronológica con la forma del sudario del Cristo, con las aplicaciones en plancha recortada, etc., y unos y otros con la cartela del INRI y con el tipo de las letras, o con la forma de la cruz. ¿Es que fueron restaurados estos ejemplares a través de los siglos medioevales o en épocas posteriores?

Lo que no tiene género de duda, es que en la evolución del gusto y de la técnica fueron estos trabajos los precursores de las delicadas y admirables piezas de forja, que con el carácter de decoración secundaria aparecen en los candelabros y llamadores y en general en todas las obras de mediados o finales del siglo xv. Y que la evolución se desarrolla siguiendo las leyes universales del arte, lo vemos en el hecho, de que empezando los trabajos de forja por la reproducción de la figura humana, cuando esa técnica llega a un cierto grado de perfeccionamiento, reproduce con mucha mayor predilección la fauna o la flora y sus labores más perfectas son esas cabezas de dragón, esos pájaros y reptiles, concebidos con delicadas proporciones, desarrollando su cuerpo en líneas armoniosas y fáciles, de un modo tanto menos ostensible cuanto más perfecto y delicado es el detalle y más hermoso es el conjunto.

Este trabajo de forja debió generalizarse muchísimo durante el siglo XV, hasta el punto de que con mucha frecuencia se trabajen de esta manera detalles que pudieron permanecer sin decoración; por ejemplo, la gruesa barra cilíndrica de los grandes cerrojos, que casi siempre es poligonal, y algunas veces cilíndrica, muy rara vez deja de terminar en una cabeza de perro o de dragón, abocetada quizás, con sólo cuatro martillazos, cuando aun la barra se conservaba caliente, puede ser que nada más que como satisfacción interna al considerar su obra terminada, o como firma del herrero que, a fuego y sobre el yunque, fué dando al ejemplar su sección uniforme a fuerza de trabajo y de paciencia; jcosa bien diferente a como se producen hoy las barras calibradas de los más distintos gruesos en los trenes de laminación de las grandes empresas siderúrgicas! 
No es esta la ocasión de discutir los orígenes de la decoración geométrica de los árabes, ni sus prescripciones religiosas sobre la reproducción de la figura humana y la de seres animados; ello es, como ya se dejó dicho, que sus trabajos de forja son en la actualidad desconocidos, o poco menos, y trabajaron en hierro como pudieron hacerlo en cobre y bronce, es decir, a lima. Tan verdad es lo dicho, que cuando producen un ejemplar que por su finalidad excepcional merezca ser decorado, aparte de las labores de cerrajería, suelen enriquecer la pieza por incrustaciones en azofar y en cobre, anillos, sobre todo los primeros, que muy fácilmente producen la impresión del oro.

Pero cuando las superficies son grandes o muy sencillas, se impone otro sistema de decoración que sea además menos entretenido que la incrustación: el dibujo geométrico lineal hecho a cincel.

Se encuentra, en efecto, en ejemplares indiscutiblemente árabes o de gusto árabe, este sistema de decoración, que en el hierro no ha tenido jamás una impórtancia decisiva, pero que se desborda por los reinos cristianos y aparece con frecuencia en trabajos casi siempre curiosos.

Dos criterios generales se siguen en este procedimiento: uno cuando se trata de superficies grandes y en general proporcionadas, otro cuando son éstas menores o muy desproporcionadas, es decir, predominando mucho una de las dimensiones sobre las demás, a manera de cenefa. En el primer caso la superficie no se rellena con decoración, en el segundo sí.

No quiere ello decir que las superficies de la primera categoría, círculos, casquetes esféricos, cuadrados o lo que sea, se ornamentan siempre de la misma manera; en el arte árabe puro se trazan cenefas más o menos anchas, desarrollando en ellas motivos clásicos del estilo, casi siempre grecas de trazos rectos, con frecuencia inspiradas en la tan conocida de "acicate»; luego en el fondo de la superficie se distribuyen uno o varios rosetones estampados a troquel sobre el plano o la plancha caliente; en el arte cristiano se soluciona el problema subdividiendo la superficie por dobles líneas simétricamente repartidas, dejando el fondo liso, los casquetes esféricos de muchos clavos llamados de "cazoleta" pueden atestiguar el sistema.

Cuando la superficie es pequeña y a modo de cenefa, enton ces se re- 
Ilena por completo, admitiendo una siempre elementalísima composición a base de rectas, simétricas alternadas y un punteado; con mucha menos frecuencia se encuentran trazados curvilíneos.

No procede terminar esta relación de técnicas medioevales sin dedicar unos recuerdos a las tan curiosas producciones de un aspecto más que artístico, militar, las comentadas rejas enigmáticas, siempre curiosas y mucho más en nuestro tiempo, cuando la fantasía popular coloca una leyenda o un sucedido en cada uno de los nudos de sus barrotes. Que fué predilección de magnates o de artífices del siglo xv colocarlas en sus castillos, lo demuestra el número, relativamente grande, que de ellas hoy se conoce. Es su aspecto el de una reja sencilla, con frecuencia reforzada y en algunos casos con sus nudos prolongados en pirámides de caras curvilíneas a manera de pinchos, dando el conjunto un aspecto amenazador y sombrío.

Una considerable parte de los ejemplares conocidos tienen su disposición invertida según los cuatro cuadrantes en que se puede considerar dividido el conjunto. Estriba, como se sabe, la dificultad del sistema, en que cada barrote tiene alternada su misión de caja y de núcleo; es decir, que así como en las rejas ordinarias existe una serie de barrotes que tienen labradas las cajas por las que atraviesan los complementarios, y éstos son macizos en toda su longitud, en las enigmáticas cada barrote es en unas partes cajas y en otras núcleo. Cuando el servicio es uniforme en cada mitad del elemento, el montaje de la reja es posible haciendo independientemente el acoplamiento de los barrotes que integran cada uno de los dos cuadrantes opuestos del ejemplar, y una vez esto hecho, en cuya operación intervienen todo los barrotes de la reja, se desplazan las dos mitades según la dirección de los núcleos que restan libres de enlace. De esta manera pudieron montarse rejas del tipo de la del Palacio de Ocaña de los Reyes de Castilla; pero cuando la función de caja y núcleo varía en cada nudo, como ocurre en el Palacio de Tordesillas, la dificultad es realmente insuperable, resultando su construcción consecuencia de un forjado sobre el ejemplar en montaje.

La reunión de los distintos procedimientos de trabajo que dejamos enumerados y su entrelazamiento y combinación en muy frecuentes oca- 
siones, dan la más justa medida del cómo entendieron la elaboración del hierro nuestros artífices medioevales; así vemos composiciones geométricas, como lo son, por ejemplo, los llamadores de anillo, cuyos trazados, personalísimos de España, tienen un sabor árabe indiscutible; el llamador propiamente tal, es en estos modelos una pieza circular de sección poligonal, cuyas caras planas anulares se cubren de una labor incisa, geométrica, repetida; el clavo que lo sustenta descansa sobre un disco, que puede ser en plancha lisa recortada en perímetros almenados o festoneados, que otras veces aparece en lámina repujada en labor menuda, con frecuencia en plancha perforada y en ejemplares de gran lujo en dos órdenes de calados góticos; complementa algunas piezas excepcionales una figura, cuello y cabeza de dragón, maciza y esbelta, que arrancando de la argolla del anillo, se desarrolla graciosamente, perpendicular al plano de la puerta; y en este caso, coexisten sobre el mismo ejemplar, el trazado árabe geométrico del anillo, su labor incisa, el trabajo de doble plancha sobre composición gótica y las obras macizas de forja en figuras quiméricas.

Los candelabros terminados en complejas disposiciones donde se combinan la forja, la plancha recortada y la varilla, son igualmente un ejemplo del alto grado a que llegó la composición y la fantasía de aquellos artífices, cuyos nombres se han perdido quizás definitivamente y cuyas obras con toda seguridad han de continuar siendo la admiración de los pueblos que nos sucedan.

Pero quizás los ejemplares más interesantes lo constituyen las cerraduras, que dentro de unos marcos constantemente rectangulares, vienen sobrepuestas a las puertas o a los muebles, unas veces colocadas sobre planchas caladas y otras decoradas con ellas en su propio cuerpo. El orificio para la llave suele quedar oculto por una maciza figura bíblica de animal fantástico, movible, forjada y cincelada, y el conjunto es un completo mecanismo, encerrado en una caja rectangular de una sola pieza, repujada en el centro a golpes de martillo y con los lados a bisel, conteniendo en no pocos casos más de un centenar de piezas y recortes, funcionando algunas veces los unos independientes de los restantes. Mascarones, ángeles o blasones, también en relieve, como las columnillas góti- 
cas de sección cuadrada que limitan lateralmente muchísimos ejemplares, dan no tan sólo la sensación escultural intrínseca de cada elemento, sino una variedad de planos y profundidades en el conjunto, que lo hace mucho más curioso e interesante.

Los cerrojos que todavía se conservan en algunas puertas y en muchísimas rejerías, están formados, como ya se ha dicho, por una barra circular de unos treinta a setenta centímetros de longitud por dos a cinco de diámetro, que pasa por las correspondientes argollas, adecuadamente distanciadas; una barra maciza unida a la primera en ángulo recto da al conjunto la forma de $\mathrm{T}$, sirviendo para correr a mano el cerrojo, y sus extremos es lo que se fija o aprisiona en el cuerpo de la cerradura.

Paralelamente a estos elementos se desarrollan en el siglo xv los llamadores de puerta de encuadramiento rectangular; las dimensiones del encuadramiento se alargan con relación a las de las cerraduras; el aldabón, que divide el conjunto en dos partes simétricas, es siempre o casi siempre una figura más o menos hábilmente forjada, que en los últimos tiempos suele ser trabajada a cincel, como ocurría en las cerraduras, y con más razón, pues ahora tenemos una figura muy principal, el aldabón, sobre el encuadramiento calado. Es frecuente encontrar en los aldabones españoles una especie de dosel o coronamiento, de plancha recortada a modo de cornisa en arco sobre el encuadramiento, que puede tener a su vez la terminación o copete correspondiente.

Por fin, la decoración de las puertas se completa en el siglo $\mathrm{xV}$ por los clavos que durante toda la Edad Media continúa desarrollándose.

Dada la misión del clavo, principalmente en nuestras puertas de quincionera, era necesaria una gran superficie de apoyo en la cabeza; consecuencia de ello fué un aumento progresivo en las dimensiones del casquete esférico, en que se les hizo terminar como solución la más sencilla y que seguramente produjo no pocas dificultades, tanto para su construcción como para su fijación en la puerta.

Parece ser que hasta mediados del siglo xIv el clavo que fué aumentando hasta entonces de tamaño de un modo progresivo, excepto en los ejemplares árabes, no se hizo independiente de la cabeza con decoración, y esta eran unas rayas dobles, circunferencias máximas que pasan por el eje. Más tar- 
de y sobre la cabeza ya independiente, las rayas dobles se transforman en nervaduras sencillas o dentelladas, que se trabajaron profusamente en los dias de Enrique IV (1). De este modo se construían en el siglo XV las nervaduras que se cortan entre sí por otros de dibujos oblicuos, dando sobre la superficie esférica una a modo de laceria, hasta que ya en el reinado de los Reyes Católicos las dimensiones y los trazados llegan a su máximum, introduciéndose como motivo ornamental entre otros el cascabel que caracteriza el reinado ${ }^{(2)}$.

Aparte de la rejería, que como queda dicho ha de constituir motivo de un estudio independiente ${ }^{(3)}$, tal era el estado de la industria del hierro en nuestra España al iniciarse el reinado de los Reyes Católicos, que habían de traer con el renacimiento la más profunda modificación de los gustos y de las técnicas.

En esta época, muy alejadas ya por el tiempo las tradiciones románicas, en pleno desarrollo del gótico que copia del natural la flora y la fauna, pujantes los gremios como no lo fueron nunca ni habían de serlo después, reconocidos constantemente sus derechos durante todo el siglo como lo hace la reina Doña María el 4 de Agosto de 1448, como después confirma en 1454 Alfonso y así sucesivamente; coincide la educación profesional dentro de los mismos, con el desarrollo y perfeccionamiento de las ferrerías vascongadas, protegiendo mediante una adecuada legislación la explotación del mineral, organizándose también en gremios los ferrones, como por ejemplo, los de Mondragón, centro en estos momentos de la más esmerada producción de hierro y acero, al igual que los de Durango y Elorrio, las ferrerías de los valles de Orozco y Oquendo, y los que trabajan utilizando saltos de agua en las rías de Guipúzcoa y alguno más en Alava y Navarra.

(1) Notas inéditas sobre «Clavos de Puerta» de D. Adolfo Herrera.

(2) Notas ya dichas de D. Adolfo Herrera.

(3) La Sociedad Española de Amigos del Arte tiene acordado como se ha dicho, la inmediata publicación de un estudio sobre la documentación de hierros en España y la evolución de la rejería. 


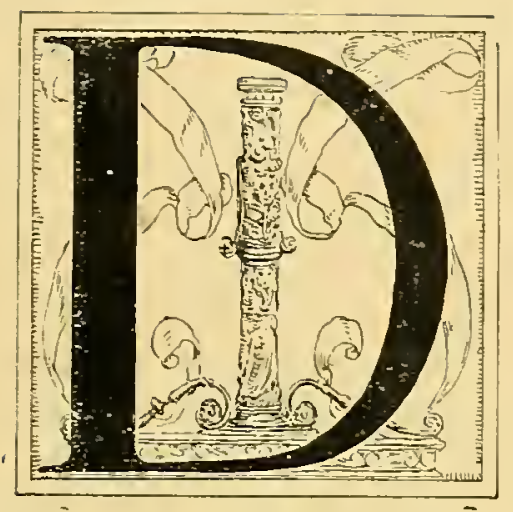

ESDE LOS DIAS EN QUE COMIENZA EL reinado de los Reyes Católicos, se encuentran en España trabajos inspirados en las composiciones "a lo romano", si bien los procedimientos y hasta el gusto mismo del Renacimiento había de tardar en aclimatarse entre nosotros, quizás mucho más en el trabajo del hierro que en el resto de las artes industriales y hasta que en la misma arquitectura, a la que tan ligada siempre estuvo en sus progresos y evolución, y más que nunca desde ahora.

Lógicamente se comprende que en este largo período de mucho más de medio siglo, desde que las nuevas formas aparecen hasta que las góticas se destierran de un modo definitivo, los trabajos son por rara excepción ejemplares concebidos exclusivamente en uno u otro sistema, siendo siempre combinaciones de las dos tendencias.

Los conjuntos es lo primero que se toma del arte nuevo, para rellenarlos y enriquecerlos con una profusa decoración gótica, en España quizás mucho más intensa, minuciosa y compleja que en otros países donde también se continuaba trabajando este estilo; con toda seguridad, debido a la influencia árabe que necesariamente pesaba sobre nuestros artifices, con la repetición de sus trazados lineales y combinaciones de lacerías.

Estos conjuntos tienen una radical diferencia si los comparamos a los góticos, porque si bien unos y otros coinciden en pretender una independencia arquitectónica intrínseca, es decir, en formar un todo completo en sí mismos y no un complemento del edificio, del mueble o del conjunto que se pretende armar o construir, los góticos buscaron esa personalidad en la vida y en la naturaleza más o menos idealizada; sus candelabros recuerdan lirios, y más tarde castillos o torres almenadas, mientras que 
los conjuntos del renacimiento son arquitectónicos, no tan sólo en el sentido de ejemplar corpóreo, sino en el frío y matemático que resulta de una consecuencia del sistema; no recuerdan sus líneas la vida ni la naturaleza, son superficies geométricas que constructivamente se superponen, suavizando sus intersecciones por cornisas escocias o elementos en definitiva, tan fríos o más que los fundamentales y siempre resueltos, como si se tratara de un edificio. No se necesita decir que pretendiendo en cada caso finalidades muy distintas, estos principios que se sostienen durante todo el periodo del renacimiento dan lugar a ejemplares de una silueta o perímetro muy diferentes, adecuados en cada pieza al empleo para que fué labrada.

Es frecuente encontrar en esos conjuntos, claro está que considerados como tales, evidentes reminiscencias de las disposiciones góticas que pasaron; es un ejemplo bien curioso, los pies y hasta en muchos casos, el tronco principal de los candelabros de la primera época, donde el soporte es en tres apoyos y el vástago muchas veces triangular, siendo en cambio cuadrada la caja del cirial, es decir, que en ejemplares donde la disposición utilitaria exige una sección cuadrada, se desarrolla parte o toda la pieza en disposiciones triangulares como en los ejemplares góticos.

Claro está que mucho más tarde, van desapareciendo los detalles y rellenos góticos siendo sustituídos progresivamente en los conjuntos arquitectónicos de la decoración de las superficies por motivos del renacimiento, también tomados de la naturaleza, pero en un sentido más realista y bien distinto del anterior; porque es una manera de entender naturalista y simbólica, no precisamente idealizada, sino todo lo contrario, realista, que copia constantemente la figura humana y que toma como argumento para sus composiciones quiméricas, las cariátides y los grutescos del renacimiento, mientras la flora es tratada también con una verdad intensa, sin estilizaciones decorativas, copiadas directamente del natural y unos y otros motivos cubren las superficies arquitectónicas de los ejemplares, usándose como elementos complementarios de ornamentación.

Supone lo que precede la posibilidad de hacerlo, y las técnicas del tiempo de los Reyes Católicos no eran las más indicadas para trabajos inspirados en el natural. En efecto, la doble plancha calada, la realzada, 
los ejemplares macizos trabajados a forja, van cayendo lentamente en desuso y siendo sustituídos por las obras ejecutadas en plancha repujada.

Dos consideraciones procede hacer al llegar a este punto: la primera, que la evolución del trabajo del hierro, desarrollándose paralelamente a la historia política de la nación, ha cambiado en este momento las proporciones del escenario; se trabaja para las corporaciones, para los grandes conquistadores que dominaron continentes, para los templos que amplían sus dimensiones para contener muchedumbres, y en estas condiciones, aquellos minuciosos trabajos en doble plancha, los detalles de una cabeza de dragón de unos pocos centímetros, desaparecerían perdidos en la inmensidad del espacio, pór eso se imponía la modificación de la técnica, y sobre planchas cosidas y siluetadas, que se unen por un elemental roblonados al armazón de varilla cilíndrica, se trabaja en grandes dimensiones por repujado los asuntos más complejos o más quiméricos, policromando las composiciones unas veces, dorando el motivo principal otras y en último término buscando una labor de conjunto y un efecto que no pierda con la distancia.

Es la segunda el que quizás como consecuencia de la demanda, tal vez por evolución propia, puede ser que completando sus procedimientos con los que pudieron observar en el resto del continente, al ponerse España en contacto con toda Europa durante aquel principio del siglo XVI, ello es, que las Vascongadas producen hierro en cantidades suficientes, y los martillos ya sin excepción movidos por ruedas hidráulicas, permiten la manipulación y labra de tochos de gran peso, facilitándose con ello el trabajo de las construcciones más grandes.

No deja de ser curiosa la evolución, mediante la cual nuestros herreros llegaron a los trabajos más perfectos del repujado en plancha. Decíamos que en un principio y como industrialización de los trabajos en calado doble, se hicieron numerosas labores en lámina siluetada y realzada, bien entendido que este realce era una ondulación repetida y alternada, independiente del asunto desarrollado en ella; algo más tarde y en cenefas o frisos donde los motivos eran sencillos y se repetían monótonamente, dando a distancia la sensación de un encaje, para que el dibujo fuera acusado con más energía, se dió a la plancha una curvatura, pero no a lo 
largo del conjunto, sino en el elemento mismo que integra el asunto; es decir, cada tallo, cada hoja, se curva o realza, presentando al espectador una superficie convexa; un poco más y los motivos florares que se entrelazan y repiten, se sustituyen por composiciones del renacimiento, donde aparecen grutescos y figuras, formando una composición sencilla aun, recortada como lo fueron los motivos florares de elementos convexos antes mencionados y donde por vez primera las figuras, destinadas a ser vistas a muchos metros (frisos de rejas, por ejemplo), y de pequeñas dimensiones todavía (las mayores no pasan de unos veinte centímetros de altura), se realzan en dos o tres niveles distintos, para avivar las distintas partes del cuerpo o los elementos distintos de la composición. Iniciada la marcha, nada de particular tiene que esos grutescos se desarrollen en las cenefas posteriores, recortando sobre la plancha composiciones asimétricas, graciosamente variadas, en las que aparecen como elementos fundamentales los medallones encerrando un busto, que se modula ya en múltiples planos y superficies, según la más refinada técnica del repujado, que muy poco más tarde no recorta la plancha y obtiene sus composiciones, destacándolas del fondo por realzado, repujando, policromando los motivos y dando un color al fondo de la plancha, para que la composición destaque con mayor energía y también para evitar la oxidación, principalmente de las partes trabajadas, en las que la plancha queda necesariamente debilitada.

Consecuencia de la tendencia detallista y menuda que domina en los días de los Reyes Católicos, se crea una escuela de repujado donde las superficies se rellenan con decoraciones del renacimiento desarrolladas en proporciones reducidas, multiplicando los asuntos, que se ejecutan con un detalle y un primor desproporcionados al valor y a las condiciones materiales del hierro. Es labor siempre realizada sobre plancha llena, con relieve, que siendo grande con relación a las proporciones del motivo que trata, es pequeño en valor absoluto, resuitado como decíamos de la tendencia detallista que le precede en el gusto de las gentes, y mucho más quizás de los sistemas arquitectónicos de ornamentación por entonces en moda, si bien una y otra cosa pueden ser consideradas como una causa única. Tal es el estilo que ha recibido la denominación de plateresco, en 
las obras de hierro con mucha mayor razón que en otra alguna, pues muchos de los ejemplares trabajados de esta manera lo fueron por artífices plateros, que labran en hierros piezas de una delicadeza de composición y de ejecución admirables, concebidas y ejecutadas de igual manera que si la primera materia fuese oro y plata.

Por esta evolución, en este grado de perfeccionamiento y en este tipo de trabajo, llegaron nuestros artífices a los días en que se implanta en España de lleno el renacimiento; y la industria del hierro, desarrollándose paralelamente a la historia política de la nación, porque las gentes vivieron en la grandiosidad de su tiempo, cuando la España de ahora era pequeña para quienes dominaban Europa mientras civilizaban América. Y el repujado del plateresco aumenta las dimensiones de sus figuras, que con cierta frecuencia, en relieves cada vez más fuertes, sobresalen de los marcos italianizados de laurel o de flores que pretendieron limitarlas, y sobre grandes superficies que pudieran ser contempladas a distancia, se trazan y se desarrollan esas bellas composiciones del renacimiento español, todo vigor y grandiosidad, dentro de una sencillez aparente tratada con rasgos de energía y de vida sin amaneramientos ni desmayos.

Seguramente que es este el momento más grandioso de nuestro trabajo del hierro, cuando se labran desde los más hermosos clavos y los más bellos candelabros a las más imponentes rejerías. Puede decirse que abraza más o menos todo el reinado del Emperador, pues nacido como un engrandecimiento del plateresco, mucho antes de terminar el primer tercio del siglo XVI, dura hasta que, al doblar la mitad del siglo, se marcan las tendencias geometrizantes que iniciaron la decadencia.

Es preciso tener en cuenta que durante este periodo las técnicas anteriores no desaparecen radicalmente sustituídas por el repujado alto; se modifican y evolucionan, buscando un ef́ecto más decorativo aunque fuese a costa de la calidad del trabajo; y al mediar el siglo, muchas obras en hierro son consecuencia de un conjunto de procedimientos, repujado, plancha calada, varillas siluetadas, torneado, etc., algunos de ellos nuevos y otros, como decíamos, modificados. La plancha calada, entre otros, adquiere una modalidad muy característica; en realidad es plancha siluetada y repujada; se recorta siguiendo el perímetro, por ejemplo, de una hoja, 
la curvatura natural de su superficie y en general todos los accidentes de la misma, se modulan por repujado; bien entendido, que, como en el natural, esos detalles son apenas perceptibles, en la plancha repujada, con un trabajo muy sencillo, resultan exageradísimos y, por lo tanto, perceptibles a gran distancia. No es eso solo, con esos motivos en plancha siluetada y repujada, después de dorarlos o policromarlos, unas veces se recubren superficies, de las que destacan y hasta se desprenden estos elementos produciendo el efecto de un repujado intenso habilidosamente realizado, y otras curvándose graciosamente sin una superficie de fondo, alrededor de un eje central macizo casi invisible, dan por el recorte calado de su perímetro una sensación de semitransparencia, que produce en el ánimo el efecto de una labor dificilísima y agradable, y que prácticamente fué ejecutada con esfuerzo bien reducido.

Pero no es únicamente de este modo como se aplica la plancha recortada en el segundo tercio del siglo XVI, llegándose a composiciones esculturales completas como las grandes águilas que sirven de atril en muchos de nuestros templos. Repujada la cabeza y cuello, el cuerpo se trabaja en tiras o zonas de plancha siluetada, siguiendo el perímetro de una faja de plumas, y muy ligeramente realzada, se superponen en parte a sus piezas análogas, montadas todas ellas sobre un núcleo macizo, dando la más agradable impresión como trabajo de conjunto, mucho más cuanto que la mayor parte de los ejemplares suelen estar por completo dorados a fuego.

Piezas análogas, quizás anteriores (en los ejemplares que hemos visto el águila tiene el limbo de San Juan, y por ello pudieran considerarse como obras aun del tiempo de los Reyes Católicos), suelen ser en plancha unida o completa repujada ligeramente, marcando el dibujo de las plumas, y luego la plancha de relativas grandes dimensiones, se curva y cose dándole la forma del ave. Es inútil decir que estos ejemplares, precursores quizás de los antes mencionados, no tienen ni la gracia ni el interés de aquéllos.

Otro nuevo elemento interviene desde ahora en la decoración, y aunque de pocos centímetros de altura en los ejemplares primitivos, crece rápidamente y llega a una importancia decisiva antes de la terminación del siglo; es el trabajo de las varillas en el torno. 
La tendencia francamente arquitectural de esta época, sobre todo en aquellas piezas que podían interpretarse en un sentido corpóreo completándose en sí mismas, como, por ejemplo, los grandes candelabros y tenebrarios, dividió su cuerpo principal en pisos o secciones, donde no falta nunca una pequeña o grande galería de columnas que aparentemente sostiene una parte considerable de la obra; estas pequeñas columnitas trabajadas con perfiles geométricos más o menos accidentados, y que en un principio se forjaron, más tarde fueron labradas a torno, modificación bien interesante, que anuncia ya nuestros años de técnica contemporánea.

Pero no es esto solo, en los finales del siglo xv se establece en Navarra, con carácter francamente industrial, la primera fábrica de balas o bombas fundidas; en los principios del siglo XVI la industria se extiende a las provincias Vascongadas y Santander, y en días de Doña Juana primero y del Emperador después, se obtienen para Granada, en hierro fundido, las primeras piezas ornamentables que son fondos de chimenea, trabajadas por moldeo del hierro líquido, por fusión.

Es verdad que el procedimiento no se generaliza para fines artísticos propiamente tales, hasta que muy entrado el siglo XIX y cuando los hornos altos modifican por completo las condiciones de la industria, pero no es menos cierto que el sistema se perpetúa desde aquella fecha, perfeccionándose los hornos de segunda fusión o cubilotes, lográndose especialmente piezas de artillería con las más bellas decoraciones.

Aquella tendencia constructiva iniciada en los principios del siglo, adquiere de día en día una mayor preponderancia, los trabajos en hierro se reservan para aquellas grandes piezas que deben ser contempladas a distancia, y con ello, como es lógico, aumentando en importancia la silueta arquitectónica del ejemplar, pierde el interés de las decoraciones repujadas, los trabajos se van haciendo cada vez más monumentales y sobrios, los motivos de la naturaleza que traducía el renacimiento, desaparecen lentamente y los ejemplares faltos de la vida que ellos les dieron, aparecen de día en día más esquemáticos y fríos.

Si pudo influir en los trabajos de los herreros el carácter vulgarmente considerado como seco y adusto del sucesor de Carlos V, es problema no tratado hasta el presente, pero desde luego puede decirse que las cir- 
cunstancias económicas y políticas porque atravesaba el país, se unieron a las consideraciones de orden estético más restringido, en una escuela que buscaba toda la belleza en la ponderación de las proporciones de la totalidad y en la distribución adecuada de las masas. Es la obra de las personas que aprendieron a dominar los conjuntos y prescinden de la ornamentación de detalle que no siempre es visible a distancias considerables.

Esta última razón por una parte, haciendo poco menos que inútil el trabajo del repujado cuyos relieves se confunden y pierden cuando, como deciamos, no pueden ser apreciados a la distancia conveniente, la tendencia arquitectónica ya mencionada, que muy poco después había de labrar El Escorial, y muy bien puede ser que una razón económica tanto más atendida cuanto menos confesada, determinaron en los trabajos de aquella segunda mitad del siglo xVI una tendencia francamente geometrizante que no decora las superficies, que distribuye armoniosamente las masas y que edifica por siluetas y por contrastes, porque edifica, porque sus obras son eminentemente corpóreas y arquitectónicas.

Se comprende, después de lo dicho, que aparezcan en esta escuela nuevos elementos constructivos, tal vez ya conocidos pero que ahora toman una personalidad característica, son ellos, en primer término, la varilla y la plancha, pero no la varilla y la plancha tal como se entendieron en la edad media, sino estos mismos elementos, pero como creadores de siluetas; por eso, ni la varilla es más que una línea en el espacio ni la plancha otra cosa que una superficie llena; y por eso también ni la varilla ni la plancha admiten decoración intrínseca, y tan sólo la primera interrumpe algunas veces su sección uniforme por aumentos progresivos de diámetro, que bruscamente se reducen para dar un mayor contraste a un disco colocado a la mitad de su trayectoria, nuevo aspecto de los pequeños barrotes torneados, aunque éstos sean de forja, todo ello, siempre impresionado por su silueta, silueta geométrica y fría, con mucha frecuencia, en composiciones adoradas con monótona simetría.

Los trabajos realizados en este último tercio del siglo XVI constituyen, por lo dicho, un rudo contraste con los ejemplares que les precedieron; las cruces procesionales que fueron antes hechas en plancha repujada $y$ 
policromada, siguiendo quizás los gustos italianos, pero de todos modos llenas de ornamentación de follaje y de grutescos, se trazan ahora por dos barras paralelas de sección rectangular colocadas de canto; el espesor, es el espacio que las separa, la decoración cuando existe es una pirámide de base cuadrada que termina en esfera; de vez en cuando cuatro varillas cilíndricas que se adelgazan progresivamente, se apartan del centro de la cruz en suaves ondulaciones, llenando los espacios vacíos de los cuadrantes; todo es elemental, esquemático y frío; ciertamente que tiene su encanto y desde luego su dificultad y mérito de composición, las masas que el ejemplar no tiene, pues son los espacios comprendidos entre las varillas paralelas, pero que dan la sensación de existencia, la ornamentación sencilla y armoniosa, el conjunto mismo, da la impresión de serenidad, de paz y de reposo tan opuesta a los trabajos que precedieron; constantemente para los remates se toman como elementos decorativos figuras geométricas sencillas, y cuando por las proporciones del conjunto éstas adquieren dimensiones algo considerables, en vez de hacerlas llenas o macizas, únicamente se traza su silueta en el espacio que se deja vacío. Tal era la industria del hierro en los días del Rey Nuestro Señor que fué Felipe II.

1. W. NTRE los múltiples aspectos que presentan los trabajos realizados 6. 1. aparecen entre nosotros y se encuentran en aquellos pueblos, destellos más o menos intensos de los gustos, de las modas y de las técnicas que recíprocamente predominaron en cada suelo.

Las cerraduras y llamadores que se fabricaron en los principios del siglo XVı en Cataluña y en Francia apenas pueden diferenciarse, por haber seguido los dos pueblos técnicas casi iguales en un período en que la ornamentación gótica llega a su último grado de complicación y amaneramiento. En cambio, poco después, al aclimatarse entre nosotros procedi- 
mientos de trabajo indiscutiblemente alemanes, éstos se modifican y adquieren personalidad propia y carácter francamente español.

En efecto, quizás en aquel primer viaje de D. Felipe I, pero desde luego no mucho más tarde de la consolidación de Carlos $\mathrm{V}$, después de la batalla de Villalar, llegan a España artífices y obras alemanas, unos que trabajaban en hierro en varias de nuestras catedrales como la de Burgos, y otras como la conocida papelera o escritorio de Carlos V, firmada en Nuremberg, y que hoy se conserva en las habitaciones que pertenecieron a Felipe II en El Escorial.

No se conocen en España obras ejecutadas al "agua fuerte» hechas con anterioridad a este tiempo; los motivos ornamentales trabajados en línea por superficies de hierro, fueron una labor realizada siempre a cincel, en trazo grueso, preferentemente recto o por lo menos muy sencillo, como se ha dicho en su lugar, de tradición morisca, que adaptó al hierro la manera de ornamentar el bronce; pero al terminar el primer tercio del siglo XVI, aparecen unas pesadas cajas de caudales, todas ellas en hierro, con cerradura de pestillo múltiple que agarra sobre un reborde seguido que presentan las caras verticales de la caja, cerradura accionada por una sola llave central que comunica su movimiento por complicadas palancas, mecanismos y resortes a los numerosos pestillos dispuestos para apoyarse sobre los rebordes; tienen de particular estas cajas, el hecho de que toda la complicación que supone la compleja cerradura descrita, viene oculta por una plancha recortada, con frecuencia en tres fajas que recorren el largo total del arca, la central más distanciada del fondo. Las superficies planas de estas fajas, representan complicados asuntos del renacimiento, donde lo ampuloso de las figuras y los motivos, superponiéndose frecuentemente, apenas dan lugar a que se descubra el fondo que es la parte de plancha recortada o eliminada del conjunto. Las composiciones se dibujan en parte, como decimos, por el siluetado que se hace cuando la figura o motivo se desarrolla sobre fondo y en parte por líneas, finas y esquemáticas que sobre la plancha pulida completan la silueta, reforzadas por los muy pocos trazos que se consideran como indispensables para que la composición resulte bien definida. Seguramente que no seria preciso el añadir que este dibujo fué grabado por un ácido (seguramente el nítrico, 
agua fuerte) que atacó las partes del metal que dejó libre o descubierto el estilete del operario al arrastrarse sobre la plancha, previamente cubierta con una tenue capa protectora de cera.

El procedimiento, como decíamos, hizo fortuna en España, y las cajas de caudales que desde entonces se fabrican, continúan ocultando sus mecanismos por planchas recortadas y decoradas al "agua fuerte», extendiéndose el procedimiento a otras múltiples aplicaciones, donde no pocas veces se trata de perpetuar tradiciones de las guerras de la reconquista o escenas de la vida militar y política de aquel entonces.

Nada tiene de particular, por otra parte, que el caso se repita a la inversa, y así vemos una serie de cerraduras muy curiosas, clasificadas por todos los tratadistas como italianas, pero de procedencia alemana, que en realidad tienen una composición española. Están constituídas por una caja recta de sección rectangular, casi cuadrada, en plancha realzada, conteniendo la totalidad de los mecanismos, y ello sería por completo corriente, si el cerrojo no presentase en todos los tipos, calados, que resultan ser góticos, aunque recordando las arquerías peraltadas de los árabes; pero lo más original es que de los cuatro ángulos, parten radios que terminan en discos de plancha realzada con labor menuda y repetida, trabajadas exactamente, fuera del tamaño del motivo que es menor, igual que los frisos y cenefas de plancha realzada que compitieron con los ejemplares de dos y tres órdenes de plancha calada. La disposición del conjunto es completamente española, siendo tan sólo una variante de las tan conocidas cerraduras de cuatro conchas, sólo que los alemanes primero y después los italianos, que no tenían por qué rendir culto al Apóstol, transformaron las cuatro conchas de sección circular en cuatro discos; la técnica es también española, la de plancha realzada, sólo que la labor es mucho más menuda; por fin, la cerradura es tipo francamente nuestro y hasta es preciso fijarse bien en los detalles del cerrojo para poder apreciar que se trata no de una arqueria musulmana sino realmente gótica.

De esta manera las recíprocas influencias recorrieron Europa, trayendo y llevando nuestro arte, que a partir de esta fecha inicia una rápida decadencia que apenas en la actualidad si puede considerarse como detenida. 


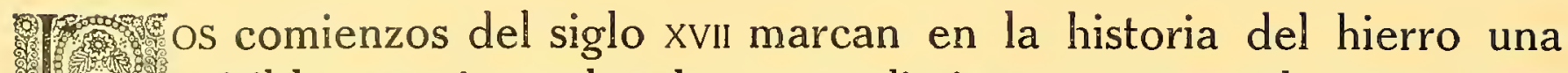
visible reacción sobre los procedimientos exageradamente geometrizantes que vimos dominaron en los días de Felipe II; se vuelve al recuerdo de la naturaleza, pero no con aquella verdad y gusto que fué la característica de los buenos tiempos del renacimiento. Como toda reacción, es francamente exagerada, y así como en los principios del siglo XVI la reproducción floral es un motivo de decoración que rellena y adorna las superficies que resultan de una concepción arquitectónica, cuyas líneas generales fueron trazadas sin tener en cuenta los detalles con que luego se enriquece y ornamenta; ya en estos principios del siglo xVII y mucho más luego, durante toda la decadencia, el detalle adquiere la importancia que sólo debió tener el conjunto, y la obra presenta unas líneas generales que son únicamente la envolvente, la consecuencia de una ornamentación desproporcionada y abusiva; en el hierro puede decirse que también como en la arquitectura se desarrolla el barroquismo, si por tal se entiende la exageración y multiplicidad del detalle, hasta el punto de oscurecer la finalidad y la concepción del conjunto.

Las obras realmente geniales desaparecen y en este momento se marcan con toda claridad dos tendencias, dos formas curiosas de decadencia, muy en armonía con la España de entonces; los trabajos ampulosamente artificiales de plancha recortada y curvada y las obras de labor menuda, apretada y detallista, que dentro de un trabajo pacientísimo, falto de originalidad casi tanto como sobrado de labor, encierran quizás una tan grande vanidad como ostentación los primeros; claro está que unos y otros son tan sólo consecuencias de la aplicación de las técnicas ya conocidas, con la sola excepción de las grandes obras de repujado que son progresivamente más raras.

Corresponden a la categoría primera, una cantidad muy considerable de trabajos que no tienen silueta propia; un eje de varilla de hierro cumple una finalidad utilitaria, y luego sobre ese eje, se amontonan florones y volutas, sencillamente justapuestas, es decir colocadas las unas al lado 
de las otras y hasta con frecuencia simétricamente distribuídas. No corresponden las decoraciones florales a un conjunto inspirado en la naturaleza, no es un tallo del que nace un capullo o una flor; es un eje de sección circular o cuadrada donde se remacha un florón compuesto de cuatro o más hojas de plancha recortada, muy ligeramente realzada y ampulosamente curvada, para dar la sensación de una flor, que aparece en el conjunto sin justificación adecuada.

La mayor parte de las veces, viene después y sin solución de continuidad, una decoración compleja de volutas, reminiscencia y reacción, todo unido, de aquellas estilizaciones geométricas que vimos dominaron el gusto de las gentes en el último tercio del siglo xvi. Por fin, la obra suele tener casi siempre un eje de simetría, y las decoraciones de volutas geométricas, como los ampulosos florones de plancha recortada, se repiten simétricamente con una fidelidad que ni fué guardada en los trabajos del renacimiento, ni había de perdurar un siglo después, cuando los modelos franceses llamados de los Luises, fueran el ideal de nuestros artífices herreros.

Corresponden a la segunda categoría las interesantes cerraduras de triángulo curvilíneo, verdaderas obras de estudio y de paciencia, compendio, por otra parte, de múltiples tradiciones y técnicas. Suelen estar formadas por la caja de la cerradura y el cerrojo: como recuerdo de los tiempos medioevales, el cerrojo que fué, como ya sabemos, una gruesa barra en $T$, tiene un eje superior, cuyos extremos giran sobre dos pequeñas argollas, prolongándose dicho eje, que se dobla en ángulo recto, para terminar en un curioso detalle cincelado, por ejemplo, unas conchas, que evitan el movimiento lateral, permitiendo el de giro. Parten desde las argollas (aunque en el mayor número de casos, separadas de ella hasta unos dos a cuatro centímetros), y arrancando de todo el eje, una fuerte plancha que limitan lateralmente dos arcos, dando al conjunto esta forma triangular, con uno de los lados recto, el del eje, y curvilineos y simétricos los laterales. Es la cerradura casi siempre una caja de sección cuadrada, realzada fuertemente, y prolongada en ancha cenefa recortada y calada que sirve para fijarla sobre la tapa del mueble que debía de cerrar. La superficie triangular antes descrita, la cuadrada de la cerradura que 
no debe quedar oculta por el cerrojo, y la cenefa que apoya sobre la tabla, todo ello viene cubierto por labor minuciosa y repetida. En la mayor parte de los ejemplares una cenefa monótona y sencilla, trabajada a cincel, recuerdo de las que ornamentaron las alguazas árabes o los anillos de los llamadores moriscos, ocupa una parte considerable de la superficie, y la central del triángulo se rellena por un florón geométrico, regular, también inciso a cincel, como en ya dichos espacios centrales de las alguazas árabes, sólo que ahora mucho mayores, hasta el punto de cubrir o poco menos la superficie, dejando solamente como fondo sin labrar los espacios irregulares que resultan de las figuras geométricas que se han trazado.

Dos variantes pueden presentar estos ejemplares, es una contener figuras forjadas sustituyendo como decoración al florón central del cerrojo; es otra, presentar esta superficie central, así como la de la caja de la cerradura, ornamentada por dibujos producidos al agua fuerte; una y otra, como vemos, recuerdo de técnicas ya pasadas. Lo clásico, lo sensacional en ellas, es producir la impresión de riqueza, de trabajo extraordinario, de complejidad y amontonamiento de labor; los artistas que las produjeron en cantidad relativamente considerable, no se preocuparon en modificar las líneas del conjunto, en producir una sensación agradable, tan sólo se cuidaron de cubrir minuciosamente unas superficies, que en parte no están justificadas más que como tablero, sobre el que poder hacer demostración de un genio y una riqueza que fueron patrimonio tan sólo del siglo que les había precedido.

Ciertamente que es una de las características de la época, la desaparición del repujado propiamente dicho; pero no debe tomarse esta afirmación de un modo radicalmente absoluto, pues, por una parte, las decoraciones florales en plancha recortada lo son asimismo ligeramente repujadas; y hasta como excepción, claro que nada más que como excepción, se encuentran trabajos repujados en grandes superficies, no como decoración auxiliar, sino siendo este último el procedimiento de ornamentación. Lo que naturalmente desaparece, es el alto concepto decorativo con que fué trabajado el repujado durante los buenos días del renacimiento del siglo XVI, y ahora marchando los tipos ornamentales paralelamente a las 
soluciones arquitectónicas más en boga, lo que impera es un barroquismo de temas complejos y recargado de detalles, tan propio de su tiempo.

Los muy pocos ejemplares repujados que se conservan, hechos en la segunda mitad del siglo XVII, son realmente curiosos e interesantes; porque en ellos, y como ya se ha dicho, ha sustituído a la concepción del conjunto, la pulcritud en la ejecución de un motivo, que se repite, o poco menos, en toda la superficie disponible, resultando como consecuencia, no una pieza decorada, sino una yustaposición de decoraciones que da como resultado de su amontonamiento un conjunto. Los frontales de altar que se labraron en este tiempo son una demostración de lo dicho. Por ejemplo, florones de un ampuloso desarrollo, llenando un espacio rectangular, se colocan los unos al lado de los otros hasta completar y cubrir la superficie disponible; eso sí, cada uno de ellos está repujado con un detalle y minuciosidad interesante, falto de gracia es verdad, pero no falto de labor y de habilidad. Tal fué en la España del xvII la decadencia del repujado que produjo durante el siglo XVı las obras más grandiosas y más geniales que se conocen en el mundo.

Falta decir ahora, que también durante el siglo xvII continuaron y hasta se mejoraron procedimientos de construcción que nacieron en el precedente, porque son una fiel continuación de aquellos procedimientos, la curiosa labor de los barrotes de balcón que se fabrican invariablemente durante todo este tiempo, los trabajos en plancha calada que decoran los bargueños y los arcones, fallebas de ventana y tantos otros: los unos admirablemente labrados y cincelados, son ejemplares como hijos del siglo XVII, que recuerdan el geometrismo de que proceden, pero con una decoración floral, siendo más que un capitel labrado, con un motivo ornamental frío pero agradable, que es con frecuencia doble y simétrico en los barrotes de huso, hecho realzando algo el metal para lograr un principio de relieve, y cincelando sobre el realce una hoja que se repite, dibujándose delicadamente hasta perderse en la superficie cilíndrica del barrote.

No pocas de las casonas que presentan sus viejas fachadas de piedra a las carreteras de las provincias vascongadas, conservan sus balcones principales con barrotes labrados de esta manera durante el siglo XVII en las ferrerías de Elorrio, de Mondragón y de Durango. Es curioso ver en 
ellas, la mezcla de un geometrismo que lucha con la decoración naturalista y el barroquismo de la época; la mayor parte de estos balcones suelen presentar un imponente medio punto que arrancando del piso, es tangente al pasamanos; barrotes radiales llenan toda su superficie, unos rectos, otros ondulados, rellenándose los espacios irregulares intermedios y el centro del medio punto, con barrotes incompletos y por labores forjadas o en plancha calada, que frecuentemente recuerdan los blasones del dueño de la casa. Cada barrote tiene su labor cincelada, los angulares son con frecuencia de sección cuadrada en su mitad primera, y el conjunto suele tener un principio de pesadez por lo recargado del tema, que no existe en cada uno de los elementos que lo componen.

Ocurre algo parecido en guardas, cantoneras y cerraduras de los típicos bargueños; en primer lugar, es en ellos donde únicamente se conservan los modelos de cerraduras de doble cerrojo, que se vulgarizaron en aquellas cajas rectangulares de doble plancha calada, del tiempo de los Reyes Católicos y que durante el resto del siglo Xvı apenas si se reproducen; pero lo clásico de estos herrajes, es que su labor es constantemente en simple plancha calada, trazando complejas composiciones estilizadas, mucho más geométricas que florales. Con frecuencia y para mayor lucimiento de la labor, fueron estos trabajos colocados en las tapas de los bargueños y los arcones sobre terciopelo rojo, dando con ello, como es lógico, un mayor contraste al dibujo, que se complica y se extiende en no pocos ejemplares, sin otra finalidad que la decorativa.

Fué durante la segunda mitad del siglo XVII cuando comienza la moda de las miniaturas, que al igual que los relicarios, exigieron marcos donde la menuda labor ejecutada, aun dentro de las dimensiones reducidas del modelo, guardase una cierta relación con la importancia que tenía el ejemplar a que se destinaba. Primero en plata y esmaltes, algunas veces en talla y con frecuencia relativa en hierro, empezaron a labrarse marcos de una labor calada compleja y diminuta, que más recuerdan una cenefa de encaje que el armazón defensivo del objeto que se custodia. Estos curiosos trabajos, de sección poligonal la mayor parte de las veces, elíptica otras, y cuadrada o rectangular muy pocas, suelen ser casi siempre ejemplares dobles, es decir trabajados por sus dos caras, y en casi la totalidad 
de los casos con piezas terminadas a cincel, esculturando los motivos ornamentales, que son casi siempre florales, dentro de un espesor que pocas veces es mayor de un milímetro. Lanzados por este camino, se construyeron de un modo parecido una porción de pequeños objetos destinados la mayor parte de las veces a manos femeninas. Pero lo curioso del caso es que tales labores sufrieron dentro del mismo siglo XVII una ampliación de escala, y como el trabajo de cincelado no era posible realizarlo con éxito al multiplicar las proporciones, para las superficies que ahora se trata de cubrir, se aplica la plancha calada otra vez, no doble sino única, y trazando en ella motivos florales complejos y entrelazados que apenas eliminan unos recortes de plancha, y dibujando la composición por un repujado y punteado elemental, que más que relieve, da la línea o la traza de la composición correspondiente. De esta manera comenzaron a ser aplicadas esas planchas perforadas que componen el fondo de los faroles de la época y hasta la totalidad de los mismos cuando su finalidad era puramente simbólica como en los ejemplares destinados a la conducción del Viático.

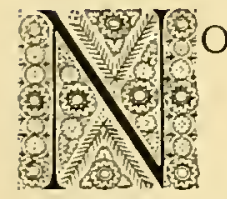

deja de tener un interés muy particular en la historia del hierro las vicisitudes políticas de la nación, que obligaron a nuestros artífices a prescindir o poco menos de todo lo que se hacía fuera de España, siendo quizás el ejemplo más elocuente, lo que ocurre con la cerrajería española, en la que tan sólo muy lentamente se va apreciando la influencia del arte francés, que en estos tiempos trabaja las llaves más perfectas y complicadas, dando modelos que se copian en todo el mundo y que son modernamente cada día más apreciados. ${ }^{(1)}$ Fueron los tipos iniciales de esa época las famosas llaves que dicen daban entrada a los departamentos privados de Enrique III (de Francia), caracterizadas, porque en sus asas o anillo se prodiga el trabajo a cincel, componiéndolo con quimeras aladas, con esfinges con mascarones y grutescos de un gusto y

(1) La llave llamada de Strozzi fué vendida hace varios años en 1.200 Libras (unas 30.000 ptas.) 
una ejecución que realmente son extraordinarios. El anillo se unía al tallo por una especie de capitel de gusto clásico, o siempre, por lo menos, de forma arquitectónica trabajado igualmente a cincel como la decoración del asa. En una llave francesa de este tipo ${ }^{(1)}$ entre el capitel corintio que une el tallo al anillo y las asas mismas, se abre un espacio minúsculo a manera de templete, dentro del cual se conserva una figurilla microscópica. Los ejemplares más definidos, suelen tener en la parte superior del asa, bien de una manera ostensible, bien como uno de los elementos decorativos, un pequeño anillo central, que servía para colgar la llave sin que ocultara la cinta, nada de la labor esculturada de las asas. Tal importancia adquieren estos trabajos en la nación vecina, que durante el primer tercio del siglo xVII, y aun antes, se publican numerosos tratados para el uso de cerrajeros, con dibujos de llaves que, más o menos modificados, sirven de modelo a todos los cerrajeros de Europa, siendo tan sólo los nuestros los que tal vez por desconocer estos tratados, quizás conociéndolos, aceptan muy lentamente los motivos franceses. ${ }^{(2)}$ Están conformes los autores de la nación vecina, y lo citamos, porque adoptado el sistema, poco más tarde por nuestros gremios, produjo aquí también excelentes resultados, que la causa más eficaz en su progresivo perfeccionamiento estaba, en la disposición gremial que exigía del aprendiz para que pudiera pasar a maestro, la presentación de una "obra de prueba» en la que a juicio del tribunal del oficio, hubiera sido preciso invertir por lo menos dos años de trabajo. A facilitar esta labor estaba destinada, entre otras, la obra publicada por Jousse, quien dió los principios fundamentales de las cerraduras de doce y de siete vueltas, publicando una serie de dibujos de anillos o asas, generalizados más tarde en toda Europa, como queda dicho.

Los modelos españoles de esta época, se diferencian esencialmente de los franceses en que sus asas o anillos no se inspiran en composiciones esculturales de quimeras esfinges o grutescos. El lujo cortesano de la llave

(1) Llave que pertenecía a Mr. Currie.

(2). Estos tratados fueron principalmente: el de Jaime Tronet de Cerceau, que murió en 1585, que se considera como el primer tratado que publicó dibujo de llaves para uso de cerrajeros; el de Pompeiu, publicado en 1612; a continuación aparecieron varios de Antonio Jaime de Poitiers, que se consideran como los más interesantes, así como el tratado de Jousse, que en 1625 publica cuarenta ejemplos de arcos de llaves; y el de Didiez Tormer, que por aquellos mismos años publicó muchos más. 
nace en nosotros realmente en la misma época que en Francia, es decir en los finales del siglo XVI, pero con la diferencia de que así como ellos adoptaron todos los elementos esculturales que les ofrecía Italia, nuestros cerrajeros tuvieron que acomodarse a aquella escuela geometrizante y estilizada que vimos dominar en los días de Felipe II, y por ello nuestras llaves de Corte tienen su anillo o asas siluetadas, y tan sólo algo más tarde, en los principios del barroco, la parte de unión del anillo elíptico invierte su curvatura para unirse al tallo. Es muy curioso en este tiempo el hecho de que la superficie que limita el asa o anillo, se rellene con decoración, que tiene un parentesco indiscutible con aquellos ejemplares hispano-árabes que se hicieron en los finales del siglo XIV o principios del XV, decoraciones geométricas, que sin serlo recuerdan el arte gótico, y que imprimen al trabajo de nuestros cerrajeros una particularidad muy en armonía con el resto de las labores españolas en hierro, la de buscar el efecto decorativo, exclusivamente por la silueta perforada, hasta el punto de que el anillo está terminado con mucha frecuencia por dos superficies planas, es decir sin un solo motivo esculturado y como consecuencia sin que el trabajo a cincel interviniese para nada.

Dos particularidades dignas de mención separan nuestra cerrajería de la francesa, y otras dos fueron copiadas de sus modelos. De las dos primeras, es una, que nunca el tallo se une al anillo por capitel arquitectónico clásico; una moldura, con mucha frecuencia demasiado compleja, suele llenar esta misión, pero ni tiene ni pretende la categoría de capitel; cosa bien natural y lógica si recordamos que nuestras llaves, como se ha dicho, salvo casos muy excepcionales, no fueron trabajadas a cincel: es la segunda, el que con extraordinaria frecuencia suele venir el tallo decorado, en superficies de revolución, recordando tipos de husos, más o menos complejos, de los entonces tan en moda en los trabajos de rejería. Pero, en cambio, en muchos de nuestros ejemplares, incluso en los más típicos españoles, aparece como en las francesas, sobre las asas, unas veces francamente, otras encubierto por la decoración general, el pequeño anillo destinado a colgar la llave, interpretado en todos los casos, exactamente a como lo hubiera colocado un cerrajero francés; pero si este detalle pudiera ser considerado como la consecuencia natural de una necesidad 
o una moda, produciendo en los dos países idénticas soluciones, no puede decirse lo mismo de otro motivo curioso; porque aparece en un número considerable de ejemplares, encima de la moldura que sirve para la unión del tallo al anillo, un pequeño espacio vacío, una a modo de diminuta capillita, que unas veces vacía y otras guardando un símbolo o una efigie de proporciones microscópicas, es la más evidente demostración de que aquellos cerrajeros de nuestro siglo XVII, copiaron de los tipos franceses un detalle de ejecución, tan en armonía con esa preocupación de multiplicidad de labor y de detalle que siempre caracteriza las decadencias

Falta decir que en España, como en Francia, los ministros y los nobles que ejercieron cargo en Palacio, ostentaban una llave, que fué siempre necesariamente ejemplar de categoría, y parece ser que en España la costumbre se fué extendiendo a las grandes casas y corporaciones, pudiendo ser esta la razón de que aparezcan con relativa frecuencia, ejemplares que llenan la superficie de su anillo, con los emblemas de las órdenes militares, los institutos religiosos o los cuarteles de armas de familias bien conocidas. Se dice ${ }^{(1)}$ que reinando Carlos II, todos los caballeros de la servidumbre del rey llevaban constantemente llaves maestras, que permitían la entrada en todos los cuartos de todos los palacios (?) con el anillo o asa exageradamente grande, llevando los criados la misma llave, con la diferencia de que la de los señores era dorada y la suya no. Si una llave se perdía, el culpable tenía la obligación de dar cuenta de ello al jefe de $\mathrm{Pa}$ lacio, quien inmediatamente ordenaba el cambio de todas las cerraduras, lo que importaba una fortuna, que tenía que pagar quien perdió la llave.

Para terminar, nuestros gremios exigieron de los aprendices para otorgarles la categoría de maestros, llaves que demostrasen una perfecta ejecución y un completo dominio de la materia, y esos trabajos con el tallo de sección poligonal, hueco, en que este, es el estuche de complicadas disposiciones, demuestran bien claramente que si nuestros cerrajeros no labraron a cincel las composiciones esculturales que tomaron los franceses del renacimiento italiano, no por eso, ni mucho menos, desconocieron en aquellos días su oficio.

(1) Ironwork.-Part. II, pág. 99 y siguientes.-V. Starkie Gardner=South Kensington Museum=Art Handbook. 


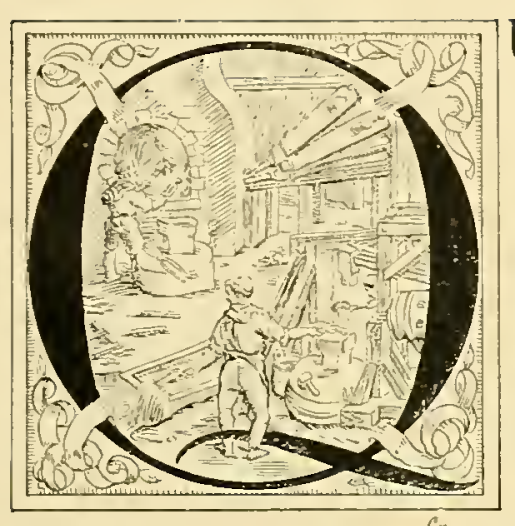

dose del primer modelo". ${ }^{(3)}$

El poema de Luis de Borbón (4) "Arte de las forjas en 1523" parece ser la obra más antigua que tenga relación con nuestro asunto, pero está en ella tratado el problema de un modo tan superficial, que no es posible lograr deducir ningún dato preciso.

Muy poco más tarde, en 1530 y en 1540, se publican en Basilea y en Venecia dos obras extraordinariamente notables, que en poco tiempo alcanzan un número crecido de ediciones, y que en pleno siglo XVII son consideradas aún como los textos fundamentales en la materia, editándose, la segunda al menos, nuevamente traducida. Son éstas, el libro De re metálica, publicado en latín por Gregorio Agrícola, médico que ejercía su profesión en Joachimzchal primero y en Chemnitz después, y la obra italiana de Vanoccio Biringuccio, no citada por el Sr. Zuaznavar y otros, y cuya noticia yo debo a mi erudito y sabio amigo el Sr. Pérez Bueno.

Del libro titulado De re metálica, deduce el Sr. Zuaznavar ${ }^{(5)}$ que "se

(1) Averiguaciones de las Antigüedades de Cantabria.-Cap. XXXIX, - P. Henao.

(2) Monografia acerca de las Ferrerías Vascongadas, por D. Mariano Zuaznavar.

(3) Historia de Vizcaya, por D. Juan Ramón de Iturriza.

(4) Zuaznavar. Monografía ya citada, escrita y publicada con ocasión de Las Fiestas de la Tradición del Pueblo Vasco.

(5) Monografia ya citada. 
trataban dos clases distintas de menas, la pura y la impura, fundiéndose la primera en hornos de forma cuadrada de 1,48 metros de lado y 1,03 metros de altura, con crisol central de 0,30 metros a 0,45 metros de profundidad, y otros de 0,45 de diámetro, alimentados de aire por fuelles de cuero". (1) Coincide con ella la obra de Vanoccio Biringuccio en establecer dos clases de hornos, con la curiosa particularidad de que el segundo de los tipos, concreta ser una disposición «muy parecida (¿igual?) a las de Bizcaya", (2) especificando dimensiones y dando una relación detallada del procedimiento, que, sin llegar a lo dicho por Agrícola, permite seguir la marcha de la operación. Es, por otra parte, de trascendencia extraordinaria, la coincidencia relativa de los dos textos, en mucho de lo que tienen de fundamental, escritos por extranjeros uno y otro, sin manifestar la localidad Agrícola y concretamente citándola Biringuccio. Esto, y el hecho de que la obra de Biringuccio sea muy poco posterior a la primera edición de Agrícola, demuestran de una manera suficiente, que lo descrito en su obra De re metálica, era la técnica seguida normalmente en

(1) Añade, como curiosidad, el Sr. Zuaznavar, tomándolo de Monasterio, que los fuelles de madera no fueron inventados por el Obispo de Ramberg en Bohemia, hasta el año 1620.

(2) DE LA PIRO | TECHNIA. | LIBRI. x. DOVE AMPIAMEEN | se si tratta non solo di ogni sorte \& di | uersita di Miniere, ma an chora quan | to si ricerca intorno a la prattica di | quelle cose di quel che si appartiene | a l'arte de la fusione over gitt de me | talli come d'ogni albra cosa simile a / questa. Composti per il S. Vanoc/ cio Biringuccio Sennere.

Con Prinilegio Apostolico \& de la | Cesarea Maesta \& del Illustriss. Sena | to Veneto.

M D X L

El texto italiano, dice textualmente:

Ahora de esta otra clase muy semejante a la de Bizcaya \& de Breniana \& de Buti xenedito cuanto re com presi.

Existe una traducción francesa de Jaegues Vincent, impresa en Roven en 1627. Contiene 230 hojas numeradas, los grabados son malas copias de la edición ita" liana.

\section{El texto reproducido dice:}

Pero de la del Elba ya os he hablado bastante. Ahora os diré que hay extendidas otras suertes semejantes a la de Bizcaya, de Eresciana y de Buti.

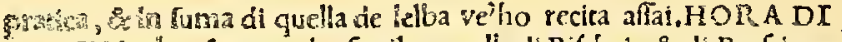
2 AESTA alts force molto finule a quella di Bichala, \& di Bs efcians

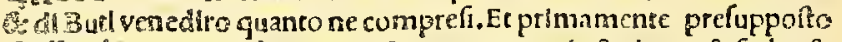
chellabbraze trouaca la miniers \& cauarone copia $\&$ rlcotta $\&$ feelta $\&$ benlffrno rifcelea de lauara ha di necesfica di hauer vno oplu forni, che cofi fi chiamano certe maniche giádi di grädisfinia tecura di carbone Tormaienel vacuo fimile ala figura che vi moftraro qui defignasa.

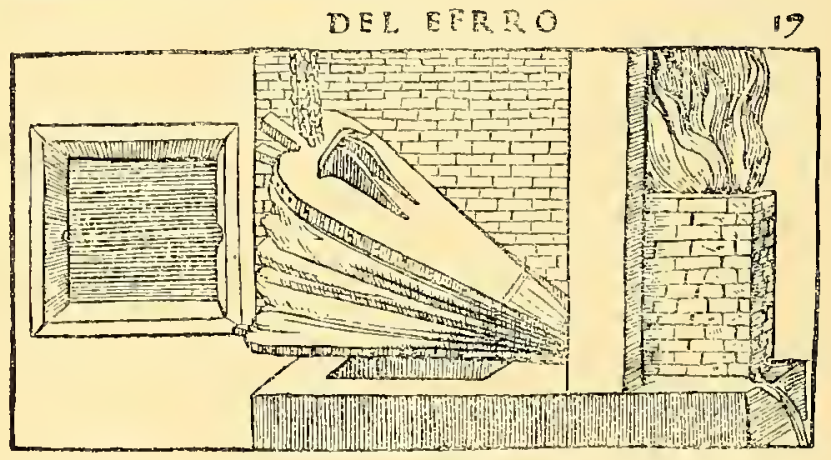

Er appreffo a quefti un gran parc di mantaci tutíi acofacijal muro de la manicha a guifa dun gran paro dale che par altezza comunemice fon dale fei alle otrobraccia, lequali mosfi da vna falda ruota de acqua \& a quella adattalt famo vno grandisfimo aperto per far confio. Et coficol lor porence \& grandisfimo fiaro mefto in cal manicha qualial

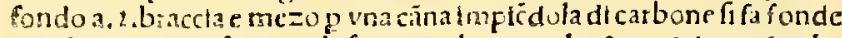
re tal infuiera, \& fecondo le forre, quale vna volu \& qual due auáa che la fiz difpolta a buon ferro da potcr date alla fucina, per diftendarfi al maglio. Ee con ructo quefto ben fpefo aduiene che per qual fi vogit di, 


\section{nuestras provincias vascongadas durante aquel primer tercio del si- glo XVI, ${ }^{(1)}$ técnica que más tarde, en el siglo XVII, parece ser que se modi- fica adoptando el hogar bajo y abierto, bien diferente de estos tipos. Las vicisitudes que luego siguió la industria, nos las describe en el año}

(1) La vena de hierro de mejor calidad debe cocerse en un horno semejante al segundo: pues el fuego ha de alcanzar tres pies y medio de altura, y cinco pies de ancho y de largo; en medio de él ha de haber una cavidad de un pie de altura y seis de anchura, aunque puede ser más alta o más estrecha, según la mayor o menor cantidad de hierro que se extraiga de la vena.

Al maestro debe dársele la medida exacta de la vena de hierro, sea mucho o poco el hierro que pueda fundir la misma vena. El encargado de la tarea debe echar primeramente carbones en la cavidad, y sobre ellos tanta cantidad de vena de hierro desmenuzada y mezclada con castina aun no apagada, cuanta quepa en la pala de hierro. Seguidamente, eche de nuevo varias veces carbones, y sobre ellos derrame de vena de hierro; y así hasta que se vaya formando poco a poco el montón, el cual finalmente, una vez encendidos los carbones, será cocido al fuego, avivado por el soplo de los fuelles artificiosamente colocados en el vientre del horno: tarea que puede llevarse a cabo en ocho o diez o doce horas. A fin de que el ardor del fuego no le queme el rostro, cubrirả su cabeza con un gorro que tendrá algunos agujeros por los cuales pueda ver y respirar. Junto al horno debe haber una barra larga, con la cual siempre que el caso lo exije, y lo exije cuando los fuelles avivan demasiado el fuego, al agregar el resto del $\mathrm{mj}$ neral y los carbones o al apartar las escorias, pueda detener o hacer girar la compuerta del canal por la cual las aguas caen sobre las ruedas y mueven el eje que comprimen los fuelles. De este modo, el hierro va fluyendo, y puede reunirse una masa que pese doscientas o trecientas libras, según fuere la riqueza de la vena. Después, el maestro, sirviéndose de un gancho dará salida a las escorias; y cuando todas estas hayan fluido, dejarả enfriarse la masa de hierro. A continuación el mismo maestro y sus ayudantes echarán al suelo la masa de hierro, sacándola del horno, y la golpearán con pequeños mazos cuyos mangos sean delgados, pero de cinco pies de longitud, a fin de que al mismo tiempo que sacuden las escorias que aún se hallen adheridas a la masa, vayan amontonando y dilatando ésta. Pues si puesta en seguida a la forja, fuese golpeada con un gran martillo de hierro ėste se romperia al ser levantado por los dientes del eje que la rueda hace girar; sin embargo, no mucho después, cogida la masa con las tenazas y sometida al martillo se cortará con un hiero agudo, en cuatro, cinco o seis partes, según fuere grande o pequeña; de las cuales partes, vueltas a cocer y puestas de nuevo a la forja, los herreros forman masas cuadrangulares, arados, aros para ruedas de vehiculos, pero sobre todo barras, cuatro, seis u ocho de las cuales pesan la quinta parte de

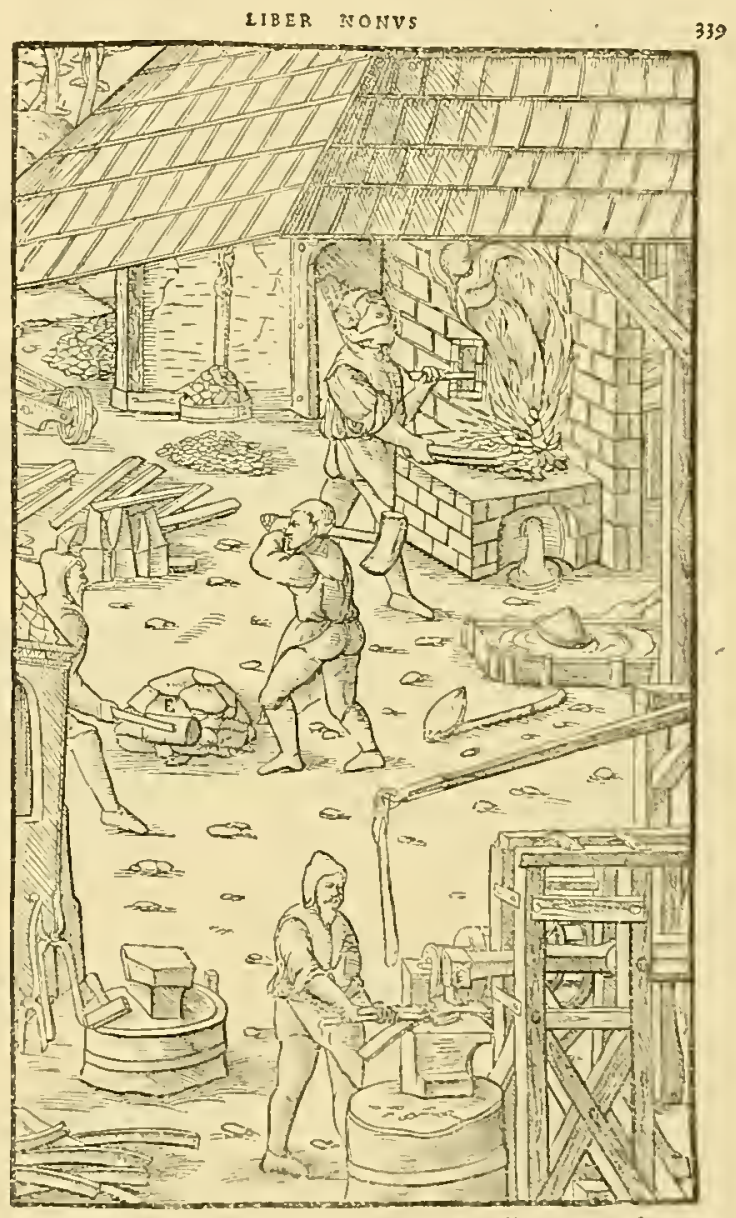

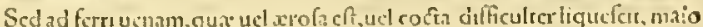

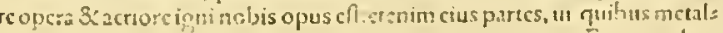

Fig. I. cien libras; a su vez de éstas suelen fabricarse instrumentos varios. A cada golpe de martillo un joven vierte agua, con una concha, sobre el hierro candente que moldean los herreros; y este es el motivo de que los golpes produzcan tan gran ruido que suele ser oido desde lejos del taller. La masa que del horno en que se cuece el filón, vierte a la cavidad, suele permanecer como hierro duro, y que con dificultad se trabaja; del cual pueden fabricarse las cabezas de hierro de las lanzas y los trabajos mús duros.

Georgii Agricolae. De re metallica libri Xll, pág. 337-338. (Basileae 1561).

Para la vena de hierro que, o está mezclada con cobre, o una ve\% cocida se liquida con dificultad, es necesario mayor trabajo y un fuego más vivo pures no sólo es preciso separar las partes del inismo que contienen metal de las 


\section{D. Pedro Bernardo de Villa-Real, cuando dice: «En lo antiguo avía dos generos de Herrerías, unas llamadas mayores, y otras menores: las mayores tenían las barquineras en otra forma, porque necefitaban de ayre más violento: fundían mafas, a que llaman AGOA de doce, y diez y feis arrobas, y con cada una hacian quatro tochos, que eran unas barras}

demás que no lo contienen, y quebrantarlas con manos de mortero secas, sino también quemarlas, para que arrojen fuera de sí los demás metales y los jugos nocivos; y asimismo es preciso lavarlas para separar de ella los cuerpos extraños. Deberán ser cocidos, sin embargo, en un horno semejante al primero, pero mucho más ancho y más alto, a fin de que pueda contener gran cantidad tanto de vena de hierro como de carbón; pues deberá llenarse parte con fragmentos de vena que no sean mayores que una nuez parte con carbones; todo lo cual verterán los encargados de

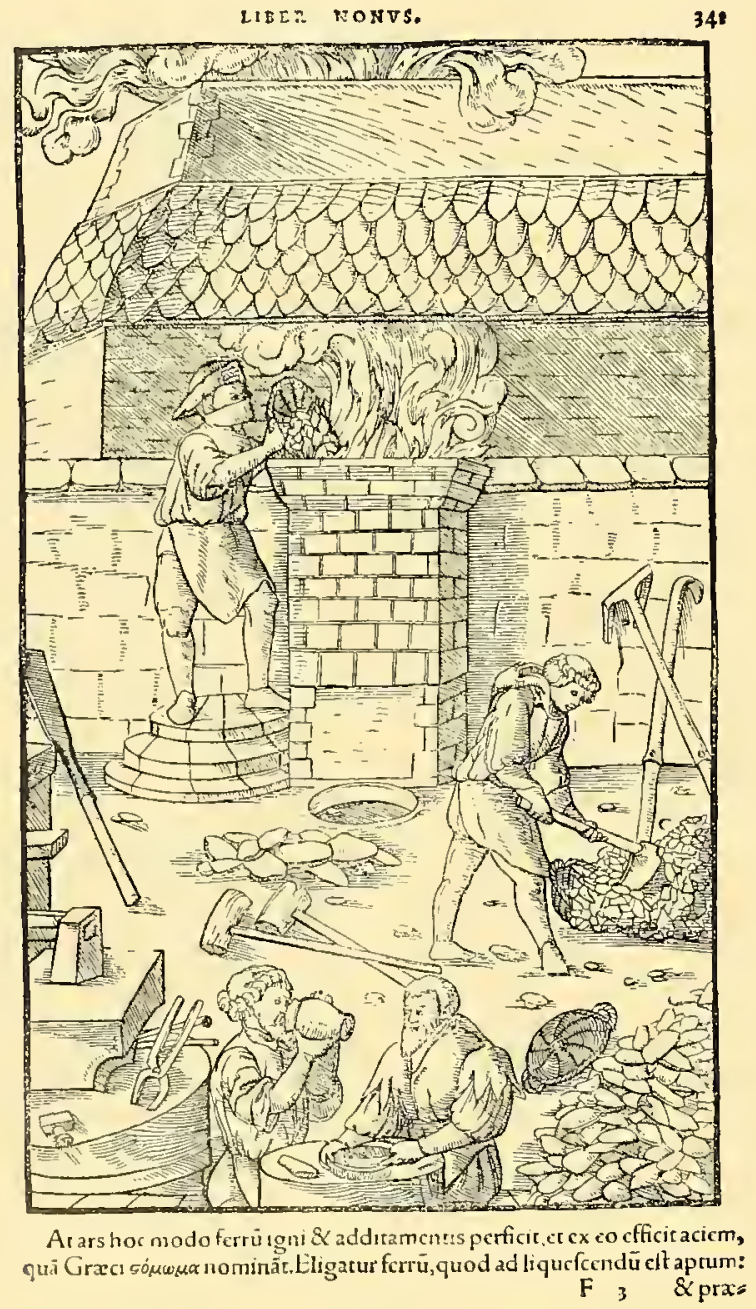

Fig. 2.

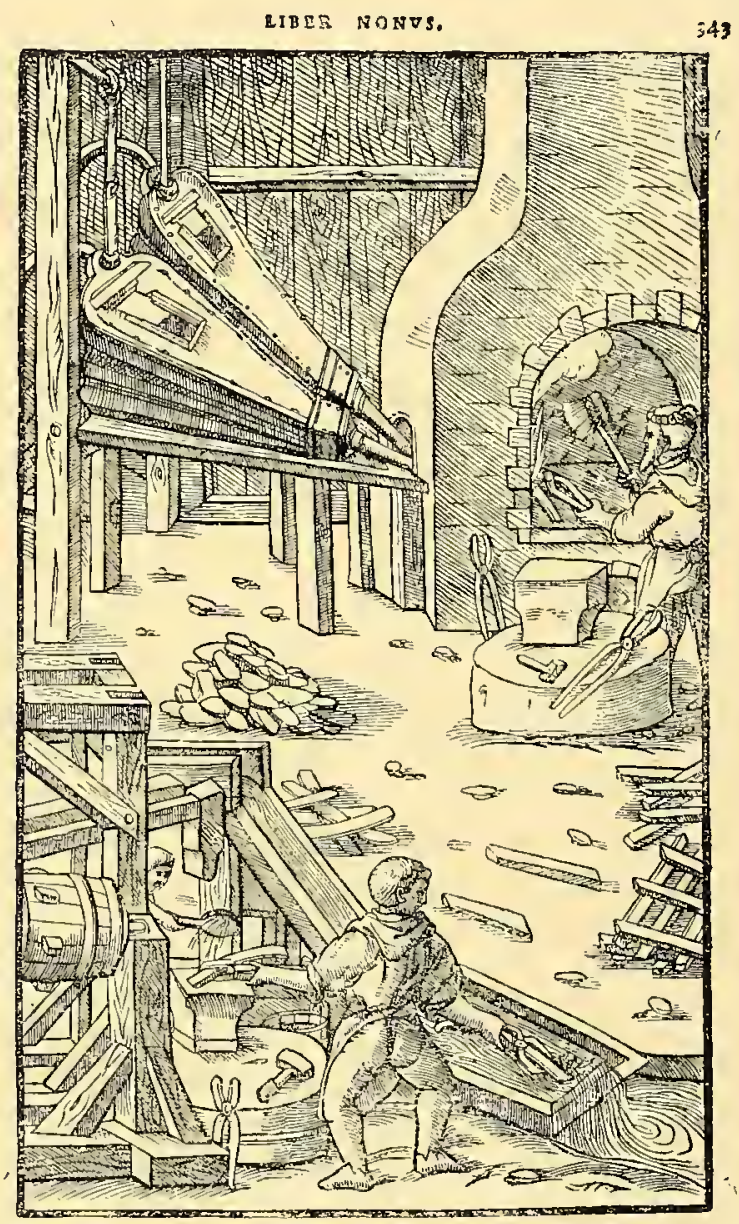

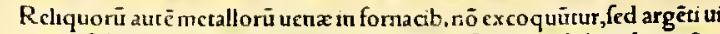

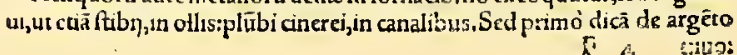

Fig. 3.

cocer el hierro subiendo por los peldaños, que están al otro lado del horno. Mas de tal vena cocida ya una sola vez ya dos veces, resulta fundido el hierro, que es a propósito para ser recalentado en el fuego del horno de hierro y para ser estiado por la acción del gran martillo de hierro, y cortado en partes con el hierro agudo.

Georgii Agricolae, De re metallica libri Xll, pág. 339-340. (Basileae 1561).

El arte perfecciona el hierro por medio del fuego y de otros medios y nace de él acero, que los griegos llaman somoma, en la siguiente forma: El hase hierro que sea adecuado para liquidarse y que además sea duro y de fácil 
de cofa de una vara de largo, y quatro y cinco onzas de grueffo: eftas fe adelgazaban en las Herrerías menores, y reducían a barras largas, como las que oy fe labran; pero defde fines del Siglo paffado dieron en ponerlas mayores, a las que llaman Cear-olas, que funden, y tiran fin valerfe de las Herrerías menores, labrando un hierro muy grueffo de dos arrobas y media, y más cada barra: y aun todavía ay algunas Herrerías de eftas; pero las más fe han reducido a Herrerías menores en que hacen fundiciones de a cinco arrobas, y tiran las barras de buena proporción, porque fiendo los mazos menores, que en CEAR-OLAS, y todo no tan torpe, ni fuerte, fe hace todo con más curiofidad: y el aver dexado el antiguo modo de labrar tocho, ha fido porque el hierro no era tan bueno, y defpués que fe ha eftablecido efta forma, es mejor el hierro: a eftas Herrerías llaman Tiraderas, que fon las de que fe ha de hablar en efte Tratado, aunque para lo que toca a la máquina de ruedas, feran las reglas generales.» (1)

"Una ferrería vascongada, dice el Sr. Zuaznavar, a quien seguiremos literalmente en esta descripción de las ferrerías vascas, refiriéndose ya a las disposiciones de los siglos XVII y XVIII, se componía esencialmente de

trabajo; pues, aunque se liquide, el que resulta de venas que le son comunes con otros metales, viene a ser o blando o frágil; tal hierro, candente aún, se cortará primero en trozos pequeños y se mezclará con piedras licuescentes desmenuzadas; se hara después en el fuego de la fragua de hierro una cavidad del mismo polvo húmedo de que se hacen las cavidades que hay delante de los hornos destinados a cocer las venas de oro o plata; tendrá seis pies de latitud por uno de altura. Los fuelles se colocarán de modo que soplen en medio de la cavidad por una abertura; llénase entonces la cavidad toda de los mejores carbones, y colócase alrededor fragmentos de piedras que retengan las partículas de hierro y los carbones esparcidos sobre ellas; y tan pronto como ardan los carbones y se encienda la cavidad los fuelles soplarán, y el maestro echará poco a poco tanta mezcla de hierro y de piedra licuescente cuanta le parezca necesaria; cuando se haya liquidado colocará sobre ella en medio de cuatro barras de hierro; cada una de las cuales pese treinta libras y a fuego vivo las cocerá por espacio de cinco o seis horas y agitará frecuentemente con un bastón de hierro licuado para que las pequeñas aberturas de las barras de hierro absorban aủn la partícula mås ligera del hierro; las cuales partículas por su misma fuerza, consumen y dilatan las partículas gruesas de las masas, que así resultan blandas semejantes a una levadura. Después, el maestro, ayudado por un operario, pondrá a la forja una de las barras, sacada con una tenaza, a fin de que el martillo, levantado de la rueda, y dejado caer alternativamente, la dilate; la cual, al instante, aún caliente, arrojará al agua y la templará, la pondrá de nuevo a la forja y la romperả golpeándola con el mismo martillo; se detendrá luego a examinar los fragmentos a fin de ver si aparecere algủn hierro por alguna parte, o si todo en cierto modo se ha condensado y cambiado en acero. Cortará después en partes las restantes barras cogidas y extraídas con la tenaza; entonces recalentará la mezcla y añadirá a ella una parte de mezcla reciente, la cual sustituye a la que absorbieron las barras, repara las fuerzas de la que restaba aún y purifica más las partículas de las barras puestas de nuevo en la cavidad. Someterá a la acción del martillo la primera barra que de entre aquellas se hubiere calentado sacándola con la tenaza, le dará forma de bastón y arrojará este aun encendido en agua muy fría corriente que esté cerca y así condensado de repente se convierte en acero que es mucho mảs duro y más brillante que el hierro.

Georgii Agricolae. De re metallica libri XII pág. 341-342. (Basileae 1561).

(1) Máquinas hidráulicas de molinos y herrerias. Por D. Pedro Bernardo de Villa-Real. - Madrid 1736. - Libro Segundo. Capitulo primero. 
un hogar bajo y abierto, que era lo que propiamente se podía llamar forja; de un aparato soplante, que casi siempre era una trompa aice-arca (Caja de agua) ${ }^{(1)}$ y de un martinete pesado para forjar el hierro obtenido. El combustible era siempre carbón vegetal, y las menas para el tratamiento eran los óxidos férricos anhidros y los hematites pardos no muy compactos, aunque también se empleaban menas hidratadas algo porosas. Cuando los minerales eran calizos o carbonatos, y aun los hematites demasiado compactos, había necesidad de calcinarlos al rojo, desagregan-

(1) Según lbran, una trompa exigía como primera condición, un salto de agua cuya altura no bajase de cinco metros, llegando algunas veces a diez. Consistía en uno o varios tubos colocados verticalmente y por los que se vertia el agua que se tomaba de un depósito superior hasta otro inferior (con frecuencia barricas), donde al chocar el liquido con un tablero horizontal, se desparramaba, desprendiéndose todo el aire que arrastraba mecánicamente el agua en su violento descenso y parte de la que pudiera tener en disolución.

El tubo no tiene sección uniforme en toda su longitud, empezando por un trozo cónico que se llamaba estrangol, que terminaba con un diámetro de diez a quince centímetros, según la cantidad de agua de que se disponía, mitad del diámetro inicial; inmediatamente después del estrangol, habia un cierto número, de dos a ocho, aberturas inclinadas, que eran aspiradores por donde penetraba el aire que arrastraba mecánicamente el agua en su movimiento de descenso.

Las cajas de viento o toneles, asentaban sobre un fondo de mamposteria, y sus dimensiones debian de ser tales que permitiesen colocar la abertura de salida del aire por lo menos a dos metros del diafragma, evitando así que el aire arrastrase gotas de agua.

La tensión del aire en las trompas no podia pasar de ciertos límites que correspondían a una altura de diez metros, lo que supone unos noventa y cinco milimetros de columna de mercurio.

Aunque la cantidad de aire dependia en gran parte del acierto en la instalación, hasta cierto punto podía decirse que era proporcional a la cantidad de agua y se consideraba para las instalaciones más modestas que un metro cúbico de agua proporcionaba un metro cúbico de aire.

El grabado que se reproduce está tomado de la Gran Enciclopedia (la francesa), cuyo artículo del trabajo del hierro fué encomendado a un maestro forjador que habia trabajado largos años en las ferrerias vascongadas.

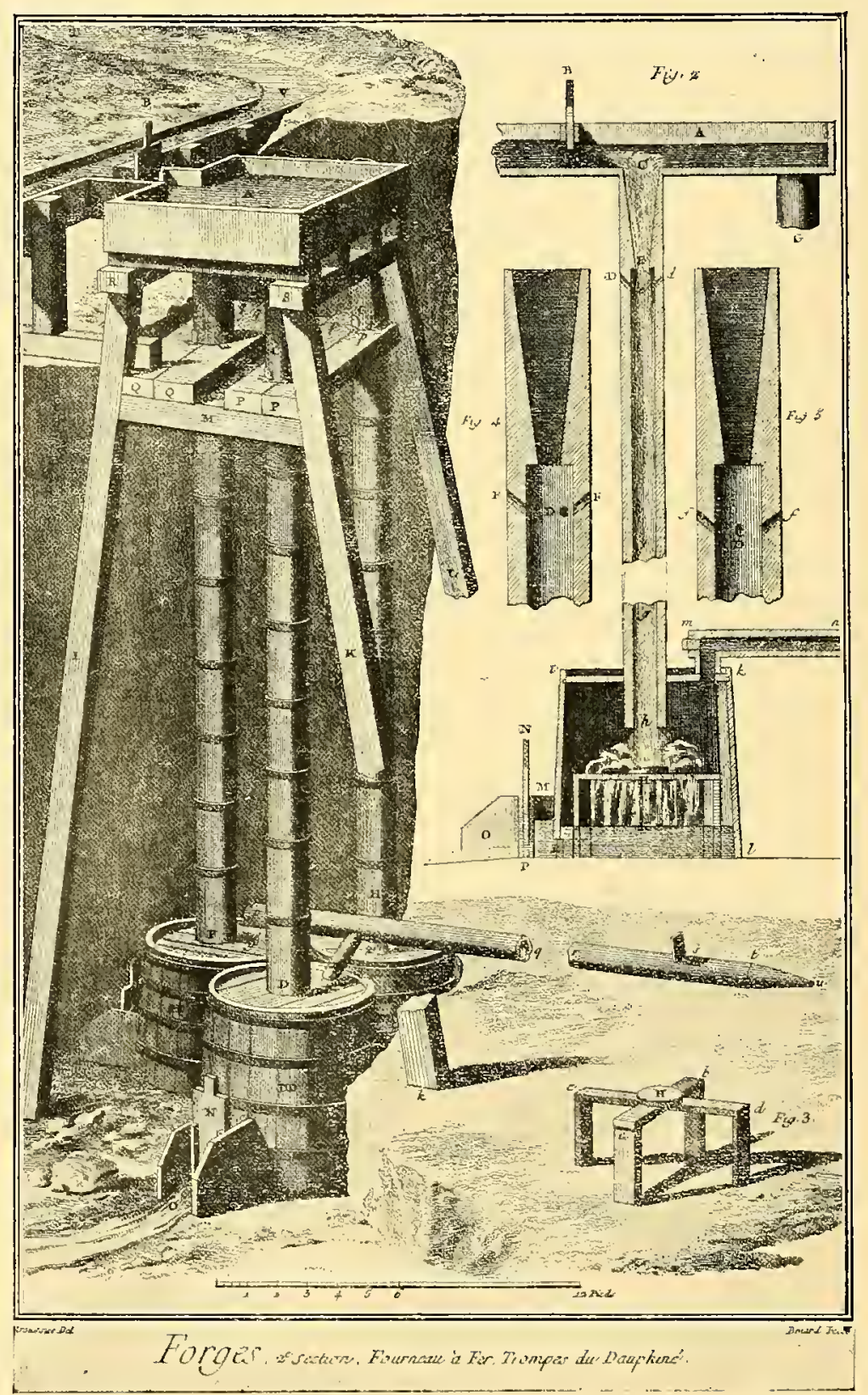


do luego los trozos por la inmersión súbita en agua cuando eran anhidros o silíceos.

La calcinación se verificaba en hornos de mampostería o de ladrillo, unas veces cuadrados, otras ovales o circulares de 1,70 a 2,30 metros de altura, por 2 a 2,50 metros de diámetro interior, cargándose en cada uno de ellos de 200 a 300 kilogramos de mineral, alternando con el combustible, cuya cantidad variaba desde $6 .^{\mathrm{m} 3}$ cuando era leña seca, a $7,3 .{ }^{\mathrm{m} 3}$ cuando estaba húmeda.

La forja, u hogar, consistía simplemente en una cavidad formada por cuatro paredes, tres de las cuales eran verticales y la cuarta presentaba una convexidad hacia el interior. La forja estaba arrimada a una de las paredes del edificio en que se hallaba y separada de él tan sólo por un pequeño murete llamado bergamazo.

Las dimensiones de la cavidad eran muy variables, y en realidad sólo obedecían al capricho del obrero, teniendo cada una de las cinco caras de la misma su nombre: la busa penetraba por el bergamazo y se llamaba a la cara adyacente chapa de la tobera: la cara opuesta chapa de la parte de la vena: ciarzulo era la cara por donde salían las escorias al ciartecua y la opuesta era llamada iduriguela. El fondo de la forja se llamaba cirillo.

El rectángulo que formaba la base de la forja, y que era de 0,60 por 0,61 metros, no tenía los lados respectivamente perpendiculares y paralelos al paramento del muro en que se apoyaba, sino que las forjas debían estar tres centímetros más separadas por la parte de la iduriguela que por el lado del ciarzulo.

Todo el macizo se debía construir sobre cimientos bien sólidos y exentos de humedad, descansando el fondo sobre un lecho de escorias troceadas, y de brasca, de 40 a 58 centímetros de espesor, que a su vez se apoyaba en otra piedra grande, la cual generalmente era una piedra de molino ya inservible. No existía chimenea en estos aparatos: y para dar salida a los productos de la combustión, se practicaba en la techumbre del edificio un agujero de cuatro a cinco metros cuadrados.

La iduriguela se distinguía de las demás caras laterales de la forja en que toda era de mampostería unida con arcilla, en lugar de ser vertical como la ciarzulo; tenía una ligera inclinación de 5 a 8 grados. 
La pared opuesta a la de la tobera, estaba formada por piezas de hierro en forma de dovelas que se apoyaban unas sobre otras formando una superficie convexa hacia el interior del hogar y que apoyaban también por sus dos extremos en la mampostería.

El ciarzulo estaba formado por dos gruesas piezas de hierro de 15 a 20 centímetros de ancho y 7 a 8 de espesor, que se empotraban verticalmente 20 a 25 centímetros por bajo del fondo, y que sobresalían de éste algo más de medio metro: el espacio intermedio lo ocupaba otra pieza también de hierro llamada palanca-aldia que no penetraba en el suelo tanto como las otras, y servía para apoyar las palancas cuando se sacaba la masa de hierro llamada Zamarra y agoa, según el P. Larramendi, en Guipúzcoa. El resto de la cara se recubría de arcilla, dejando en la parte inferior algunos orificios para la salida de escorias.

La cara llamada chapa de la tobera se constituía por unas barras de hierro rectangulares de 12 y 15 centímetros de sección, colocadas de plano unas sobre otras, y que formaban así un muro, cuya altura era la que había desde el fondo del crisol a la tobera; desde ésta hacia arriba se construía un muro de mampostería ordinaria.»

El problema de dar al hogar la cantidad necesaria de aire, fué resuelta, como se sabe, de dos maneras bien distintas, por fuelles y por trompa: que uno y otro sistema merecieron la más esquisita atención de los ferrones vascongados, lo demuestra no tan sólo la obra antes citada de D. Pedro Bernardo de Villa-Real, denominada Máquinas hidráulicas de molinos y herrerias, ${ }^{(1)}$ sino el hecho de que un tal Pablo Antonio Ribadeneira, hubiera logrado en 1639 privilegio de invención por cincuenta años, para un sistema que le permitía fundir sin fuelles y con sólo un arca de agua, experimentando su sistema en las herrerías de Salazar, situadas

(I) De tan interesante obra copiamos a continuación lo que a las ruedas hidráulicas empleadas en herrerias se refiere:

"De dos generos de ruedas ufan en las Herrerias, unas de palas, y otras cerradas, que llaman de potos: las primeras fe ponen oy en los ufos mayores del mazo en todas las Herrerías; y las fegundas en las ruedas de barquines, efpecialmente en Herrerias de mucho falto, por el error de creer, que neceffitan de menos agua, que las ruedas de palas, que llaman de Carramas (y defpues fe demoftará necefsitan mas): fon de mayor cofte, y de menor firmeza, afsi para la duración, como para el movimiento.

Y aunque las fupoficiones puesftas en el cap. 4, del lib. 1, fon, como las que se pondrám aquí, fundadas en unos mifmos principios: por variar en algunas circunftancias, fe pondrán de nuevo en efte Libro, para que firvan de govierno para las ruedas. 


\section{en las Encartaciones de Vizcaya; ello no obstante y a pesar de la respe- table opinión del Sr. Zuaznavar, es de suponer que las trompas no fueron}

\section{S U P O S I C I O N E S}

1. El mayor falto, ó altura peppendicular del agua necefsita menos cantidad de agua, que el menor falto; y al contrario, el menor falto necefsita mas agua, que el mayor en proporción dupla: de fuerte, que fi una Herreria de 15 . pies de falto necefsita 40. cantidades de agua: una Herreria de 30. pies de falto necefsitará 20. cantidades de agua.

II. Los diametros de las ruedas tienen la mifma dupla proporcion: de fuerte, que fi una rueda de IO. pies de diametro, ha menefter 40. cantidades de agua: una de 20. pies de diametro necefsitará 20. cantidades de agua; y al contrario.

11I. Los furtideros, ó cañones por donde fale el agua, tienen fu dupla proporción con fus alturas: de fuerte, que el cañon de guzur-afca de 20. pies de altura perpendicular con 60 . onzas quadradas de boca, arrojará tanto y medio de agua, que otro cañon igual con 10. pies de altura perpendicular hafta el furtidero, donde encuentra con las palas.

IV. La altura perpendicuiar del agua, á que vulgarmente llaman falto, debe medirfe defde lo concabo de la ondaafca, hafta la fuperficie del agua en lo mas alto de la antepara, ó caxa donde fe recoge el agua.

V. La altura perpendicular del furtidero es lo que tiene la guzur-afca de alto defde donde encuentra con las palas hafta lo mas alto del agua en la antepara.

VI. Una Herreria de 21. pies de falto en la rueda del ufo mayor con 13. pies de diametro, necefsita de 154 onzas

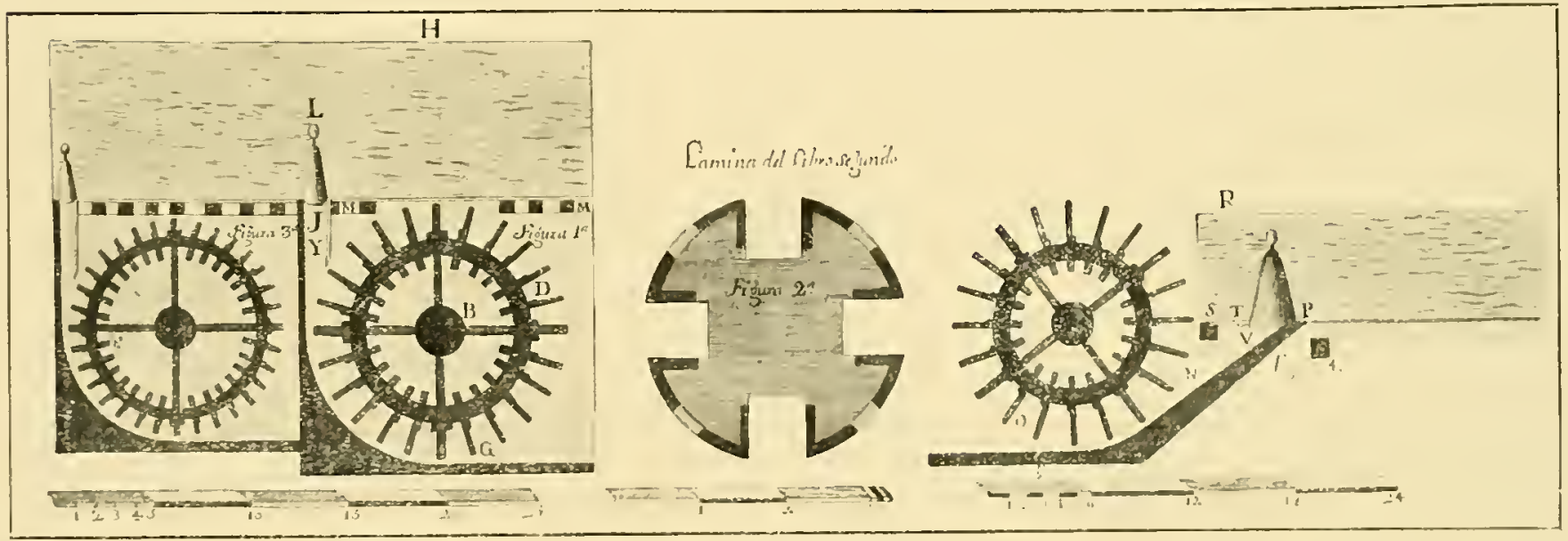

quadradas de agua en el furtidero del cañon, ó guzur-afca, por donde cae la agua: y en la rueda de los barquines de 19. pies de falto, 24. onzas quadradas en dicho furtidero de la guzur-afca. con 11. pies de diametro.

La fexta fupoficion fe eftá actualmente experimentando, defpues de muchas pruebas en las Herrerias de Bengoleá, y fe pone aqui por fer precifa para formar las reglas de proporción de mayores, y menores faltos, y ruedas: van delineadas en la lámina de efte fegundo libro; y para mejor inteligencia, y explicacion de fu conftrucción, fe pondrán aqui todas fus partes en la forma figuiente.

A. fig. I. perfil del ufo mayor, que firve para el mazos: fu largo „nas proporcionado es de 20. á 22. pies; advirtiendo, que fi es mas corto, ferá duro el movimiento del mazo, á que llaman majeo; y fi mas largo, que 22. o 24 . pies, estará expuefto á blandear, y durará menos: fu grueffo en los mazuqueros de 3 . pies á 3 1/ de diametro, aunque hay algunos ufos, que no tienen, fino 2 \% por falta de madera de baftante grueffo: el diametro del fin, ó cabeza del ufo por la parte de la Herrería, á que llaman de los brazos, á quatro pies de los mazuqueros, tendrá de diametro 2 1/a pies, y' en la otra cabeza de la eftolda, á quatro pies de las cruces, tendrá de diametro 2. pies; pero eltas medidas, y tamaños varian fegun la necefsidad, y circunftancias, que fiempre que eftas no lo impidieren, fe practicarán las medidas expreffadas.

Y por que muchos maeftros no faben redondear los ufos, fe explicará aqui brevemente el modo de executarlo.

En primer lugar fe labrarả la madera en quadro con buenas plomadas, dando los quadros con las diminuciones prevenidas defde los mazuqueros ácia uno, y otro lado: folo en dichos mazuqueros en un pie, y quarto fe labrará con igual diametro, y grueffo fin diminucion. 


\section{lo que más aceptación tenía en el país, como lo demuestra el hecho de que el mismo Villa-Real no les dedica en su libro la atención que parece merecerían, ni se deduce esa preferencia, de las diferentes investigaciones}

Luego fe tirará una linea por medio de cada quadro de punta á punta, de tal forma, que tirando en las dos cabezas de linea á linea, hagan dos diametros, haciendo cruz en angulos rectos en el centro del grueffo de cada cabeza.

Luego fe partirá en diez partes cada lado, ó en cinco cada mitad: y porque el quadro, dado al priricipio, no conviene, fea perfecto, porque fe gaftaria la madera: con dos reglas pueftas en las lados, fe fabrá el grueffo, que fe ha de repartir en diez partes, afsi á un lado del parage de los mazuqueros, como el otro; en la cabeza de ácia la Herreriá fe hará la mifma repartición; y en la de la eftolda, repartiendo en todos los quatro parages dichos en diez partes el grueffo, ó fu mitad en cinco.

Defpues fe abrirá el compás en el tamaño, y abertura de dos partes de las diez dichas, y fe marcarán puntos, po. niendo el un pie del compás en la linea hecha en la mitad de los quadros: advirtiendo, que dichas dos partes en los lados de los mazuqueros ferán del grueffo de aquel parage, y en las dos cabezas del grueffo que tuvieren.

Tiradas las lineas de punto á punto defde los mazuqueros ácia una, y otra cabeza, fe labrará entre hilo, y hilo, y quedará formado un octogono, u octavo perfecto. Defpues cada poligón, ó lado del ochavo, fe dividirá en fiete partes, y dos de ellas fe marcarán, poniendo el un pie del compás en el angulo del ochavo, y con el otro pie fe harán 'en uno, y otro lado marcas en todos los ocho lados: y de marca a marca, tirado el hilo, fe labrarán los angulos, y quedará con diez y feis lados, cafi redondos, que no tendrá, fino quitar los vivos de los diez y feis angulos con azuelas; y fe ad. vierte, que en los ultimos hilos, que forman los diez y feis lados, al labrar fe han de dexar las lineas, fin llegar á ellas, porque no fe entre en el vivo del redondo; y para fu govierno fe han de hacer defde el centro dos circulos del diametro correfpondiente en las dos cabezas, que eftarán cortadas en buena efquadria con mucho cuidado.

Los ahugeros para los mazuqueros fe abrirán en el ufo en la forma que representa la figura 2 . en dicha plancha, con fu pitipie proprio: los quatro ahugeros han de tener 8 . onzas de ancho, y 8. de profundo, y de largo 14. ó 15. onzas, y fe han de guarnecer con gimelas de hierro de canto, que tengan onzas y media de grueffo, 6 . u 7 . de ancho, y 4 1/2 pies de largo, y han de tener fu lomo, ó la figura, y grua, que tiene el ufo en el barril, para que en todo el largo vengan iguales con el redondo de ufo; y fe ha de abrir en el ufo un hueco muy ajuftado para cada gimela, las cuales han de hacer frente de cada lado del ahuguero; y contra ellas fe han de poner otras ocho planchas de ancho, que tengan una onza, donde hacen la junta con las de canto, y ácia los dos eftremos han de ir adelgazando: fu ancho ferá cinco o feis onzas, y fu largo cinco pies, y en cada punta un ahugero, para que fe claven con clavos, y no fe muevan al echar los fellos, como fucede, fin embargo que fe embuten en la madera: lo que fe executará, ajuftandola con mucho cuidado, y la junta entre planchas de canto, y de plano, fe hará de muy ajuftada union, componiendo los hierros á martillo, y aun á lima, feria mejor: y con el largo dicho cogerán á dichas ginelas á lo menos tres fellos por cada lado, y á las de plano quatro. Todo fe demueftra en dicha figura 2 . en perfil.

En las cruces fe herrará el ufo en la mifma forma y con el mifmo cuidado, y fe fellará defpues con fellos no muy anchos, ni grueffos, y fumamente ajuftados, teniendofe en todo grande prolixidad, porque en herrarfe bien, eftá toda la feguridad del ufo.

La madera para el ufo, debe cortarfe en la menguante de Enero, ó Febrero: y cortada, dexarla con fu corteza hafta Junio, y entonces desbaftarla, y conducirla á la Herreria, donde fe ha de labrar, y redondear luego, y convendrá mucho darla dos, ó tres, ó mas manos de alqui'rán, conforme le vaya bebiendo, como fe execura con los maftes de Navios: lo cual importará mucho, y evitará el que fe abra la madera, y haga grietas: y defpues por Septiembre, ú Octubre fellar el ufo con gran cuidado: para lo qual ayuda tambien el alquitrán; porque como los fellos fe ponen calientes, derriten algo de alquitrán, y como es oleofo, corren mejor los fellos, los quales fe han de unir, y apretar a pura fuerm za, fin reparar en que falten algunos.

Los ufos de buen tamaño, y pueftos en la forma explicada, duran cinquenta, y mas años, como no aya defcuido, viendo floxos algunos fellos, ó hierros, y al cabo de algunos años de averfe metido el ufo, fi le quitan todos los fellos, y hierros, y fe labra con azuela hafta quitarle toda la coftra ${ }_{r}$ y gaftado de la madera con la continuación del agua, y fe buelve á herrar con el mifmo cuidado, quedará mejor que nuevo, como lo tengo experimentado; pero esto fe ha de executar en tiempo de Verano, estando feco el ufo, y fi fuere facandole de fu fitio fuera, ferá mejor.

Sobre meter los pujones con ariete, que llaman drao, no ay que advertir, porque es cofa fabida.

F. Y, J. fig. 1. la guzur-afca, que aunque debe fer de madera entera, en que fe abre la canál del ancho y circunfe. rencia de la rueda, en la figura folo fe pone el perfil de lo interior.

Y. garganta eftrecha, ó furtidero del agua, donde encuentra con las palas de la rueda, en donde como fe ha dicho 


\section{realizadas por la Sociedad Vascongada de Amigos del País, de que nos ocuparemos más tarde. \\ «El martinete, aparato que se empleaba en el forjado del hierro, con- tinúa el Sr. Zuaznavar, se movía siempre por medio de una rueda hidráu-}

en la fupoficion 4. tiene 154. onzas quadradas de cañon, 14. ácia lo largo de las palas, y 11. ácia lo ancho, que multiplicadas uno por otro, hacen dichas 154. onzas, y en efte tamaño de ruedas, y falto, debe tener la guzur-afca tres onzas mas á un lado, que al otro, y en ruedas menores, y de mayor falto dos onzas á poca diferencia. El ahugero, ó cañon de dicha guzur-afca en J. debe tener, poco mas, o menos, tanto, y tercio, como en el furtidero, que añadido a los 154 1/3 hacen 205 1/3. onzas y fe hará de 15. onzas á un lado, y 14. al otro á poca diferencia, procurando, que quadrando, haga las 205 1/3 . onzas, 5. ú 6. mas ó menos: y aunque Ozanam en el lugar citado arriba, y, es de la mifma opinion Pafchal, dice, que el tener el cañon mayor la entrada. no aumenta la fuerza, y que es lo mifmo fea todo el largo del cañon igual: tengo experimentado, que en cañones cortos fe debe aumentar la arca de la boca fuperior, á lo menos una quarta parte mas que el arca de furtidero, y en cañones largos una tercia parte: y el que efto no ofende, tambien es conforme dichos Autores.

Conviene mucho, que el furtidero $Y$. no fea mayor, ni menor que lo neceffario; porque fi es mayor, baxa floxa la agua, y no hace el debido efecto; y fi menor que lo neceffario, no tiene baftante fuerza. En la boca J. en el falto fupuefto no conviene tenga mas que lo dicho, ni menos; porque fi tiene mas, anda á borbollones el agua, como quando hierbe en un caldero, y no ay fuerza que detenga el chimbo L. y la agua que cae por la guzur-afca, pierde fu celeridad, y hace menor efecto: y fi es menor que lo dicho, y que no llega á tenor á lo menos la quarta parte mas que en $Y$ no tendrá fuerza baftante, por no entrar el ag a competente: y efta medida de la boca J. fe entiende fin el chaflán, que fe hace en el remate de la guzur afca en forma de embudo quadrado, para que encaje mejor el chimbo, el qual dá baftante trabajo en algunas Herrerias, por no poner con las debidas medidas la guzur-afca, además del defperdicio del agua: el cañon de dicha guzur-afca ha de ponerfe muy lifo azuelado, y aun cepillado, porque cualquier encuentro hace perder la celeridad del agua.

B. las cruces, cuyo ancho es de catorce onzas, porque fiendo la garganta $Y$. de once onzas de ancho, deben tener las cruces tres onzas mas, y de grueffo feis onzas: fe hacen de roble limpio fin nudos, afferrando tablones de fiete onzas de grueffo, y dexandolo fecar: y la referva de grueffo mayor, es, para que quando fe labren y pongan en regla no fean efcafas.

D. palas, cuyo largo, que fale de la cinta ó maco, debe fer del tamaño de la diagonal del quadrado de la garganta $Y$. de la guzur-afca, que como fe ha dicho, ácia el largo de las palas es de catorce onzas: las quales quadradas hacen 196. onzas: y añadidas otras tantas por el otro lado, fon 392. cuya raiz quadrada fon cafi 20 . con que otras tantas onzas tendrán de largo las palas, y fu cuenta fe facará por la raíz quadrada, ó por Geometria, formando el triangulo que vá aqui:

El grueffo de dichas patas ferá de quatro onzas, y ácia la parte contraria, de donde pega el agua, fe labrarån las efquinas, cogiendo dos onzas por el canto, y otras dos por el embés de la pala, porque todo fu ancho conviene para recibir el impetu del agua, y la buelta tomará menos ayre en la parte del circulo, que voltea fuera del agua: y en la onda-afca G. E. cortarả mejor el agua. Las diftancias de las palas ferán iguales, y porque las quatro de las cruces fon mas gruefas, el cuadrante entre cruz, y.cruz, fe reparte en cinco, ó mas palas, como demueftra dicha fig. 1 .

Sabido el diametro de la rueda, y cañon de la guzur-afca, el numero de palas fe regulará, formando una linea orizontal, que reprefente el femidiametro de la rueda, y perpendicular á dicha

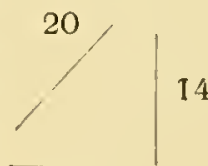

14 linea: cerca de fu extremo fe delineará el cañon de la guzur-afca, y defcribiendo un quarto circulo, abierto al compás en la cantidad del femidia metro, fe dividirá dicho quarto circulo en los pnntos de las palas que correfponden: de fuerte, que la pala tercera, contando defde la orizontál, entre una onza á poca diferencia en el cañon, como fe vé en la rueda de la fig. 1 . en que la pala $Y$. fe acerca al cañon: y efta demoftracion fe hace mejor en punto grande.

C. maco, ó cinta, cuyo ancho ferả de catorce onzas, como las palas, y cruces: el grueffo diez onzas es proporcionado, y mas delgado no conviene, porque el pefo grande trae firme el movimiento del mazo, y las efpigas de las palas queden bien affeguradas en efte grueffo.

E. G. la onda-afca, que es la canál, que unida con la guzur-afca está orizontal, formandofe en ella el circulo de la rueda hafta fu perpendicular, y defpues corre orizontál, para que defpida el agua, como mueftra dicha figura: entre el circulo que forma la rueda, y la que forman la gruzur-afca, y onda-afca, ha de aver una onza de diferencia en el femidiametro, para que la rueda tenga efta holgura, y efpacio: y en lo anclıo tendrán dichas canales de onda-afca, y gu- 
lica de 2,50 a 3,50 metros de diámetro, verificando el agua su efecto más bien por el choque, que por su peso. En el eje de dicha rueda de madera recubierto por un cilindro hueco de fundición y atravesado por cuatro agujeros practicados a tal fin, se fijaban las levas de hierro forjado que ponían en movimiento el martinete, que era una pieza de fundición de hierro de la forma de un martillo de mano, sin orejas, y de 600 a $700 \mathrm{ki}$ logramos de peso, cuyo mango por decirlo así, que era una viga de haya de 0,35 de escuadria y 4,30 metros de largo, reforzada con zunchos de hierro, pasaba por el centro del martinete.

zu-afca también una onza por cada lado: esto es, que leniendo, como fe ha dicho, las palas de la rueda catorce onzas de ancho, deben tener dichas canales diez y feis de ancho, y de profundo pie y medio, ó más: y además con unos tablones bien ajuftados fe aumenta lo profundo de dichas canales, efpecialmente en el angulo que forman onda-afca, y guzur-afca, poniendo tablones diagonalmente.

M. G. altura de la on da-afca á la antepara, que fon $131 / 3$. pies, poco mas que el diametro de la rueda.

H. M. altura del agua en la antepara, que es de $71 / 2$. pies, como fe vé en dicha fig. 1 . y hace todo 21 . pies de falto, ó altura perpendicular de la Herreria de la fupoficion 6.

No importa, que la onda-afca E. G. efté metida en agua un pie, y aun dos, porque no impide para la velocidad de la rueda. En Bengolea ay al fin de la eftolda un Molino con Prefa baxa de piedra en la qual ay unos pies derechos de piedra, que fe levantan quatro pies con fus canales, para levantar la Prefa, ó fu agua coa tablas en Verano, quaudo no andan las Herrerias: dicha Prefa de piedra eftá alguna onza mas baxa, que lo concabo de la onda-afca G. y tiene pueftas falcas, ó tablones de diez y feis onzas de alto; y fe ha experimentado con ampolleta, que con ellas, y fin ellas es igual la velocidad de la rueda, que ande un mazo folo, ó que anden los de las dos Herrerias á un tiempo; en vifta de lo cual, aun quando trabajan las Herrerias, eftá puefta dicha falca de 16. onzas de alto, y defpues de Julio, paradas las Herrerias, fe ponen las demás falcas, ó tablones mas altos; fe vé en las Herrerias quando las crecidas de los Riosque aun cuando llega el agua al ufo, anda la rueda, aunque con menos velocidad, pero lo baftante para andar la He, rreria, como pueda andar la rueda de los barquines, que como la agua que necefsita es menos, y el impetu tambien fufre menos la repompa, y afsi fe pone la onda-afca de la rueda de la barquinera un pie, dos, ó tres mas alta, que la onda-afca de la rueda del mazo, fegun la difpoficion de las Herrerias, y caudalofo del Rio, y falto: y en Bengolea eftá dos pies mas alta, que la de la rueda del mazo.

Y para que fe tengan prefentes, y promptas las proporciones, y medidas de la rueda del ufo mayor, fig. 1 . fe pone la tabla figuiente.

Rueda del ufo mayor, fu guzurafca en la garganta, ó en lo mas eftrecho, donde encuentra el agua con las palas 17. onzas á un lado, y 14, al otro, y en el chimbo 14. onzas á un lado, y 16. al otro.

Las cruces: largo, 13..00. ancho, 01..02. grueffo, 00..06.

Las palas 24. inclufas las crufes: largo, 01..08. ancho, 01..02. grueffo, 00..04.

Cintas: largo, 00..00. ancho, $01 . .02$, grueffo, 00..10.

La rueda de la barquinera, fig. 3. fe conftruirá con las mifmas proporciones, y reglas, que fe han dado para la rueda del mazo, governandofe para el tamaño de las palas por el grandor del furtidero de la guzur-afca, como tambien para la regulacion del numero de palas en la forma demoftrada.

Las reglas dadas para eftas dos ruedas fervirán de govierno para todas las otras ruedas de mayor, y menor diametro. Ponefe tambien aqui la tabla de las medidas, y proporciones de dicha rueda de barquines, cuya guzur-afca en lo mas eftrecho, donde encuentra el agua con las palas, tiene 4. onzas á un lado. y 6 . al otro; y arriba en el chimbo, fin hacer quenta del chaflán, 5. onzas á un lado, y $61 / 4$. al otro.

\section{Rueda de barquines.}

Las cruces: largo, 11..00. ancho, 00..07. grueffo, 00..05.

Palas, inclufas cruffes 32.: largo, 00..09. ancho, 00..07. grueffo, 00..03. 
La viga se llamaba en Guipúzcoa gabia, según Larramendi, y se hallaba provista en el centro de otro cincho con dos pivotes, que apoyándose en unas muñoneras, le permitían tomar movimiento circular alternativo al-. rededor de los citados pivotes.

Cuando un martinete marchaba bien, debía dar de 100 a I25 golpes por minuto.

Los dentellones o mazuqueros, se decían en vascuence guipuzcoano màisucariac (maisuca-aridiranac) o sea, los que andan y se mueven magistralmente, según el citado P. Larramendi, quien dice también que se llamaba quezurasca y ond-asca las salidas de agua agregando con admiración "tan a nivel la primera; ían alta con hueco tan liso y tan medido a la "cantidad de agua que se precipita sobre la rueda, y tan estrecha y ceñida "la ond-asca por sus lados, y que sin embargo, deja tan libre el movimiento "de la rueda, que no puede discurrirse mayor proporción."

El yunque era de hierro, y tenía 0,70 metros de longitud, siendo algo más ancho por el centro (0,25 metros) que por los extremos ( 0,22 metros), empotrándose en un trozo de fundición, que a su vez descansaba en el hueco hecho en una gran piedra.

El personal de una ferrería en las Provincias Vascongadas, se componía de cuatro individuos llamados ferrones, los cuales acudían al trabajo encamisados o cubiertos con obreras, que así se llamaban a los camisones que les cubrían desde el cuello a los pies.

El uno preparaba la vena ya calcinada en la arragua y la desmenuzaba con un martillo pequeño; a éste se le llamaba mealtea o mealle, es decir, preparador de la vena.

Cintas: largo, 00..00. ancho, 00..07. grueffo, 00..09.

Efta rue da tenia baftante con feis onzas de ancho en palas, y cinta; pero aunque no llevan las palas fino una efpiga; en feis onzas avria poco para la efpiga, y los macizos de los dos coftados; y fiempre que la rueda tiene baftante ancho, fe affeguran las palas con dos efpigas: y quando tienen poco ancho, como efta, folo con una efpiga.

La rueda de los barquines de una de las Herrerias de Bengolea, llamada la mayor, necefsita de doblada agua, por mover dos pares de barquines, que firven á un tiempo á dos fagares, y la tabla de fus medidas fe pone aqui.

Rueda de la mayor de Bengolea, fu guzur-afca en ha garganta, donde encuentra con las palas, 0 . onzas, á un lado" y 8. al otro, y arriba en el chimbo $81 / 2$ onzas a un lado, y $71 \%$ al otro, fin el chaftán.

l.as cruces: largo, 11. ps. 00, ancho, 00..08. grueffo, 00..03.

Palas 28. inclufas las cruces: largo, 01..00. ancho, 01..08. grueffo, 00..03.

Cintas: largo, 00..00. ancho, 00..08. grueffo, 00..09.

(1) Páginas 81 y 82 . Tomo VI. Corografia de Guipúzcoa. 


\section{El otro, el que manejaba una gruesa palanca que metía hasta el fondo} de la fragua para ver el estado de la zamarra o agoa se llamaba Urtzallea, o sea fundidor.

El tercero, que recibía el agoa con grandes tenazas en la mano, curricas, con las que agarraba, sujetaba, movía y gobernaba debajo de la gabia y sobre el yunque, el agoa, se llamaba yele o ujele, tirador. Ultimamente el cuarto era el Jefe, que en ausencia del yele hacía sus veces; en presencia, dirigía a los tres, y se llamaba arotza, en las cearrolas y chiquetzalle en las herrerías menores, achicador y macero.»

Tal era una ferrería desde finales del siglo XVI hasta muy entrado el XVIII; sus costumbres y su vida, fueron descritas cuidadosamente por don Juan Antonio de Moguel ${ }^{(2)}$ en su curiosa obra «El Doctor Peru Abarca,

(1) Pảgina 83, tomo VI. Corografía de Guipúzcoa.

(2) P. Ondo dinozu; eldu gara olara, ta euco dogu cer icusi, ta ceri verba eguin.

M. J. Jesus, ¿̇ce gente modu da au? Impreinuba dirudi. ¡Ce suba, ta gaarrac! ¡Ce erremienta, ta toqui tristiac! Guizonen ichuraric eztauquee emen dacustazanoc. Ezteuscube agur bat bere eguiten. Eztauquee arpeguijan balcitu bagaco gauzaric.

P. Maisu Juan; icer uste cenduban emen ediro? ¿Guizon ederto apaindubac? Beguiratu eguijezu ondo buruti biatzetara: eztabe aguiri ez begui, ez betuleric baltzaren baltzaz: ederrac dirá maurubac oneen aldian. Capela igartu ta erdiquin bat buruban, zapi quedartu bat becoqui erdiraño icerdija artu, ta subaren berotasuna arinduteco. Obrera uts, idunian lotuba; ezta cer escatu jaqueric, ez calcerdi, ez abarca, ez ta pracaric bere. Oera etzuteco ta jaguiteco eztauquee nequeric cer artu.

M. J. Ori da bada: eta ¿nunguac dira guizon oneec?

P. Bizcaitar garbijac, odolian zuri ecer zor ezteutsubenac.

M. J. ¿Ceimhat opiciale dira, ta cer aloguer emoten jaquee?

P. Dira Iau biarguiñ; Igelia, Urtzalla bi, ta Gatzamallia. Aloguera aimbestecua da; baña bai ondo irabacija. Ijeliac darua biarsari, edo aloguer gueijago, ta onec izan daruaz egunecuaz ostian, escupeco edo atseguin sarijac.

Burdiña asco eguin bada, ondo irabazten da; bestelan guichi. Gatzamalle gaissuac darua nequeric gogor ta gogaitgarrijena, ta irabazteric laburrena.

M. J. ¿Celan ori cristau errijan?

P. ¿Eztozu enzun inos praile-echeetan jazoten dana?
P. Dice usted bien. Hemos llegado a la fábrica y tendremos qué ver y de qué hablar.

M. J. ¡Jesús! ¿Qué clase de gente es ésta? Parece el infierno. ¡Qué fuego y llamas! ¡Quẻ herramientas y lugares tristes! Estos que veo aquí no tienen figura de hombres. Ni nos dirigen un saludo. No tienen en la cara cosa (de) sin ennegrecer.

P. Maisu Juan, ¿qué esperaba usted hallar aquí? ¿Hombres bien adornados? Miradlos bien de la cabeza a los dedos del pie: no manifiestan ni ojo ni cejas, a puro de negras: hermosos son los moros en comparación de estos. Un sombrero seco y reducido a la mitad en la cabeza, un pañuelo cubierto de hollin para recoger el sudor hasta el medio de la frente y aligerar el calor del fuego. Sólo camisón atado al cuello. No hay que pedir chaquetas, ni medias, ni abarcas, ni siquiera pantalom nes. Para echarse a la cama y levantarse no tienen a qué tomarse fatiga.

M. J. Eso es pues: ¿y de dónde son éstos hombres?

P. Bizkaino puros, que en sangre no le deben a usted nada.

M. J. ¿Cuántos oficiales son y qué jornal se les dá?

P. Son cuatro operarios: laminador, dos fundidores y el marmitón. Los jornales son proporcionados, pero si bien ganados. El laminador lleva más sueldo o jornal y éste suele llevar, después del jornal diario, propinas (lit. premios de placer). Si se hace mucho hierro, se gana mucho, si no poco. El pobre marmitón lleva los trabajos más duros y fastidiosos y la más corta ganancia.

M. J. ¿Cómo es eso en tierra de cristianos?

P. ¿No ha oído usted nunca lo que sucede en los 


\section{Catedrático de la lengua bascongada en la Universidad de Basarte o diá- logos entre un rústico solitario bascongado y un barbero callejero llama-}

Praile gaztechu edo sartubarrijac darue nequeric gogorrena. Ezta oneentzat bigungarriric: sendo sendó, osoz osó daruez aguindu guztijac. Alan biar da, jaquin daguijen cetara juan dirian. Lenengo urtian bigunegui balerabillez, ta euren burubetan icusi baga pisu guztija, guerom ra esango leuquee guzurtaubac gueratu ciriala, ogui biguna eracutsi ta emonaz birzaiz eguinico balz ta jangacha. Alan bada gatzamalliac bere, izanic sartu barrijac, icasten dabee neque andijen ta irabaci laburraren videz cer icharaten deutseen, ta gueroco obiaguaren penzudaan egonaz, igaro erraza eguiten jaquee, daruen biar gogor ta necatsuba. Cela alan, dinue euren artian, igaroco ditut iru urte, icasico dot biar eguiten; guero sartuco naz urtzalla; eguingo nas guizon oguija irabazteco duin, ta alan gueroco nequiai emongo deutseet arpegui, irabazte obiaz, ta gogorraguac icusita nagualaco. Lur argaleco munteguijan aci dirian landara gaztiac, iragoten badira lur coipatsuco basora, ezta esatecua ceimbat irabaci daruen; ta cein marduac guero aci: ez ala lur gozatsuti badaruez lur agorrera.

M. J. ¿Cer esan gura dabee icen oneec ljelia, Urtzallia ta Gatzamallia?

P. Ijeliac esan gura dau jjeztu, edo irunduten dabela burdiñia. ¿llcusi dituzu sarri gorulac, celan amulu edo quirru goruban biribilduba ijezten, edo iruten dabeen, moltsoti ari meia eguiteco? Bada Ola-ijeliac burdiña biribildu ta moltsotuta daguana, dacar miatubaz; ta esan guiñai iruten dabela. Beraz ondo ipinija dauca Ijeliaren icena. Esaten da barriz Urtzallia, cerren urtu eraguiten daben mia suteguijan, Icentetan da Gatzamallia, onec jaon, edo zaindu biar dabelaco lapicua, ta oni gatza ezarri edo emon. Au da beste iruren morroe edo otseiña leguez, aguinduten jacon guztija eguiteco, ta ljelia guztien jaola, iracasla ta buruba.

M. J. Eta ¿ce biar eguin biar dau bacochac?

P. Urtzalliac bete biar dau suteguija miaz; ezarri biar dan icatza, ta eguin biar dan guztija, agoia aterateco prestau artian. Auspuac gueratu ta atala gorituten imini, ta ecin esan beste cereguin ditu suteguijan. Lagunduten deutsee agoia su azpiti ateraten ijela ta gatzamaIliac, bacochac bere burdinaga edo palanquiaz. Ateraten dabee suteguiti aguirira, ez icerdi tanta, ta bero asco botabaga. Botaten dabee beera, ta chiriquiña edo burdin cato bat iraastsiric, darue gabipera. An ezarten deutsee atala oracarri ta quirtentzat. Gabi a ibilli dedin emoten deutsa ura ijeliac uraguiaz. Asten da durundija, orma ta conventos? (lit. casas de frailes). Los frailes jovencitos o novicios (lit. recièn entrados), llevan el trabajo más duro. No hay consideración para éstos: hacen sin titubear y por completo lo que se les manda ( 1 ). Así tiene que ser para que sepan a qué han ido. Si en los primeros años se les trataran demasiado blandamente, y sin ver todo el peso en si mismos, más tarde les pueden decir que quedaron engañados, enseñandoles pan tierno $y$ dándoles pan negro y difícil de comer, hecho con salvado. Asi, pues, también los marmitones, siendo recién entrados (en la fábrica); aprenden, por medio de trabajos penosos y poco retribuidos, lo que les espera, y estando pensando en los mejores que vendrán después (lit. en los de después), se les hace fácil, el pasar los trabajos duros y penosos que tienen que sobrellevar. Así, así-dicen entre si mismos-, pasaré tres años y aprenderé a trabajar; después entraré de fundidor, me haré hombre capaz de ganar el pan, y asi daré cara a los trabajos posteriores con mejor ganancia, porque ya estoy hecho (lit. estoy visto) a (trabajos) más duros. Las plantas jóvenes que han crecido en viveros de tierras flojas, si se las pasa al bosque de tierra sustanciosa, no hay qué decir cuảnto suelen ganar y qué robustas crecen después; no así si de la tierra fértil las llevan a la tierra seca.

M. J. ¿Qué quieren decir estos nombres: Iielea, Urtzailea y Gatzamailea?

P. lielea quiere decir que hila el hierro. $2 \mathrm{Ha}$ visto usted a menudo cómo las hilanderas, envolviendo el lino en la rueca hilan para hacer del pelotón (de lino) un hilo delgado? Pues el hilador de ferrería, al hierro que está redondeado y apelmazado lo adelgaza y podemos decir que lo hila. Por lo tanto, tiene bien puesto el nombre de Iielea. En cambio se Ilama Urtzailea, porque hace derretirse el hierro en el horno. Se le nombra Gatzamailea, porque este tiene que cuidar el puchero y echar o añadir a este la sal. Este es como el criado de los otros tres, para hacer todo lo que se le manda, y el laminador él es guardador, instructor y jefe de todos.

M. J. Y zque trabajo tiene que hacer cada uno?

P. El fundidor debe Ilenar el horno con mineral, echarle el carbón que se necesita y hacer todo lo necesario hasta preparar la masa para sacarla; detener el fuelle, poner candente la pieza accidental y no se puede decir cuantos otros quehaceres tiene en la fragua. Le acompañan para sacar la bola debajo del fuego el laminador y el marmitón, cada uno con su palanca. Lo sacan del horno al descubierto, pero no sin verter gotas de sudor y $\sin$ mucha calor. Lo echan a tierra y aplicándole las tenazas grandes lo llevan debajo del mazo. Mlli

(1) No es posible traducir litembente essa fruse. 


\section{do Maizu Juan" y hoy, gracias a ella, podemos reconstituir toda su com- plicada trama material y moral, curiosa y llena de misterioso encanto, y al}

lur berari icara eraguiten deutsana. Duarua agoia urtzalliac mallutzarpeti gabi-igunaren azpira. An asten da beste soñu, belarri atara ez eguiñac, zurtuten ditubana. ljeliac bere uraguiaz darabill gabija miats edo sarri, celan gura daben; ta ondo dan ura gueitu edo guichitubaz, beguira dagoca urtzalliari; ta iracasten deutsa cer eguin, nos aurreratu, nos atzeratu, ta nos albotu burdin oratzar edo agoia. An dira su chipristin urrinera duazanac: an ascatu ta bota eraguitia gueratu jacozan lojac, cepa ta chatarrac.

Alan igunpian ta mallupian apainduten dau agoia urtzalliac; gogortu ta chiquituten dau, ta erdibitu biar danian, iminten deutsa gatzamalliac achurra, ta gabimallubac emoten deutsan joaldi edo colpiaz erdibituten da; zati bata gueratuten da atal edo quirten eraatsijaz, cein daruen barriro suteguira; ta aric aurreraco biar edo lanac gueratuten dira ijeliarentzat, ceñi jagocan ijestea edo irutia burdiñia, ecarri artian burdin-barra izatera, emoten deutsala vitartian gatzamalliari uragia, gabija erabilli daguijan, berac aguinduten deutsan arintasun edo guelditasunaz. Amaitu dabenian urtzalla agoia zaindu dabenac, esan dogun biarguintzia, dua lotara gura dabenian; eta artuten dau bigarren urtzalliac beste agoe ta eguiquizunen arazo, ta arduria.

Gatzamalliac chiquíndu, edo jó biar dau agoe guztietaraco mia malluca chicar bategaz, batian belaunico daguala, bestean alboquerara etzunda, celan otuten jacon. Oni jagoca mandatubac eguitia nora nai; ta icuscarrija da vide aguiri ta caleetati ciar igaroten bere obrera erdi gorritu, erdi balcitubaz zaraguichu bat escu, edo lepuan dabeela. ardaua olaguizonai eruateco. Ecanduta dagozan beguijac, ez dira orregaitino mimberatuten. Oneec bai bene benetan irabazten dabeela jan biar dabeen oguija euren becoquico, ta corputz guztico icerdijaz. ¿Cer dinozu, Maisu Juan?

M. J. ¿Cer esan neiquezu? Ni baño buru obiagua zan, ola ta biarguintza au asmau ebana. Eta ¿ce on jatorco bizcaijari ola oneetaric?

P. ¿Ori itanduco cenduque? $\dot{i}$ Cer eguingo neusquijue nic neure basuetaco abe vicijai, olaric ezpalego? ¿Badacutsuz aimbezte baso ain ederto jantzijac? Igaroco baciña Bizcai guztico beresi ta mendijetara, etzenduque esango aimbeste egur ebagui leitequiala. Guizon bacocheco, ¿ceimbat milla arich, arte, pago, castaña? Bada azcoriac inausten ditu, ta subac daruaz eurrez leguez. Dirianac, eche-sucaldetan biar dirian apur batzubez os- le añaden un trozo para agarradero y mango. Para que ande el mazo, el liminador él da agua con la bomba. Empieza la resonancia, haciendo temblar las paredes y a la misma tierra. Lleva el fundidor la masa debajo del gran martillo a debajo de la viga de donde pende el mazo. Allí empieza otra música que asombra a los oídos no acostumbrados. El laminador con su bomba mueve el mazo con intérvalos o menudo, segün quiere, y aumentando o disminuyendo el agua suficiente, le está mirando al fundidor y le anseña lo que hacer, cuándo adelantar, cuándo atrasar y cuándo aproximar el tocho o la bola. jAllí si que hay chispas de fuego que van lejos! jAllí el soltar y el echar las suciedades, restos y re siduos que se le quedan!

Asi, bajo la viga y bajo el mazo adereza la masa el fundidor, la endurece y achica; y cuando es necesario dividirla, la pone el fundidor la azada, y con el golpe que da el mazo-martillo, la divide. Uno de los trozos queda adherido al mango, al cual lo llevan de nuevo al horno; y los trabajos de allí en adelante quedan para el laminador, al cual le corresponde laminar el hierro hasta convertirlo (lit. hasta llegar a ser) en barras (de hierro); y mientras tanto le da la bomba al fundidor para que ande el mazo con la rapidez o lentitud que él le manda. Cuando ha acabado el fundidor que ha cuidado el tocho el quehacer que hemos dicho, se va a dormir cuando quiere y toma el segundo fundidor la obligación $y$ el cuidado del otro tocho y trabajos.

El marmitón tiene que desmenuzar o pegar el mineral necesario para todas las masas, unas veces estando de rodillas, otras echado de costado, como se le ocurra. E este atañe el hacer recados a cualquier parte, y es de verle pasando por caminos descubiertos y a través de las calles con su camisón medio enrojecido y medio ennegrecido, teniendo en la mano o en el hombro un pellejito para llevar vino a los ferrones. Los ojos que están acostumbrados no se escandalizan (lit. se resienten) por ello. ¡Estos sí que ganan verdaderamente el pan que han de comer con el sudor de su frente y de todo su cuerpo! ¿Qué dice usted, Maisu Juan?

M. J. ¿Qué puedo decirle? Que era de mejor cabeza que yo el que inventó esta ferrería y este trabajo. ¿Y qué beneficio le viene a Bizcaya de estas ferrerías?

P. ¿Eso habría usted de preguntar? ¿Qué haría yo de los árboles de mis bosques si no hubiera ferrerías? ¿Ve usted tantos bosques tan hermosamente vestidos? Si pasara usted a los jaros y montes de toda Bizcaya, no diría usted que se puede cortar tanta leña. Para cada hombre ¿cuándos miles de robles, encinas, hayas, castaños? Pues el hacha los poda y el fuego los lleva como por delante. Todos, fuera de algunos pocos que se necesitan 


\section{mismo tiempo conservamos el más completo inventario de todo lo que se consideraba necesario a su trabajo y a su vida.}

tian, burdiñatuten dira esateraco, ta sartuten dabee cidar, ta urre asco. ¿Ceimbat irabazten eztabee icatzguiñar? ¿Ceimbat itzañac icatzac olara eruaten, errenterijetatic mia ecarten, burdiñia bera eraasten? Eta ¿ceimbat ola-guizonac eurac? Eta ¿ceimbat emparetan jaquee olajaunai gauzaac zucen badabilz? Ezta Bizcaijan arraa bete lur alperric galduten; besteric ezpada, toquiric agorrenian billatuten da iraurquina, ta eguiten da simaur edo satsa lurraren ongarritzat. Coipe bagaco lapicuac eztau aragui mamintsu ta mardoric eguingo, ezda simaur bagaco lurrac bere gari ta arto ugariric.

M. J. ¿Nun ló eguiten dabee, ta nos olaguizon oneec? D.custanaz gau ta egun dabill olia.

P. ljeliac badaucaz une luciac agoe aldi bacochian, ta emoten jaco astija ló aldijac eguiteco, ez zazpi ta zortzi ordu, baña bai ordu binaan leguez. Urtzalle batac agoia zainduten daben artian, guichi gora bera lau orduban, dua bestia lotara. Gatzamalle gaissuac, aurreratuta badauca bere mia jotia, aimbestian dabill; baña celan agoia aterateco uneetan lagundu biar deutsan urtzalliari, jó biar badau mia, ta zaindu lapicua, lua arina jabilco. Erdu neugaz oneen oetoquija ta oia icustera. Eztozu icusico ez uarcaric, ez etzun-toqui jaso ta adardunic. Lurraren gañian lastamarraga bat estalqui zantarragaz, ta burco ez obia. ¿Cer derichu?

M. J. Dacustanaz, capuchino ta cartujo batec baño vicitza gogorragua dacusee oneec.

P. Baj eguijaz: alan bere ez daquit nic cer dan bacocha bere burubaren jaube izatia, ta catebagaco vicitzia. Ez litzatequez guizon oneec egongo illa betian sartuta praile-eche baten gauza asco gaiti, ta gogorragotzat euquico leuquee illa beteco vicitza ezcutucua, emen negu guztico ló chaarra ta biar gogorra baño. Gurago dau otsuac baso vicitzia, jaatecua nequez billatu biarra, eche-chacur catiaz lotubaren eregu ta ogui biguna baño.

M. J. Baña celan ló eguin leije emengo gabiots, auspuen illeta soñu, ta subaren 'argui zabaldute, ta nosian beingo illundutiaz? Ate quisquet baten otsac esnaatu narua ni, ló zorro gogorrenian banago bere.

P. Maisuba, zez daquizu guizona guztira eguiten dala? ¿Ez dozu enzun errotarijari ez deutsala lua galerazoten errota-soñu jarraitubac, ta iratzartuten dala soñuba gueratuten bada? Gabijaren ots, ormaac icara iminten ditu- en las cocinas, se convierten por decirlo asi en hierro e introducen mucha plata y oro. ¿Cuánto no ganan los carboneros? ¿Cuánto los boyeros, llevando carbones a la fábrica, trayendo el mineral de las renterias, bajando el mismo hierro? ¿YY cuándo los mismos ferrones? ¿Y cuánto les sobra a los dueños de fábricas, si las cosas andan derechas? No se pierde inútilmente en Bizcaya un palmo de tierra; si no es otra cosa, en el sitio más seco se busca la maleza y se hace el estiẻrcol para abono de la tierra. Puchero que no tenga manteca no producirá carnes crasas y robustas, ni tampoco la tierra (de) sin estiẻrcol, trigo y maiz abundantes.

M. J. ¿Dónde duermen y cuándo estos ferrones? Por lo que veo, la fabrica anda noche y día.

P. El laminador tiene largos intervalos cada vez que se hace el tocho y se le da tiempo para dormir, no siete y ocho horas, pero si (ratos) como de dos horas cada uno. Mientras un fundidor cuida el tocho, unas cuatro horas con poca diferencia, va el otro a dormir. El pobre marmitón, si tiene adelantado el despachurramiento del mineral, anda regularmente; pero como en los intervalos de sacar el tocho tiene que acompañar al fundidor, si tiene que despachurrar el mineral y cuidar del pucheso, le anda ligero el sueño.

Venga usted conmigo a ver el dormitorio y la cama de éstos. No verá usted ni catre ni cama levantada y con patas. Sobre la tierra un jergón con cubiertas sucias y no mejor almohada.

¿Qué le parece a usted?

M. J. Por lo que veo, vida más dura sufren (lit. ven) estos que un capuchino y cartujo.

P. Sí, en verdad; y con todo eso no sé lo que tiene (lit. lo que es) el ser cada uno dueño de si mismo y el vivir sin cadenas. Estos hombres no estarian un mes entero metidos en un convento por nada del mundo (lit. por muchas cosas) y tendrian por más dura la vida retirada de un mes que aqui el mal dormir y el duro trabajo de todo el invierno. El lobo prefiere la vida de la selva, la necesidad de buscar el sustento con trabajo, al mimo y al pan blando del perro "casero atado con cadena.

M. J. Pero ¿cómo pueden dormir con el ruido del mazo (que hay) aqui, con la música fúnebre del fuelle $y$ con la luz del fuego esparcida y de vez en cuando apagada? El ruido de un pestillo de la puerta me suele despertar a mi, aun cuando estẻ en el sueño mảs profundo y diro.

P. Maisu: ¿no sabe usted que el hombre se hace a todo? 2 No ha oido usted que al molinero no le impide el dormir la música monótona (lit. seguida) de la rueda, y que se despierta si la música cesa? El ruido del mazo, 


\section{Por fin, siguiendo a D. Luis Barinaga, describe Zuaznavar la marcha de la operación de la siguiente manera: "La operación o calda de una}

banac, ez deutsa guilliric eguiten olaguizon lotan dagozanen belarrijai. Eta eurac iratzartuten dira ao chistubaz, soñuba joten dabenian biarrian daguanac.

\section{J. Eta ¿̌ce jaten dabee?}

P. lcatzguiñac baño lapico obia. Beteten dabee sabela ogui beratu ta ondo coipetuz, otuten jaqueenian, ta ezdozu zuc iños jan gauza gozuagoric. Escu atz ta ezpanac bere miazcauco cenduquez gozuaren gozoz. Nun illten da oleetan baño sesinguei, edo idi guicendubagoric? Andiquijac eurac datoz nos bait olara beste cereguin baga, oneen lapicuan oguija beratu ta coipetuta jatera; eta esan darue euren echeetan sesin ta urdai ederracaz lapicua eguinarren, esin dabeela ain gauza gozoric jan; ta neuregango dator au, suteguico icatz ondo erriaz gar baga iraquiten dabelaco emengo lapicuac gueldi gueldi gañecic eguin baga. Guizateguijan dau-

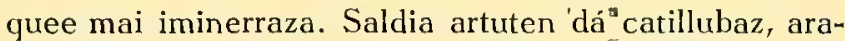
guija chiquindu ta aoratutaten dá atzamar Jangoicuac emonicuacaz; ura edaten da galletiaz, ta au da lau vici izatia ta asmo baga.

M. J. ¿Eta Peru, jango cenduque orreecaz mai baten?

P. Bai, ta igüin baga: ez neuque cocadaric eguingo, ez errebesau guraric eracutsico oneen obrera baltz ta escu cetacatubac icusi arren; eta derichat euren janguriac gueituco leuquiala neuria.

M. J. Eta ¿eztabee ardaoric edaten?

P. Ez egunoro ta guichiago bere. Asteazquenian dauqee edanaldi bat ola jaunaren lepora, ta nos edo nos zu ta ni orain leguez, itorrita cerbait emoten deutseenian euren icenian edateco.

M. J. Ori "niri esatia, da, ichi biar dogula cerbait edan daijen.

P. Bai, gura ezpadogu esan daijen atzeti biotz cimel, edo chimurtubac daucaguzala, ta dollorraren icenic eztau enzun gura guizon prestu batec.

M. J. ¿Ceimbat emongo deutsegu?

P. Guíchienez amasei laucoco bana, edo errialbico bat bijoen artian, ta au emon ezquero, "aguindu eguijezu gura dozun guztija.

M. J. Emon eguijezu bada bijoc gaiti, ta guero alcar aituco gara.

P. Ordu onian. Ijelia, eutsi au gure icenian sabel liortu orreec busti daizubezan.

lJEL. Esquerric asco; urte ascotan eguin dai zubela beste onembeste. Aguindu guri gura dozuben guztija. que pone temblando las paredes, no les hace cosquillas a las orejas de los ferrones que están durmiendo; y ellos se despiertan con un silbido de la boca cuando producen un sonido (lit. cuando pegan la música) los que están en el trabajo.

M. J. ¿¿Y qué comen?

P. Mejor puchero que los carboneros. Llenan la tripa con pan remojado y bien untado de grasa cuando se les ocurre, y nunca ha comido usted cosa más sabrosa. Se relameria usted los dedos y los labios de puro gusto. ¿En dónde se matan los bueyes mejor cebados sino en las ferrerias? Los mismos señores vienen algunas veces a la ferrería, sin más quehacer, a remojar el pan en el puchero de éstos y comerlo; y suelen decir que, a pesar de hacer el puchero en sus casas con hermosa cecina y tocino, no pueden comer cosa tan sabrosa; y esto viene, a lo que yo entiendo, porque hierven el puchero de aquí con carbón bien quemado de la fragua, sin llamas, poco a poco, sin rebasar. En el comedor (salón) tienen mesa fácil de ponerse. Se toma el caldo (con) en taza, la carne se parte y se lleva a la boca con los dedos dados por Dios; el agua se bebe con el acetre y esto es vivir muy llanamente y sin pretensiones.

M. J. ¿̇Y Peru comería usted con esos en una mesa?

P. Sí y sin asco: no tendría empacho, ni mostraría ganas de vomitar, a pesar de ver los camisones negros y manchadas manos de éstos; y me parece que su apetito acrecentaría el mío.

M. J. ¿Y no beben vino?

P. No diariamente, ni aún menos. El miércoles tienen ocasión de beber a costa del dueño de la fábrica y alguna vez cuando, viniendo (algunos) como ahora usted y yo, les dan algo para que beban en su nombre.

M. J. Eso es decirme que debemos"dejar algo para que beban.

P. Sí, si no queremos que por detrás digan que tenemos corazones enjutos o arrugados; y un hombre noble no quiere oir el nombre de ruin.

M. J. ¿Cuánto les daremos?

P. Cuando menos cada uno una (moneda) de diez y seis cuartos o entre los dos una de dos reales (1), y en dándoles esto ordéneles usted todo lo que usted quiera.

M. J. Déles usted, pues, por los dos y luego nos entenderemos.

P. Enhorabuena. Laminador: Tome usted esto en nuestro nombre, para que mojen ustedes esos secos estómagos (lit. vientres).

Lamin. Muchas gracias: que hagan ustedes otro tanto en muchos años. Ordénenos ustedes cuanto desean.

(1) Peseta. 


\section{forja podía dividirse en cinco períodos; se empezaba por pesar una carga de 487 kilogramos de mineral, que se quebrantaba bajo el mis-}

P. Nire lagun onec gura leuque agoia atera, apaindu ta iruten icusi. ¿Nos prest egongo da?

IJEL. Bere beriala; urreratu dedilla ciarzulora. Nua vidia edeguitera urten biar daben cepa-guejari.

M. J. Jesus, ¿au cer da? Emendi dua burdiña urtu guztia.

P. Ez Maisu Juan: au da miaren errauts ta loiquerija. Onelan garbitaten da burdiñia. Au astunago dan leguez gueratuten da ora bat eguinda suteguijan, ta urten dau gañeztu jacon loiquerijac cein gueratuco dan cepatuta.

M. J. ¡Oneec dira icustecuac! Aimbeste urte Bizcaijan eguin ta ¿oneec icusi baga egongo nintzan?

P. Auspuac guelditu ditube; orainche icusico dituzu bein banaan, nic len adierazo deutsudazan gauza guztijac. Ez da bardin enzutia ta icustia. Begui ichi edegui bateco icustia gueijago da icasteco, verba luceen jarduna ta equiña baño.

M. J. Asteguin ta arreta andi bategaz jarraituco deutseet biar guintza miragarri oneei neure beguijacaz, ¡Ai guizon gaisso ta errucarrijac! Igues "eguiten dot nic urrinera iraun ecinic agoetzar aren chipristina ta berotasuna. Ara celan dabiltzan burruca oratzarragaz zucendau ecinic, ta bere albo albuan... Oneec dira otsac: lurra bere badabil colpe bacochian... Peru, eguin eguiña: zuc esan ceunstana, ta icusi dodana. Badaruat cer esan. ¡O egun ederto igarua! Esaiozu orain ijeliari eracutsi daiguzala eche baltz onetaco toqui, erremienta ta icusquim zun guztijac.

P. Ijelia; eracutsi eijozuz guizon oni emengo zurculu, tresna, erremienta ta icusquizunac, ta esan eijozuz gueldiró ta banaan euren icen guztijac.

El tirador muestra a Maisu Juan todos los instrumentos, máquinas, etc.

M. J. Guizon ona, esaidazuz opicialen icenac, ta alan beste gauza guztijenac, bada gura ditut eruan paperian escribiduta.

IJes. Ona bada gueutati asi ta beste guztijac.

Olia.

Biarguinac lau.

Ijelia.

Urtzalla bi.

Gatzamallia.

Auspuac.

Auspo-ardatza.
La fábrica.

Oficiales cuatro.

El tirador.

Fundidores dos.

El prestador.

Fuelles, barquines.

Eje de id.

P. Este mi compañero quisiera ver sacar, aderezar y laminar la masa de hierro. ¿Cuảndo estará dispuesta?

Lamin. Inmediatamente. Que se acerque al agujero del través. Voy a abrir camino a la materia de la escoria que debe salir.

M. J. ¡Jesús! ¿̨Qué es esto? De aqui va todo el hierro fundido.

P. No, Maisu Juan: esta es la escoria y suciedad del mineral. Asi se limpia el hierro. Como éste es más pesado, queda en el crisol hecho una masa y ha salido la suciedad que le ha rebasado, la cual quedará endurecida y escoriada.

M. J. ¡Cosas de verse son éstas! Habiendo pasado (lit. hecho) tantos años en Bizcaya ¿hubiera estado sin ver estas cosas?

P. Han detenido los fuelles: ahora verá usted una por una todas las cosas que le he manifestado. No es lo mismo ver que oir. Para aprender es más el ver de un abrir y cerrar de ojos que el discurso e insistencia de palabras largas.

M. J. Con un gran placer y atención seguiré con mis ojos (a) estos admirables trabajos. ;Ay cuitados y pobres hombres! Yo huyo a lo lejos sin poder aguantar la chispa y el calor de aquella gran masa. Mirad como andan luchando con la enorme masa sin poder enderezarla, y junto a ella... ¡Qué ruidos estos! Aún la tierra se mueve en cada golpe... Peru, cabal: lo que usted me dijo y lo que he visto. Ya llevo que decir. ¡Oh dia bien transcurrido! Diga usted ahora al laminador que nos muestre los lugares, herramientas y todas las cosas que haya que ver en (lit. de) esta casa negra.

P. Laminador: muestre usted a este hombre los escondrijos, los trebejos, herramientas y obietos visibles de aquí; y digale usted luego poco a pcco y uno por uno todos sus nombres.

El tirador muestra a Maisu Juan todos los inst rumentos, máquinas, etc., etc.

M. J. Buen hombre: digame usted los nombres de los oficiales y asi de todas las demás cosas, pues quiero llevarlos escritos en el papel.

Lamin. Pues he aqui, empezando de nosotros, todos los demás:

Escamelac.

Chimbua.

Ujaiquija, edo uaguia.

Cañuba edo aisevidia.

Toberia.

Suteguija.

Beelarrija.

Aisa-arrija.
Brazos de los fuelles.

Chimbo, émbolo.

Bomba.

Ventilador.

Tobera.

Fragua.

Mango de hierro.

Pared trasera del horno. 


\section{mo martinete de la ferrería, y se reducía después a trozos, de cinco a seis centímetros, tamizándolos por una criba de tela metálica, cuyos agujeros tenían un centímetro, aproximadamente.}

Aga-arrija.

Ciarzulua.

Estolda-aldia.

Guzur-asquia.

Onda-asquia.

Tiquinoia edo erruedia.

Auspo pujoia.

Pujo-macurra.

Ardatz-nausija.

Tiquinoemnausija.

Zutoiac edo cepuac.

Cepo-amia.

Mazucarijac.

Gabija.

Gabiguna.

Boguia.

Aldabarrac.

Burcuac.

Jungudia.

Dendala.

Dendal-arrija.

Chimela.

Macubac.

Cateiac.

Guiltzac.

Curutziac.

Cepa-amia.

Cepotilluba.

Nardaquia.

Bergamalluba.

Bandijua.
Piedra en que se golpea el hierro.

Boca de trabas.

Vertedero de residuos, alcantarilla.

Pesebre falso.

Pesebre con fondo,

Rodete, turbina.

Tirador del barquín.

Tirador torcido.

Eje principal.

Turbina principal.

Cuatro postes de madera que sostienen el mazo.

Cuatro piezas de madera que, alternativamente, van metiéndose entre las palas de la turbina.

Mazo, martillo pilón.

Sostén del mazo.

Pieza de hierro que sostiene el gabigun.

Puntales del boga.

Cuñas grandes que ajustan los aldabar.

Yunque.

Apoyo del gabigun.

Piedra bajo el dental.

Llantas de la rueda.

Pieza grande de madera en que se apoyan los postes del martillo pilón.

Postes en que se apoya la rueda mayor.

Cadenas.

Llaves para apretar las llantas.

Cruces.

Sinónimo de auspopuici.

Escudo, pieza de piedra que se coloca tras el fogón para contrarrestar el efecto del fuego. Llámase también bergamaso.

Boca de salida del hierro.

Cuñas.

Horquillas.

Arcos.

Tejavana de la fragua.
Urculia.

Usteijac.

Arrogo echia.

Arragoia.

Achurra.

Epailla.

Durmiendia.

Biarguinen erremientac.

Orricaac

Chiriquiña.

Palanquia edo burdinagaac.

Mallubac.

Porroia.

Caicuba.

Galbaia.

Zaraac.

Paria.

Burdingaija

lcatza.

Idurija.

Mia.

Jancija.

Obreria.

Capelia.

Capela zapija.

Guizateguija.

Issilluba.

Sucalde tresnaac.

Topiña.

Topin-estalquija.

Catillubac.

Erretilluba.

Burdun zalija.

Bitsadera.

Galletia.

Toquijac.

lcazguelaac.

Auspoteguija.

Gabiteguija.
Montón de mineral.

Azada.

La pieza mayor de la ferrem tería: sirve de apoyo a todas las demás.

Tajadera.

La pala.

Las tenazas.

El gato.

Herramientas de los oficiales.

La criba.

La porra.

Las palancas.

Los mazos.

Los cestos.

El cuenco.

El pañuelo de la cabeza.

El mineral.

El cisco.

El depósito del mineral.

El carbón.

El camisón.

Marmita.

El vestido.

El salón donde comen.

El sombrero.

El cobertor.

El departamento del mazo.

Asiento, escaño.

Enseres de cocina.

La fuente.

El cucharón.

Las tazas.

La espumadera.

El material de hierro.

El sitio del barquín.

EI acetre.

Los lugares.

El almacén del carbón.

La masa del hierro, tocho o lobo.

El asidero de íd. 
Dividida la mena en dos partes, la que pasaba por la criba se llamaba grillada, y la que no pasaba era llamada mena resultando, si el mineral era bueno, próximamente del mismo peso.

Hecha la carga de combustible y mineral, se daba viento con toda la presión posible para que se propagase bien la combustión; y apenas comenzaba la corriente de aire, se manifestaban llamas azuladas de seis a diez centímetros de longitud. Poco tiempo después se disminuía el viento a 36 milímetros de presión y se tapaba con arcilla el sitio por donde habían de salir las escorias.

A medida que se consumía el combustible se rebajaba la altura de la carga y se añadía carbón húmedo y grillada, estratificándose por capas sucesivas, con intervalo de ocho minutos de carga a carga, continuando así durante hora y cuarto próximamente.

El segundo período era de sesenta y nueve minutos, y se aumentaba la presión del viento a 45 milímetros, haciéndose nueva carga rociándola bien con agua, a fin de impedir un consumo inútil de combustible. Siete

Miateguija.

Agoia.

Atala edo agoequirtena.

Bertaaguia.

\section{Pieza de madera con que se carga el carbón al cesto.}

La mitad del agoe provista del mango.

Los residuos de hierro.

Mitad del agoe sin el mango.

M. J. Noc asmau ete cituban aimbeste icen, ta tresna?

P. Biarrac, ta demporiac.

M. J. Emengua icusita dago, ta guazan, Peru gura badozu ceure echera.

P. Ondo dinozu, bada eztago urrin egubardija; baña esquerrac emonaz, eguin daijegun agur gozo bаnа guizon onei.

M. J. Bai, esan eztaguijen dongaro acijac gariala. Aurra bada esan daijuegun aldabatera... Agur guizonac esquerric asco eguin deuscuzuben arrera ona gaiti, aguindu guri aldaigun edocein gauzatan.

I.os oriciates. Zeubei esquerrac emon deuscuzun diruba gaiti. Ondo ibilli, osteraco artian.

P. Asco da goiseraco cer iguinic: guazan echera ecertan gueratu baga, ta jan ostian urtengo dogu deste gauza batzuc icustera.
Belaiquija.

Burutia.

Chatarraac.

Tochuba.

Galdabatecuac.

Burdin-barria.
Cuatro pinzas con que se parte el agoe, lobo.

La barra de hierro.

Hierro viejo.

Tocho (trozo de hierro).

Asidero.

Palanqueta.

M. J. ¿Quién habrả inventado tantos nombres y trabajos?

P. La necesidad y el tiempo.

M. J. Está visto lo de aquí y vayamos, Peru, si usted quiere, a su casa.

P. Dice usted bien, pues no está lejos el mediodia; pero, dando las gracias, hagamos a estos hombres los correspondientes saludos...

M. J. Sí, para que no digan que somos mal criados. Ea, pues; digámosles a un tiempo... Adiós, hombres, muchas gracias por la buena acogida que nos han hecho ustedes: mandennos en cualquier cosa que podamos.

Los oficiales. A ustedes las gracias por el dinero que nos han dado. Anden ustedes bien, hasta otra vez.

P. Basta de quehacer para la mañana: vayamos a casa sin detenernos en nada y después de comer saldremos a ver otras cosas. 
cuartos de hora después de empezada la operación, se cargaba en vez de grillada cierta cantidad de las escorias que se separaban de la última $z a-$ marra o agoa, y al cabo de dos horas se habría por primera vez el agujero para salida de escorias, que resultaban espesas; y rociadas con agua, se volvían a la forja recubriéndolas de carbón por ser ricas en hierro metálico.

El tercer periodo duraba cuarenta y dos minutos. A las dos horas y veintidós minutos de la carga inicial, se aumentaba más la presión del viento hasta 63 milímetros y se rebajaba un poco la altura del mineral, introduciendo entre su masa y las piezas que forman la chapa de la vena un espetón, y sirviéndose de él para llevar hacia la tobera la parte inferior de la carga; entonces se agregaba mena, y se continuaba añadiendo carbón, grillada y agua, hasta que poco antes de pasar las tres horas, se hacían correr de nuevo las escorias, dejando abierto el agujero de salida, hasta que la llama que salía por éste se hacía blanca y brillante, como la producida por la comdustión del hierro en el oxígeno, en cuyo momento se volvía a tapar.

Cuarenta y cinco minutos duraba el cuarto período, aumentando la presión del viento hasta 72 milímetros a las tres horas, repitiéndose las mismas operaciones que en el anterior, volviendo de nuevo al horno las escorias demasiado espesas; durante este período, especialmente al terminar, se recubría el carbón incandescente, de una ceniza amarilla, semejante en su aspecto exterior al azufre.

El quinto y último período era de ciento treinta y tres minutos, y haciendo tomar al viento toda la presión posible, se cargaban alternativamente carbón y mena; el mineral había desaparecido por completo bajo la capa de carbón, y éste ardía en toda la superficie del hogar con una llama algún tanto azulada; poco después se daba salida a las escorias y se proyectaba por el agujero de escorias la llama, con un ruido semejante al de un trueno lejano. A las cuatro horas y diez y nueve minutos se cargaba bien de carbón, se hacian correr las escorias, que ya eran bastante fluídas, y se volvía a introducir mineral por la chapa de la parte de la vena.

A las cinco horas y media se redondeaban las aristas que la masa de hierro formada tenía en la parte del ciarzulo, y se introducía en la forja 
un espetón, con el cual se buscaban los trozos de hierro que estaban diseminados en la masa de las escorias y se unían al trozo principal.

Formada la zamarra o agoa, del mejor modo posible, se arrimaban bien los trocitos de hierro adheridos a las caras del crisol.

A las cinco horas y cuarenta y tres minutos la llama se hacía blanca y brillante, lo que indicaba que se quemaba algo de hierro. Se separaba el carbón que recubría la zamarra o agoa, reuniéndole o apagándole en la banqueta, y con una gruesa palanca la hacían desprender los operarios del fondo del hogar.

Cuando se sacaba del fuego se encontrada al rojo blanco, se dejaba enfriar un poco, y se llevaba al martinete, para darle compacidad con los golpes, dividiéndola después en tres segmentos.

El aspecto de las escorias indicaba la marcha de la operación; si ésta iba bien, debían ser de un negro azulado y bastante fluídas; las primeras escorias eran muy ricas en hierro y por esto volvían a las cargas.

El hierro producido era nervioso, duro, muy maleable y muy tenaz; pero poco homogéneo, porque contenía en su masa muchos granos de acero, y porque las escorias no se separaban perfectamente de la zamarra, y le hacían algo poroso.

Podian producir dos clases de hierro; el dulce y el acero natural.

El consumo de carbón en las ferrerías era enorme, lo cual recargaba extraordinariamente el coste de su fabricación.

Se consumían en las ferrerías vascongadas siete cargas de carbón que pesaban próximamente 560 kilogramos; y teniendo en cuenta el peso de la zamarra obtenido y la merma al convertirlo en hierro del comercio, se deduce, que el consumo total de carbón para obtener 100 kilogramos de hierro llegaba a 463 kilogramos.

MM. Petigand y Bonna, en una nota de la traducción francesa de la obra del Dr. Percy, ${ }^{(1)}$ consignan como consumo de carbón para las ferrerías:

En Francia más de 3 de carbón por 1 de hierro. En España ... 4,5 y 5,5

(1) Tomo II, pág. 491 . 


\section{En Calabria .... 4,25 de carbón y 6 de hierro.}

En Córcega ....8

D. Carmelo Echegaray, mi respetado y erudito amigo, ha podido consignar el dato interesante de que en aquellos tiempos como ahora, cuando los Reyes de España caminaban en compleja comitiva hacia la frontera de Francia, detenían su peregrinación un momento, para contemplar en las ferrerías de Beasain establecidas junto a la carretera, la manera de hacer el hierro. Y de este modo, lo mismo que en 1615 Felipe III, más tarde y en 1660 Felipe IV, cuando para dar cumplimiento a la Paz de los Pirineos, recientemente firmada en la Isla de los Faisanes, caminaba acompañando a su hija María Teresa de Austria, que marchaba a ser la esposa de Luis XIV, sentaban un precedente de lo que centurias después había de hacer en pleno siglo xx nuestro Monarca. 


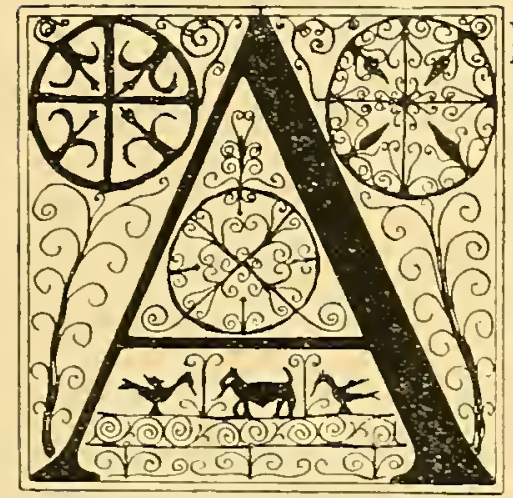

L TERMINAR EL SIGLO XVII, APARECE PRIMEro en Extremadura y más adelante en toda la zona de Salamanca y Zamora por el N. y Andalucía hasta el Guadalquivir por el S., un curioso estilo de ornamentación, recuerdo tal vez de modelos primitivos, pero más fácilmente quizás, producto espontáneo de una técnica sencilla y personal, nacido sin grandes pretensiones, decorando los útiles más caseros, y encerrando precisamente en ello, en haber nacido humilde y no haber salido apenas de entre la gente del pueblo, una parte muy grande del secreto que guarda su espiritualidad y su gracia.

Son las características del estilo, una, el decorar por volutas repetidas y superpuestas, con frecuencia en sólo una circunferencia incompleta, rarísima vez por múltiples circunferencias concéntricas como en los ejemplares románicos; otra, el empleo de la figura como elemento de decoración, pero no modulada, sino únicamente siluetada en plancha llena; como en las volutas, el motivo se repite a lo largo de una trayectoria sencilla, pero el ejemplar es variado; un caballo, un león, un toro, y así varios animales colocados en fila, recortados gallardamente, en la plenitud de su movimiento y de su vida, forman una a modo de cenefa, de friso o de coronamiento, a una superficie geométrica sencilla, por ejemplo un rectángulo, macizado todo él por series de volutas que se repiten paralelas.

Falta decir para completar la determinación de esta escuela, que trabaja siempre sobre una superficie; plana o curva, parece como si todo el ejemplar hubiera sido perforado por una moderna prensa de estampar, sin que el detalle de una figura, ni el extremo libre de una voluta, se hubieran separado de la superficie de la plancha de que procede; y es ello tanto más curioso cuanto que el procedimiento de fabricación ha sido muy 
otro, obteniéndose el conjunto por trabajo de forja, que modula uno a uno cada elemento de la ornamentación del conjunto.

No podía ser extraña la escuela que describimos, al ambiente general de su época. La yustaposición de elementos decorativos sin un plan marcado y preciso, vimos que fué característica del siglo XVII en sus modalidades barrocas; del mismo modo se conservaron los motivos geométricos, haciéndolos ampulosos y repetidos; consecuencia de todo ello fué que desapareciese casi por completo el elemento utilitario del ejemplar, oculto tras un macizo de ornamentación floral y geométrica; esta escuela extremeña, por ser popular y modesta, simplificó la ornamentación, pero conservó su esencia, las superficies aparecen como macizos de decoración yustapuesta hasta el punto de que apenas se puede precisar la finalidad utilitaria de algunos de sus ejemplares como terminamos de decir que sucedía en las piezas de arte barroco y que presenta con ellos la diferencia, de que la extremeña, dá la sensación de trasparencia y la barroca no; pero seguramente este último detalle que llena de gracia los ejemplares extremeños, fué consecuencia de una imposición económica, que se produjo quizás con verdadero pesar de los artífices que los labraron. Son las dos obras más importantes de esta época y de este modo de de hacer, y las que marcan por otra parte de una manera más definida, tanto la escuela extremeña como su aclimatación en el Sur de España y más concretamente en Sevilla, el torna-puntas o brazo de lámpara existente en la Catedral de Coria, y la Cruz de la Cerrajería hecha en Sevilla en los finales del siglo XVII por Sebastián Conde. Esta última, muy principalmente, marca una nueva orientación en el arte de la cerrajería, porque combinándose con las orientaciones francesas que llegan a España, dan la norma para una parte considerable de nuestras obras decadentes del siglo XVIII. En ellas trabajando por silueta con una interpretación geometrizante parecida a la que se hizo en tiempos de Felipe II, pero sin el espíritu de aquellas obras, dan por una parte la impresión de ampulosidad por medio de curvas y contracurvas de gusto rococo, importadas de Francia, y por otra la pobreza de una fabricación que trabaja por línea en barra de sección rectangular, no colocada en arista y sin la valentía que supone la forja de trozos macizos, apareciendo 
como un dibujo recargado y complejo hecho con trazo grueso, sin la vida que daba a las composiciones anteriores el juego de luz, que resultaba de los macizos, de los repujados y de la colocación de sus barras cuadradas, siempre en aristas.

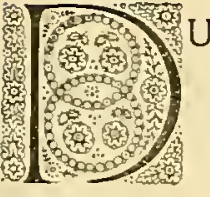

URANTE este tiempo, también, y en contraposición a lo que ocurre con las grandes producciones de un carácter francamente arquitectónico, la cerrajería y el trabajo minucioso de detalle adquiere una preponderancia y un interés extraordinario. Es digno de notar que, precisamente cuando nuestros rejeros del siglo xvi terminaban de hacer sus obras más geniales, la cerrajería y el trabajo a cincel, es decir, todo lo que es labor minuciosa y detallista se encuentra en España en una manifiesta decadencia, que empieza a recobrar categoría poco a poco, y va adquiriendo valor y mérito a medida que el arte de la forja va perdiendo progresivamente en importancia; y cuando en los finales del siglo XVII y todo el XVIII, puede decirse que nuestros trabajos de forja apenas tienen otro interés que el de imitaciones vulgarísimas de las obras francesas, los cinceladores llegan al apogeo de sus obras, trabajándose ejemplares de una maravillosa perfección y gusto. Es decir, que las grandes concepciones de nuestros rejeros y el trabajo detallista de los cinceladores y cerrajeros, se han desarrollado en España siguiendo dos evoluciones rigurosamente inversas.

Es una demostración de esa marcha progresiva del arte de la cerrajería en nuestro suelo desde el siglo XVI al XVIII, en primer lugar, la documentación publicada por el Sr. Rico Sinobas, referente a los cinceladores españoles de finales del siglo XVI, en la que comenta la comunicación dirigida al rey Felipe II, manifestándole, que, para enseñar el arte del cíncelar a la española, el artífice Bartolomé Somarriba era muy poca cosa; que el cincel de Alonso de Vallejo, para galanterías y follajes en metales duros era mal acondicionado y muy escabroso; que Diego de Nalda y Pedro de la Puente, estaban impedidos, el uno por falta de vista y el otro por estar 
casi tullido de las dos piernas, por lo cual se había suplicado muchas veces a Su Majestad se trajesen de fuera de estos Reinos, algunos artífices fundidores y cinceladores en bronce y hierro, pues de otro modo no habría medios para remediar tan importante falta; no dando al olvido lo que manifestó el Consejo de Guerra a Su Majestad con fecha 22 de Septiembre de 1590, llamando la atención sobre los grandes inconvenientes de que en la España ferrera, a fines del siglo XVI, no había ya quien supiera hacer un arnés completo, por lo cual convendría traer de Milán un par de buenos maestros.

Es muy curiosa la serie de vicisitudes que ocasionó la determinación del Rey, trayendo, en efecto, a la fábrica de Eguí, en Navarra, artífices extranjeros, de los cuales los navarros y vascongados, se negaron o poco menos a aprender, mientras aquéllos por su parte hacian todo lo posible por ocultar sus procedimientos de trabajo; tuvieron de todos modos estos esfuerzos oficiales un feliz resultado, y hallaron su complemento cuando a mediados del siglo XVII vemos al Cardenal Infante, que al retirarse a Madrid terminadas sus campañas de Flandes, protege a un núcleo de buenos cinceladores, que, a base de aquella protección en un principio, y a su valor intrínseco después, evolucionan, crean la llamada escuela de Madrid, de la que es maestro y genial inspirador Alonso Martínez, y al terminar el siglo, sus trabajos constituyen poco menos que la admiración de los artífices extranjeros, mientras el arte de la forja en general inicia su decadencia.

La certeza de esto último lo demuestran diferentes documentos, en los que consta como los cerrajeros, cinceladores y armeros extranjeros trabajan imitando las obras españolas, sin al parecer, conseguir igualarlas. El caso es que en nuestros mercados de América se venden las obras españolas con un marcado sobreprecio respecto a las inglesas y francesas, hasta el extremo de que los de aquellos países para trabajar en América falsifican nuestras producciones y las imitan en todos sus detalles, mientras nosotros, que en la ejecución éramos los primeros, en la composición y en el dibujo, copiábamos sus tipos y sus modelos. Es notable el hecho citado por el Sr. Rico y Sinobas, de que precisamente ese contrabando que hacia el año 1800 llega al apogeo más escandaloso, es una de las 
causas de la decadencia de nuestro arte de cincelar que termina con la llamada escuela de Madrid y con la propia de las provincias vascongadas.

El límite de la habilidad entre los cinceladores y cerrajeros tiene lugar, sin género de duda, en este tiempo de franca decadencia de las artes del hierro, quizás como consecuencia de la evolución de generaciones educadas en estos trabajos de minuciosidad y paciencia, y se cuenta de Antonio Gutiérrez, herrero relojero y arcabucero, que cierto día, le enseñó la Reina Amalia, esposa de Fernando VII, una aguja inglesa de coser, lamentándose de la imposibilidad de adquirirlas en España, lo que le obligaba, dada su afición al bordado, a tenerlas que mandar traer de Inglaterra; rogó el maestro a la Reina le dejase una aguja para examinarla, y transcurrido que fué un corto espacio de días, se la devolvió acompañada de la que él había hecho. Cuéntase que la Reina celebró la perfección de la obra, y entonces el maestro Gutiérrez pudo decirle que la pieza que tenía en la mano no era la aguja sino el alfiletero que la encerraba. ${ }^{(1)}$

De aquella escuela de Madrid de cinceladores y cerrajeros que vemos se organiza por la iniciativa del Cardenal Infante, y que después continúa dando ejemplares de una labor maravillosa, fué maestro a mediados ${ }^{2}$ del siglo xviII, un tal Pedro Pastrana, quien en 1738 labraba los artísticos herrajes de la puerta de la Catedral de Sigüenza. Poco después modifica este artífice las condiciones generales de trabajo en el gremio, introduciendo aplicaciones mecánicas y piezas fundidas, que hasta dicha época apenas se habían empleado para otra cosa que para la confección de cañones, y que son la primera manifestación de una evolución en el sentido industrializado que caracteriza la cerrajería moderna; porque si bien en tiempo de $\mathrm{Pe}$ dro Pastrana, mediante la adición de elementos fundidos adquiere la obra un mayor realce y suntuosidad, pierde el mérito especial y la espiritualidad característica que les comunicaba el obrero al ser todas aquellas, por necesidad, forjadas a mano.

(1) Orduña.-Rejeros españoles. 
- Fr. Tr. 21.:2 de de las circunstancias económicas porque atraviesa el país. La decadencia del arte del hierro llegó a su fecha más culminante a mediados del siglo XviII, como puede comprobarse por la relación de las ferrerías que trabajaban en Vizcaya, pues nos encontramos con que de las trescientas que, en mayor o menor escala, elaboraban el hierro en los últimos años del reinado de Felipe II apenas si la mitad trabajaban al mediar el reinado de Felipe $V$.

Esta general decadencia fué quizá menos profunda en toda la región de Cataluña, donde al finalizar el siglo XVII, continuaba el gremio con un número considerable de asociados, a los que representaba en el Consejo de Ciento, el Canciller maestro Miguel Dalé, y poco tiempo después, cuando Cataluña se decide por la causa del archiduque y organiza sus tropas contra Felipe $\mathrm{V}$, se crea exclusivamente con cerrajeros y agujeros la 4. ${ }^{a}$ compañía titulada de la Santísima Trinidad mandada por el maestro Ignacio Sanahuja, batiéndose denodadamente en los años de 1713 y 1714, y más especialmente durante el sitio de la ciudad.

Al terminar el siglo xVII, nos dice el $\mathrm{P}$. Henao en sus "Averiguaciones de las antigüedades de Cantabria", (1) "que por los años de 1658 las herrerías del Señorío de Vizcaya eran 107 mayores, en que se labraba la primera vez en barras grandes el hierro que llaman tocho, y 70 menores, en que se adelgaza y perfecciona el hierro que proporcionan las mayores. El hierro que labraban se calculaba en cien mil quintales, poco más o menos». Terminada la Guerra de Sucesión, e iniciada por Felipe V una reconstrucción industrial del país, se da vida en Liérganes y en la Cavada, a ingenios donde se trabaja el hierro, haciéndose con la balería y otros pertrechos de artillería, la ayuda correspondiente para el servicio de los navíos. ${ }^{(2)}$

De esta misma fábrica escribía años más tarde el Marqués de la En-

(1) Henao.-Antigüedades de Cantabria.--Salamanca, 1689.-Pág. 209.

(2) Jerónimo Gustáriz. -Theoría y práctica del comercio y de la marina.-1724. 
senada, Secretario del despacho de Guerra, Hacienda, Marina e Indias, en exposición dirigida a Fernando VI en 1748, lo siguiente: "Las fábricas de fierro de la Cavada y Liérganes en la montaña su dueño el marqués de Villacastel, son las celebradas de toda Europa, porque la materia de las de Francia, Holanda, Inglaterra y Alemania es muy vidriosa". Y más tarde, el Intendente de Marina ${ }^{(1)}$ D. Juan Antonio Enriquez (Ministro principal de Marina, como entonces se llamaba), en sus memorias dirigidas a Carlos III en 1787 sobre las fábricas de anclas de palanquetas de baterias de fierro, la fondería y otros establecimientos en la provincia de Guipúzcoa, al ensalzar la perfección a que habían llegado los vacongados en las fábricas de anclas y otras de efectos también de hierro, decía que «Su Majestad, derramando el oro de Real Erario sobre los aplicados guipuzcoanos notariamente hábiles para todas las obras macizas, le corresponden éstos con útiles pertrechos para su Real Armada y el Ejército, verificando con más propiedad lo que se cuenta de Midas, que saben por sus laboriosas tareas convertir el tosco fierro de sus minas en el fino oro que producen las ambas Américas.»

Según datos oficiales recogidos en el Señorio de Vizcaya, el número de ferrerias existentes en 1796 en esta provincia era de 154, dando una producción anual de 7.300 toneladas, y, poco más tarde, al publicarse el Diccionario de la Academia a principios del siglo XIX, existían, según sus autores, 180 ferrerías, extrayéndose anualmente 4.000 toneladas de vena de la comarca vasca denominada las Encartaciones, para con ella abastecer las 280 ferrerías que existían en las provincias de Alava, Guipúzcoa y Vizcaya, inclusas las mismas Encartaciones, otras de Navarra y del valle de Mena, montañas de Santander y Principado de Asturias. La guerra de la Independencia hizo sentir sus efectos en la vida de las ferrerías, y según datos oficiales, en 1816 la producción fué de 3.660 toneladas y en 1830 había nada más que 127 ferrerías en actividad.

Por esta misma época, el año de 1832, funda el Sr. Heredia en Marbella el primer establecimiento siderúrgico industrial, con horno alto, y algunos años después, en 1849, se funda en los arrabales de Bilbao la fá-

(1) D. Benito de Alzola.-Estudio relativo a los recursos de que la industria nacional dispone para las construcciones navales. Pågs. 18 y siguientes. 
brica de Santa Ana de Bolueta, siendo este, el golpe de gracia para la vida de las ferrerías que ya estaba en plena decadencia. No obstante, tardaron en aclimatarse en Vizcaya los altos hornos, el número de ferrerías que existian en las provincias vascas fué disminuyendo paulatinamente, como no podía menos de suceder, mucho más desde que el año 1859 se estableció en Baracaldo la fábrica de Nuestra Señora del Carmen, base de la manufactura actual, donde se establecen los primeros hornos para obtener el hierro dulce de la esponja metálica, por el procedimiento Chenot, los cuales en número de ocho funcionaron hasta el año 1871, en que ya se abandonan, pues si bien llevaban grandes ventajas a las forjas catalanas, eran casi tan costosos como los altos hornos al carbón vegetal, por cuyo sistema indirecto se obtenía a la sazón, en la misma fábrica, el hierro laminado en barras. ${ }^{(1)}$

La época de florecimiento relativo que se desarrolla en las vascongadas poco después de mediar el siglo xviII, tiene una explicación lógica y natural en la meritísima labor realizada por aquel entonces por un número de entusiastas del progreso y del adelanto de la nación, que reunidos primero en Azcoitia y después en Vergara, constituyen la Sociedad Bascongada de Amigos del País, y desde el año 1768 intervienen directamente en todo lo que sea fomento y adelanto de la industria siderúrgica de la región.

Un curioso estudio financiero redactado dentro de la Sociedad, por D. Tomás de Robles el año 1768, hace el cálculo detallado del coste de una libra de acero, del precio de un quintal de hierro reducido a clavos de herrar, cuchillos, tijeras, agujas y otros elementos fabricados con hierro y acero de la región, ${ }^{(2)}$ constituye un prólogo extraordinariamente curioso a aquella obra tan meritoria de la Sociedad Bascongada de Amigos del País, origen, como es sabido, de todas las Sociedades Económicas de Amigos del País, que, repartidas por España, fueron el mayor elemento de progreso en los últimos años del siglo xvIII.

El año 1771 en la junta general celebrada en Vizcaya por esta Socie-

(1) Alzola.-Obra citada.

(2) Extractos de las Memorias y juntas generales celebradas por la Real Sociedad Bascongada de Amigos del País en distintas localidades. Facilitados por la Biblioteca de la Sociedad bilbaína, gracias a la cooperación de su ectual bibliotecario D. Alvaro de Gortázal. 
dad, se da cuenta de una Memoria sobre calcinamiento de venas, aparatos soplantes o barquines y manufacturas de hierro, y buscando el modo de perfeccionar la fábrica de cuchillos en Vergara, enlazando su gestión con la de la Real Compañía General de Caracas, pretende hallar nuevos mercados para los talleres que trabajan en la región, interviniendo asi del modo más eficaz en el progreso y desarrollo de la industria, pues no sólo se preocupa la Sociedad Bascongada de Amigos del País de lo que pudiéramos llamar técnica de la fabricación, sino también de crear los correspondientes mercados en España y fuera de España, para que las sociedades creadas como consecuencia de sus iniciativas, tengan una vida económica adecuada a sus necesidades.

Desde esta fecha vemos constantemente que esta Sociedad interviene en la marcha de las ferrerías en Vizcaya, y así vuelve, el año de 1772, a publicar una segunda Memoria sobre calcinamiento de venas, barquines y obras de agua en una fábrica de hierro, acompañando un curioso estudio sobre las ferrerías de Suecia, y una comparación entre los distintos barquines de tabla, llegando a conclusiones en extremo curiosas é interesantes.

Continúa su labor por todo lo que se refiere a la parte comercial de los diferentes establecimientos, y empieza a hacer el estudio crítico, preparatorio de los trabajos de implantación del entonces asombroso procedimiento de Reaumur sobre el arte de convertir el hierro en acero, que fué por aquellos días la última palabra de la siderurgia moderna fuera de España.

De igual manera podíamos ir mencionando la labor de esta Sociedad en los años sucesivos, hasta llegar a su intervención social en las ferrerias, publicando Memorias, que no sólo tratan del establecimiento de nuevas fábricas creando las compañías de ferrones para perfeccionar la fundición y laboreo del hierro, sino también de las relaciones sociales entre los mismos ferrones y sus oficiales. Consecuencia de su labor fué que la guerra de la Independencia no anulase de un modo definitivo una industria establecida sobre bases tan detalladamente estudiadas, siendo lástima que en los años que sucedieron a la guerra interviniese de un modo menos directo en la vida económica, moral y financiera de la región. 


\section{De todos modos, que la industria del hierro continuaba siendo en Viz-} caya la clásica y fundamental, lo demuestra en esta época el hecho notable de que el Señorío obsequiase a los Reyes sus Señores, D. Fernando VII y Doña María Josefa Amalia en el viaje realizado a dicho Señorío el año 1828, presentando a SS. MM. un carro triunfal de hierro, obra del país, para que entrasen en él a la villa de Bilbao. ${ }^{(1)}$ Después la evolución de la técnica, antes relatada, lleva la industria al estado en que todos la conocemos.

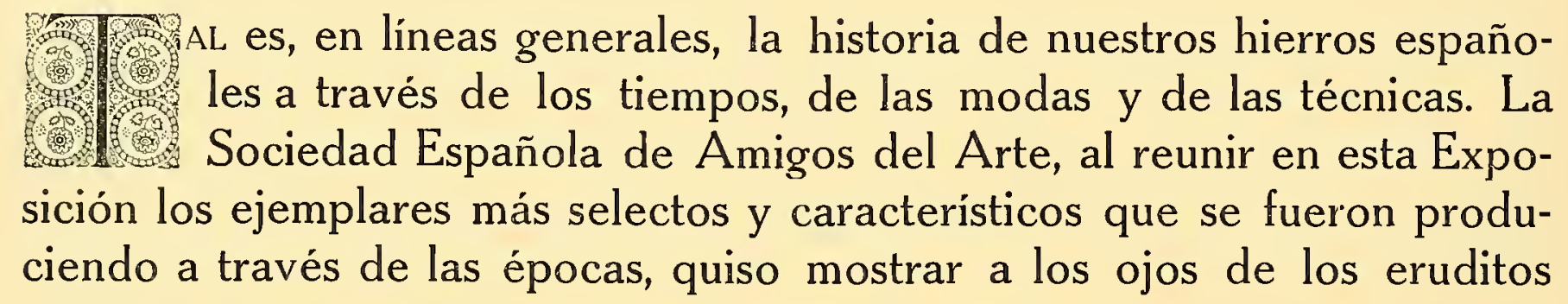

(1) Esta nota la debemos a la amabilidad de nuestro particular amigo, el sabio arqueólogo D. Juan Allendesalazar, que graciosamente nos la ha procurado.

Relación de los festejos con que han sido obsequiados los Reyes y Señores Don Fernando VII y Doña María Josefa Amaíia en el M. N. Y. M. L. Señorío de Vizcaya, desde el día 14 de Junio de 1828, en que pisaron su suelo, hasta el $26 \mathrm{del}$ mismo en que salieron para la ciudad de Vitoria._Con licencia._Bilbao, imprenta de Dorozábal.

«A las nueve y media de este día ha sido el precioso momento del arribo de SS. MM. al punto llamado del Morro, sitio en la carretera de Castilla, en donde han sido recibidos por una Comisión de la Diputación, compuesta de los dos segundos Diputados y Rejidores y escoltada por veinte caballos, cuyos jinetes llevaban el traje de Moros Abencerrajes. La Comisión ha presentado a SS. MM. un carro triunfal de hierro, obra del País, ejecutado en el corto espacio de treinta días, y se han dignado aceptar SS. MM. entrar en él para bajar a esta Villa, tirándole...»

Bilbao y Junio 16 de 1828 . (Parte oficial de este día redactado en Bilbao).

«Este cortejo estaba destinado para recibir a SS. MM. en el punto llamado del Morro, que se había hermoseado por los cuidados del caballero corregidor a dos tiros de bala de la jurisdicción de esta Villa, y presentándole el bellísimo carro de triunfo, construido en Durango, bajo la dirección de D. Manuel de Naveran, por D. Juan de Iparraguirre. La figura es parecida a la de una bonita jaula; en la proa tiene una chapa de bronce con las Armas Reales y las del Señorio en relieve. A los costados de los asientos dos leones de bronce que sirven de apoyo a los brazos; debajo de éstos, por un codo, los cuernos de la abundancia y por el otro los jeroglíficos de la Religión: en el respaldo una lápida de chapa de hierro bruñida y pavonada, con una inscripción de bronce en relieve que dice:

\footnotetext{
Con su industria Ios honores

Hace Vizcaya gustosa

A Fernando y a su esposa

Sus legítimos Señores.
}

A la derecha se ven los atributos del comercio y a la izquierda los de la agricultura. El asiento y la espalda están forrados de terciopelo encarnado, con galón y fleco de plata, y encima tiene una corona de hierro perfectamente bruñida, sostenida por medio de cuatro varillas y cubierta interiormente con tafetán carmesí. El armazón, rueda, ejes y lanza son de hierro: los costados y parte safuera están cercados por una fresa seguida de hojas de bronce. Su Majestad se ha servido aceptar esta carroza y será sin duda un monumento que hará siempre honor a la industria de este pais en que ha sido elaborado.» 
como a la fina sensibilidad del estudioso, una página abierta de la historia de la cultura de nuestra patria, su grandeza no igualada por nación alguna en aquellos reinados que supieron organizar un pueblo que tomaba Granada y vencía en Lepanto, como la dolorosa decadencia que más tarde sufre su industria, cuyas sensibles consecuencias aun se palpan en pleno siglo xx a pesar de los esfuerzos laudables y provechosos de aquella Sociedad Bascongada de Amigos del País.

$Y$ en estos momentos en que las civilizaciones pretenden buscar nuevos caminos, y en que los hornos altos, base de las técnicas hasta hoy contemporáneas, parece como si amenazaran derrumbarse entre las gigantescas convulsiones de la guerra que acaba, y que en su fiebre de producción el darles forma industrial vulgariza las instalaciones de hornos eléctricos para la obtención del hierro, a nosotros, dotados por la naturaleza de todos los elementos necesarios para ser grandes, era preciso que, como entonces, la Sociedad Bascongada de Amigos del País, al recordarnos la Sociedad de Amigos del Arte la historia del pasado, nos diese todo el valor y el entusiasmo necesario en la lucha que se prepara para el porvenir.

\section{Pedro Miguel de ARTiñanO}

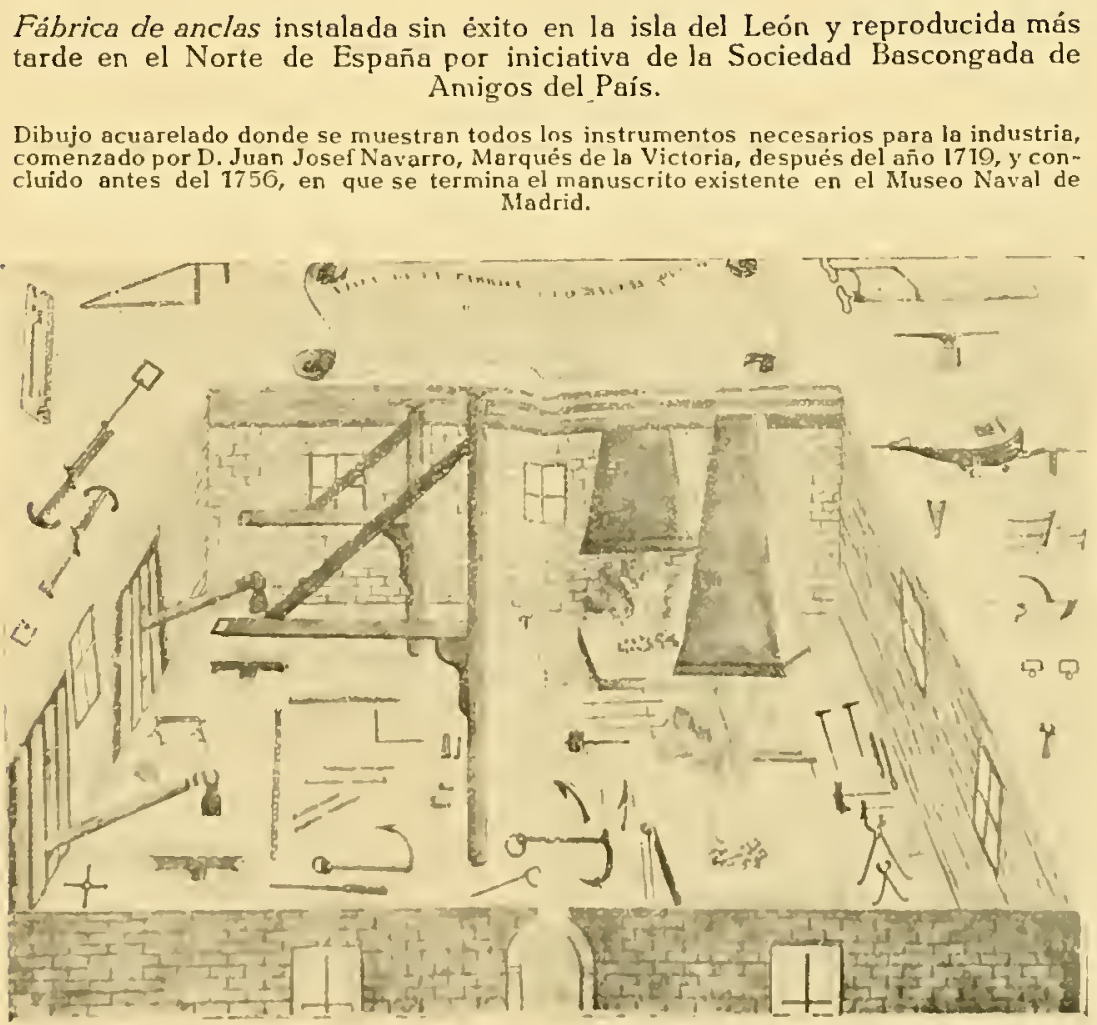





$$
\text { CA TÁl OGO }
$$





\section{A T A L O G O}

\section{La primera Edad del Hierro en España}

\section{Los más antiguos documentos conocidos del uso del hierro en España}

Los números 1 al 25 proceden de las excavaciones en las necrópolis celtibéricas realizadas por el Sr. Marqués de Cerralbo en las provincias de Soria, Guadalajara y Zaragoza.

El método adoptado en la presente Exposición en cuanto al orden cronológico de las espadas y puñales de la colección del Sr. Marqués de Cerralbo, es el que siguió dicho ilustre arqueólogo en la Exposición del Congreso de la Asociación española para el Progreso de las Ciencias, verificado en Sevilla en Mayo de 1917; y debemos a su amabilidad el exponer en este Catálogo las primicias de parte de la Memoria inédita que ante las sesiones del mismo Congreso leyó el citado Sr. Marqués.

Se trata del intento de explicar el origen de la espada ibérica y su desenvolvimiento desde el puñal del siglo vil, antes de J. C. a las de antenas del v (números 1 al 7) y las que originaron el célebre Gladius Hispalensis hasta las de La Tène de los siglos iv y III, antes de Jesucristo, sirviendo como prólogo a esta serie un puñalito de antenas, de bronce, muy raro, procedente del campamento ibero-romano de Aguilar de Anguita (Guadalajara).—Longitud: $17 \mathrm{~cm}$., que es el que pudiera ser del siglo vir.

Todas las espadas de antenas que se catalogan a continuación corresponden al período denominado de Hallstatt, que en España se clasifica como de la primera Edad del Hierro, por que las más primitivas deducidas de la Edad del Bronce no se han encontrado aún en la Iberia. 
Núm. 1. - Espada de antenas con hoja de lanza y cuchillo metidos en los puentes de la vaina. Este lote es muy interesante $y$, como varios que después de él se han hallado en alguna otra Necrópolis, demuestra que la lanza, como otros objetos, acostumbraron introducirlos en las abrazaderas de la vaina de la espada des-

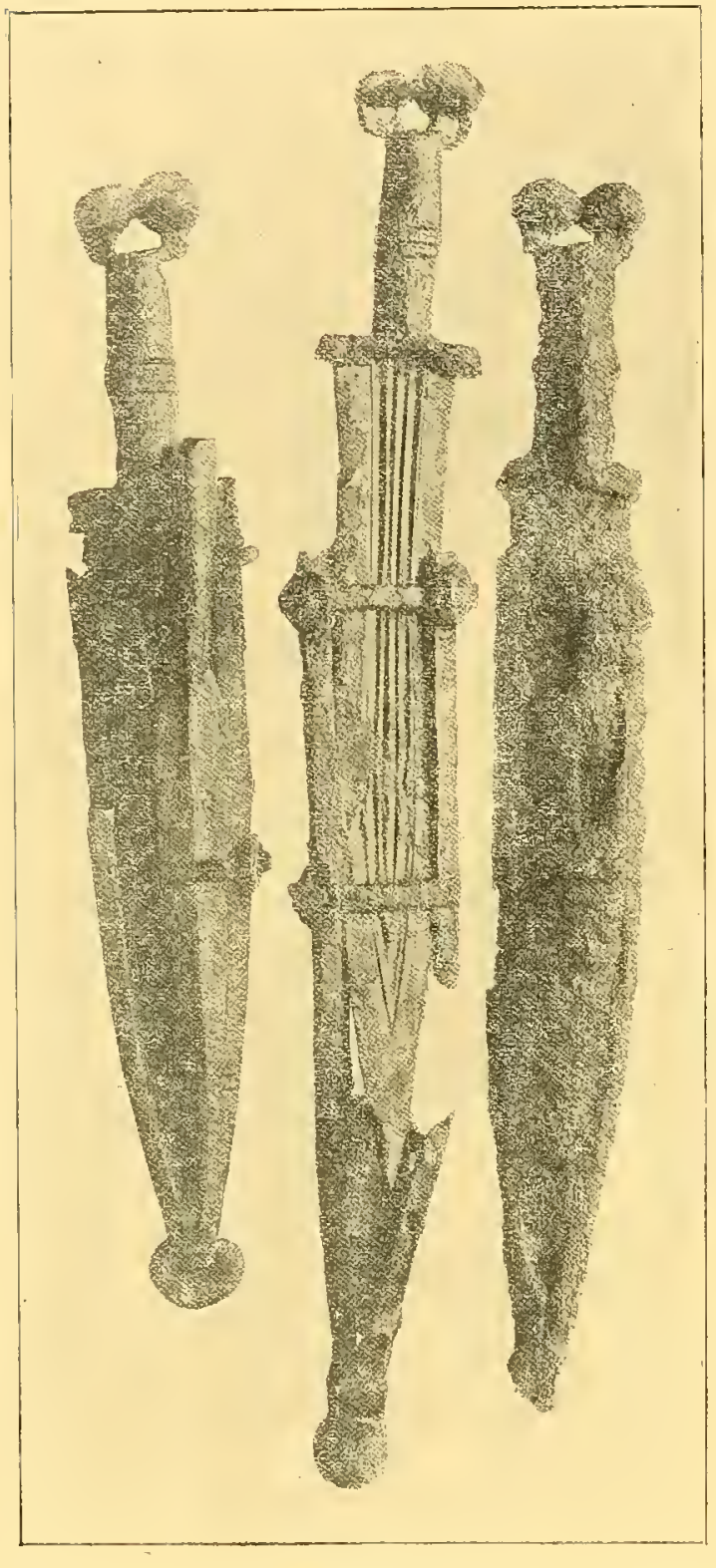

Núms. I, 2 y 3. pués de hecha la cremación del cadáver, para formar así un solo conjunto funerario que se depositó al lado de la urna cineraria.

Procede de la Necrópolis de Alpanseque, en Soria.-Longitud: $41 \mathrm{~cm}$.

Expositor: Excmo. Sr. Marqués de Cerralbo, su descubridor.

Núm. 2. - Espada de antenas con su vaina que tal vez fuese de cuero, con los contornos o armaduras de hierro.

Conserva la vaina sus dos puentes para guardar el puñal.

Esta espada es un ejemplar de interés por hallarse una de las caras de la hoja en tan buen estado de conservación que permite apreciar la serie de acanaladuras o estrías que la ornamentan, y así nos explican el adelanto metalúrgico de los celtíberos del Centro de España en el siglo v, a. de J. C.

Procede de la Necrópolis de Alpanseque, en Soria.-Longitud: Espada sin vaina, $40 \mathrm{~cm}$.; con ella, $51 \mathrm{~cm}$.

Expositor: Excmo. Sr. Marqués de Cerralbo, su descubridor.

Núm. 3.-Espada de antenas con su vaina y puñalito en ésta. Es de gran novedad por ser la primera que se descubrió en España, con el detalle de llevar en la vaina un puñalito; circunstancia de singular interés, porque también fué el primero (su descubridor, el Marqués de Cerralbo) en explicar un pasaje indeterminado de la lliada en su canto XIX.

Procede de la Necrópolis de Higes (Guadalajara).-Longitud: $44 \mathrm{~cm}$.

Expositor: Excmo. Sr. Marqués de Cerralbo, su descubridor.

Núm. 4.--Espada de antenas, procedente de la Necrópolis de Aguilar de Anguita (Guadalajara).--Longitud: $43 \mathrm{~cm}$.

Exposiror: Excmo. Sir. Marqués de Ceirralbo, su descubridor. 
Núm. 5. - Espada de antenas con su vaina de hierro de una sola pieza, muy singular por su terminación en forma rectangular.

Procede de Aguilar de Anguita (Guadalajara), en su Necrópolis._Longitud: $65 \mathrm{~cm}$.

Expositor: Excmo. Sr. Marqués de Cerralbo, su descubridor.

Núm. 6.--Espada de antenas, procedente de la Necrópolis de Aguilar de Anguita (Guadalajara).-Longitud: $41 \mathrm{~cm}$.

Expositor: Excmo. señor Marqués de Cerralbo, su descubridor.

Núm. 7.-Espada de antenas. Esta espada tiene la empuñadura compuesta de tres láminas separadas entre sí, para dejar hueco a otra materia que completase y ornamentara el puño, que ha desaparecido. El hierro de dichas láminas, como el de toda la espada, tiene el aspecto y condiciones de acero, lo que atestigua el tan renombrado adelanto metalúrgico de la región bilbilitana, tan celebradísimo por su paisano Marcial, uno de los elogiadores del temple admirable de las aguas del Jalón para el alto valor de sus armas. Este ejemplar, tanto en la forma de la empuñadura como en la hoja, a dos vertientes sin estrías centrales, recuerda a la espada núm. $\sigma$, y ambas a varias de la época del bronce en la Europa Central.

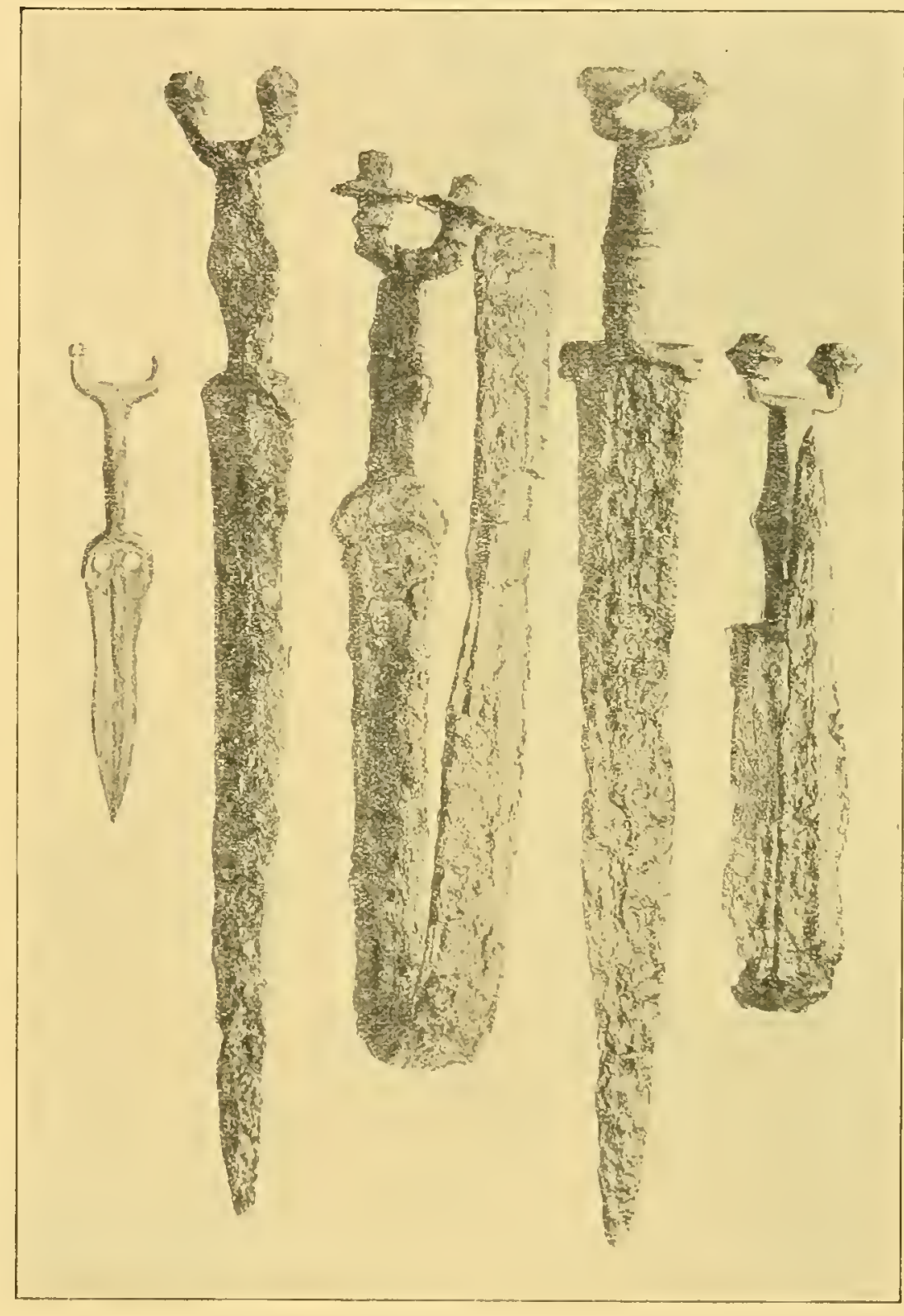

Nưms, 6, 5, 4 y 7 .

Procede de la Necrópolis de Aguilar de Anguita._Longitud: $48 \mathrm{~cm}$.

Expositor: Excmo. Sr. Marqués de Cerralbo, su descubridor.

Núm. 8.-Espada de empuñadura plana con su vaina y puente para su cuchillo. Este ejemplar es una variante de la típica espada de Hallstatt de antenas, cuyo tipo más clásico 


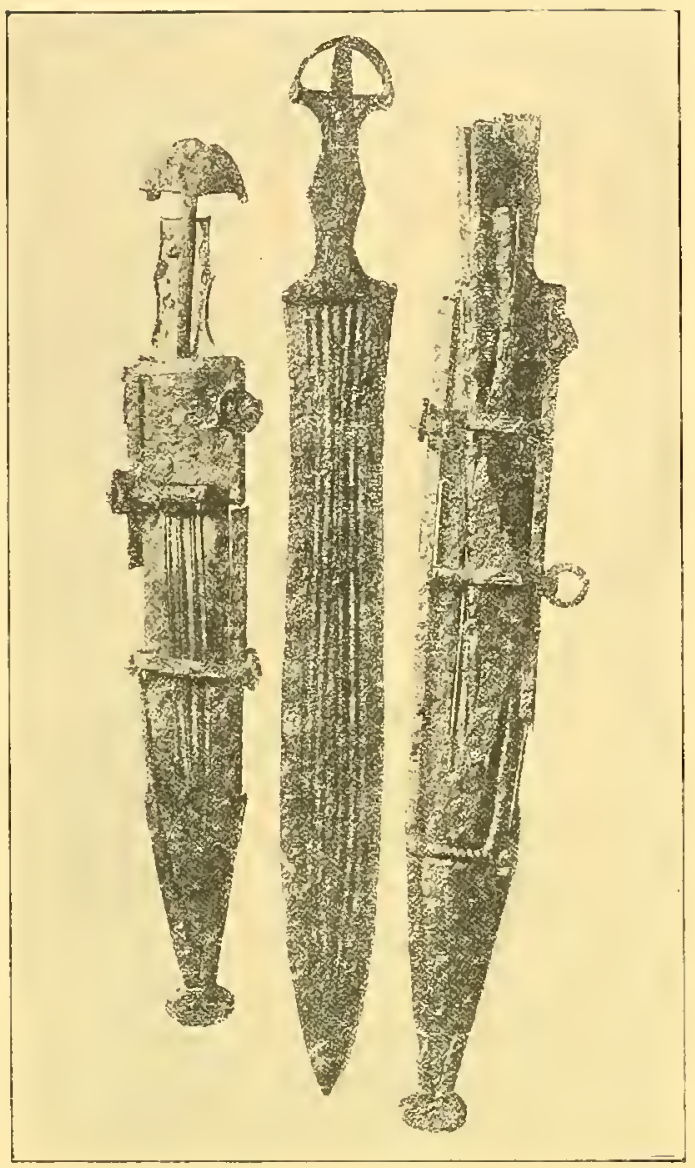

Núms. 8,9 y 10.

en España son los de Aguilar de Anguita, caracterizados por sus vainas terminadas en una esfera, siendo de hierro únicamente la parte que protege los dos cortes del arma, y, además, por las perfectas estrías y acanaladuras de la hoja de la misma espada.

Lo que principalmente determina esta variante es la terminación de la parte superior de la empuñadura en forma de semicírculo, y otras particularidades cuyo estudio no es de este somero Catálogo, y por las que hacen a este ejemplar y a los dos siguientes como únicos hasta el presente en Europa.

Procede de la Necrópolis de Alpanseque, en Soria.-Longitud: $43 \mathrm{~cm}$.

Expositor: Excmo. Sr. Marqués de Cerralbo, su descubridor.

Núm. 9. - Espada de empuñadura plana, sin vaina, del mismo tipo que la anterior.

Procede de Illora (Granada).-Longitud: $54 \mathrm{~cm}$.

Expositor: Excmo. Sr. Marqués de Cerralbo, su descubridor.

Núm. 10.-Espada de empuñadura plana con su vaina de doble puente para el cuchillo. Cuantos detalles singulares se expusieron en la descripción de la espada núm. I, pueden aplicarse, y con mayor fundamento a ésta en particular, pues además de la hoja de lanza tiene en la vaina el regatón, y el cuchillo está introducido en la vaina en el puente inferior y en sentido inverso; prueba evidente de que se introdujo después del acto de la cremación del guerrero a que perteneció.

Procede de la Necrópolis de Alpanseque, en Soria.-Longitud: $56 \mathrm{~cm}$.

Expositor: Excmo. señor Marqués de Cerralbo, su descubridor.

Núm. 11.-Puñalito con su vaina. Este puñal, por cierto rarísimo entre las armas de los prerromanos españoles, es contemporáneo de la espada núm. 1O, pues se encontró en la misma sepultura de la Necrópolis de Alpanseque.

La hoja de este puñal es a dos vertientes y muy estrecha, y está pro-

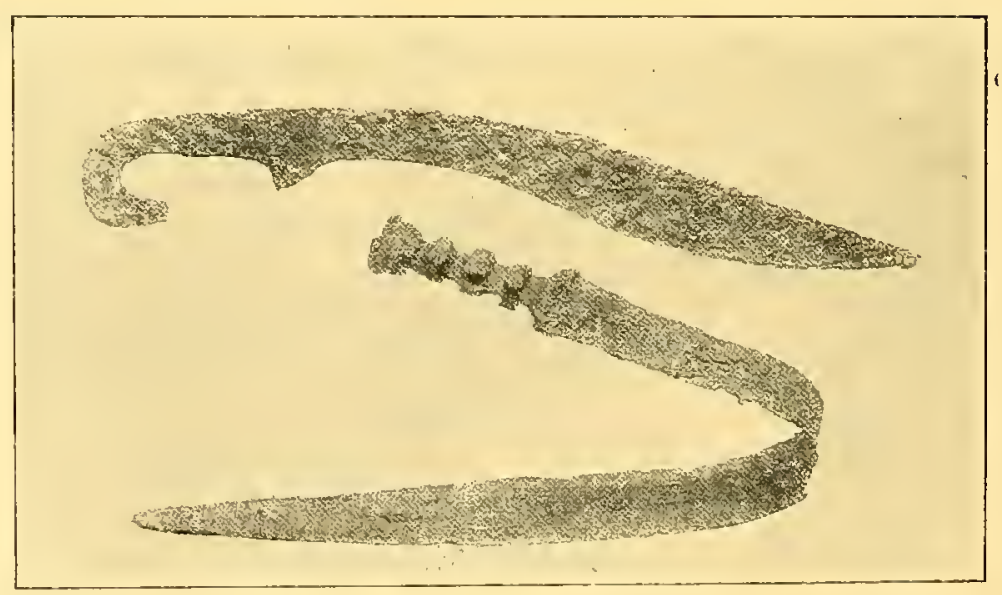

Núms. 12 y 23. 
tegida por una vaina de dos rebatidas una a la otra en los bordes laterales, la cual termina en una contera muy ancha y desproporcionada con el resto de la misma, y generalmente sus cuatro esquinas terminan en una esfera, teniendo, además, casi todas estas conteras, así como el resto de la vaina, incrustaciones de plata, como las de Alar del Rey, Mirabeche, etc.

Procede de la Necrópolis de Alpanseque, en Soria.-Longitud: $26 \mathrm{~cm}$.

Expositor: Excmo. Sr. Marqués de Cerralbo, su descubridor.

Núm. 12.-Espada de Antenas. A pesar de ser de antenas, la empuñadura es plana, recordando la de los núms. 6 a 10; pero en vez de verse en esta espada una o tres láminas separadas entre sí para retener las cachas, hay tres abrazaderas, unidas por sencillas aplicaciones de hierro. Por su tamaño, forma ondulada de la hoja y por haberse hallado en una necrópolis de transición de la época de Hallstatt a la de la Tène, y a pesar de sus estrías en la hoja, este ejemplar, indica el Sr. Marqués de Cerralbo, que quizá sea uno de los precursores de la espada del tipo La Tène, en España.

Procede de la Necrópolis de Atance, en Guadalajara.-Longitud: $67 \mathrm{~cm}$.

Expositor: Excmo. Sr. Marqués de Cerralbo, su descubridor.

Núm. 13. - Espada de La Tène, con parte de su vaina. Esta espada, por las acanaladuras, de su hoja, recuerda todavía las de la época anterior.

Procede de la Necrópolis de Atance, en Guadalajara.-Longitud: $57 \mathrm{~cm}$.

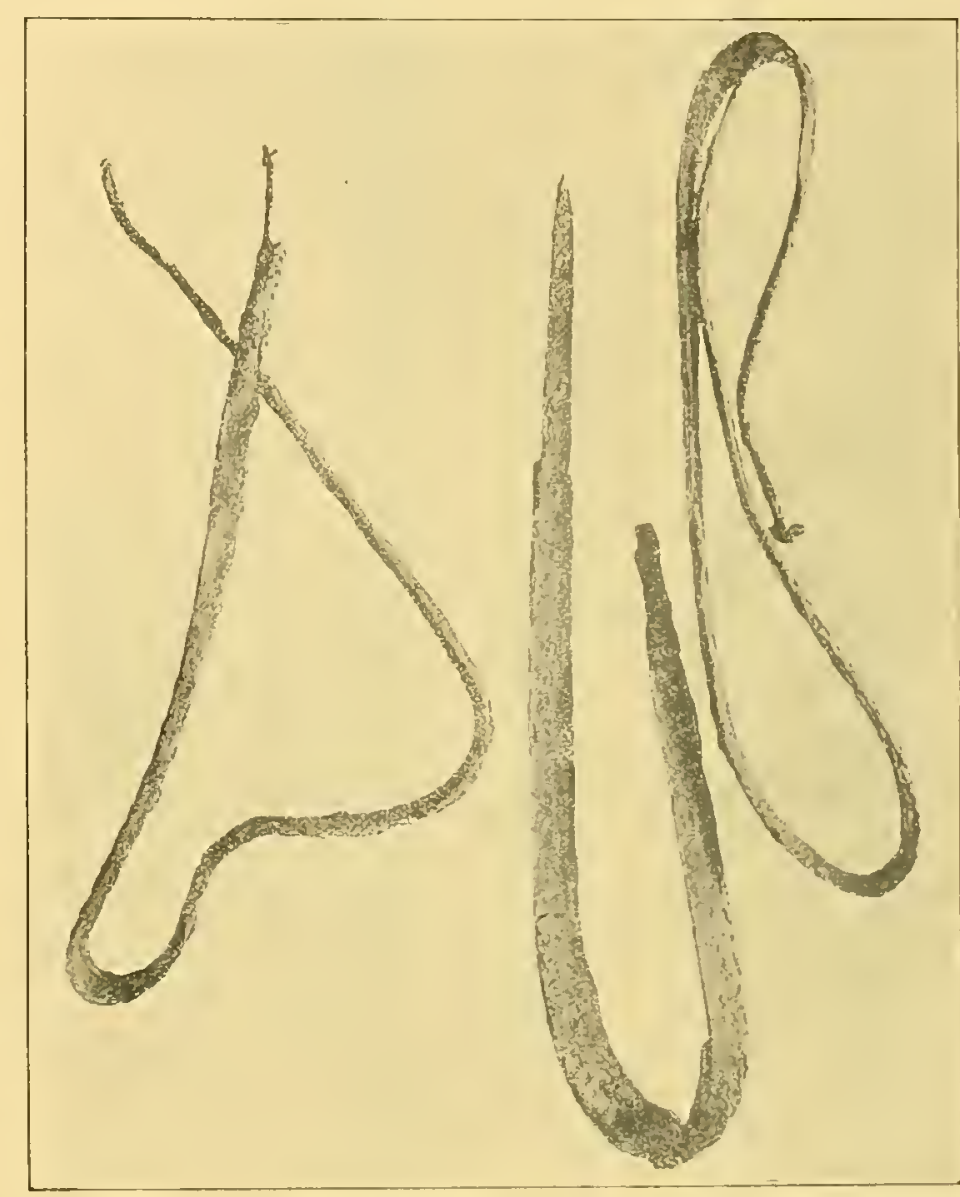

Núm. 15, 13 y 14

Expositor: Excmo. Sr. Marqués de Cerralbo, su descubridor.

Núm. 14.-Espada típica de La Tène.

Procede de la Necrópolis de Atance, en Guadalajara.-Longitud: $81 \mathrm{~cm}$.

Expositor: Excmo. Sr. Marqués de Cerralbo, su descubridor.

Núm. 15.-Espada de La Tène. Dada la forma ondulada de su hoja y a pesar de ser ésta de dos vertientes, dicho ejemplar recuerda otras espadas de la misma localidad del tipo de antenas que tienen nervaturas en la hoja. 
Procede de la Necrópolis de Atance, en Guadalajara.—Longitud: $67 \mathrm{~cm}$.

Expositor: Excmo. Sr. Marqués de Cerralbo, su descubridor.

Núm. 16. - Espada de La Tène que ofrece la curiosidad de manifestarse doblada cuatro

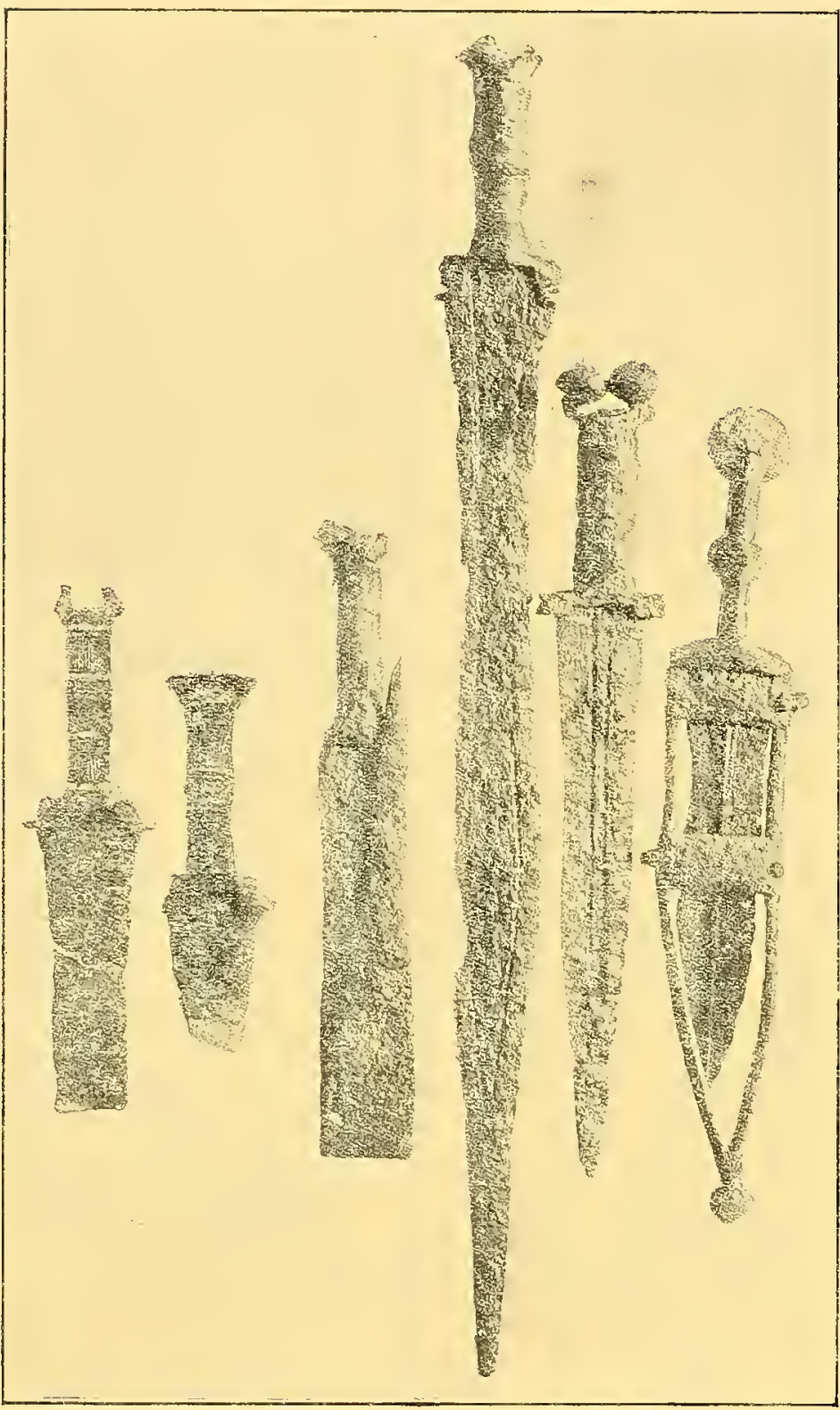

Núms. 17, 18, 20, 19, 21 y 24. veces, como arrollada quizá en homenaje a su dueño y para que así no pudiera servir a nadie más.

Procede de la Necrópolis de Arcóbriga.-Monreal de Ariza (Zaragoza).

Expositor: Excmo. Sr. Marqués de Cerralbo, su descubridor.

Núm. 17.-Espada incompleta de antenas con incrustaciones de plata y cobre en su empuñadura. Esta espada de antenas, así como la de los núms. 18 a 20 , enriquecidas por adamasquinados, de seguir un orden cronológico en las armas celtíberas deberían colocarse a continuación de las que terminan con el núm. 7, pero atendiendo a la singularidad de la alta estimación que lograrían en su tiempo y a las que les concede hoy la Arqueología, las reunió el Sr. Marqués de Cerralbo para formar una sección exclusiva de riqueza ornamental.

Procede de Turmiel (Guadalajara).Longitud: $22 \mathrm{~cm}$.

Expositor: Excmo. Sr. Marqués de Cerralbo, su descubridor.

Núm. 18.-Empuñadura de una espada de antenas avalorada por incrustaciones de plata y cobre como la precedente.

Procede de Atance, en Guadalajara.-Longitud: $16 \mathrm{~cm}$.

Expositor: Excmo. Sr. Marqués de Cerralbo, su descubridor.

Núm. 19. -Espada de antenas. Ejemplar rarísimo que a pesar de coincidir en forma, tamaño y labores de la hoja con los de la época del bronce, es, sin embargo, de principios de la época de La Tène, pues sus antenas se reducen a expresión mínima y las incrustaciones de cobre y plata de su empuñadura son determinantes y típicas de La Tène I. 
Procede de la Necrópolis de Arcóbriga, en Monreal de Ariza (Zaragoza).-Longitud: $57 \mathrm{~cm}$.

Expositor: Excmo. Si. Marqués de Cerralbo, su descubridor.

Núm. 20.--Espada doblada de antenas con incrustaciones de cobre y plata en su empuñadura. Es del mismo estilo y época de las tres anteriores.

Procede de la Necrópolis de Atance (Guadalajara)._Longitud: $50 \mathrm{~cm}$.

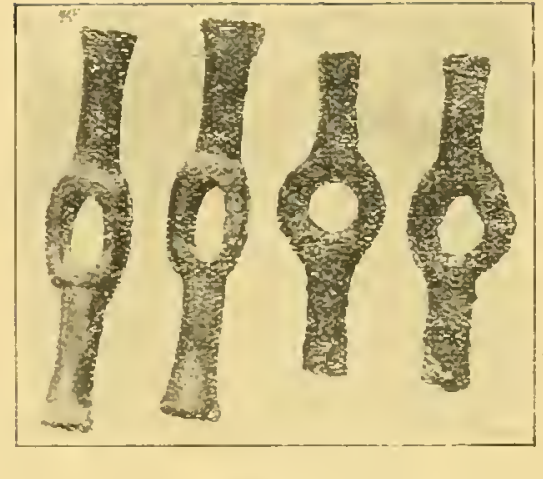

Núms. 26 y 27.

Expositor: Excmo. Si. Marqués de Cerralbo, su descubridor.

Núm. 21. - Espada de antenas. Este tipo de espada, teniendo en cuenta la forma corta y ancha de su hoja, ligeramente ondulada, su empuñadura muy plana, y las antenas muy pequeñas y estrechas, pertenece a las postrimerías de la época de Hallstatt.

Procede de la Necrópolis de Atance, en Guadalajara.-Longitud: $34 \mathrm{~cm}$.

Expositor: Excmo. Sr. Marqués de Cerralbo, su descubridor.

Núm. 22.-Espada de antenas. Del mismo tipo y época de la anterior y de la misma necrópolis. Tiene varias fajas de incrusta-

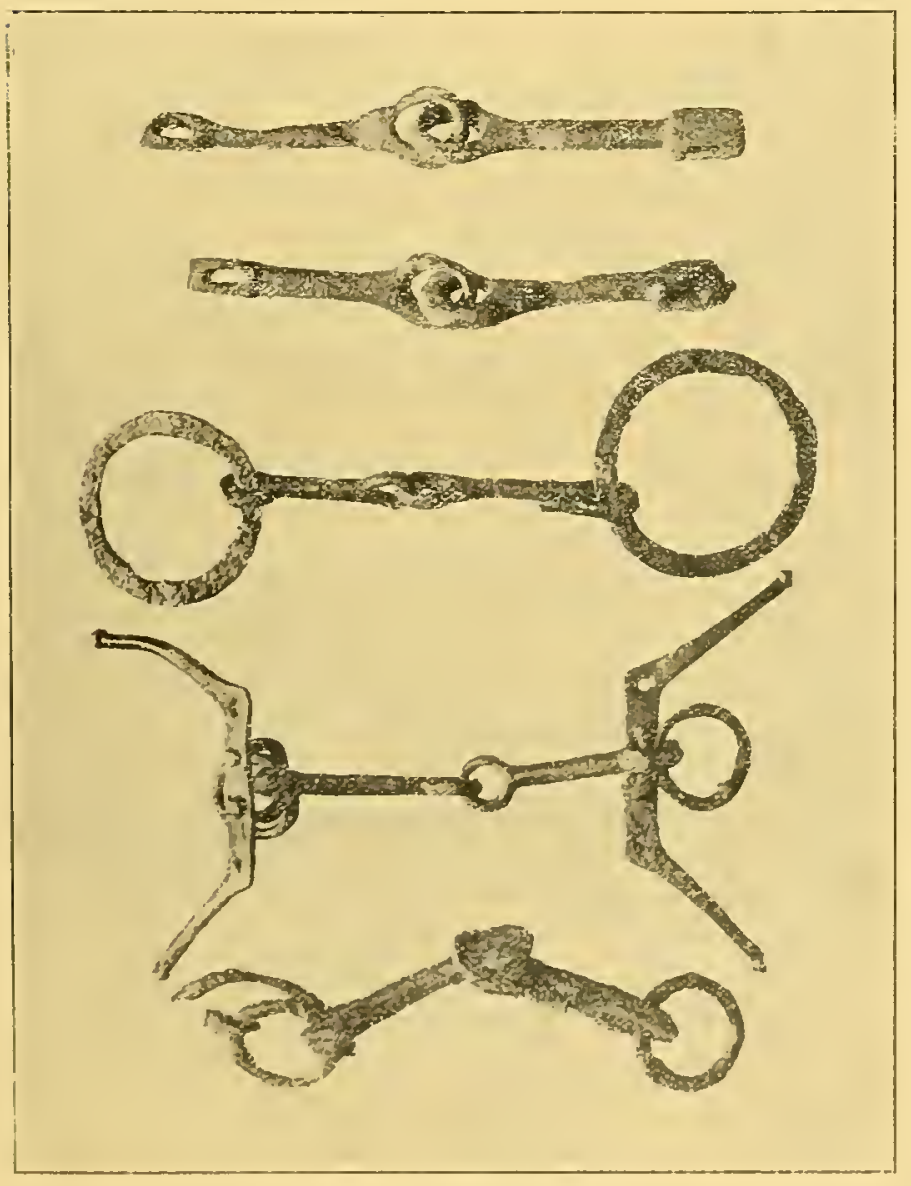

Núns. 28, 37, 46 y 48. ciones de cobre en su empuñadura. - Longitud: $46 \mathrm{~cm}$.

Expositor: Excmo. Sr. Marqués de Cerralbo, su descubridor.

Núm. 23.- Espada tipo Falcata, de gran excepción en la Celtiberia y coetánea de La Téne II.

Procede de la Necrópolis de Caravias (Guadalajara).-Longitud: $47 \mathrm{~cm}$.

Expositor: Excmo. Sr. Marqués de Cerralbo, su descubridor.

Núm. 24.-Puñal con su vaina y de empuñadura doble globular. Es el arma típica de los celtíberos en los tiempos de la destrucción de Numancia y es el puñal de las célebres estatuas de guerreros de Portugal y de muchos bronces del Santuario de Despeñaperros (Jaén).-Longitud: $35 \mathrm{~cm}$.

Exisositor: Excmo. Sr: Marqués de Cerralbo, su descubridor. 
Núm. 25.-Puñalito del mismo tipo del anterior.

Procede del campamento ibero-romano de Aguilar de Anguita (Guadalajara)._Longitud: $17,5 \mathrm{~cm}$.

Expositor: Excmo. Sr. Marqués de Cerralbo, su descubridor.

Núms. 26 y 27 -Dos camas de bocado de la época de Hallstatt II, de gran rareza. Ese tipo de bocado es copia exacta de otros de bronce, cuyo modelo se expone a su lado y que procede de la misma Necrópolis de Aguilar de Anguita, el cual recuerda a la ve $z_{r}$ al más primitivo de los conocidos de los protohistóricos y de los hallados en los palafitos de Robenhausen.

Procede de la Necrópolis de Aguilar de Anguita, en Guadalajara.--Longitud: $9 \mathrm{~cm}$.

Expositor: Excmo. Sr. Marqués de Cerralbo, su descubridor.

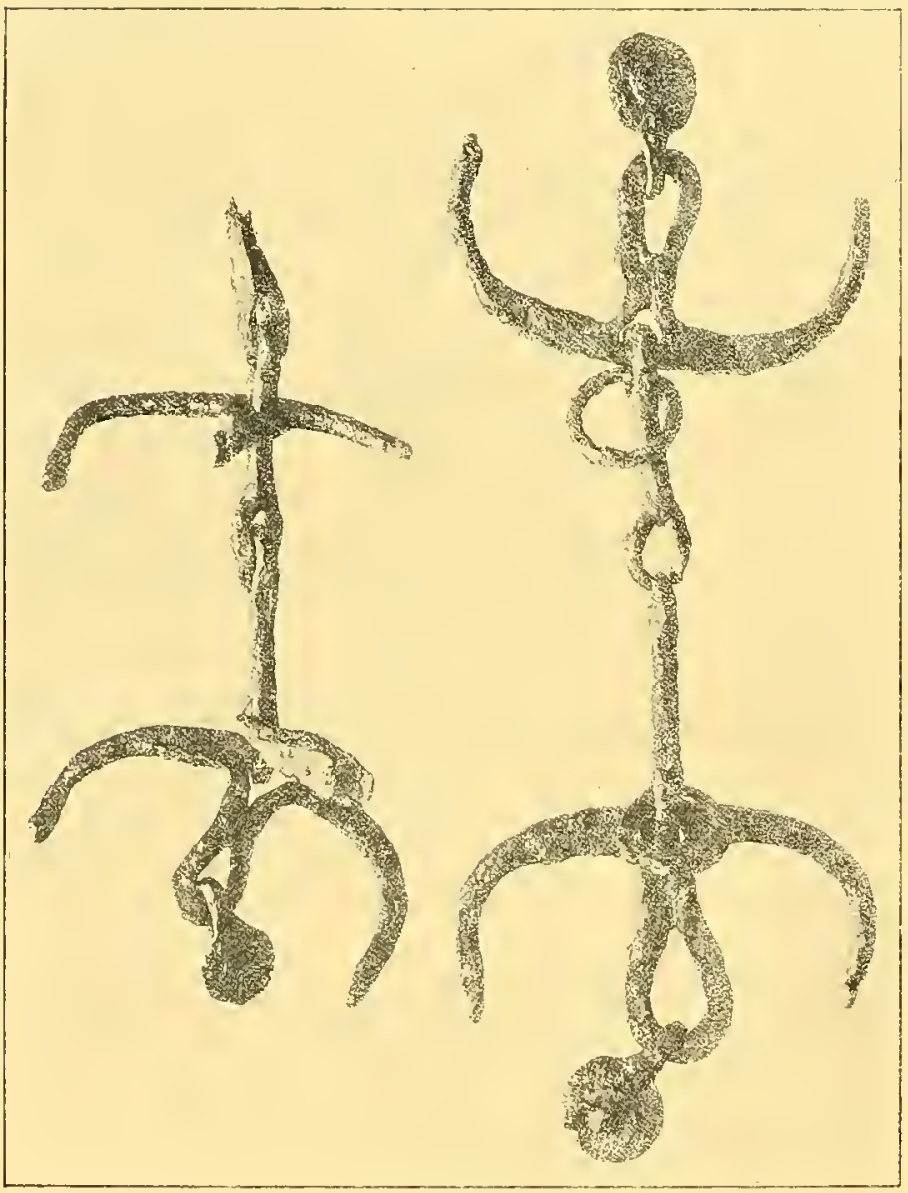

Nứms. 29 y 31.

Núms. 28 y 29. -Dos fragmentos de bocado de bronce a los que faltan las camas. Epoca de Hallstatt II. Muy raros.

Proceden de la Necrópolis de Atance (Guadalajara).-Longitud: 22 y $19 \mathrm{~cm}$.

Expositor: Excmo. Sr. Marqués de Cerralbo, su descubridor.

Núm. 30.—Filete de caballo. Ejemplar notabilísimo por tener una de sus camas movibles como algunas de la Edad del bronce. Epoca de Hallstatt II. De mucha rareza.

Procede de la Necrópolis de Aguilar de Anguita, en Guadalajara. - Longitud: 26 centímetros.

Expositor: Excmo. Sr. Marqués de Cerralbo, su descubridor.

Núm. 31.-Filete de caballo, del mismo tipo que el anterior, pero sin cama movible. Tiene adherido a él una de las piezas que servían para el embrace del escudo del guerrero a quien perteneció el caballo. Epoca de Hallstatt II.

Procede de la Necrópolis del Valdenovillos, Alcolea de las Peñas (Guadalajara).

Expositor: Excmo. Sr. Marqués de Cerralbo, su descubtidor.

Núm. 32.-Filete de caballo, de igual tipo que el anterior. Epoca de Hallstatt II. Procede de la Necrópolis de Aguilar de Anguita, en Guadalajara.-Anchura: $35 \mathrm{~cm}$.

Expositor: Excmo. Sr. Marqués de Cerralbo, su descubridor. 
Núms. 33 y 34. - Filete de caballo del mismo tipo que los anteriores, pero sus camas tienden a evolucionar de la forma de media luna celta a la cuadrilátera, y fíbula de bronces con su aguja de hierro, que se halló junto con el bocado. La fíbula es clásica de la época de Hallstatt II.

Procede de la Necrópolis del Tesoro, Caravias (Guadalajara).-Miden: bocado, $30 \mathrm{~cm}$.; fíbula, 9,5 centímetros.

Expositor: Excelentísimo señor Marqués de Cerralbo, su descubridor.

Núm. 35. - Filete de caballo, de camas cuadriláteras. Epoca de Hallstatt.

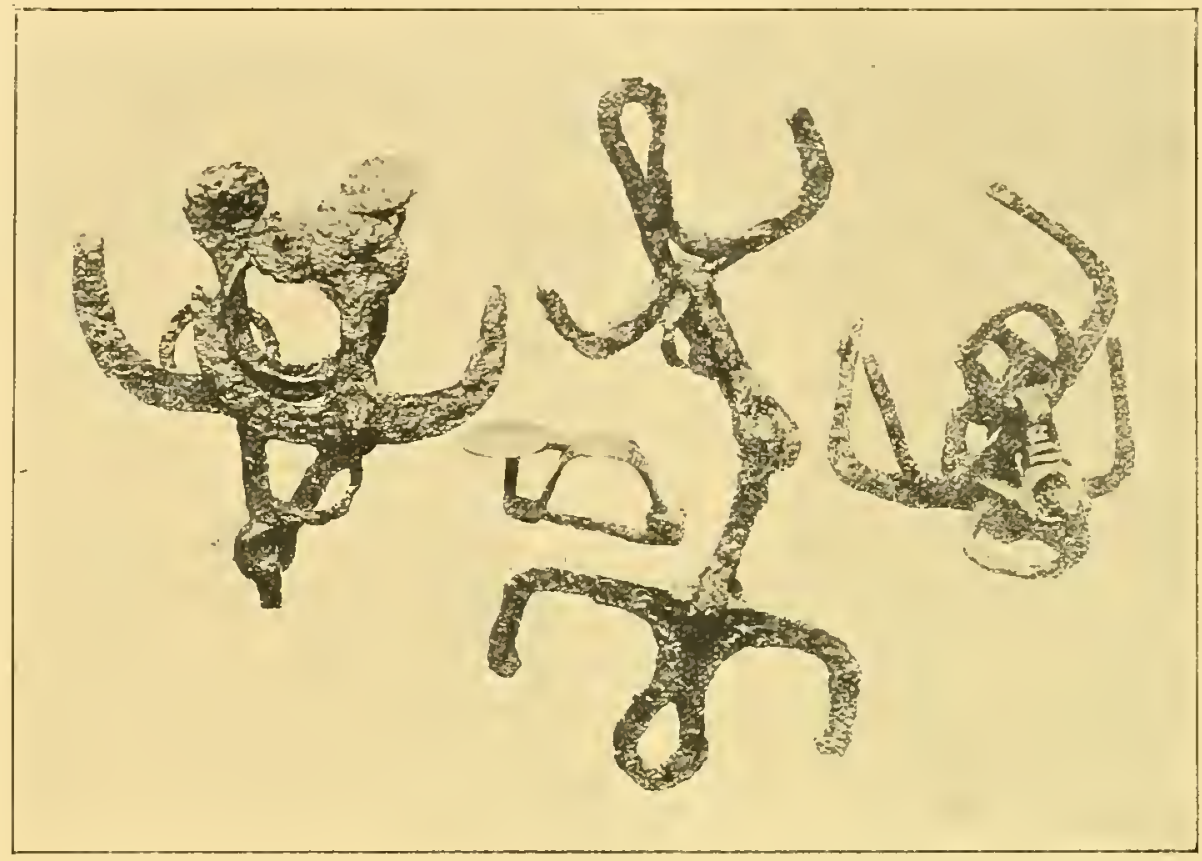

Núms. 34,32 y 30

Procede de la Necrópolis de Atance (Guadalajara)._Longitud: $20 \mathrm{~cm}$.

Expositor: Excmo. Sr. Marqués de Cerralbo, su descubridor.

Núm. 36. - - Filete de caballo de castigo y camas cuadriláteras. Epoca de Hallstatt. Procede de la Necrópolis de Atance (Guadalajara).

Expositor: Excmo. Sr. Marqués de Cerralbo, su descubridor.

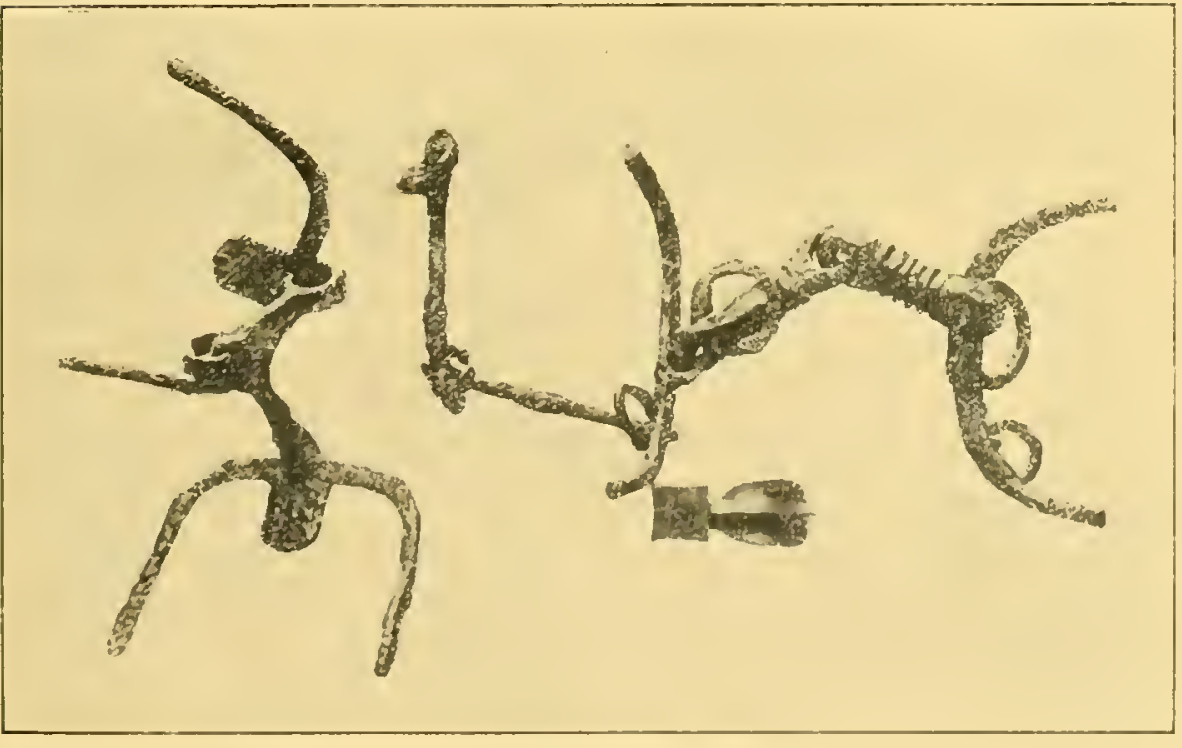

Niums. 33 y 39.
Núm. 37. - Filete de caballo de castigo y camas de forma liriforme. Epoca de Hallstatt.

Procede de la Necrópolis de Higes (Guadalajara). Longitud: $26 \mathrm{~cm}$.

ExPOSITOR: Excelentísimo señor Marqués de Cerralbo, su descubridor.

Núm. 38. - Filete de caballo de camas de forma 
liriforme. Ejemplar notable por la serie de anillas para el arranque de correas de la brida, que parten de ambas camas. Epoca de Hallstatt II. Procede de la Necrópolis del Tesoro, Caravias (Guadalajara).-Longitud: $23 \mathrm{~cm}$.

Expositor: Excmo. Sr. Marqués de Cerralbo, su descubridor.

Núm. 39.-Filete de caballo, de forma parecida al anterior, aunque más incompleto. Epoca de Hallstatt II.

Procede de la Necrópolis de Aguilar de Anguita (Guadalajara)._Longitud: $32 \mathrm{~cm}$.

Expositor: Excmo. Sr. Marqués de Cerralbo, su descubridor.

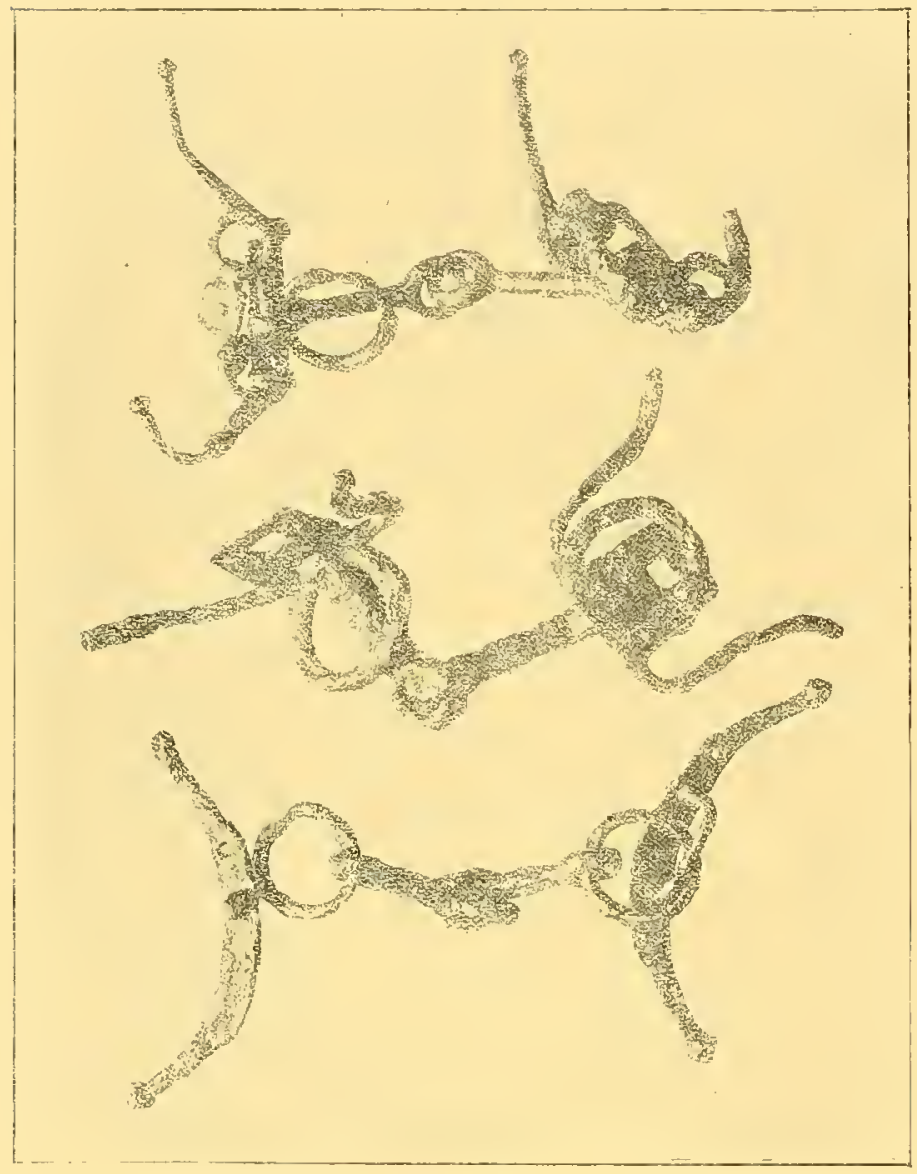

Núms. 36.35 y 40 .

Núm. 40.-Filete de caballo, de la misma forma que los dos anteriores, pero que tiene además la novedad de la pieza complementaria de la barbada.

Procede de la Necrópolis de Aguilar de Anguita (Guadalajara).

Expositor: Excmo. Sr. Marqués de Cerralbo, su descubridor.

Núm. 41 y 42.-Pieza de filete de caballo de gran castigo, del mismo modelo que los anteriores, con sus piezas complementarias para cadenilla de barbada o entronque y fíbula de bronce, clásica de Hallstatt II, como la del núm. 34.

Procede de la Necrópolis de Alpanseque (Soria).-Longitud: $40 \mathrm{~cm}$.

\section{Expositor: Excmo. Si: Marqués de Cerralbo, su descubridor.}

Núm. 43.-Filete de caballo, de camas en forma de media luna. Epoca Hallstatt II.

Procede de la Necrópolis de Aguilar de Anguita, en Guadalajara._Longitud: $26 \mathrm{~cm}$. Expositor: Excmo. Sr. Marqués de Cerralbo, su descubridor.

Núm. 44. -Bocado de camas completamente rectas. Epoca de la Tène I, siendo un gran adelanto para el mando, con respecto a los anteriores filetes.

Procede de la Necrópolis de Aguilar de Anguita, en Guadalajara.-Longitud: 26 cm.

Expositor: Excmo. Sr. Marqués de Cerralbo, su descubridor.

Núm. 45.--Bocado de caballo, de camas rectas. Epoca de la Tène I; ofrece la singularidad de tener unidas las camas por una planchuela de hierro en la parte inferior. 
Procede de la Necrópolis de Caravias (Guadalajara)._Longitud: $41 \mathrm{~cm}$.

Expositor: Excmo. Sr. Marqués de Cerralbo, su descubridor.

Núm. 46.-Fragmento de bocado con una pieza singular que pudo dar origen a la cadenilla de barbada celtibérica. Recuerda la pieza análoga del filete núm. 40. Epoca de Hallsttat II.

Procede de Aguilar de Anguita, en Guadalajara._Longitud: $13 \mathrm{~cm}$.

Expositor: Excmo. Sr. Marqués de Cerralbo, su descubridor.

Núm. 47.-Filete de caballo; idéntico a los actuales, perteneciendo éste al siglo iv, antes de J. C.

Procede de la Necrópolis del Tesoro de Caravias.-Longitud: $20 \mathrm{~cm}$.

Expositor: Excmo. Sir. Marqués de Cerralbo, su descubridor.

Núm. 48.-Filete de caballo, exactamente como los actuales, aunque éste debe datar del siglo iv antes de J. C.

Procede de la Necrópolis de Aguilar de Anguita, en Guadalajara. - Longitud: 26 centímetros.

Expositor: Excmo. Sr. Marqués de Cerralbo, su descubridor.

Núm. 49. - Filete de caballo, igual a los modernos usados en las carreras de caballos, corrrespondiendo éste al siglo iv antes de J. C. Epoca de Hallstatt II.

Procede de la Necrópolis de Aguilar de Anguita, en Guadalajara. - Longitud: 35 centímetros.

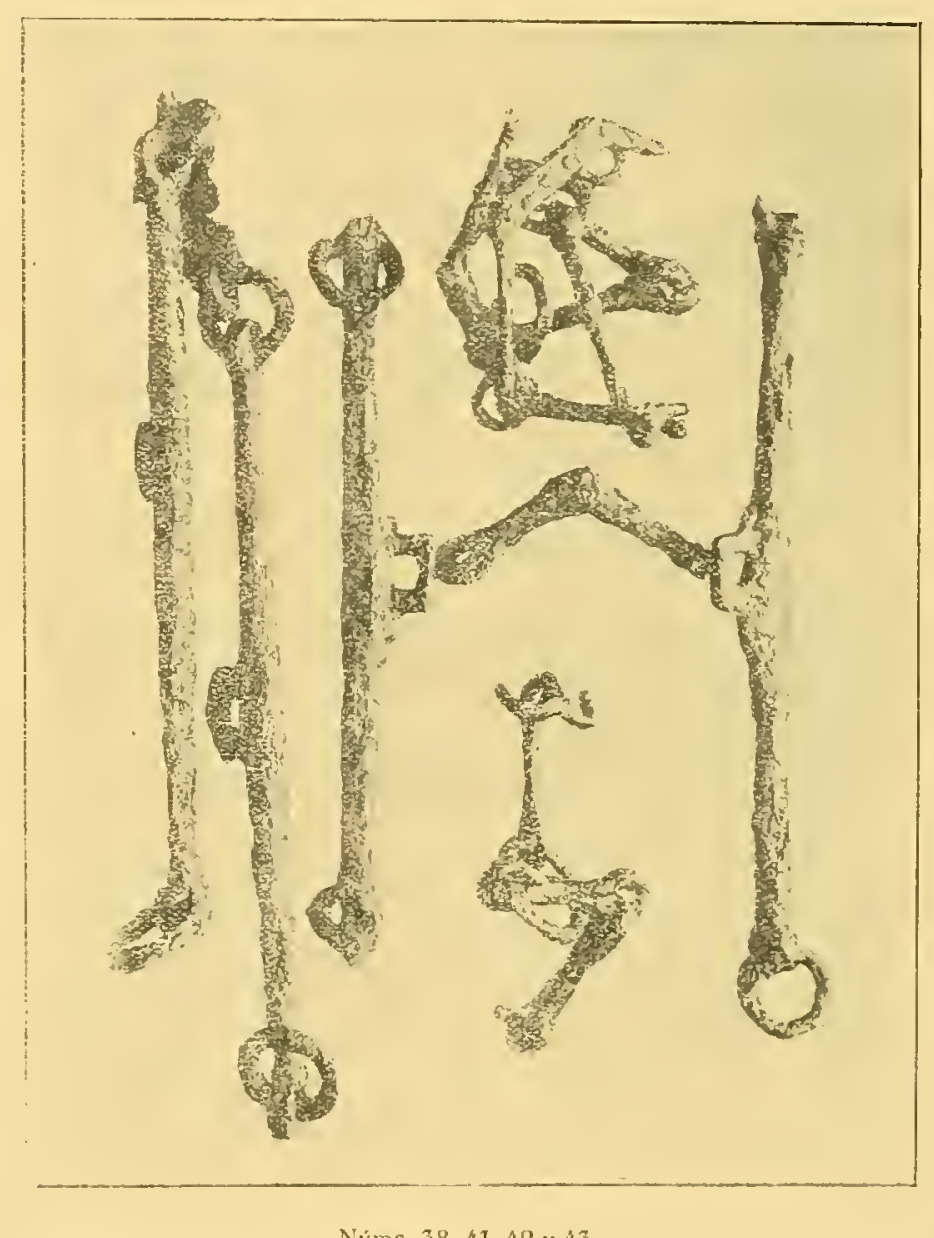

Expositor: Excmo. Sr. Marqués de Cerralbo, su descubridor.

Núm. 50.-Cabezón de doma de caballo. Hallstatt II. Objeto de gran rareza y de tal época, inédito en Arqueología.

Procede de la Necrópolis de Alpanseque, en Soria._Longitud: $31 \mathrm{~cm}$.

Expositor: Excmo. Sr. Marqmés de Cerrallo, su descubridor.

Ním. 51.-Cabezón de doma de caballo. Epoca de Hallstatt II. De igual rareza y novedad que el anterior y los que le siguen. 


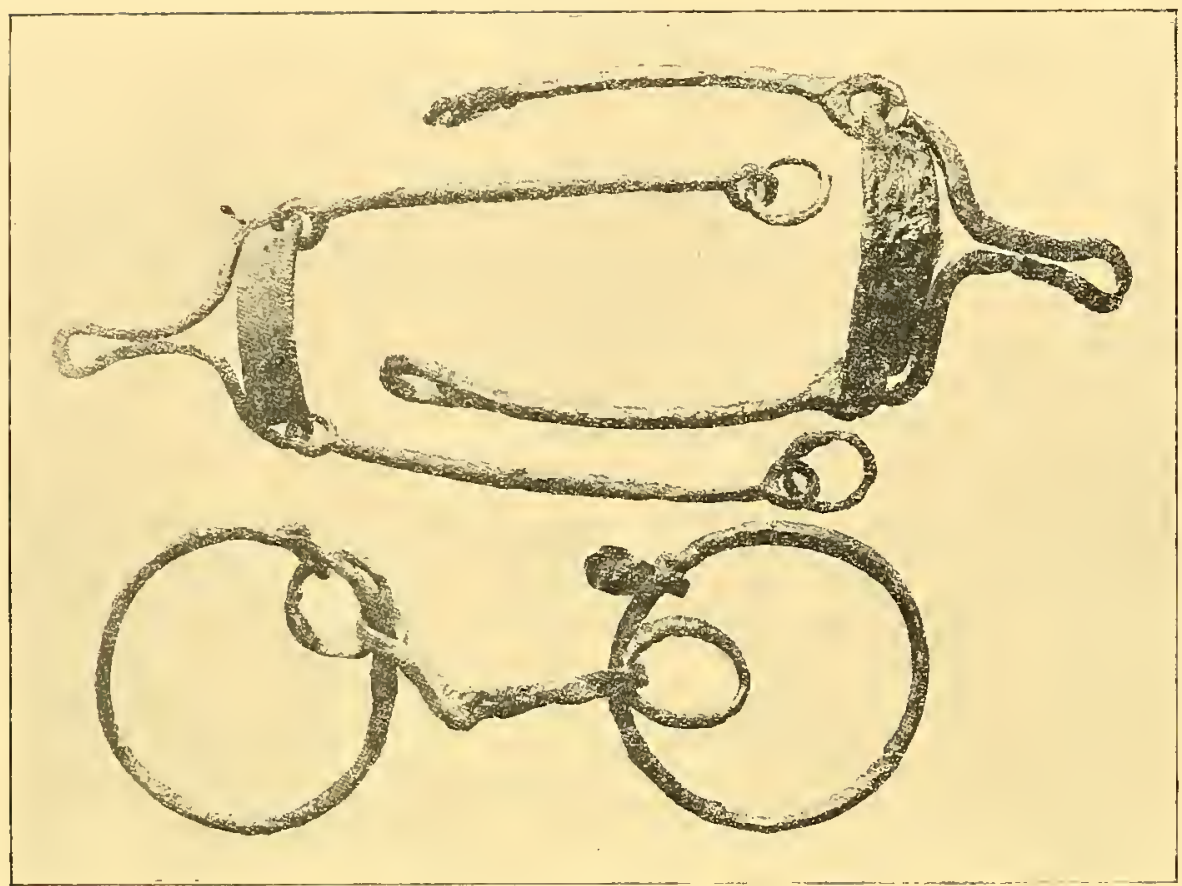

Núms. 49, 50 y 51 .
Procede de la Necrópolis de Aguilar de Anguita, en Guadalajara. - Longitud: 30 centímetros.

Expositor: Excelentísimo Sr. Marqués de Cerralbo, su descubridor.

Núm. 52. - Cabezón de doma de caballo. Epoca de Hallstatt II. Notable y único hasta el presente por tener cinco piezas, de las que arrancaban las correas de la brida.

Procede de la Necrópolis de Aguilar de Anguita, en Guadalajara. - Longitud: 28 centímetros.

Expositor: Excmo. Sr. Marqués de Cerralbo, su descubridor.

Núm. 53.-Cabezón de doma de caballo. Epoca de Hallstatt II, o sea de los siglos v y iv antes de Jesucristo.

Procede de la Necrópolis de Aguilar de Anguita, en Guadalajara._Longitud: $27 \mathrm{~cm}$.

Expositor: Excmo. Sr. Marqués de Cerralbo, su descubridor.

Núm. 54.-Cabezón de doma de caballo. Notable por sus charnelas. Epoca de Hallstatt II.

Procede de la Necrópolis del Tesoro, en Caravias (Guadalajara).-Longitud: 22 centímetros.

Expositor: Excelentísimo Sr. Marqués de Cerralbo, su descubridor.

Núm. 55-Cabezón de doma de caballo. Epoca de La Tène I.

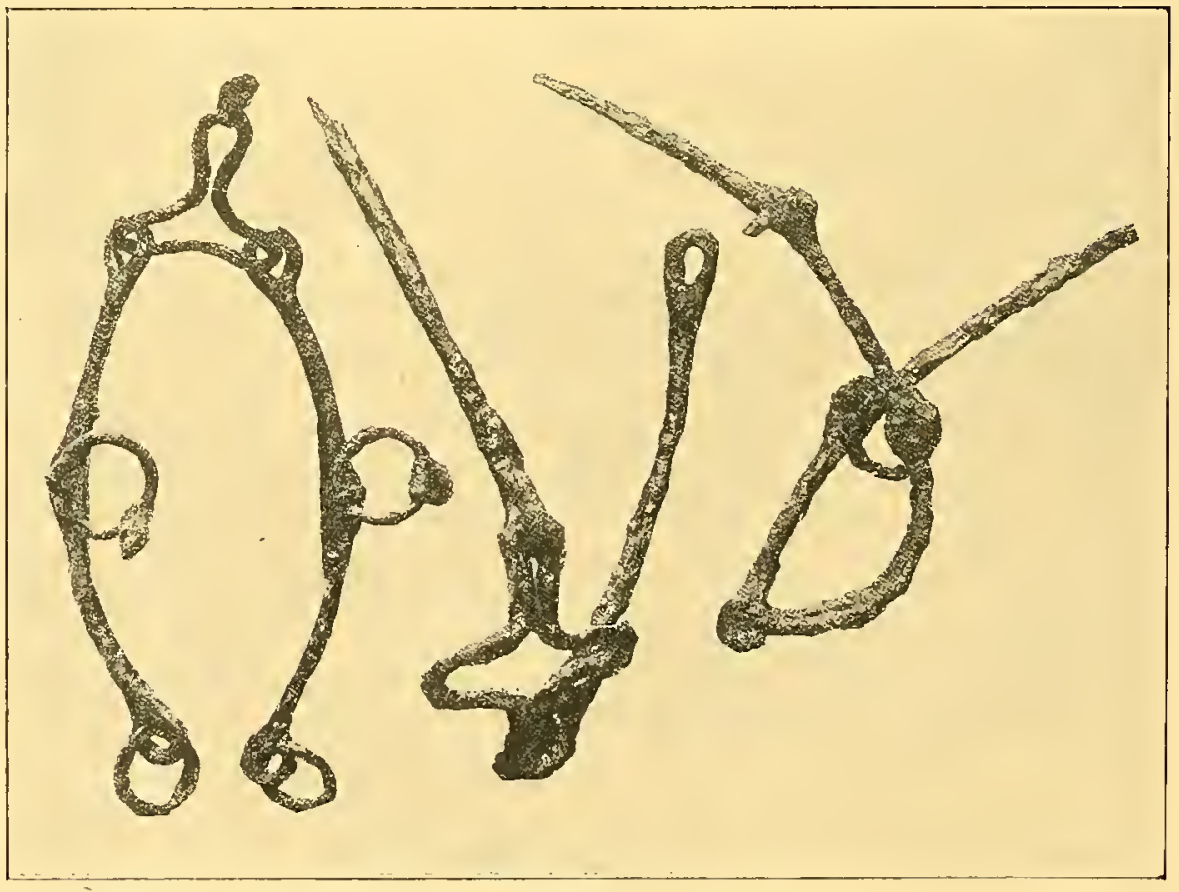

Núms, 54, 53 y 52 . 
Procede de la Necrópolis de Arcóbriga, en Monreal de Ariza (Zaragoza).--Longitud: $20 \mathrm{~cm}$.

Expositor: Excmo. Sr. Marqués de Cerralbo, su descubridor.

Exposición de diversos tipos de lanzas que indican el desarrollo y transformación desde la época de Hallstatt a la de La Tène I y II.

Núm. 56. - Soliferrium de la Necrópolis de Aguilar de Anguita. Epoca de Hallstatt: arma arrojadiza muy celtibérica y rara.-Longitud: 1,92 m.

Expositor: Excmo. Sr. Marqués de Cerralbo, su descubridor.

Núm. 57.-Parte inferior de un soliferrium.

Procede de la Necrópolis de Aguilar de Anguita. Epoca de Hallstatt._-Longitud: 26 cm.; es singular su remate en bronce.

Expositor: Excmo. Sr. Marqués de Cerralbo, su descubridor.

Núm. 58.- Muy larga y singular lanza, que indica el Sr. Marqués de Cerralbo, su descubridor, que pudiera haber dado origen al pilum romano. Epoca de Hallstatt.

Procede de la Necrópolis de Valdenovillos.-Longitud: $77 \mathrm{~cm}$.

Expositor: Excmo. Sr. Marqués de Cerralbo, su descubridor.

Núm. 59. - Lanza con su regatón, a la que se clasifica como la anterior. Epoca de Hallstatt.

Procede de la Necrópolis de Alpanseque, en Soria.-Longitud: $67 \mathrm{~cm}$. y 25 íd.

Expositor: Excmo. Sr. Marqués de Cerralbo, su descubridor.

Núm. 60.-Lanza y su regatón, semejante a la anterior. Epoca de Hallstatt.

Procede de Aguilar de Anguita (Guadalajara).-Longitud: $46 \mathrm{~cm}$. y el regatón II cm.

Expositor: Excmo. Sr. Marqués de Cerralbo, su descubridor.

Núm. 61.-Lanza de la época de Hallstatt.

Procedente de Valdenovillos.-Longitud: $67 \mathrm{~cm}$.

Expositor: Excmo. Sr. Marqués de Cerralbo, su descubridor.

Núm. 62. - Lanza y su regatón con su espiga (que es una rareza) para asegurarla al måstil.

Procede de la Necrópolis de Aguilar de Anguita, en Guadalajara, Hallstatt II.-Longitud: $53 \mathrm{~cm}$. la lanza y $18 \mathrm{~cm}$. el regatón.

Expositor: Excmo. Sr. Marqués de Cerralbo, su descubridor. 
Núm. 63.-Lanza y regatón. Epoca Hallstatt. Ambos ejemplares son muy interesantes, porque además de estar retorcidos para inutilizarlos, son éstos prueba de tal propósito, al mostrarse cortadas exprofeso cada pieza de las dos en que enchufaba el mástil.

Procede de la Necrópolis de Clares (Guadalajara).-Longitud: $48 \mathrm{~cm}$. la lanza y 62 centímetros el regatón.

Expositor: Excmo. Sr. Marqués de Cerralbo, su descubridor.

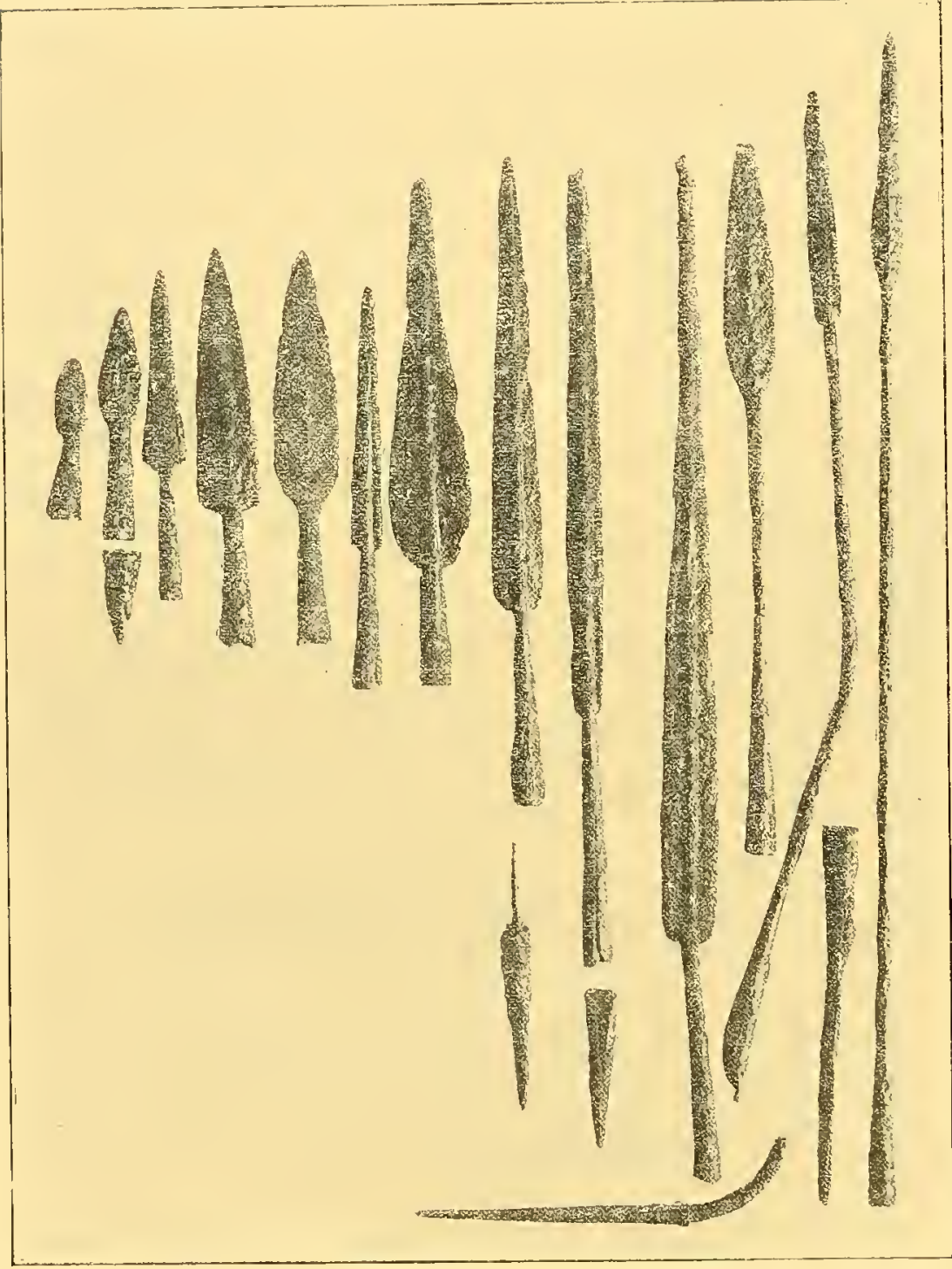

Núms. $70,69,71,68,67,65,66,64,62,61,60,59,58,60$ y 63.

Núm. 64. - Lanza de la época de Hallstatt.

Procedente de Aguilar de Anguita, en Guadalajara.-Longitud: $43 \mathrm{~cm}$.

Expositor: Excmo. señor Marqués de $\mathrm{Ce}$ rralbo, su descubridor.

Núm. 65.-Lanza de la época de Hallstatt.

Procede de la Necrópolis de Alpanseque, en Soria.-Longitud: $27 \mathrm{~cm}$.

Expositor: Excmo. señor Marqués de Cerralbo, su descubridor.

Núm. 66.-Lanza de la época de Hallstatt.

Procede de la Necrópolis de Alpanseque, en Soria.-Longitud: $33 \mathrm{~cm}$.

Expositor: Excmo. señor Marqués de Cerralbo, su descubridor.

Núm. 67. - Lanza de la última fase de la época de Hallstatt.

Procede de la Necrópolis de Alpanseque, en Soria.-Longitud: $26 \mathrm{~cm}$.

Expositor: Excmo. Sr. Marqués de Cerralbo, su descubridor.

Núm. 68.-Lanza de la última época de Hallstatt.

Procede de la Necrópolis de Aguilar de Anguita, en Guadalajara.—Longitud: $27 \mathrm{~cm}$.

Expositor: Excmo. Sr. Marqués de Cerralbo, su descubridor. 
Núm. 69.-Lanza de la época de Hallstatt.

Procede de la Necrópolis de Aguilar de Anguita, en Guadalajara.—Longitud: $16 \mathrm{~cm}$.

Expositor: Excmo. Sr. Marqués de Cerralbo, su descubridor.

Núm. 70. - Lanza y regatón de la época de Hallstatt.

Procedente de Valdenovillos. - Longitud: 11 centímetros la lanza y 6 el regatón.

Expositor: Excmo. Sr. Marqués de Cerralbo, su descubridor.

Núm. 71. - Lanza típica de la época de La Tène, en hierro acerado.

Procede de la Necrópolis de Arcóbriga, Monreal de Ariza (Zaragoza).-Longitud: $26 \mathrm{~cm}$.

Expositor: Excmo. Sr. Marqués de Cerralbo, su descubridor.

Núm. 72. - Lanza de la época de La Tène del poblado Ibérico de Castejón, Luzaga (Guadalajara). - Longitud: $32 \mathrm{~cm}$.

Expositor: Excmo. Sr. Marqués de Cerralbo, su descubridor.

Núm. 73. - Gran cuchillo afalcatado. Epoca de Hallstatt.

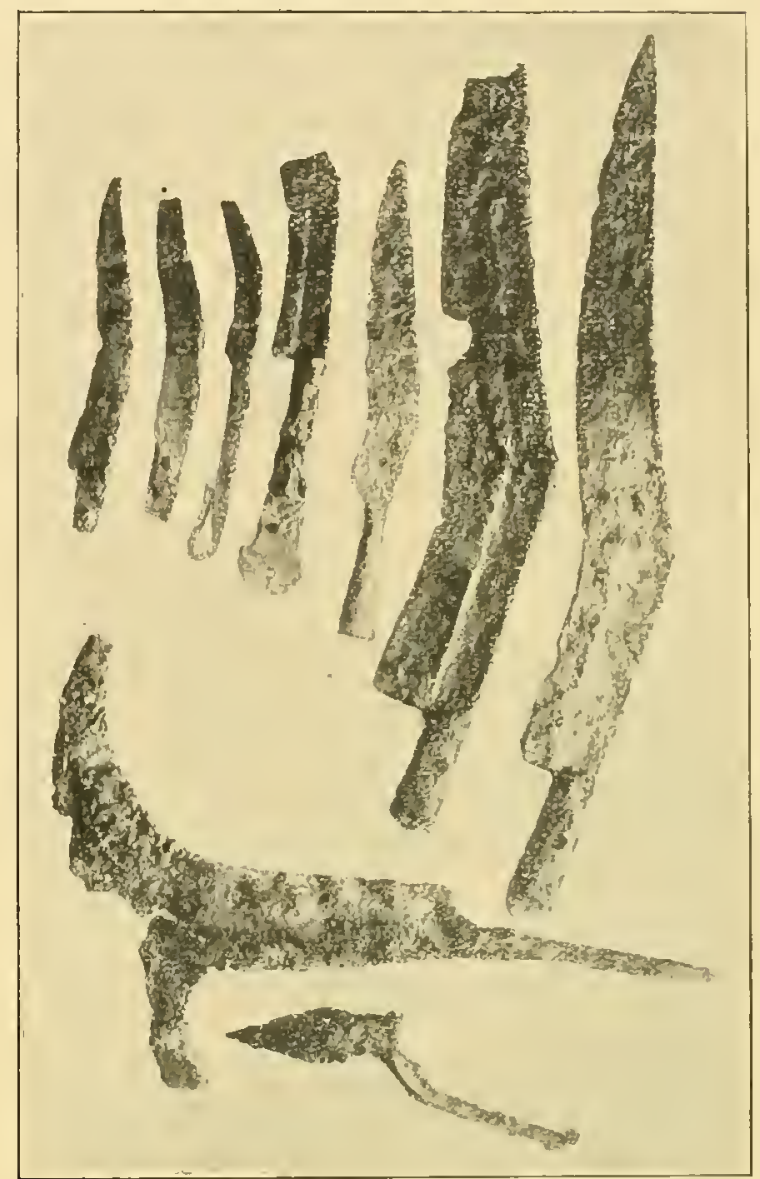

Nủms. $77,78,79,76,75,74,73,143$ y 144

Procede de la Necrópolis de Aguilar de Anguita.-Longitud: $38 \mathrm{~cm}$.

Expositor: Excmo. Sr. Marqués de Cerralbo, su descubridor.

Núm. 74.-Gran cuchillo curvo afalcatado, de la época de Hallstatt.

Procede de la Necrópolis de Aguilar de Anguita._Longitud: $23 \mathrm{~cm}$.

Expositor: Excmo. Sr. Marqués de Cerralbo, su descubridor.

Núm. 75. - Cuchillo corvo con enchufe en el mango. Epoca de la Tène.

Procedente del campamento ibero-romano de Aguilar de Anguita, en Guadalajara; muy singular.-Longitud: $19 \mathrm{~cm}$.

Expositor: Excmo. Sr. Marqués de Cerralbo, su descubridor.

Núm. 76. - Cuchillo incompleto, corvo, conservando la forma de los de la época del Bronce; perteneciente al siglo $\mathrm{v}$, antes de J. C. 
Procede de la Necrópolis de Aguilar de Anguita._Longitud: $18 \mathrm{~cm}$.

Expositor: Excmo. Sr. Marqués de Cerralbo, su descubridor.

Núm. 77. - Hoja de cuchillo. Epoca de Hallstatt II.

Procede de la Necrópolis de Aguilar de Anguita, en Guadalajara._Longitud: $15 \mathrm{~cm}$.

Expositor: Excmo. Sr. Marqués de Cerralbo, su descubridor.

Núm. 78. - Hoja de cuchillo con un fragmento de las cachas de hueso del mango. Epoca de Hallstatt II.

Procede de la Necrópolis de Aguilar de Anguita, en Guadalajara._Longitud: $14 \mathrm{~cm}$.

Expositor: Excmo. Sr. Marqués de Cerralbo, su descubridor.

Núm. 79. - Cuchillito de la época de Hallstatt II.

Procede de la Necrópolis de Aguilar de Anguita.-Longitud: $16 \mathrm{~cm}$.

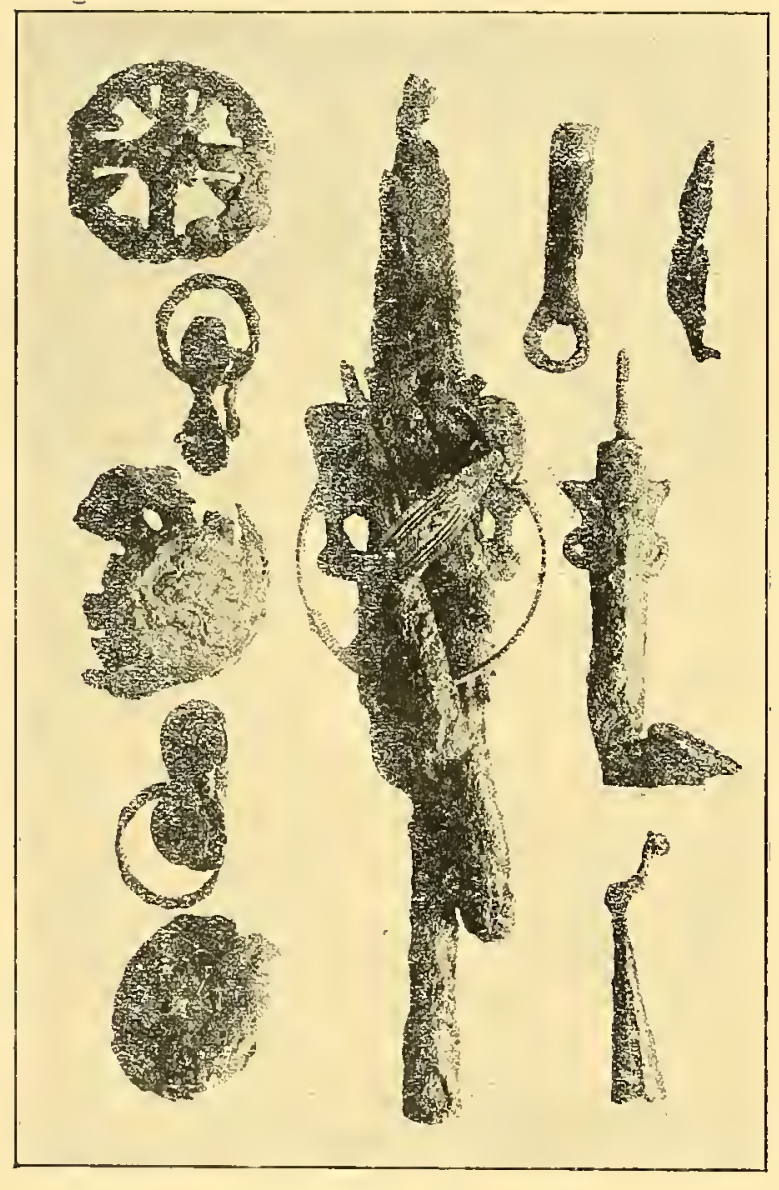

Núms. 81, 84, 80, 83, 82, 92, 85, 87, 11 y 86.
Expositor: Excmo. Sr. Marqués de Cerralbo, su descubridor.

Núms. 80, 81 y 82.-Tres omphalos o cenros de escudo redondo, de guerrero de la época de Hallsttat II; piezas de gran novedad y rareza en Arqueología.

Procede de la Necrópolis de Aguilar de Anguita, en Guadalajara.

Expositor: Excmo. Sr. Marquiés de Cerralbo, su descubridor.

Núms. 83 y 84.-Dos piezas de escudo de alta novedad y rareza en Arqueología: cada una de ellas se compone de dos planchuelas de hierro cortadas en forma de $\mathrm{S}$ y asociadas por clavillos que las sostienen unidas y separadas, y así el espacio intermedio determina el espesor del escudo, pues tales piezas sirvieron para que, en las anillas que tienen y pendían al interior, se enganchasen las correas para embrazar el escudo.

Proceden de la Necrópolis de Aguilar de Anguita y corresponden al siglo $\mathrm{v}$, antes J. .C

Expositor: Excmo. Sr. Marqués de Cerralbo, su descubridor.

Núm. 85. - Regatón (?) de la época de Hallstatt II.

Procede de la Necrópolis de Clares.-Longitud: $10 \mathrm{~cm}$.

Expositor: Excmo. Sr. Marqués de Cerralbo, su descubridor. 
Núm. 86.-Porta-enseña (?) 'de' la época de la Tène. Raro.

Procede de la Necrópolis de Arcóbriga, en Monreal de Ariza.-Longitud: $11 \mathrm{~cm}$.

Expositor: Excmo. Sr. Marqués de Cerralbo, su descubridor.

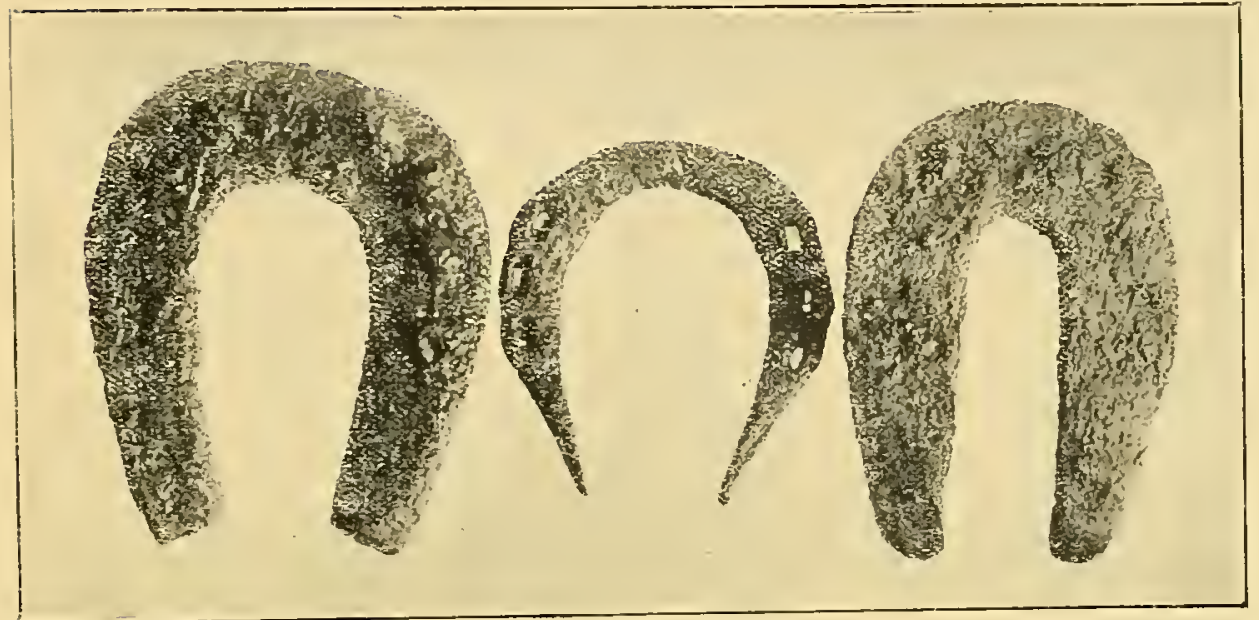

Nủms. $88,89,88$.
Núm. 87. - Rarísimas medias tijeras de la época de Hallsttat.

Procede de la Necrópolis de Aguilar de Anguita, en Guadalajara. - Longitud: $9 \mathrm{~cm}$.

ExPOSITOR: Excelentísimo Sr. Marqués de Cerralbo, su descubridor.

Núm. 88.-Dos herraduras de caballo de la época de Hallstatt II. Piezas de extrema rareza y las primeras que se encontraron en Europa, del siglo $\mathrm{v}_{r}$ antes de J. C.

Procede de la Necrópolis de Aguilar de Anguita.-Longitud: $14 \mathrm{~cm}$.

Expositor: Excmo. Sr. Marqués de Cerralbo, su descubridor.

Núm. 89. Herradura de caballo de la época de la Tène (siglo $\mathrm{I}_{\text {r }}$ antes de J. C.)

Procede de la Necrópolis de Luzón (Guadalajara).-Longitud: $11 \mathrm{~cm}$.

Expositor: Excmo. Sr. Marqués de Cerralbo, su descubridor.

Núm. 90.--Rarísima pieza, la primera hallada en España, y que, según Artemidoro, la usaban las damas iberas para sostener el manto que cubría la cabeza y que, según el Marqués de Cerralbo, habrá dado origen a la peineta y mantilla españolas. Artefacto que describe minuciosamente Artemidoro, llamándole moda bárbara de las damas ibéricas, aunque el manto

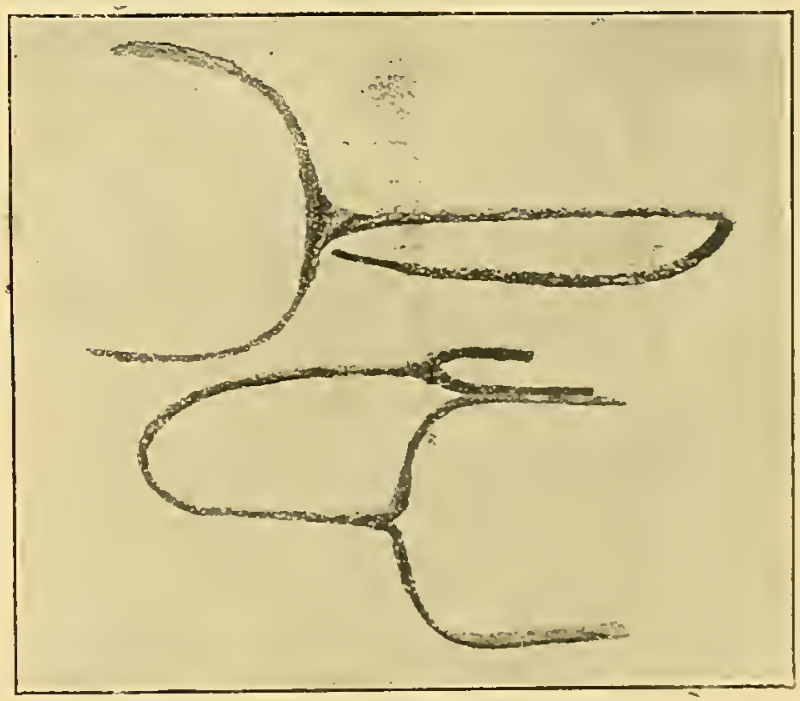

Núrns. 90 y 91 así colocado realzaba la belleza de las damas prerromanas del interior de la Península Ibérica. La época de iniciación pudo ser el siglo v antes de J. C.

Procede de la Necrópolis de Aguilar de Anguita, en Guadalajara.-Longitud: $57 \mathrm{~cm}$.; faltan, por rotas, las varillas de la parte superior.

Expositor: Excmo. Sr. Marqués de Cerralbo, su descubridor. 


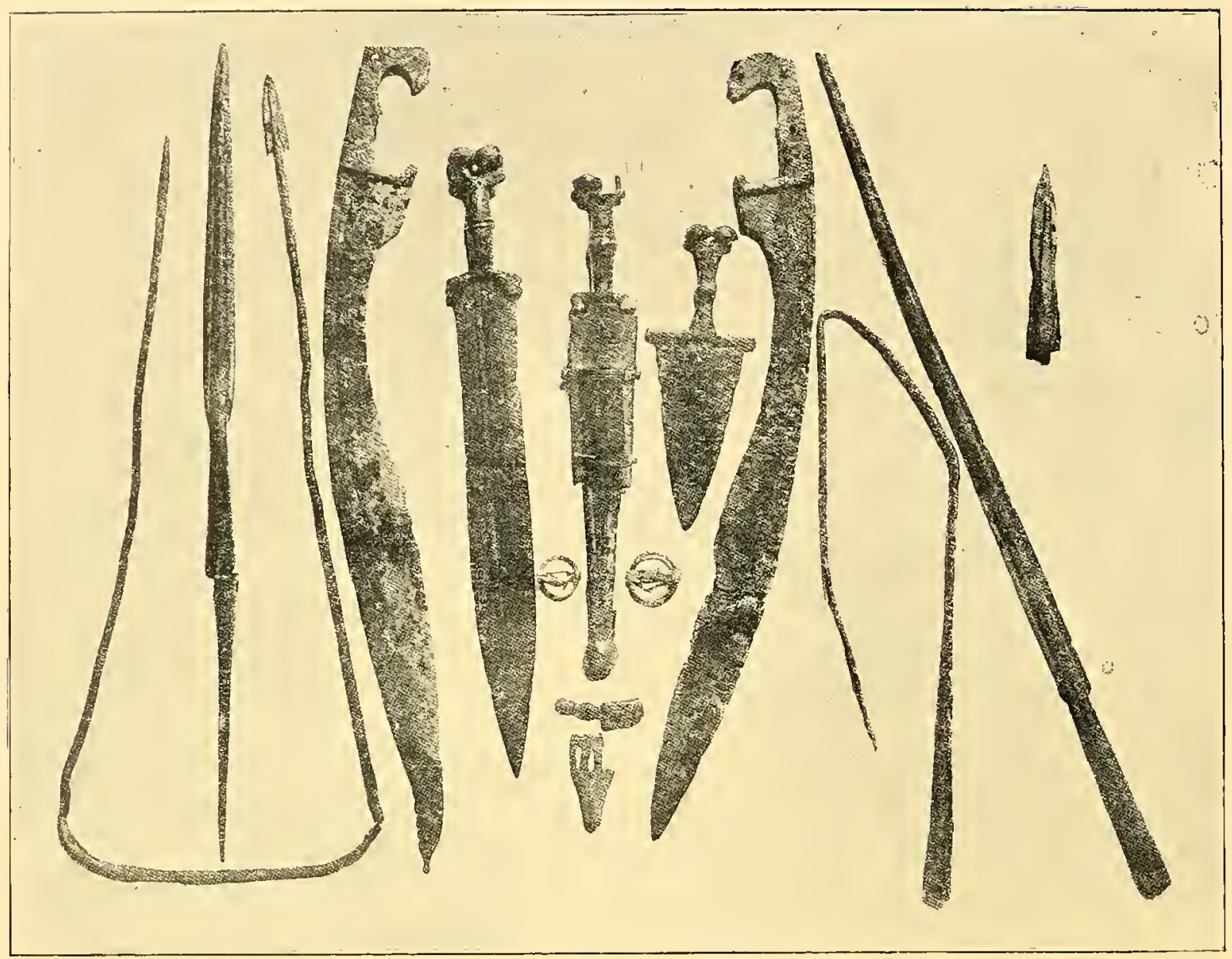

Núms. 100,102,94,97,99,98,95,101,103,105, 104, 95 у 106.

Núm. 91.- Pieza análoga a la anterior.

Procede de la Necrópolis de Arcóbriga, Monreal de Ariza, en Zaragoza; están rotas y faltas las puntas extremas superiores. - Longitud: $52 \mathrm{~cm}$.

Expositor: Excmo. Sr. Marqués de Cerralbo, su descubridor.

Núm. 92.-Sepultura completa de un guerrero ibérico en el mismo estado que se encontró, cuyas piezas, formando un haz, son las siguientes: dos lanzas con sus regatones, cuchillo, broche de cinturón de los llamados grecohispanos por Déchélètte, pero que el Marqués de Cerralbo sostiene son de invención celtíbera, una gran fíbula hispánica, etc. Epoca de Hallstatt II.

Esta sepultura se expone para dar idea de cómo eran las tumbas celtibéricàs, siempre por incineración, y de las cualas ha descubierto millares en sus exploraciones arqueológicas de sus diez y siete Necrópolis ya excavadas el Excmo. Sr. Marqués de Cerralbo, expositor de esta sepultura del siglo iv antes de J. C.

Procede de la Necrópolis de Valdenovillos.-Longitud: $43 \mathrm{~cm}$.

Núm. 93.- Sepultura de un personaje ibero, completa, que se compone de una espada de antenas $(46 \mathrm{~cm} .)_{r}$ dos lanzas $(31$ y $25 \mathrm{~cm}$.), fragmentos de un soliferium, un bocado de 
caballo $(27 \mathrm{~cm}$.) y tres cuchillitos $(15,17$ y 11). Epoca de Hallstatt II. Siglos v a iv antes de Jesucristo.

Procede de la Necrópolis de Aguilar de Anguita, en Guadalajara.

Expositor: Excmo. Sr. Marqués de Cerralbo, su descubridor.

Núms. 94 a 106.-Conjunto notabilísimo de armas ibéricas procedentes de una Necrópolis de Illora (Granada). Epoca de Hallstatt II y III.

94. - Espada falcata con extremo de vaina primorosamente trabajada._Longitud: $65 \mathrm{~cm}$.

95. - Espada falcata con restos de incrustaciones de plata en la empuñadura.

Longitud: $62 \mathrm{~cm}$.

96.-Fragmento de una empuñadura de falcata con una cabeza de león e incrustaciones de plata.-Longitud: $7 \mathrm{~cm}$.

97.- Espada de antenas.-Longitud: $50 \mathrm{~cm}$.

98. - Puñal corto de hoja ancha.-Longitud: $24 \mathrm{~cm}$.

99.-Puñal de antenas con restos de vaina y de otra superpuesta a la anterior y más pequeña para el cuchillo. - Longitud: $39 \mathrm{~cm}$.

100.-Soliferium. - Longitud: $140 \mathrm{~cm}$.

101.- Gran lanza con su regatón.-Longitud: 73 y $87 \mathrm{~cm}$. respectivamente.

102. - Lanza y su regatón.-Longitud: 42 y $23 \mathrm{~cm}$.

103.-Lanza pequeña. - Longitud: $16 \mathrm{~cm}$.

104.-Fíbula hispánica de bronce.-Longitud: $4,5 \mathrm{~cm}$.

105. - Idem id. id. - Longitud: $3,5 \mathrm{~cm}$.

106. - Medio broche de cinturón.--Longitud: $7,5 \mathrm{~cm}$.

Expositor: Excmo. Sr. Marqués de Cerralbo.

Núm. 107.- Sepultura de un labrador de la época de La Tène $\mathrm{I}$, que se compone de la urna cineraria, reja de arado $(36 \mathrm{~cm}$.), anillas del timón (diámetro 11 y $10 \mathrm{~cm}$.), dos azuelas $(23$ y $16 \mathrm{~cm}$.) y otra pieza indeterminada $(23 \mathrm{~cm}$.).

Procedente de la Necrópolis de Turmiel, en Guadalajara.

Expositor: Excmo. Sr. Marqués de Cerralbo, su descubridor.

Núms. 108 a 115. - Objetos domésticos

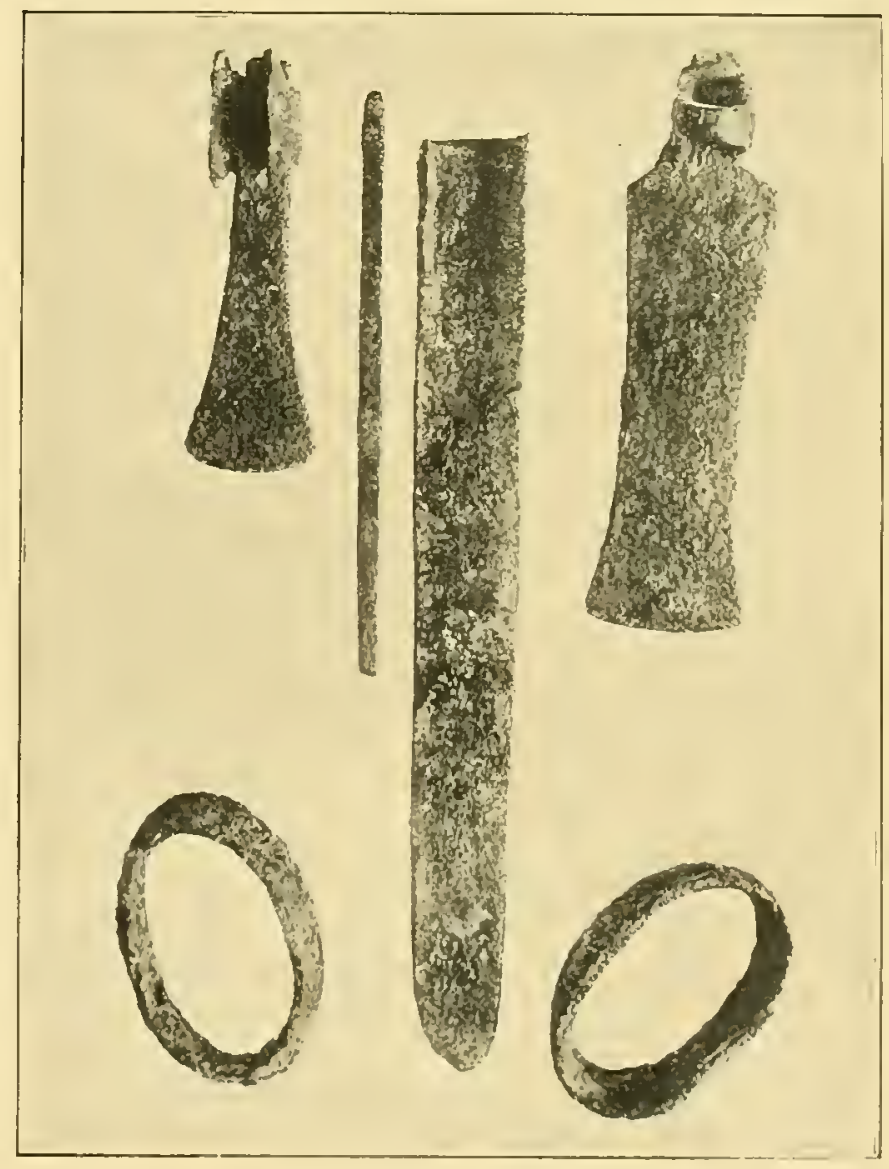

Nium. 107. 
encontrados en el campamento ibero-romano de Aguilar de Anguita. Epoca de la Tène.

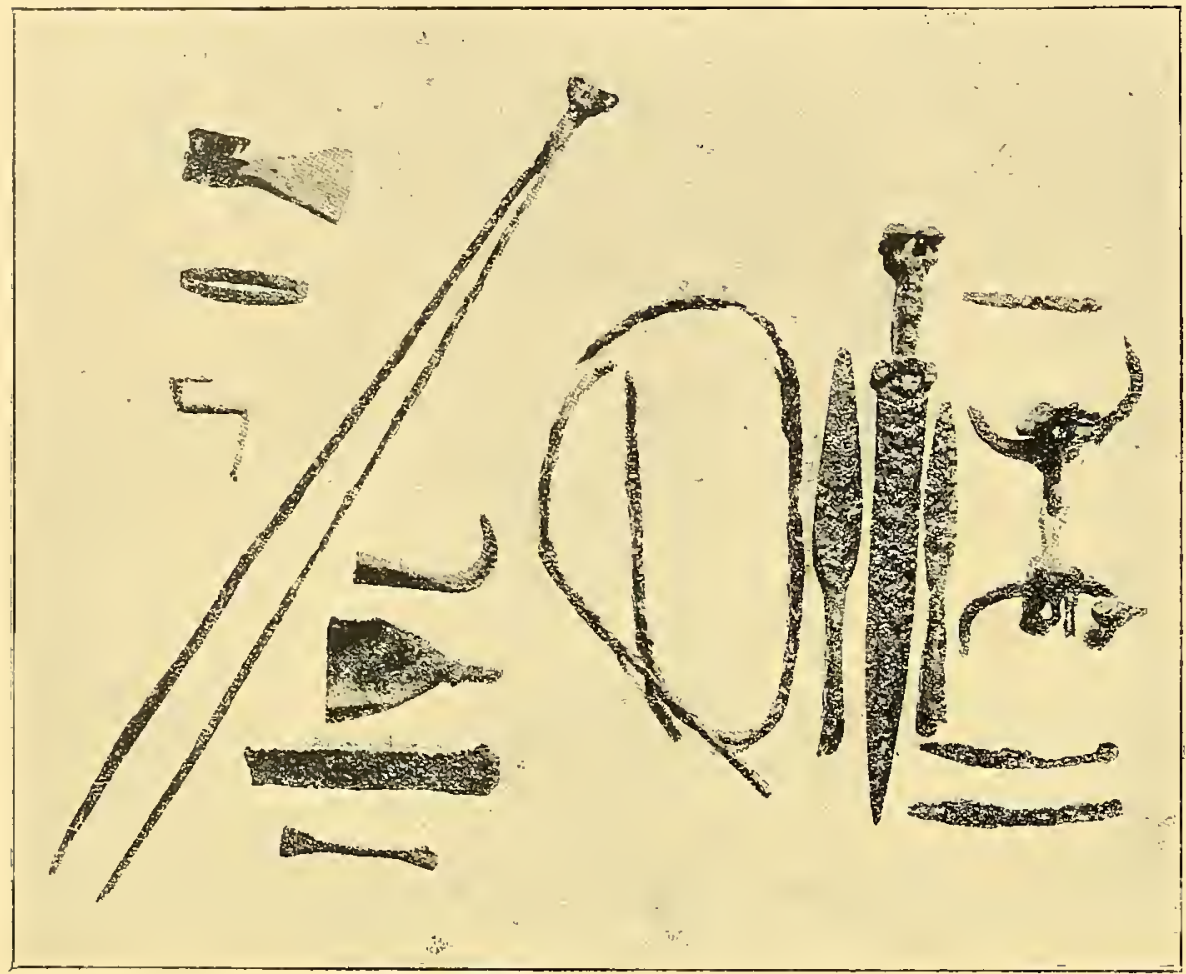

Núms. 115, 112, 109, 108, 113, 110, 111, 114 y 93.
108. -- Tenazas de hogar $(73 \mathrm{~cm}$.$) .$ 109.- Una llave (10 centímetros).

110.- - Una hachuela (14 cm.).

111.-Fragmento de sierra $(20 \mathrm{~cm}$.).

112. - Un eslabón (10 cm.).

113.- Un hocino (11 centímetros).

114.-Doble escoplo (12 cm.).

115. - Una hachuela (13 cm.).

Expositor: Excelentisimo Sr. Marqués de Cerralbo, su descubridor.

Núms. 116 a 122. - Conjunto de objetos industriales procedentes del Perical. Acrópolis celtibérica de Valdenovillos, Alcolea de las Peñas, en Guadalajara.

116. - Hacha de for-

ma arcaica co-

mo las de la

primera época

del bronce (14 centímetros).

117. - Hachuela (12 centímetros.).

118. - Hachuela (11 centímetros).

119.- - Reja de arado (24 cm.).

120. - Anilla del timón (II cm.).

121. - Otra anilla (7 centímetros).

122. - Pieza de uso desconocido $(10 \times 15 \mathrm{~cm}$.)

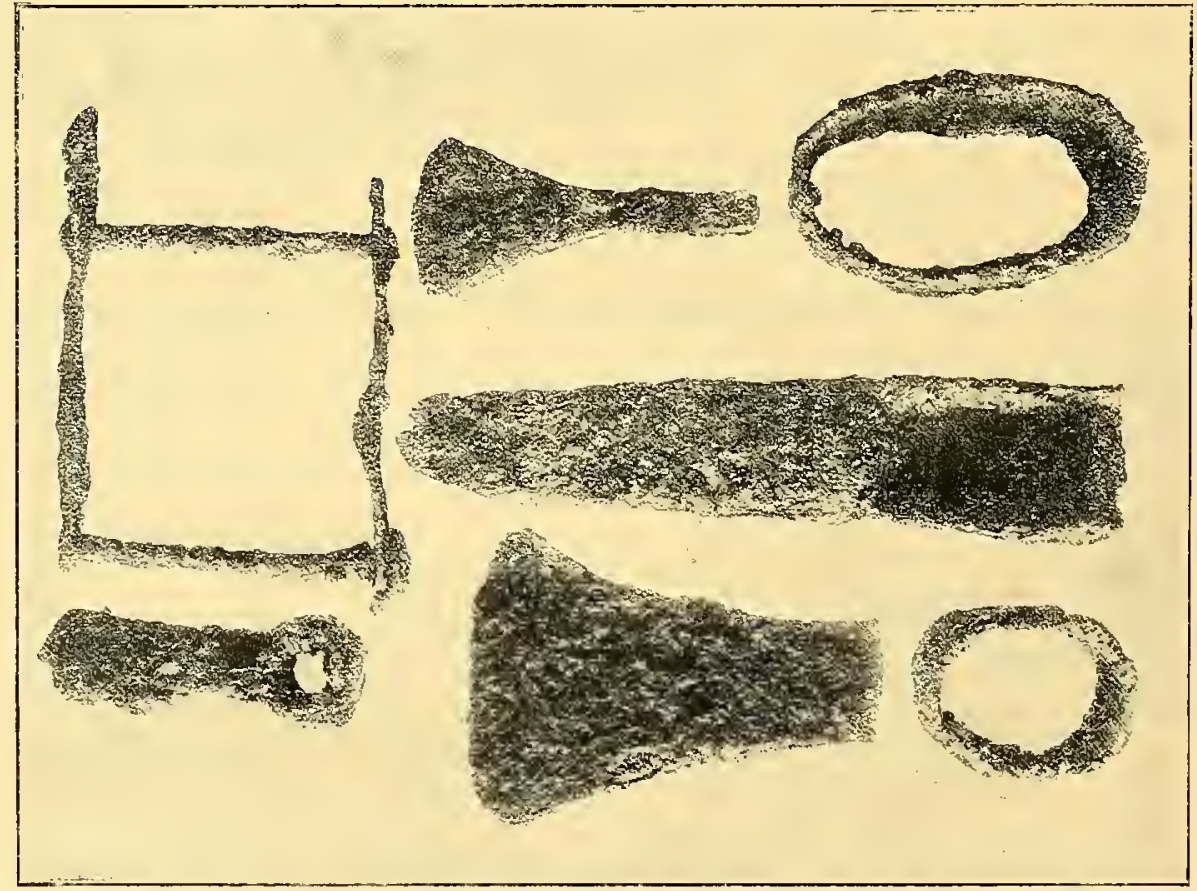

Núms. 122, 117, 120, 119, 118, 116 y 121. 
Expositor: Excelentísimo Sr. Marqués de Cerralbo, su descubridor.

Núms. 123 a 131.-Diversos objetos procedentes de Castejón. Acrópolis celtíbera de la Necrópolis de Luzaga. Epoca de La Tène II.

123 y 124.- Hachas de forma arcaica $(13$ y $11 \mathrm{~cm}$.). 125 y $126 .-\mathrm{Re}-$ jas de arado (49 y $42 \mathrm{~cm}$.).

127.- Hachuela para mango de enchufe; adherida a ella se ven res-

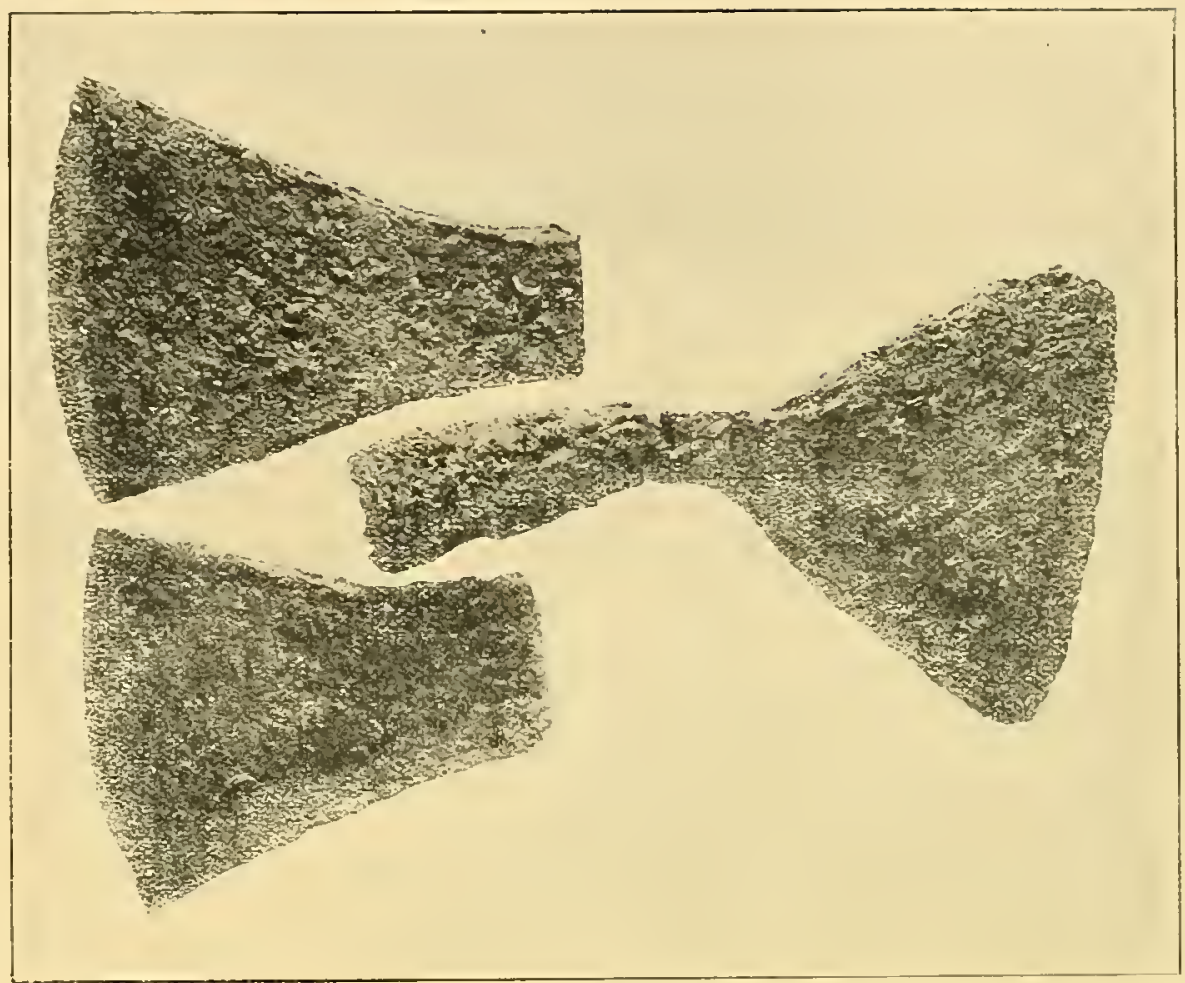

Nüms. 124,123 y 127.

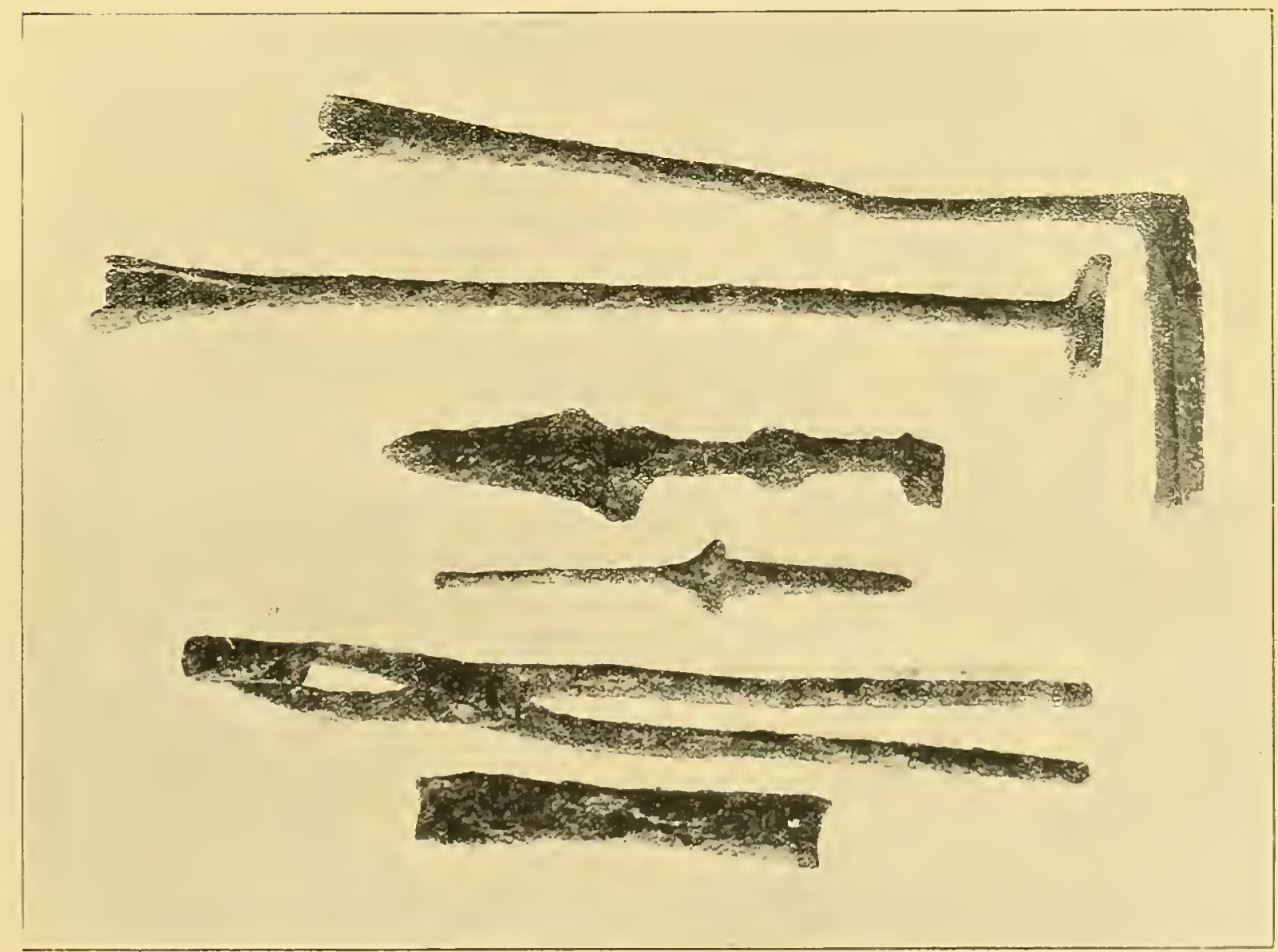

Núms. $134: 135,25,132$ y 133. 


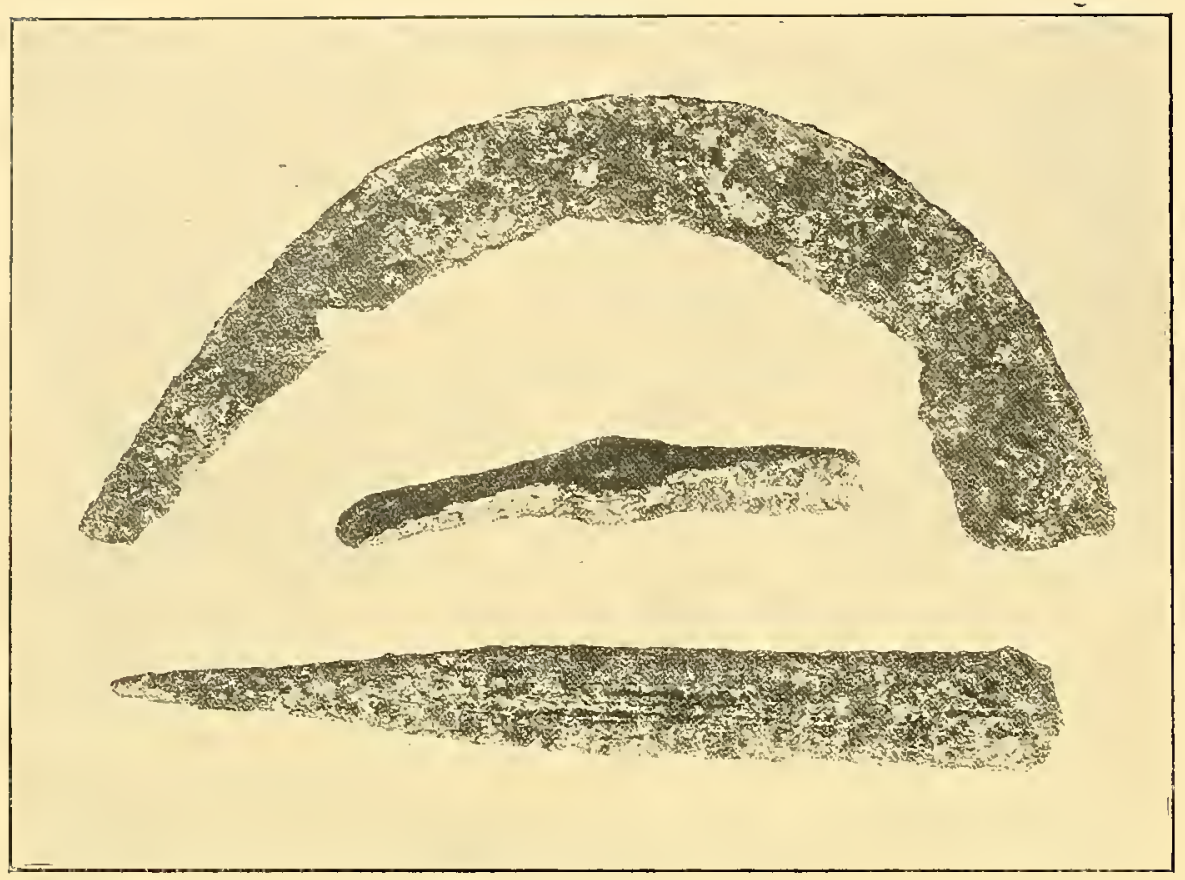

Núms. 137, 138 y 136. tos de tejidos de la época $(19 \mathrm{~cm}$.).

128.-Cuchillo de dos filos $(38 \mathrm{~cm}$.).

129.-Objeto cortante de tres filos $(17 \mathrm{~cm}$.).

130. - Anilla de forma trapezoidal $(12 \mathrm{~cm}$.).

131.-- Puente de cerradura $(30 \times 10 \mathrm{~cm}$. $)$.

Expositor: Excmo. señor Marqués de Cerralbo, su descubridor.

Núm. 132. - Tenazas del campamento de Aguilar de Anguita. Epoca de La Tène II. Longitud: $28 \mathrm{~cm}$.

Expositor: Excmo. Sr. Marqués de Cerralbo, su descubridor.

Núm. 133. - Dos escoplos del campamento de Aguilar de Anguita.

Longitud: $13 \mathrm{~cm}$. y $15 \mathrm{~cm}$.

Expositor: Excmo. Sr. Marqués de Cerralbo, su descubridor.

Núms. 134 y 135.Dos marcas de ganado.

Proceden de Termes, en Soria. - Longitud: 30 y 27 centímetros.

Expositor: Excelentísimo señor Marqués de Cerralbo, su descubridor.

Núms. 136 a 138. Objetos procedentes del poblado de los Castillejos. Acrópolis celtíbera de Atance (Guadalajara).

136.- Hoja de espada de antenas (3I cm.).

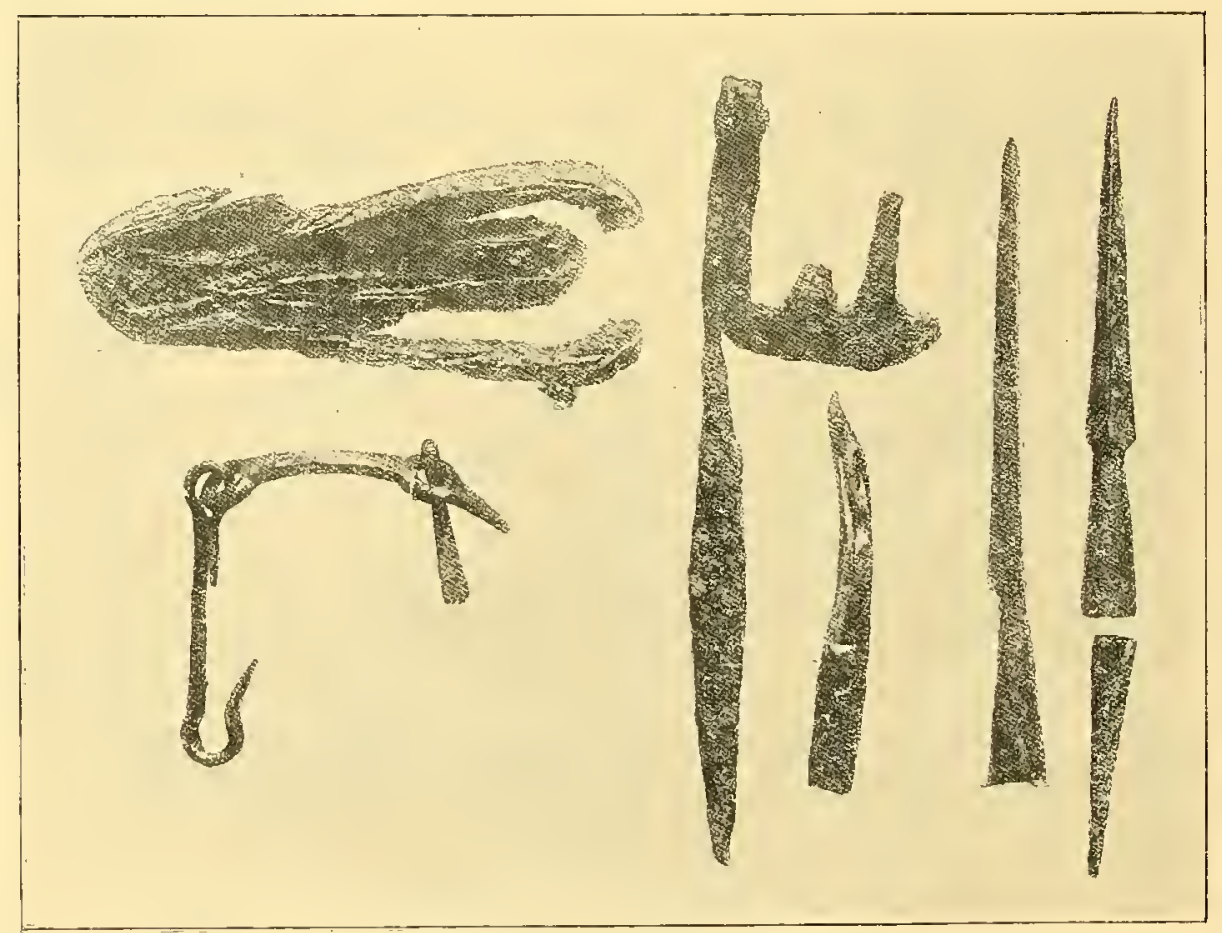

Núms. 15, 141, 139, 140, 55 y 142. 
137.- - Hoja de hoz (33 centímetros).

138. - Doble hachuela (17 cm.).

Expositor: Excmo. señor Marqués de Cerralbo, su descubridor.

Núm. 139.-Hoja de lanza triangular.

Procedente del poblado de Turmiel, en Guadalajara.-Longitud: $20 \mathrm{~cm}$.

Expositor: Excino. señor Marqués de $\mathrm{Ce}$ rralbo, su descubridor.

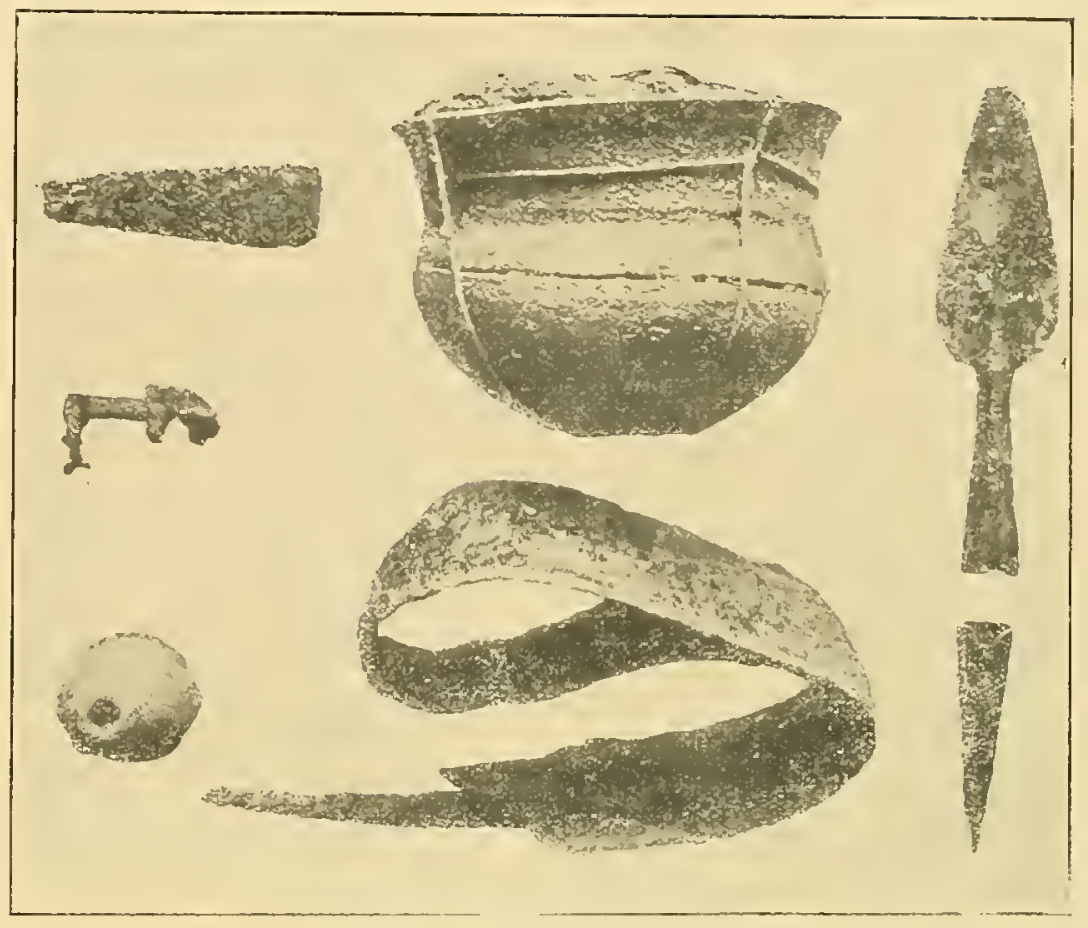

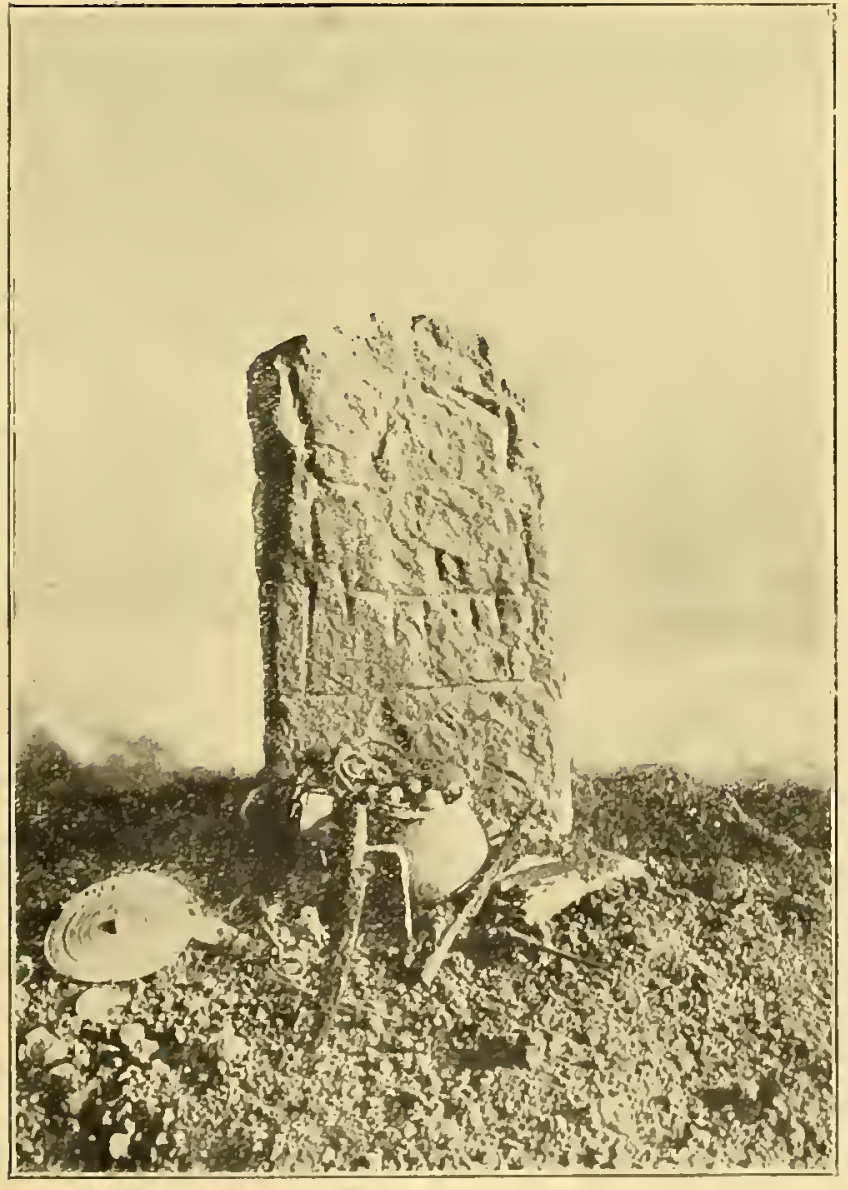

Núm, 146.

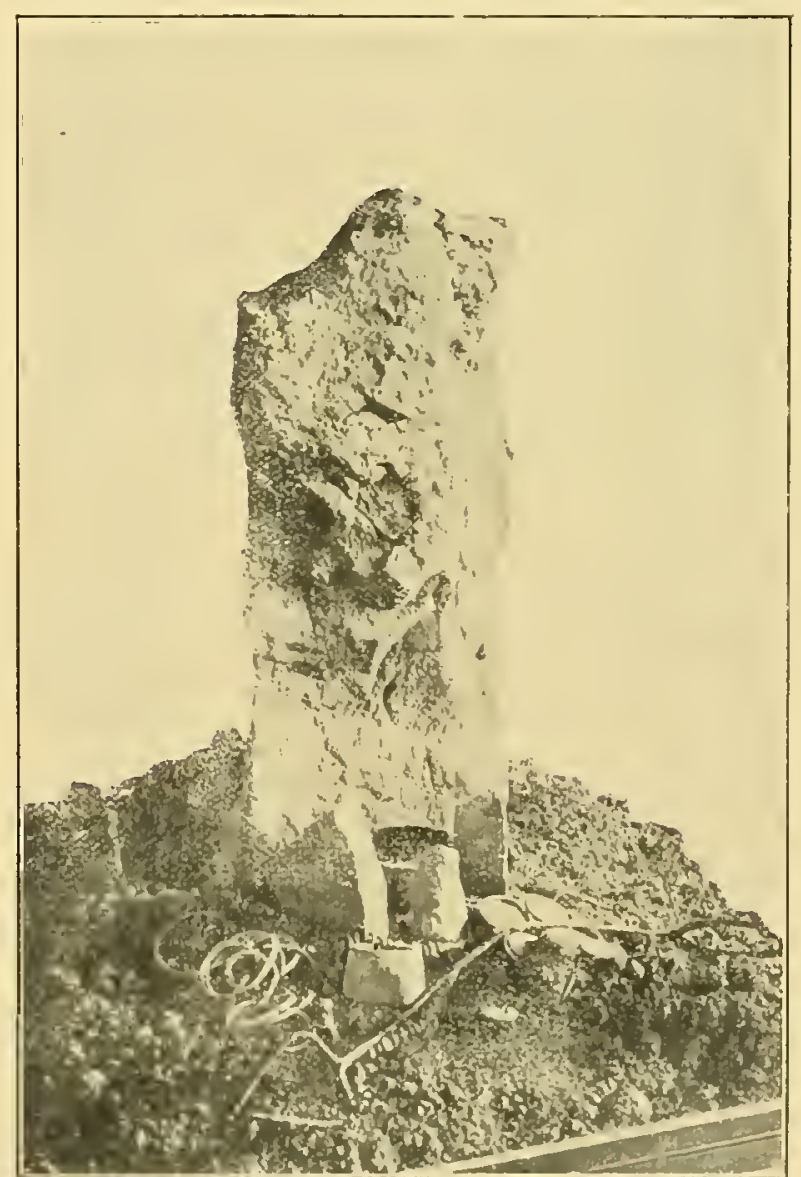

Nủin. 147. 
Núm. 140. - Hoja de lanza triangular con su regatón.

Procede de la Necrópolis de Cuevas Labradas (Guadalajara)._Longitud: $16 \mathrm{~cm}$. la lanza y 8 el regatón.

Expositor: Excmo. Sr. Marqués de Cerralbo, su descubridor.

Núm. 141.-Llave procedente de Beltejar (Soria).-Longitud: $52 \mathrm{~cm}$.

Expositor: Excmo. Sr. Marqués de Cerralbo, su descubridor.

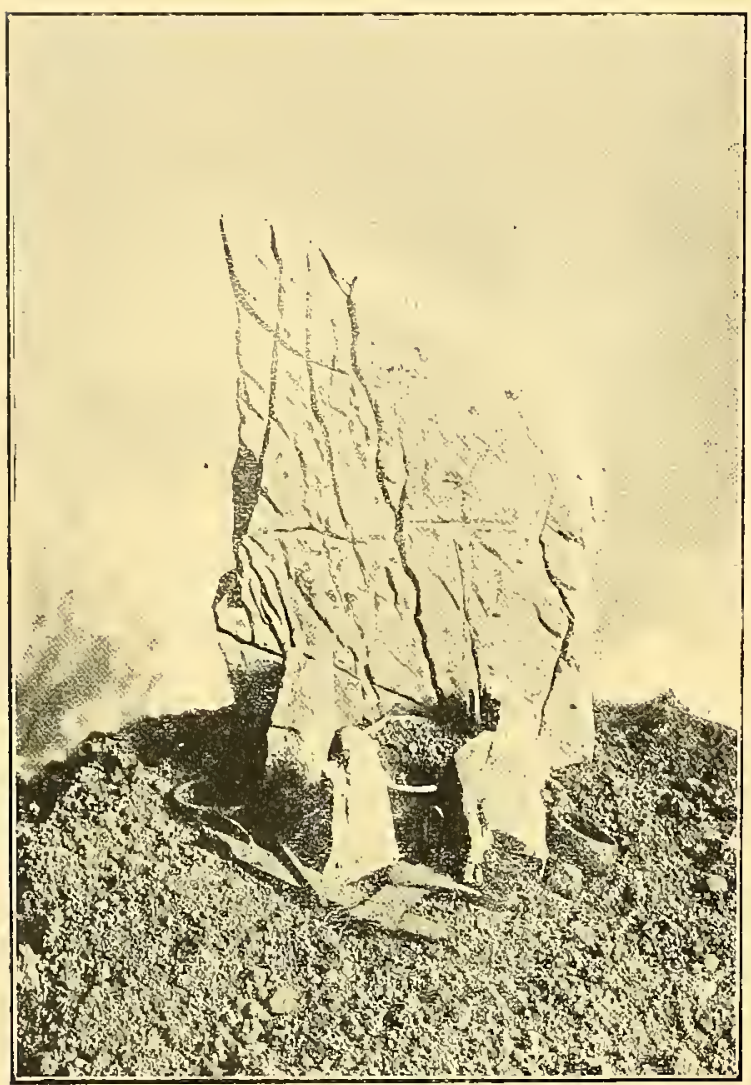

Nưm. 107.

Núm. 142.-Cuchillo procedente de Beltejas, en Soria.-Longitud: $13 \mathrm{~cm}$.

Expositor: Excmo. Sr. Marqués de Cerralbo, su descubridor.

Núm. 143.-Doble hoz visigótica.

Procedente de Renales, en Guadalajara. - Longitud: $31 \mathrm{~cm}$.

Expositor: Excmo. Sr. Marqués de Ce rralbo, su descubridor.

Núm. 144. -Espuela visigótica.

Procedente de Renales, en Guadalajara.Longitud: $16 \mathrm{~cm}$.

Expositor: Excmo. Sr. Marqués de Cerralbo, su descubridor.

Núm. 145.-Sepultura de guerrero celtíbero de la Necrópolis de Arcóbriga, en Monreal de Ariza (Zaragoza). Epoca de La Tène I. Consta de su urna cineraria con su tierra natural y sin abrir; espada de La Tène I $(70 \mathrm{~cm}$.); lanza y regatón $(15$ y $7 \mathrm{~cm}$.); hoja de rasurar $(9 \mathrm{cen}$ tímetros); fíbula de forma de torito y su fusaiola de barro.

Exposiror: Excmo. Sr. Marqués de Cerralbo, su descubridor.

Núm. 146. - Sepultura completta de un guerrero ibérico, que consta de su estela de piedra labrada toscamente y en la que se grabó una figura de caballo y otra humana de una manera muy esquemática; la urna cineraria; espada de antenas; dos lanzas con sus regatones; cuchillos y anillas del escudo; filetes del caballo y un juego de grandes discos de bronce. Esta sepultura se expone en la misma forma que se halló en la Necrópolis. Epoca Hallstatt II.

Procede de la Necrópolis de Aguilar de Anguita.

Expositor: Excmo. Sr. Marqués de Cerralbo, su descubridor. 
Núm. 147.-Sepultura completa de una dama ibérica, tal como se encontró en su $\mathrm{Ne}$ crópolis. Consta de la estela de piedra, urna cineraria, fíbula de bronce, brazaletes y espirales de bronce, y la pinza que describe Artemidoro conque las damas ibéricas sostenían el manto que cubría su cabeza y que dió origen a la peineta española. Epoca La Tène I.

Procede de la Necrópolis de Arcóbriga, Monreal de Ariza (Zaragoza).

Expositor: Excmo. Sr. Marqués de Cerralbo, su descubridor.

Núm. 107. - Sepultura de un labrador, con su estela (véase el lugar correspondiente).

Núm. 148. - Sepultura de un sacerdote con cuchillo de sacrificio y su vaina, compuesta, además, de dos lanzas, broche greco- hispano, una fíbula con cabeza de cisne, de $\mathrm{La}$ Tène I, sus pinzas, espirales en bronce y anillos. Epoca de La Tène I. Gormaz.

Procede de la Necrópolis de Quintanar de

Expositor: D. Ricardo Morenas de Tejada, su descubridor.

Núm. 149. - Sepultura de guerrero con puñal de antenas de bronce, y su vaina, tres lanzas y un regatón. Una fíbula de hierro de La Tène I.

Procede de la Necrópolis de Quintanar de Gormaz.

Expositor: D. Ricardo Morenas de Tejada, su descubridor.

Núm. 150. - Sepultura de un guerrero, compuesta de un gran omphalo de escudo, tres lanzas, dos fíbulas hispánicas y una fusaiola.

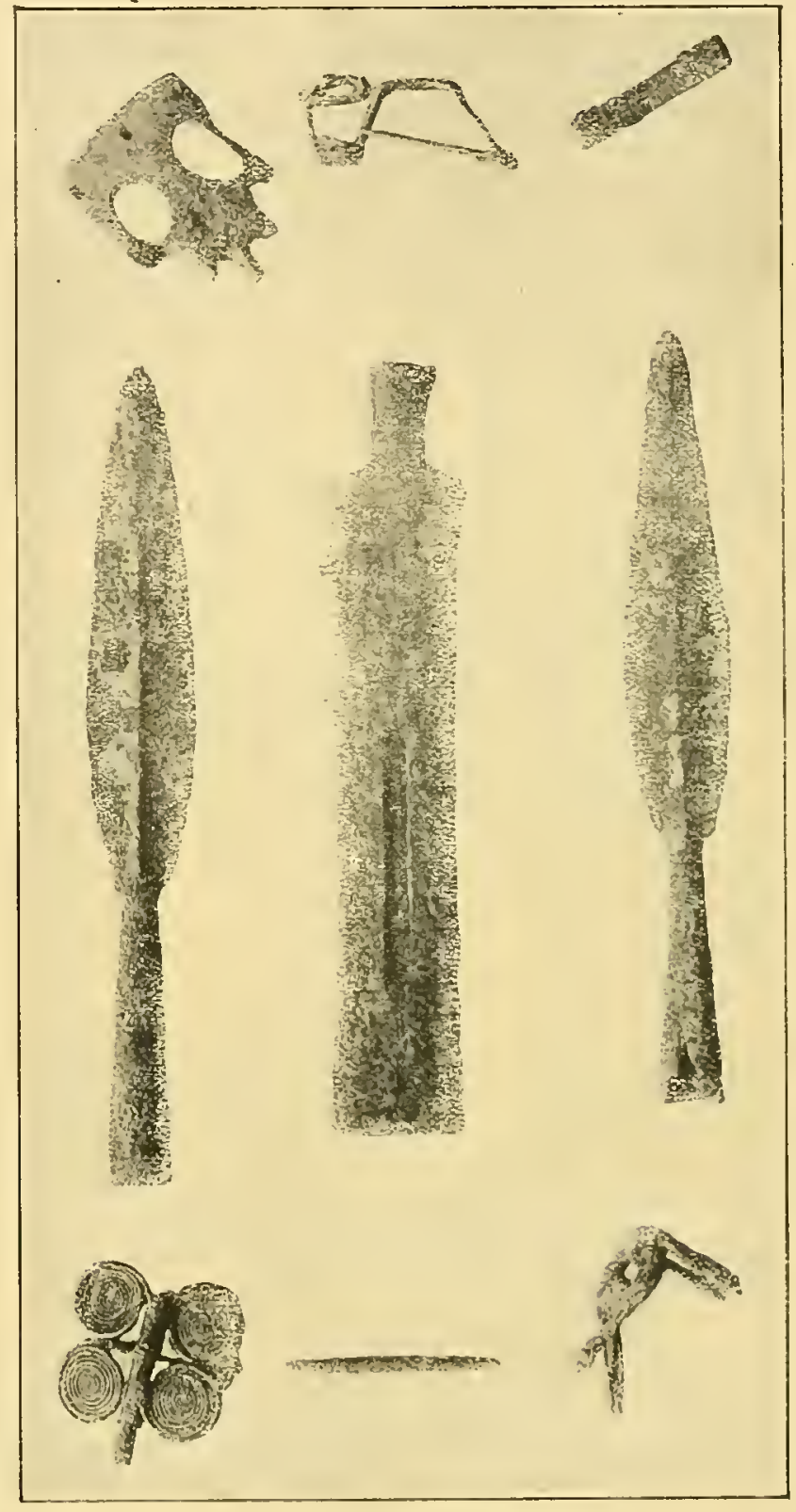

Nủm. 148 .

Procede de la Necrópolis de Quintanar de Gormaz.

Expositor: D. Ricardo Morenas de Tejada, su descubridor.

Núm. 151.- Sepultura de guerrero con lanza de La Tène I, espada doblada y vaina separadas, en muy buen estado de conservación, fíbula de bronce con cuchillo y anilla de soporte del escudo. 


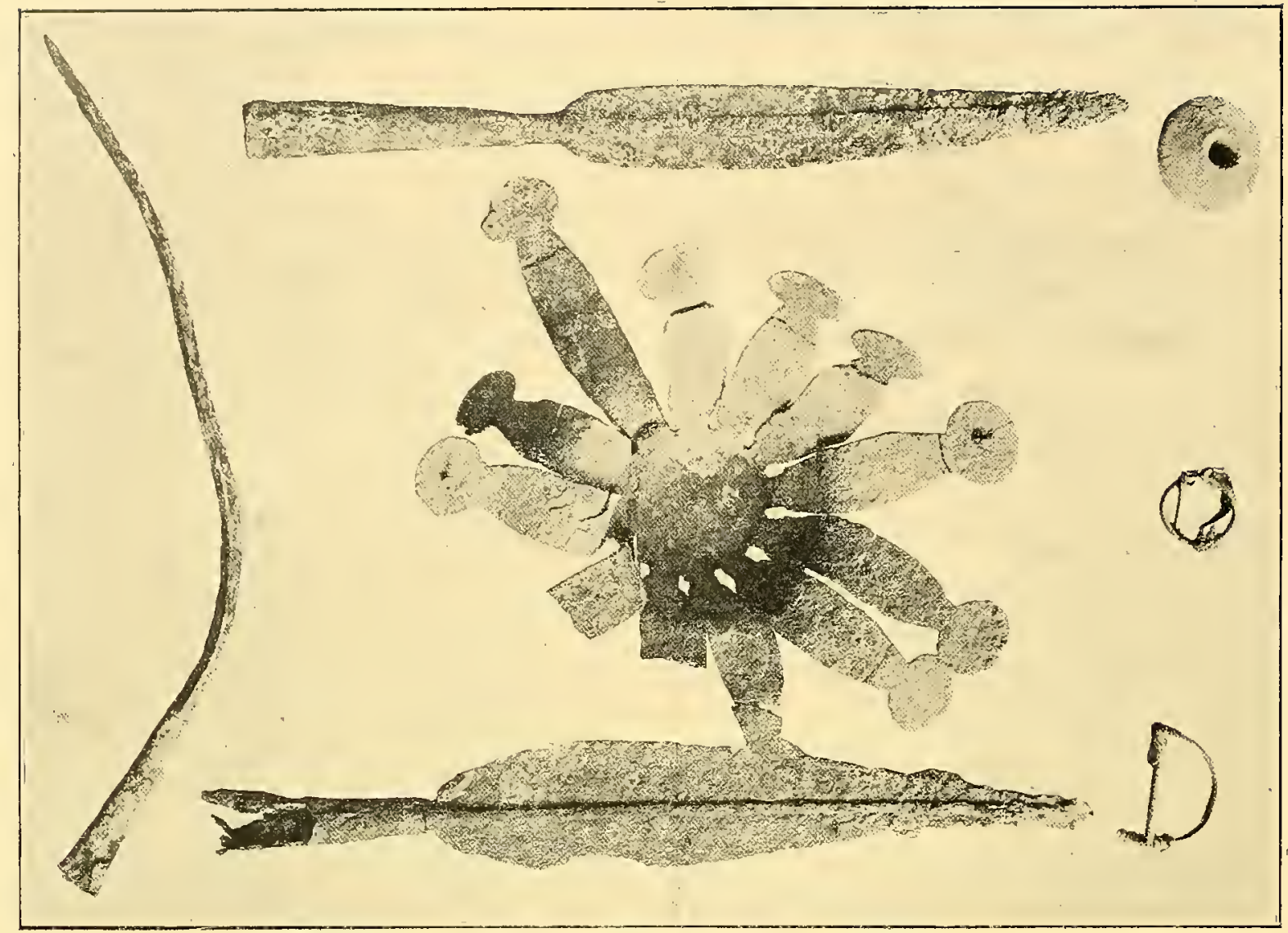

Nủm. 150

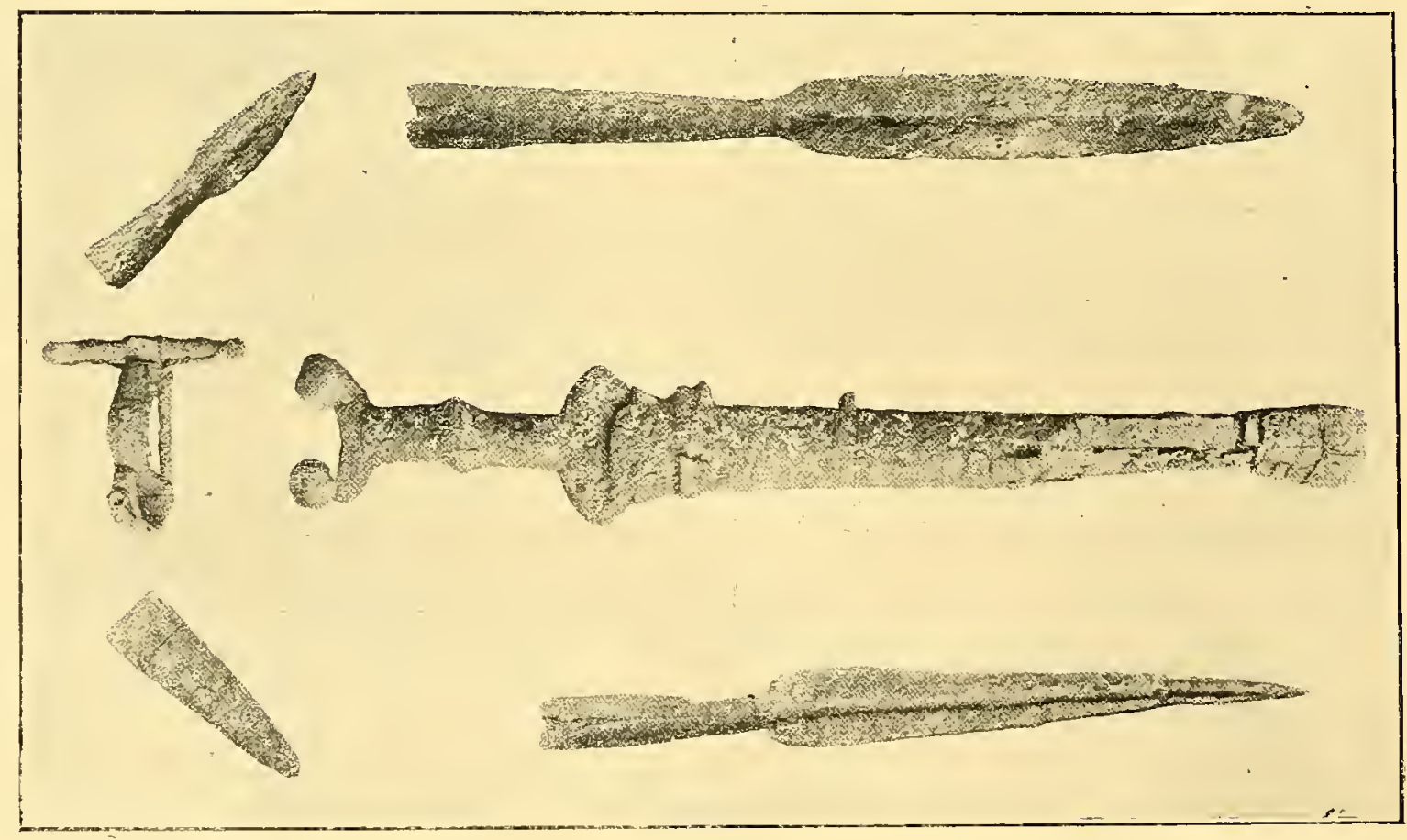

Nủm, 149. 
Procede de la Necrópolis de Quintanar de Gormaz.

Expositor: D. Ricardo Morenas de Tejada, su descubridor.

Núm. 152. - Sepultura de guerrero, compuesta de tres lanzas y un cuchillo, dos anillos de escudo y un filete de caballo, fíbula hispánica incompleta, broche de cinturón incompleto y una fusaiola de barro. Epoca de La Tène I.

Procede de la Necrópolis de Quintanar de Gormaz.

Expositor: D. Ricardo Morenas de Tejada, su descubridor.

Núm. 153.-Puñal con su vaina, verdadera obra de arte de incrustación prerromano. Este ejemplar, por la profusión de sus dibujos en plata y cobre

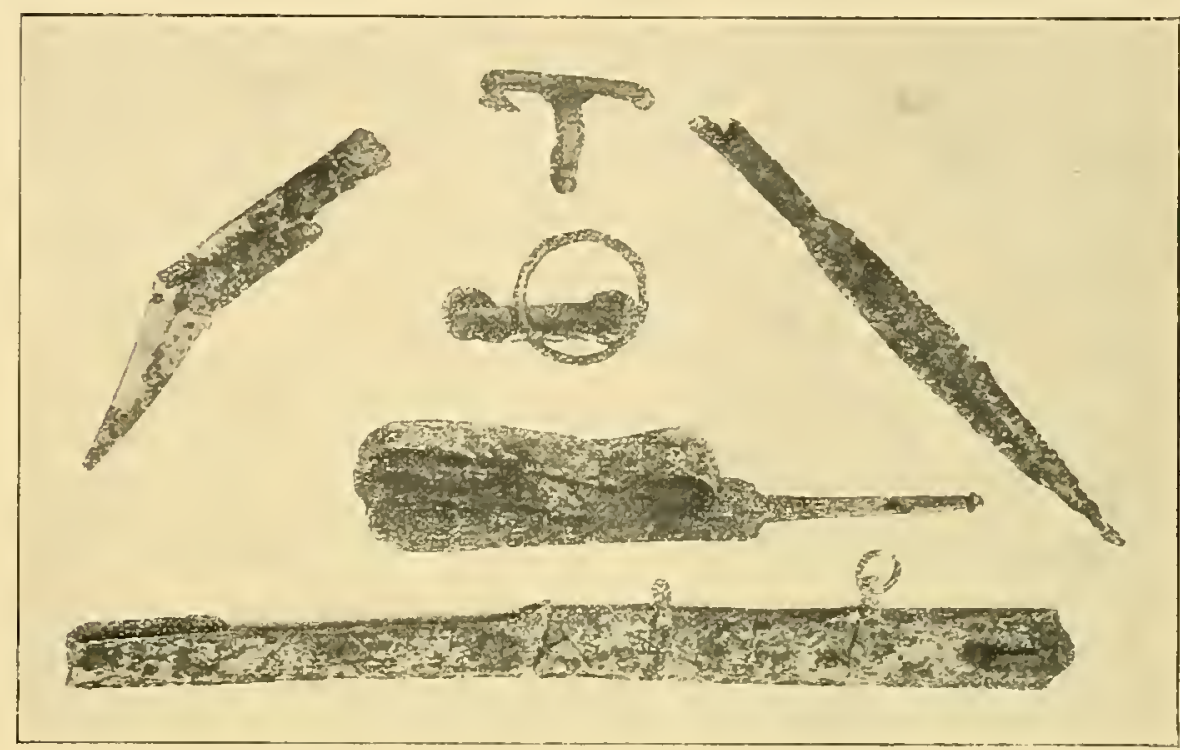

Nüm. 151. y por la variedad y composición de los mismos, es, sin duda alguna, el mejor modelo hoy día conocido en la orfebrería ibérica. Tiene, además, su pieza de hierro, que servía para suspenderlo del cinturón del guerrero. Epoca Halstatt Il. Procede de Monte Bernorio, Alar del Rey (Burgos).-Mide el puñal $36 \mathrm{~cm}$. y la pieza complementaria $20 \mathrm{~cm}$.

Expositor: Excmo. Sr. Marqués de Comillas.

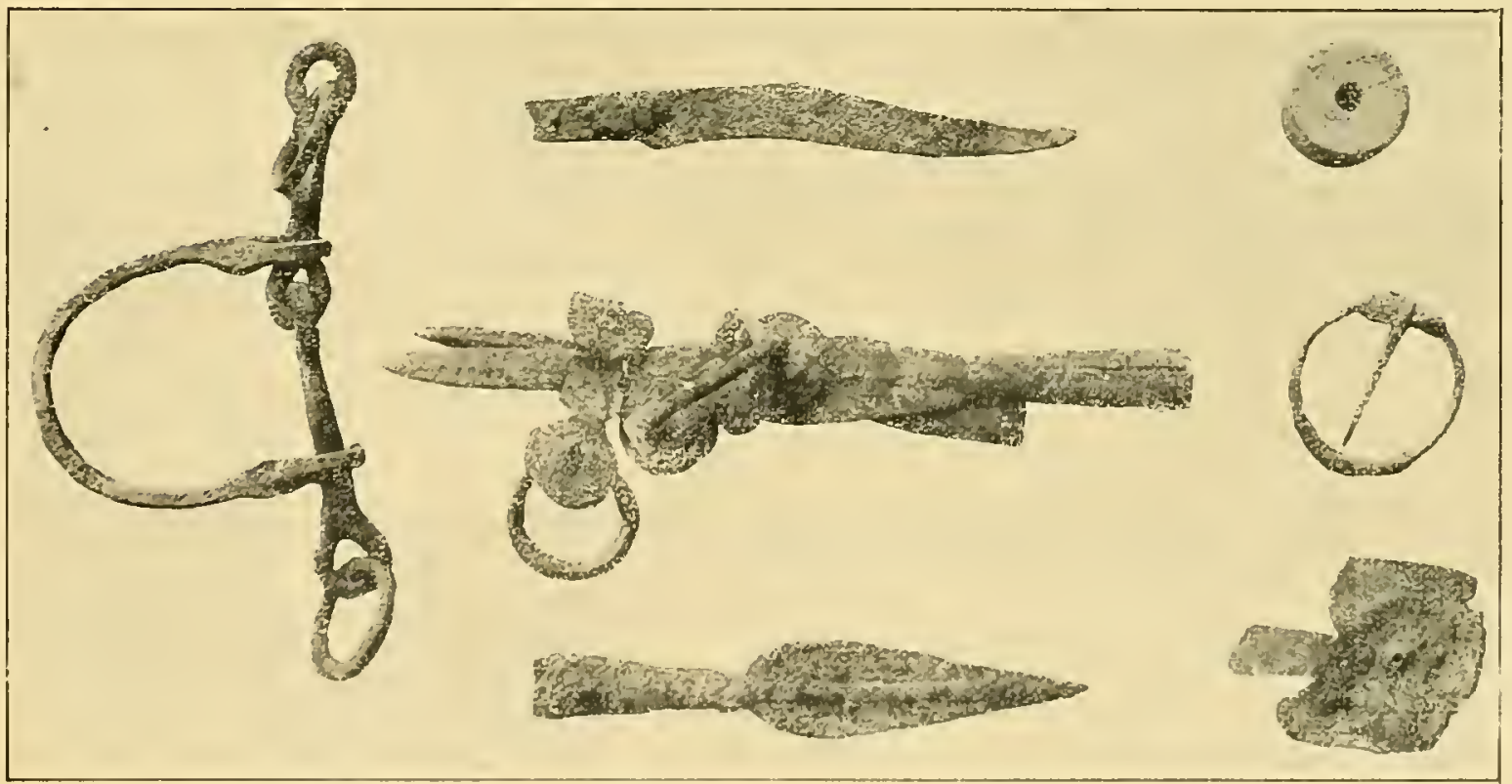

Nủm. 152. 


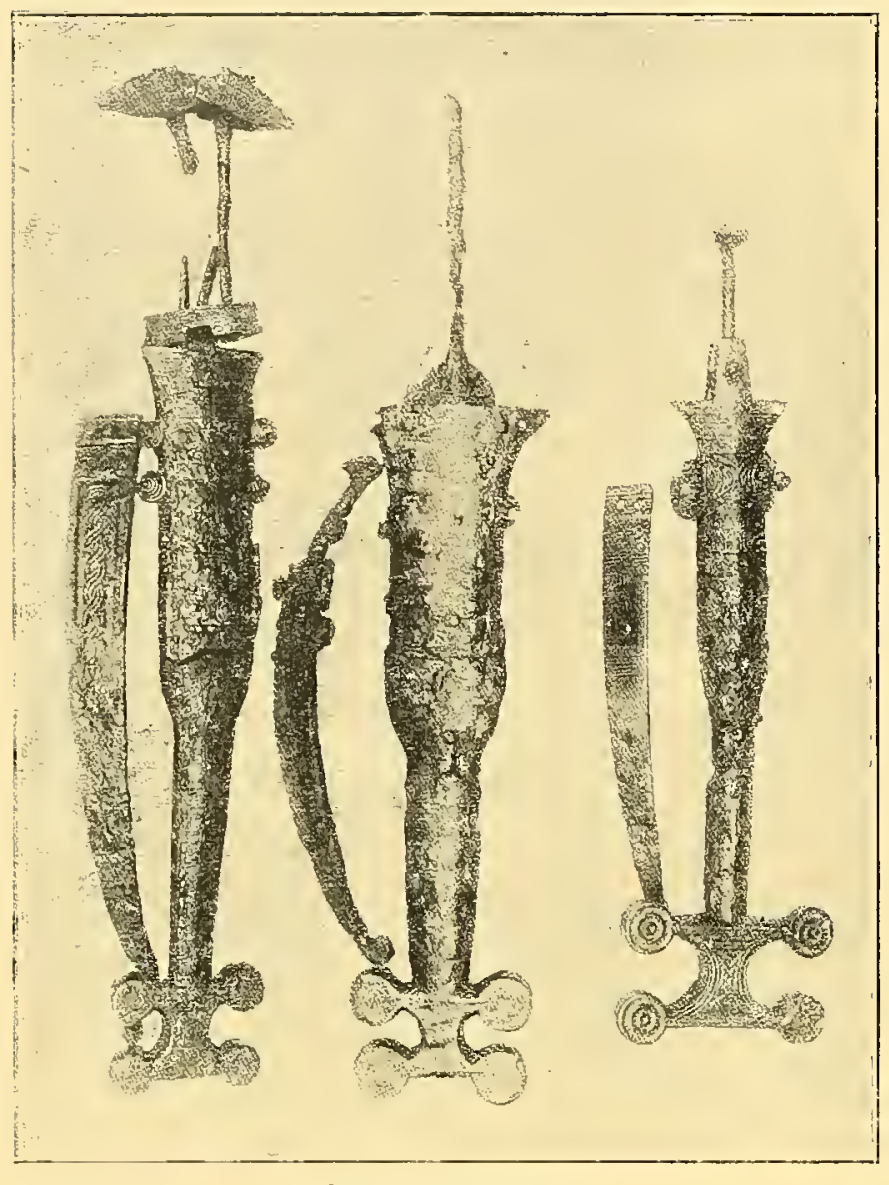

Núms. 154,153 y 155.

Expositor: Excmo. Sr. Marqués Comillas.

Núm. 156. - Puñal con su vaina muy cincelada y cuyas labores tal vez se incrustaron en cobre. Tiene su pieza complementaria de suspensión al cinturón. Epoca Hallstatt II.

Procede de Monte Bernorio, Alar del Rey (Burgos).-Longitud: $38 \mathrm{~cm}$.

Expositor: Excmo. Sr. Marqués de Comillas.

Núm. 157.-Puñal con su vaina muy cincelada y cuyas labores en plata y cobre también fueron incrustadas. Tiene su pieza complementaria de suspensión al cinturón. Epoca Hallstatt II.

Procede de Monte Bernorio, Alar del Rey (Burgos).-Longitud: $36 \mathrm{~cm}$.

Expositor: Excmo. Sr. Marqués de Comillas.
Núm. 154.-Puñal con su vaina, primorosamente incrustada en cobre. Este puñal, por sus cadenillas al dorso, por su pieza complementaria también grabada, por la serie de gemelos en la parte superior de la vaina y por la original y muy nueva forma de su empuñadura, se considera, así como el anterior ejemplar, como las piezas más interesantes en su género en la Península ibérica, teniendo que hacer presente además, que semejantes a ambas'no se han hallado fuera de España. Epoca Hallstatt II.

Procede de Monte Bernorio, Alar del Rey (Burgos).-Mide $35 \mathrm{~cm}$. y la pieza del cinturón $23 \mathrm{~cm}$.

\section{Expositor: Excmo. Sr. Marqués de Comillas.}

Núm. 155.-Puñal con su vaina muy cincelada y cuyas labores tal vez se incrustaron en cobre. Tiene la pieza complementaria de su suspensión al cinturón. Epoca Hallstatt II.

Procede de Monte Bernorio, Alar del Rey (Burgos).-Longitud: $28 \mathrm{~cm}$.

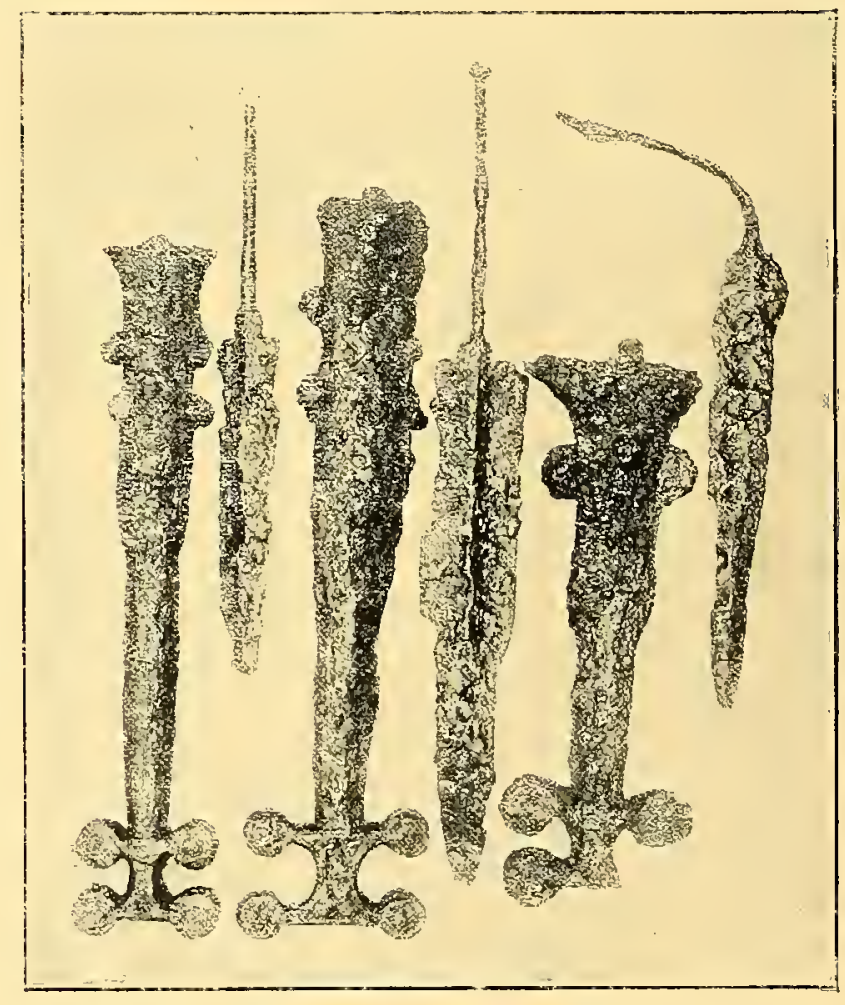

Núms. 158, 159 y 60. 
Núm. 158.-Puñal con su vaina cincelada, pero en mal estado de conservación. Epoca Hallstatt II.

Procede de Monte Bernorio, Alar del Rey (Burgos). - Longitud: $39 \mathrm{~cm}$.

Expositor: Excmo. Sr. Marqués de Comillas.

Núm. 159.--Puñal con su vaina cincelada, pero en mal estado de conservación. Epoca Hallstatt II.

Procede de Monte Bernorio, Alar del Rey (Burgos).-_Longitud: $28 \mathrm{~cm}$.

ExPositor: Excmo. señor Marqués de Comillas.

Núm. 160.-Puñal con su vaina de la misma forma de los siete anteriores. Epoca Hallstatt II.

Procede de Monte Bernorio, Alar del Rey (Burgos). - L Longitud: $32 \mathrm{~cm}$.

Expositor: Excmo. señor Marqués de Comillas.

Núm. 161.-Puñal con su vaina. Este ejemplar y los dos siguientes es contemporáneo a todos los anteriores descriptos del Monte Bernorio, aunque la contera de la vaina difiere esencialmente de estas últimas y recuerda a la de algunos puñales y espadas contemporáneas del resto de España. Epoca de Hallstatt II.

Procede de Monte Bernorio, Alar del Rey (Burgos). - Longitud: $34 \mathrm{~cm}$.

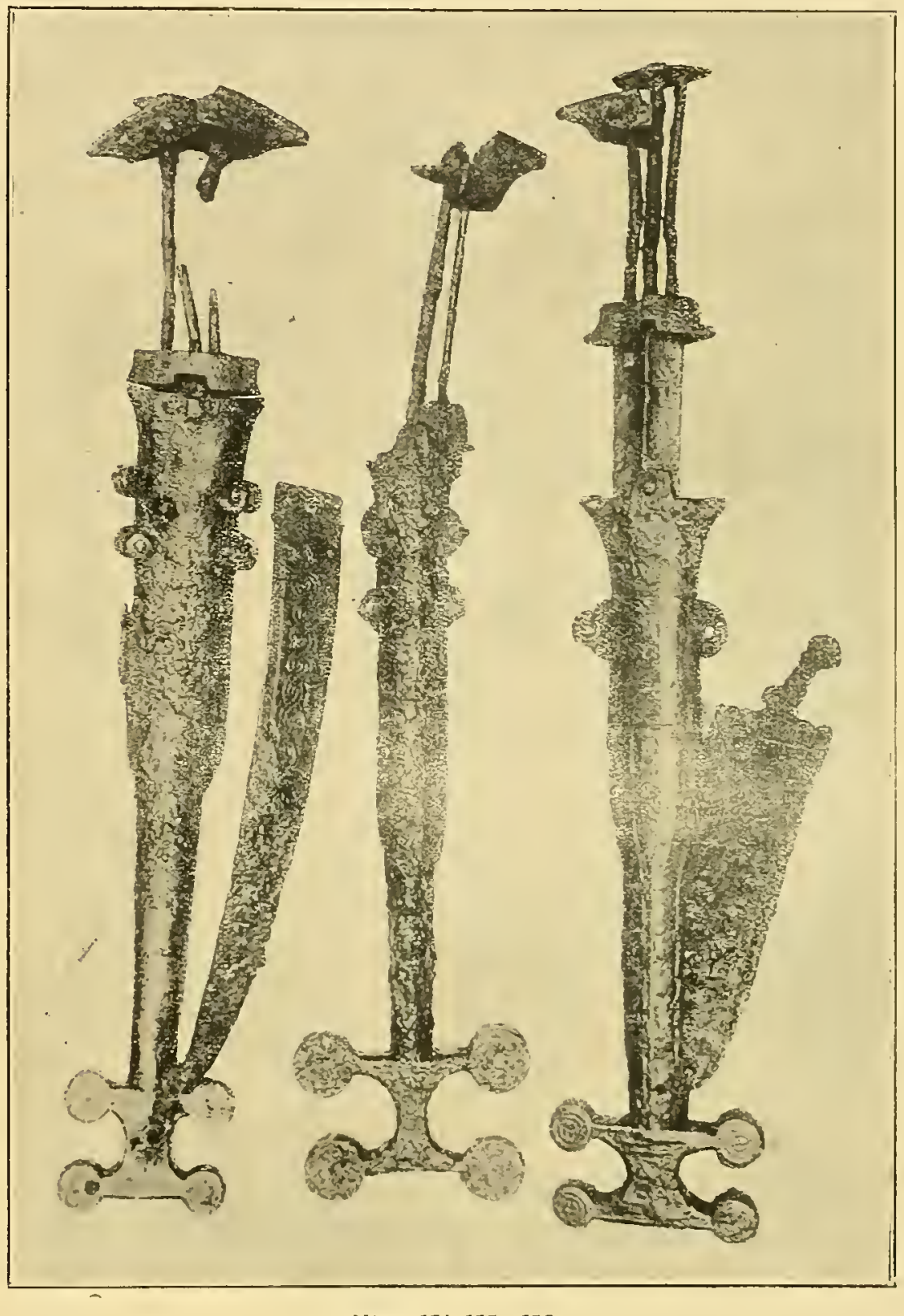

Nüms. 154, 157 y 156.

Expositor: Excmo. Sr. Marqués de Comillas.

Núm. 162.-Puñal con su vaina. Las dos piezas separadas una de otra miden respectivamente 25 y $31 \mathrm{~cm}$. Epoca de Hallstatt II.

Procede de Monte Bernorio, Alar del Rey (Burgos).

Expositor: Excmo. Sr. Marqués de Comillas. 
Núm. 163.-Puñal con su vaina. Epoca Hallstatt II.

Procede de Monte Bernorio, Alar del Rey (Burgos). - Longitud $29 \mathrm{~cm}$.

Expositor: Excmo. Sr. Marqués de Comillas.

Núm. 164.-Cuatro omphalos o centros de escudos redondos de guerreros prerromanos. Por su forma cónica truncada son ejemplares todos ellos mưy diferentes de los conocidos hasta la fecha en la Península Ibérica. Epoca Hallstatt II.

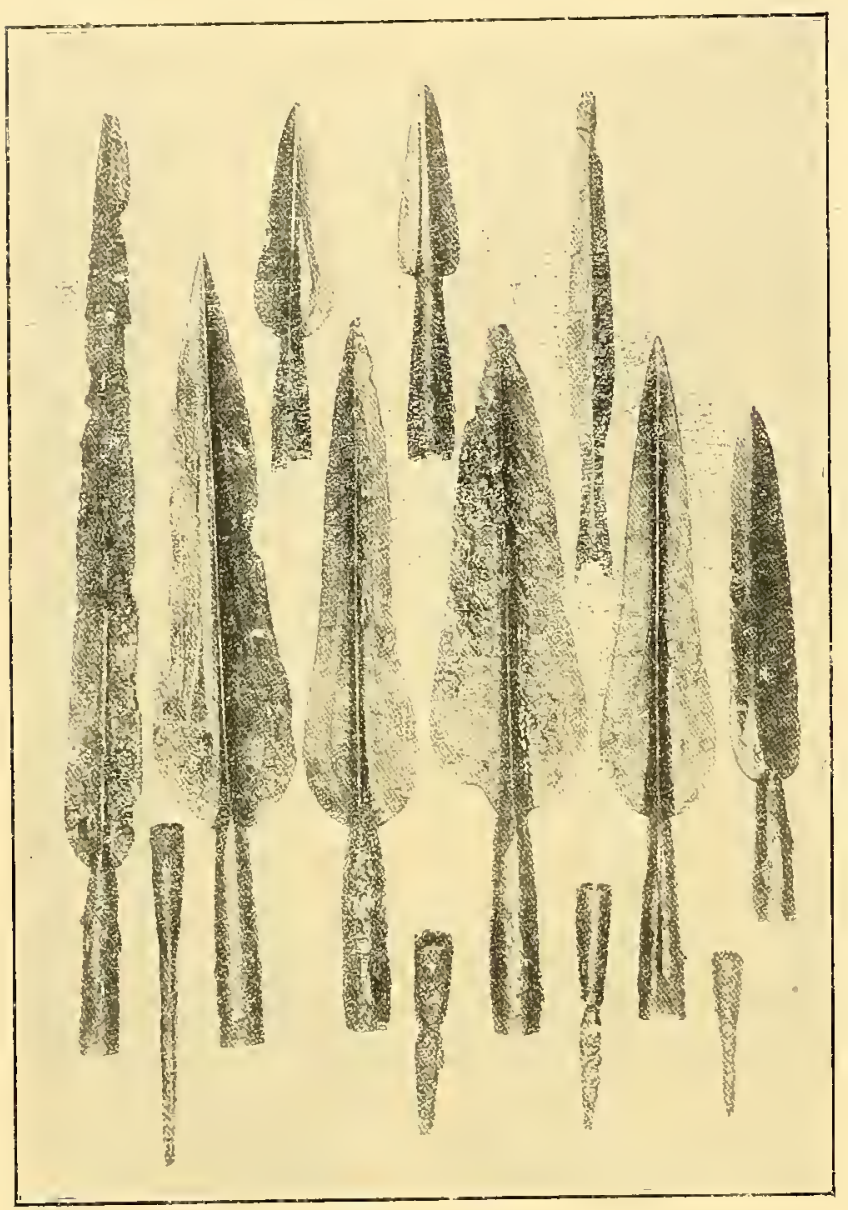

Núm. 165.

Procede de Monte Bernorio, Alar del Rey (Burgos).-Longitud: 12 y $11 \mathrm{~cm}$.

Expositor: Excmo. Sr. Marqués de Comillas.

Núm. 165.-Diez y seis lanzas y cuatro regatones de lanza de varios tamaños, las cuales oscilan entre 34 y 11 y 13 y $6 \mathrm{~cm}$. respectivamente. A juzgar por la forma especial de la mayoría de las lanzas, muy anchas en el arranque de la hoja y estrechas en el centro, por la delgadez de las hojas y por su nervio central muy pronunciado, así como por la serie simétrica de estrías que ornamentan ambas caras de la hoja, pueden considerarse estos ejemplares como producto de una industria muy primitiva, pues recuerdan a ciertos modelos de la época anterior del bronce. Epoca de Hallstatt II.

Procede de Monte Bernorio, Alar del Rey (Burgos).

Expositor: Excmo. Sr. Marqués de Comillas.

Núm. 166. - Cinco fragmentos de piezas complementarias de puñales, dos fusayolas de barro y serie de objetos de bronce y oro que se exponen como documentos de clasificación de todos los anteriores puñales y lanzas del Monte Bernorio, por encontrarse unos y otros objetos conjuntamente. Entre los objetos de cobre, son muy determinativos de la época Hallstatt II las cinco fíbulas, cuyo tipo se encuentra por toda España y Europa: a la vez son muy clasificadores los dos fragmentos de broche de cinturón, de un modelo que sólo es peculiar de la región de Burgos y limítrofes, así como las cuatro fíbulas hispánicas, entre las cuales una de ellas es muy singular, por tener el muelle de la aguja a medias simulado, lo cual moderniza bastante este tipo de imperdibles, y por lo tanto, los objetos que con ellos se encontraron. Entre los restantes objetos de cobre llaman la atención los tres fragmentos de fíbula de forma de caballo y una esquemática cabeza de toro con su enchufe, que por su tamaño tal vez tenga carácter sagrado, un informe fragmento, que por su forma recuerda, 


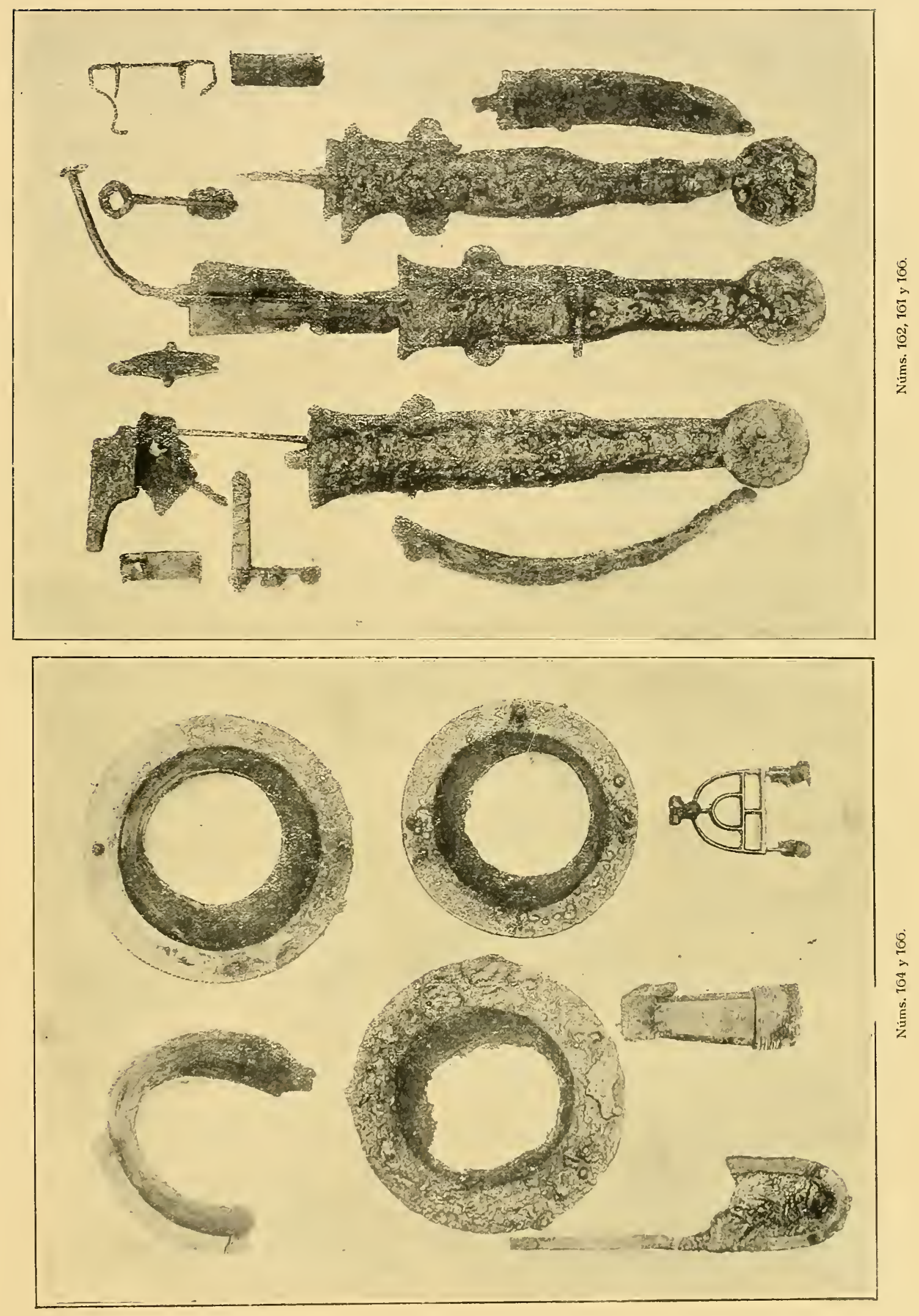


en cierto modo, a una especie de cetro que descubrió el Sr. Cabré en el Valle Bureba, en Miraveche, y por último varias terminaciones de vainas, de puñales o espadas, una de ellas muy curiosa por sus esmaltes.

Expositor: Excmo. Sr. Marqués de Comillas.

Núm. 167.- Una espada de antenas de $30 \mathrm{~cm}$. de longitud y análoga a las descritas del Excmo. Sr. Marqués de Cerralbo. Epoca de Hallstatt.

Expositor: D. José María Florit.

Núm. 168.-Hoja de lanza de $26 \mathrm{~cm}$. de longitud, perteneciente a la época de Hallstat, análoga a las descritas.

Expositor: D. José María Florit.

Núm. 169.-Puñal de hierro ibérico de la época de La Tène I y de $24 \mathrm{~cm}$. de longitud, análogo a los descritos del Excmo. Sr. Marqués de Cerralbo.

Expositor: D. José María Florit.

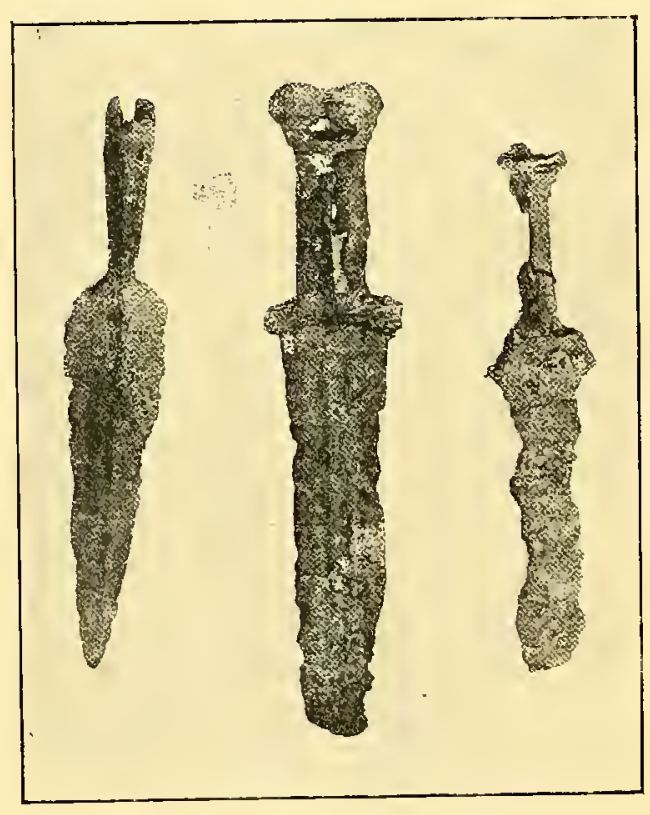

Núms. 168, 167 Y 169. 


\section{El trabajo del hierro en los tiempos históricos}

\section{La época romana}

Núm. 170.-Cinco tenazas de 29 a $47 \mathrm{~cm}$. de longitud. Procede la más pequeña de una mina de Plasenzuela (Cáceres) y las otras de Purullena (Granada), siendo la primera donación de los Sres. Garay al Museo Arqueológico Nacional y las cuatro últimas corresponden a la colección Góngora, en el mismo Museo. Epoca ibérica o romana.

Expositor: Museo Arqueológico Nacional.

Núm. 171.-Tres llaves de la época romana, de 24, 22 y $16 \mathrm{~cm}$. de longitud; la primera, que procede de Espejo, fué donada al Museo Arqueológico por el Ministerio de la Guerra, y las dos últimas pertenecieron a la colección del Gabinete de Ciencias Naturales, figurando en la actualidad en la colección del Museo.
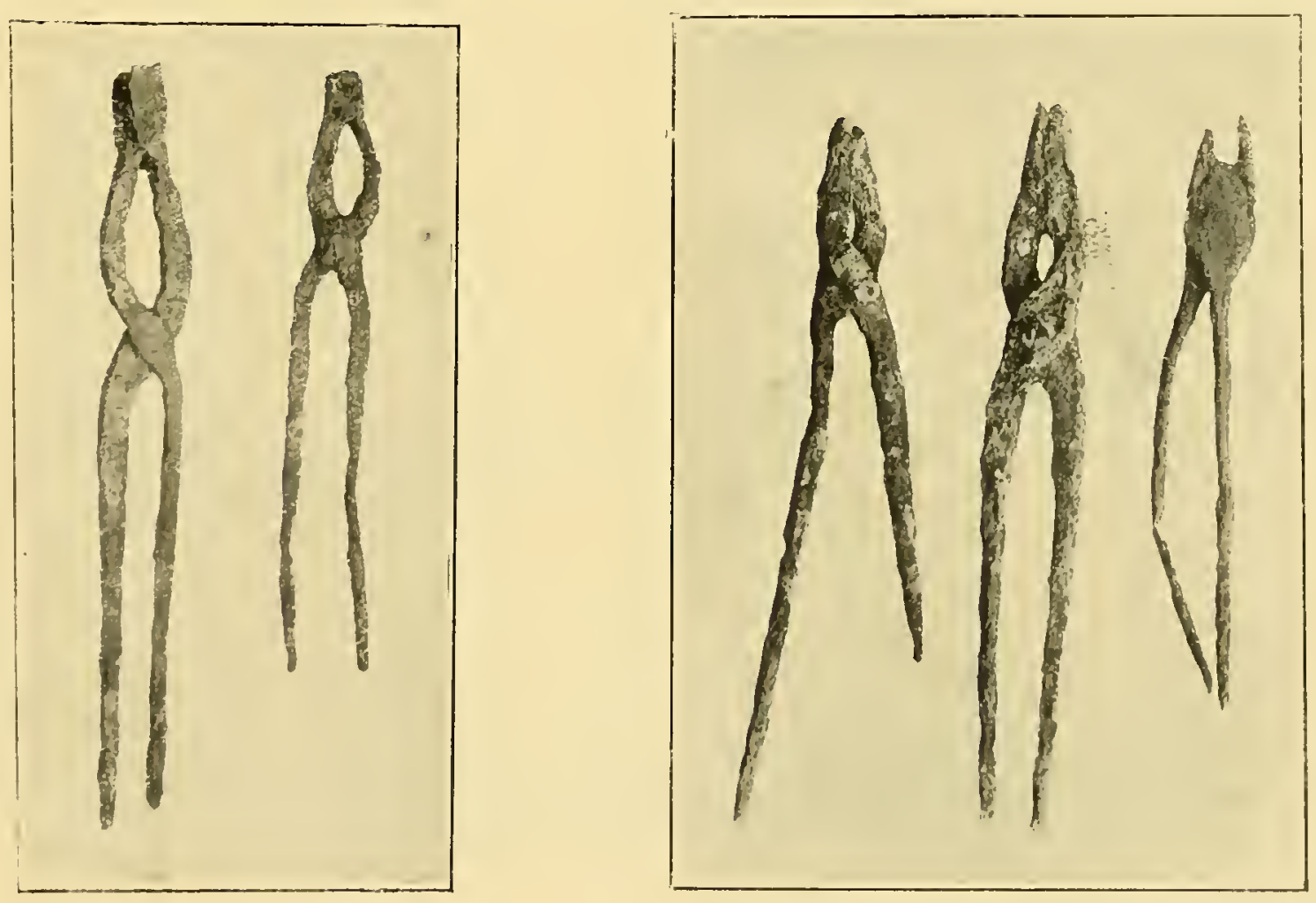


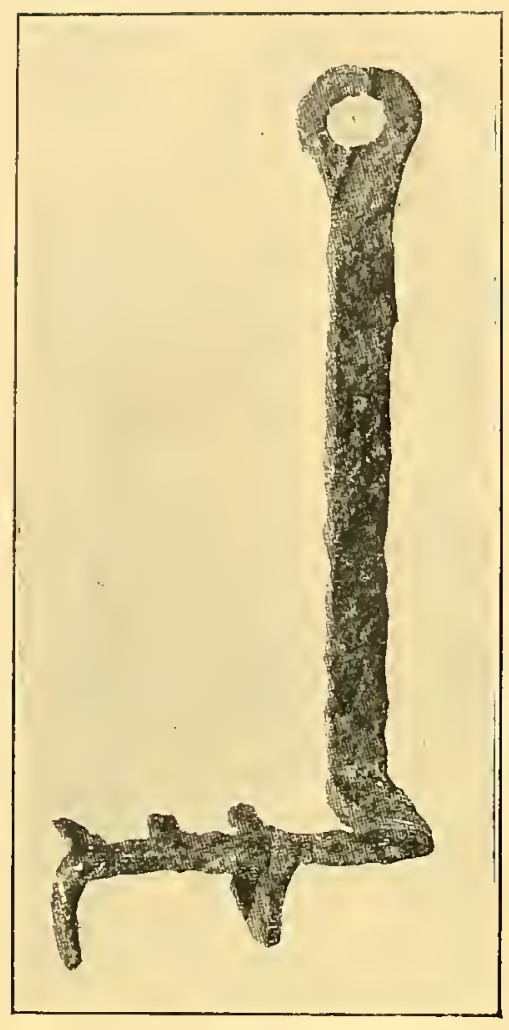

Num. 171.

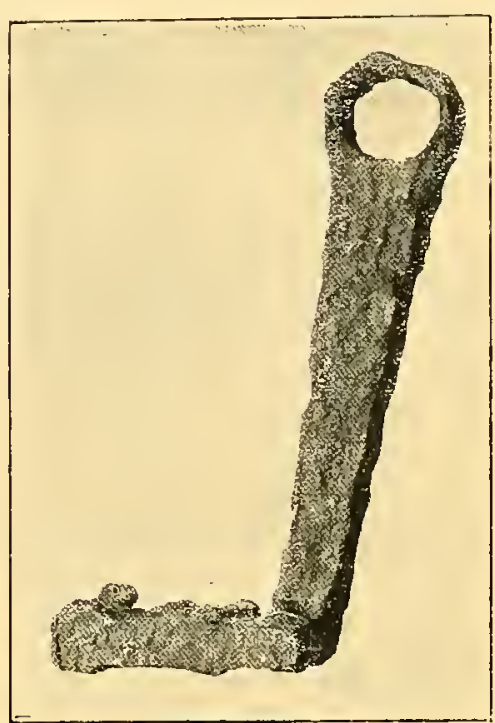

Núm, 171

Constituyen tipos absolutamente clásicos dentro de la tecnología de la época.

Expositor: Museo Arqueológico Nacional.

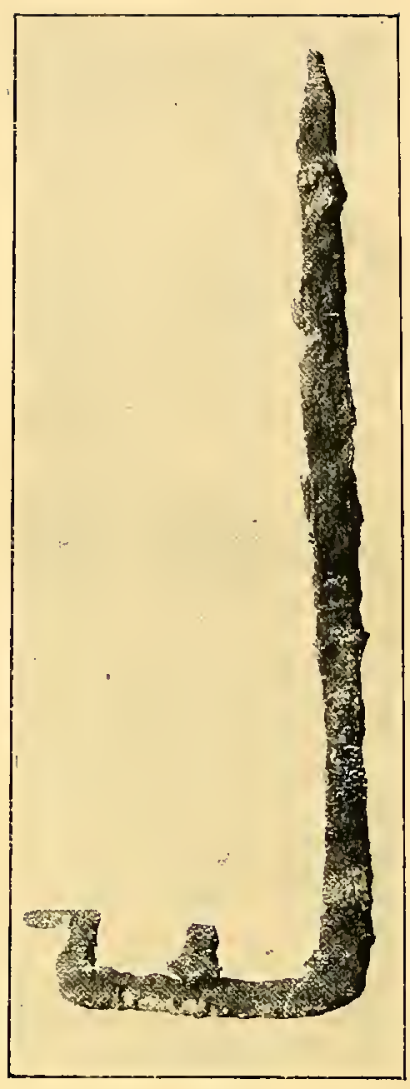

Nưum. 171.

Núm. 172.-Dos hojas de sierra de 71 y $64 \mathrm{~cm}$.

Proceden de Espejo, en la provincia de Córdoba, y fueron donación del Ministerio de la Guerra.

Expositor: Museo Arqueológico Nacional.

Núm. 173.--Pieza de uso desconocido, compuesta por dos eslabones articulados, en

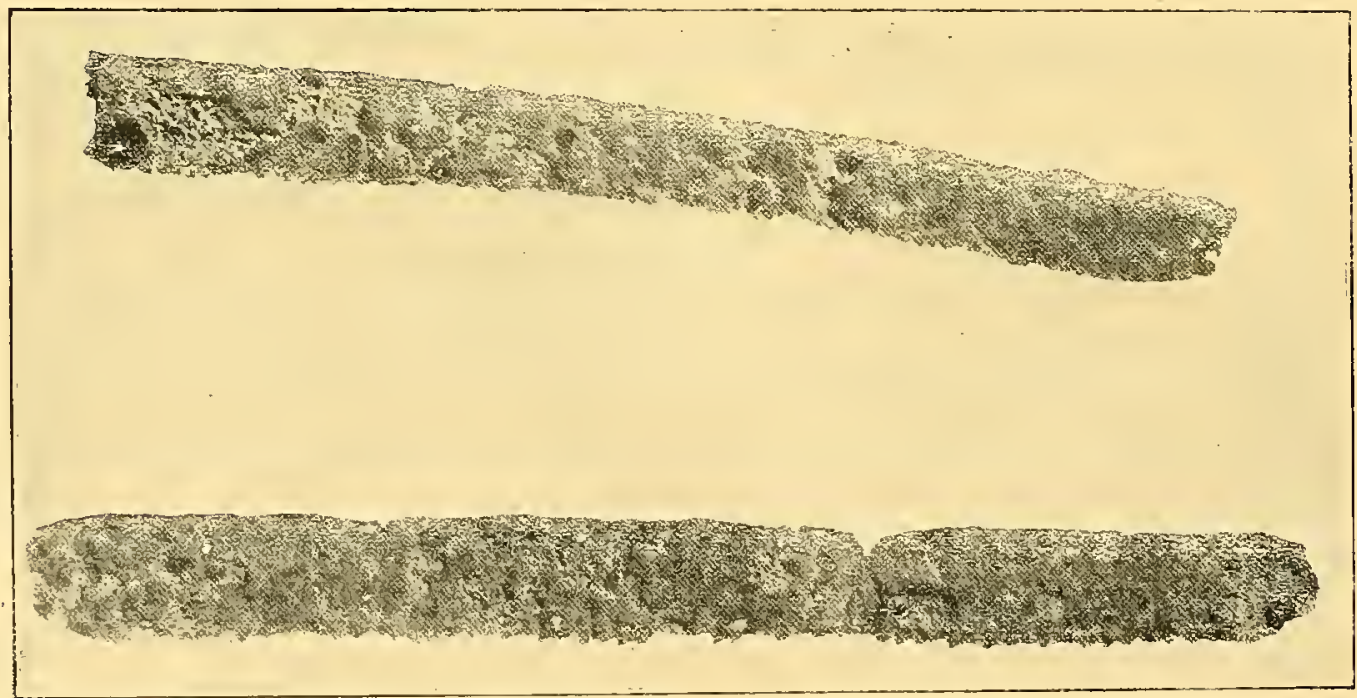


cuyos extremos hay dos grandes anillas. Su aspecto es el de un gran bocado, pero su tamaño hace más bien pensar que pudo utilizarse como grillete.

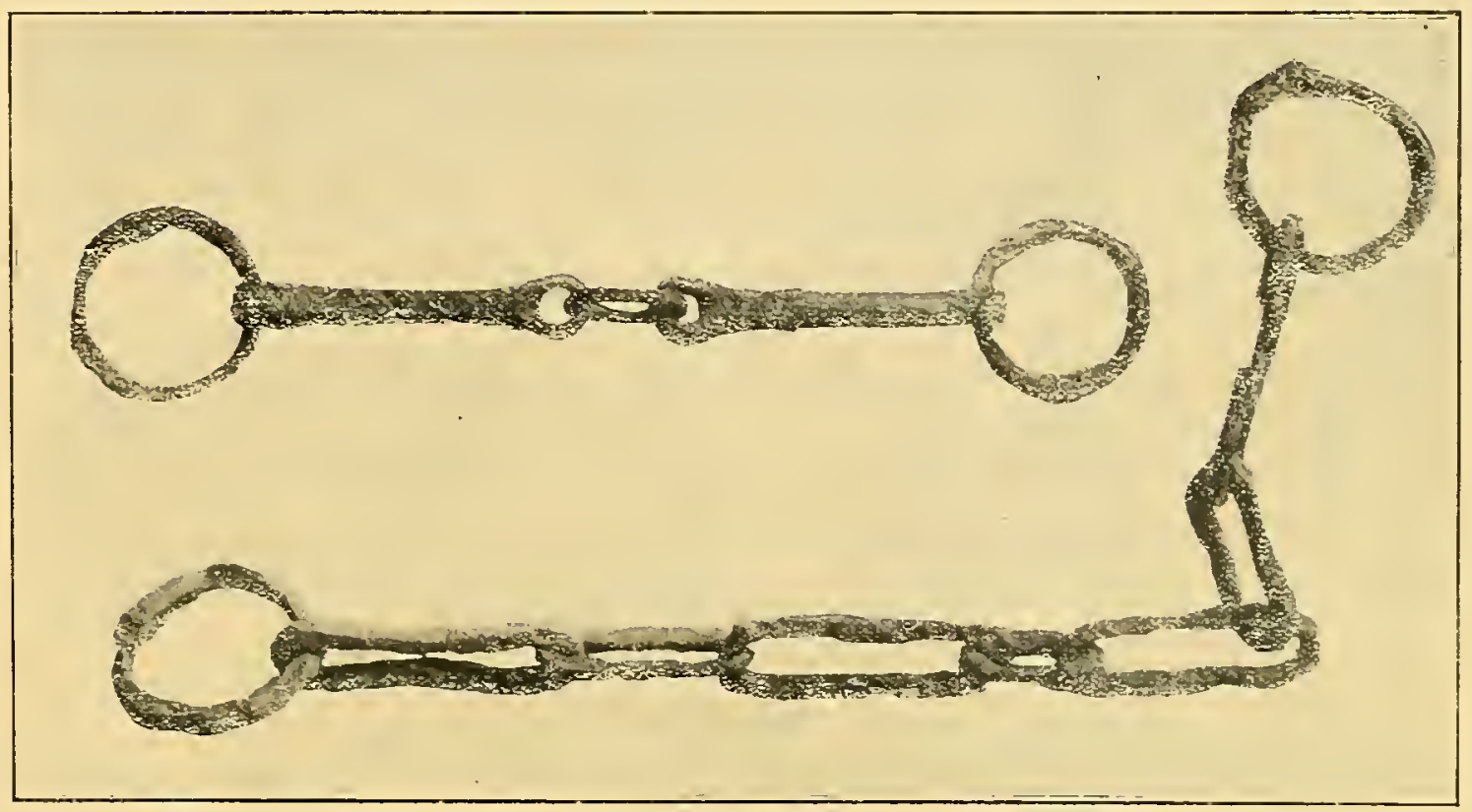

Núms. 173 y 174 .

Procedencia desconocida.-Longitud total: $58 \mathrm{~cm}$.

Exposiror: Museo Arqueológico Nacional.

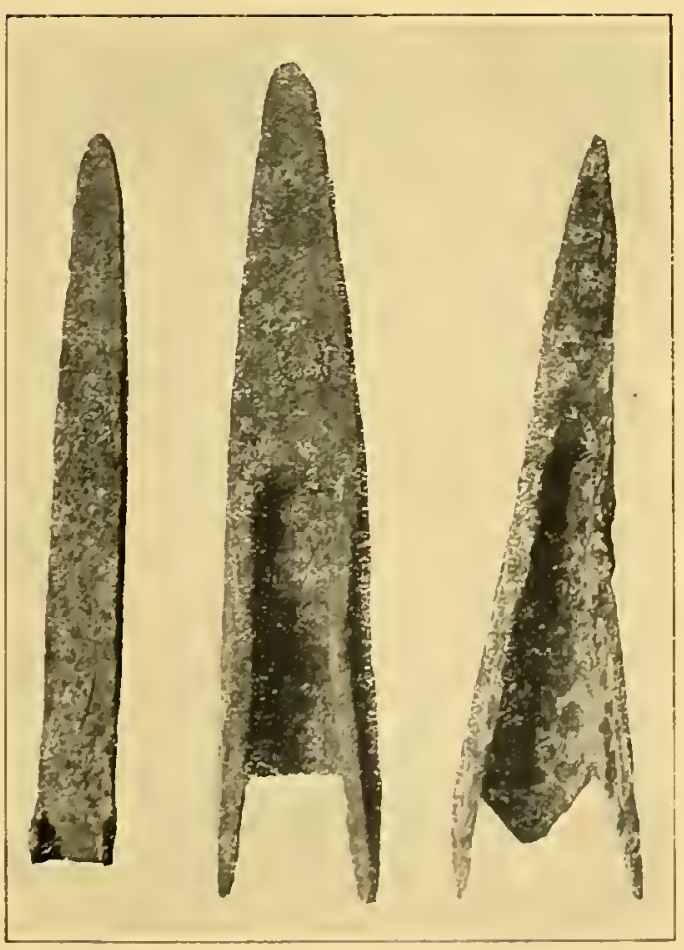

Nủm. 175

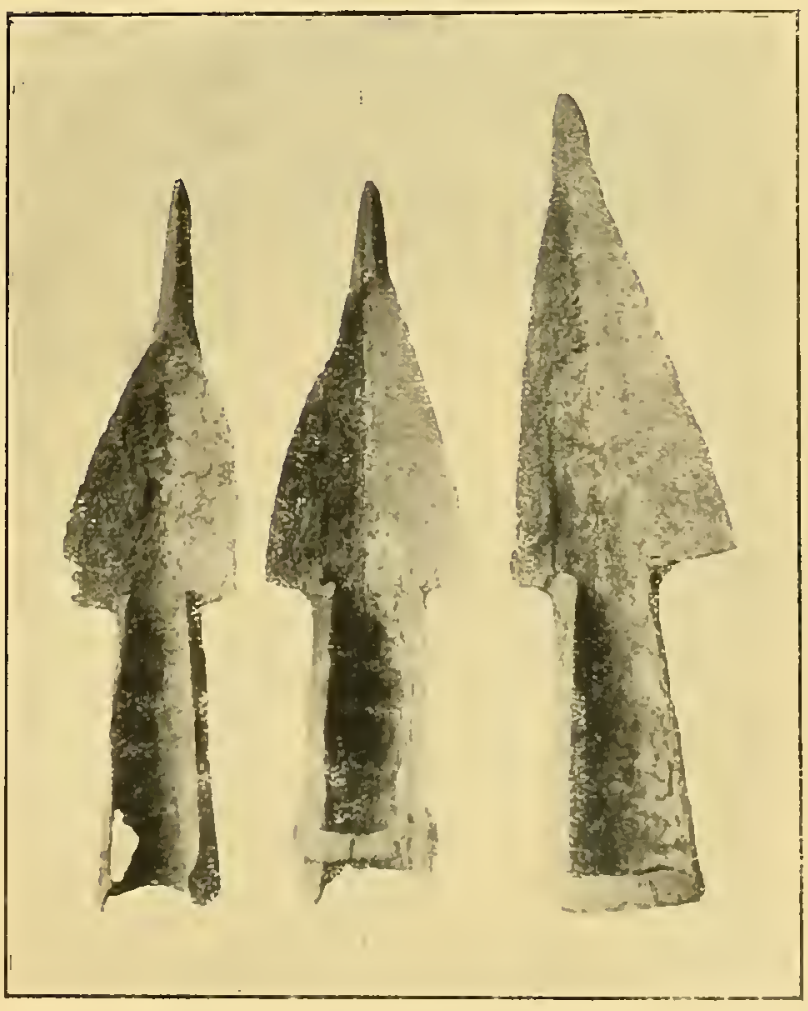

Nüm, 175. 


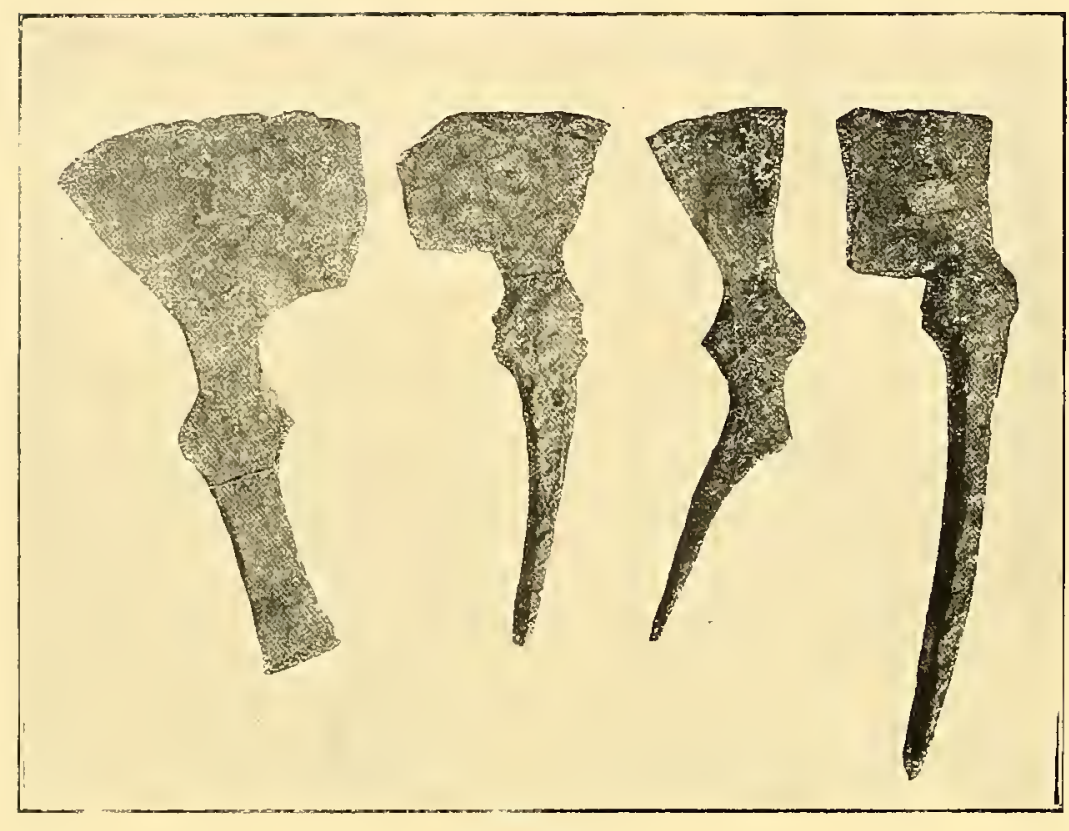

Núm. 176.

Núm. 174. - Gruesa cadena formada por tres eslabones alargados, unidos por uno circular y terminada por dos anillos abiertos que se cierran o pueden cerrarse por un perno. Su longitud es de $98 \mathrm{~cm}$.

Se encontró en una mina de cobre de la provincia de Huelva, junto a un esqueleto humano, y la disposición de los anillos extremos, análoga a la de la pieza anterior, hace pensar que fuera utilizada como grillete.

Expositor: Museo Arqueológico Nacional.

Núm. 175. - Ocho rejas de arado, marcando la evolución desde los tipos ibéricos hasta el final de la época romana.

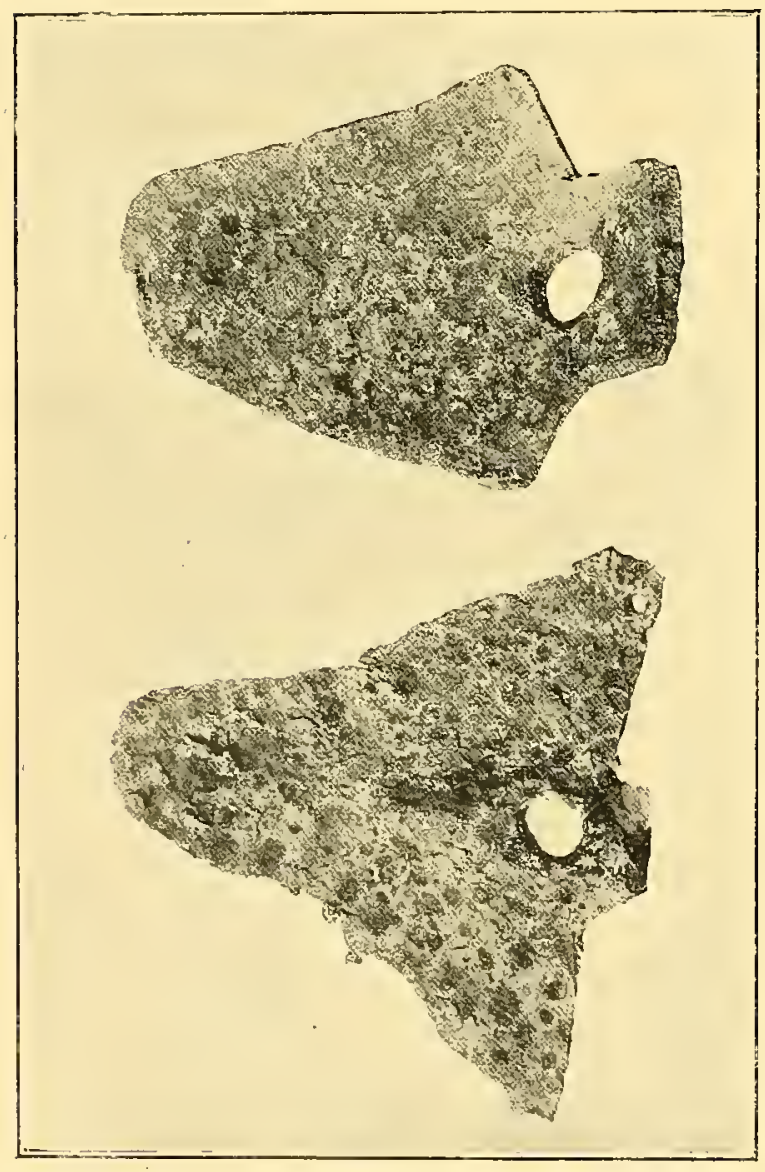

Núrn. 177.
Procedencias diversas. Miden 27 a $57 \mathrm{~cm}$. de longitud.

Expositor: Museo Arqueológico Nacional.

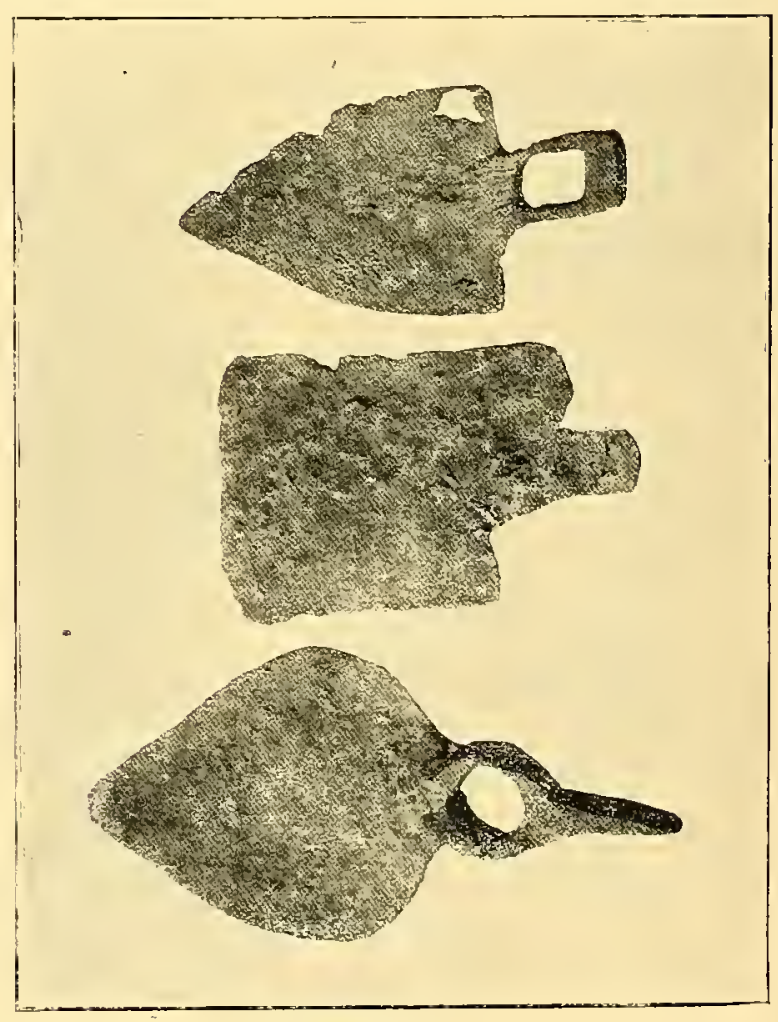

Núrn. 177. 
Núm. 176. - Hacha y pico. Cuatro ejemplares de 22 a $27 \mathrm{~cm}$. Epoca romana.

Procedentes de la colección Miró.

Expositor: Museo Arqueológico Nacional.

Núm. 177. - Cinco azadas procedentes de Lancia, en León; de Espejo, en Córdoba, y de la mina Plasenzuela, en Cáceres. Constituyen los distintos tipos usados durante la época romana.

Expositor: Museo Arqueológico Nacional.

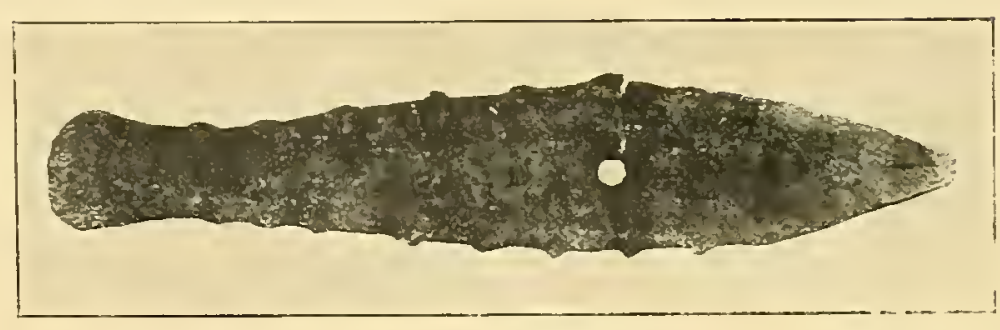

Núm. 178

Núm. 178. -Figura de pez en hierro dulce de $16,7 \mathrm{~cm}$. por 2,5 , usado como amuleto romano-cristiano para llevarlo suspendido de la perforación que tiene en su centro. Siglos iv al v.

Expositor: Museo Arqueológico Nacional.

Núms. 179 a 181.- Material para la fabricación de monedas en la época romana. Expositor: D. Faustino Díaz de Rada.

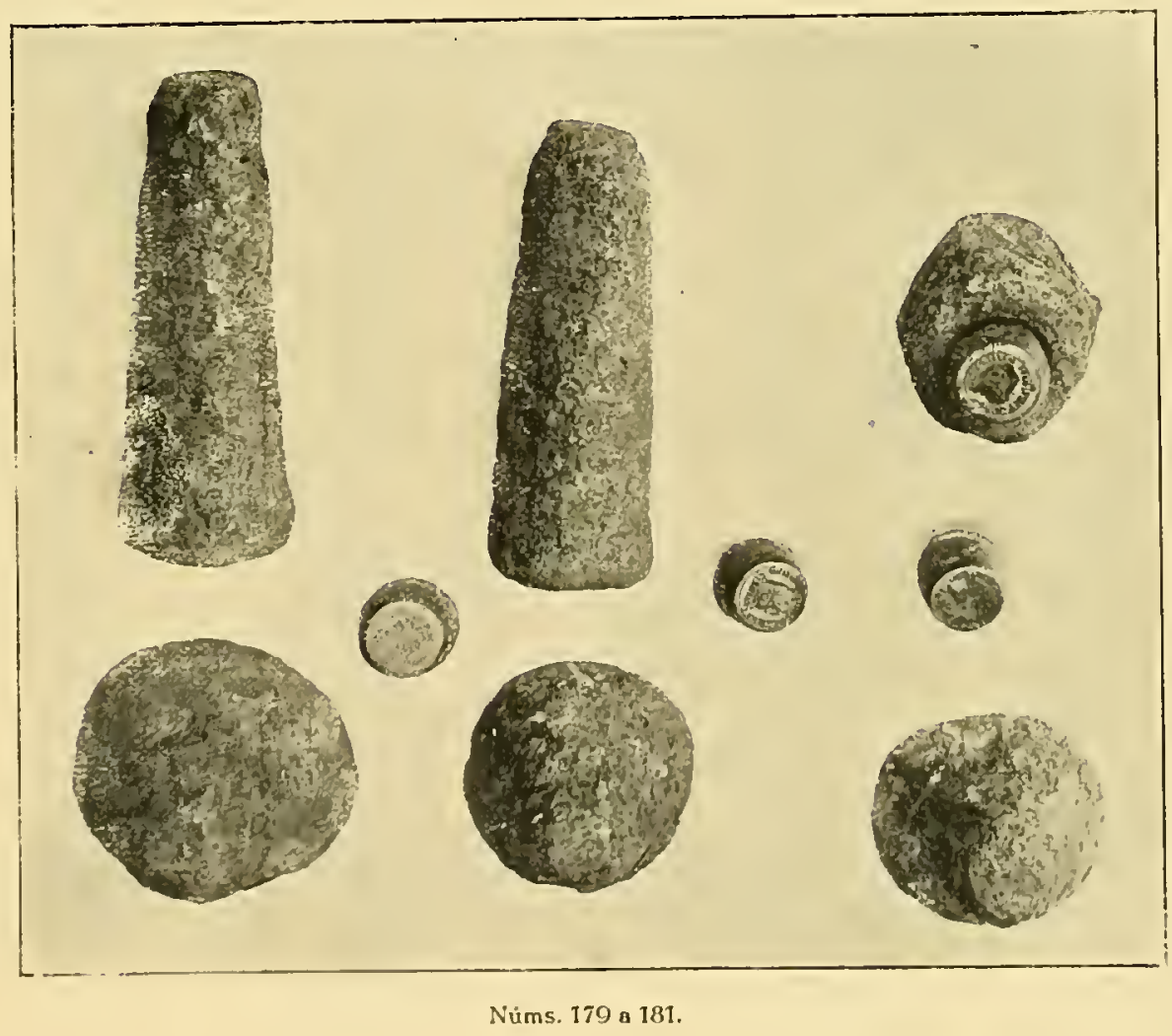




\section{Epoca visigoda}

Núms. 143 y 144. -Doble hoz y espuela visigótica (véase en el lugar correspondiente y la figura de la página 17 ).

Núm. 182. -Freno o bocado labrado toscamente en hierro dulce, asemejándose al fre-

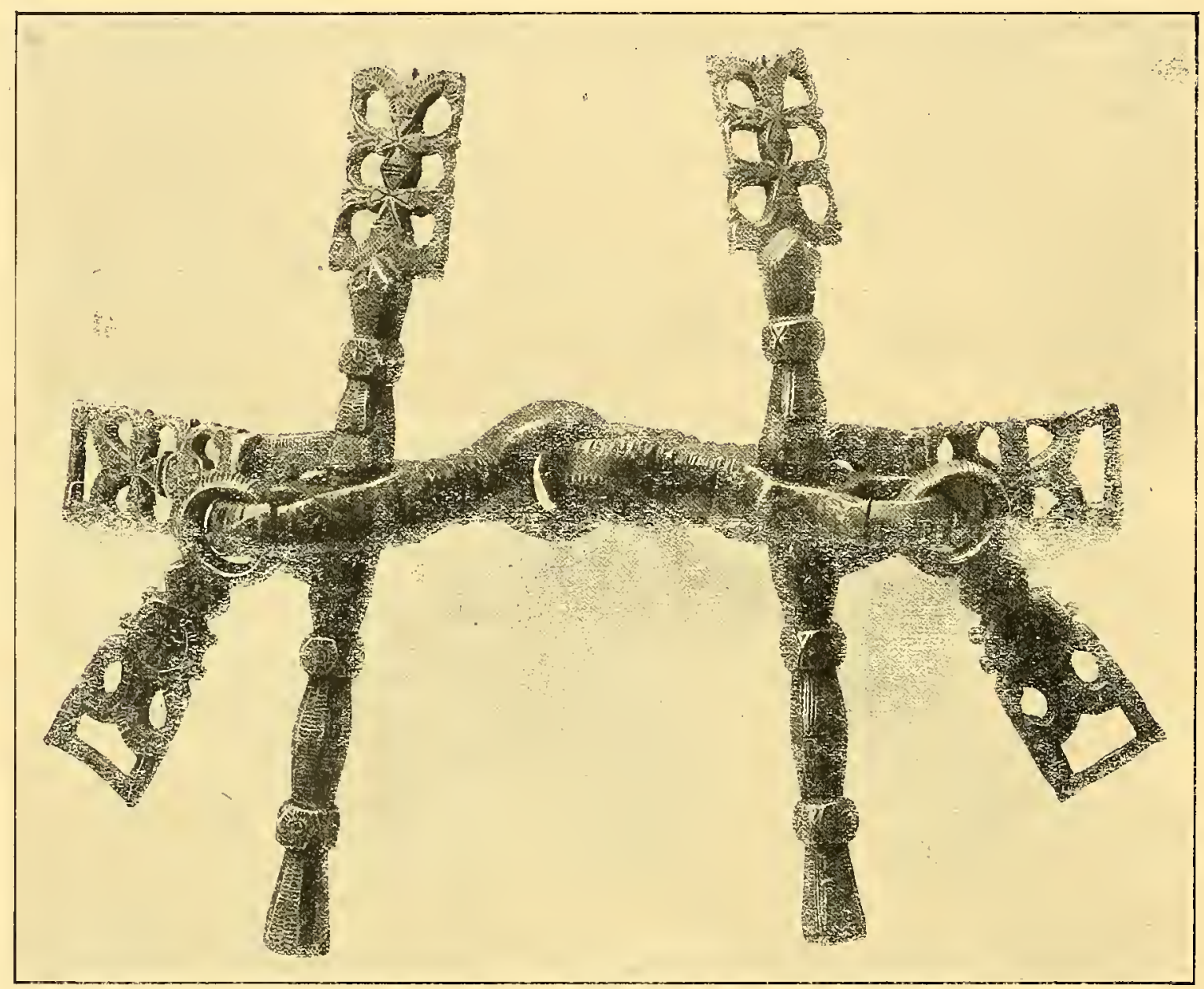

Núm. 182.

no romano, con dos cañones movibles en la embocadura y largas camas en vez de argollas; todo él trabajado en hierro con incrustaciones de plata, siguiendo el mismo gusto de los obietos escandinavos de los siglos vi al vill. Los monogramas cruciformes que aparecen en el citado freno han dado lugar a interpretaciones según las cuales pudo haber pertenecido el freno al caballo de Witiza.

Desde los años 570 a 711 , y cuando en las monedas, además del nombre del monarca 
reinante, se colocó en el reverso el nombre del príncipe heredero, la ceca o localidad donde la acuñación se verificaba solía indicarse por monogramas dispuestos en igual forma a como aparecen en este ejemplar.

Según opinión de algunos arqueólogos, esta pieza debe pertenecer a los finales del siglo xil o principios del xiI. Esta opinión resulta mucho menos documentada que la precedentemente expuesta.

Dimensiones entre ejes de camas, $13 \mathrm{~cm}$.; altura de las mismas, 23; piezas laterales soldadas a ellas perpendicularmente, 9; piezas adicionales, $8 \mathrm{~cm}$.

\section{Expositor: Real Armería.}

Núm. 183.-Bocado visigodo. Disposición idéntica a la anterior. Estado de conservación menos perfecto, impidiendo apreciar exactamente los motivos ornamentales formados por las incrustaciones que, como en el ejemplar anterior, decoran la totalidad de su superficie.

Epoca igual que el ejemplar anterior; seguramente visigodo.

\section{Expositor: D. Félix Rodríguez Rojas.}

Núm. 184.-Bocado de hierro con incrustaciones de plata y oro. Tipo distinto a los pre-

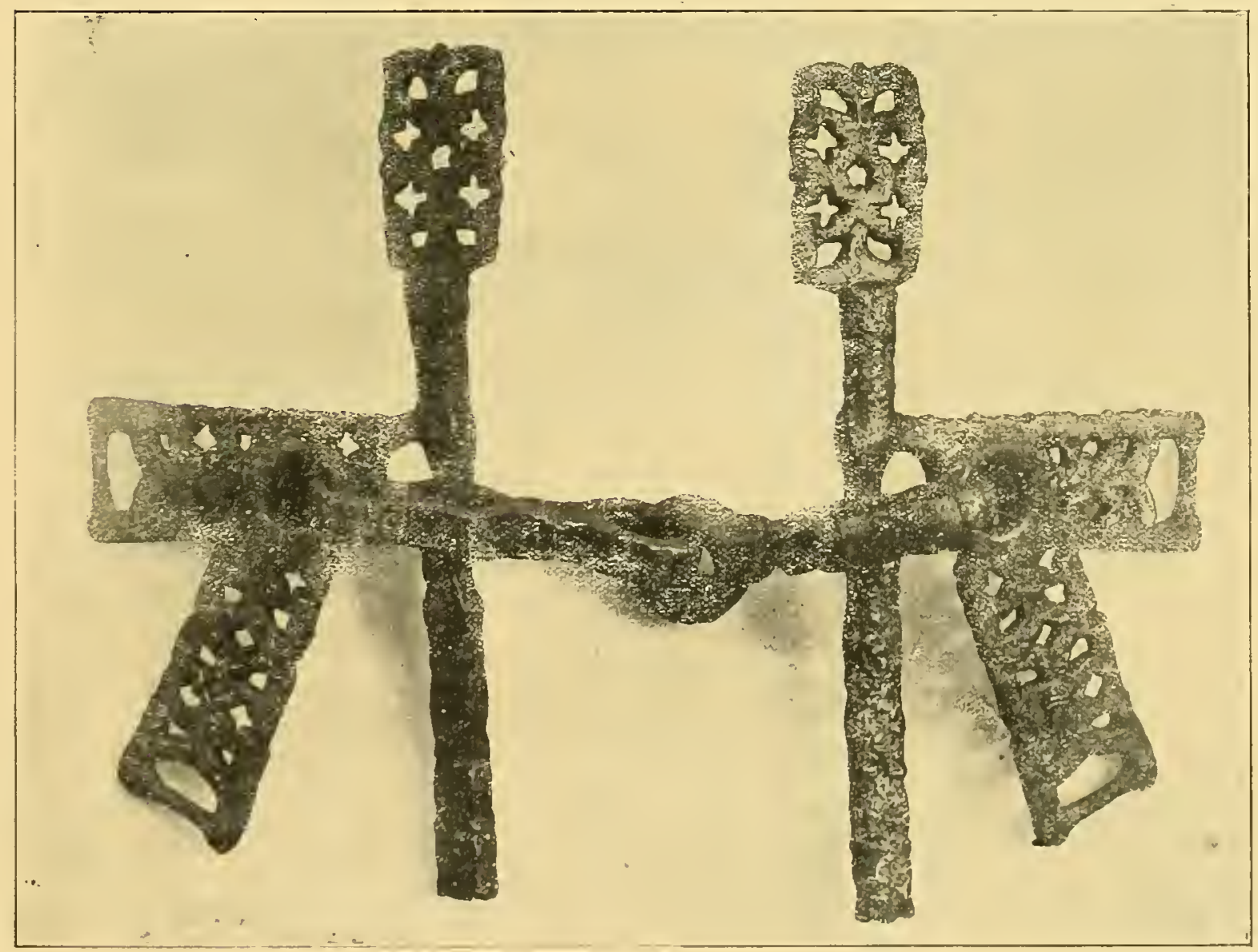


cedentes, formado por dos camas unidas a sus ${ }^{4 / 5}$ de la altura por un travesaño soldado, originariamente rectangular y con dos anillas soldadas a él y promediadas. La separación de las camas varía entre 10,3 y $13,5 \mathrm{~cm}$. Las piezas accesorias laterales presentan una extraor-

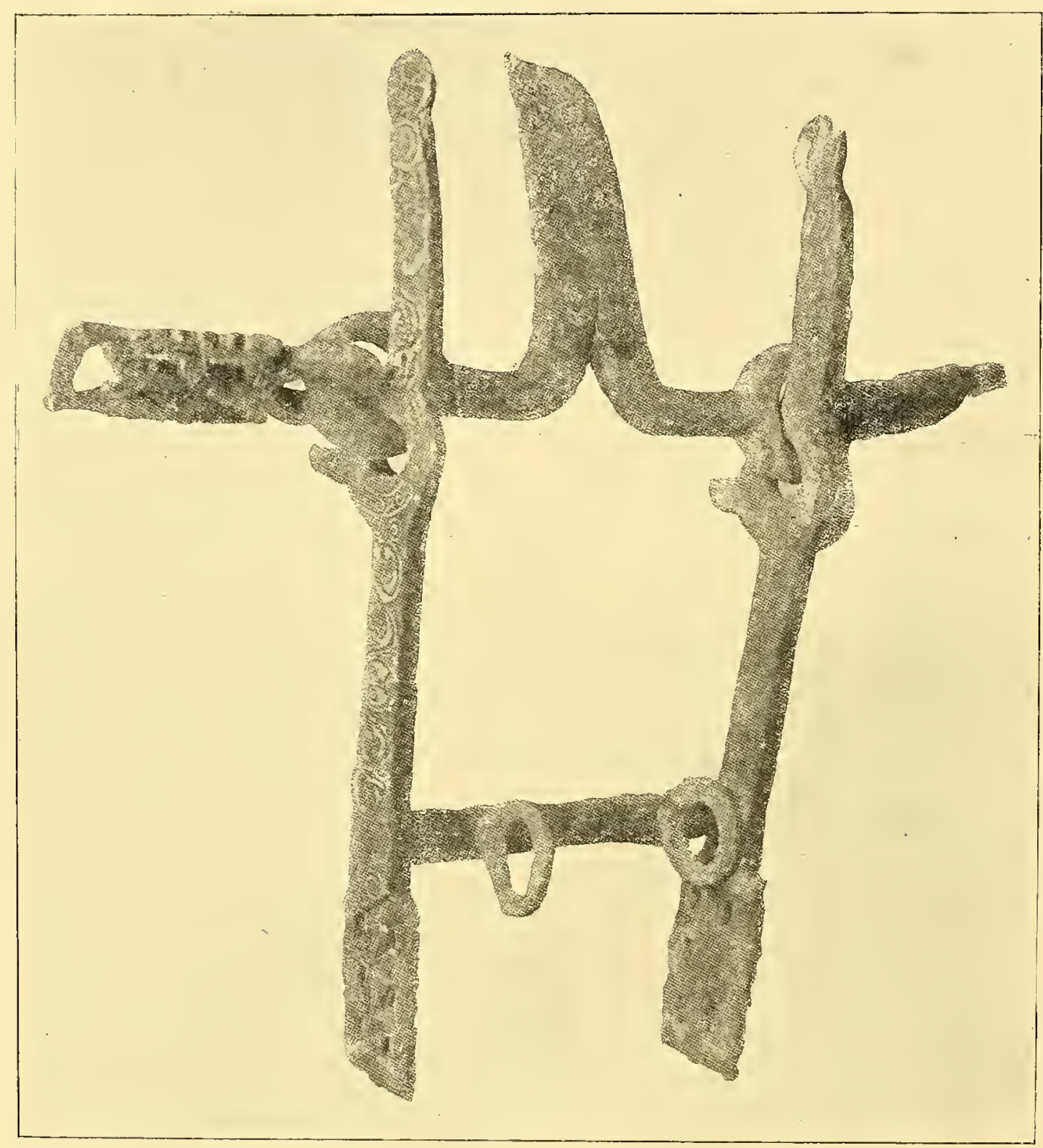

Nứm. 184.

dinaria semejanza a las del ejemplar anterior. Ocurre lo propio con el extremo de las camas. Las incrustaciones, a lo largo de éstas, están formadas por una doble greca, que puede considerarse como círculos tangentes, alguno de los cuales representa caras. Pertenece, seguramente, como los anteriores, a la época visigoda. Es ejemplar rarísimo por su forma, que al parecer no tenía riendas, atando el caballo por dos cintas que arrancaban de las anillas y conducidas por pajes, todo lo cual hace suponer que se trata de una pieza de ceremonia. 
Dimensiones: longitud de las camas, 26,5 cm.; piezas accesorias laterales, $8 \mathrm{~cm}$.

Expositor: D. Rafael Garcia Palencia.

Núm. 185. - Bocado de tipo análogo a los números 180 y 181 , pero mucho más elemental y sin que en él puedan apreciarse, ni es fácil que hayan existido, trabajos de incrustación. Altura de las camas, $13 \mathrm{~cm}$. Separación, 12. Piezas adicionales, 7,5 cm.

Puede considerarse como ejemplar corriente o popular de la época visigoda.

Expositor: D. Manuel López Ayala.

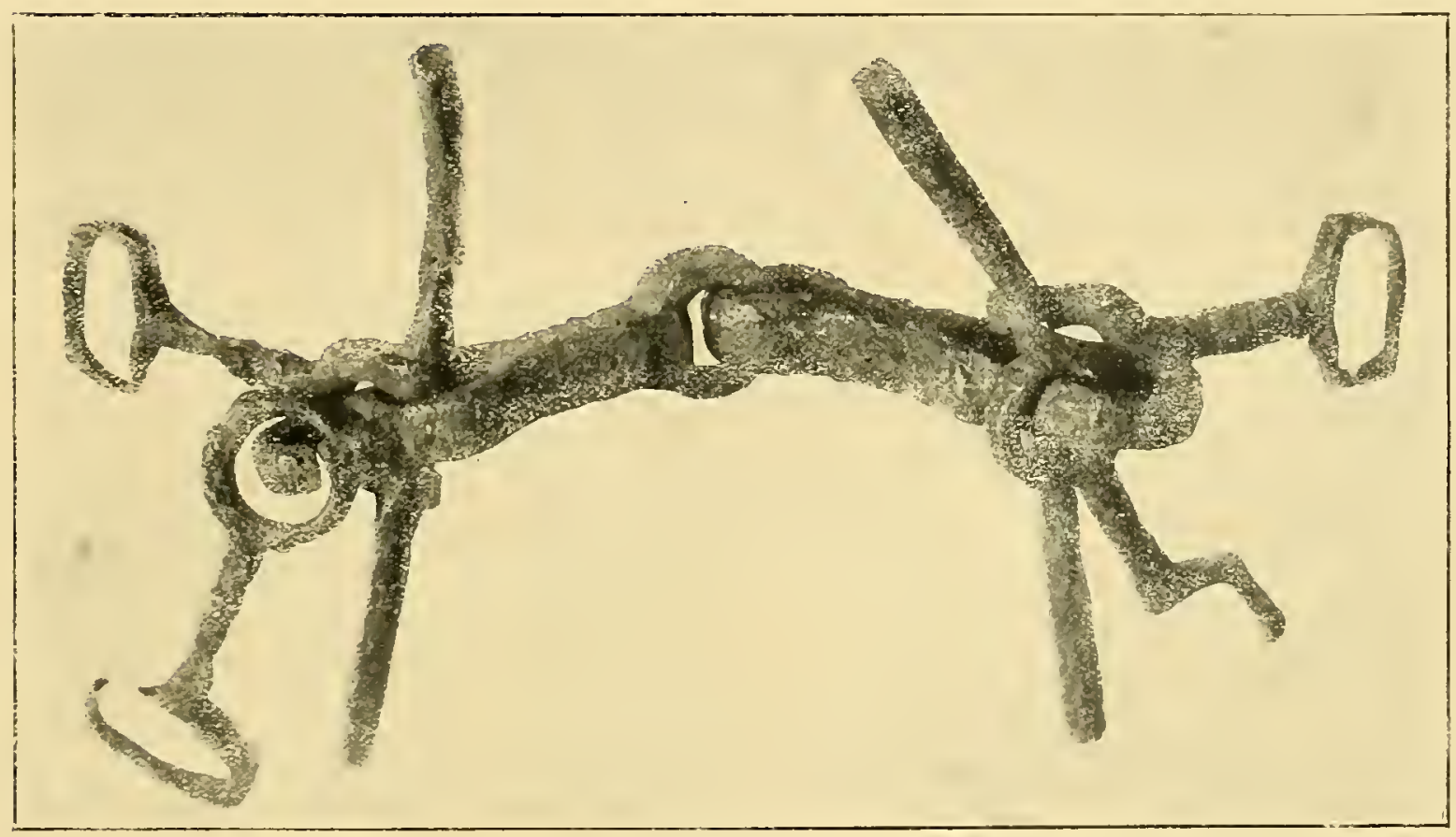

Núm. 185. 



\section{La segunda Edad del Hierro}

desde los tiempos medioevales hasta el comienzo de la industria contemporánea

\section{Edad Media}

Núm. 186.-Cruz de hierro de brazos divergentes con incrustaciones circulares en cobre y azófar, un calado en cada uno de los brazos, lanceolado y terminado en dos lóbulos; el brazo superior mutilado. Ejemplar exageradamente interesante. Siglo xI.

Expositor: Excmo. Sr. Marqués de la Torrecilla.

Núm. 187. - Figura de pájaro con el cuerpo alargado en arco formando la cola. Trabajo de plancha soldada por forja, que puede ser atribuído a los finales del siglo xir.

Expositor: Museo Arqueológico $\mathrm{Na}$ cional.

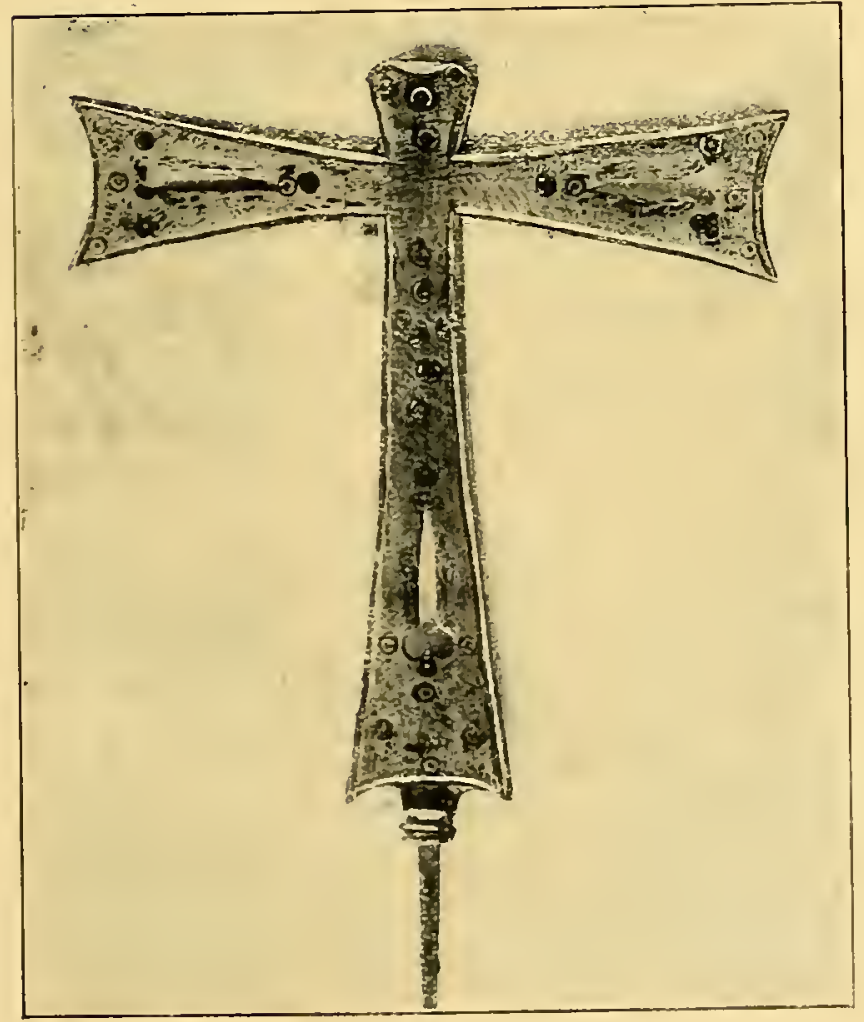

Nim. 786.

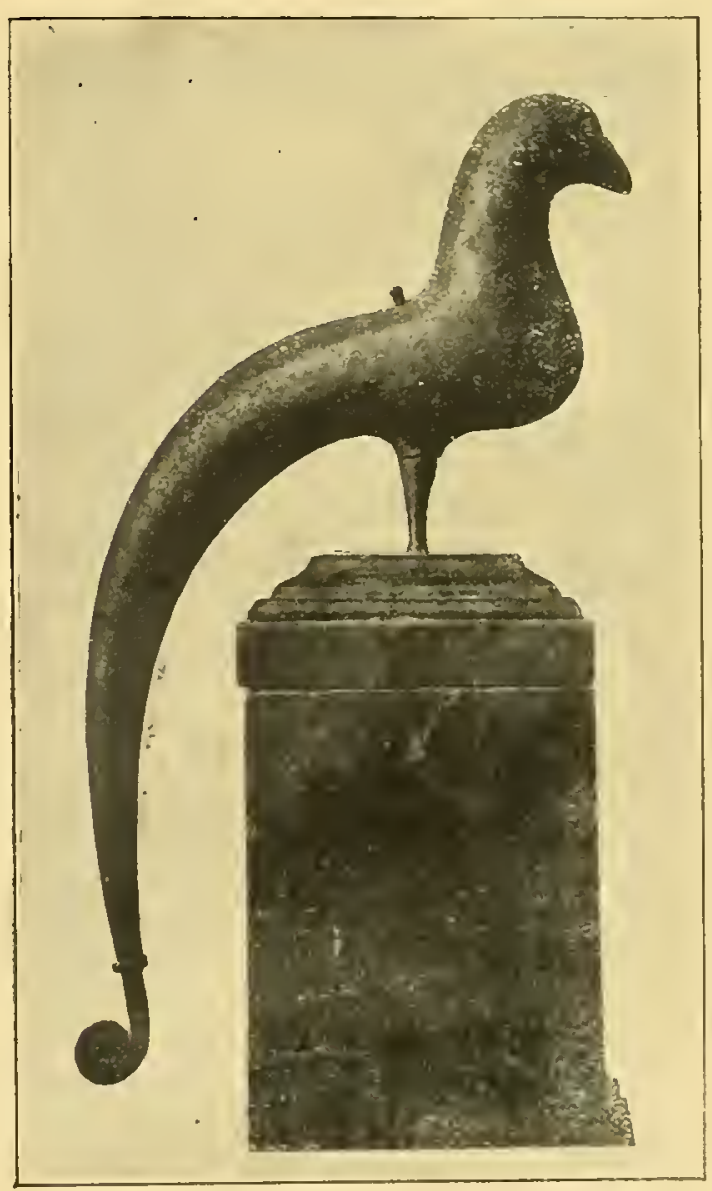

Nium. 187. 
Núm. 188.-León de hierro forjado en piezas distintas soldadas por forja.

Ejemplar hallado en un Monasterio en Cataluña. Puede ser un trabajo del siglo xı1..Longitud: $11 \mathrm{~cm}$. y 12 de altura.

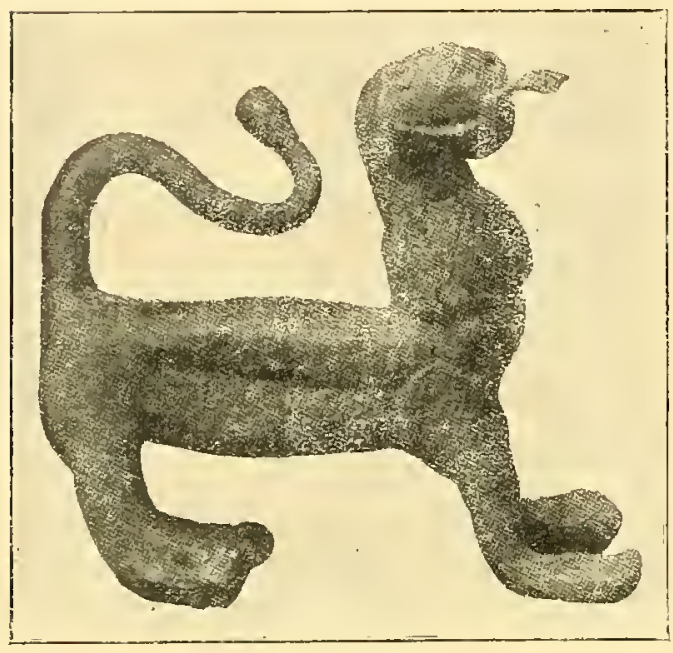

Núm. ¿188.
Expositor: Sr. Tachart, de Barcelona.

Núm. 189.-Cuadro conteniendo 16 llaves medioevales desde tipos inmediatos a la época romana hasta mediados del siglo xiv. Las guardas se encuentran en el mismo plano que el eje, diferenciándose en ello los tipos más arcaicos de los romanos.

\section{Expositor: Excmo. Sr. Duque de Santa Lucía.}

Núm. 190.-Dos llaves de 24 y 26 cm. Eje cónico; las guardas colocadas a $1 / 6 \mathrm{y}^{1 / 5}$ de la longitud total. Siglo xiv.

Expositor: D. Enrique Montero.

Núm. 191.-Llave árabe con incrustaciones anulares de azófar. Según documentación que arranca del tiempo de los Reyes Católicos; esta llave perteneció a la puerta principal

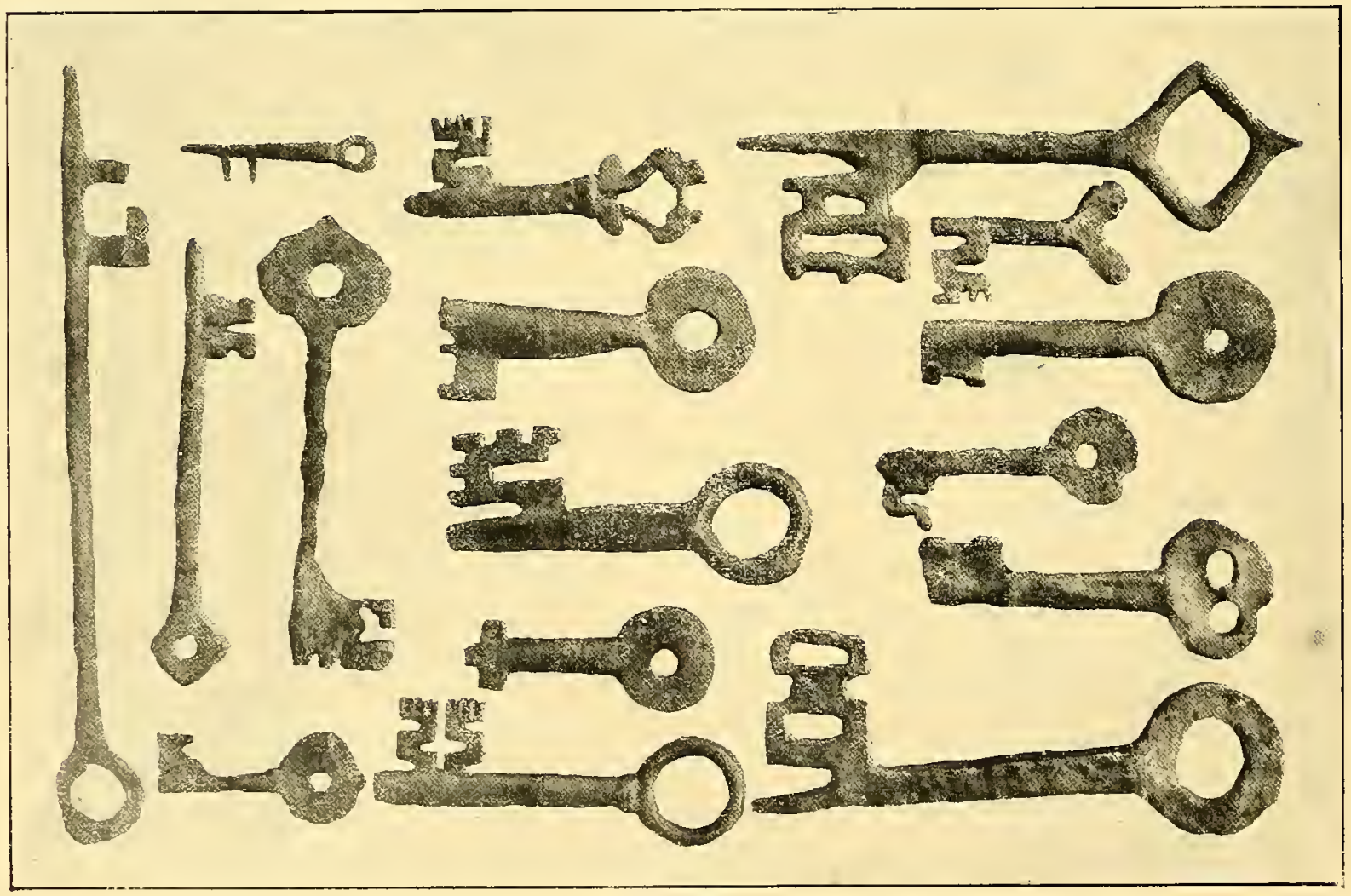




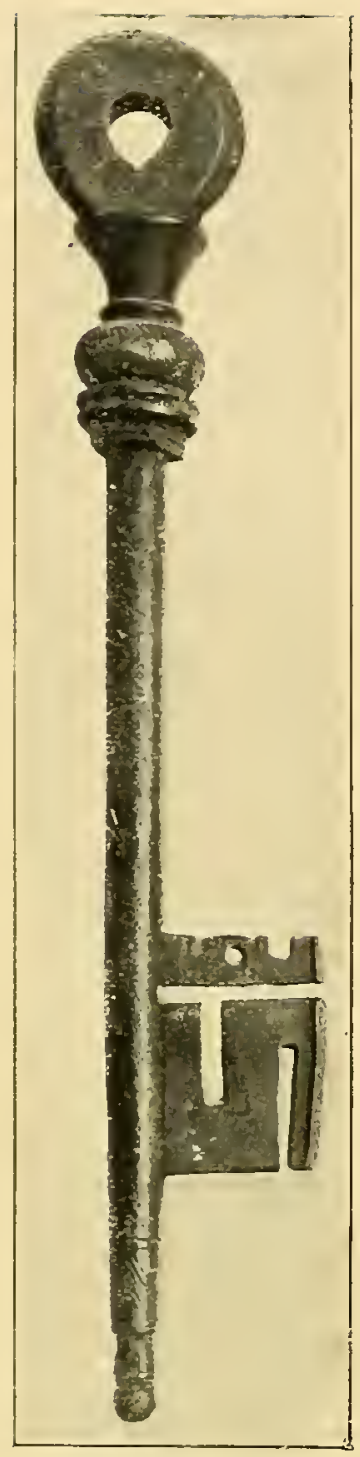

Núm. 191.

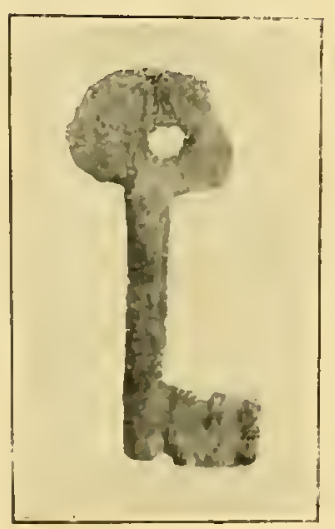

Nüm. 192.

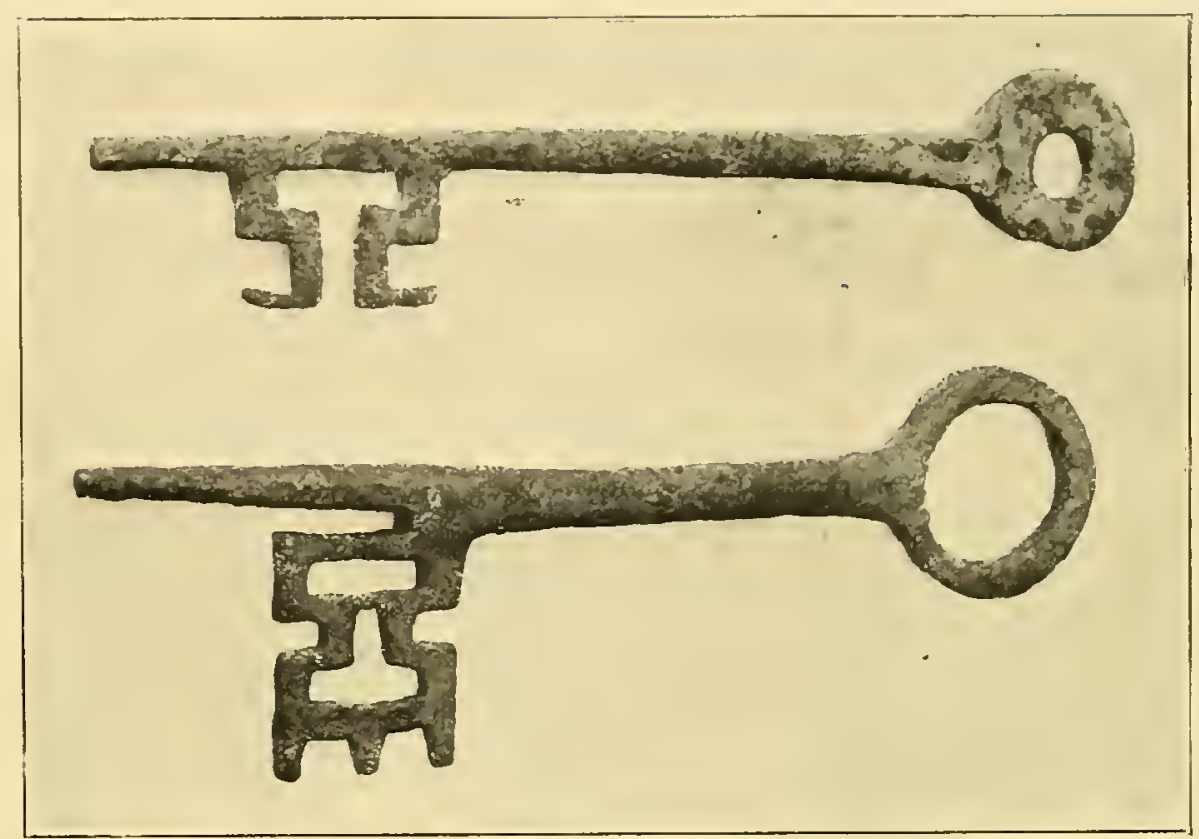

Núm. 190

del alcázar de la Alhambra y fué entregada por los Reyes Católicos a los antecesores de su actual poseedor, Sr. Conde de los Infantes. Siglo xiv.

Expositor: Excmo. Sr. Conde de los Infantes.

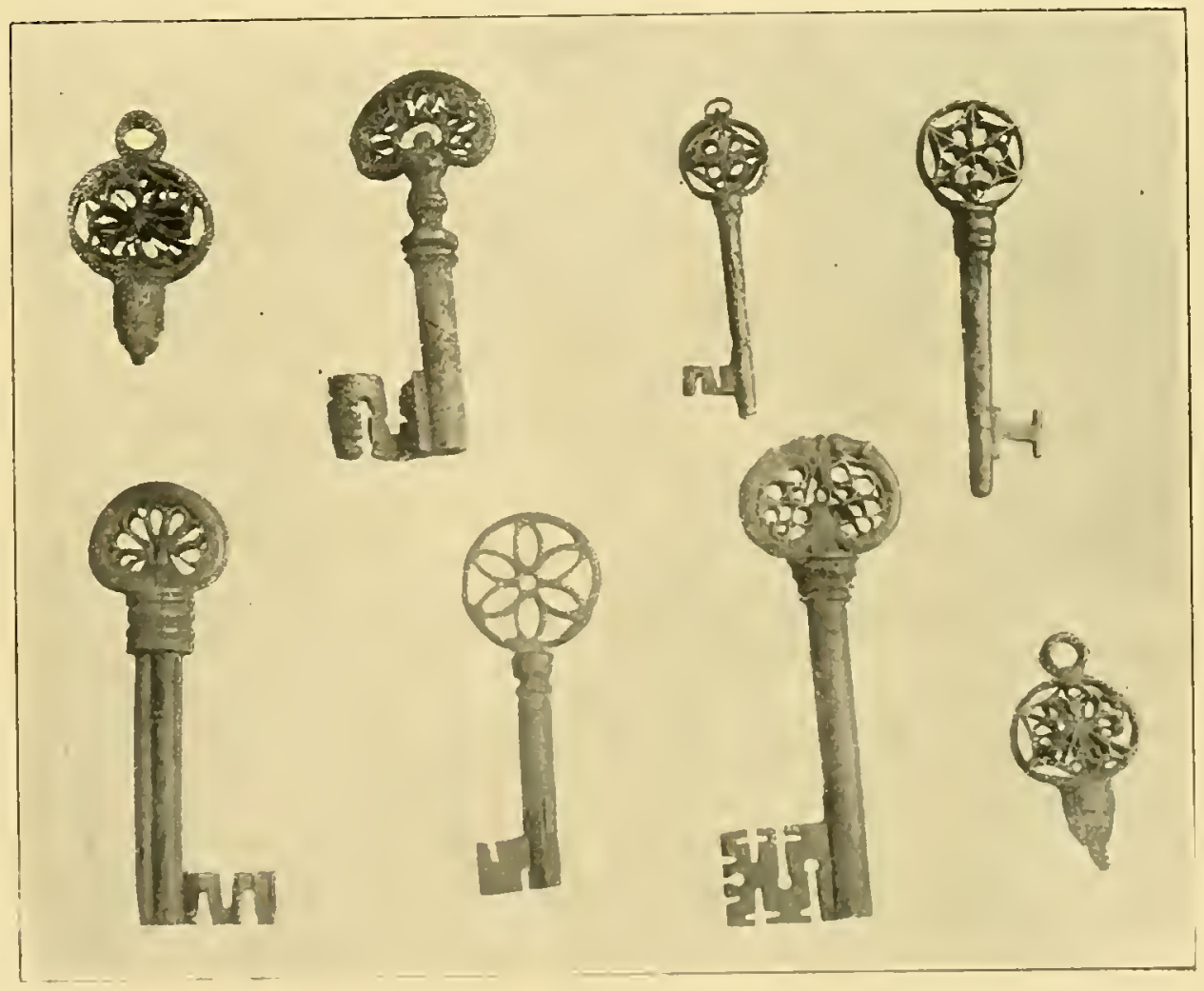

Nứm, 193. 
Núm. 192.-Llave de $7 \mathrm{~cm}$. de longitud; eje cilíndrico; las guardas colocadas al extremo del eje y el anillo superior muy cerrado. Finales del siglo xiv.

Expositor: D. Frutos Barbero y Delgado.

Nứm. 193.--Cuadro conteniendo seis llaves y dos cabezas de llave con vástago de sec-
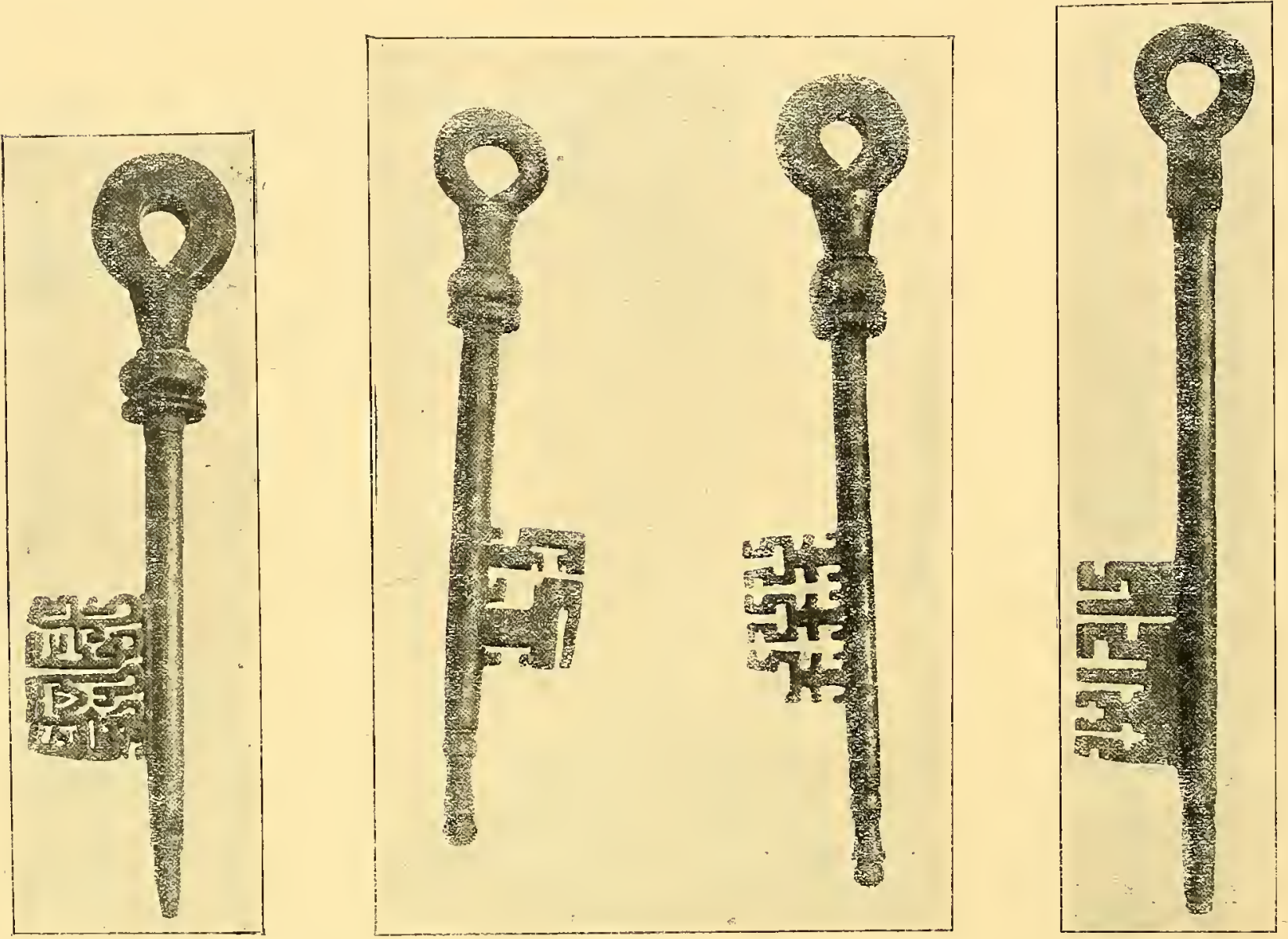

Núm. 194.

ción lobulada o poligonal, cónico en una y cilíndrico en tres. Corresponde de los finales del siglo xv a principios del xvı.

Expositor: Excmo. Sr. Duque de Santa Lucía.

Núm. 194.-Cuatro llaves de hierro de eje cónico y las guardas colocadas a $1 / 6 y^{1 / 5}$ de la longitud. En una de ellas el trabajo de las guardas traza una inscripción cúfica; un motivo del laberinto se repite en otra y las restantes presentan un trazado variado.

Expositor: Museo Provincial de Bellas Artes de Segovia.

Núm. 195. - Freno de varilla retorcida dando una dimensión máxima de $24 \mathrm{~cm}$. de 
abertura y total del ejemplar de $49 \mathrm{~cm}$. Seguramente corresponde a un tipo popular del siglo xIv.

Expositor: D. José María Florit.

Núm. 196. --Dos llaves de 7 y $8 \mathrm{~cm}$. de longitud, eje cónico, las guardas en el extremo del eje y en su mismo plano.

Principios del siglo xv.

Expositor: Museo

Provincial de Bellas Artes de Segovia.

Núm. 197.-Fragmento de reja de $46 \mathrm{~cm} .{ }^{.} \mathrm{de}$ altura por 42 de ancho. Está formada por un nervio central al que vienen unidos, por medio de grapas, elementos siempre iguales, formados por volutas doblemente simétricas, adosadas, rellenando los espacios in-

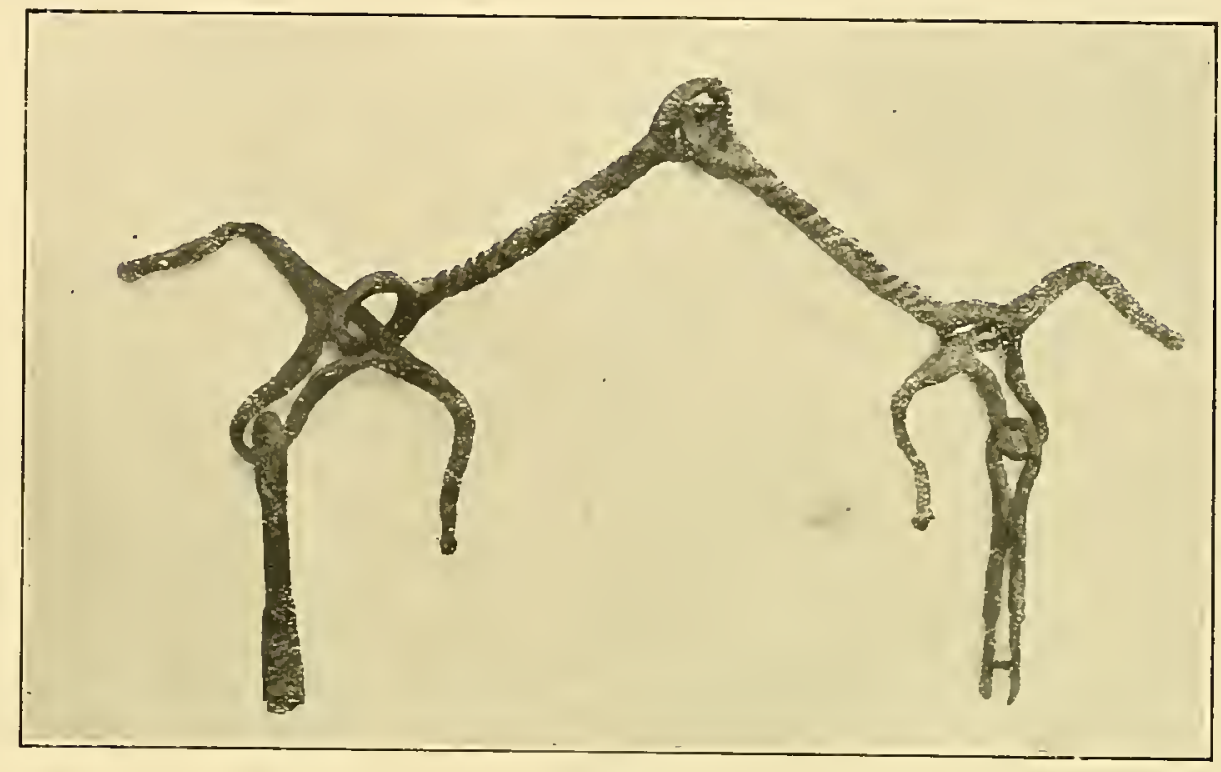

Nủm. 195.

termedios por pequeños hierros de igual ancho y mucho menor espesor, curvados en sen-

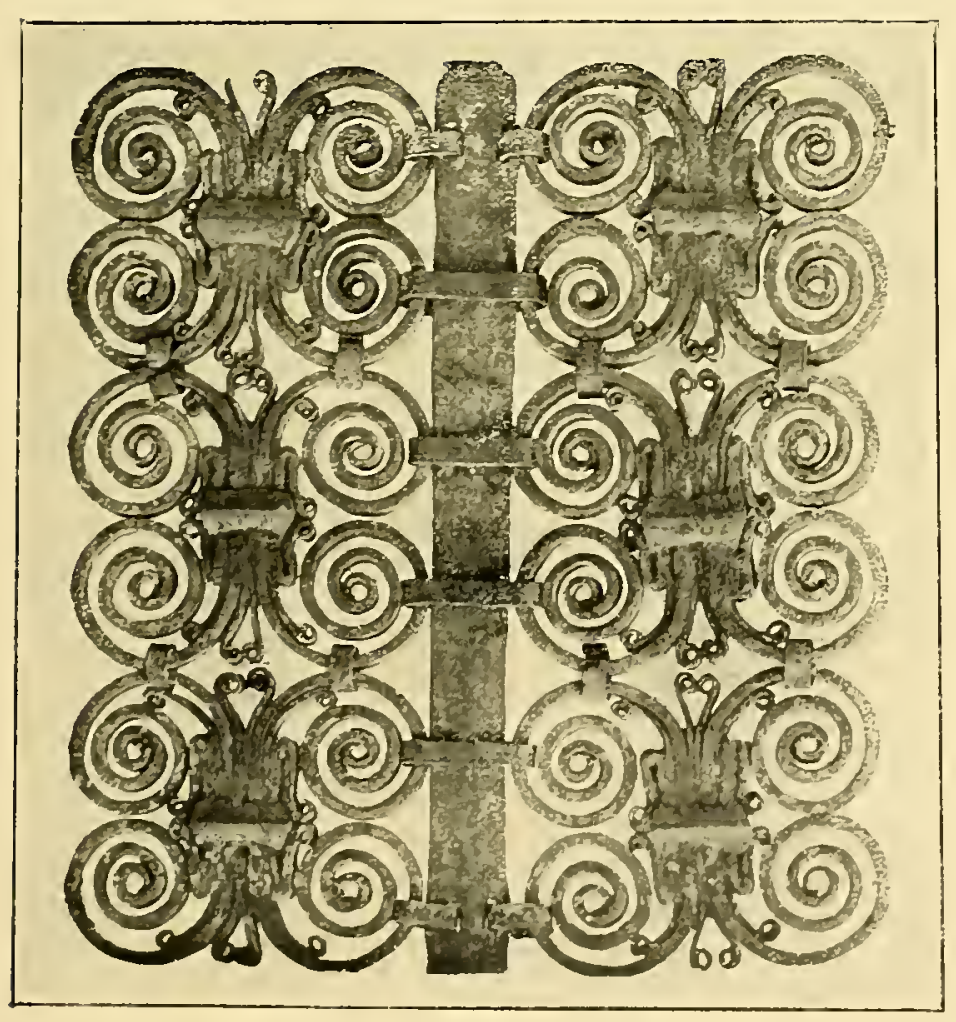

Nưm. 197. tido inverso o doblados sobre sí mismos para dar mayor cuerpo al núcleo central que abraza un hierro en arista.

Mediados o finales del siglo xII.

Expositor: D. Rafael García Palencia.

Núm. 198.—Fragmento de reja ro-
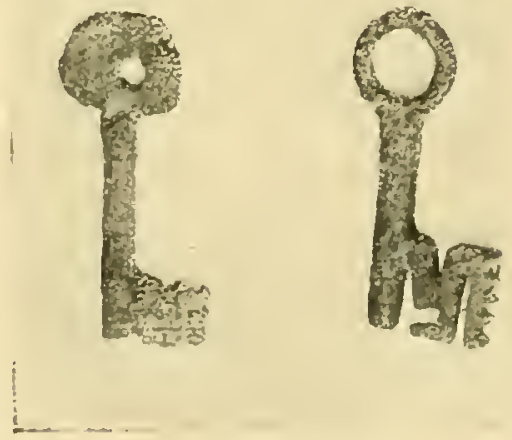
mánica de $53 \mathrm{~cm}$. de altura por 60 de ancho. Su composición y trazado es exactamente igual al ejemplar que precede, pero presenta la particularidad de que los dos barrotes centra-

les se resuelven en volutas en

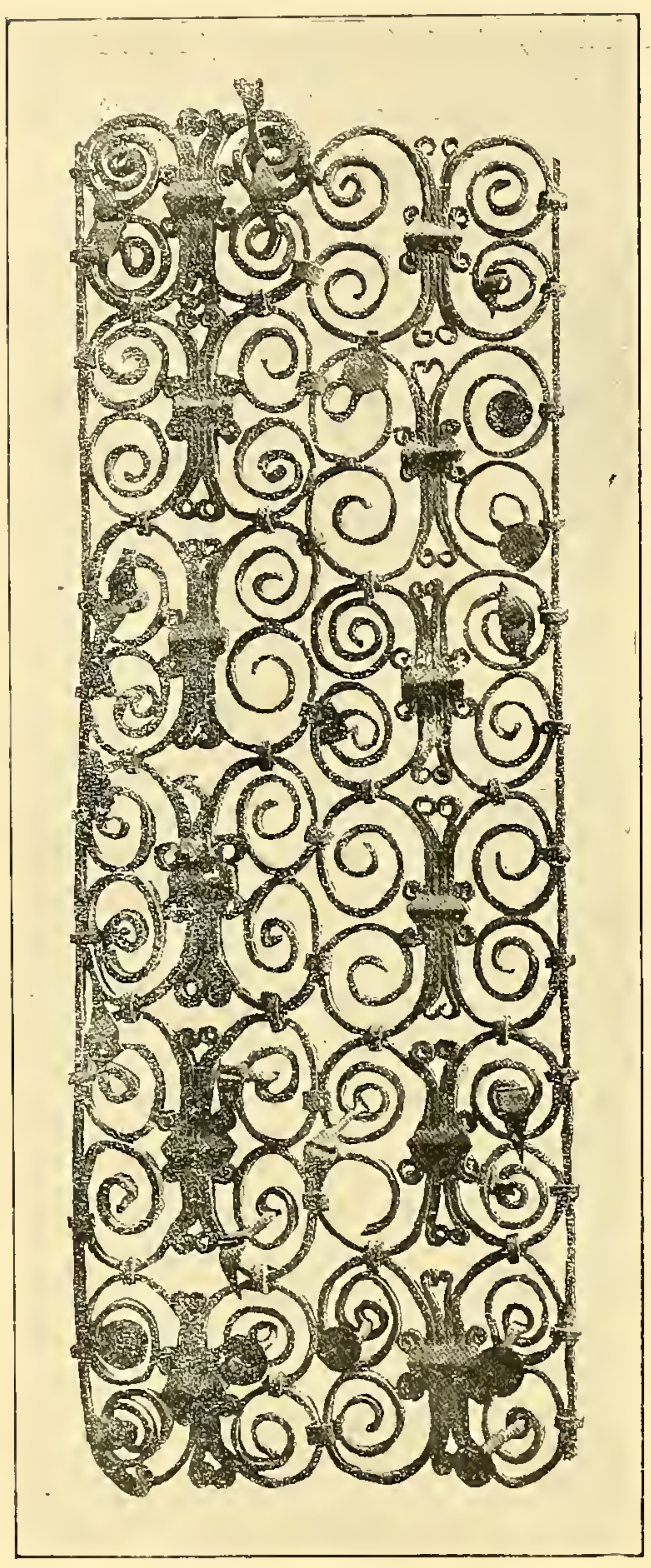

Núm. 199.

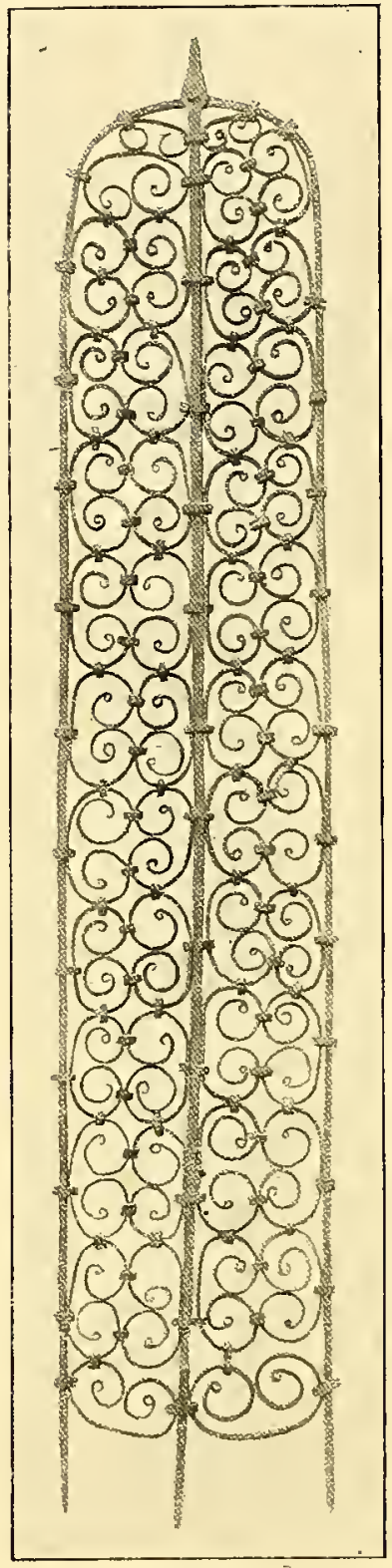

Núm. 200. forma análoga al motivo general de la reja.

Puede pertenecer al último tercio del siglo xiI.

\section{Expositor: D. Domin- go Guerrero, de San Sebastián.}

Núm. 199.-Trozo de reja románica de $70 \mathrm{~cm}$. de altura por 28 de ancho. Está formada por dos ejes o barras laterales, sobre las cuales se unen, por medio de grapas, elementos formados por volutas dobles y simétricas con núcleo central, en todo análogo a los tipos que preceden, pero trabajadas en hierro más delgado formando un conjunto más diáfano, uniéndose, además, cada doș elementos entre sí, y suprimiendo por consecuencia, el eje central de los tipos que preceden. En la terminación de la voluta arranca un hierro que sale de la reja perpendicularmente a su plano, en unos 5 a $6 \mathrm{~cm}$. de altura y que termina en un disco o en una lámina lanceolada, pretendiendo recordar estambres o pétalos de flores.

Principios del siglo xil.

\section{Expositor: Museo Arqueológico Nacional.}

Núm. 200.- Reja románica de 1,50 m. de longitud por $30 \mathrm{~cm}$. de ancho. La forman un eje central y dos laterales, todos de sección cuadrada, rellenando el espacio hierros que forman volutas encontradas, tangentes y simétricas, análogas a los ejemplares anteriores y unidas entre sí y a los ejes por grapas, como en el caso anterior, presentando la diferencia de no existir el núcleo central ni hierrecillos que rellenen los espacios romboidales, arrolla- 
dos en sentido inverso, siendo además el hierro de menor sección y el conjunto mucho menos ornamental y mucho más diáfano.

Siglo xill.

Expositor: Museo Provincial de Bellas Artes, de Segovia.

Núm. 201.-Reja románica de $68 \mathrm{~cm}$. de ancho por 87 de alto, formada por ejes de sección cuadrada, sobre los cuales se reunen por grapas volutas dobles simétricas con núcleo central y hierros rellenando los espacios romboidales, aquí por excepción arrollados en el mismo sentido. Las dimensiones de cada elemento decorativo son mayores; la varilla de hierro delgada; la separación de los ejes, más grandes; todo lo cual da una mayor transparencia al conjunto. Procede de una iglesia románica de Cuenca.

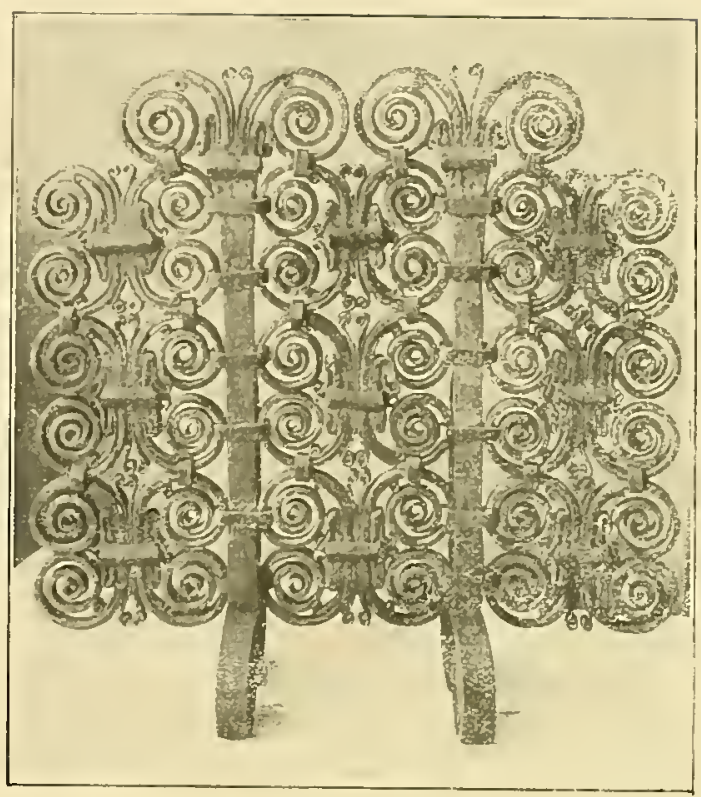

Finales del siglo xuı.

Exposıror: D. Juan Jiménez Aguilar, de Cuenca.

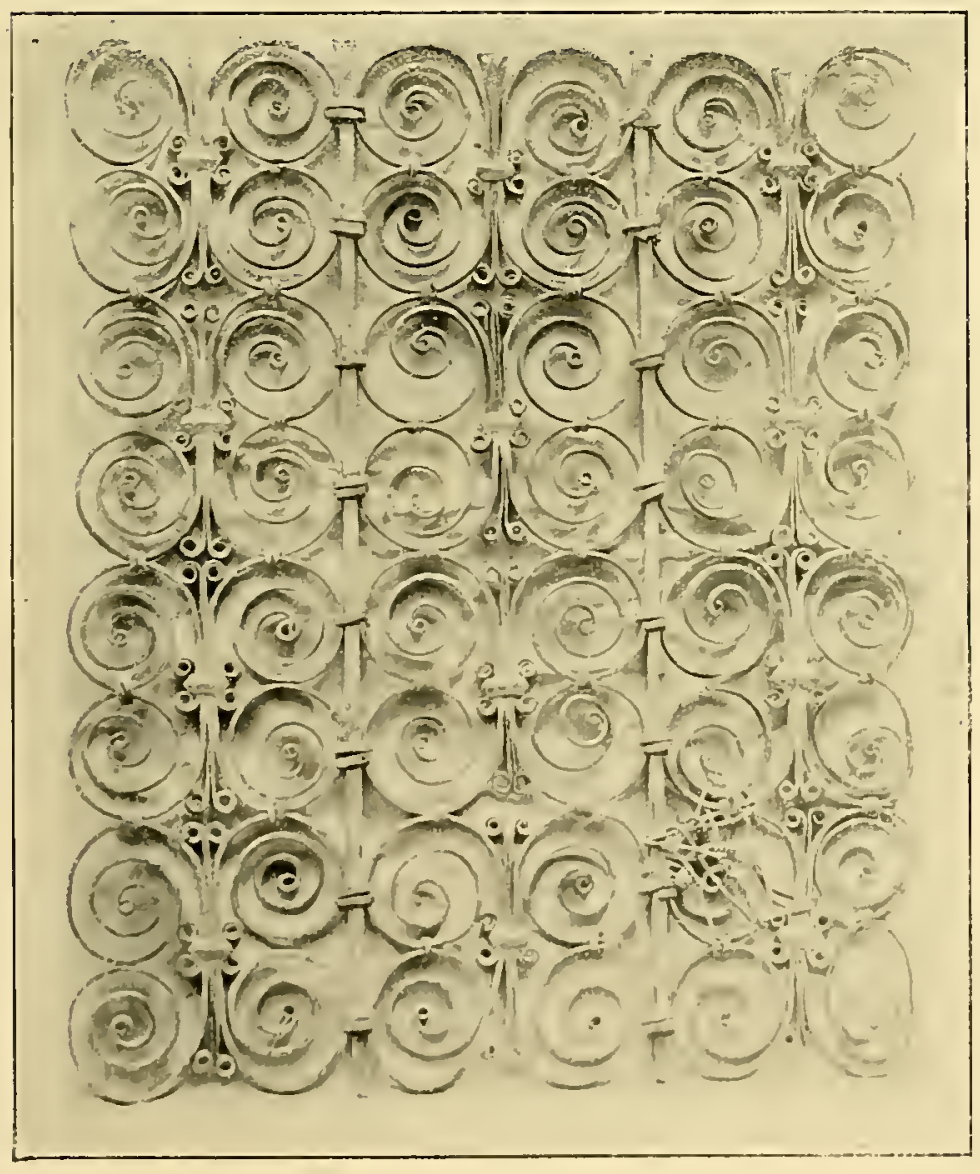

Núı, 201.
Núm. 202. - Reja románica de I,O4 m. de altura por $95 \mathrm{~cm}$. de ancho, muy parecida a la anterior, pero la separación de los ejes es más grande. El conjunto mucho más transparente; el núcleo central resulta más alargado y los hierros que en la otra cubrieron los espacios romboidales, son ahora de igual sección que los que forman las volutas, prolongándose los horizontales hasta los ejes o vástagos. del xiv.

Finales del siglo xill o principios

Expositor: Convento de Carmelitas Descalzas de Segovia.

Núm. 203.-Reja románica de 40 centímetros de alto por 36 de ancho, formada por voluias simétricas enlazadas entre sí por grapas, siguiendo la tradición anterior. Las que ocupan el lugar que en los ejemplares preceden- 
tes fomaban el núcleo, presentan una sección en arista que recuerdan aquellos tipos. Han desaparecido los ejes o barrotes verticales que constituían el armazón de la reja. Los ele-

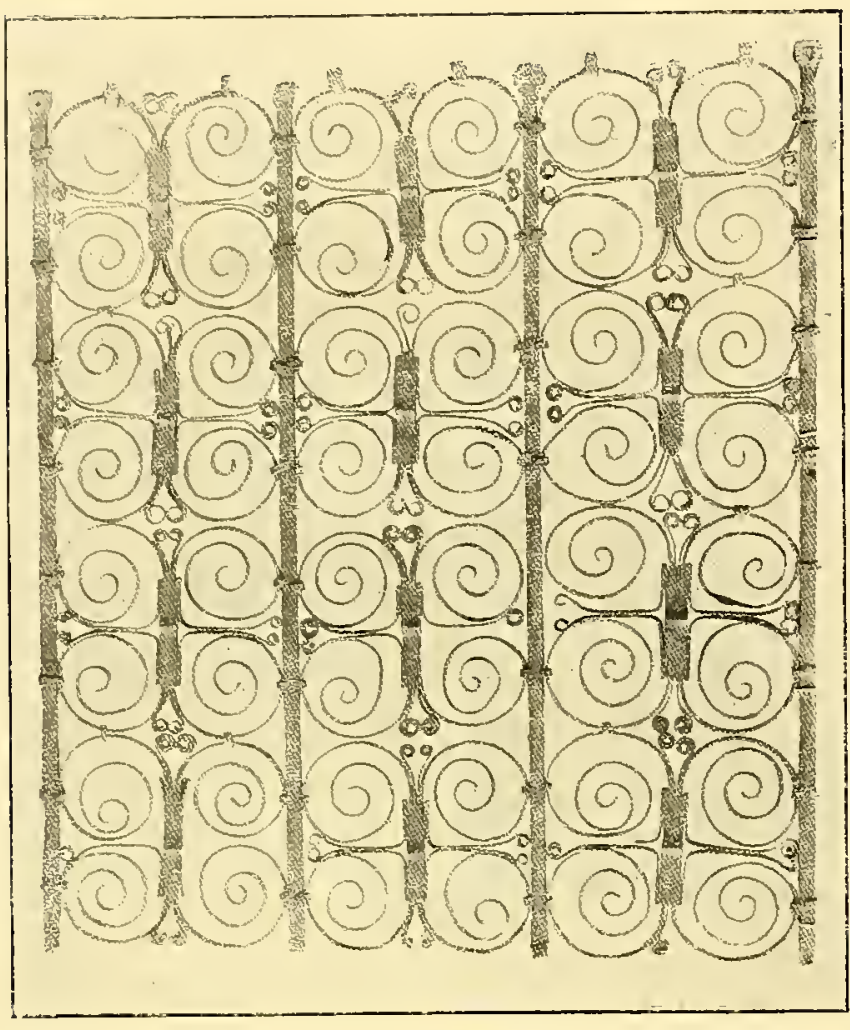

Núm. 202. mentos son pequeños y de sección reducida, y el conjunto resulta de suficiente transparencia.

Siglo xiv.

Expositor: Excmo. Sr. Duque de Santa Lucía.

Núm. 204.--Reja románica de 40 centímetros de alto por 50 de ancho, análoga por completo al ejemplar que precede, $y$, como él, acusando una influencia italiana, o quizá un elemento precursor de las rejas italianas del siglo xv.

Siglo xIv.

Expositor: D. Domingo Guerrero, de San Sebastián.

Núm. 205.-Brasero románico de 54 por $56 \mathrm{~cm}$., formado por cuatro varillas colocadas en los ángulos, con ruedas en los extremos inferiores y anillos en la parte superior. El frente está formado por dos barras rectangulares, sobre las que se unen por remache elementos en volutas simétricas y dobles, análogos a los constitutivos de las rejas románicas, pero cuyo eje termina en disposición doble lanceolada. Finales del siglo xill a principios del xiv.

Expositor: Seminario Conciliar de Lérida.

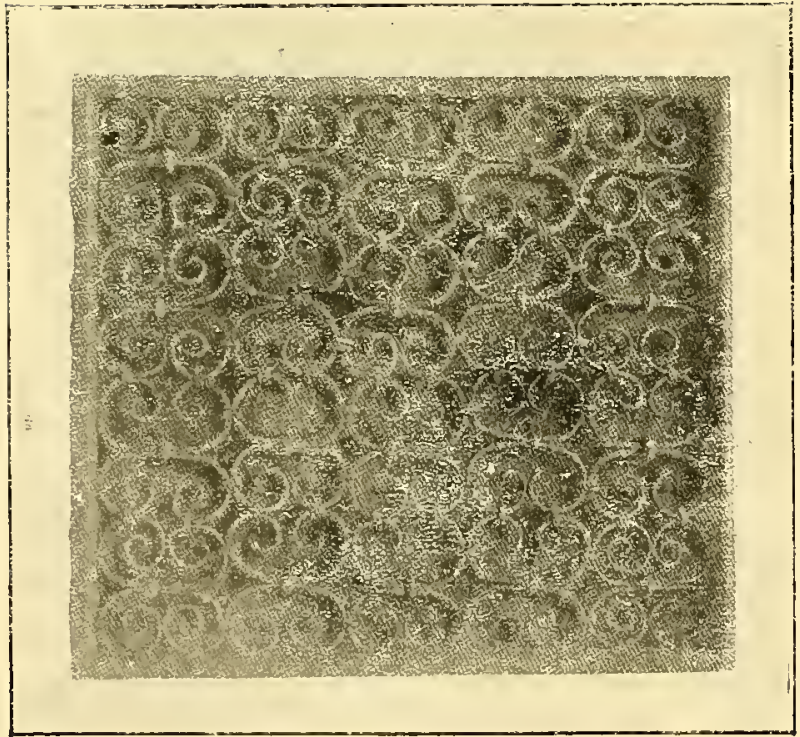

N'úm. 203.

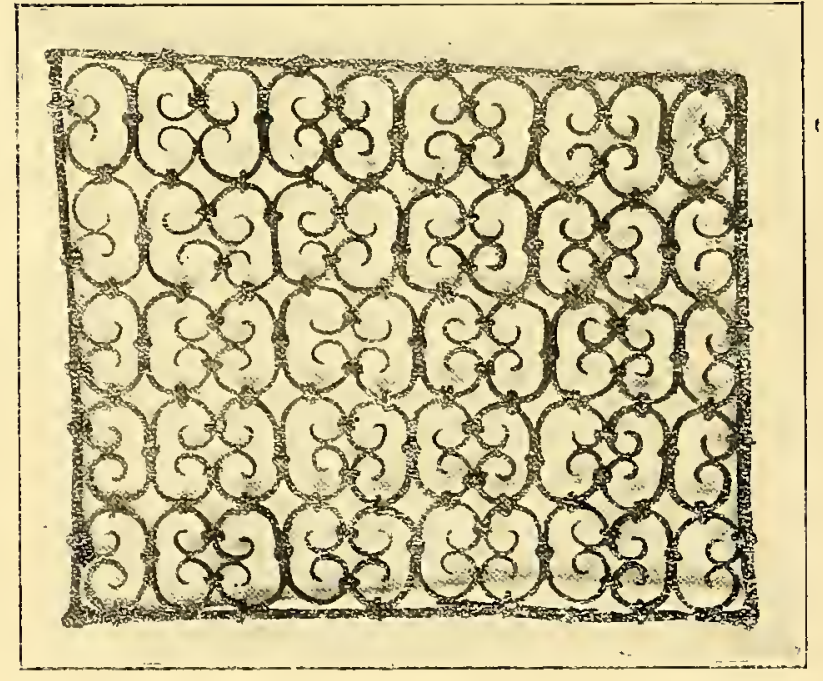

Nưm, 204. 
Núm. 206. - Brasero románico análogo al anterior, de $36 \mathrm{~cm}$. en cuadro, pero con las varillas de los ángulos mucho más prolongadas, dando una mayor elevación a la caja del brasero. Finales del siglo xill y principios del xiv.

\section{Expositor: Cabildo de la Ca- tedral de Tarragona.}

Núm. 207.--Brasero románico de 58 por $48 \mathrm{~cm}$.; análogo en un todo al ejemplar precedente de la Catedral de Lérida, pero con las volutas mucho más elementales. Estilo de finales del siglo xul a principios del xiv.

Procedencia Cau Ferrat.

Expositor: D. Santiago Rusiñol.

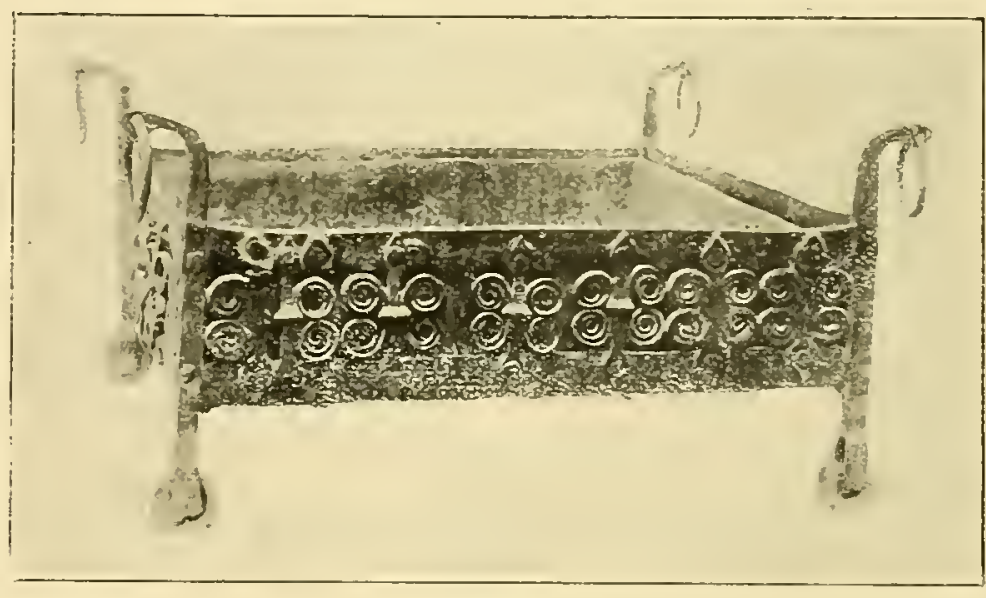

Nửn. 205.

Núm. 208.-Molde para hacer barquillos, con motivo ornamental estilizado y una leyenda que dice: QUI DAQUE STE S NEULS COMPRARA AL GOY DE PARAIS SRA (quien de estos barquillos comprara, al gozo del Paraíso será). Siglo xiv.

Existen en España ejemplares análogos al descrito, en el Museo Diocesano de Vich y parecidos pero todos ellos posteriores en diferentes Museos extranjeros, habiendo dado origen a interesantes monogra-

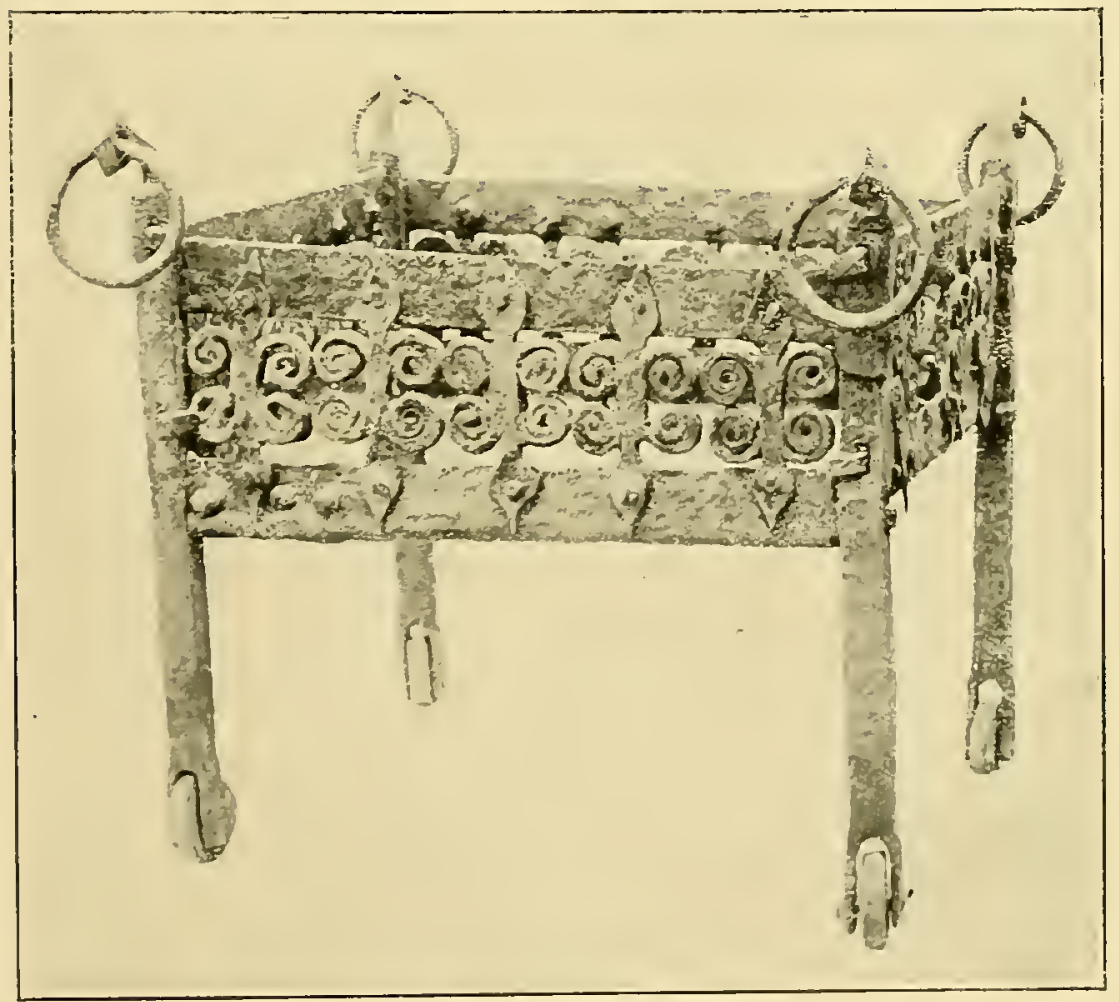

Núm. 200. fías publicadas recientemente por la Sociedad de Anticuarios de Londres.

El estado de conservación es excelente en todos los ejemplares, siendo ello curioso por ser piezas que fueron sometidas al fuego; se supone que tal estado es debido a una película de grasa producida durante el uso y que recubre la superficie.

El estudio del tipo de letra y de la decoración no deja lugar a duda sobre la fecha que les asignamos, tanto a este ejemplar como al que le sigue. Trabajo a cincel muy interesante.

Expositor: D. Domingo Torrent y Garriga, de Manlleu. 


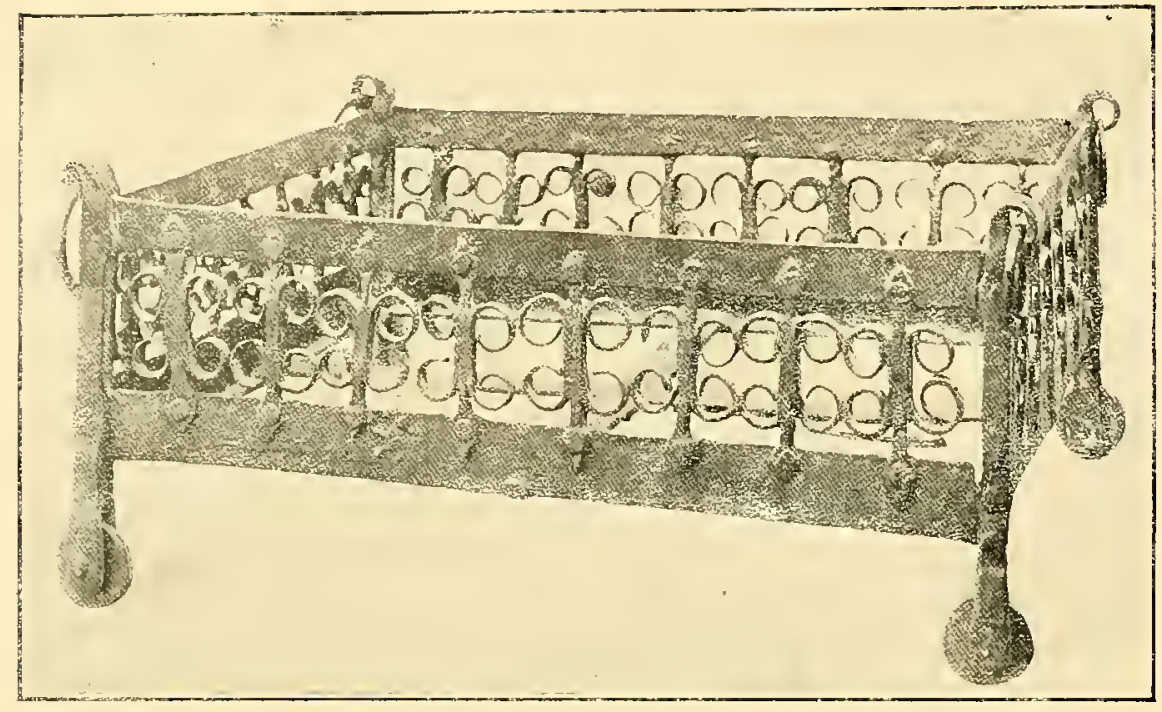

Núm. 207.

Núm. 209. - Molde de hacer barquillos, con la representación de un caballero armado y una inscripción que dice: IO SON DEN BERNAT CUGOT (yo soy de Bernardo Cugot). Siglo xiv.

Expositor: D. Domingo Torrent $y$ Garriga, de Manlleu.

Núm. 210.-Molde para hacer hostias, análogo a los precedentes, pero doble y

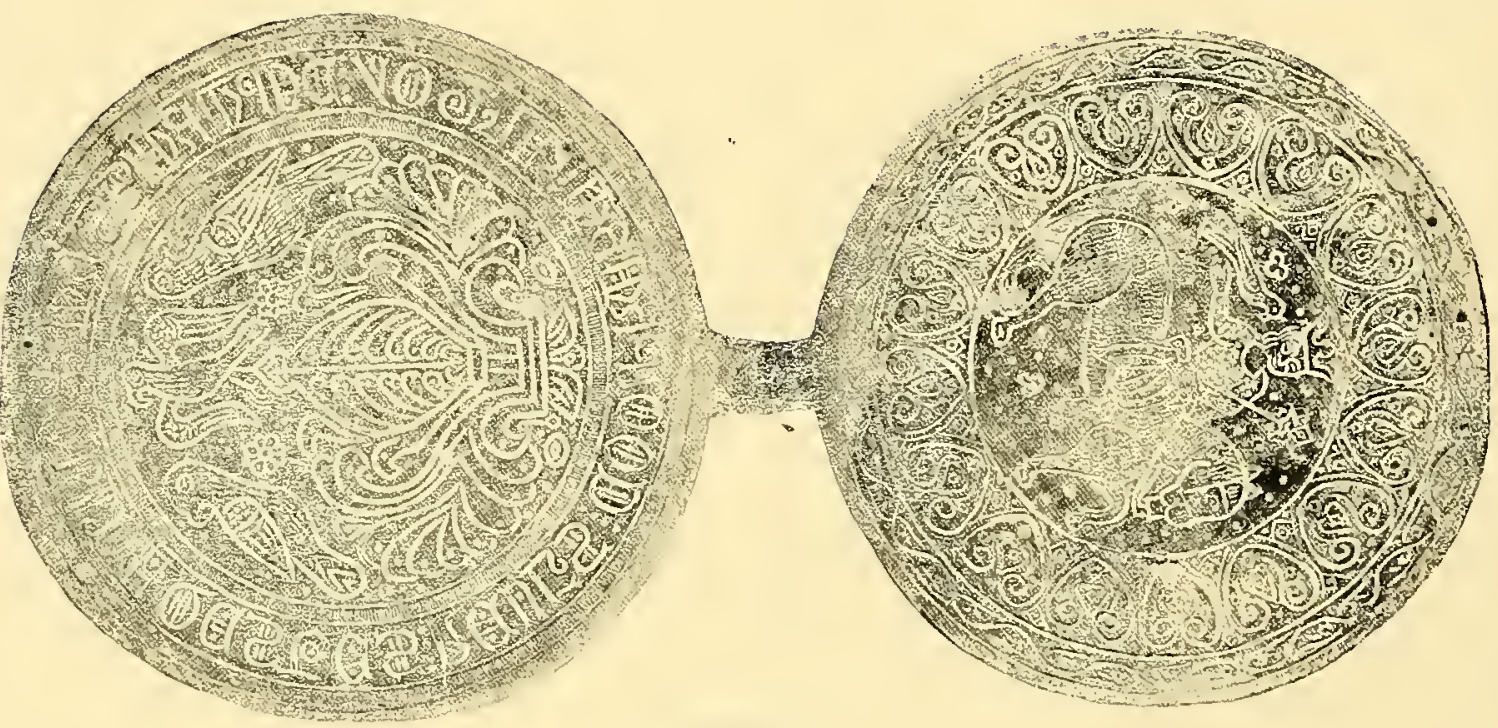

Núm. 208.
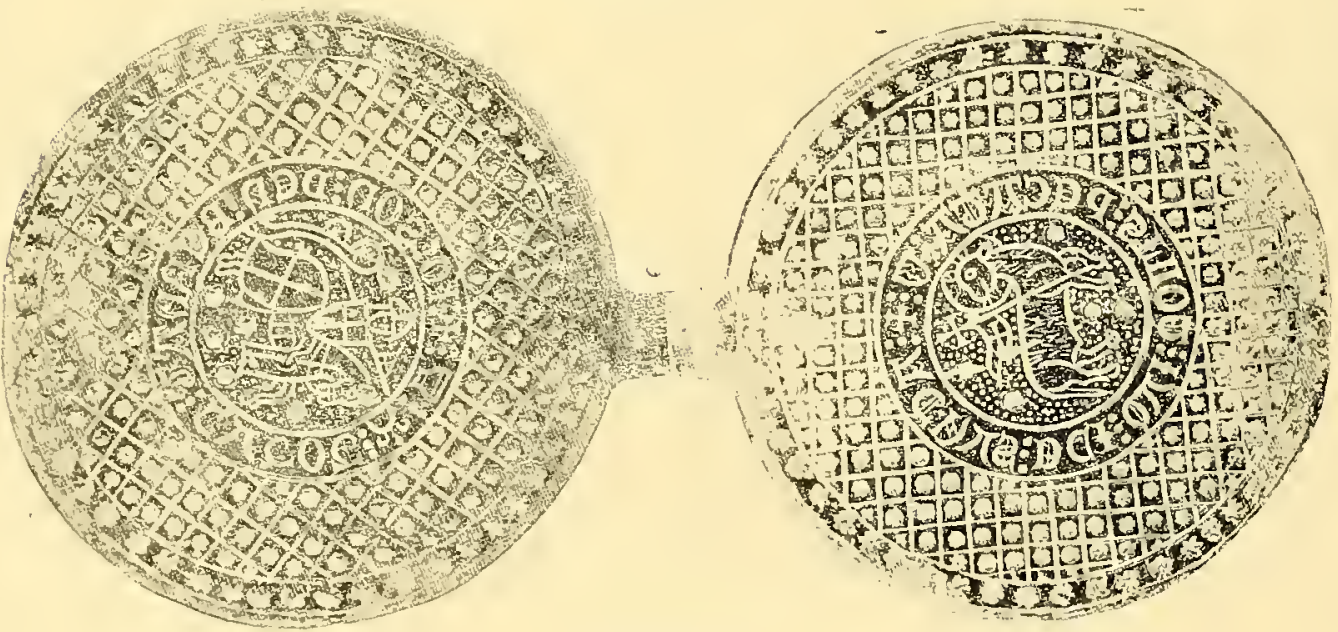

Núm. 209. 


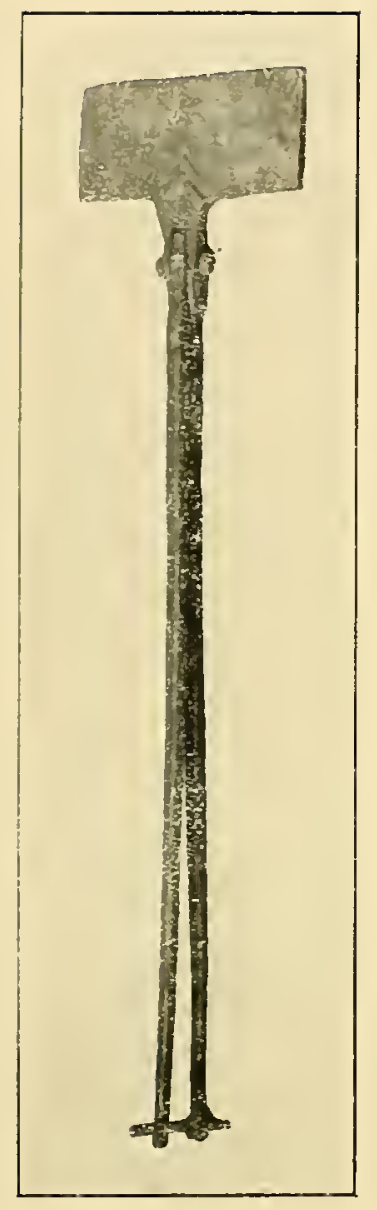

con decoración tan sólo por una cara. Siglo xv.

Expositor: Cabildo de la Catedral de Tarragona.

Núm. 211.-Cruz de hierro forjado. El Cristo con tres clavos y los pies separados. Procede de San Marín de

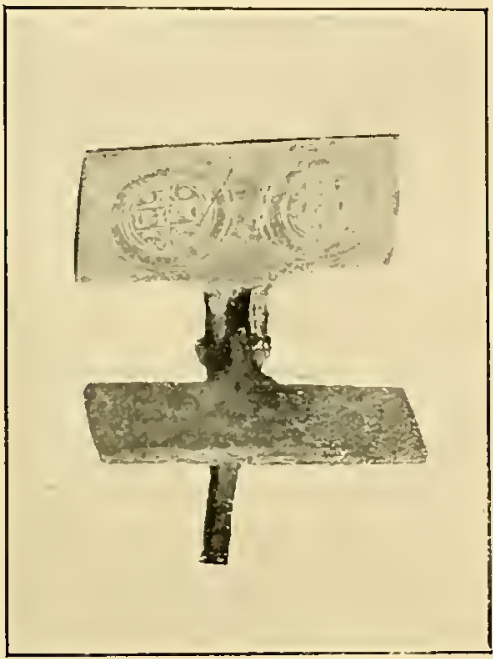

Nüm. 210.

Sarroca, en el Panadés. Epoca, siglo xIIl. Dimensiones: 27 centímetros por $205 \mathrm{~mm}$.

Es ejemplar en el que aparece por vez primera una figura de hierro trabajada toscamente a martillo, constituyendo el precedente de las composiciones complejas que en el siglo xIv y xv decoran las cruces procesionales $y$ de término.

ExPOSITOR: Junta de Museos de Barcelona.

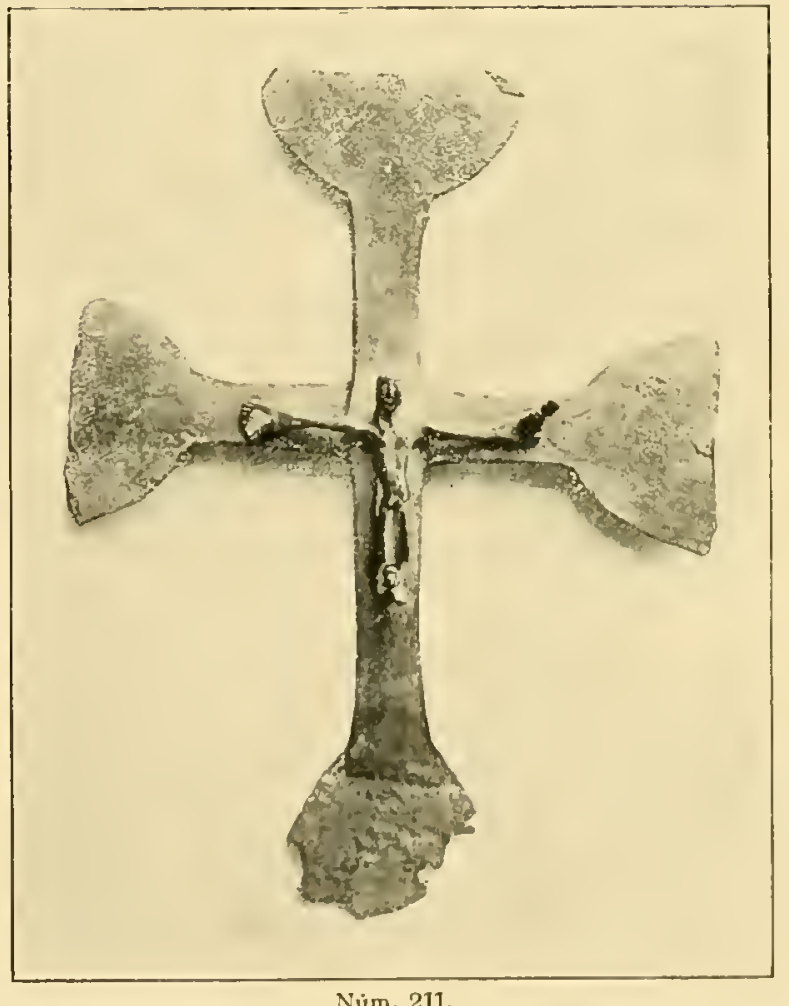

Nủm. 211.

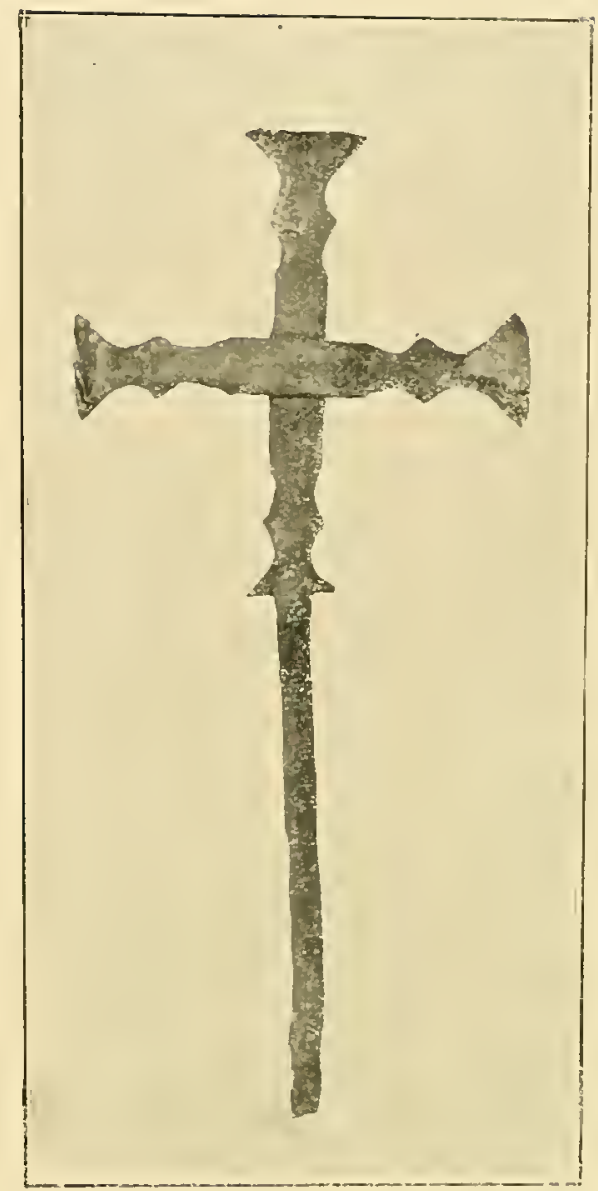

Nủm. 212.

Núm. 212. - Cruz formada por dos planchas de hierro recortadas, roblonadas en su centro. Perímetro lobulado, recordando el tipo precedente. Tiene $29,5 \mathrm{~cm}$. de alto por 27 centímetros de ancho.

Siglo xiv.

ExPOSITOR: Cabildo de la Catedral de Tarragona.

Núm. 213. - Cruz de linde con el Cristo 
en el anverso y la Virgen con Niño en el reverso. La posición del Niño en la figura de la Virgen hace suponer una época anterior a la correspondiente a detalles, como el sudario del Cristo y la plancha sobre la cual, en letras romanas, aparece el I. N. R. I.

Ejemplar muy interesante, cuyo conjunto puede corresponder a fines del siglo xiv. Procede del Caut Ferrat.

Altura, $52 \mathrm{~cm}$. por 42 de ancho.

Expositor: D. Santiago Rusiñol.

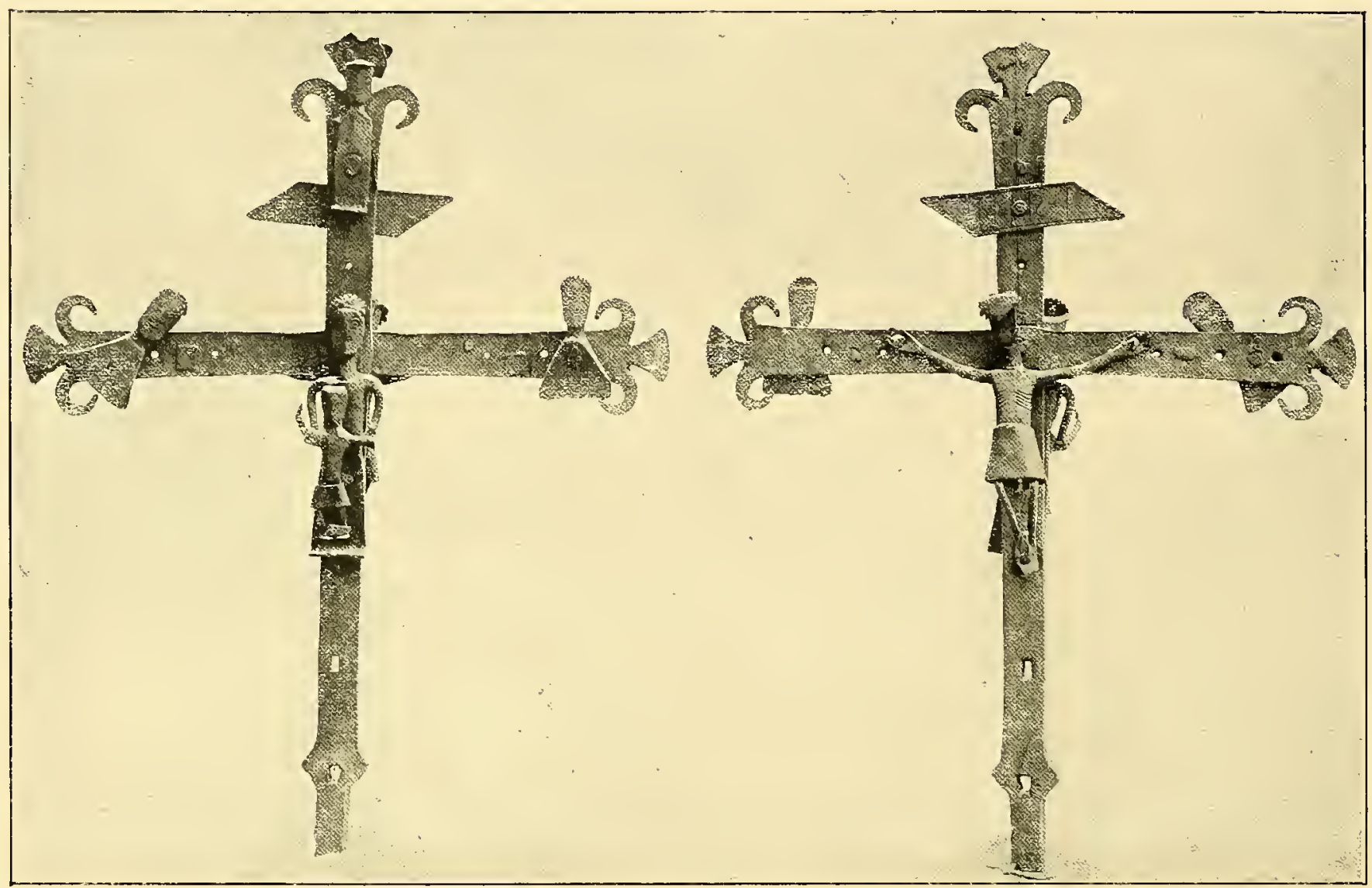

Núm. 213.

Núm. 214.-Cruz de linde con el Cristo en el anverso, la Virgen y el Niño en el reverso, figuras y atributos. El tipo de la Cruz principal es más arcaico que el precedente, pero el conjunto de la obra no puede ser clasificado como anterior a los finales del siglo xiv.

Procede del Cau Ferrat.

Expositor: D. Santiago Rusiñol.

Núm. 215. - Cruz de linde flordelisada con el Cristo en el anverso, la Virgen en el reverso y figuras y atributos, forjados y complementados con plancha recortada. Ejemplar análogo al precedente, pero más complejo y decorado.—Mide $84 \mathrm{~cm}$. de alto por 50 de ancho. Finales del siglo xiv o principios del xv.

Expositor: Junta de Museos de Barcelona. 
Núm. 216.-Cruz de cuatro brazos sensiblemente iguales, unidos sus extremos por una varilla cuadrada retorcida que a su vez se decora con rombos terminados en flores, cruces o figuras. Los brazos de la cruz se decoran por figuras y multitud de atributos que rellenan por completo toda la superficie. Algunos de los detalles de las figuras pudieran ha-
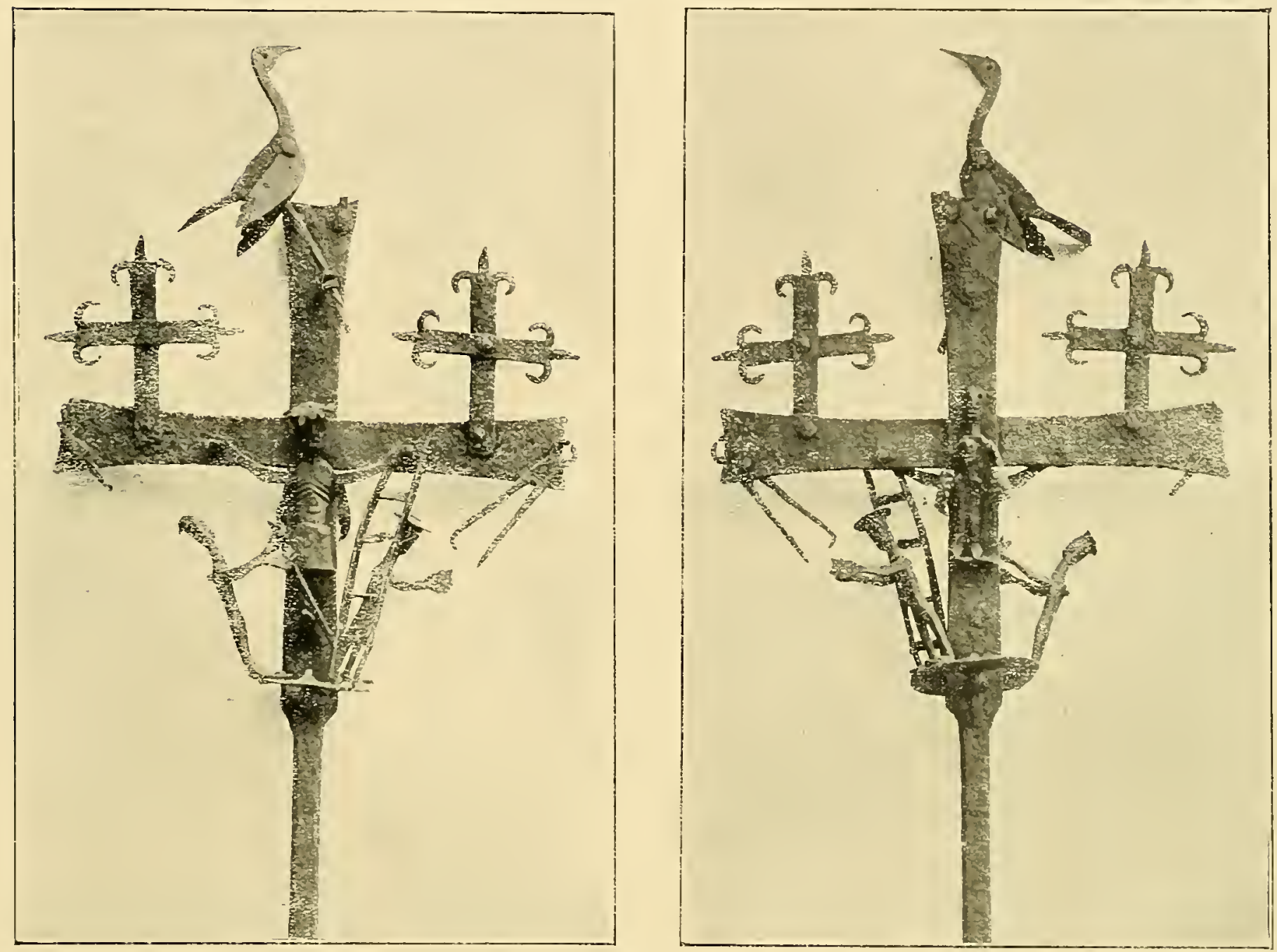

Nùm. 214.

cer pensar en trabajos del siglo xiII, peró.la varilla retorcida, la terminación de la Cruz en hojas de lámina recortada, da la impresión de una obra del siglo xv ya muy avanzado.

Procede del Caut Ferrat.

\section{Expositor: D. Santiago Rusiñol.}

Núm. 217. - Cruz de hierro forjado con el Cristo bajo el doselete gótico, remate flor delisado, escudo catalán y espiga de hierro retorcido.

Procede del Pueblo de San Miguel, colindante a la Cerdeña francesa y española.-Mide $2,25 \mathrm{~m}$. por $32 \mathrm{~cm}$.

Expositor: Junta de Museos de Barcelona. 
Núm. 218. -Dos candeleros románicos de $21 \mathrm{~cm}$. de altura, formados por una espiga terminada en punta y tres pies. Ejemplares interesantes por constituir el punto de partida de los candelabros góticos.

Proceden de la Catedral de Lérida. Epoca indeterminada, desde principios del siglo xı a mediados del xul.

\section{Expositon: Cabildo de la Catedial de Lérida.}

Núm. 219. - Dos candeleros de espiga cuadrada terminada en punta, tres pies sobre los cuales descansa un platillo circular de plancha con el borde festoneado; sobre el vástago cuadrado se aprecian sencillas labores geométricas incisas.

Proceden de la Catedral de Lérida. Pueden pertenecer a la primera mitad del siglo xıı.

Expositor: Cabildo de la Catedral de Lérida.

Núm. 220.-Candelero románico de $44 \mathrm{~cm}$. de alto y 30 por $26 \mathrm{~cm}$. en el plato. Vástago de sección poligonal con el nudo central característico con sus vértices achaflanados;
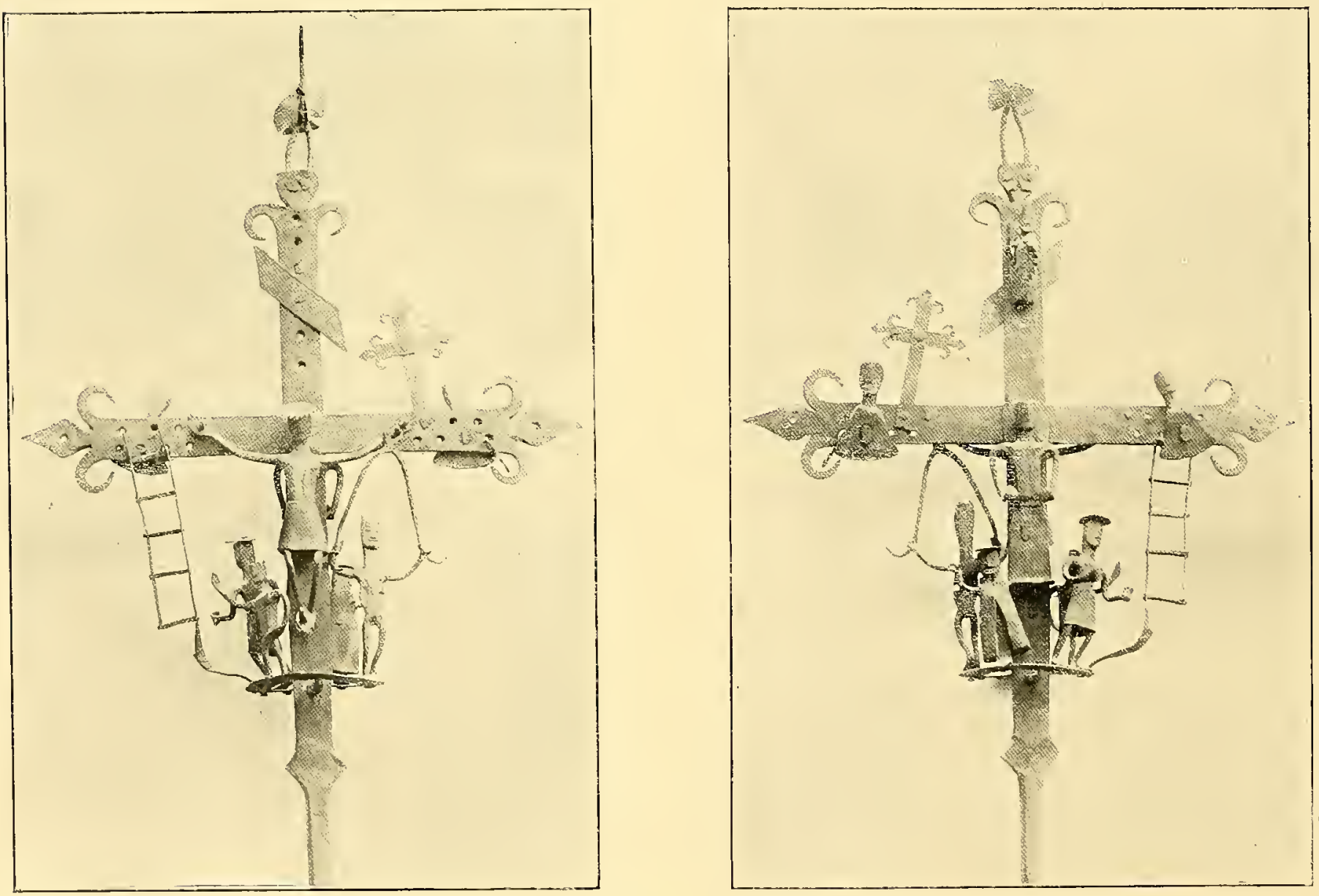


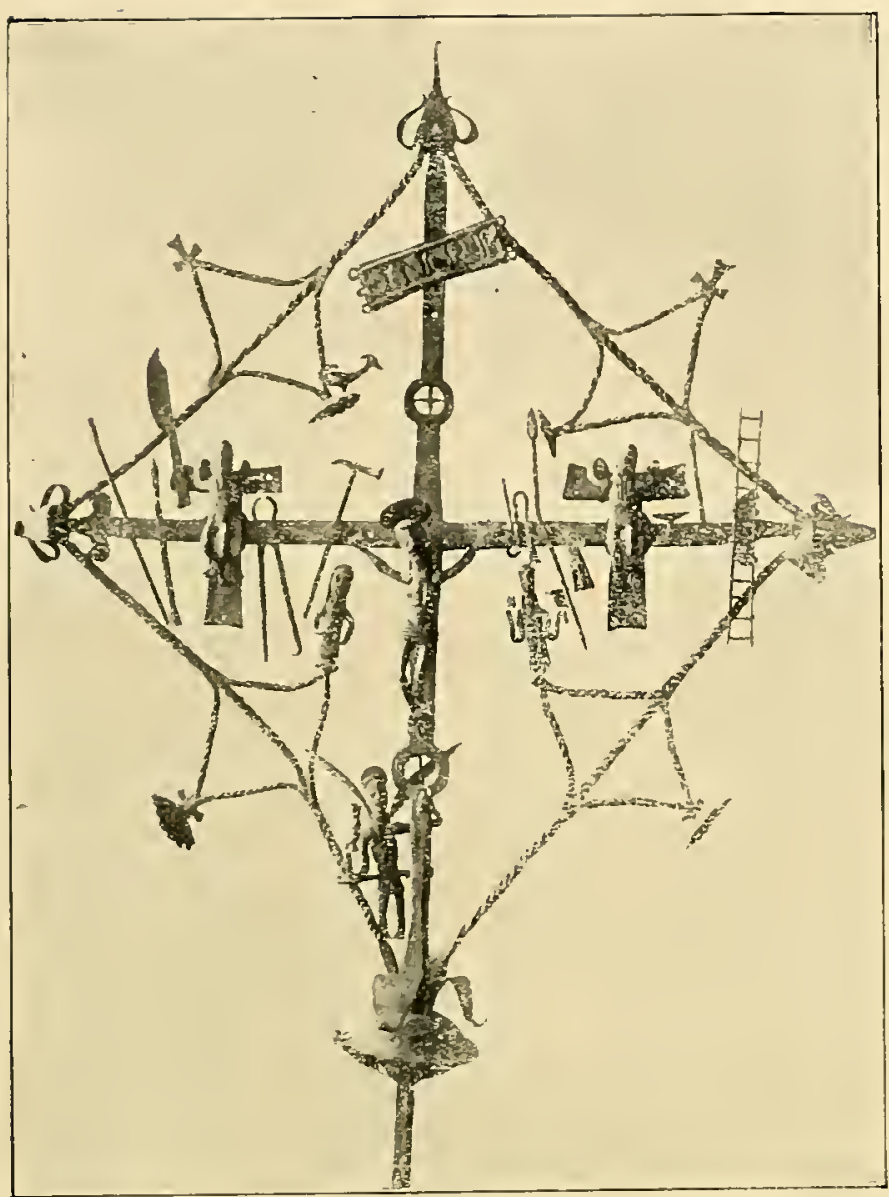

Nủm. 216.

el plato, de plancha y rectangular con los bordes doblados y los ángulos en pico. Es interesante y determinativo el apoyo sobre tres pies. Epoca de transición del románico al gótico. Finales del siglo xill a principios del xıv.

Expositor: Junta de Museos de Barcelona.

Núm. 221. - Candelero de plato circular. Altura $40 \mathrm{~cm}$. El vástago de varilla retorcida terminado en punta; nudo central cúbico con los vértices achaflanados; apoyo sobre tres pies. Procedencia desconocida. Finales del siglo xiv.

\section{Expositor: D. Juan Lafora.}

Núm. 222.-Candelero de plato circular de $53 \mathrm{~cm}$. de altura, varilla retorcida terminando en pincho; apoyo sobre tres pies; una corona de

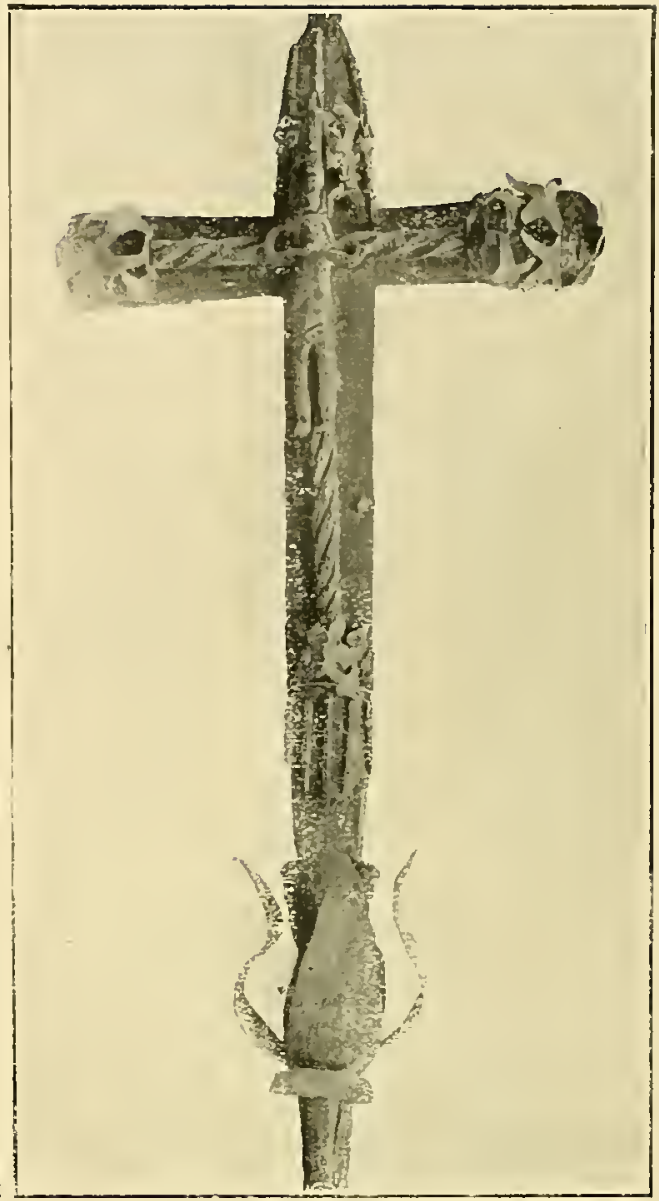

Núm, 217.

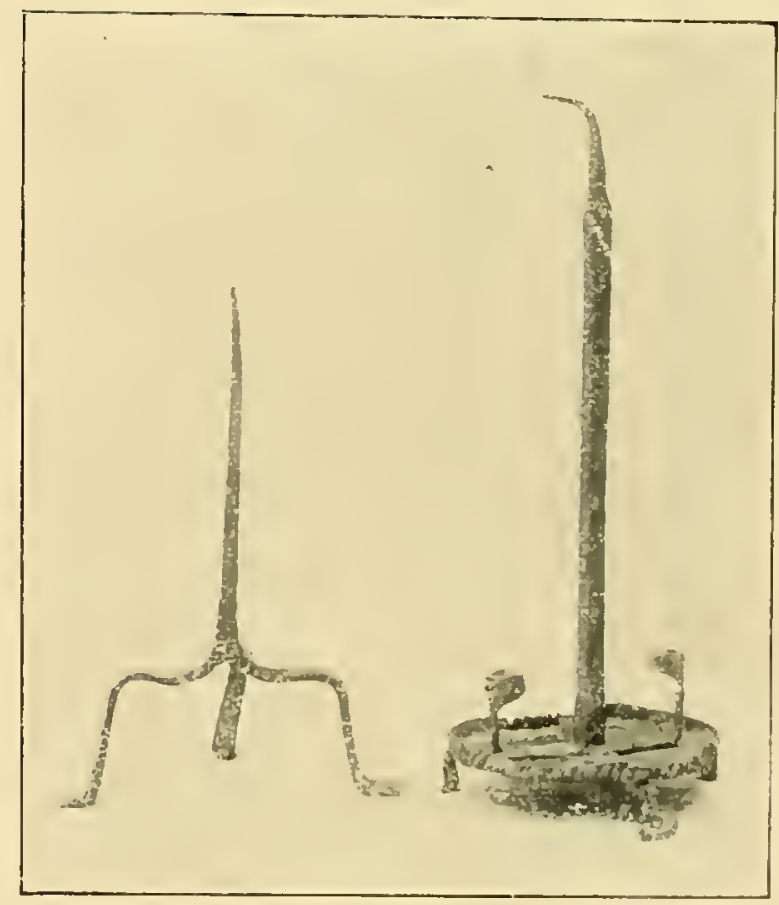

Núns. 218 y 219. 


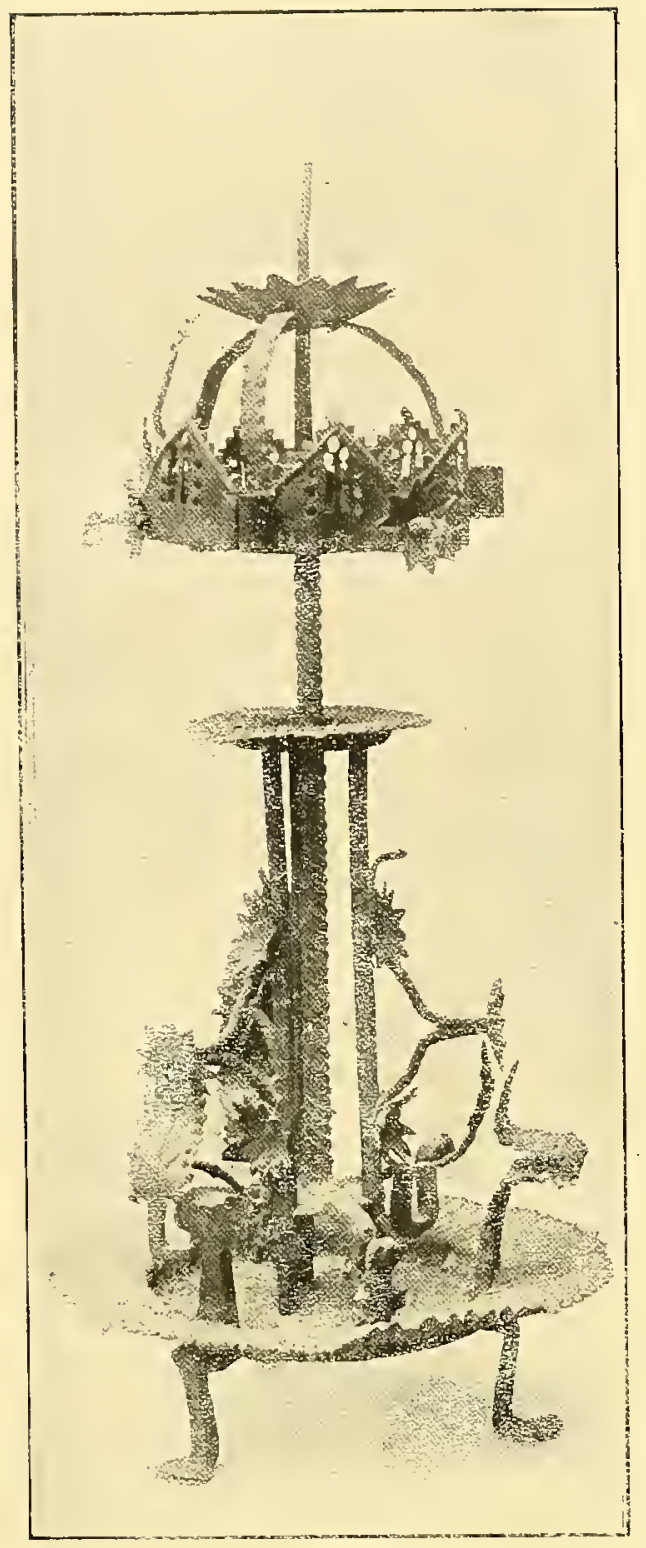

Nưm. 222.

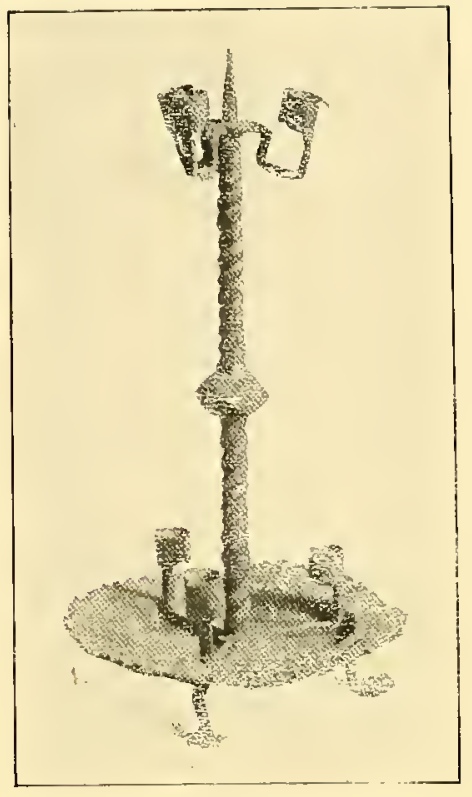

Nủm. 221.

plancha calada con adornos también de plancha, pende de la terminación del vástago por medio de tres arcos; una pequeña arandela o platillo en la mitad de la longitud del vástago y puramente ornamental viene sostenido por tres ejes auxiliares que parten del plato principal decorados con plancha recortada y varilla retorcida. Ejemplar de un interés excepcional y del siglo $x v$.

Expositor: Junta de Museos de Barcelona.

Núm, 223.-Candelero gótico de $35 \mathrm{~cm}$. de altura; de varilla retorcida, terminado en pincho y apoyado en trípode de varilla cuadrada colocada en arista, arriostradas en su base por arcos y rectas. Procedencia desconocida. Principios del siglo xv.

Expositor: D. José A. Weissberger.

Núm. 224.-Candeleros de 54 y $43 \mathrm{~cm}$. de altura, de varilla cuadrada retorcida con adornos en voluta for-

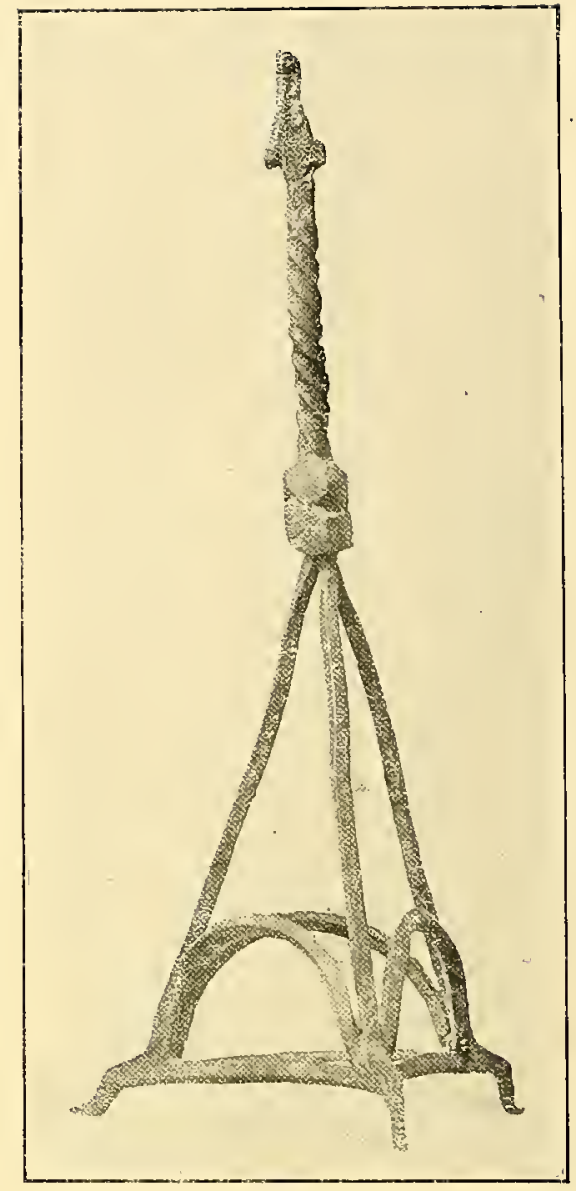

Núm. 223.

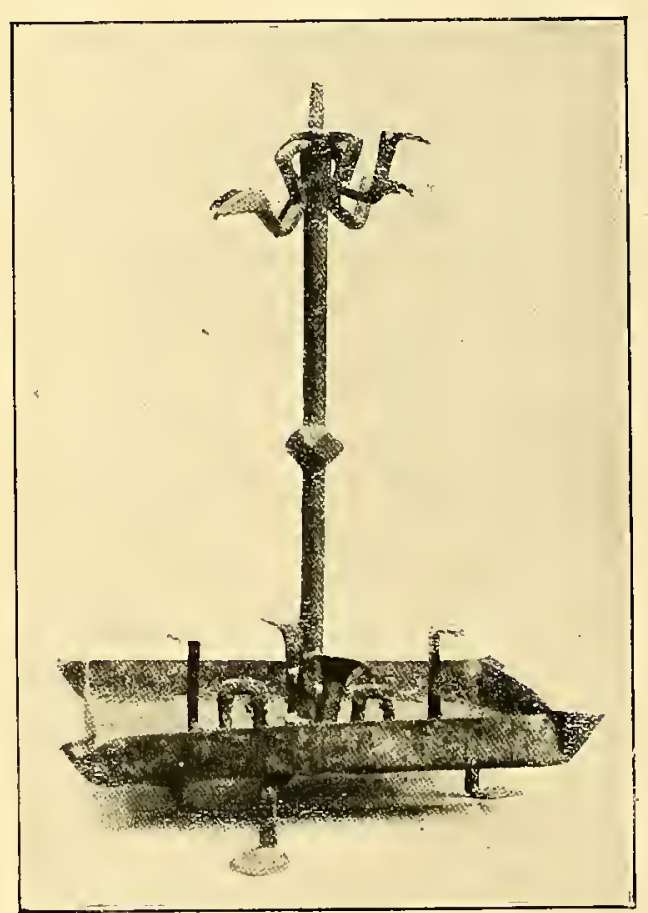

Nủm. 220 , 
madas en cada nudo por dos planchas cortadas y torcidas. Pie triangular trilobulado, terminación en tubo.

Proceden de la provincia de Toledo. Principios del siglo xv.

Expositor: Excmo. Sr. Conde de Cedillo.

Núm. 225. - Candelabro gótico de 1,77 m. de altura, formado por una varilla circular
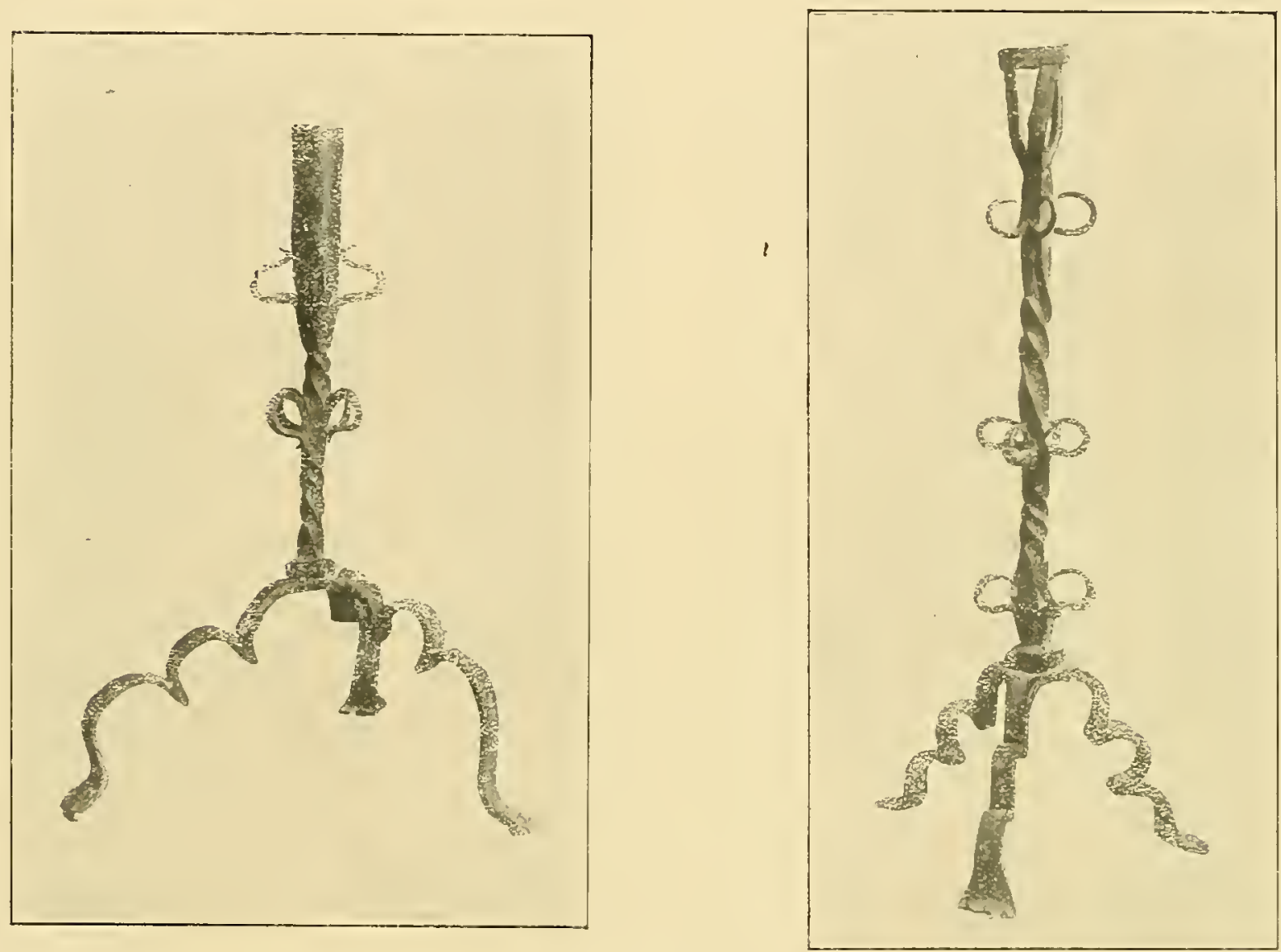

Nưm. 224.

con seis nudos, terminado en pincho; pie de tres varillas en arco, acusándose muy débilmente el nudo central; de la base y correspondiendo a los espacios del soporte arrancan tres vástagos de unos $65 \mathrm{~cm}$., casi paralelos al principal y terminados en pincho, naciendo, unidas por forja en el nudo, cuatro hojas que completan una flor; análogamente, en el vástago principal parten del último nudo cuatro hojas, entre las cuales caen en arco cuatro varillas que sostienen un capullo. Ejemplar del siglo xiv y de un interés extraordinario.

\section{Expositor: Junta de Museos de Barcelona.}

Núm. 226.-Candelabro gótico de 1,57 m. de alto, terminado en pincho; formado por un vástago principal a que vienen unidas por soldadura cuatro varillas accesorias. En la base, terminación y centro, aparecen unos casquetes estéricos, haciendo el oficio de aran- 
delas, por debajo del cual se desarrollan para continuar verticales en toda la longitud del tramo las cuatro varillas complementarias, que se decoran con plancha recortada formando lirios.

Procede de la Iglesia de Urg, en la Cerdeña. Siglo xiv.

Expositor: Junta de Museos de Barcelona.

Núm. 227. - Candelero gótico de 1,17 m. de altura; formado por un vástago terminado

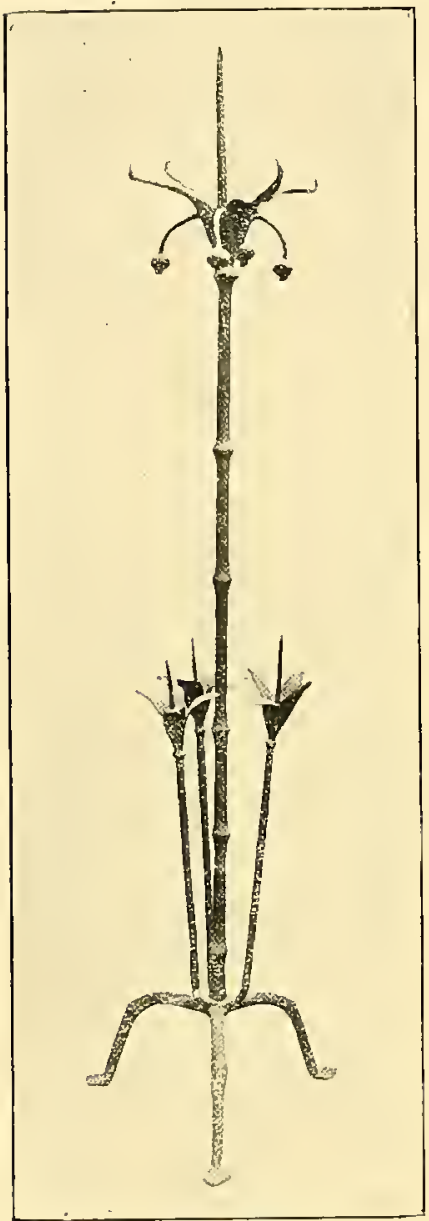

Núm. 225.

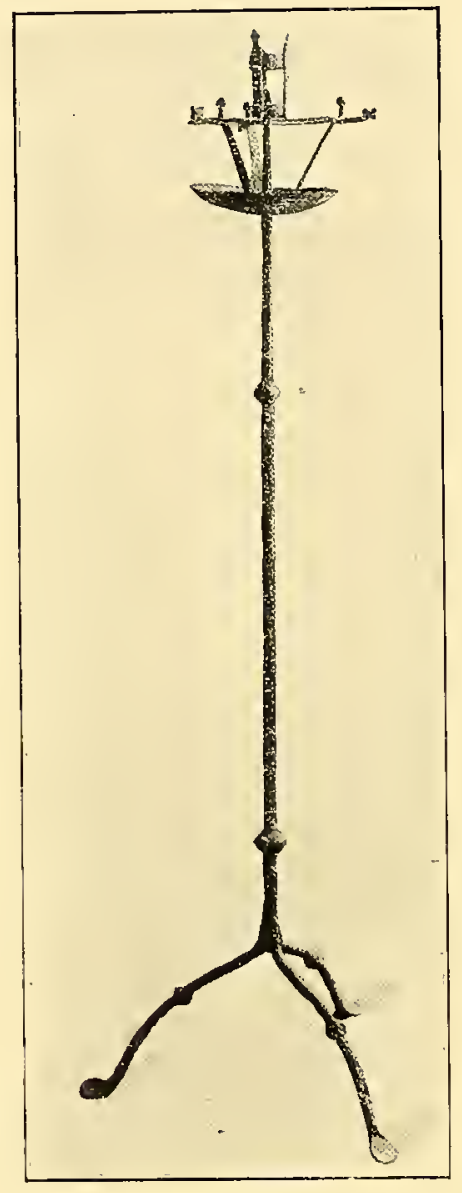

Nưm. 227.

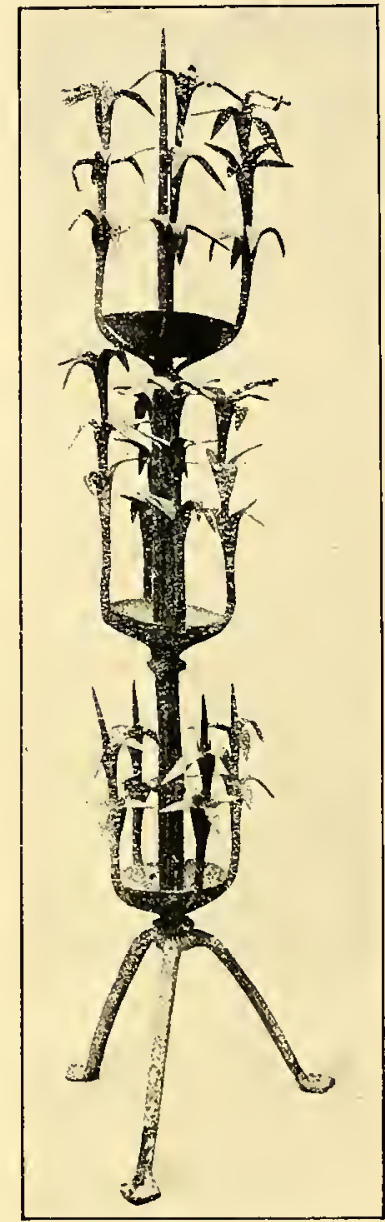

Núm. 226.

en pincho, sostenido por tres pies en arco con nudo central; el vástago con dos nudos, arandela de casquete esférico y sobre ella una segunda arandela en anillo festoneado, sostenido por tres brazos recortados en plancha y doblados en pirámide invertida. El anillo, a su vez, sostiene el tubo formado por tres generatrices y dos aros. Siglo xiv.

Expositor: D. Alberto Salzedo.

Núm. 228.-Pequeño candil árabe, sostenido por una palomilla, también de hierro. Siglo xiv.

Expositor: Museo del Instituto, de Huelva. 
Núm. 229. - Llar de chimenea, para colgar calderos u otros utensilios sobre las llamas del hogar. Rectángulo de vértices redondeados, decorado exteriormente por volutas e interiormente por sinusoides.

Altura $43 \mathrm{~cm}$., ancho $16 \mathrm{cen-}$ tímetros. Finales del siglo xiv.

Expositor: D. Juan Lafora.

Núm. 230. - Llar de chimenea con flameros en los vértices superiores y barras de sección cuadrada terminadas en cabeza de dragón. Siglo xv.

Expositor: D. Juan Lafora.

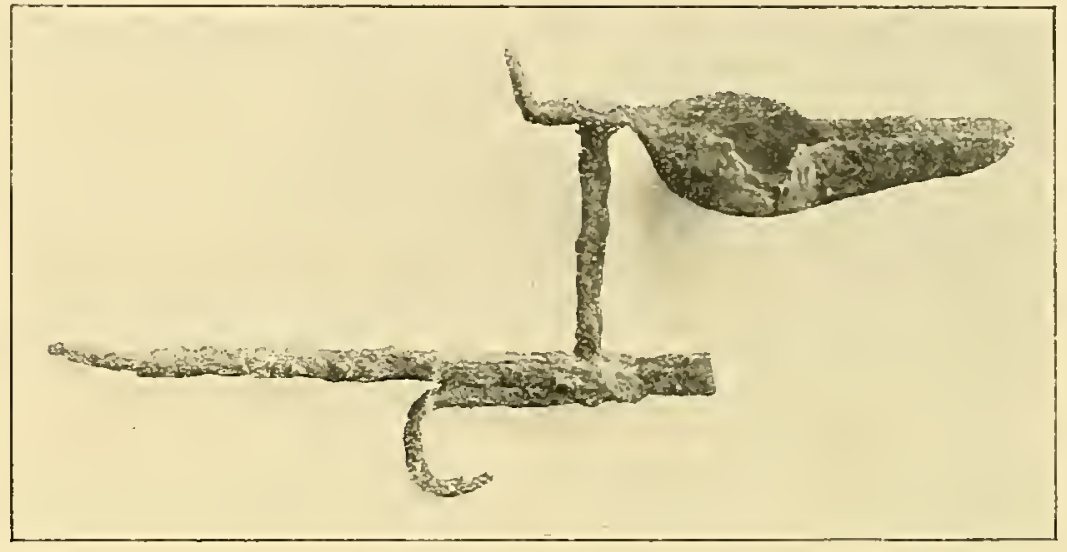

Nüm. 228.

Núm. 231.-Pequeño cepillo de carpintero, todo él en hierro. Epoca indeterminada, seguramente medioeval. En los descubrimientos de Sierra Elvira (Granada) se ha encontrado un ejemplar que difiere muy

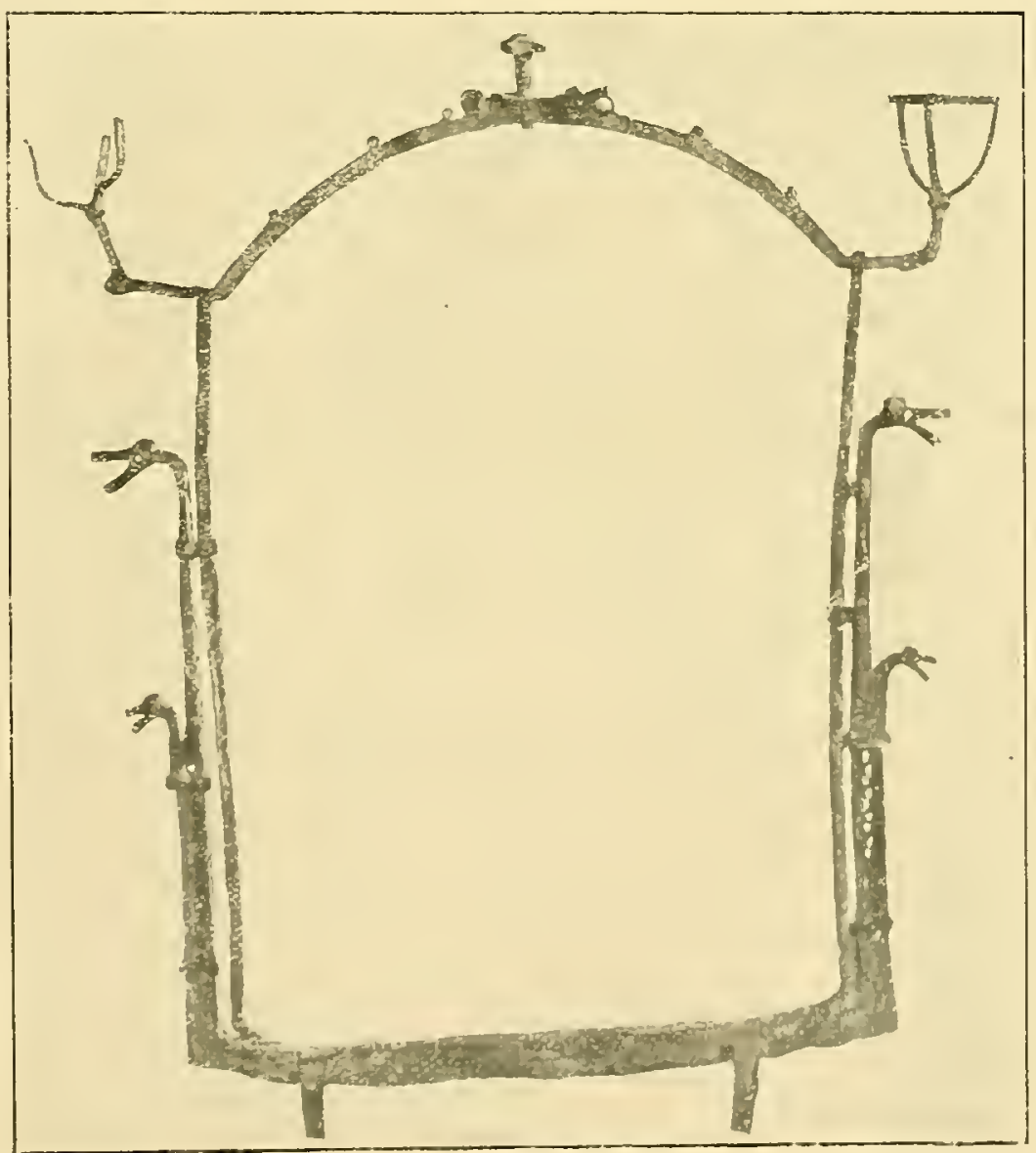

Núm. 230. poco del presente.

Expositor: D. Benito Mur.

Núm. 232.--Cerrojo de ba-

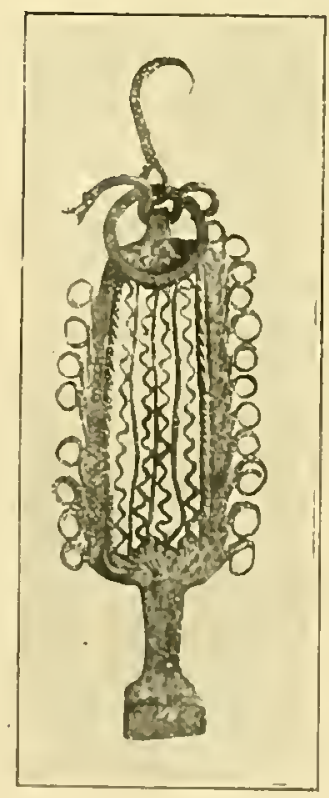

Nún. 220. 


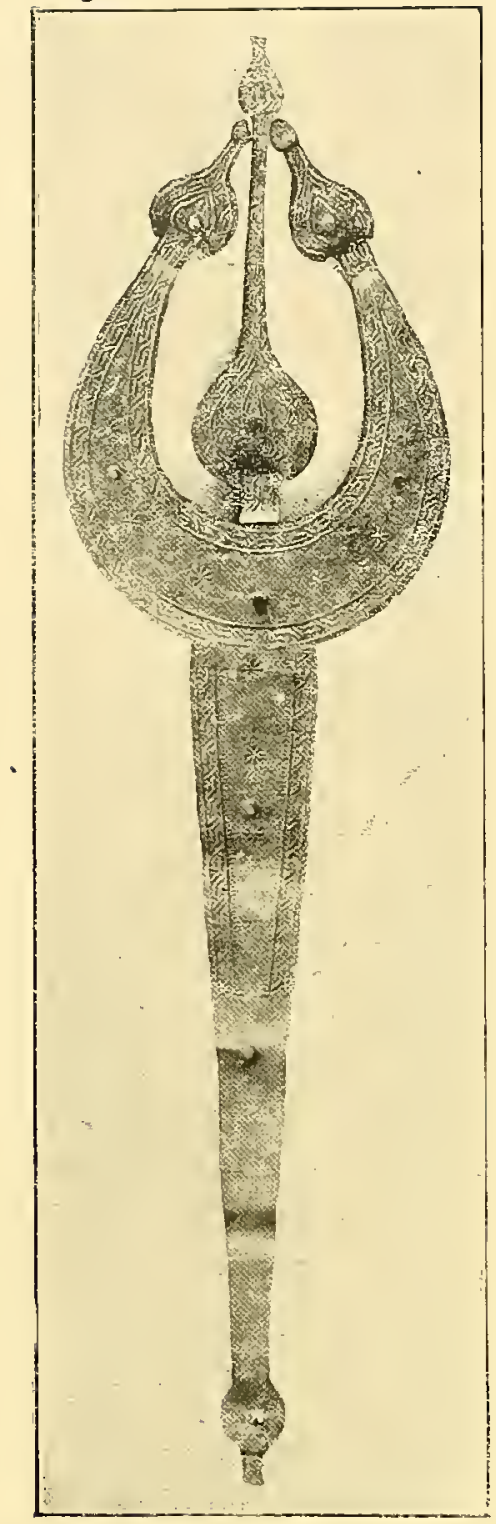

Nứm. 234.

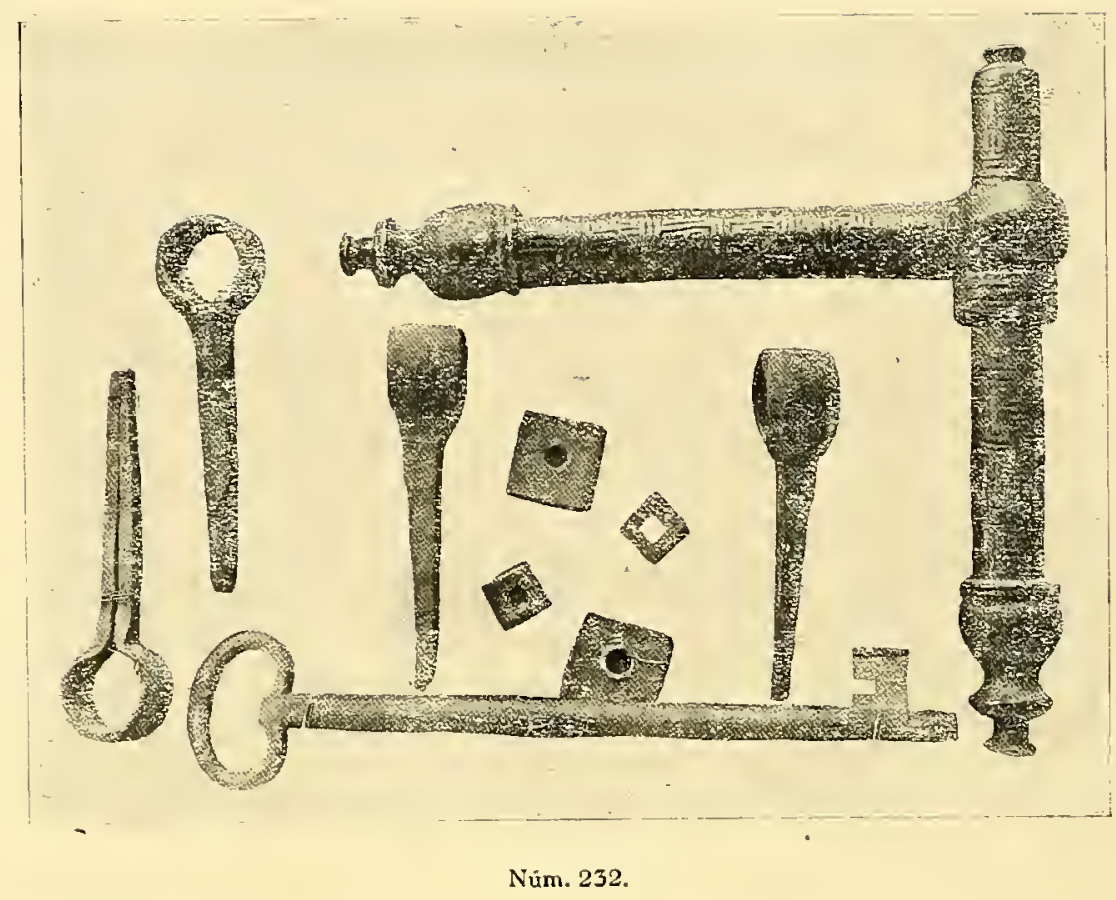

rras cilíndricas con sus anillos y llaves. Decoración rectilínea incisa. Siglo xIv.

Expositora: Excelentísima Sra. Marquesa Viuda de Medina.

Núm. 233. - Alguaza árabe, formada de dos piezas de gruesa plancha con cenefa incisa. Las extremidades en perímetro lanceolado recordando las composiciones persas. Ejemplar del siglo xIv.

Expositor: D. Antonio Vives.

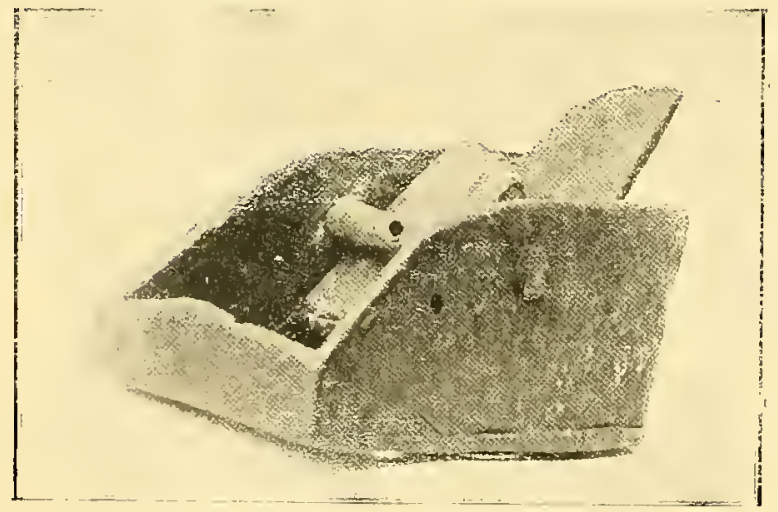

Núm. 231.

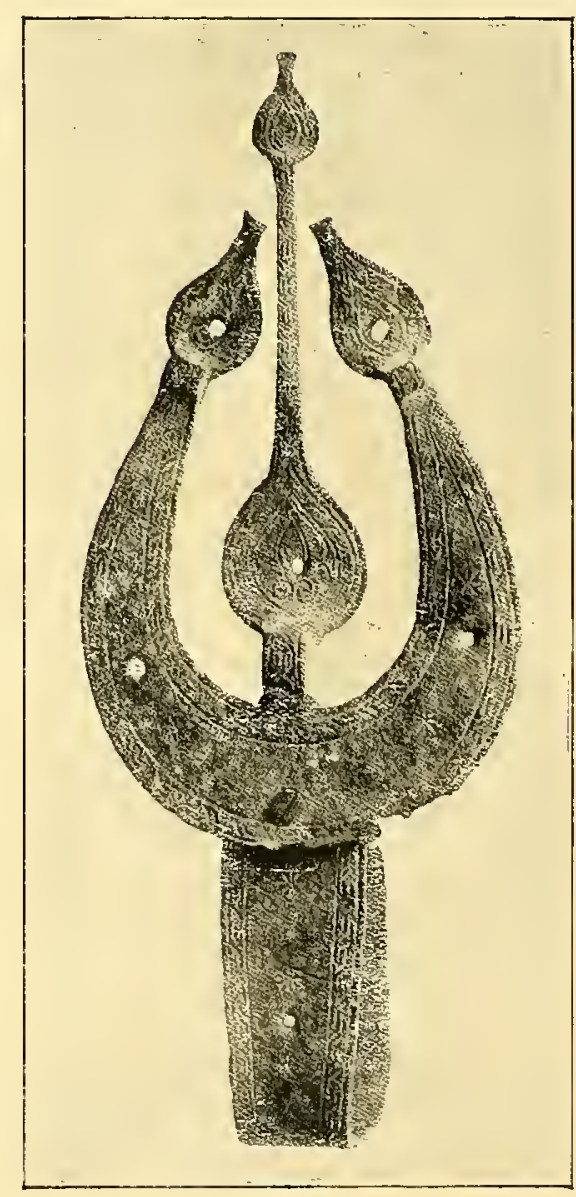

Núm. 233. 
Núm. 234. - Alguaza árabe casi igual a la precedente, pero con la abrazadera rectificada. Siglo xiv.

Expositor: Museo Arqueológico Nacional.

Núm. 235.-Dos grapones de puerta del siglo xv. Estilo mudejar. Trabajo en forja muy elemental, y decoración incisa característica del tipo. El conjunto recuerda perfectamente las alguazas árabes de los números anteriores.

Proceden de la provincia de Segovia.

Exposiror: D. Domingo Guerrero, de San Sebastián.

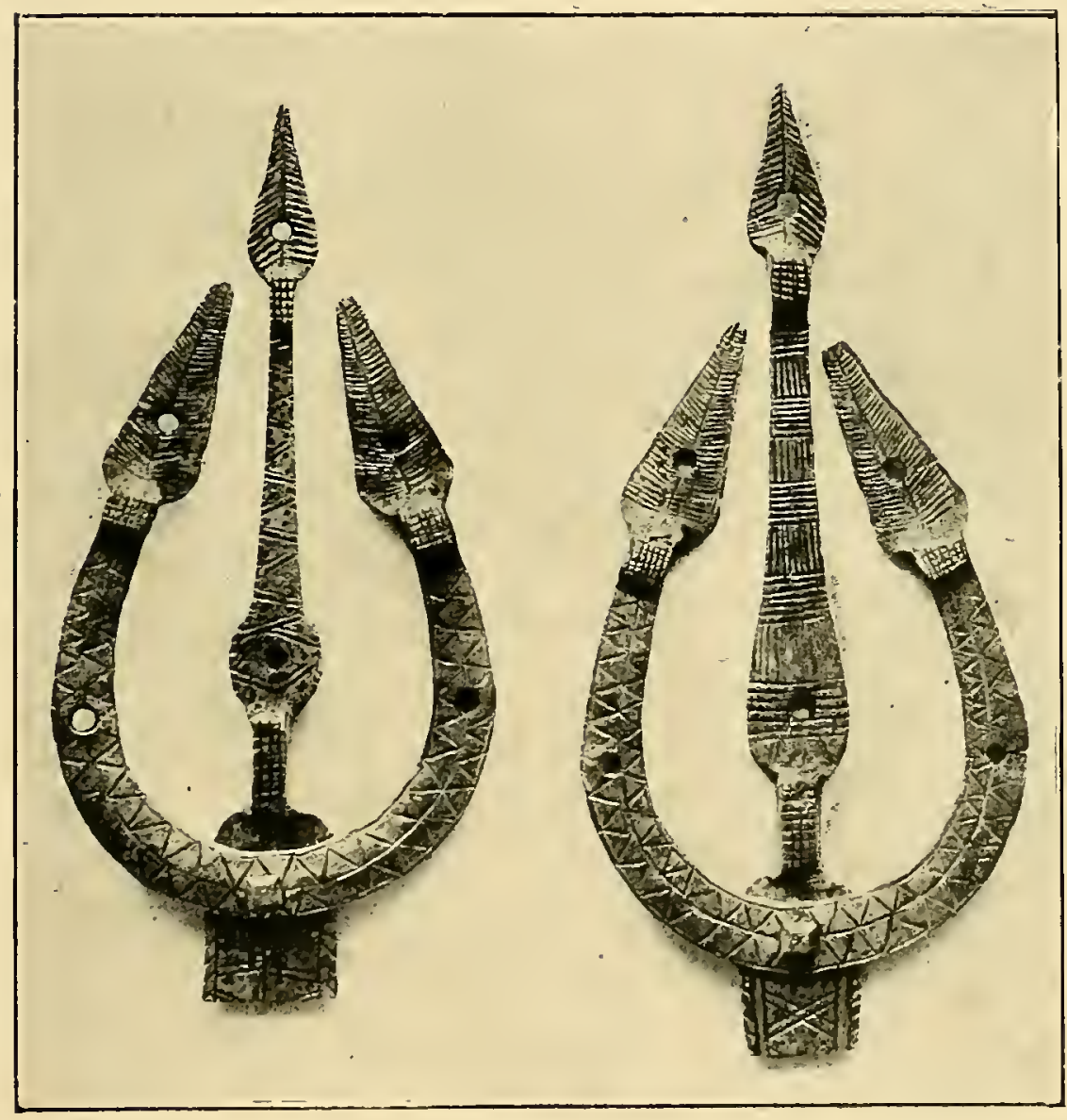

Nưm. 235

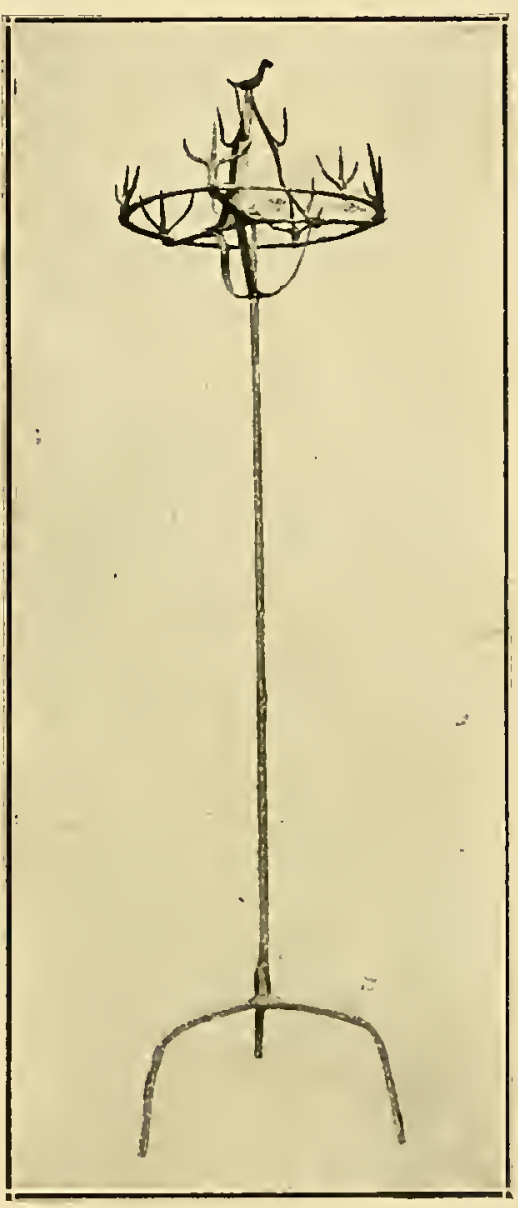

Nủm. 236.

Núm. 236.-Candelabro de 1,60 m. de alto; formado por un vástago sobre pie en tres varillas arqueadas. Sostiene un aro que soporta tres pinchos que recuerdan una flor. Sobre las tres varillas que lo unen al vástago, se halla una pirámide también con pinchos, rematada en un pájaro. Siglo xiv.

Expositor: D. Rafael García Palencia. 
Núm. 237.-Candelabro gótico, de $1,44 \mathrm{~m}$. de alto, formado por un vástago fino que termina en tres varillas retorcidas y arqueadas, sosteniendo los tubos. El pie, que es lo más interesante del ejemplar, está formado por tres elementos en pirámide, que en su base vienen arriostrados en arco. Cada una de estas líneas o ejes está formada por dos finas varillas retorcidas, entre las cuales se desarrolla en sinusoide una tercera. El pie y el vástago pertenecen a los finales del siglo xiv.

Expositor: D. Juan Lafora.

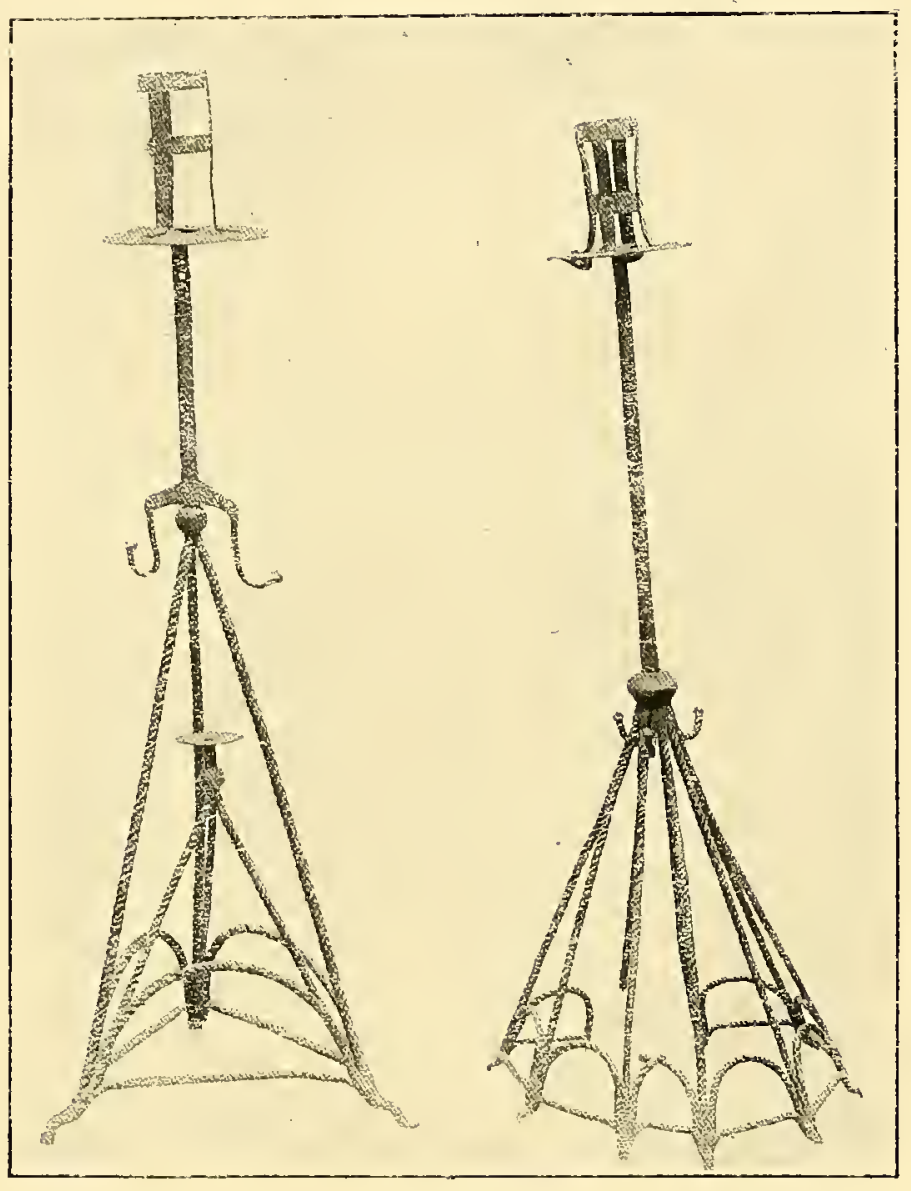

Nürs. 238 y 239.

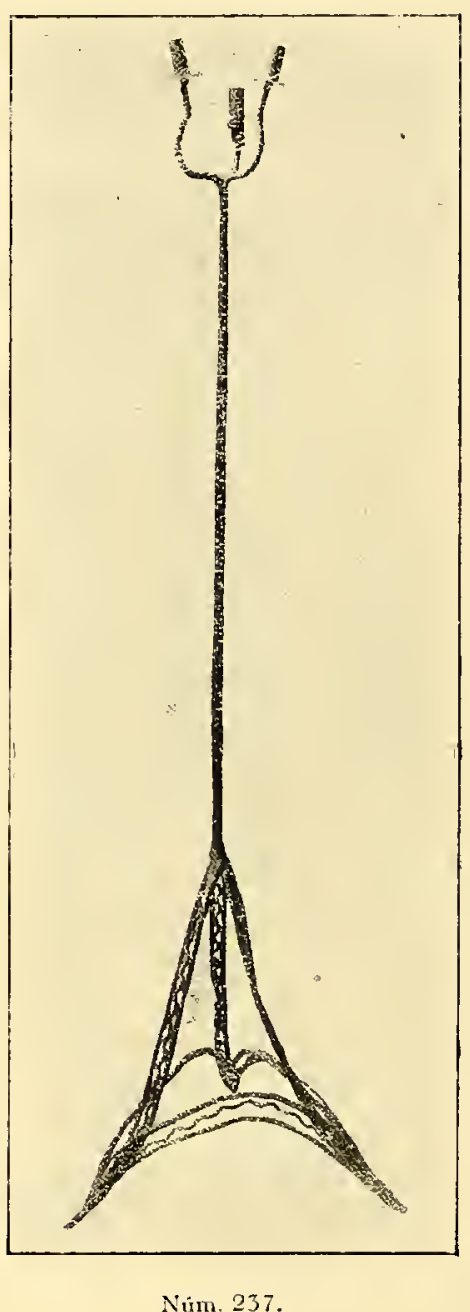

Nún. 237.

Núm. 238.-- Candelabro de 1,29 m. de altura; arandela circular plana, que sostiene el tubo de tres generatrices y dos aros; pie en pirámide triangular de varilla retorcida, arriostrada en su base por rectas y arcos, presentando en su interior otra pirámide triangular análoga. Vástago de sección rectangular. Dos varillas en arco, a modo de colgadores, en la base del vástago. Estilo de finales del siglo xiv.

Procede de Cau Ferrat.

Expositor: D. Sanílago Rusiñol. 


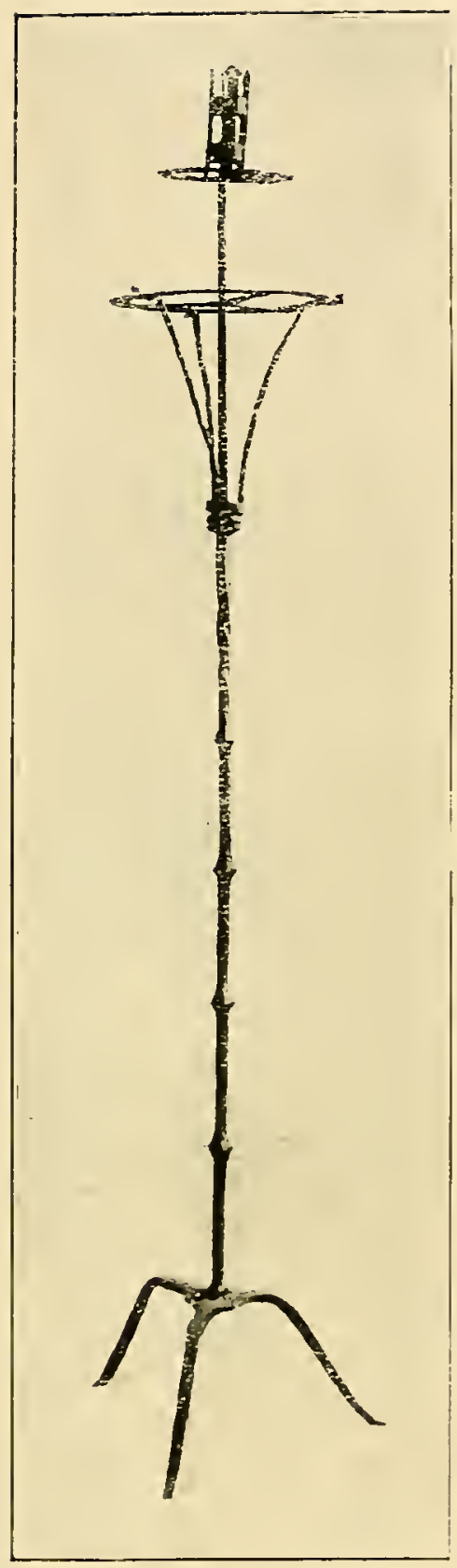

Núm. 240.

Núm. 239. - Candelabro de $1,24 \mathrm{~m}$. de alto; pie cónico, de generatrices en varilla retorcida arriostradas 'en recto y en arco; vástago de sección poligonal. Tipo análogo al anterior. Tipo y escuelas análogos al anterior.

Procede de Cau Ferrat.

Expositor:D. Santiago Rusiñol.

Núm. 240. - Candelabro de $1,78 \mathrm{~m}$. de alto y tipo análogo al anterior; el vástago central es de varilla cuadrada con nudos y tiene su terminación ligeramente retorcida como las varillas que sostienen el primer anillo festoneado. Finales del siglo xiv.

Expositor: D. Alberto Salzedo.

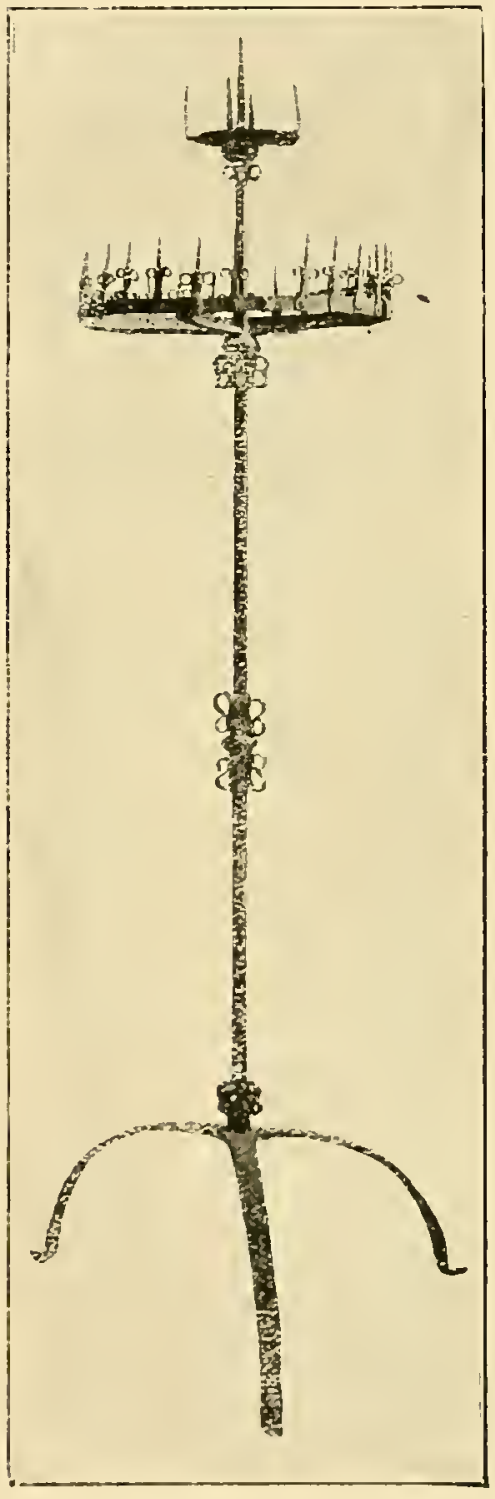

Nửn. 241.

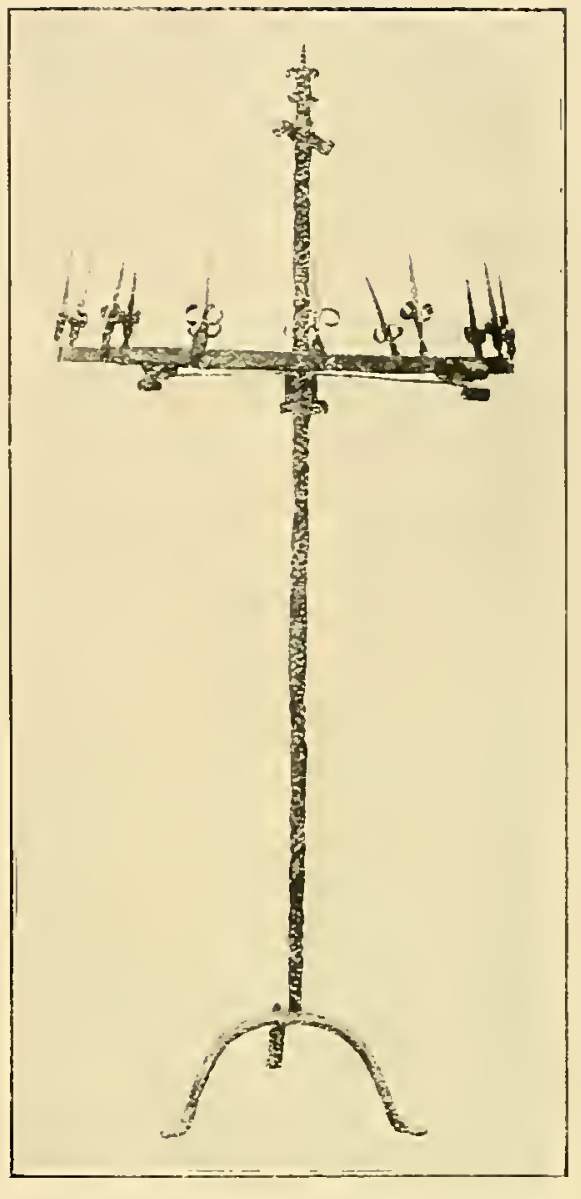

Núm. 242.

Núm. 241. - Candelabro de $1,80 \mathrm{~m}$. de alto, formado por un vástago de sección cuadrada, con nudo central decorado por plancha retorcida. Apoyo por tres pies en arco, y el vástago que termina en pincho sostiene una arandela circular con otros cuatro. Un anillo de $45 \mathrm{~cm}$. de diámetro sostiene por remache unas planchas cortadas en tres partes, siendo la central en pincho y revolviendo en volutas las laterales, completando una flor de lis. La corona de luces pertenece a los finales del siglo xiv.

Expositora: Excma. Señora Marquesa de Bermejillo del Rey. 
Núm. 242.-Candelabro para corona de luz. Altura 1,73 m. Vástago de varilla cuadrada intermitentemente retorcida. Corona de luz de $70 \mathrm{~cm}$. de diámetro. Escuela idéntica al anterior.

\section{Expositora: Excma. Sra. Marquesa de Bermejillo del Rey.}

Núm. 243.-Dos candelabros iguales, de 1,74 m. alto. Vástago poligonal, con anillo en el centro; debieron terminar en pincho. Tres varillas retorcidas sostienen la arandela en casquete esférico, sobre la que se apoya el tubo. Apoyo sobre tres varillas poligonales en arco. El vástago y el apoyo pertenecen al primer tercio del siglo xiv.

Expositora: Excma. Sra. Duquesa de Parcent.

Núm. 244. - Candelabro de $1,50 \mathrm{~m}$. de alto. Vástago poligonal con nudo central. Apoyo sobre tres pies cuadrados. Debió terminar en pincho correspondiendo esta parte al siglo xiv. Posteriormente en el siglo xv se

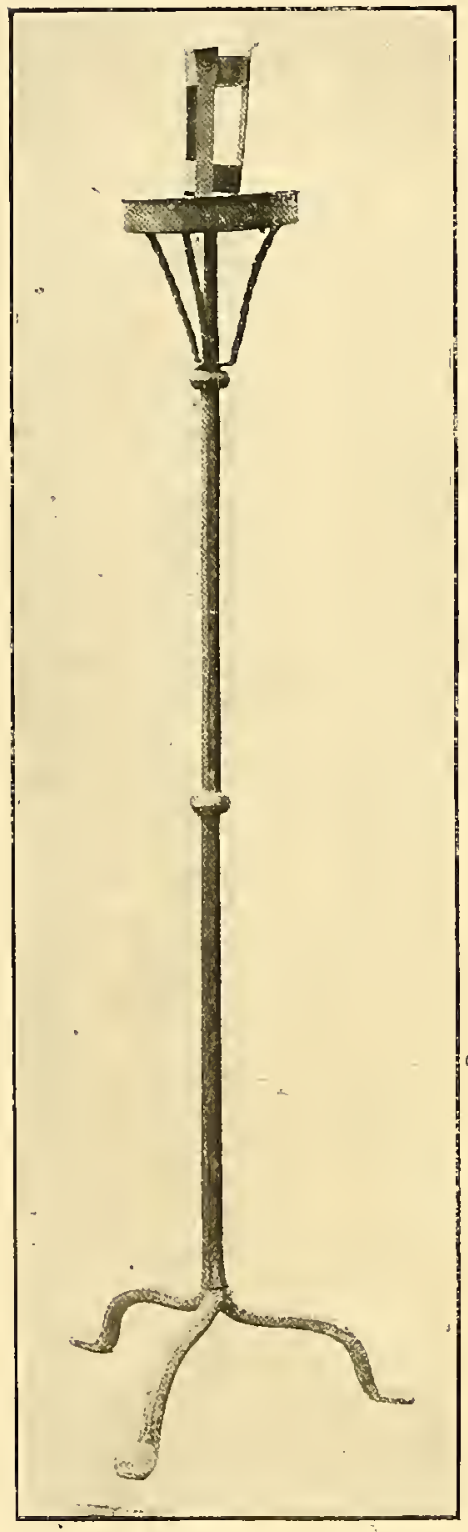

Nóm. 243. le añade una doble arandela almenada de hierro festoneado, unida al vástago por tres hierros dobles soldados en pincho. Siglos xiv y xv.

Expositor: Seminario Conciliar de Lérida.

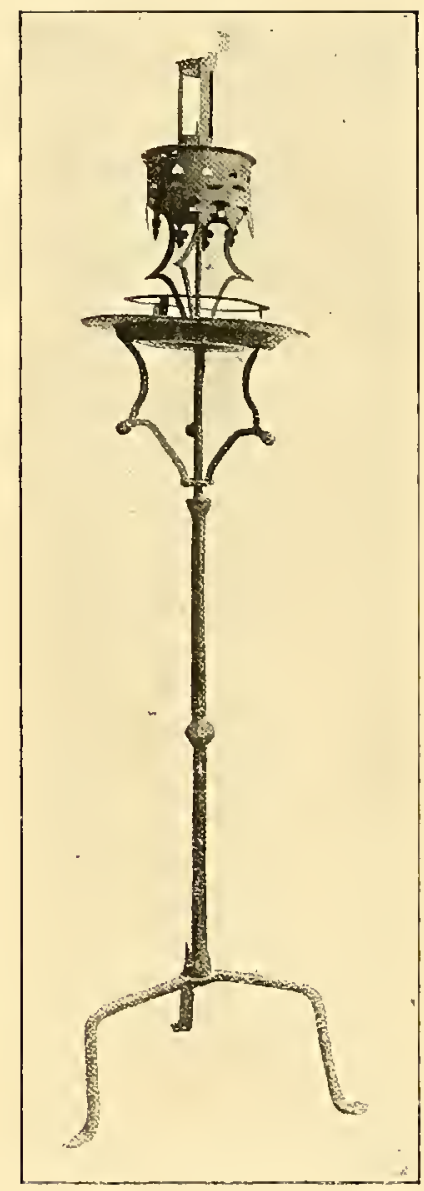

Núm. 245.

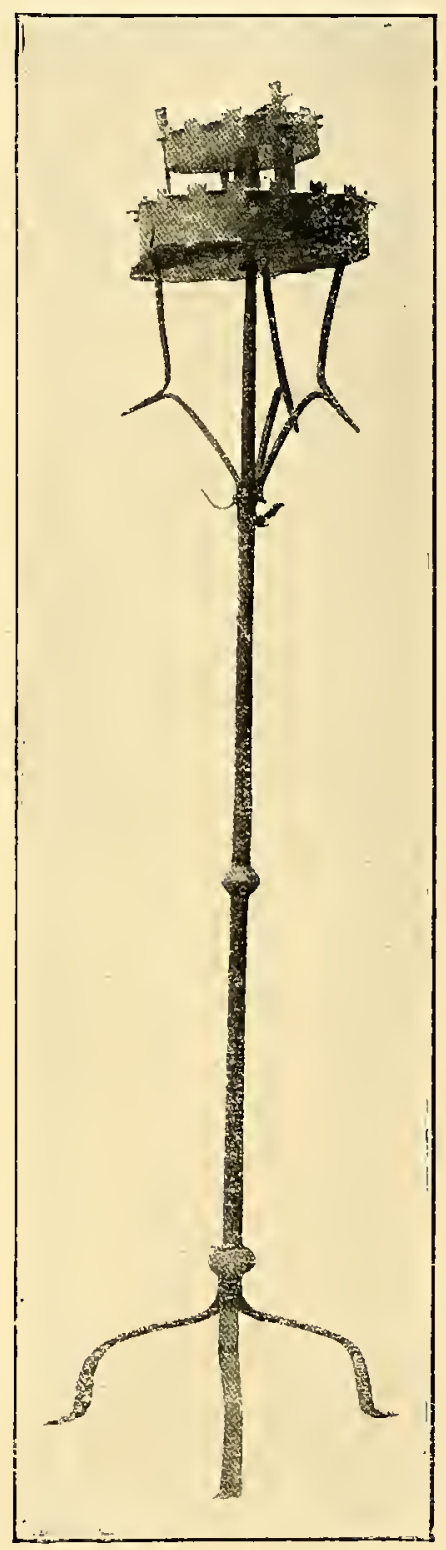

Núm. 244. 


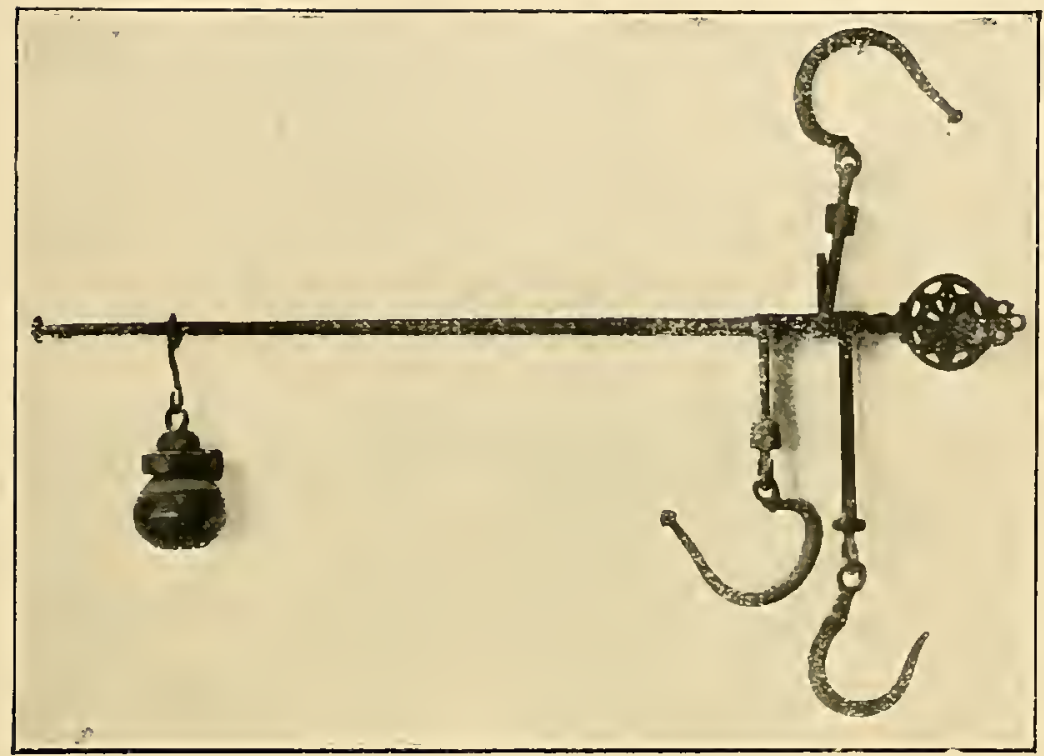

Nüm. 246. varilla terminado en disco, trabajado con motivos góticos, en igual forma que las llaves de finales del siglo xiv a principios del xv.

\section{Expositor: Junta de Museos de Barcelona.}

Núm. 247.- Chapa de fondo de chimenea con crestería de lirios. Tiene $76 \mathrm{~cm}$. de longitud por $90 \mathrm{~cm}$. de anchura. Escuela castellana. Siglo xv.

\section{Expositor: Junta de Museos de Barcelona.}

Núm. 248.-Dos candiles góticos. Son de plancha perforada, con decoración de pináculos góticos y varilla retorcida. El conjunto es un cilindro vertical incompleto, abierto por una generatriz como una puerta de dos hojas. Sobre una plancha colocada casi en el fondo aparece el candil.

Proceden de la Catedral de Zamora.-Longitud $47 \mathrm{~cm}$.

\section{Expositor: Sr. Fabriciano.}

Núm. 249.-Llamador gótico de anillo, de $16 \mathrm{~cm}$. de diámetro máximo sobre plancha toscamente recortada, con dos vértices achaflanados, sujeto con anillo de plancha. Puede pertenecer a la segunda mitad del siglo xv.

Expositor: Excmo. Sr. Marqués de la Torrecilla.

Núm. 245. - Candelabros de $1,85 \mathrm{~m}$. de alto, formados por vástago poligonal con nudo y pie triangular. Debieron pertenecer a candelabros del siglo xiv. Posteriormente en el siglo xvı se les añade una doble arandela, formada la mayor por platos de bronce agallonados y la superior decorada por una corona invertida de plancha recortada. Siglos xIv y xv.

Expositor: Excmo. Sr. Conde de Cedillo.

Núm. 246.-Romana pequeña de barra cuadrangular, anillo decorado por incisiones y el extremo de la

$$
\text { goticos, en igual forma que las llaves de }
$$




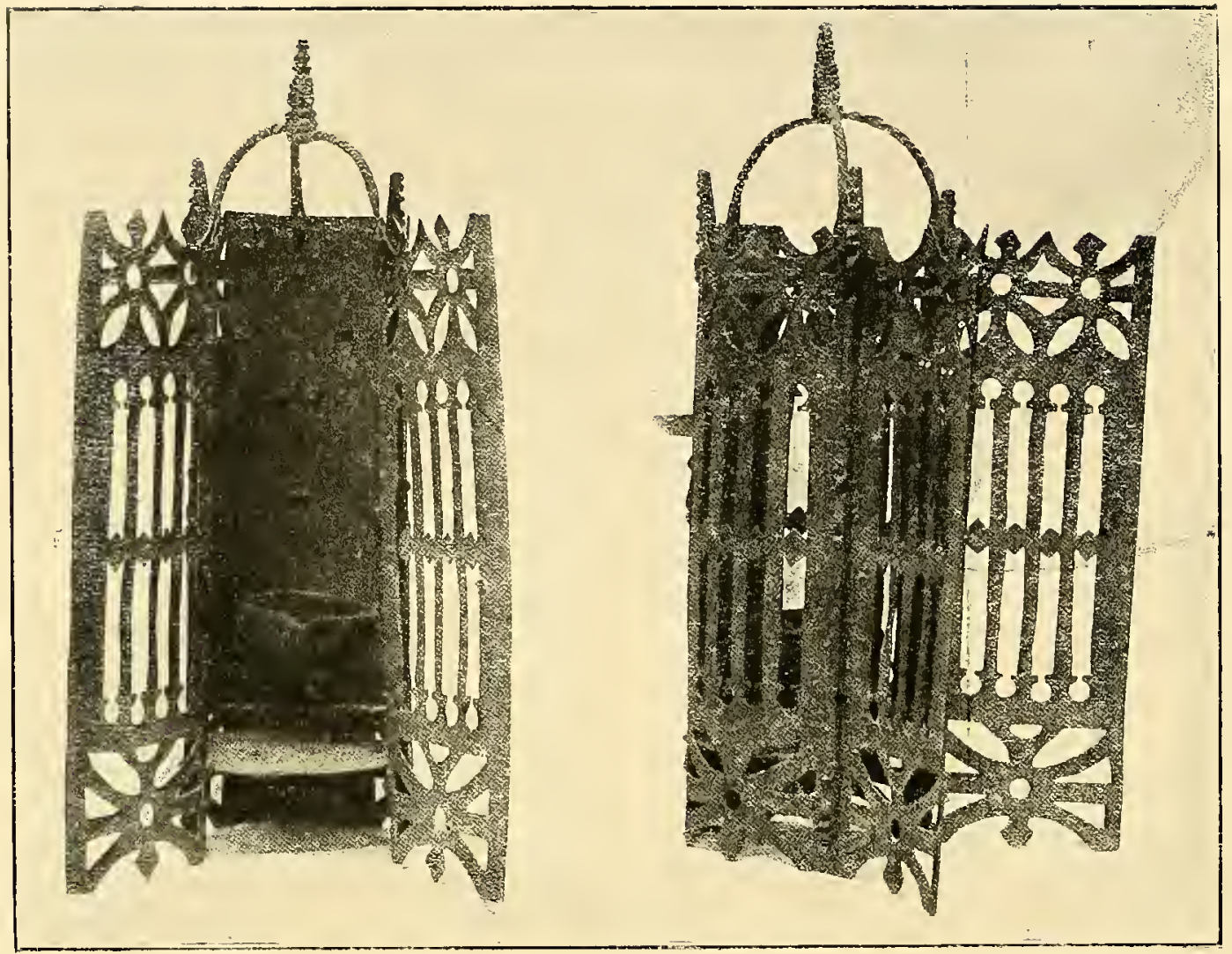

Núm. 248.

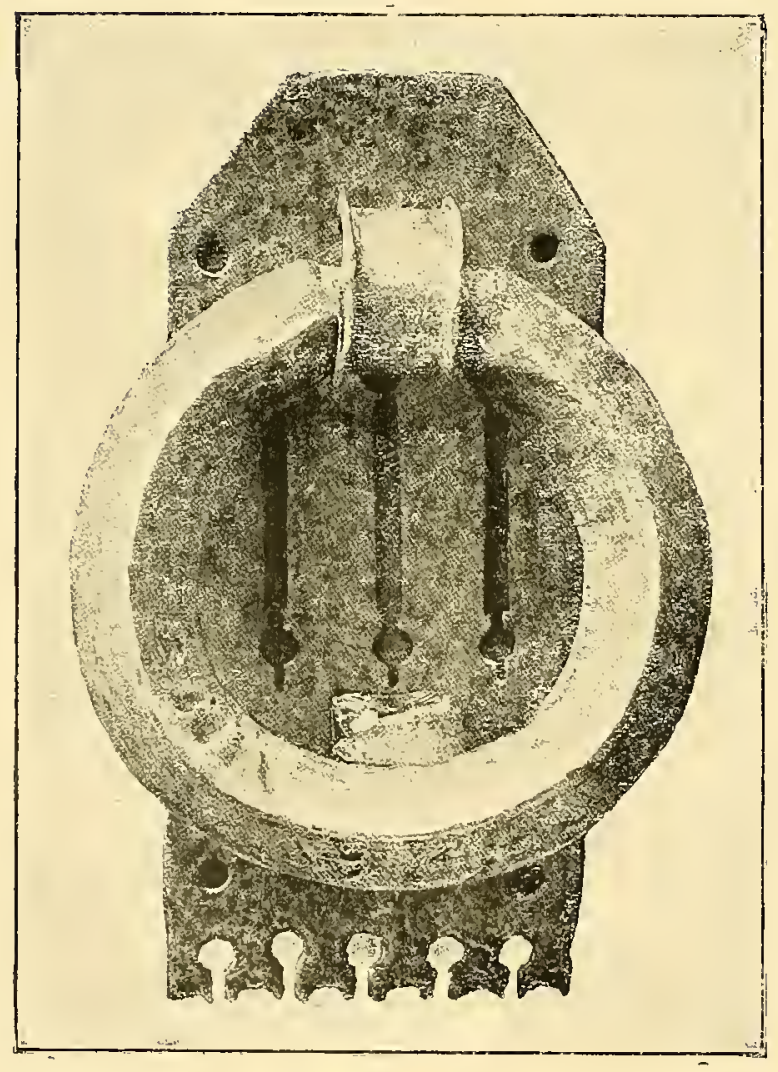

Núm. 249.

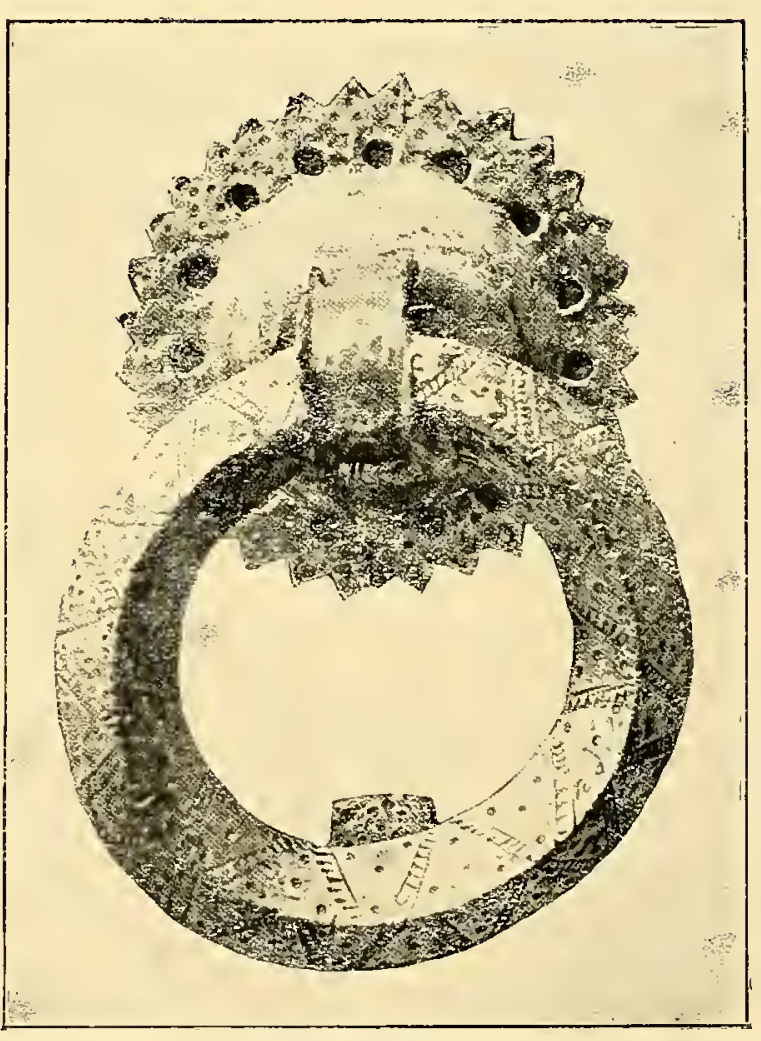

Núm. 251. 
Núm. 250.--Llamador gótico de anillo de 13 centímetros de diámetro. La argolla sobre gruesa plancha festoneada y realzada en casquete esférico recordando los clavos de la época. Todo el ejemplar, con labor incisa rectilínea y punteada. Siglo xv.

Expositor: Excmo. Sr. Marqués de la Torrecilla.

Núrn. 251.-Llamador gótico de anillo sobre plancha circular festoneada, punzonada y realzada en casquete esférico. El anillo con labor incisa, rectilínea y punteada. Finales del siglo xv.

Expositor: Excmo. Sr. Marqués de la Torrecilla.

Núm. 252.-Llamador gótico de anillo sobre plancha cuadrada, recortada, con la parte superior almenada; en el centro un sencillo calado gótico, y el anillo decorado con incisiones rectilíneas. Finales del siglo xv.

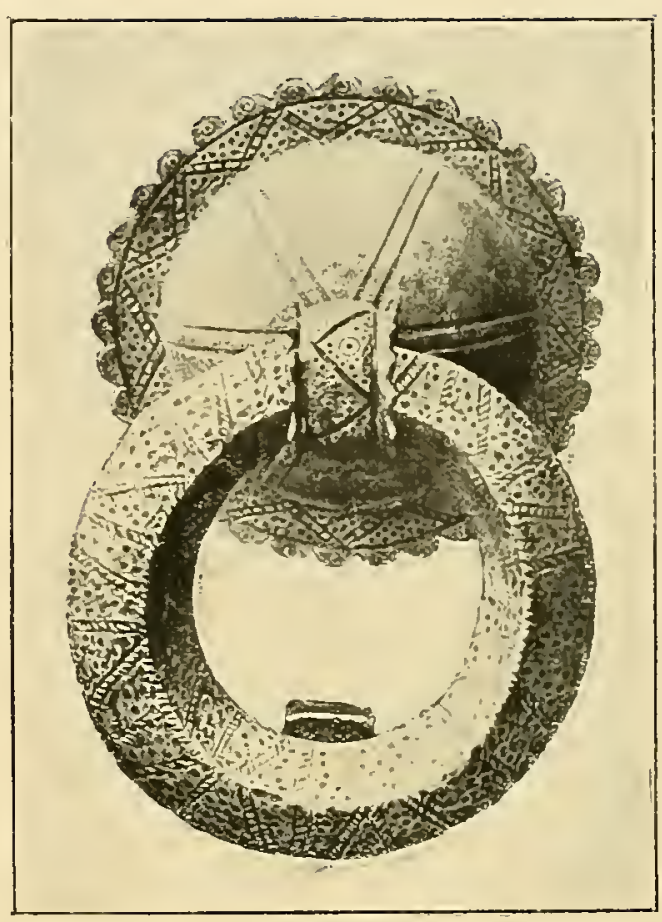

Núm. 250.

Expositor: D. Domingo Guerrero, de San Sebastián.

Núm. 253. - Llamador gótico de anillo. La argolla sobre plancha circular festoneada y decorada en sectores punteados. Finales del siglo xv. Diámetro del anillo: $13 \mathrm{~cm}$.

Expositor: D. Domingo Guerrero, de San Sebastián.

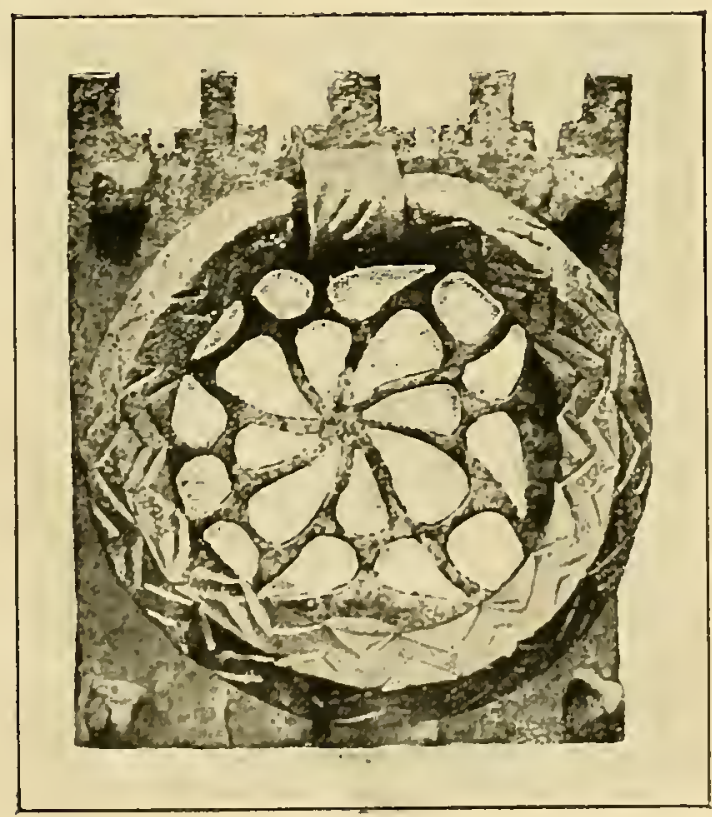

Núm. 252

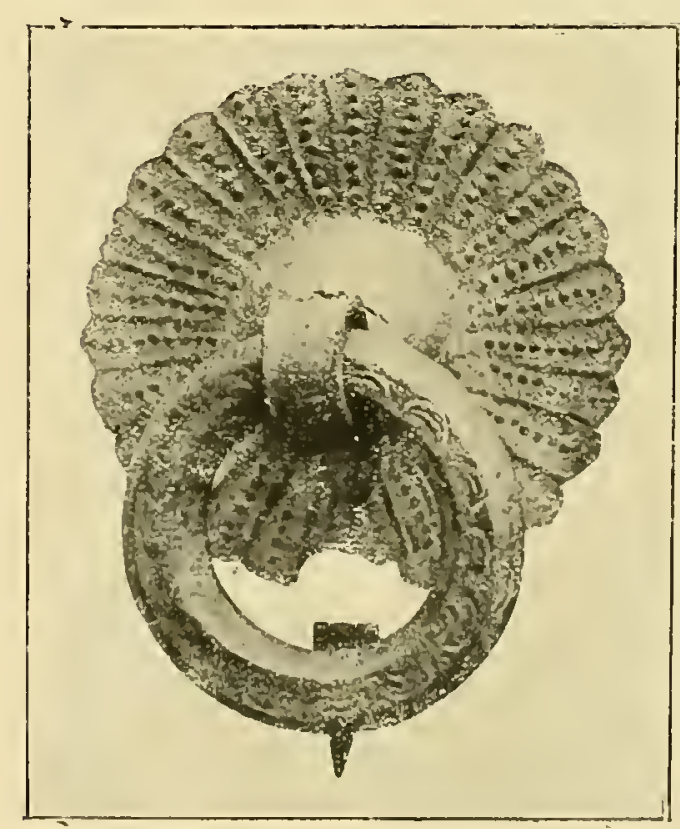

Nüm. 253. 


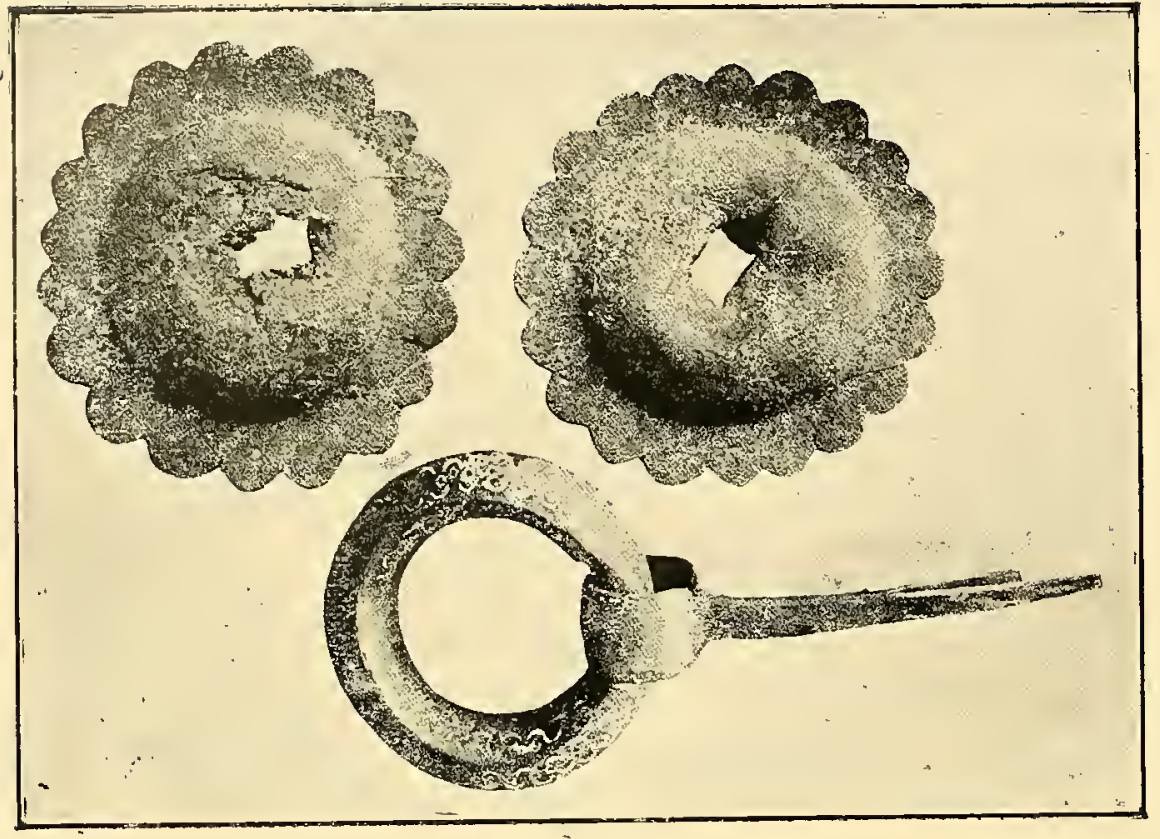

Núm, 254.
Núm. 254.-Llamador gótico de anillo, con la argolla y el clavo (que falta) sobre plancha circular realzada y festoneada. Finales del siglo xv.

Diámetro del anillo: $12 \mathrm{~cm}$.

Expositor: D. Juan liménez Aguilar, de Cuenca.

Núm. 255.-Dos llamadores góticos de anillo. La argolla sobre plancha realzada en casquete esférico, todo él con labor incisa rectilínea, formando cuadrados. Finales del siglo $\mathrm{xv}$.

Proceden de la provincia de Granada.-Diámetro máximo $17 \mathrm{~cm}$.

Expositor: D. Domingo Guerrero, de San Sebastián.

Núm. 256. - Llamador gótico de anillo plano con los ángulos achaflanados. La argolla acanalada sobre plancha realzada en su centro en casquete esférico y calada en corona cir-

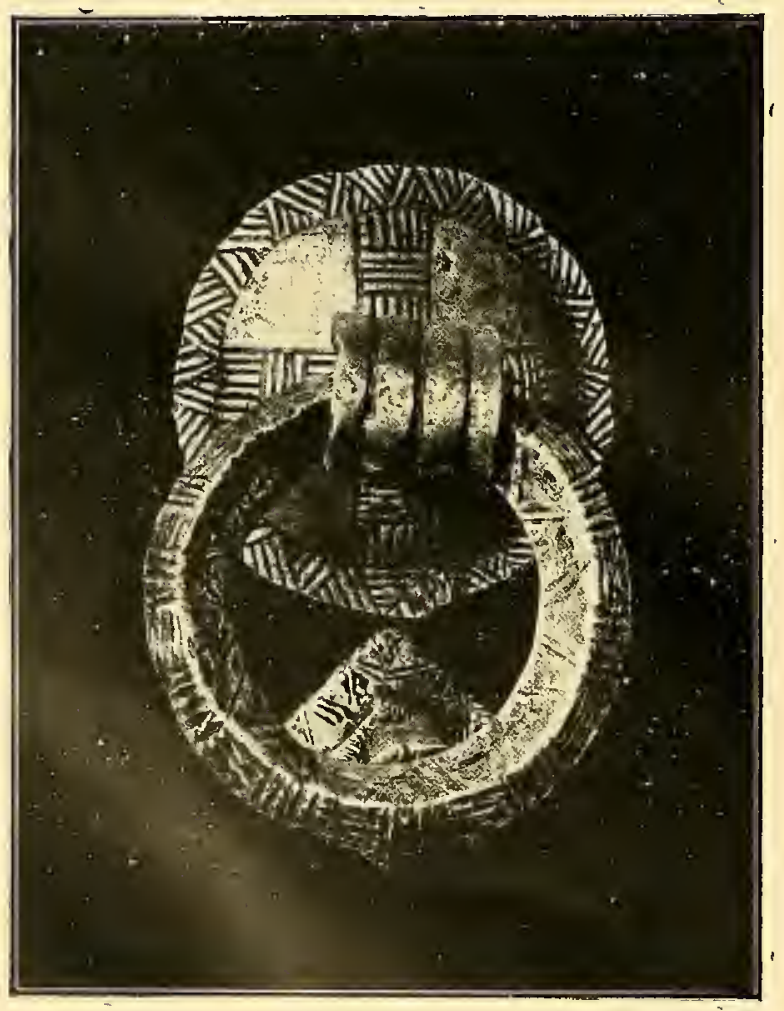

Núm. 255.

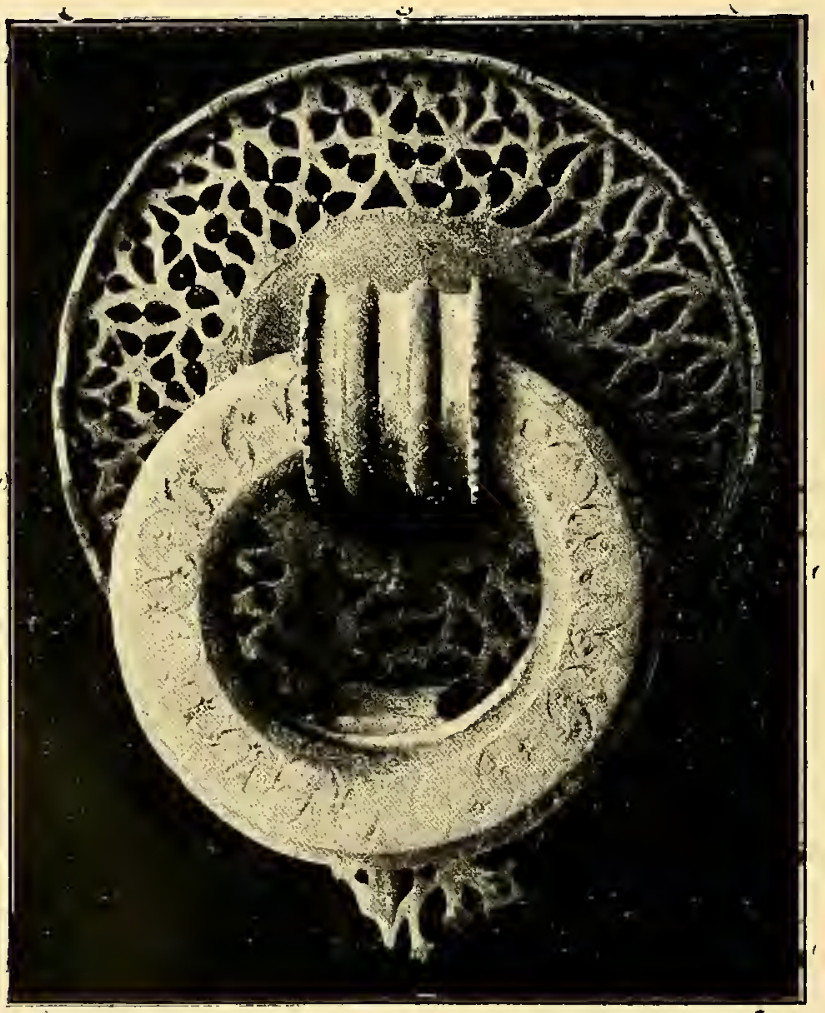

Núm. 256 


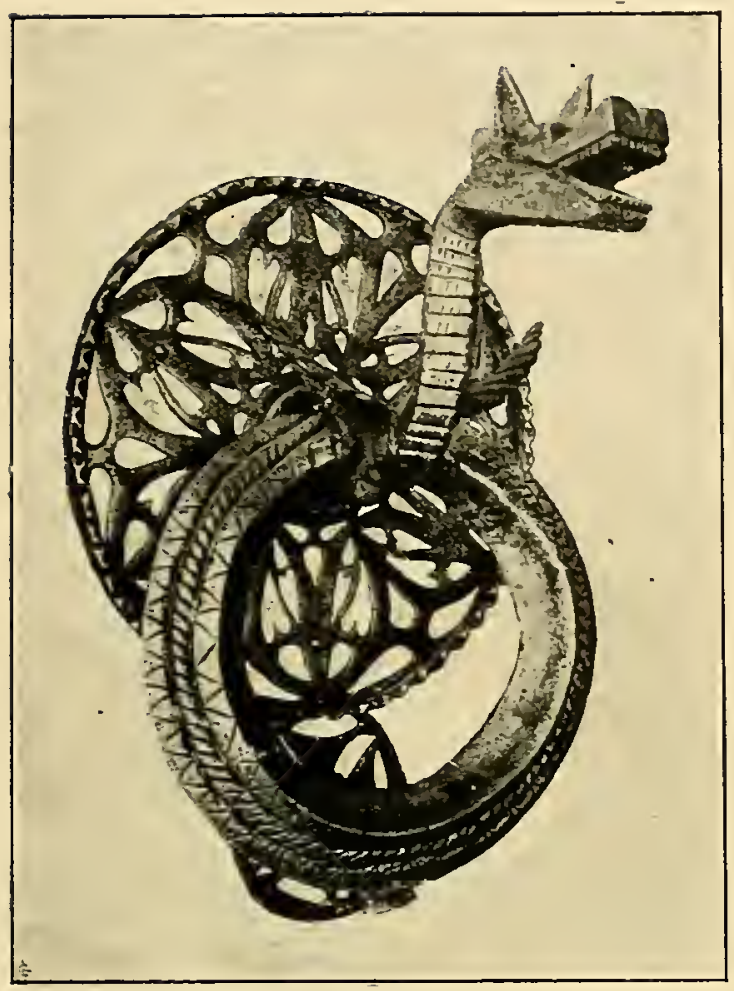

Nưm 258.

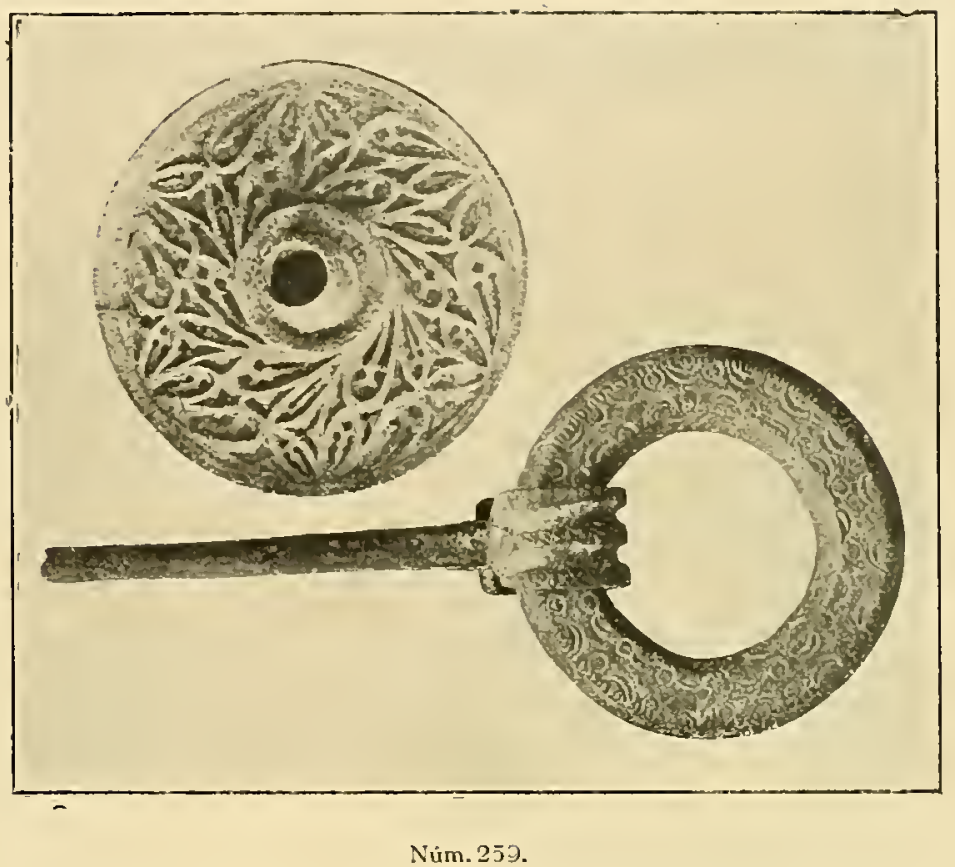

cular, según motivos góticos. El clavo representa un yunque. Siglo xv.

Diámetro $12 \mathrm{~cm}$.

Expositor: D. Domingo Guerrero, de San Sebastián.

Núm. 257.--Llamador gótico de anillo de 18 centímetros de diámetro, análogo al anterior. Siglos $x v$ al xvi.

\section{Expositor: Junta de Museos de Barcelona.}

Núm. 258.-Llamadores góticos de anilio, de $17 \mathrm{~cm}$. de diámetro, con la argolla prolongada en cabeza de dragón y el clavo representando asimismo una cabeza de dragón que se coloca sobre una segunda arandela de menor diámetro. Las aran-

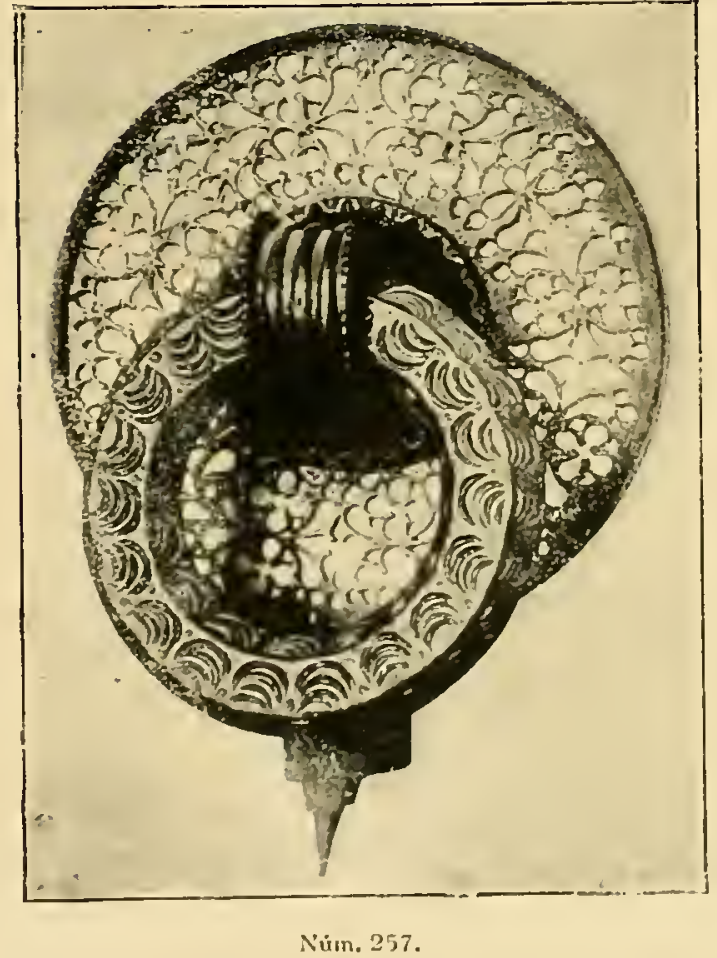

delas sin casquete esférico realzado y todas ellas en plancha calada de motivos góticos. Ejemplares clásicos de la costa mediterránea (Barcelona, Tarragona, Valencia). Siglo $x v$ al xvı.

Expositor: D. Domingo Guerrero, de San Sebastián.

Núm. 259. Dos aldabones góticos de anillo de 13,5 cms. de diámetro, con la arandela de doble plancha calada en motivos góticos, flamígeros de una 
complicación y delicadeza verdaderamente admirables. Siglo xv al xvi.

Expositon: Excmo. Sr. Marqués de Valverde de la Sierra.

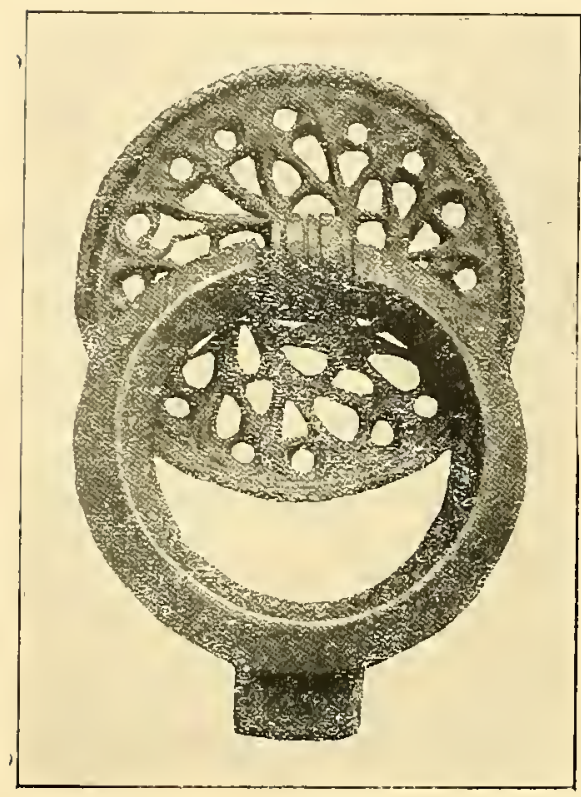

Nủm, 260.

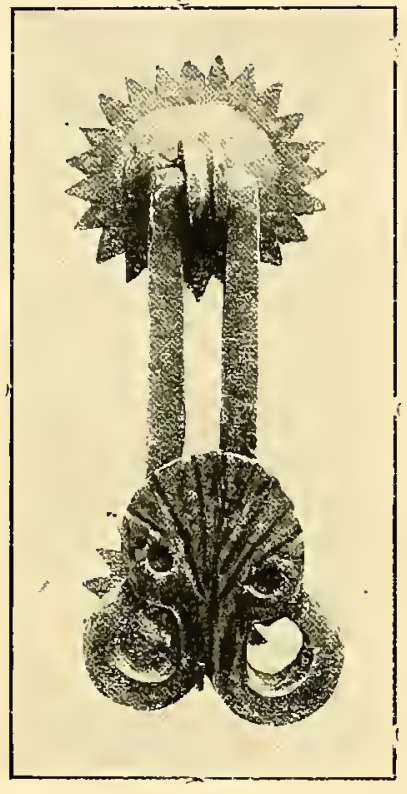

Nưm. 262.

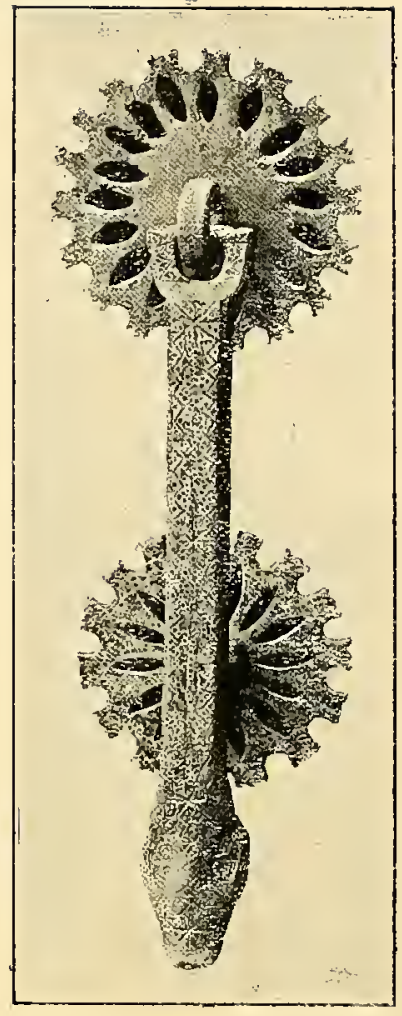

Nì่m, 263.

Núm. 260.-Pequeño llamador gótico de anillo de $59 \mathrm{cms}$. de diámetro con argolla de bronce calada en motivos góticos. Siglo xv al xvl.

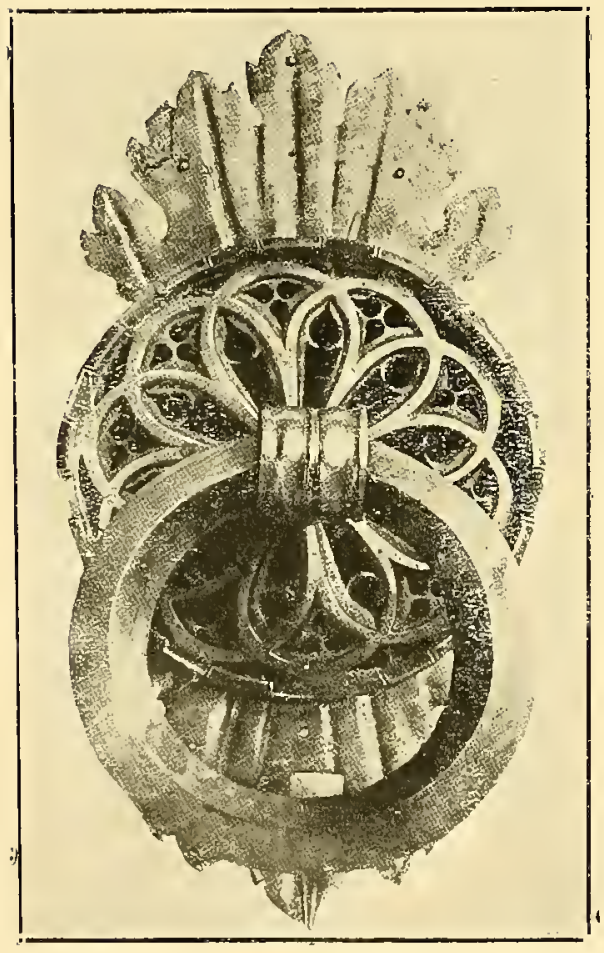

Nủm. 261.
Expositor: D. José Lázaro.

Núm. 261.--Llamador gótico de anillo sobre plancha calada en motivos góticos, crestería con plancha recortada y realzada en repujado incipiente.

\section{Expositor: D. Isidoro de Urzáiz.}

Núm. 262.-Llamador gótico de doble varilla gruesa y cuadrada, terminada en grandes volutas cerradas 'sobre el eje; la argolla y el clavo sobre plancha circular, festoneada y realzada en casquete esférico. Mediados del siglo xv.Longitud del llamador, $22 \mathrm{~cm}$; ancho máximo, 10.

Expositor: Excmo. Sr. Marqués de la Torrecilla.

Núm. 263.-Llamador de barra cuya argolla y clavo descansan sobre planchas circulares caladas y festoneadas. El llamador con labor rectilínea incisa y terminado en cabeza de dragón. Finales del siglo xv.

Expositor: Excmo. Sr. Marqués de la Torrecilla. 
Núm. 264.--Llamador gótico análogo al que precede, terminando la argolla en una cabeza de dragón; labor incisa de rectas y círculos. Longitud máxima $17 \mathrm{~cm}$., anchura 14,5. Finales del siglo xv.

\section{Expositor: Excmo. Sr. Marqués de la Torrecilla.}

Núm. 265.-Doble llamador gótico en disposición análoga a los que preceden. Varilla retorcida y la argolla termina en un segundo llamador que golpea sobre la soldadura de las volutas. Estilo del principio del reinado de los Reyes Católicos.

\section{Expositor: Excmo. Sr. Duque de Santa Lucía.}

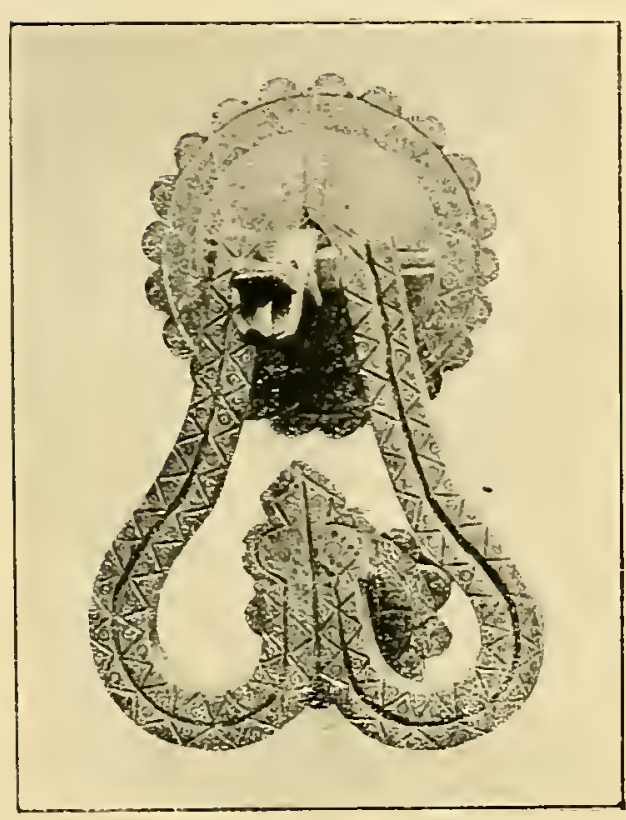

Núm. 264.

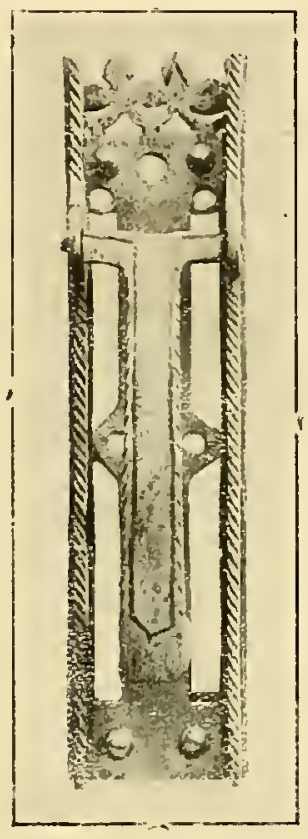

Nüm. 267.

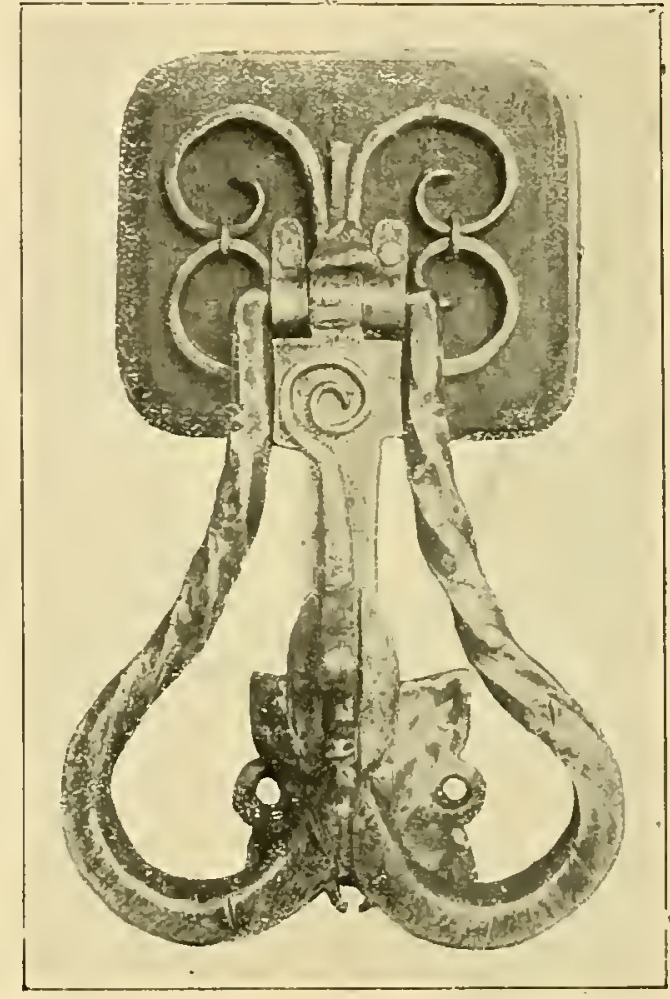

Nim. 265.

Núm. 266.-Llamador gótico formado por doble gruesa barra rectanguiar terminada en dos arcos que se sueldan formando una cabeza quimérica. Finales del siglo xv.

Expositor: Excmo. Sr. Conde de Cedillo.

Ním. 267.-Llamador en barra arqueada sobre un elemento de plancha calada, limitada por dos varillas estriadas que contienen los orificios sobre que gira el martillo. Finales del siglo xv y principios del xvı.

Expositor: Excmo. Sr. Marqués de la Torrecilla.

Núm. 268.-Llamador gótico de plancha recortada. Lleva en la chapa sujeta con grapas, una figura que debió tener lanza o espada como símbolo de guarda o defensa y un aguilucho en el martillo. Siglo xv. Mide $37 \mathrm{~cm}$. de alto por ocho de ancho.

Expositor: D. Domingo Guerrero, de San Sebastián. 
Núm. 269.-Llamador gótico sobre cuadro rectangular de doble plancha calada en motivos góticos que forman dos zonas desiguales, limitadas por columnillas góticas macizas y un coronamiento de hojas recortadas y realzadas. El llamador representa una figura de San Pedro en su hornacina o capilla gótica con su pináculo correspondiente. El conjunto es de una labor esmerada y compleja. Guarda estrecha relación con el que fué llamado de la Cartuja de Miraflores, transformado actualmente en mirilla por conservarse únicamente la placa rectangular. Finales del siglo xv.

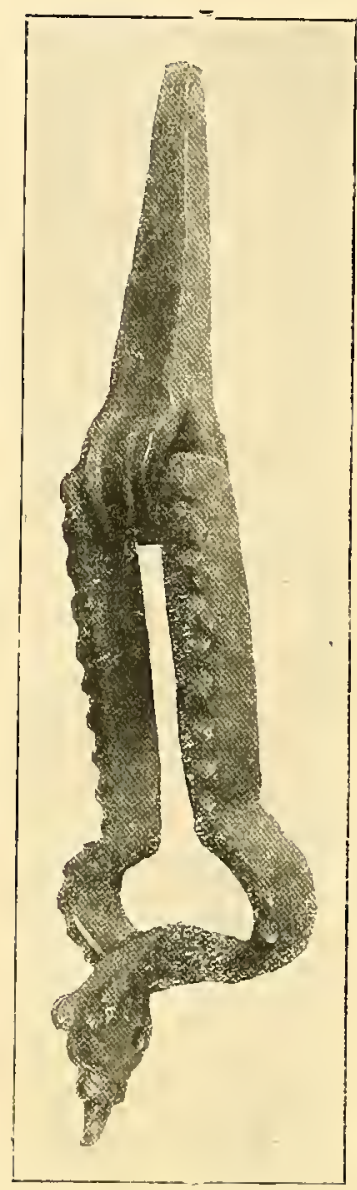

Nủm. 200.

\section{Expositor: D. Domingo Guerrero, de San Sebastián.}

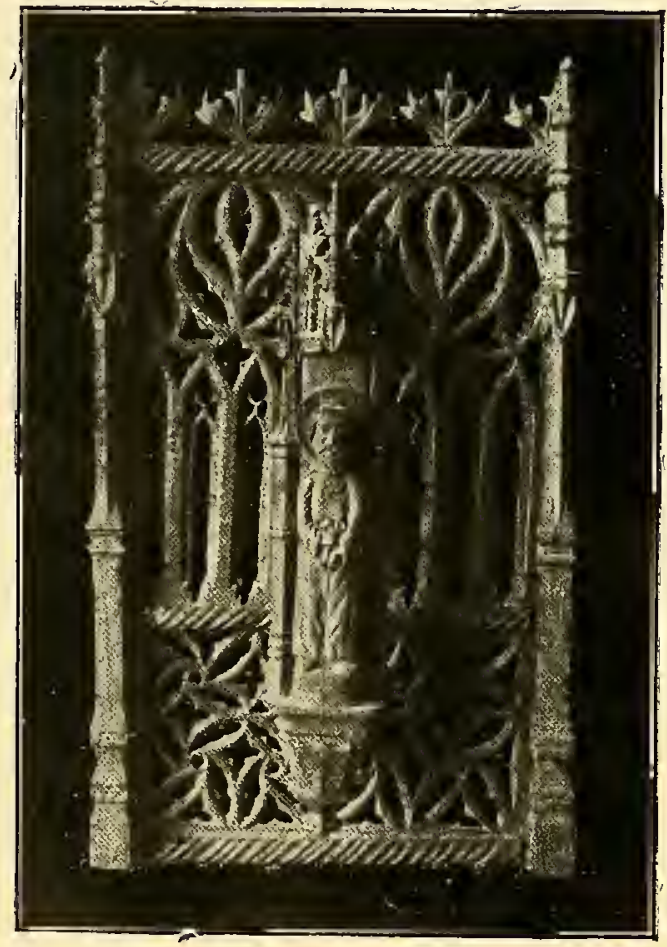

Nủm. 269.

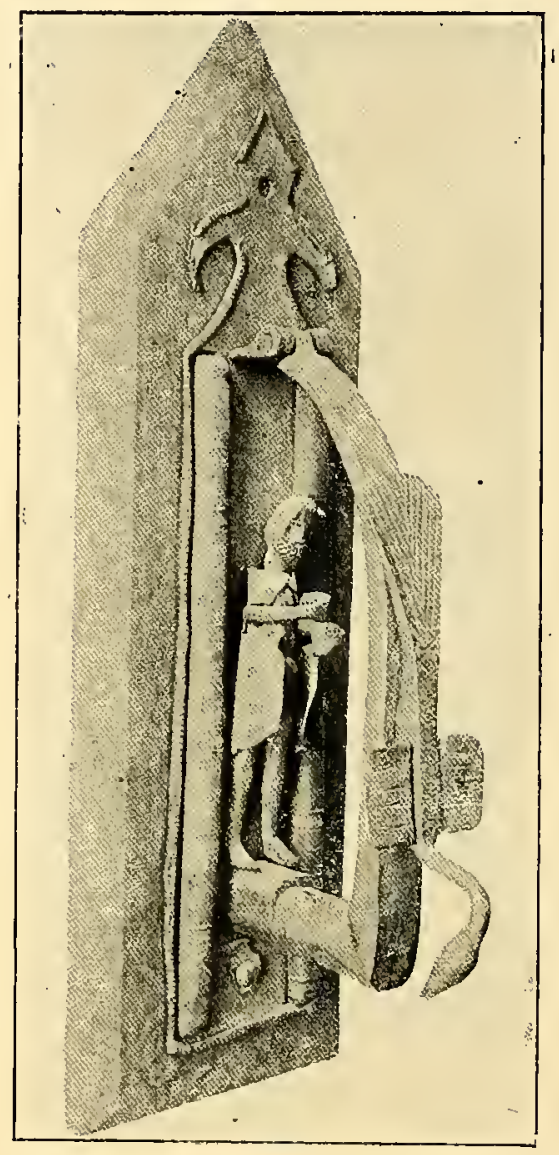

Nỉm. 268.

Núm. 270.--Llamador gótico, del tipo de los que preceden, de múltiple y compleja labor; con la argolla sujeta a una plancha rectangular, fijada por cuatro clavos ornamentados de plancha con un doble doselete de coronas en plancha recortada y realzada la exterior sobre el llamador, dos dragones quiméricos y una concha. Guarda estrecha relación con la época en que fueron trabajados los clavos de la Universidad de Salamanca. Segundo decenio del siglo xvı.

Expositor: D. José Lázaro.

Núm. 271.-Llamador gótico, de hierro cincelado, representando dos figuras quiméricas superpuestas. El eje de giro sobre plancha rectangular cuyos dos tercios exteriores son calados y realzados. Procede de la meseta castellana. Principios del siglo xvı.

Expositor: D. Domingo Guerrero, de San Sebastián. 


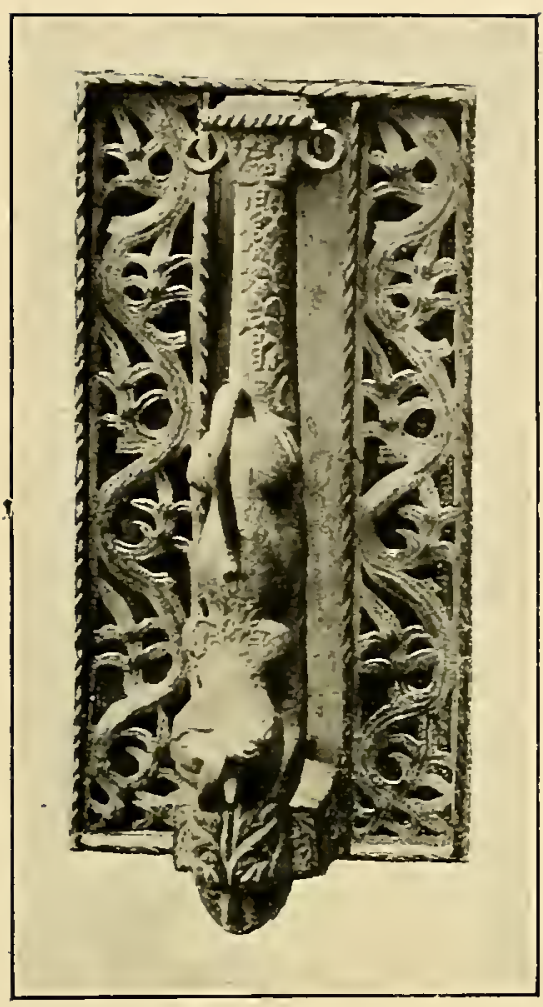

Nứm. 271.
Núm. 272.-Aldabón de martillo arqueado con una figura de diablo cincelada. El eje sobre plancha rectangular calada y almenada. Se conservan vestigios de un doselete en arco. Principios del siglo xvı. Procede de Cau Ferrat.

Expositor: DoII Santiago Rusiñol.

Núm. 273 - Cerradura sobre marco rectangular en plancha calada y doble plancha con motivos góticos. - Siglo xv. - Procede del Cau Ferrat. Expositor: D. Santiago Rusiñol.

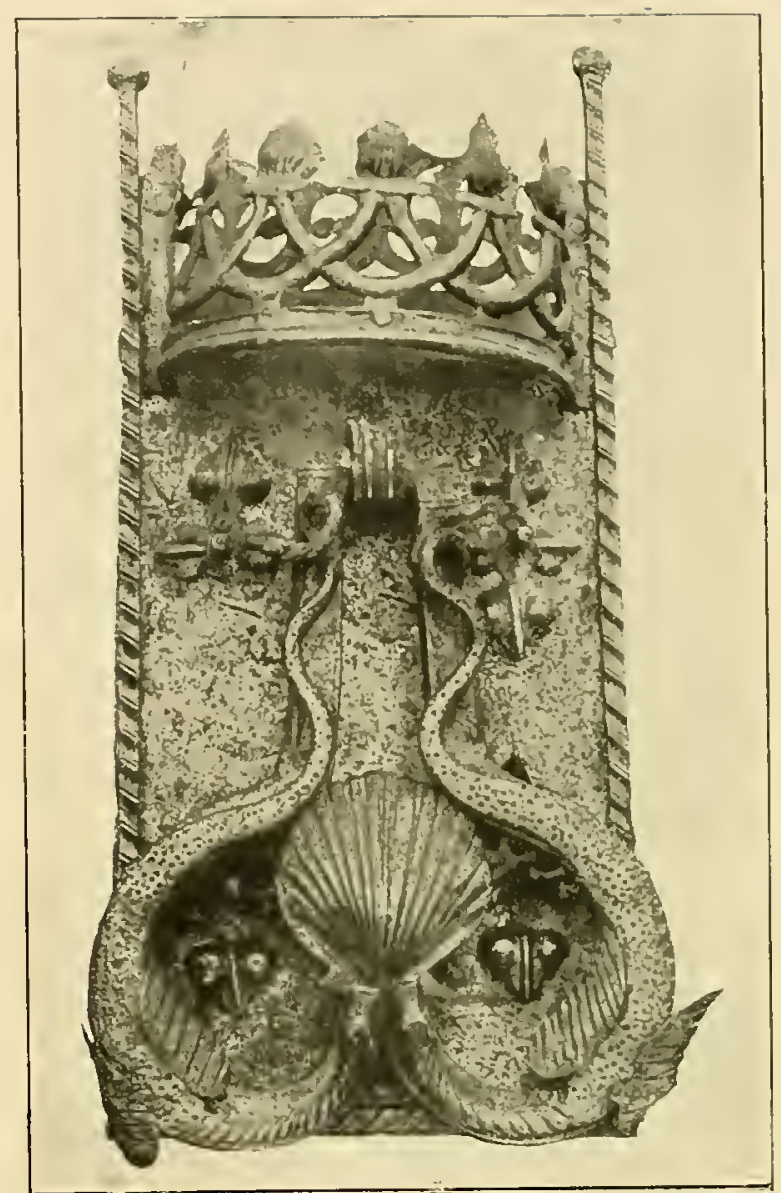

Nüm. 270.

Núm. 274.-Placa de cerradura en plancha calada terminada por dos pináculos retorcidos. Trabajo español de finales del siglo xv.

Expositor: D. Domingo Guerrero, de San Sebastián.

Núm. 275.-Cerradura gótica rectangular de plancha calada y realzada en dos órdenes de planchas; los cuatro vértices están ocupados por cuatro cabezas haciendo el oficio de clavos. Trabajo español siguiendo la Escuela francesa de finales del siglo xv.

Expositor: D. Domingo Guerrero, de San Sebastián.

Núm. 276. - Cerradura gótica análoga a la precedente con cuatro ángeles en los vértices y una figura, al parecer, Santiago, en el cerrojo. Estilo del tiempo de los Reyes Católicos. Procede del Cau Ferrat.

Expositor: D. Santiago Rusiñol.

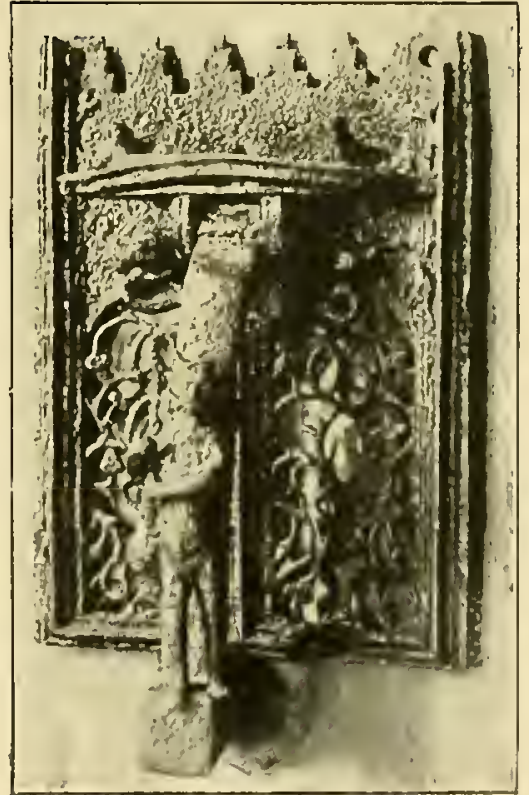

Nưm. 272 


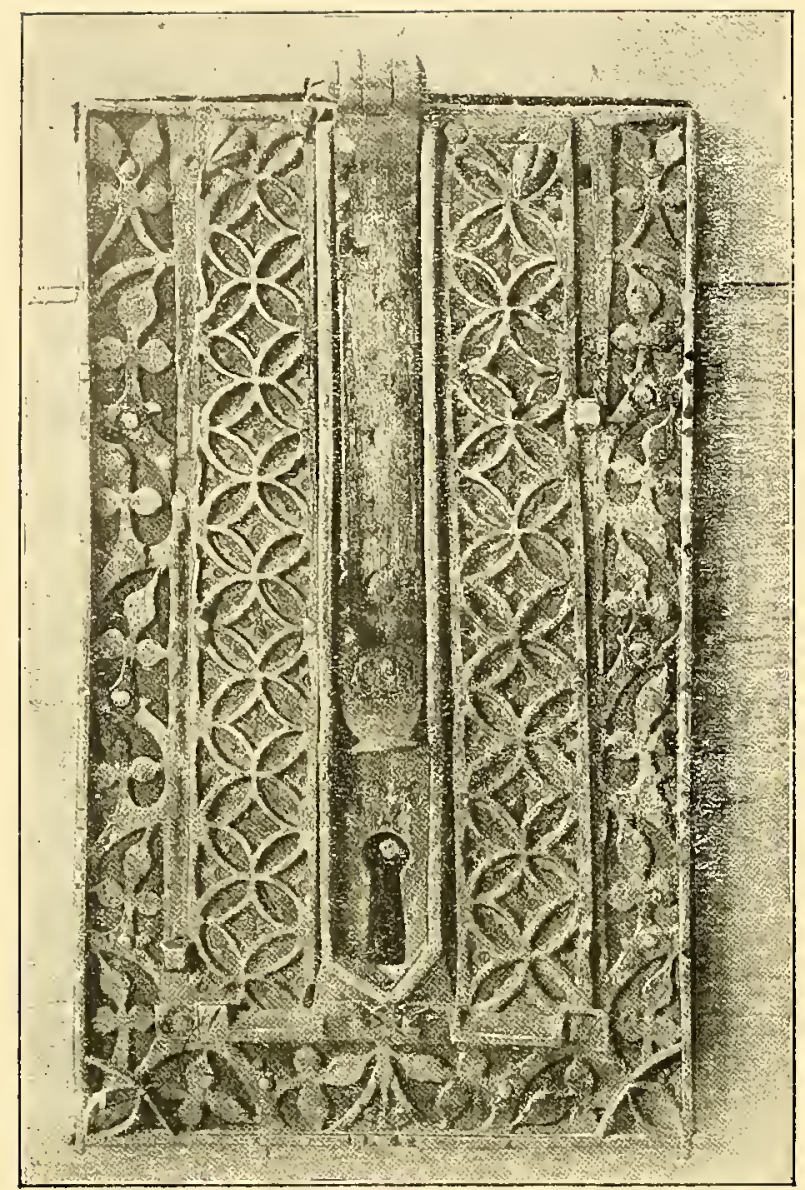

Núm. 275.
Núm. 273.

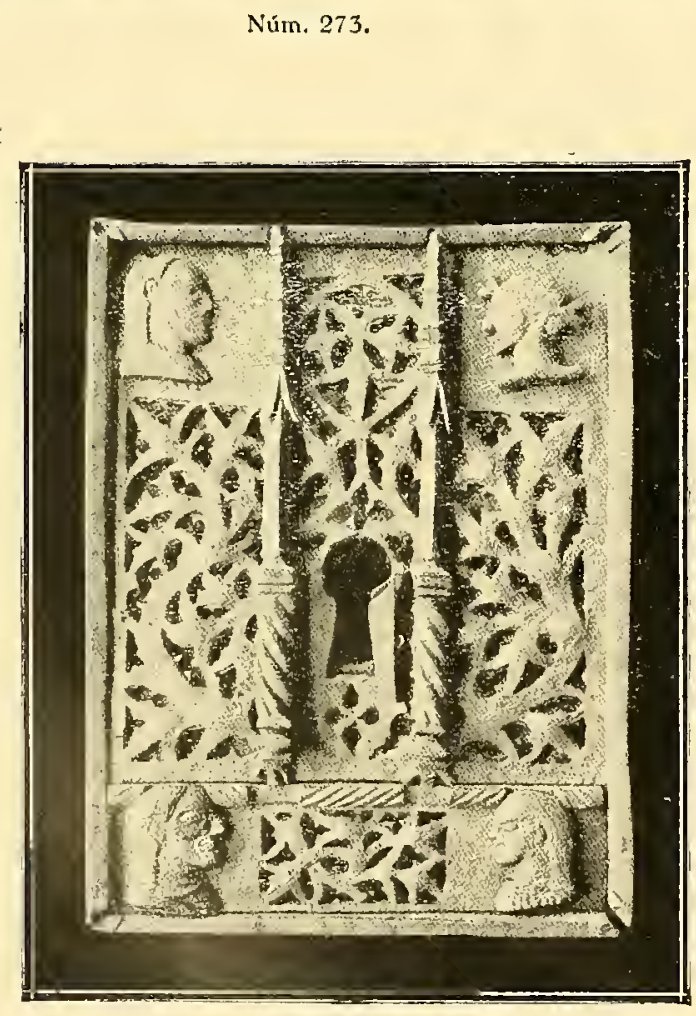

Núm. 277. - Cerradura inspirada en el estilo gótico, cuadrada con escudos heráldicos, bordura de plancha recortada y realzada; cuatro cabezas como clavos de sujeción en los ángulos. Influencia marcadamente francesa y trabajo poco español, quizás provenzal.

Procede del Cau Ferrat.

\section{Expositor: D. San- tiago Rusiñol.}

Núm. 278.-Cerradura gótica cuadrada en dos órdenes de plancha calada en motivos góticos con pináculos macizos laterales; una figura de santo con dosel gótico. Estilo del tiempo de los

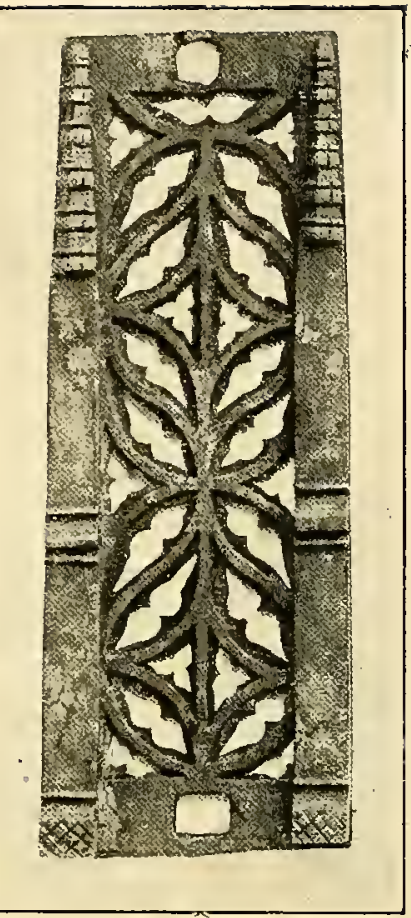

Núm. 274.

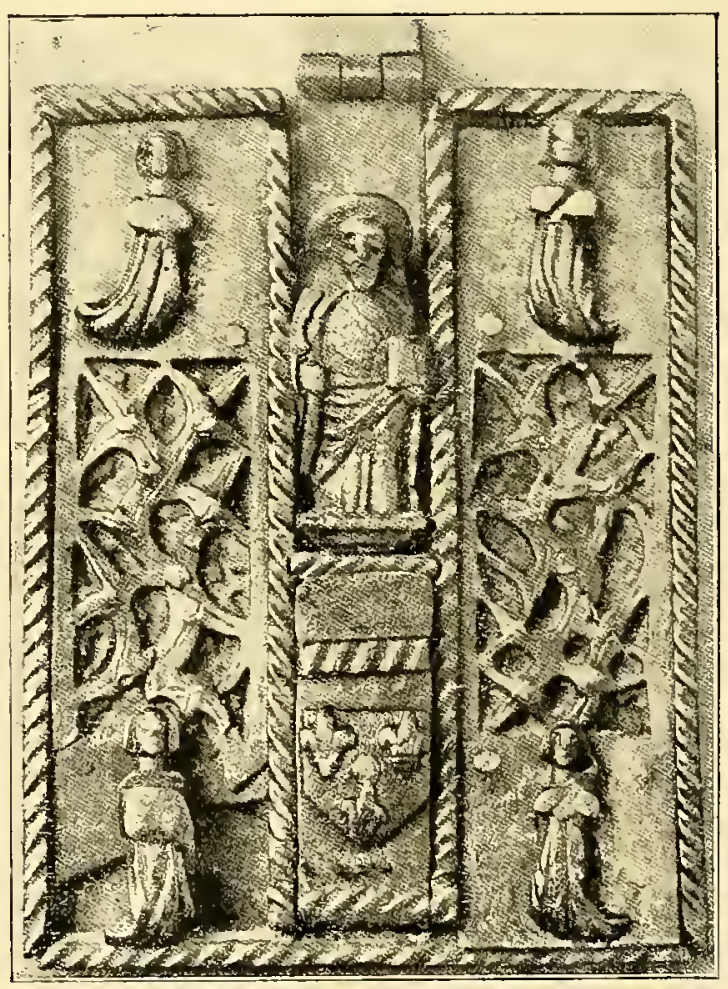

Núm, 276. 


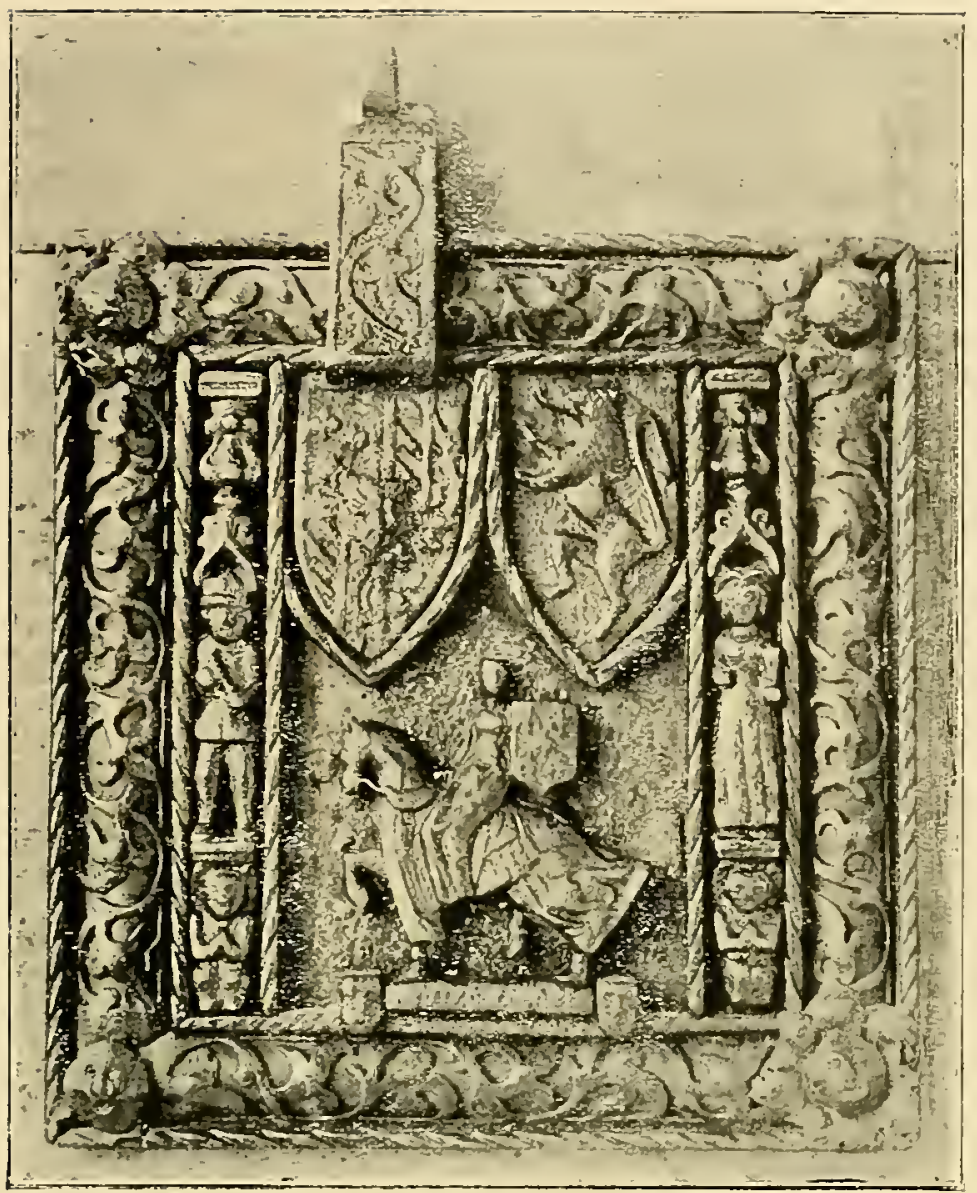

Nüm. 277.

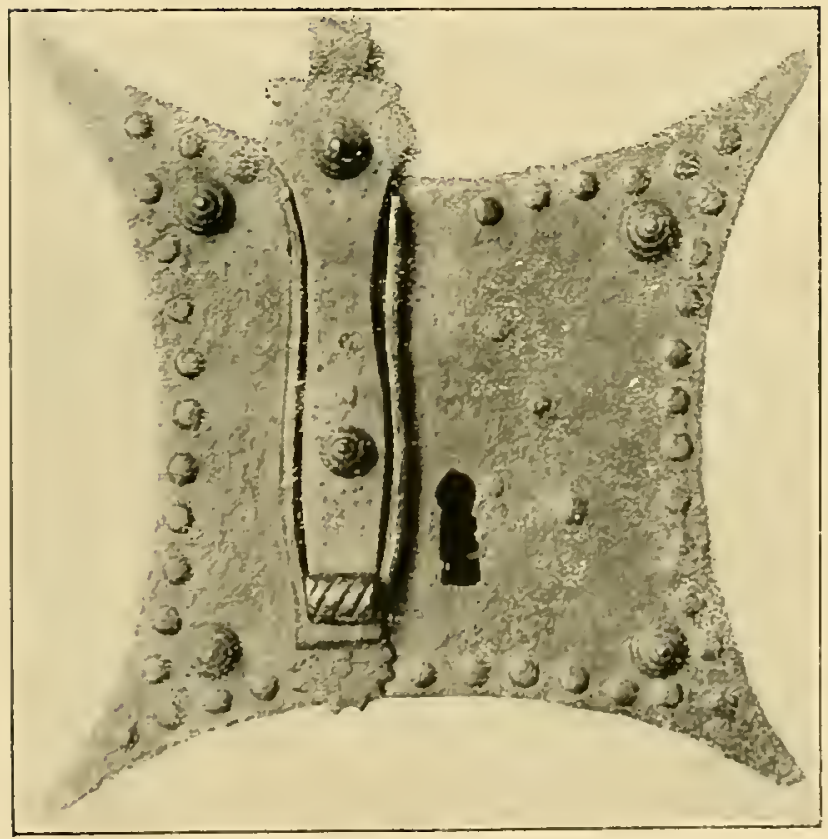

Nứm. 281.
Reyes Católicos. Procede de Cau Ferrat.

\section{Expositor: D. Santia- go Rusiñol.}

Núm. 279. - Cerradura gótica rectangular de dos órdenes de

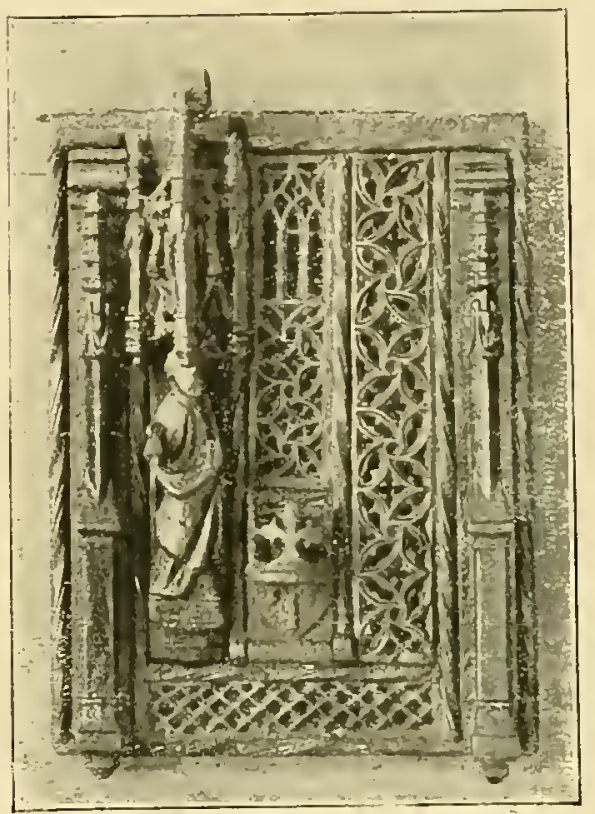

Nưm. 278.

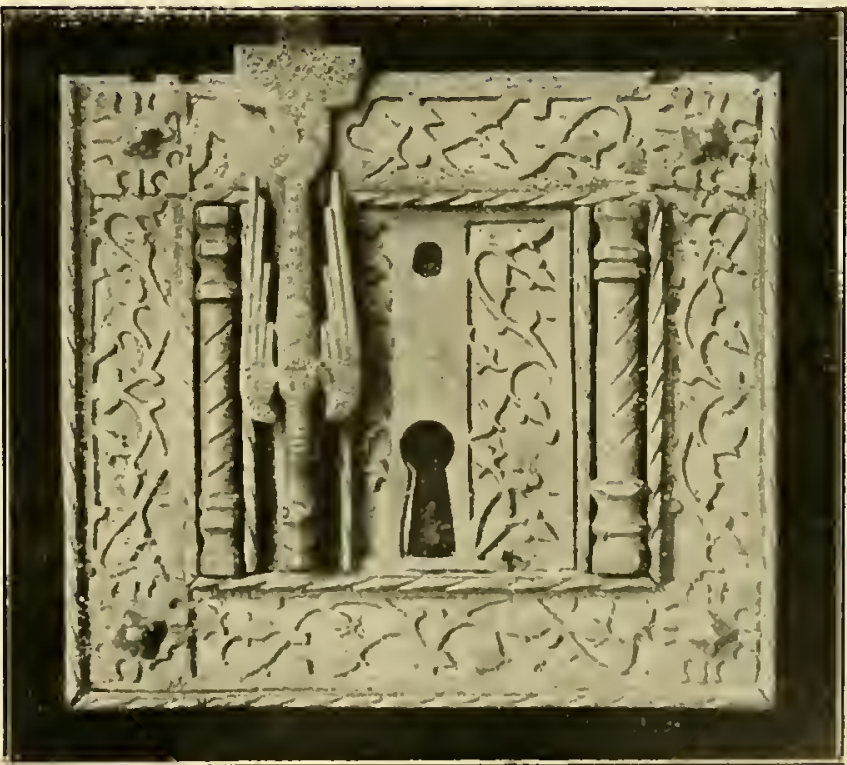

Nưm. 283. 


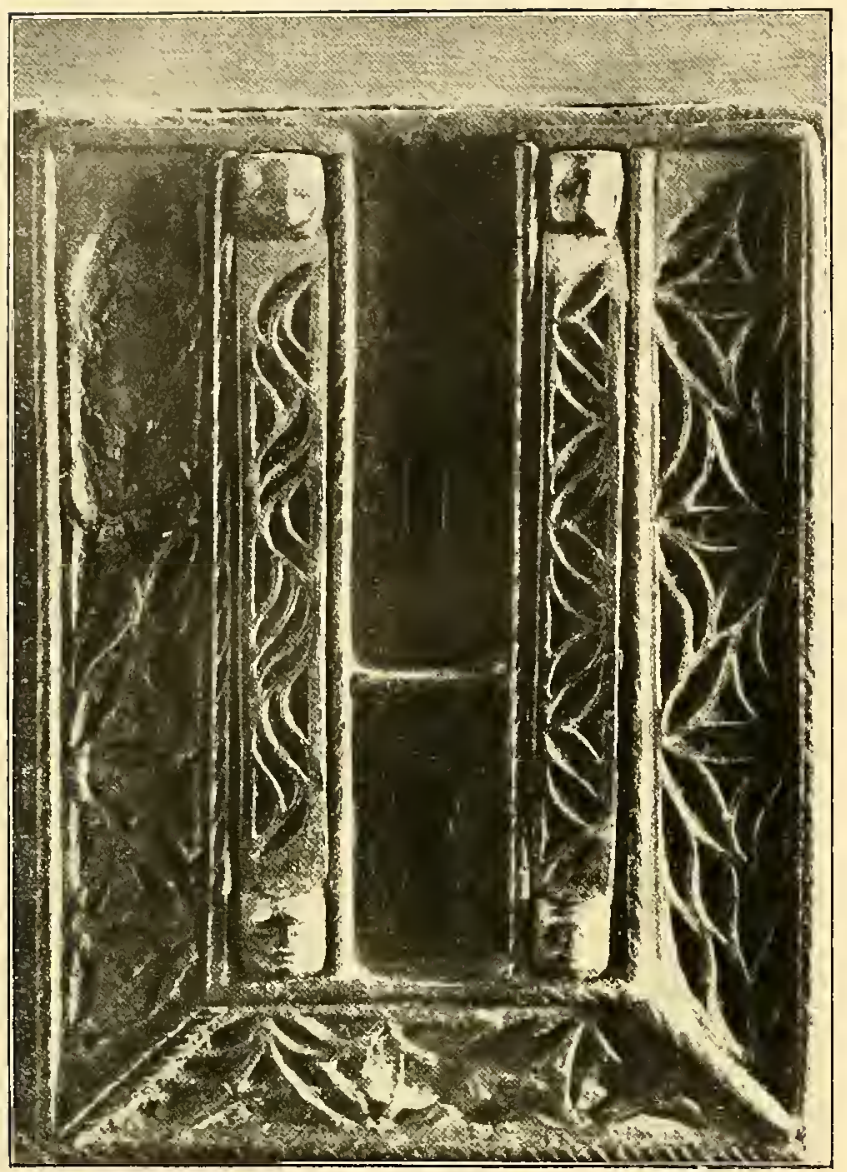

Nüm. 279. planchas caladas y con el cerrojo en la faja central. Estilo del tiempo de los Reyes Católicos. Procede del Cau Ferrat.

\section{Expositor: D. Santiago Rusiñol.}

Núm. 230 -Cerradura gótica rectangular con el cerrojo centrado, de doble plancha calada, dos figuras con dosel simétricamente colocadas. Estilo del tiempo de los Reyes Católicos.

\section{Expositor: D. Santiago Rusiñol.}

Núm. 281. - Cerradura en plancha rectangular con los cuatro ángulos en arco. Epoca de los Reyes Católicos.

Expositor: D. Domingo Guerrero, de San Sebastián.

Núm. 282.-- Cerradura gótica, cuadrada, relativamente sencilla, de doble plancha calada con clavos en los cuadros de los ángulos. Estilo del tiempo de los Reyes Católicos. Procede del Cau Ferrat.

Expositor: D. Santiago Rusiñol.

Núm. 283.-Cerradura gótica en marco rectangular con recuadro y centro de plancha calada. El cerrojo representa un dragón alado.

Finales del siglo vx o principios del vxı:

Expositor: D. Domingo Guerrero, de San Sebastián.

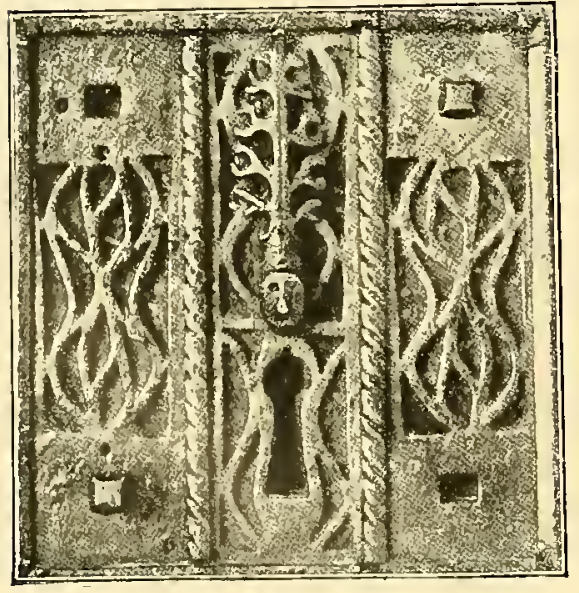

Núm. 282,

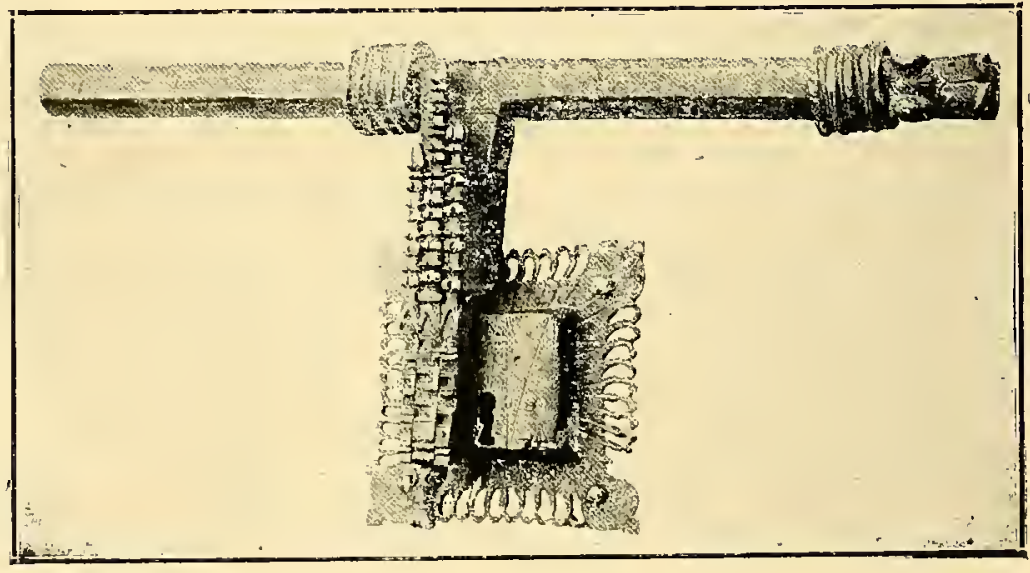

Nứm. 284. 
Núm. 284. - Cerrojo sobre cerradura en caja realzada. El vástago de cierre con decoración de pináculos góticos. Epoca de los Reyes Católicos. La cerradura de época posterior.

\section{Expositor: D. José Lázaro.}

Núm. 285.-Colección de clavos españoles de todas las épocas, empezando por los ejemplares de cazoleta correspondientes a los principios del siglo xv, los ejemplares agallonados, semiesféricos, inspirados en los tipos granadinos de finales del siglo xiv, los de dentellones que llegaron hasta el tiempo de los Reyes Católicos y continuando por los de plancha recortada y realzada de los principios del Renacimiento que se emplean también algo después y los ejemplares de varias planchas recortadas superpuestas, para terminar en los tipos decadentes de finales del siglo xvil y xvilı.

Finales del siglo xıv al xvilı. Forman la colección 221 clavos.

\section{Expositor: D. Adolfo Herrera.}

Núm. 286.-Tres cuadros conteniendo veinticinco clavos de puerta que comprenden desde los tipos góticos de Cazoleta hasta los usados a finales del siglo xvı; son interesantes, entre ellos, el de Cazoleta y dentellones de la iglesia de Santo Tomás de Avila y

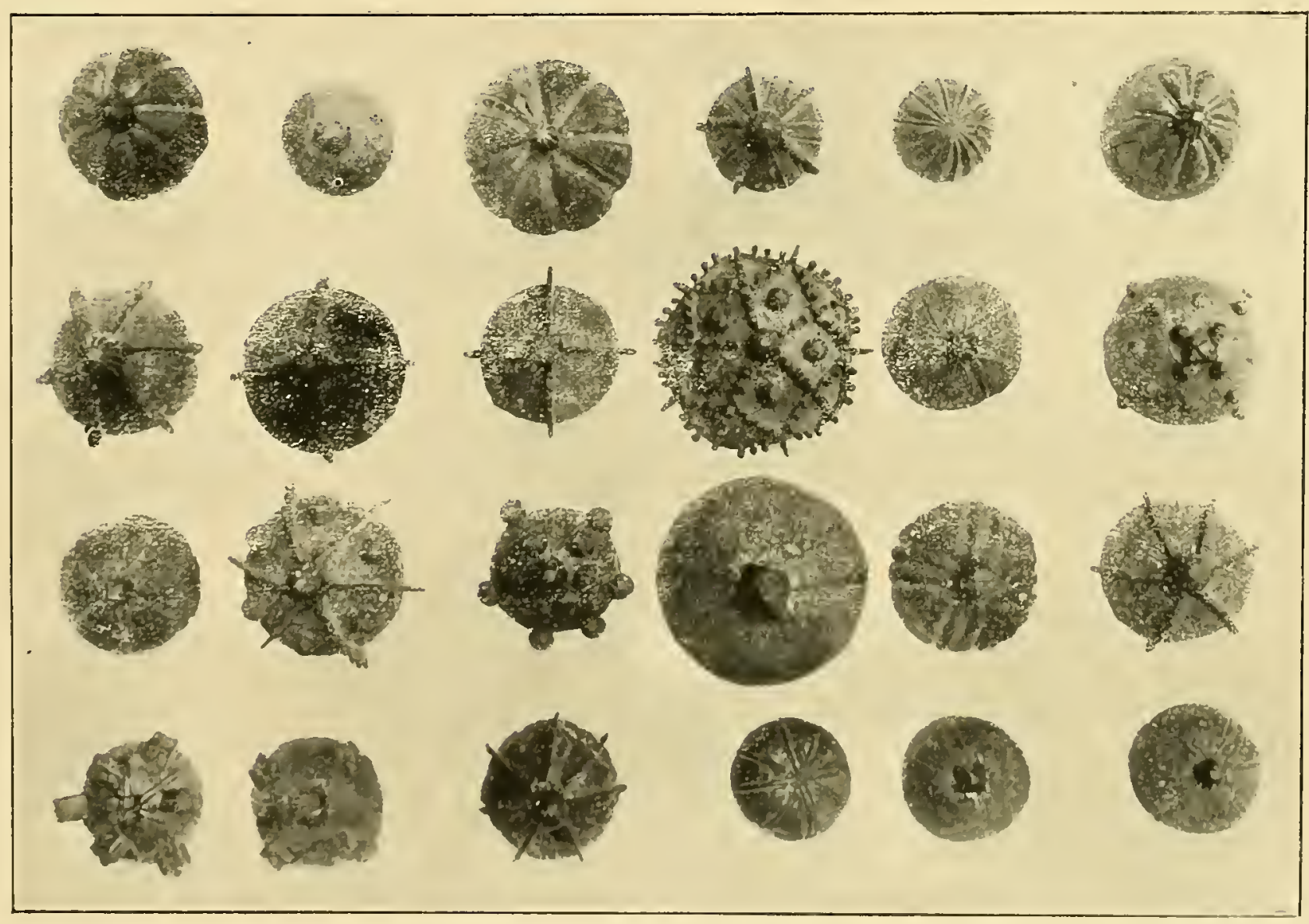

Nim. 285. 

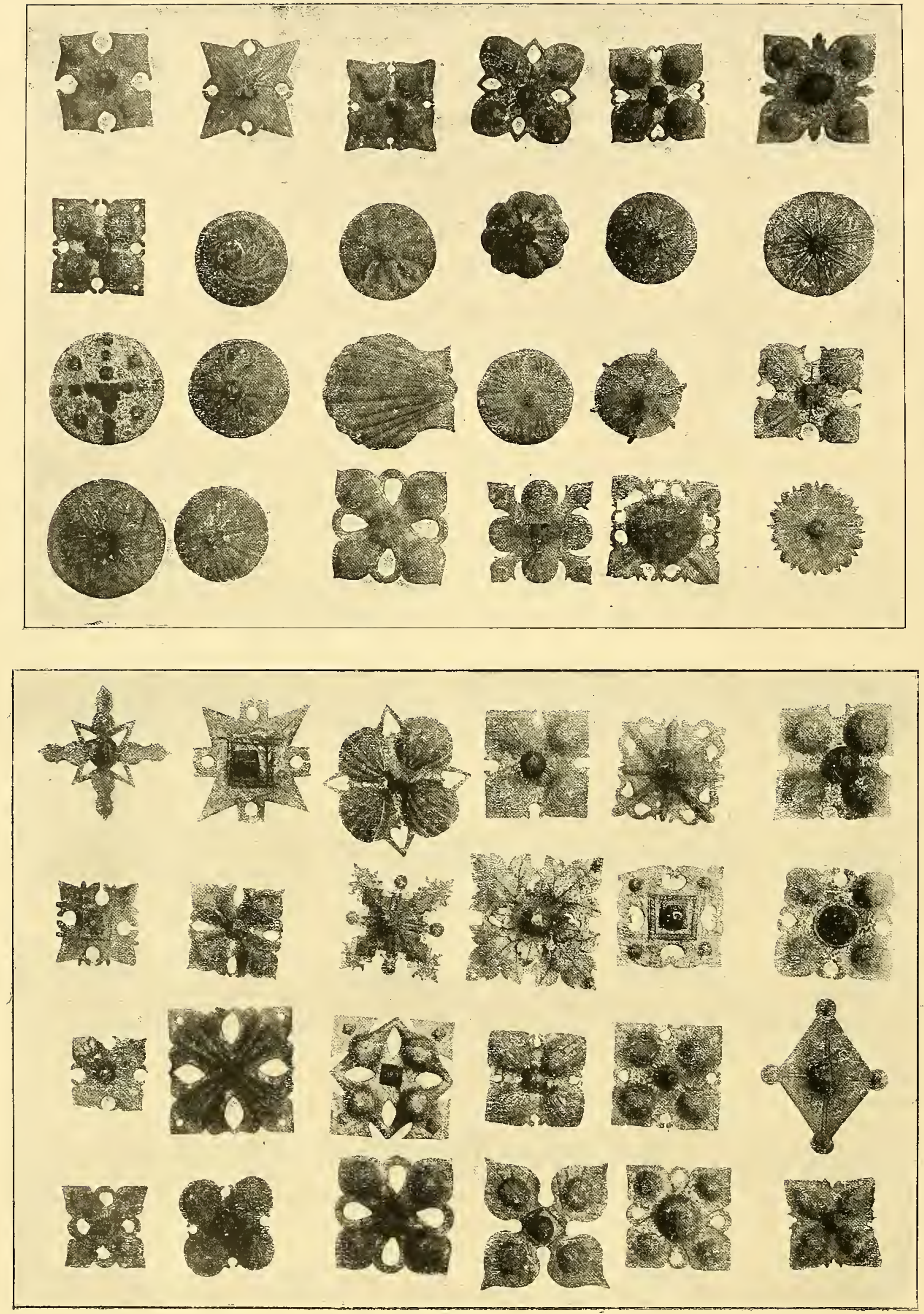


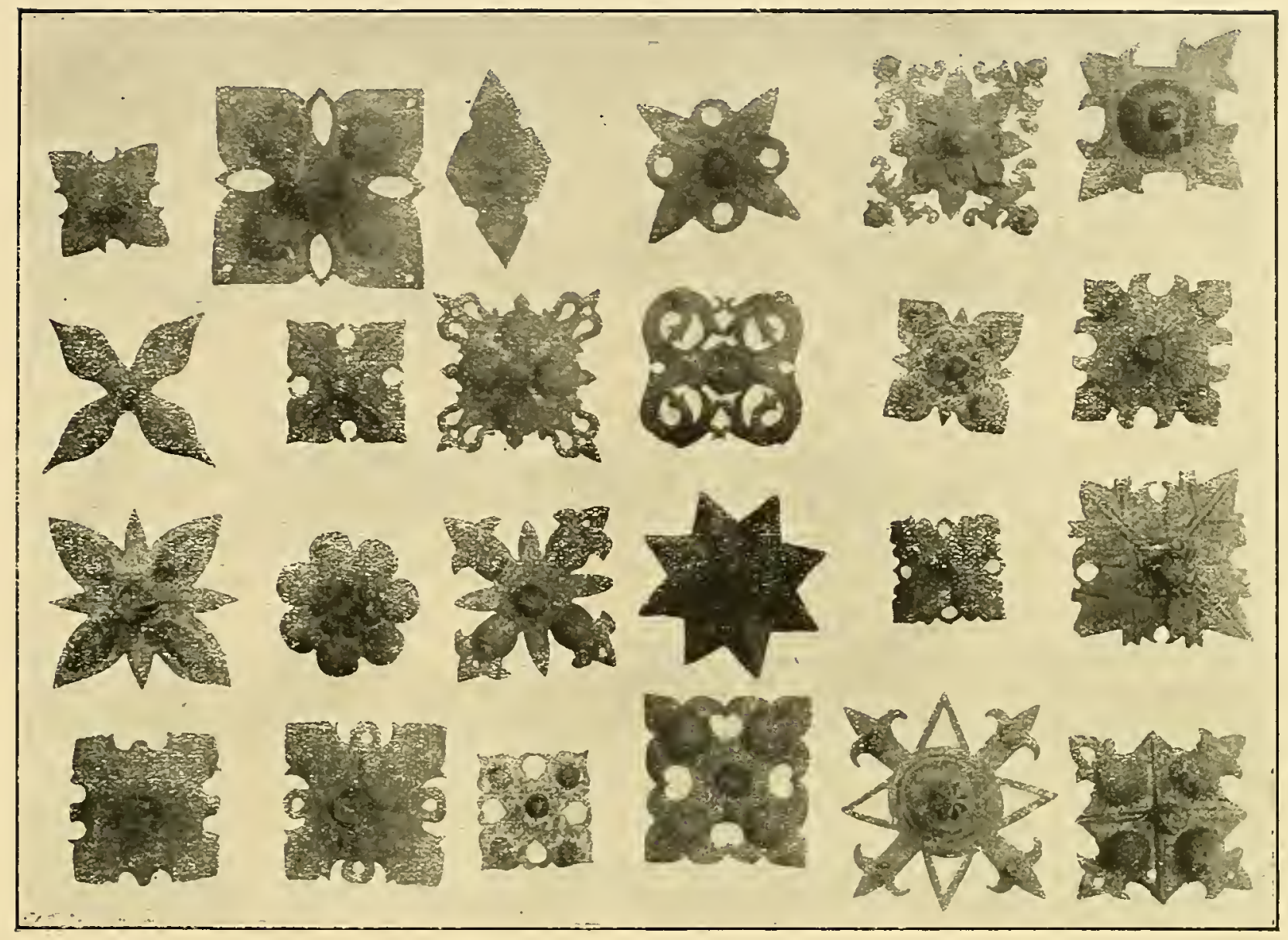

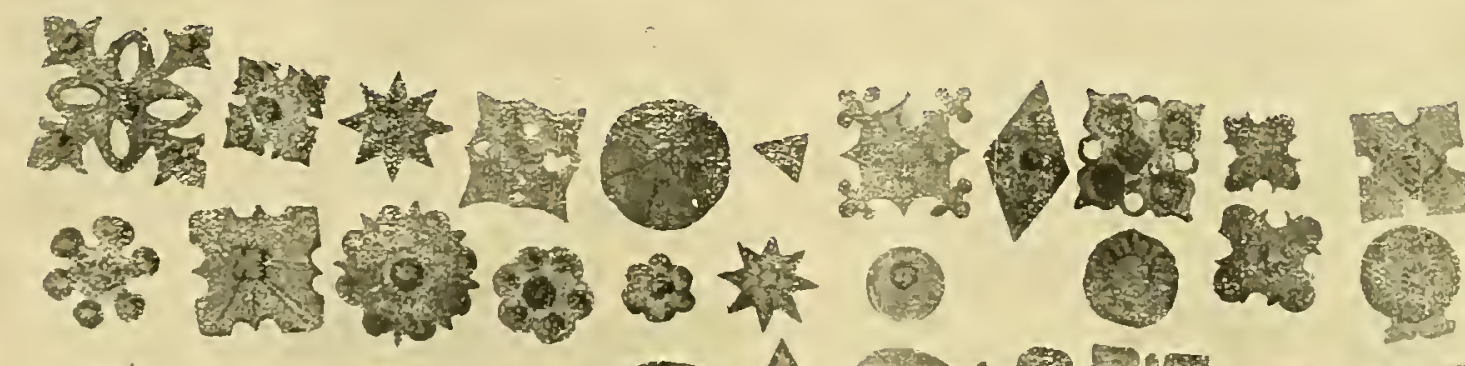

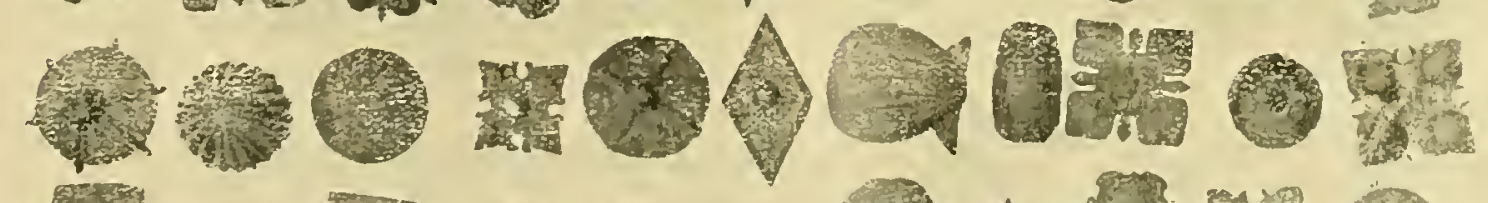

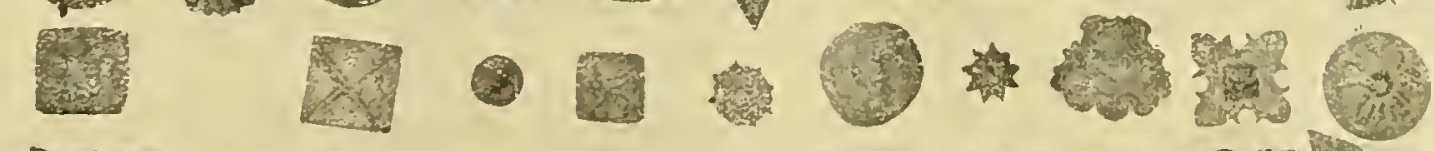
54 6 -

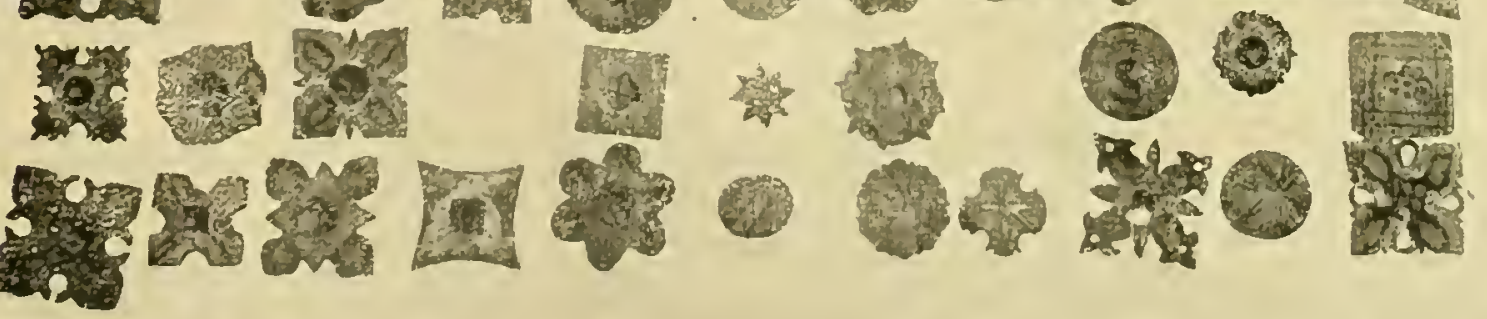



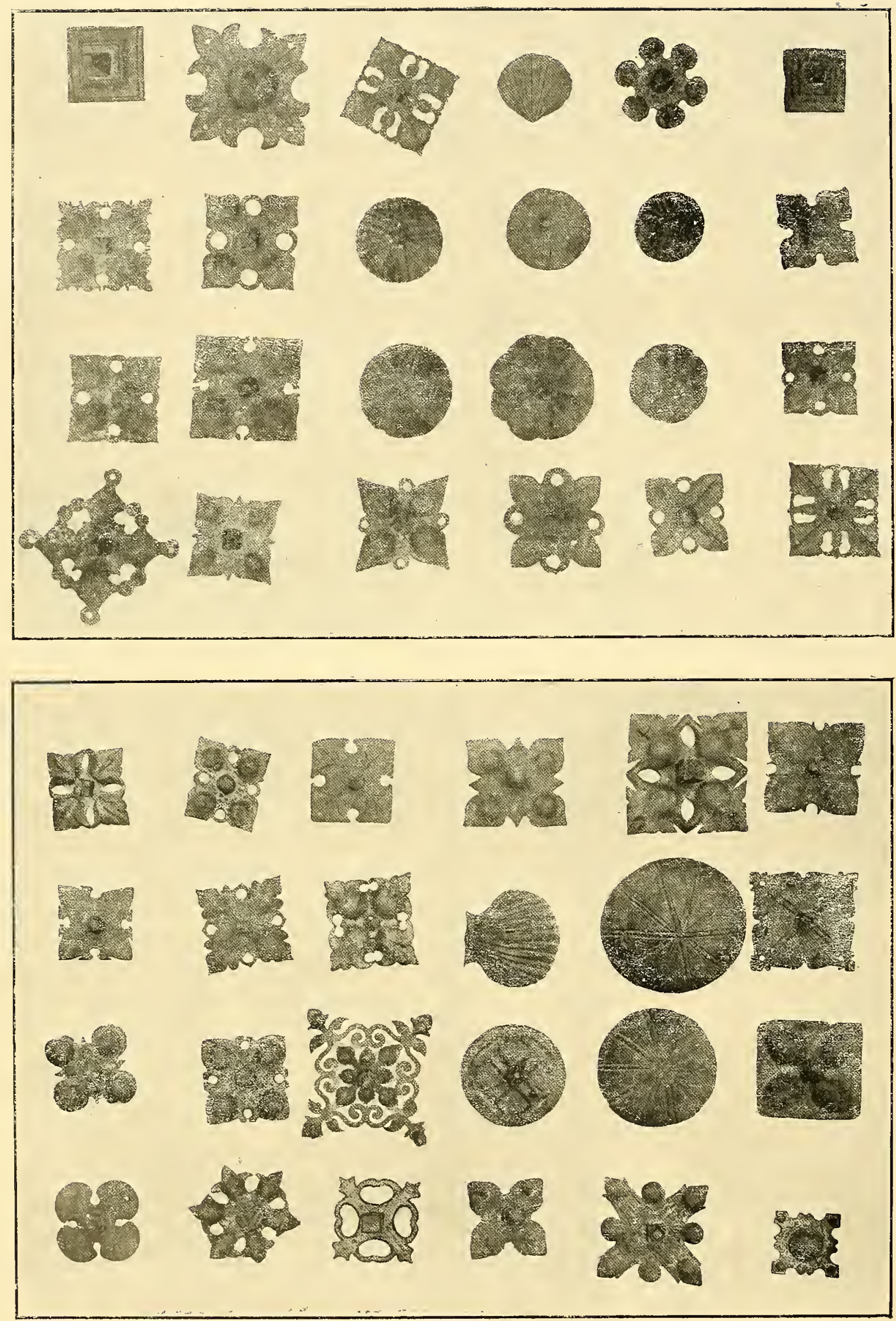

Nuim 285. 


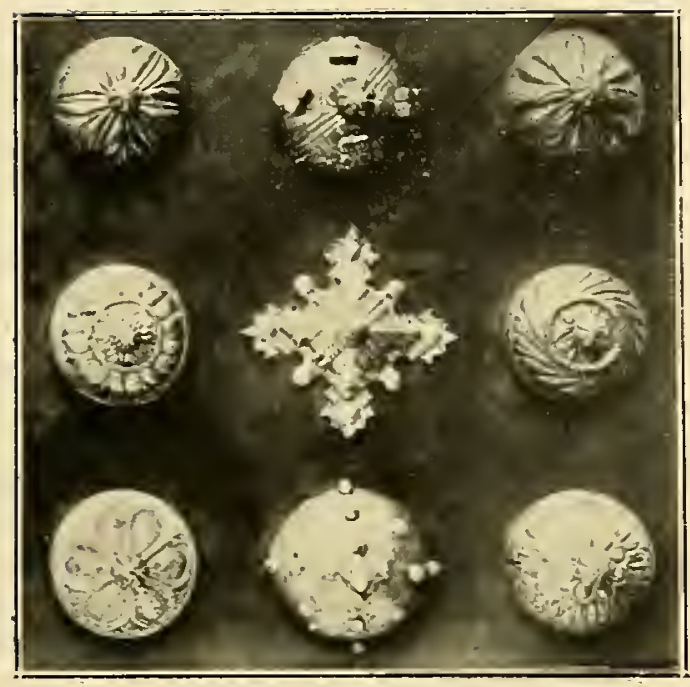

[Nủm. 286. el de la puerta de la Universidad de Salamanca.

ExpOSITOR: D. José Lázaro.

Núm. 287. Tres clavos de Cazoleta de concha lobulados tipos ya descritos.

Expositor: Sr. Grediana.

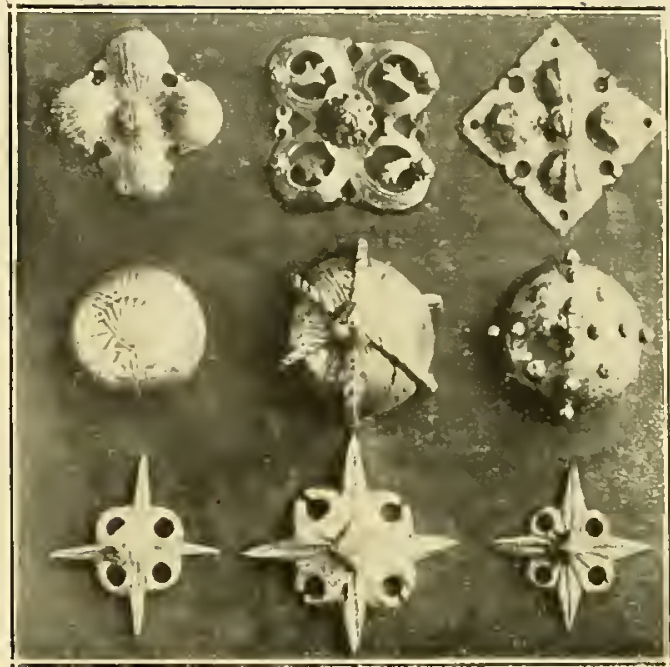

Nủm. 280.

Núm. 288.-Tres clavos góticos de Cazoleta correspondiendo a los tipos anteriormente descritos.

Expositor: D. Anastasio Páramo.

Núm. 289.-Once clavos de los tipos ya descritos.

Expositor: D. Otto Dub.

Núm. 290.-Dos clavos de cazoleta, análogos a los descritos anteriormente.

Expositor: $D$. José $A$. Weissherger.

Núm. 291. - Dos clavos de plancha recortada en dos órdenes de distinto diámetro. Expositor: Cabildo de la Catedral de Tarragona.

Núm. 292. - Dos clavos cuadrangulares de plancha recortada y realzada; ejemplares muy interesantes de la época y escuela de los de la Universidad de Salamanca.

Expositor: D. Rafael García Palencia.

Núm. 293.-Arcón forrado de cuero, de 1,44 m. de longitud por $54 \mathrm{~cm}$. de profundidad y $58 \mathrm{~cm}$. de altura. Todo él con aplicaciones de hierro, de plan-

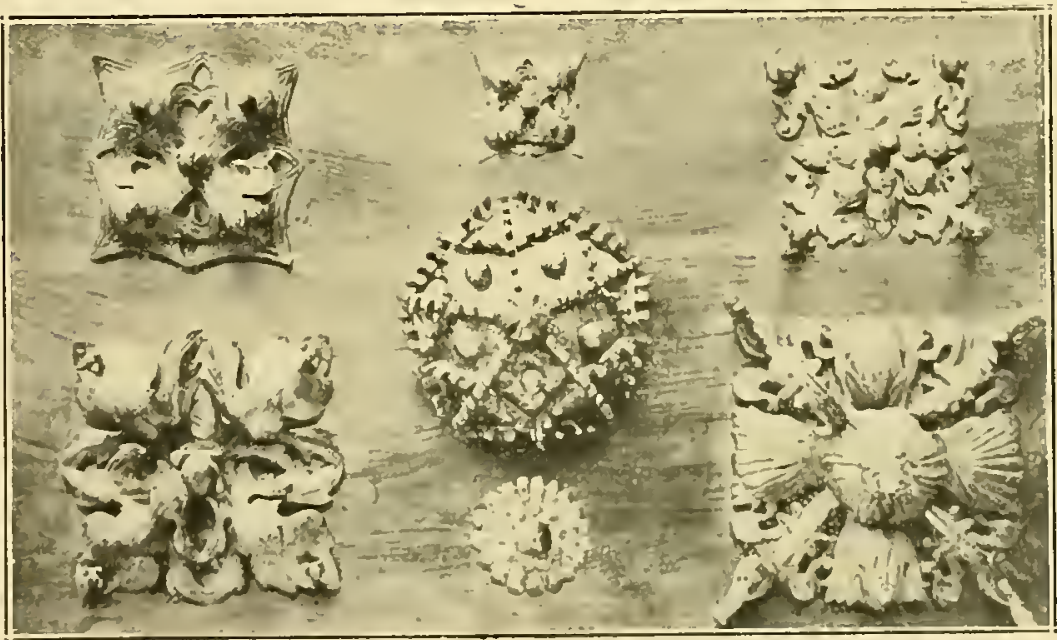

Nür. 280, 


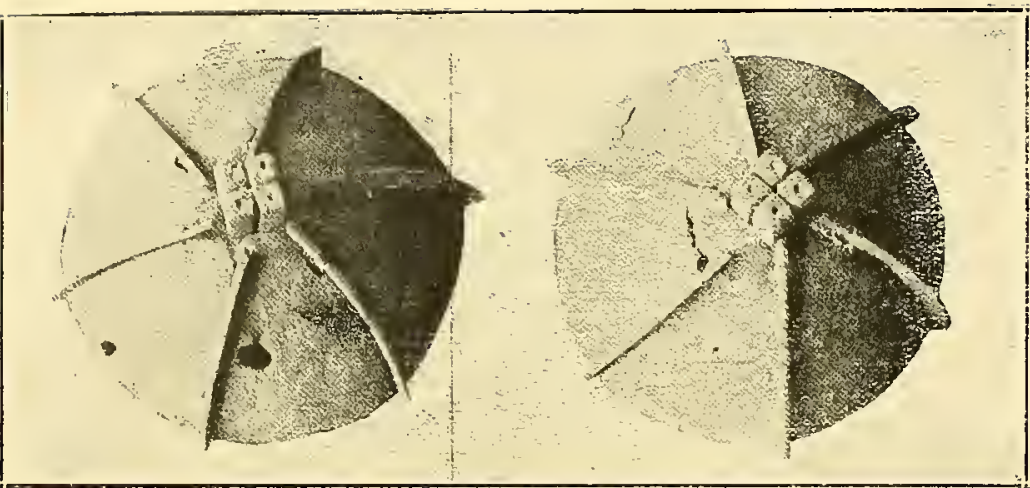

Nủm. 287.

cha recortada en discos lobulados que recuerdan flores. Los bordes estuvieron defendidos por plancha festoneada, cuya superficie es un ajedrezado de cuadrados lisos y punteados. Anterior a los Reyes Católicos.

Expositor: D. José Lázaio.

Núm. 294. - Arquita gótica, en cuero decorado, de $42 \mathrm{~cm}$. de longitud por $15 \mathrm{~cm}$. de profundidad y altura poco menos. Reforzada toda ella por varillas de hierro con discos intercalados. El decorado del cuero recuerda las ornamentaciones de los azulejos valencianos del último tercio del siglo $\mathrm{xv}$.

Expositor: D. José Lázaro.

Núm. 295.-Arquita de madera, de $55 \mathrm{~cm}$. de longitud por $15 \mathrm{~cm}$. de ancho y $15 \mathrm{cen}$ -

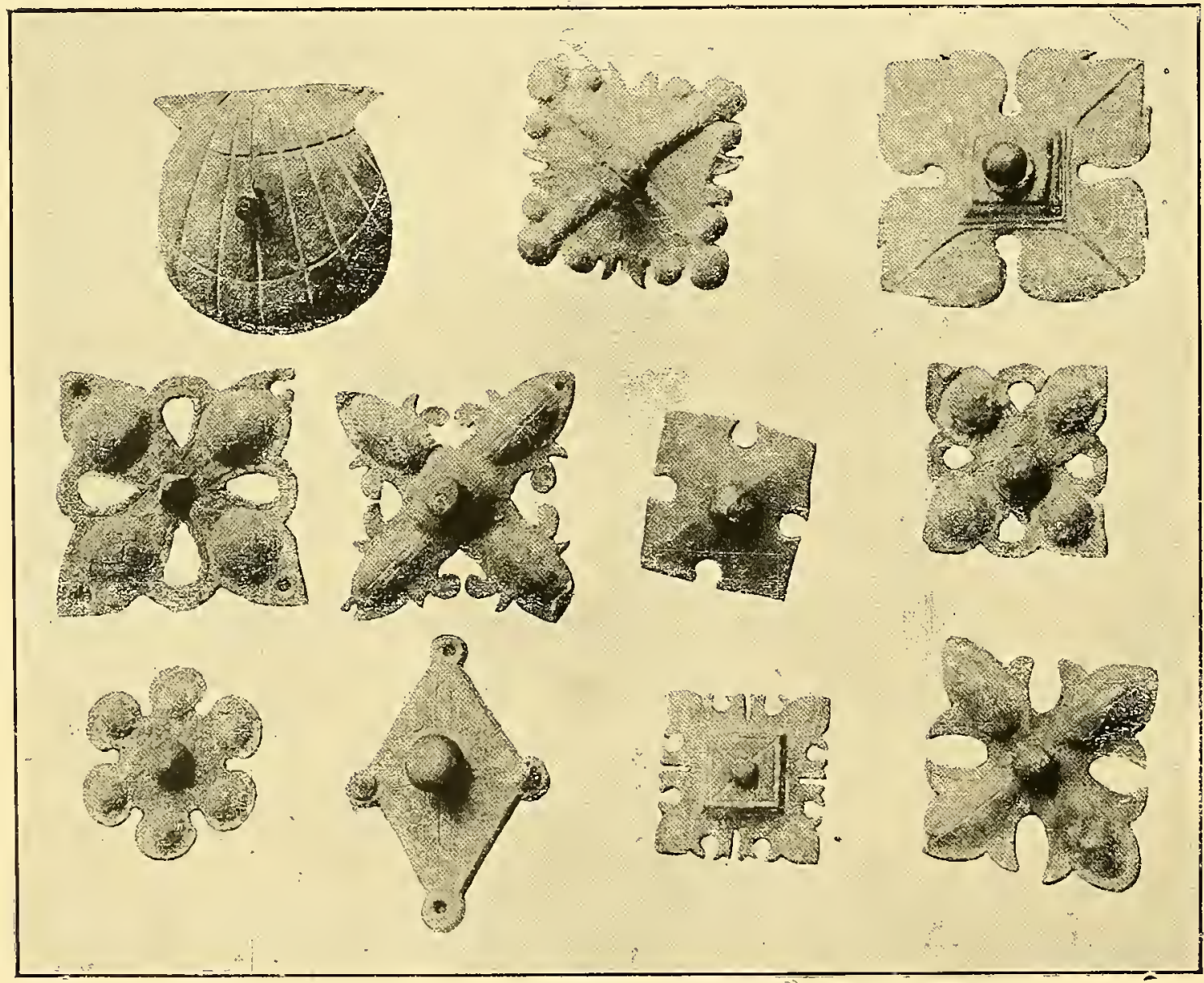

Nüm, 289. 
tímetros de altura; armada de varillas y discos como el ejemplar anteriormente descripto. Expositor: D. losé Lázaro.
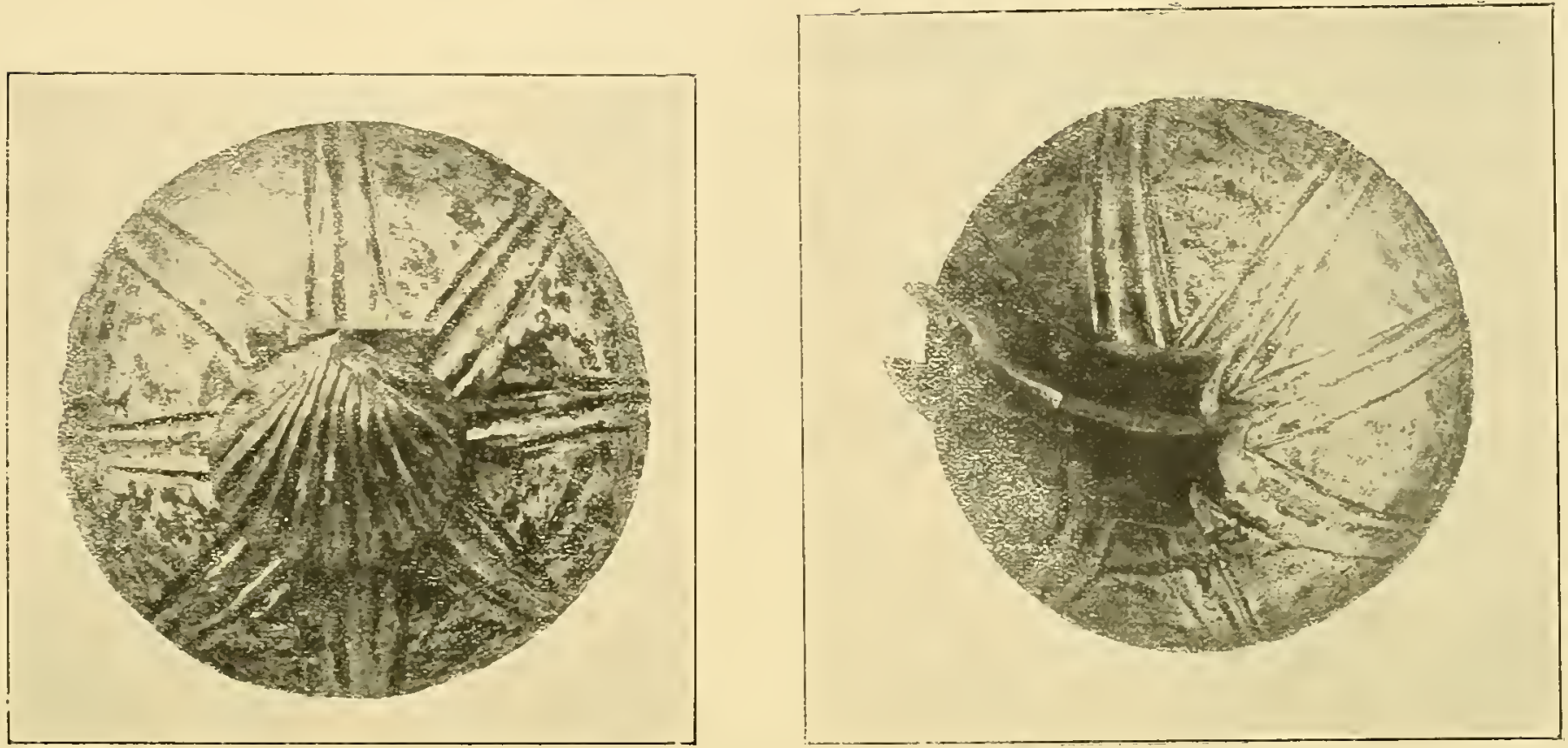

Nứm. 290.

Núm. 296.-Caja de cuero negro con herrajes de varillas y discos pentalobulados, representando flores. Siglo xv.

Largo $19 \mathrm{~cm}$., ancho $16 \mathrm{~cm}$. y alto $7 \mathrm{~cm}$.

Expositor: D. José Lázaro.

Núm. 297.--Arqueta de cuero rojo, recubierta de plancha formando cruces o flores pentalobuladas, de $37 \mathrm{~cm}$. de larga, 24 de profundidad y 20 de alta. Finales del siglo xv. Expositor: D. José Lázaro.

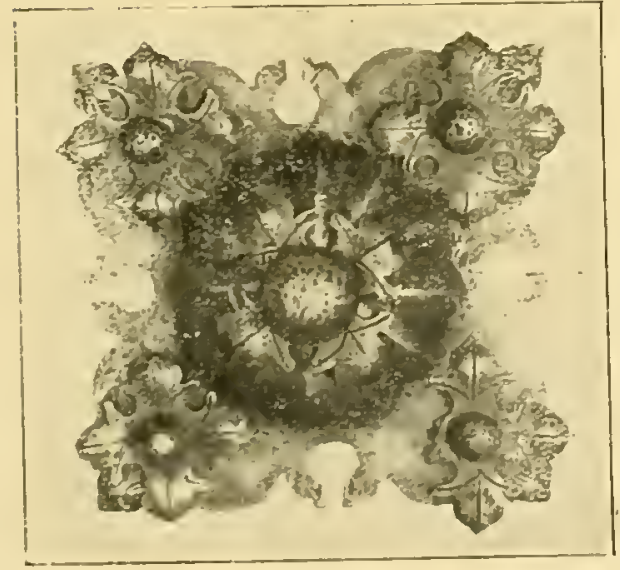

Ni(i). 292.

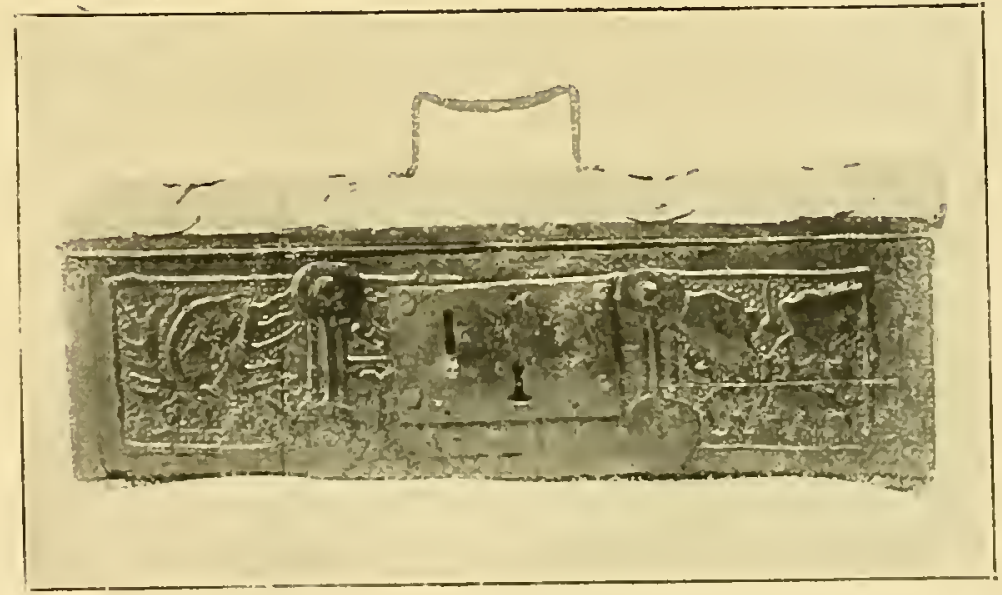

Nim, 264. 


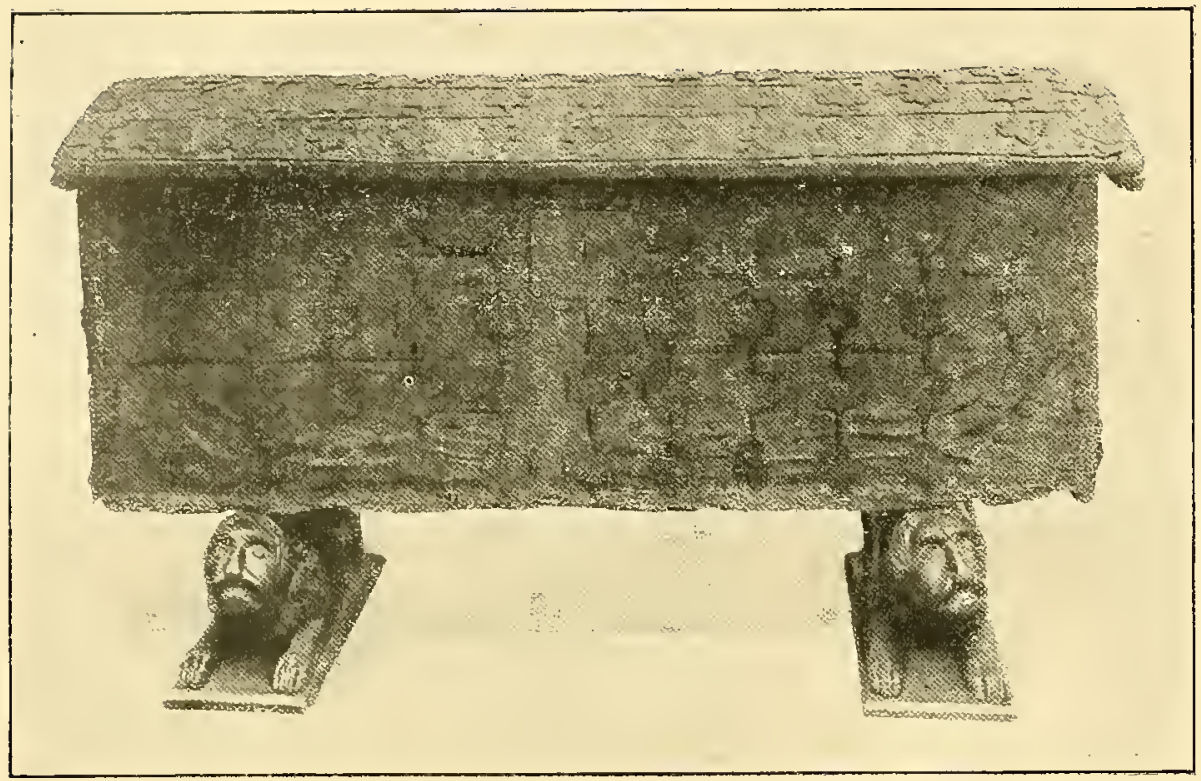

Núm. 293.

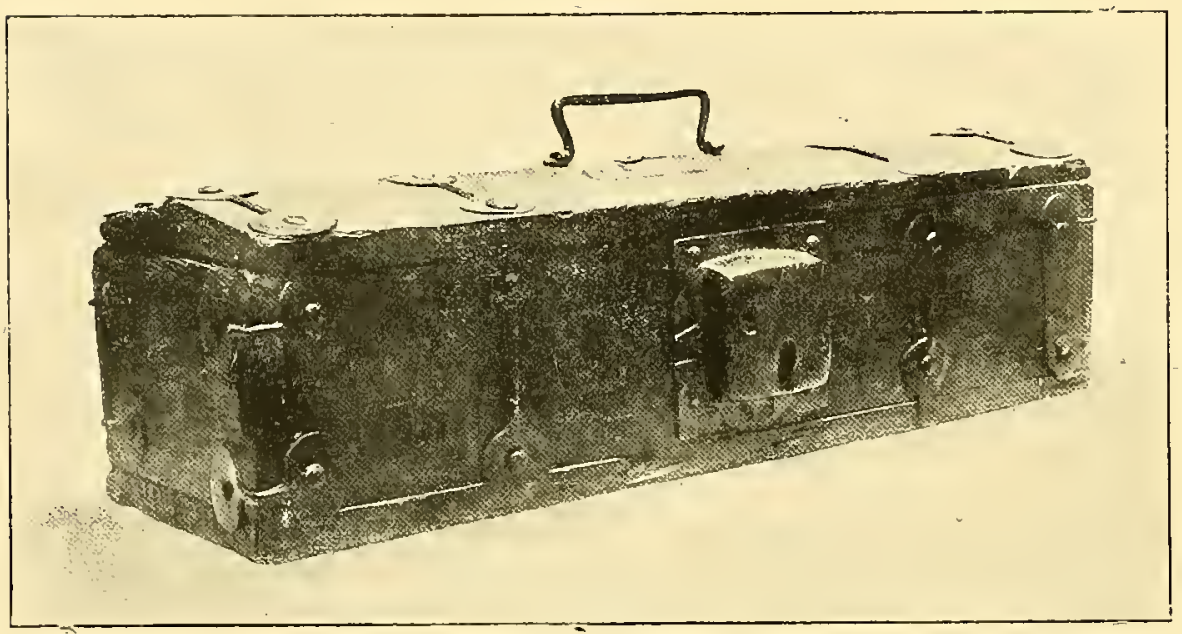

Núm. 298.-Arqueta de $44 \mathrm{~cm}$. de longitud por 22 $\mathrm{cm}$. de profundidad y 25 $\mathrm{cm}$. de altura, de terciopelo rojo, cubierto por plancha repujada, formando un ajedrezado en losange y reforzados los ángulos y bordes con ancha cenefa, también de plancha. Epoca de los Reyes Católicos.

Expositor: D. José Lázaro.

Núm. 299. - Arquita rectangular, de $23 \mathrm{~cm}$. de ancha, por 32 de profundidad y 13 de altura. Toda ella de terciopelo rojo, cubierta de plancha perforada; cerradura doble de pináculos góticos. El motivo generol es gótico y los del frente acusan la influencia del Renacimiento. Este tipo de cajas es el que figuraba en el inventario de Margarita de Borgoña en 1524, como fa-

Nüm. 295

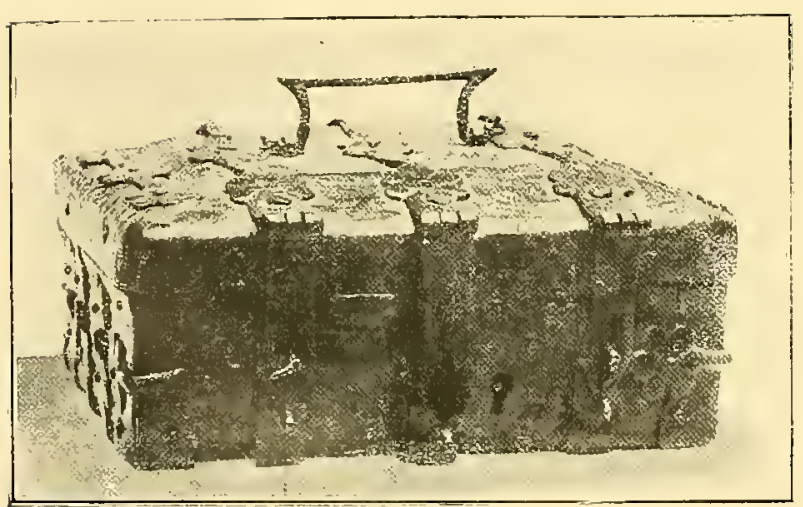

Núm. 296.

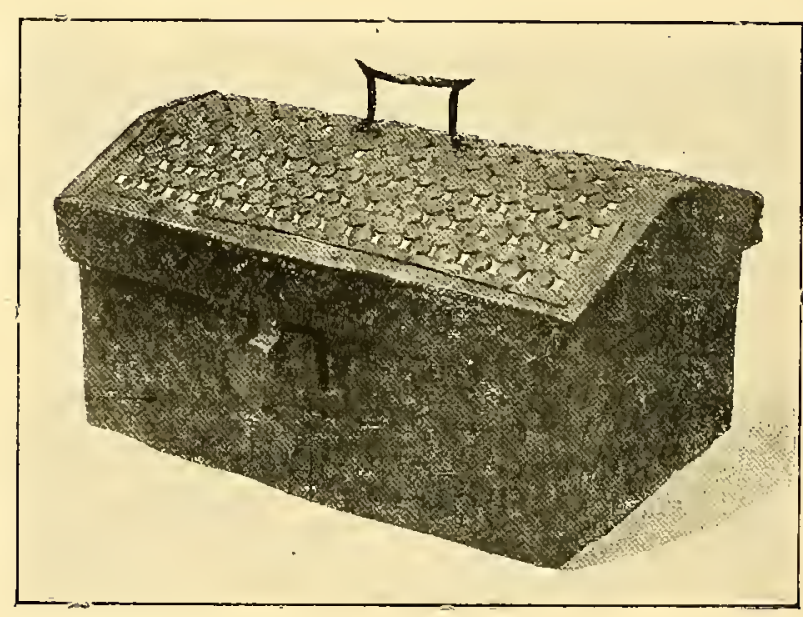

Núm. 297 
bricados a la «manière d'Espagne». Principios del siglo xvi.

Expositor: Excelentísino Sr. Conde de Guendulain.

Núm. 300.-Arqueta de cuero negra, cubierta de plancha perforada, de 18 $\mathrm{cm}$. de larga por 26 de profurididad y 13 de altura. Análoga en un todo a la que precede.

Principios del siglo xvı.

Expositor: Museo Arqueológico $\mathrm{Na}$ cional.

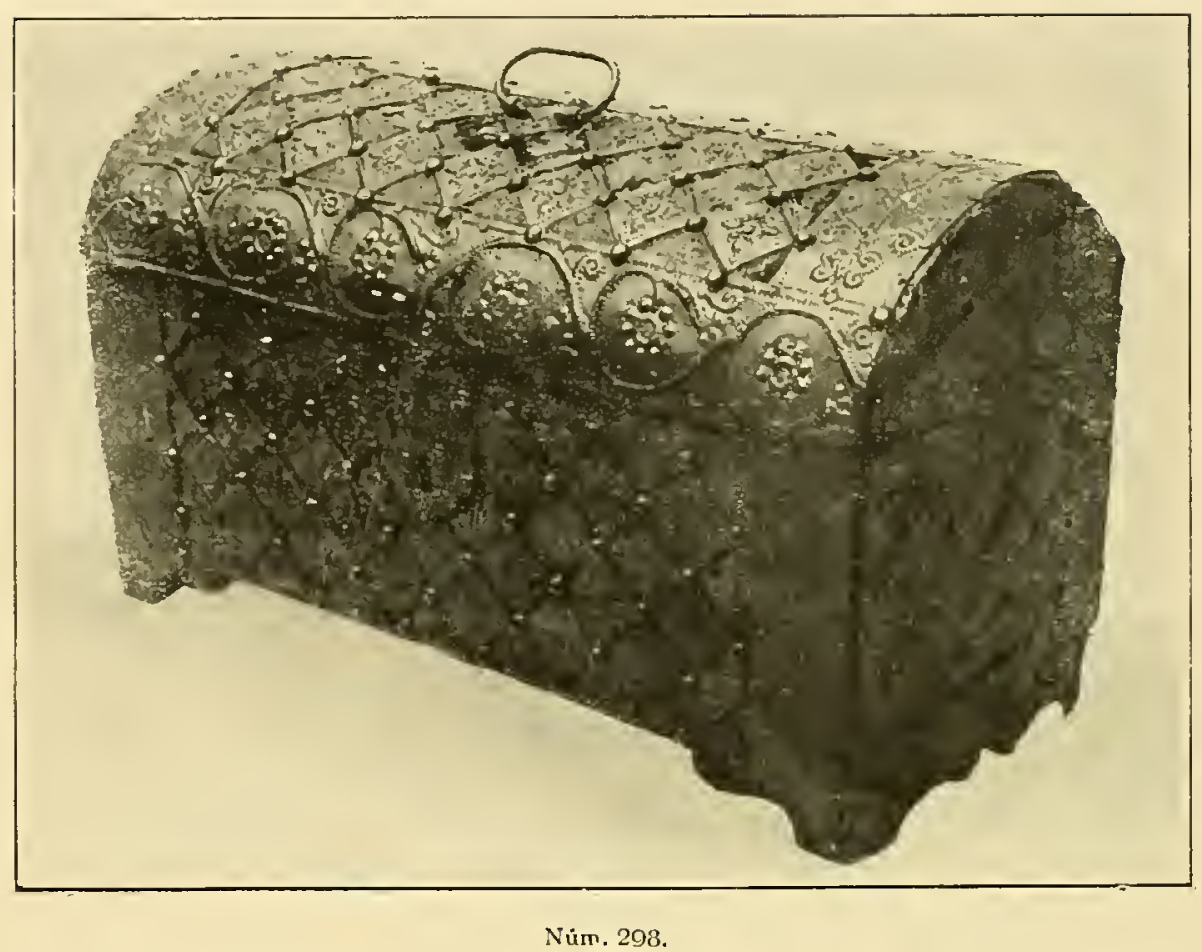

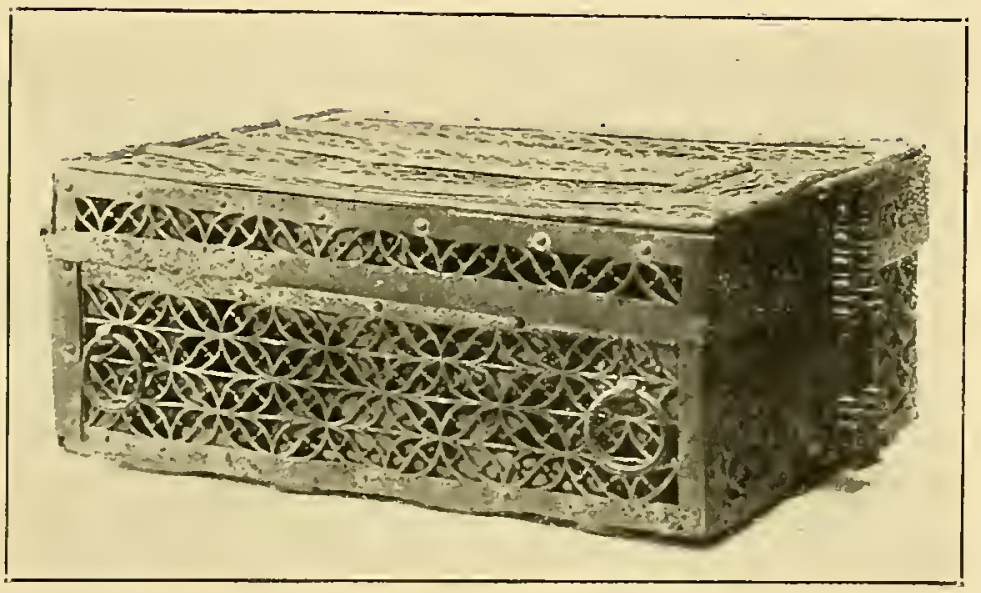

Nüm. 290.

Núm. 301.- Arqueta de cuero negro de $18 \mathrm{~cm}$. de largo por $26 \mathrm{~cm}$. de profundidad y más de $12 \mathrm{~cm}$. de altura. Ejemplar idéntico a los precedentes. Principios del siglo xvı.

\section{Expositora: Excma. Sra. Mar- quesa de Bermejillo del Rey.}

Núm. 302.-Arqueta de cuero negro decorado, de $51 \mathrm{~cm}$. de ancho por $26 \mathrm{~cm}$. de ancho y $28 \mathrm{~cm}$. de alto.

Tapa de sección poligonal. Epoca de los Reyes Católicos.

\section{Expositora: Doña Beatriz Lafora.}

Núm. 303.-Arqueta gótica con candado de bola, toda ella trabajada en dos y tres órdenes de planchas caladas, con inscripción en una de las caras. Decoración gótica minuciosa, pináculos en los ángulos, toda ella trabajada dentro del gusto gótico del tiempo de los Reyes

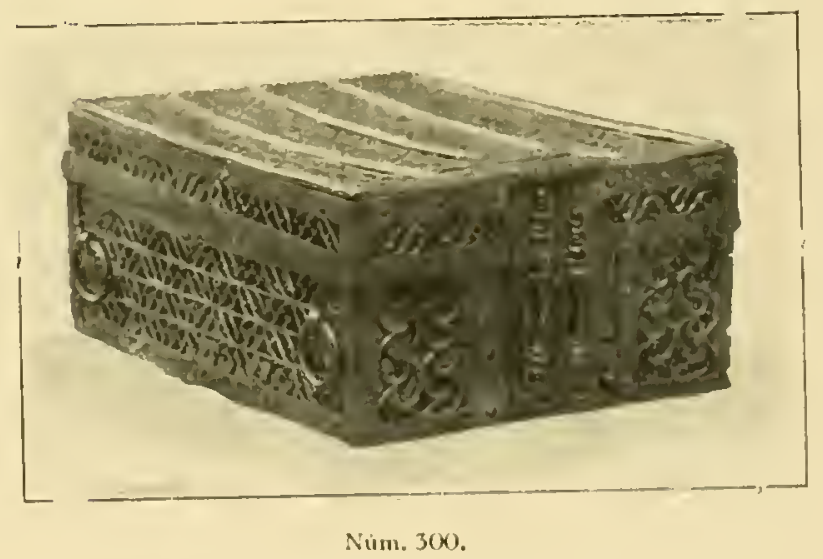




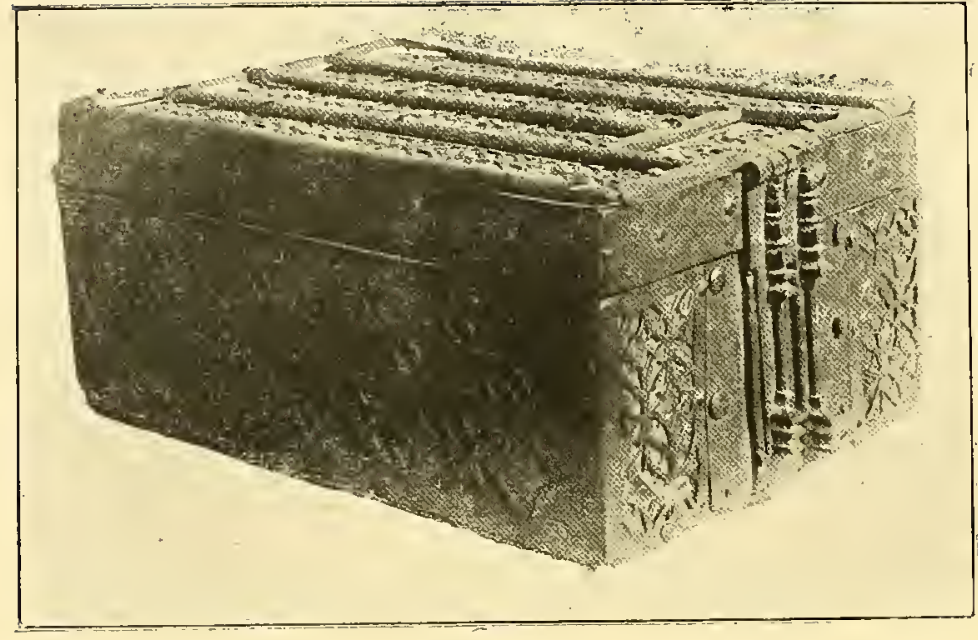

Núm. 301 .
Católicos. Mide $17 \mathrm{~cm}$. de larga por 15 de ancha y por 11 de alta.

\section{Expositora: Sra. de Lázaro.}

Núm. 304.-Arcón de piel con aplicaciones de hierro de 1,19 de longitud por $48 \mathrm{~cm}$. de profundidad y 52 de altura. Dos cerraduras góticas de conchas y candado en medio. Coronación de doble chapa calada. Finales del siglo xv.

\section{Expositor: Jinta de $\mathrm{Mu-}$ seos de Barcelona.}

Núm. 305. - Arcón de piel con aplicaciones de hierro y cerraduras góticas, $94 \mathrm{~cm}$. de largo, 49 de profundidad y 55 de altura máxima. Tapa semicilíndrica. El motivo ornamental que decora el borde de la tapa está trabajado en doble plancha calada. Cerradura con conchas. Epoca de los Reyes Católicos.

Expositor: D. Juan Lafora.

Núm. 306.-Arcón gótico de $87 \mathrm{~cm}$. de longitud por 46 de profundidad y 54 de altura. Análogo en un todo al que precede, diferenciándose de él en tener dos cerraduras en lugar de una. Epoca de los Reyes Católicos.

Expositor: D. José A. Weissberger.

Núm. 307. - Arcón gótico de $1,09 \mathrm{~m}$. de longitud por 45 de profundidad y 55 de altura. Tapa de sección poligonal, forrado todo él de terciopelo rojo. Dos cerraduras y un candado central.

Estilo de la época de los Reyes Católicos.

Expositora: Excelentísima Señora Duquesa de Parcent.

Núm. 308. - Arcón gótico, de $65 \mathrm{~cm}$. de longitud por $58 \mathrm{~cm}$. de pro-

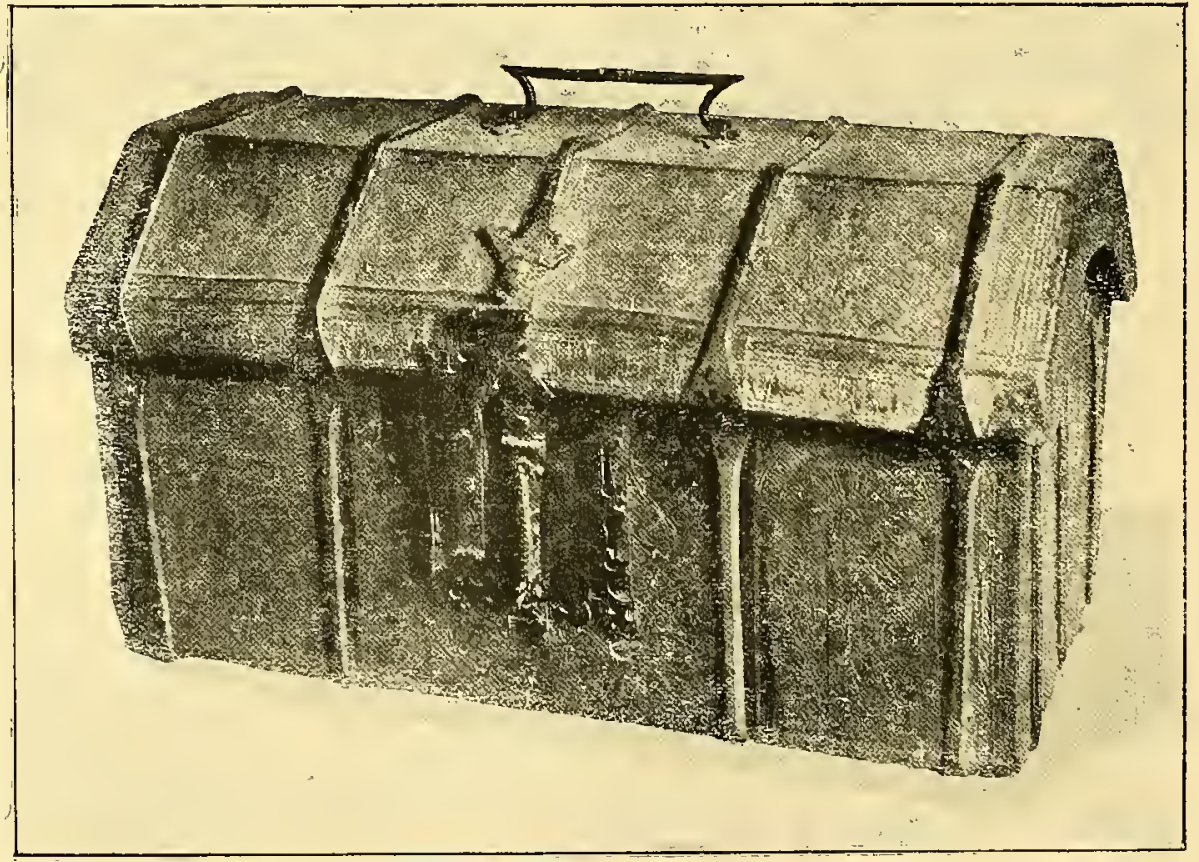

Nứm. 302. 
fundidad y $33 \mathrm{~cm}$. de altura, en cuero labrado, con herrajes, dos cerraduras góticas de conchas y candado central. Epoca de los Reyes Católicos.

Expositor: Excma. D:putación Provincial de Segovia.

Num. 309. - Arquilla de cuero decorado, de 43 centímetros de longitud por 28 de ancha y $24 \mathrm{~cm}$. de alta. Una cerradura de conchas y dos laterales para candados, con pináculos góticos. Epoca de los Reyes Católicos.

Expositora: Excelentisima Sra. Duquesa de Parcent.

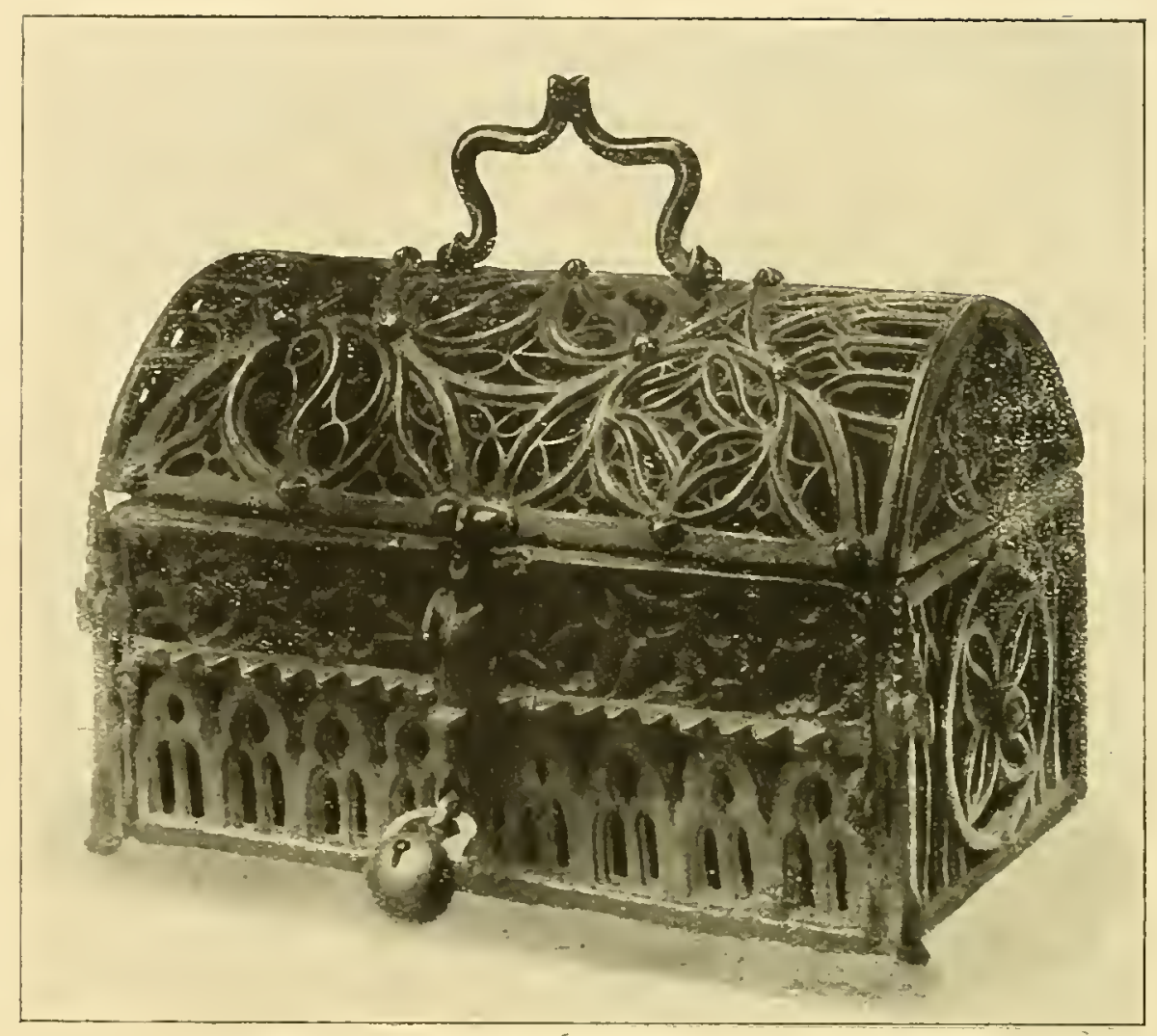

Nürn. 303.

Núm. 310.-Cerradura de cuatro conchas, decorada por pináculos góticos de plancha calada, terminados por conos. Ejemplar del tiempo de los Reyes Católicos.

Expositor: Excmo. Si. Marqués de Bay.

Núm. 311. - Candado de bola. Ejemplares usados en el tiempo de los Reyes Católicos. Expositora: Excma. Sra. Marquesa de Bermejillo del Rey.

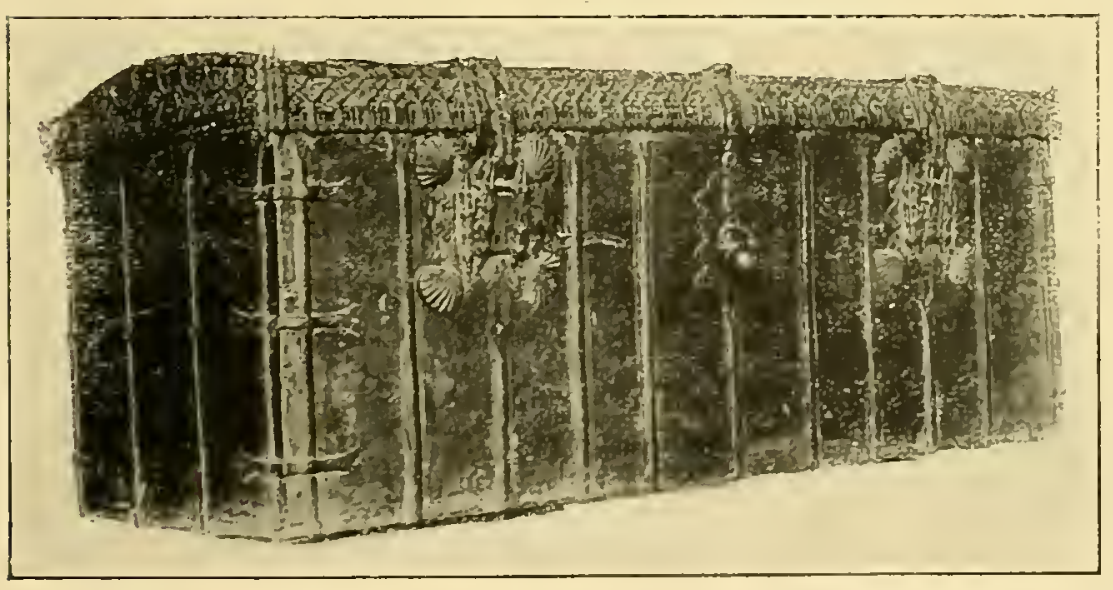

Nim. 301.
Núm. 312. - Candado de bola análợo al precedente.

Exiositor: D. Lugchio Gimano Regnie:.

Núm. 315.-Candelabro de corona, decorado con dos grifos y escudos, ostentando una campana. Decoración en plancha recortada y repujada, vástago central circular con anillo. 


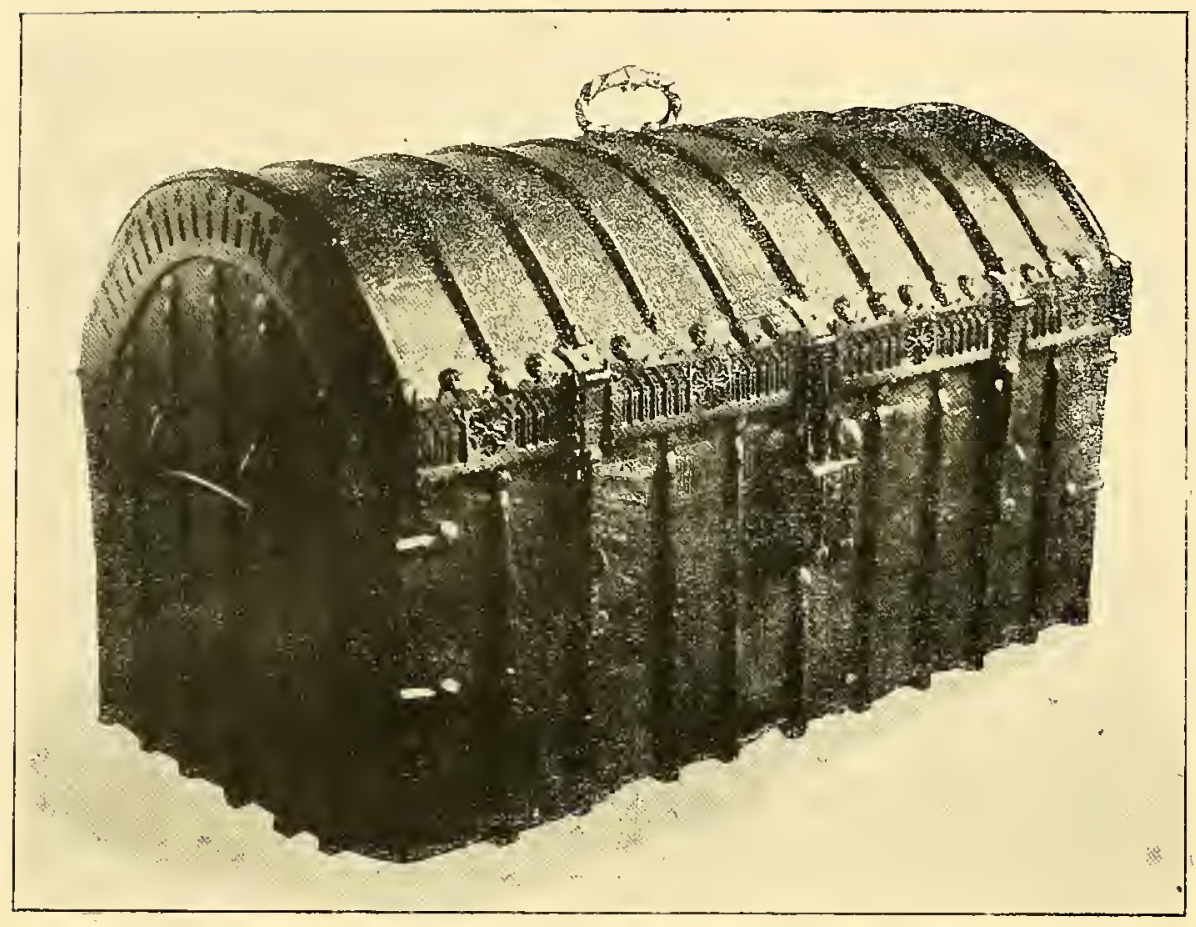

Nürn. 305.
Ejemplar extraordinariamente interesante del tiempo de los Reyes Católicos.

Expositor: Junta de Museos de Barcelona.

Núm. 311.- Candelabro de corona de luz, de $1,70 \mathrm{~m}$. de alto, con cuatro grifos que sostienen candeleros en pincho sobre la $\mathrm{co}^{-}$ rona, y escudos en los espacios intermedios. Vástago poligonal con nudos, candelero en tubo, por generatrices que terminan en grifos.

Restos de haber sido dorado. Ejemplar interesantísimo y de la época de los Reyes Católicos. Expositor: Junta de Museos de Barcelona.

Núm. 3।5.- Veleta de hierro forjado, formada de lirios y flores, con un gallo por remate añadido al darle la aplicación dicha.

Procede del pueblo de San Miguel, colindante a la Cerdeña Española y Francesa.-Mide $1.79 \mathrm{~m}$. de altura. Siglos xv y xvı.

Expositor: Junta de Museos de Barcelona.

Núm. 316.- Reja de $2 \mathrm{~m}$. de longitud por 1,50 metros de ancho formada por barrotes de sección cuadrada colocados en arista y curvados en sus extremros

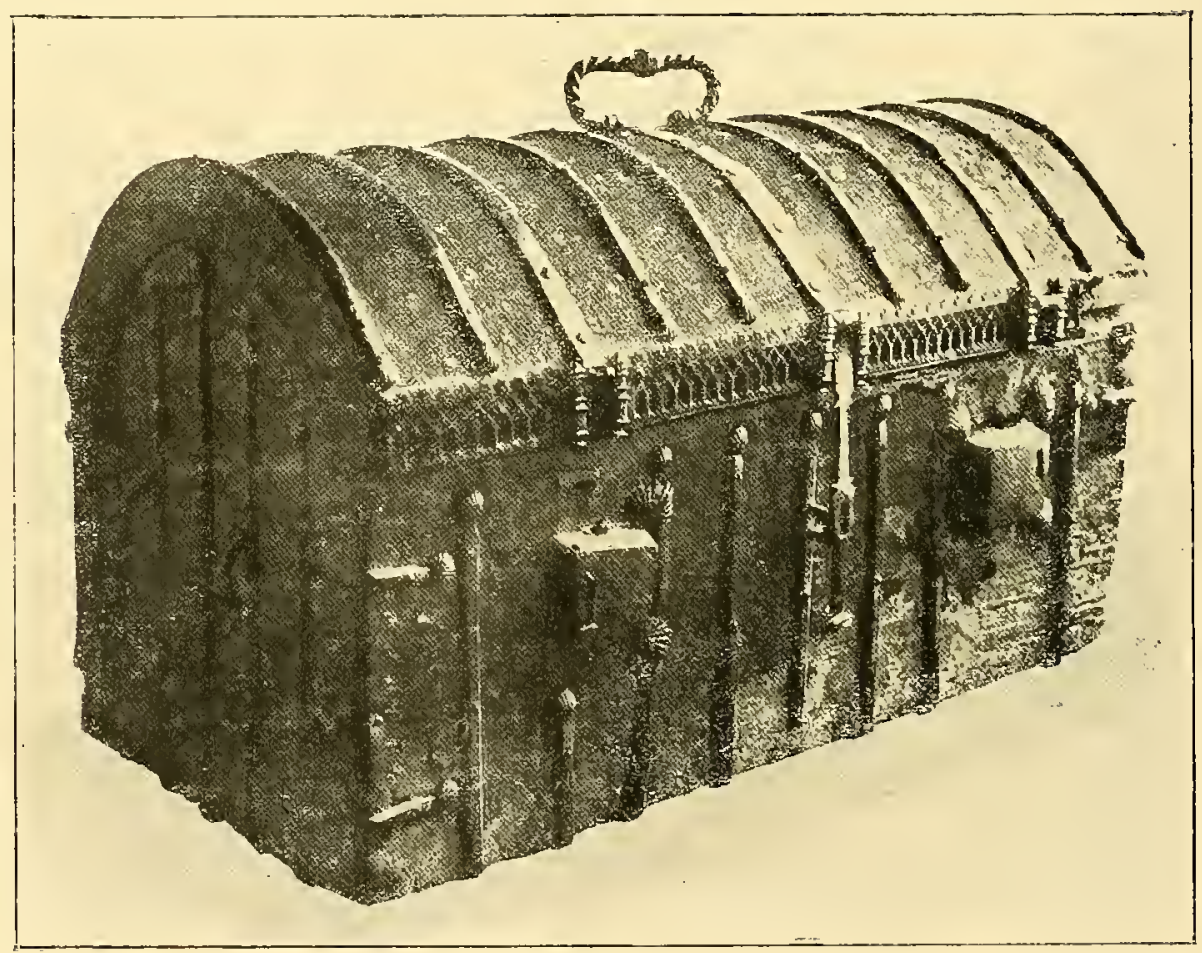

Nưm. 306. 
para empotrarla en la pared, dejando un saliente de unos $30 \mathrm{~cm}$. Presenta la particularidad, que caracteriza este tipo de rejas, de que los barrotes son en una primera mitad hembras y en el resto machos, dando el conjunto un tipo de construcción denominado enigmático. Procede de Ocaña, del Palacio de los Reyes de Castilla. Mediados del siglo xv.

Expositor: D. José de Goicoechea y Calderón.

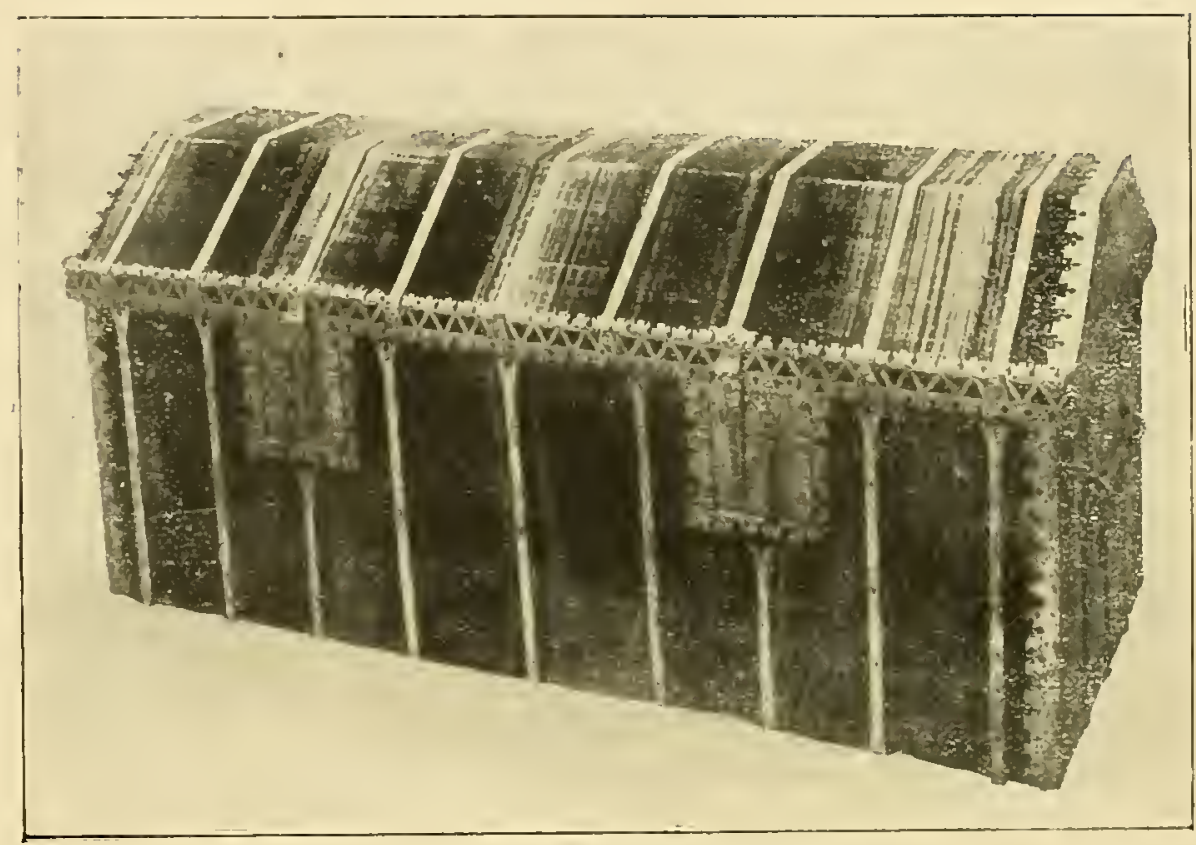

Nim. 307.

Núm. 317.-Reja de $84 \mathrm{~cm}$. de altura por $43 \mathrm{~cm}$. de ancho y de construcción análoga a la precedente. Siglo xv.

Expositor: Excmo. Sr. Marqués de la Torreciila.

Núm. 318.-Reja de 1,68 m. por 1,35 m., de barras verticales cuadradas, parcialmente retorcidos con un rombo en los tres

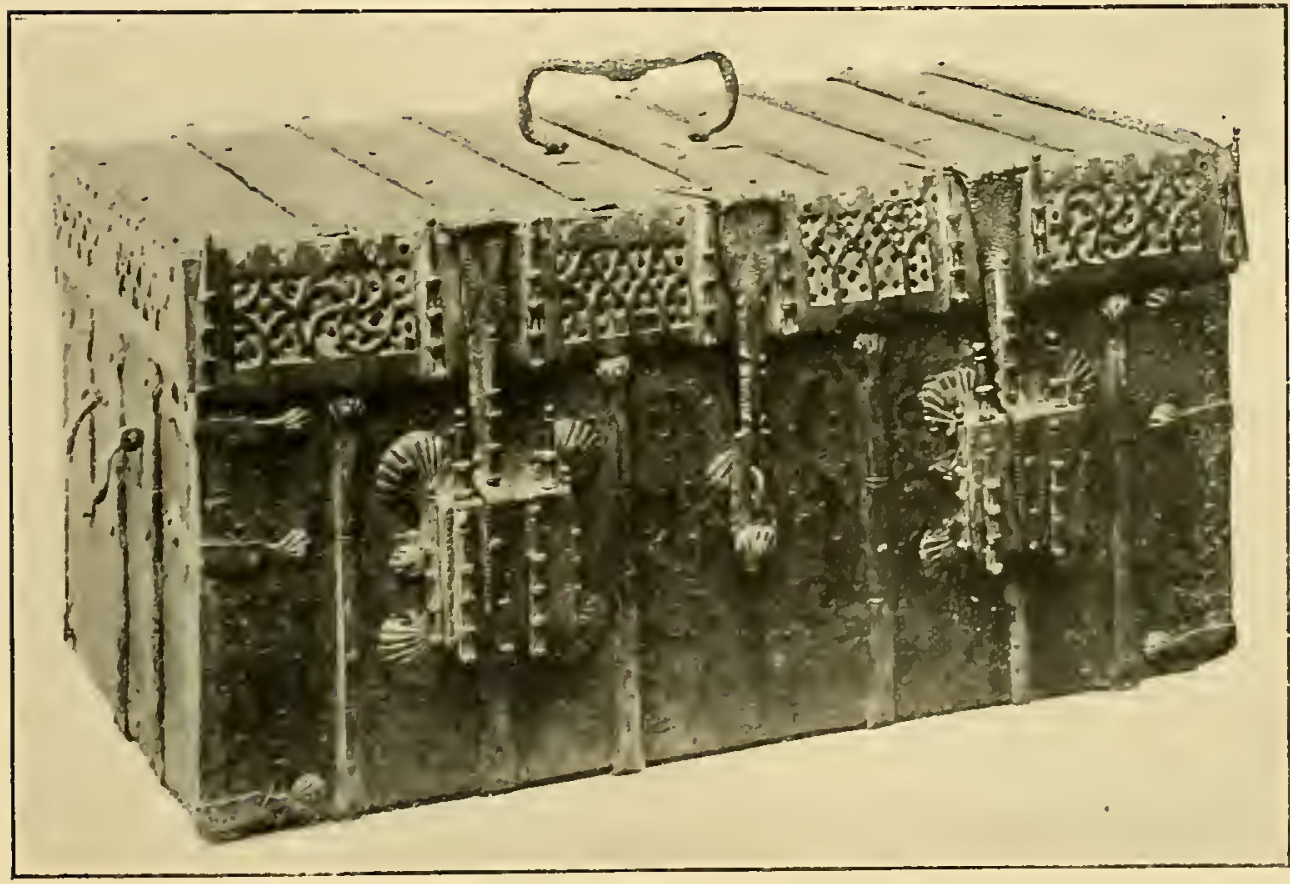

Nim 308. cuartos de su longitud. La colocación alternada de barrotes invertidos da mayor armonía al conjunto. Las barras verticales en arista. Finales del siglo $\mathrm{xv}$.

Expositor: D. José Lázaro.

Núm. 319. - Reja de $1,10 \mathrm{~m}$. de alta por $1,10 \mathrm{~m}$. de ancha, formada por barrote verticales retorcidos alternando con barrotes que se resuelven en su par- 


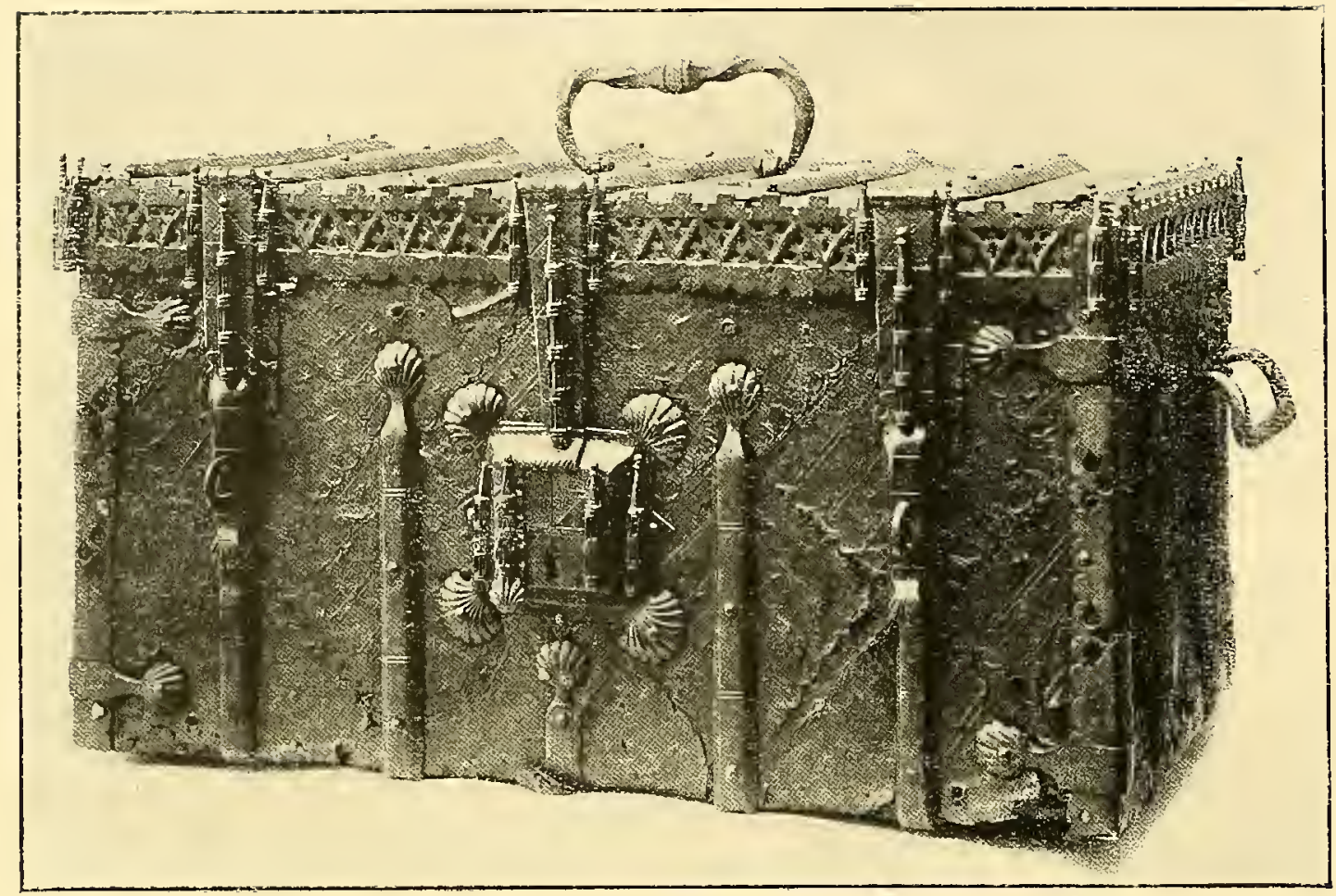

Núm. 309.

te central por corazones invertidos. Los barrotes de empotramiento terminan en cabezas de dragones.

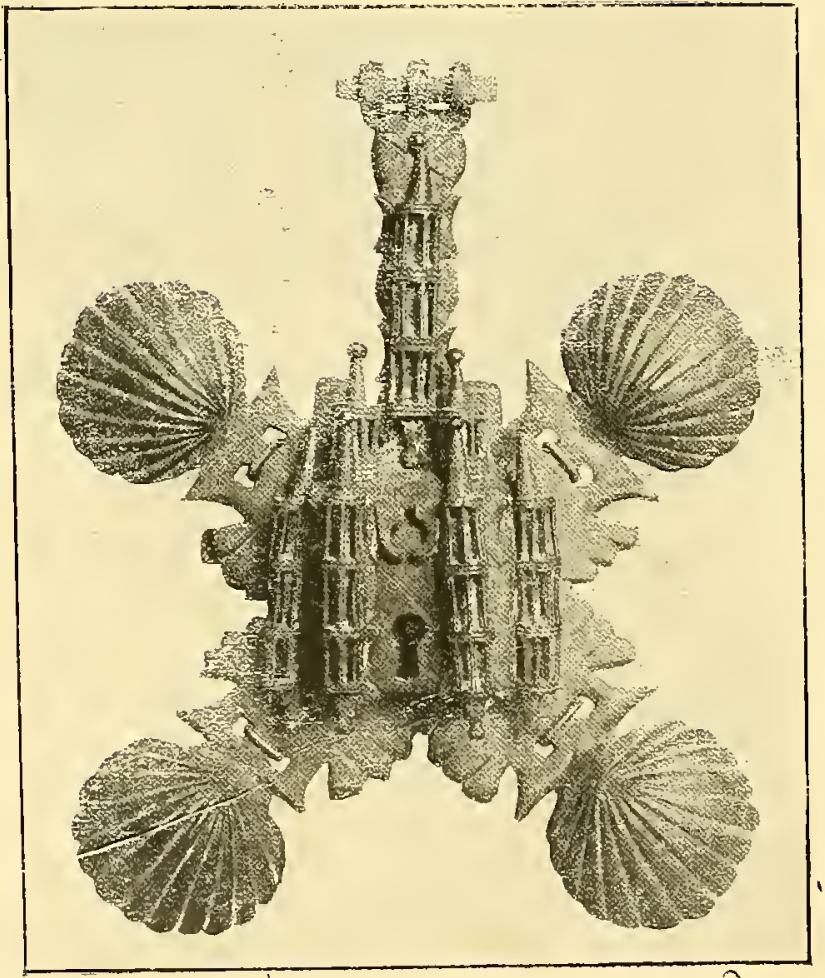

Núm. 310.
Finales del siglo xv.

Expositor: D. Fernando Márquez de la Plata y Echenique.

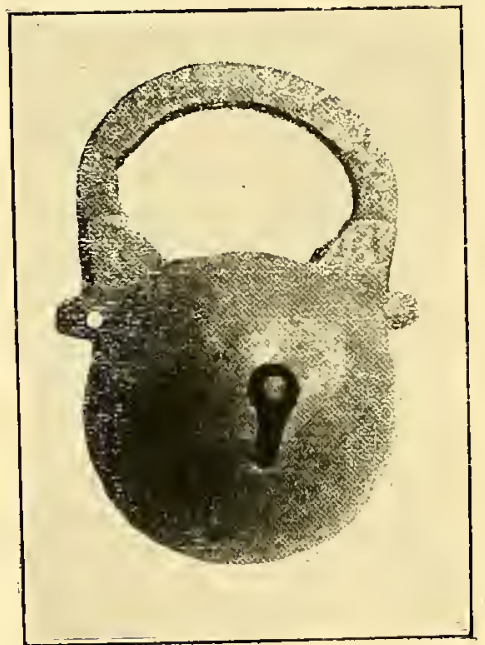

Nủm. 311. 
Núm. 520. - Reja de $42 \mathrm{~cm}$. de larga por $32 \mathrm{~cm}$. de ancha, formada por listones planos cruzados, y sujetos en su intersección por clavos de cabeza redonda adornados con chapas recortadas pentalobuladas. Procede de la provincia de Burgos. Siglo xv.

\section{Expositor: D. Domingo Guerrero, de San Sebastián.}

Núm. 321.-Reja de $1,25 \mathrm{~m}$. en cuadro, formada por elementos curvados sobre sí mismos, unidos en la voluta por grapas conteniendo un eje de doble cuña. El conjunto forma cuadrados lobulados que se unen análogamente por grapas con dobles cuñas.

El tipo recuerda exactamente las rejas venecianas y en general del Norte de Italia fabricadas a principios del siglo xvı. Procede de un convento de Salamanca.

Expositor: D. Félix Rodr'iguez Rojas.

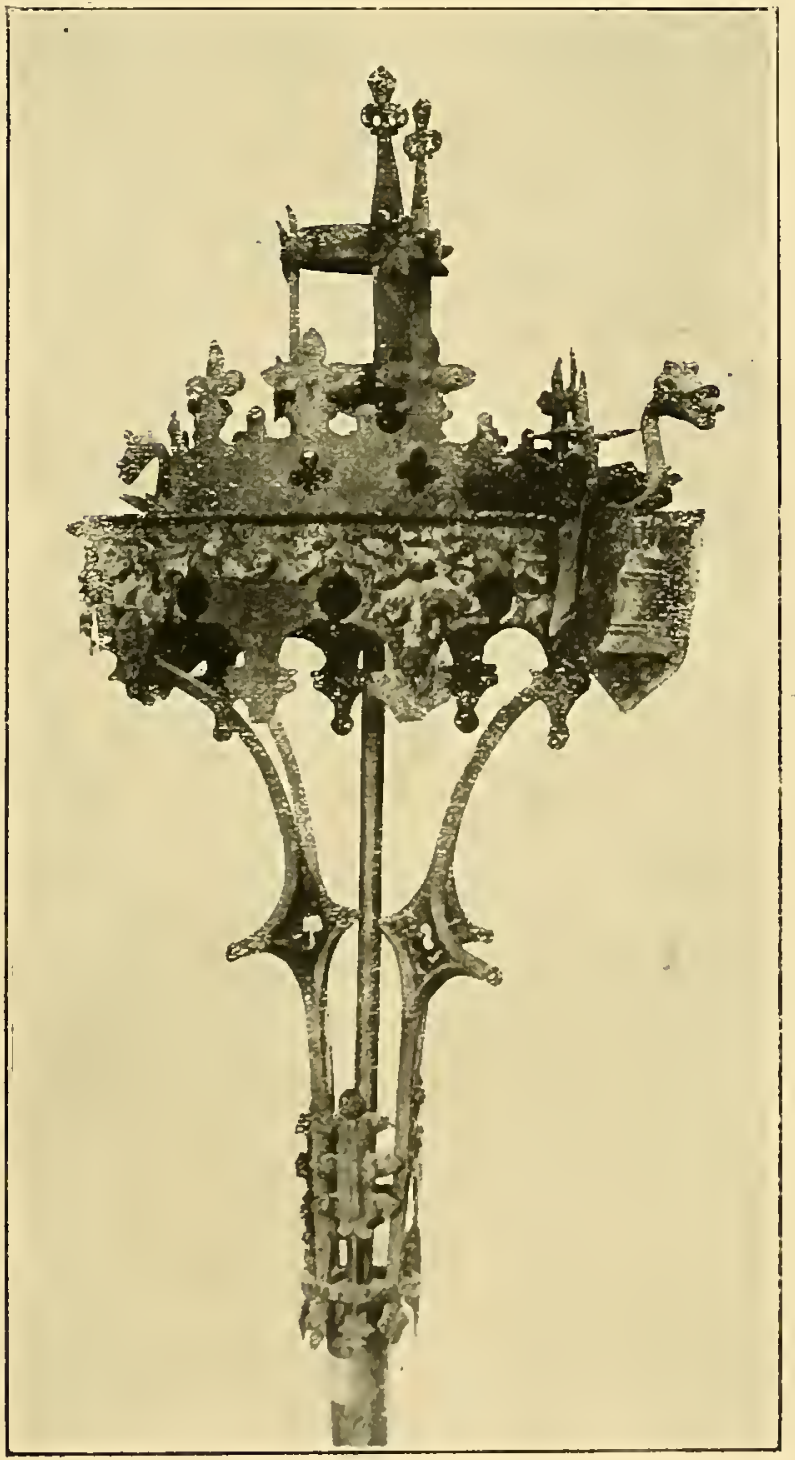

Nüm. 313

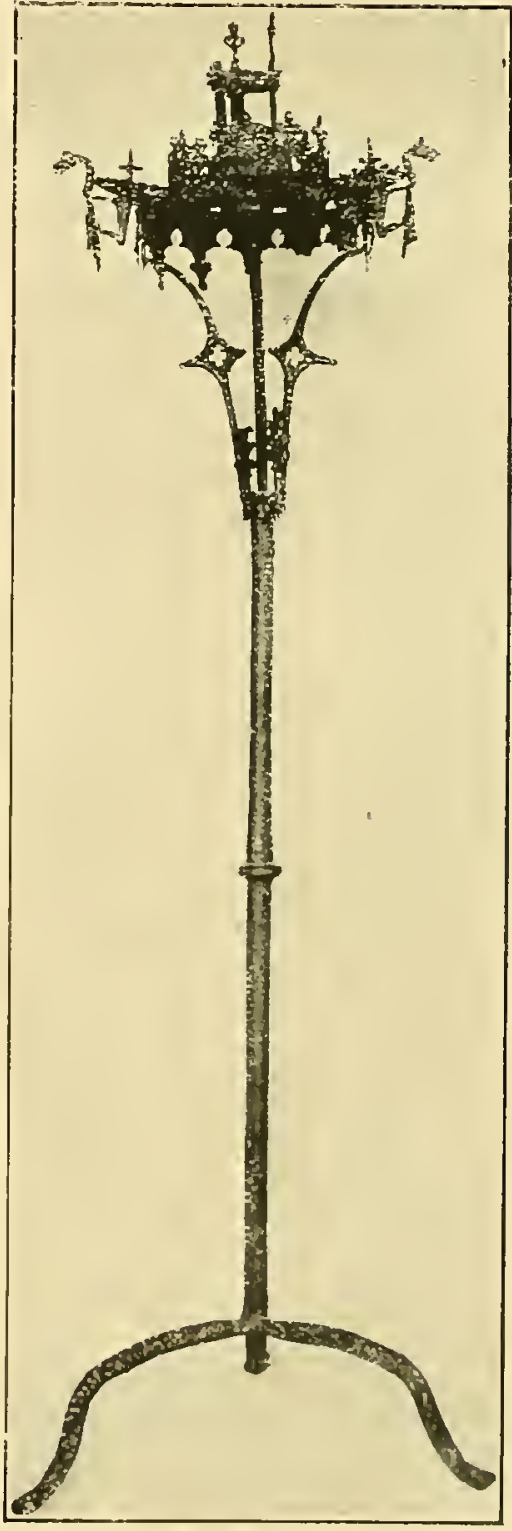

Nưนเ. 313. 


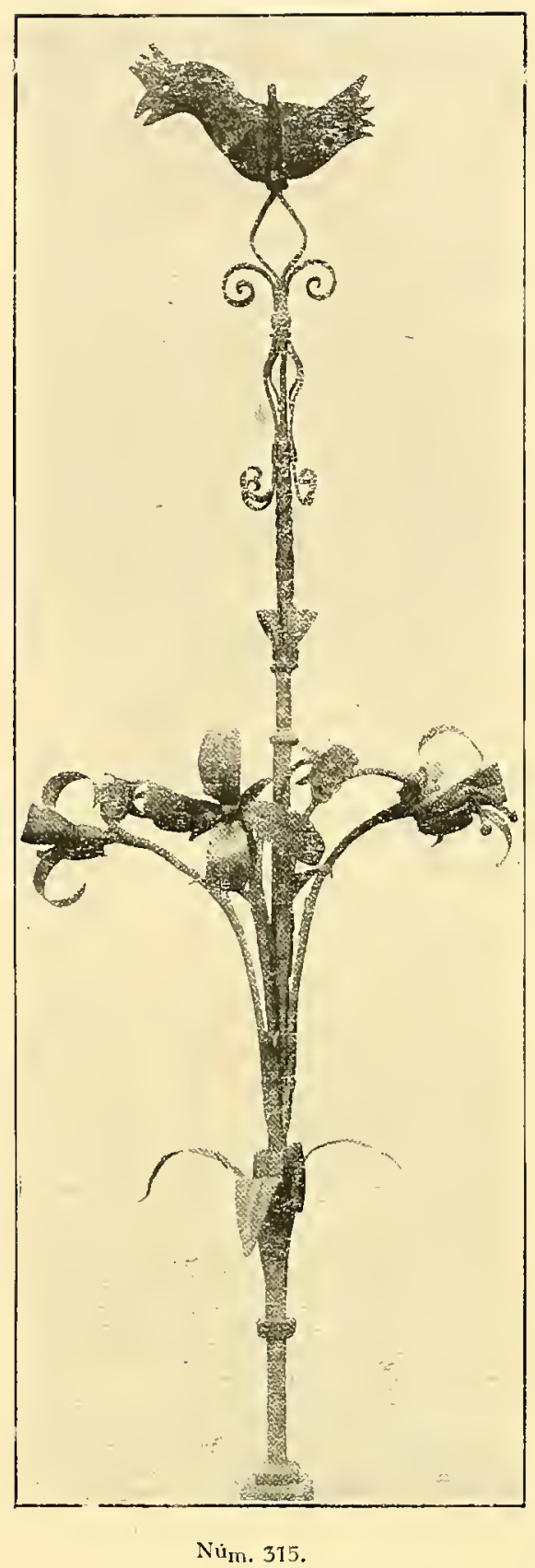

Núm. 322.- Una llave gótica con las guardas exageradamente complicadas recordando los trabajos árabes. Epoca de los Reyes Católicos.

Expositor: D. José A. Weissberger.

Núm. 323.-.-Dos hacheros de pared de plato circular 'de $33 \mathrm{~cm}$. de diámetro; en el plato central soportes para tres gruesos hachones, más otro central. El plato circular tiene una cenefa o barandilla de ocho centímetros de altura en doble plancha calada con motivos góticos flamígeros del gusto más depurado. Primer tercio del siglo xvi.

\section{Expositor: Museo Arqueológico Nacional.}

Núm. 324. - Hachero de pared de sección exagonal, cuyos vértices ocupan pináculos góticos $\mathrm{y}$ Cuyas superficies se decoran por plancha calada con motivos ornamentales de la primera época del Renaci-

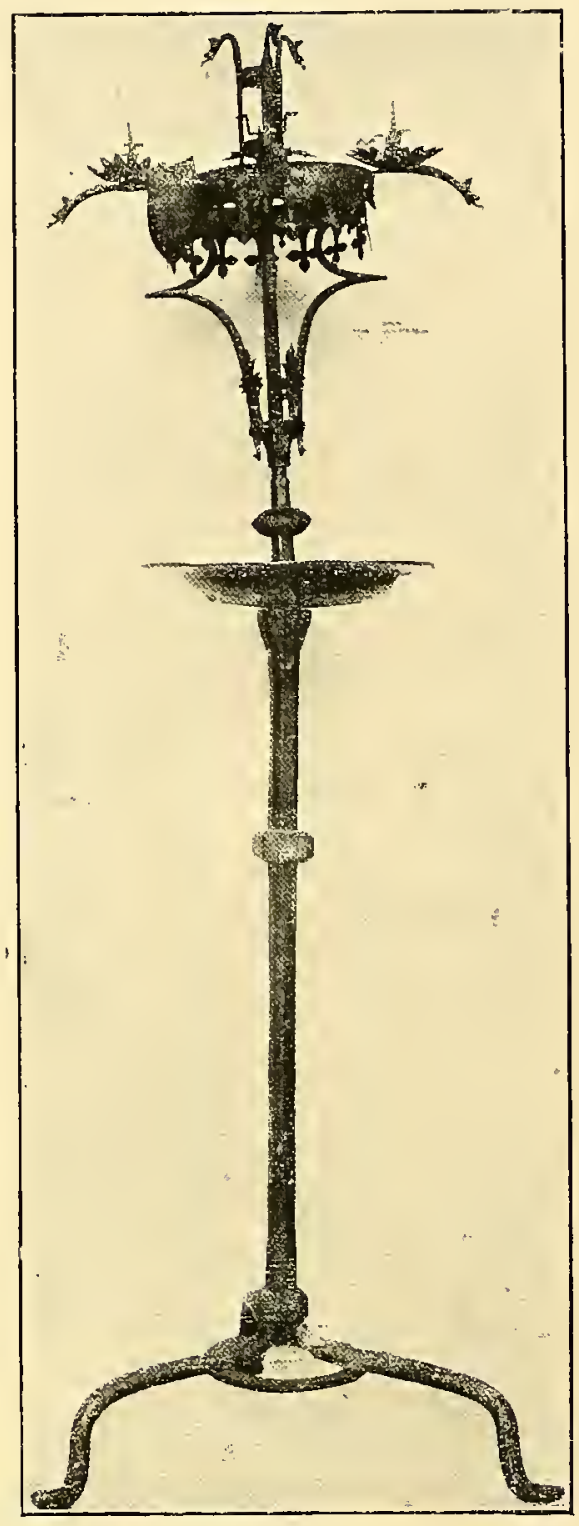

Núm. 314.

miento. Segundo decenio del siglo xvı. Fué construído para la Catedral de Burgos, de donde procede. - Altura $37 \mathrm{~cm}$.

\section{Expositon: Cabildo de la Catedral de Burgos.}

Núm. 325. - Hachero de pared análogo al precedente; las superficies poligonales están decoradas en plancha con motivos góticos. Segundo decenio del siglo xvı.

Construído también para la Catedral de Burgos de donde procede.

Expositor: Cabildo de la Catedral de Burgos. 
Núm. 326.-Dos hacheros múltiples rectangulares, de I,60 m. de largo por 26 centímetros de ancho, apoyados en cuatro pies de gruesa barra poligonal terminada en garras. El cuerpo"principal consta de dos frentes mayores, divididos por columnillas góticas macizas, y otros dos pequeños laterales. Los frentes principales están formados por una decoración gótica en dos órdenes de planchas, caladas sobre un fondo, también de plancha, que remata en un coronamiento de almenas escalonadas. Principios del siglo xvı. Expositor: Seminario Conciliar de Lérida.

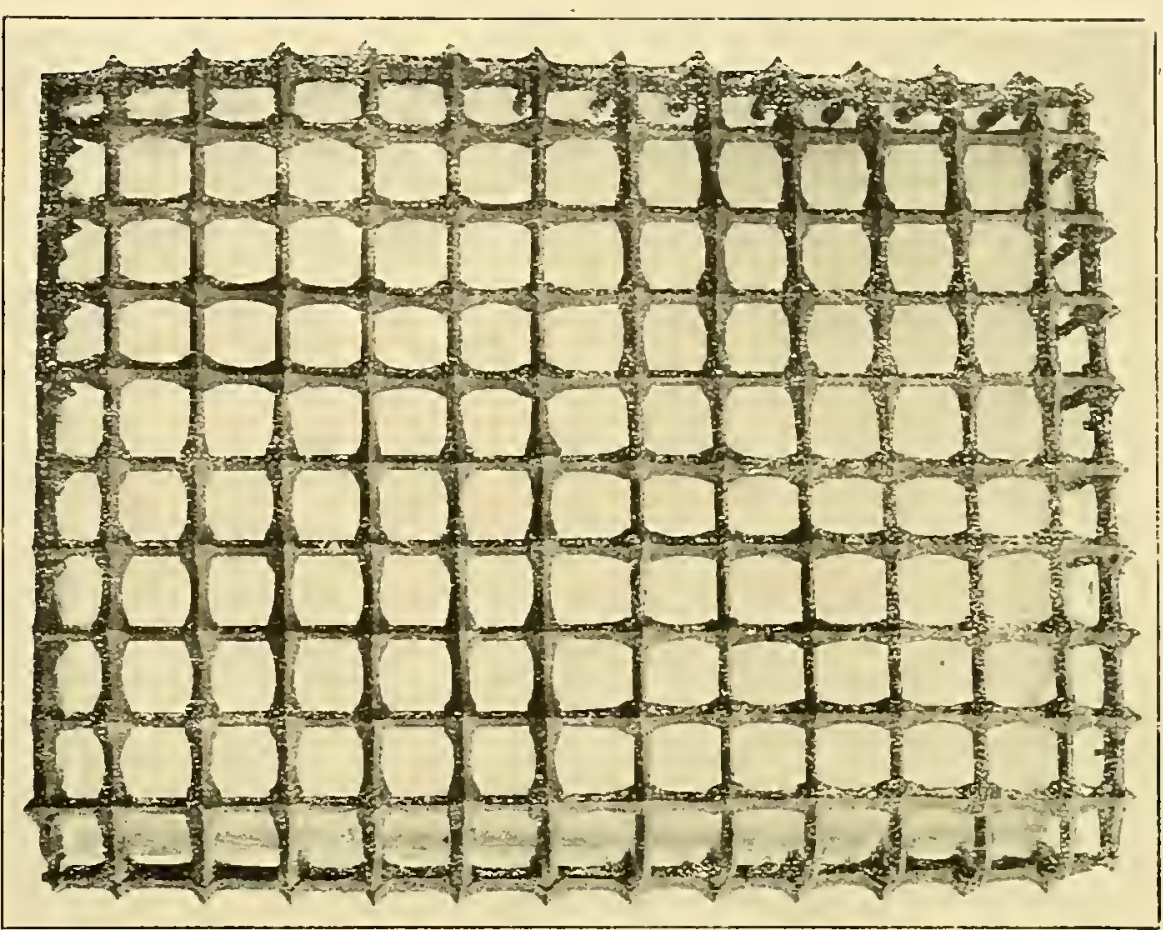

Núm. 316.

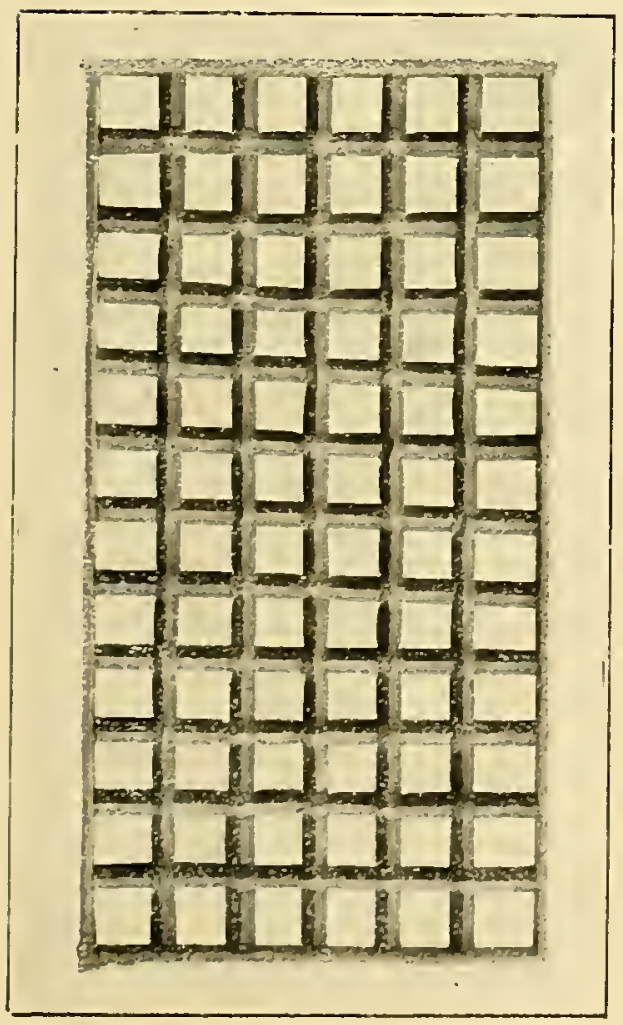

Num. 317.

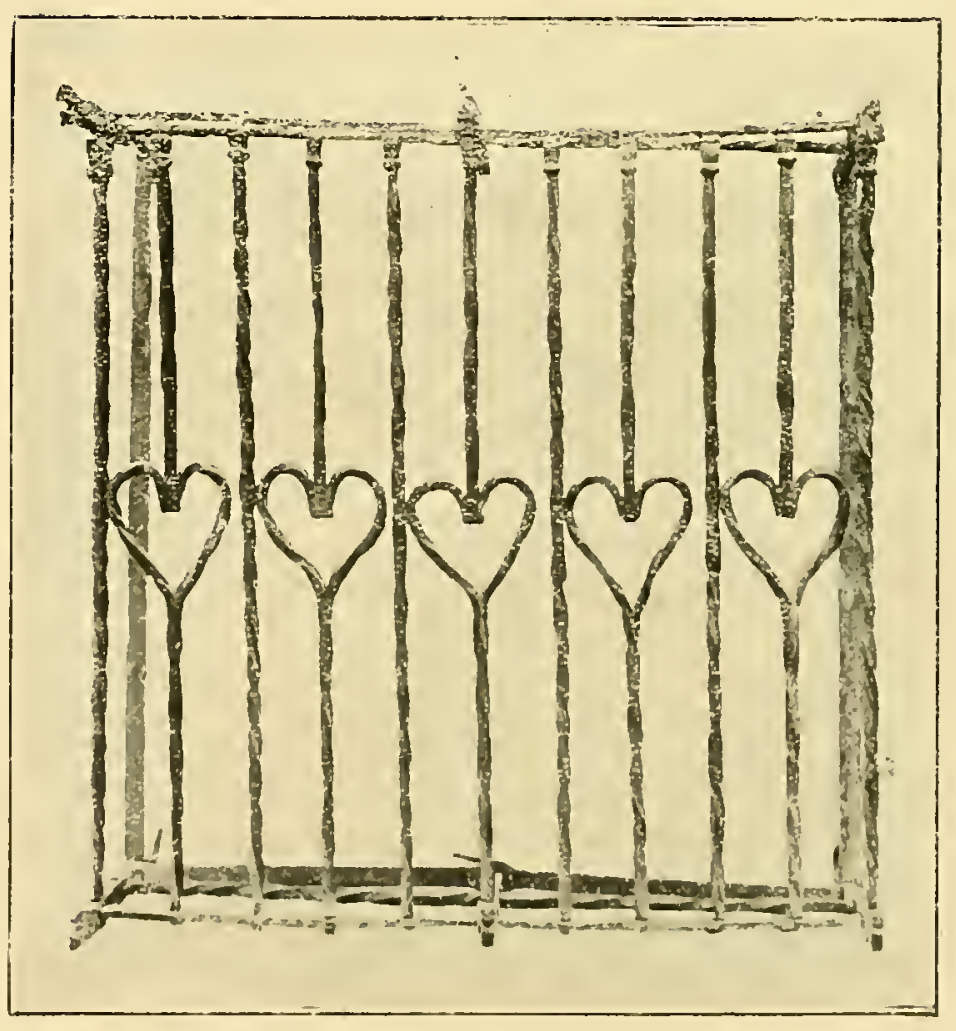

Nưm. 319. 


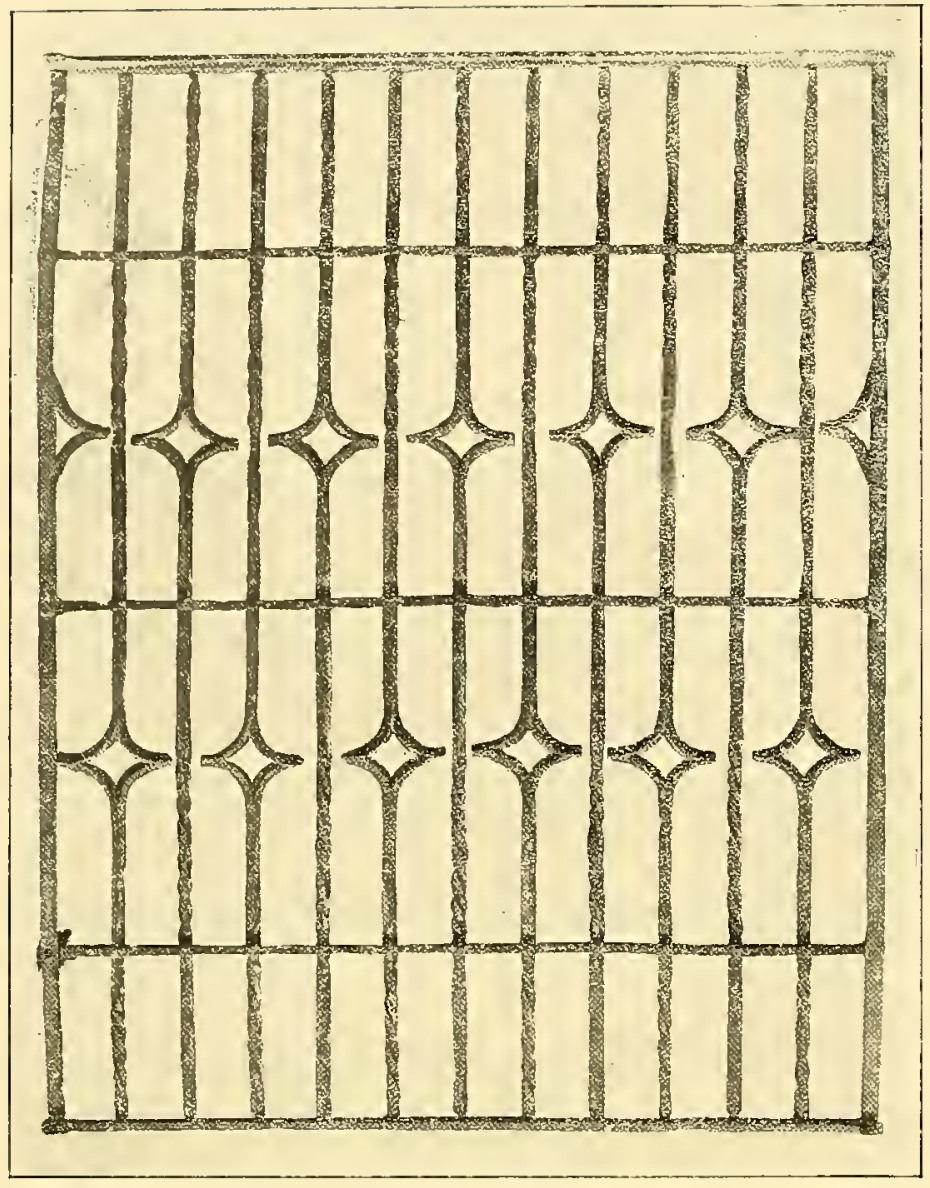

Núm. 318.

Núm. 327.-Corona de plancha recortada y realzada, tallos que se cruzan en ángulo con una crestería de flores. Epoca de los Reyes Católicos.

\section{Expositor: D. Juan Lafora.}

Núm. 328.-Alguazas de puerta, formadas por una barra recta, central, terminada en una concha, sobre la que se apoya otra en semicircunferencia, terminada también en conchas.

Siglo xvi.

Procede de Olmedo (Valladolid).

EXPOSITOR: D. Domingo Guerrero, de San Sebastián.

Núm. 329. - Friso de reja de $1,05 \mathrm{~m}$. por

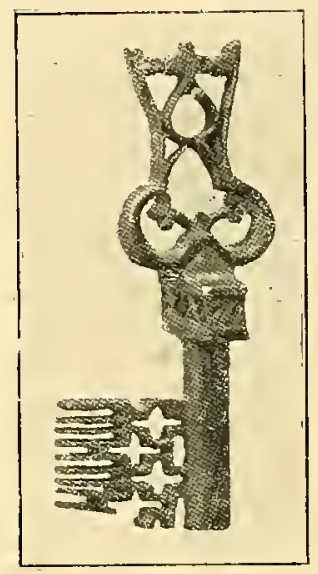

Núm. 322.

$13 \mathrm{~cm}$. Decoración gótica en doble plancha calada. Epoca de los Reyes Católicos.

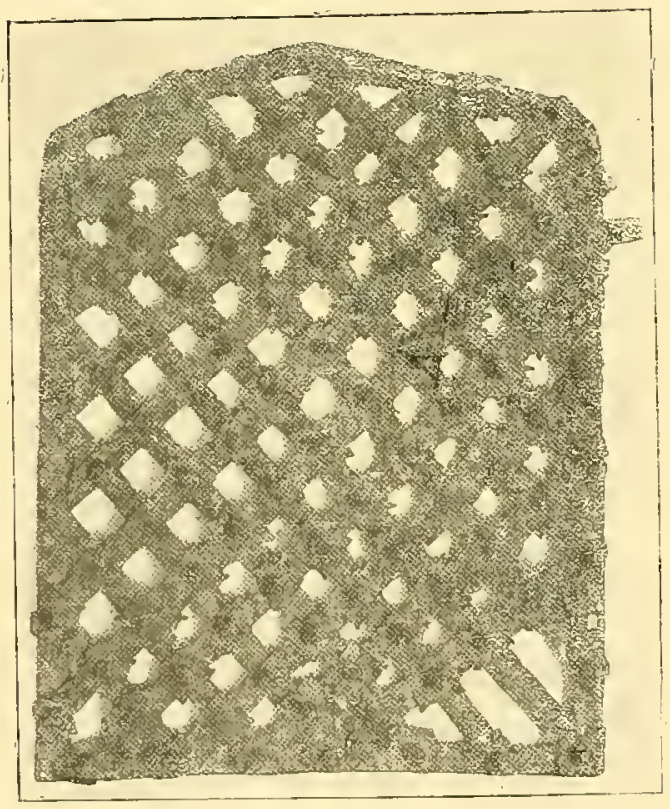

Nưm. 320.
Expositor D. José Lázaro.

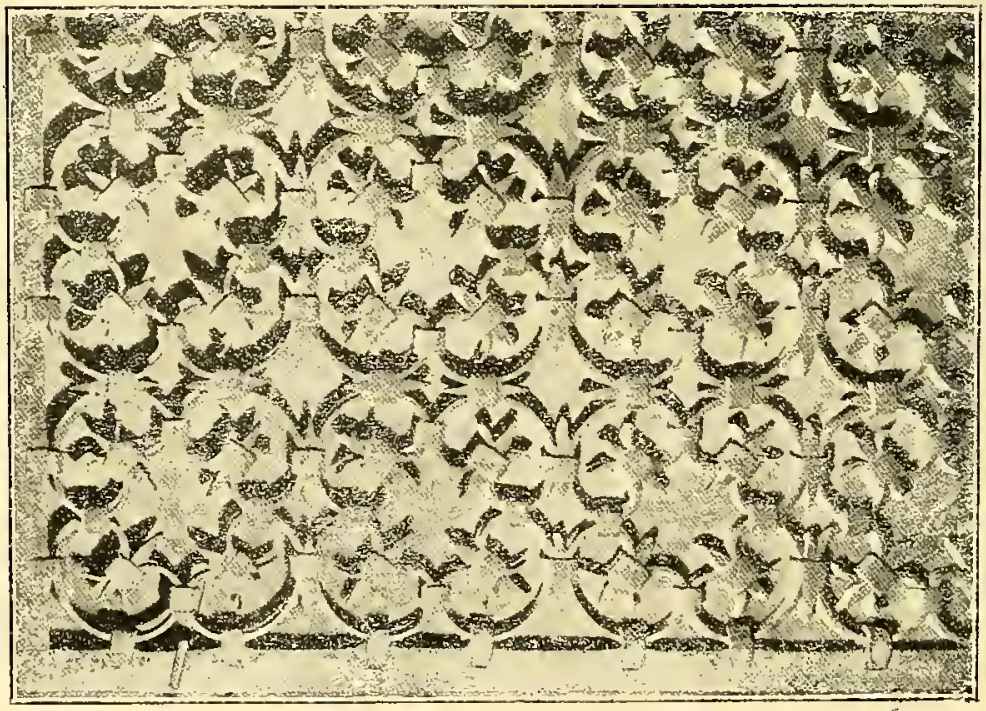

Núm. 32T. 


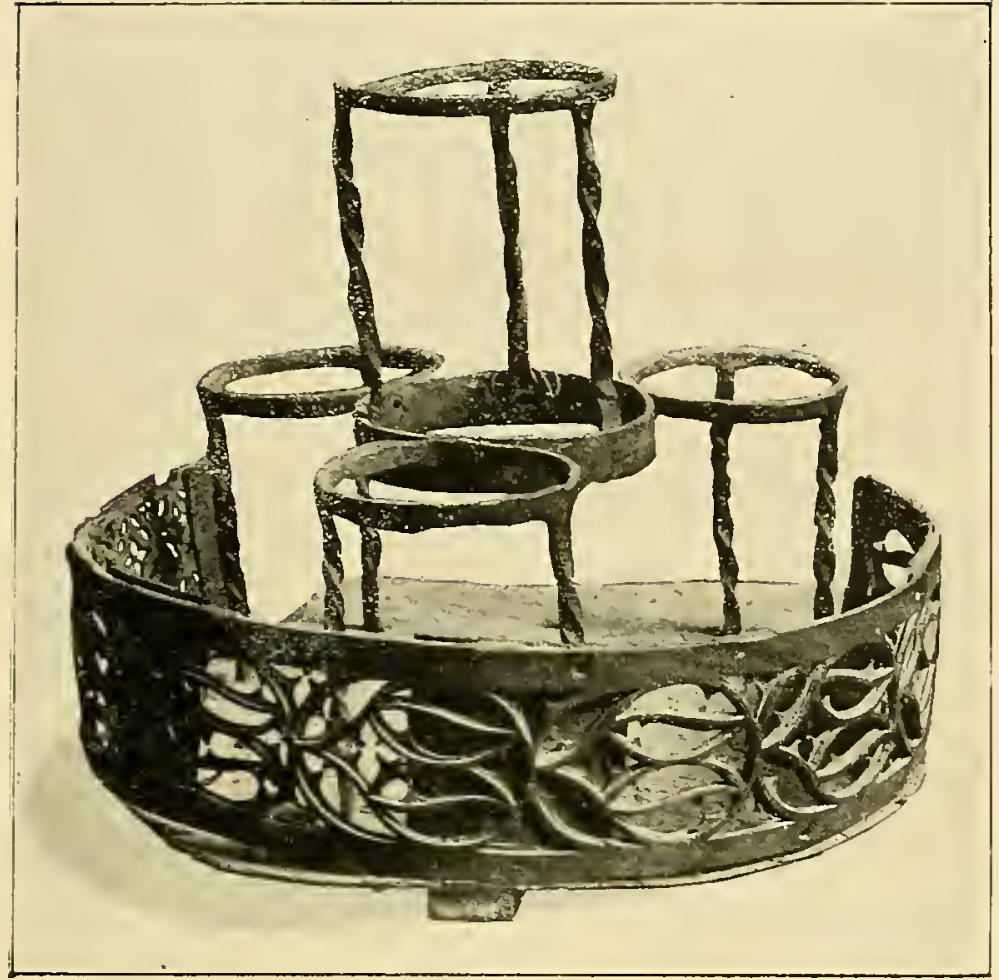

Nứm. 323.

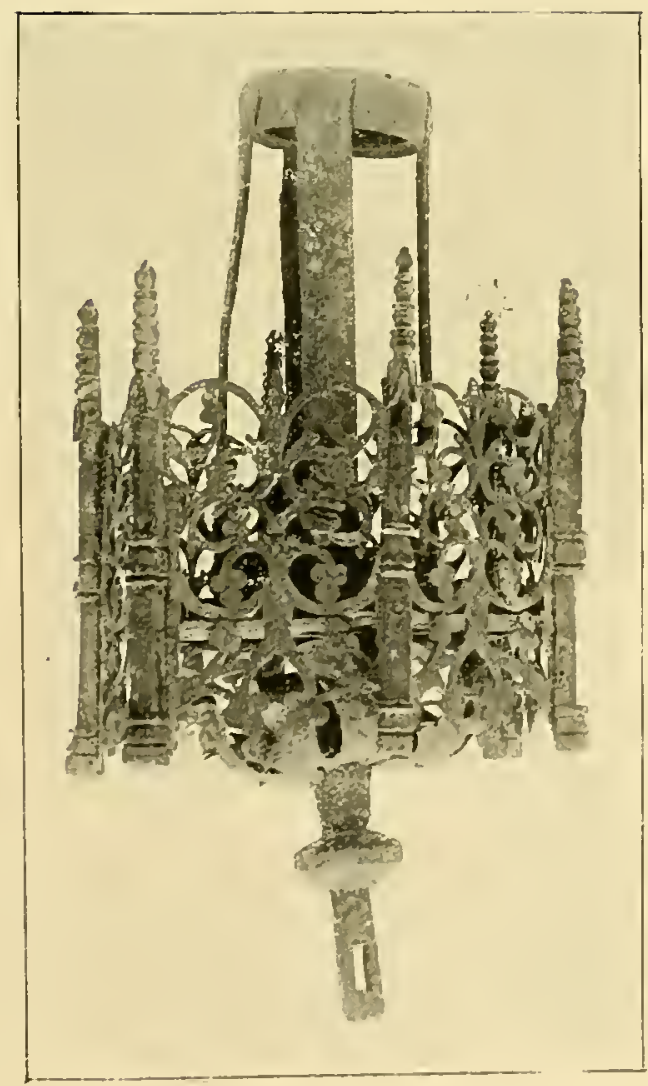

Nim. 324.
Núm. 330.-Friso de reja, de 1,37 m. de longitud por $17 \mathrm{~cm}$. de anchura. Decoración gótica en doble plancha calada. Epoca de los Reyes Católicos.

\section{Expositor: D. Domingo Guerrero, de San Sebas- tián.}

Núm. 331.--Fragmento de friso de verja, de $82 \mathrm{~cm}$. por 16. Decoración de hojas de cardo sobre un tallo desarrollado en sinusoide. Coronamiento en plancha almenada.

Finales del siglo xv y principios del xvi.

Expositor: D. Domingo Guerrero, de San Sebastián.

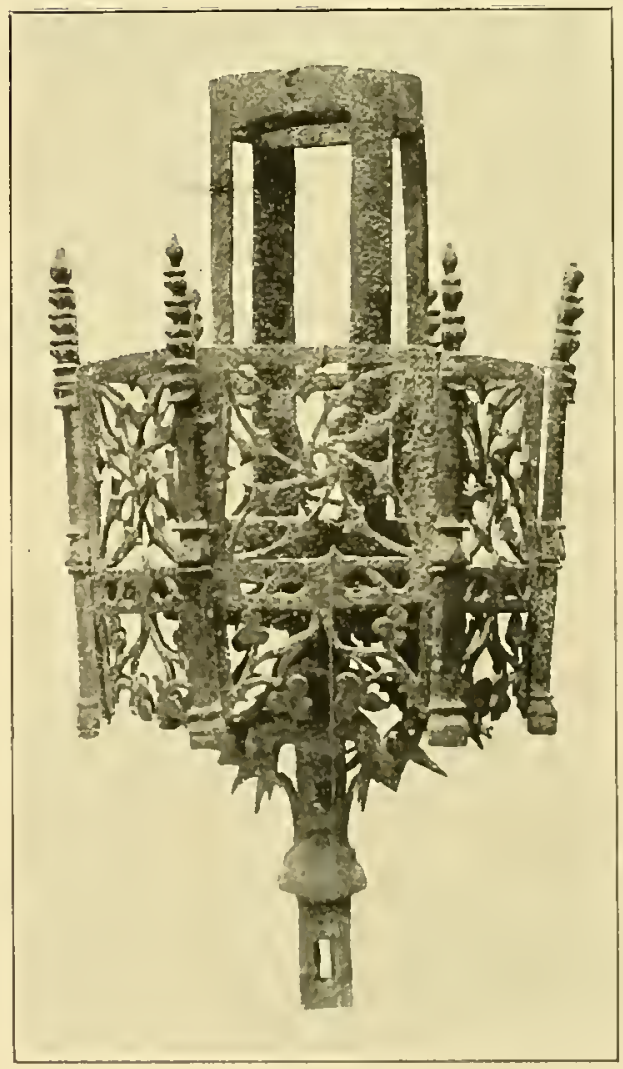

Nim. 325. 


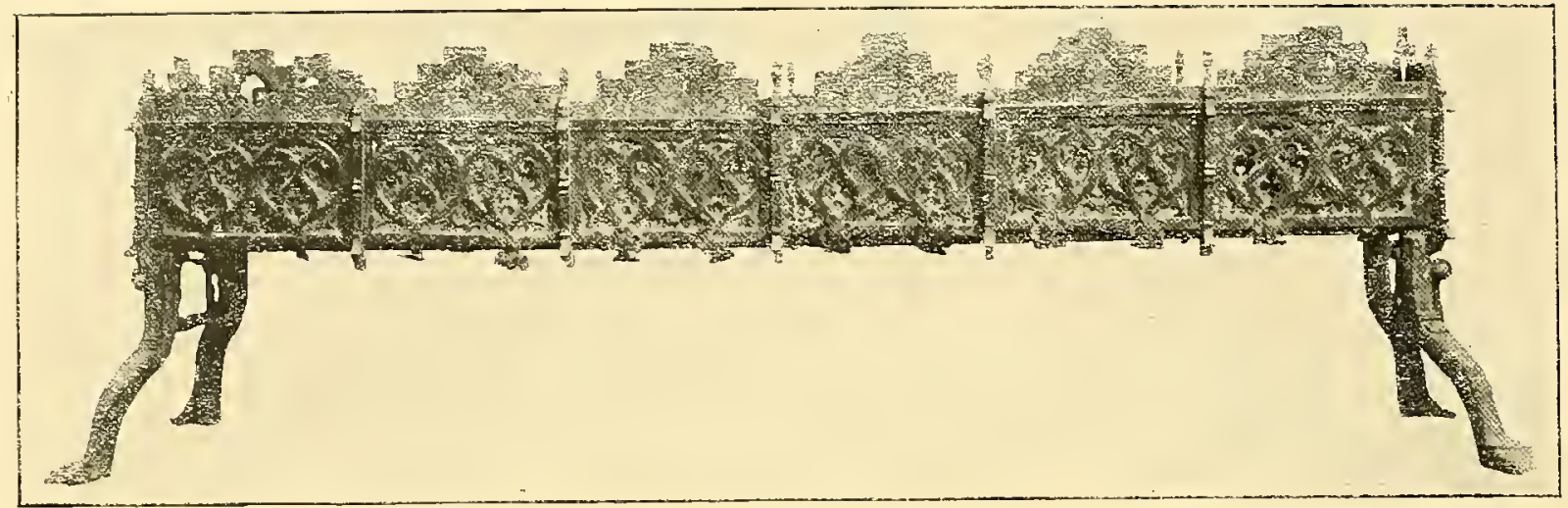

Nưm. 326.

Núm. 332. - Friso de reja de $77 \mathrm{~cm}$. por 22 . En plancha recortada y realzada. Un tallo en sinusoide, ramificado en hojas de cardo con líneas incisas por decoración. Uin dragón en uno de los extremos y una figura de pájaro en el centro. Epoca de los Reyes Católicos.

Expositor: Sr. Rodriguez Rojas.

Núm. 333.--Un friso de reja, de $2,40 \mathrm{~m}$. de longitud, de plancha real-

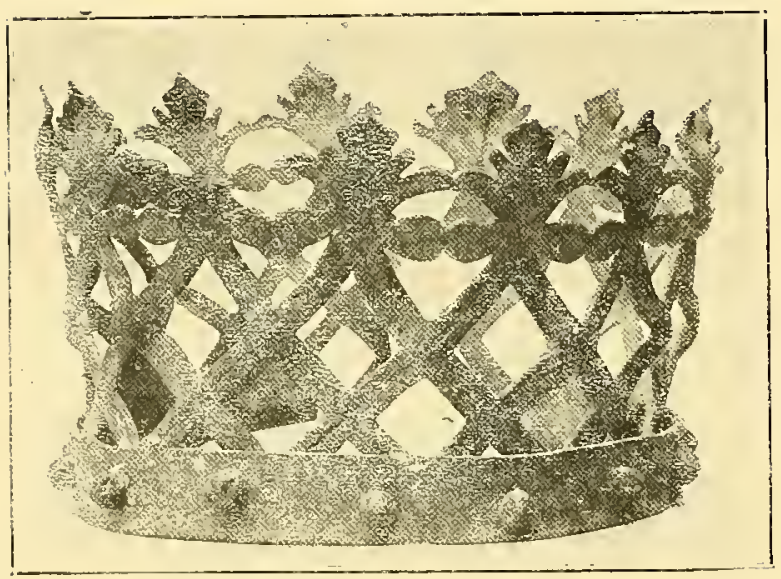

Núm. 327. zada. Decoración en forma de tallo en sinusoide con hojas de cardo, decoradas por líneas indecisas.

Epoca de los Reyes Católicos.

ExPOSITOR:

D. José A. Weissberger.

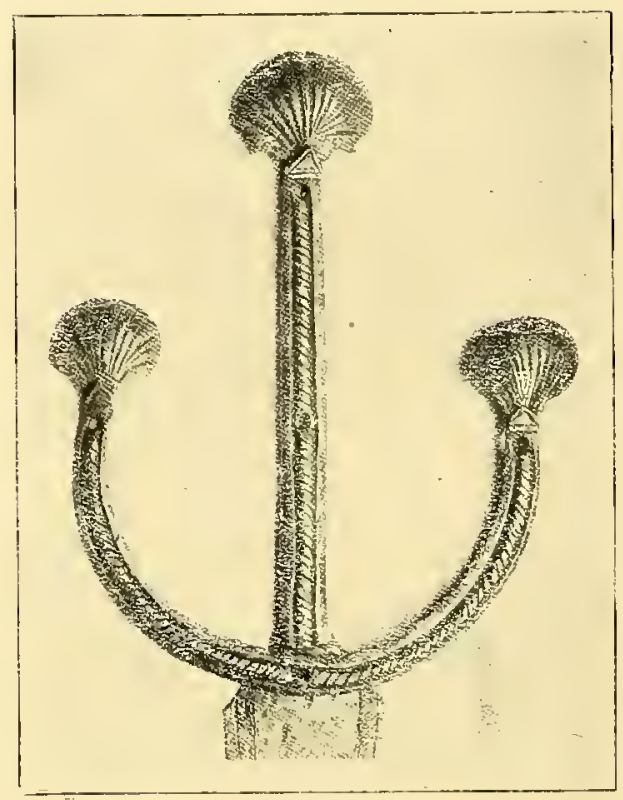

Núm, 328.

Núm. 334.-Friso de reja, de $85 \mathrm{~cm}$. por 14 . Decoración de plancha realzada en hojas de cardo con líneas incisas. Coronamiento almenado. Basamento festoneado.

Epoca de los Reyes Católicos.

Expositor: D. Anastasio Párano.

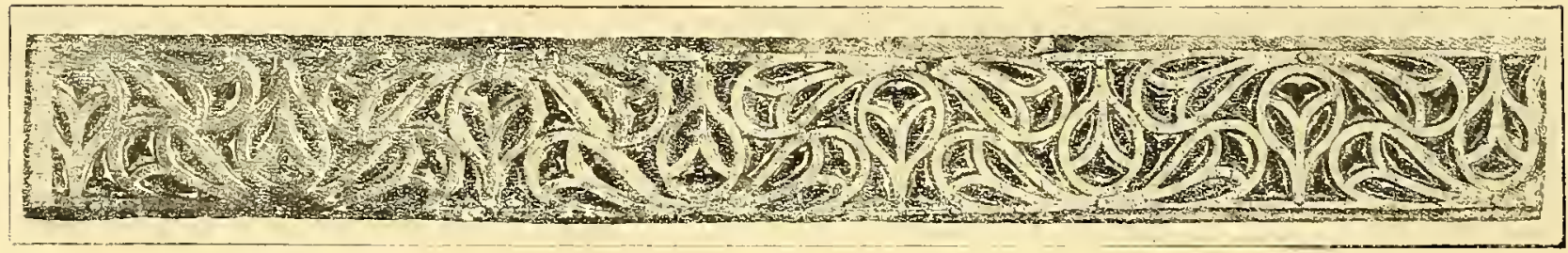




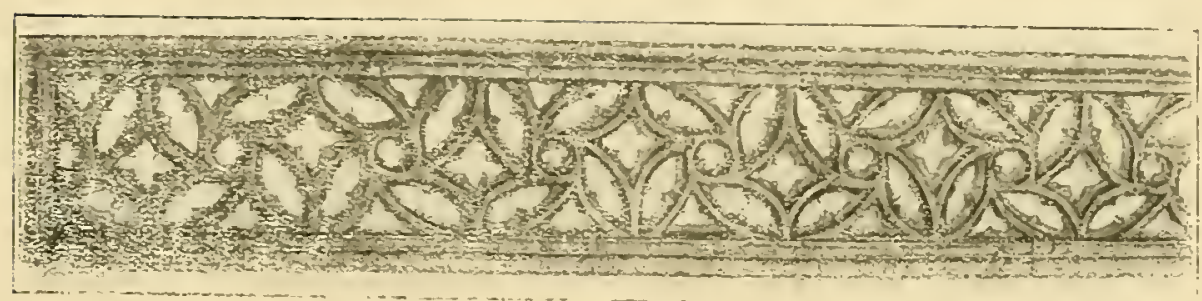

Nüm. 330.

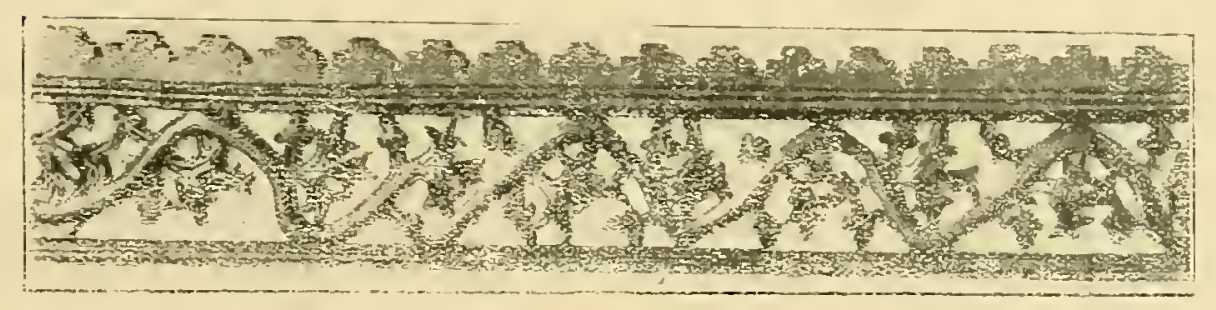

Nưm. 331.

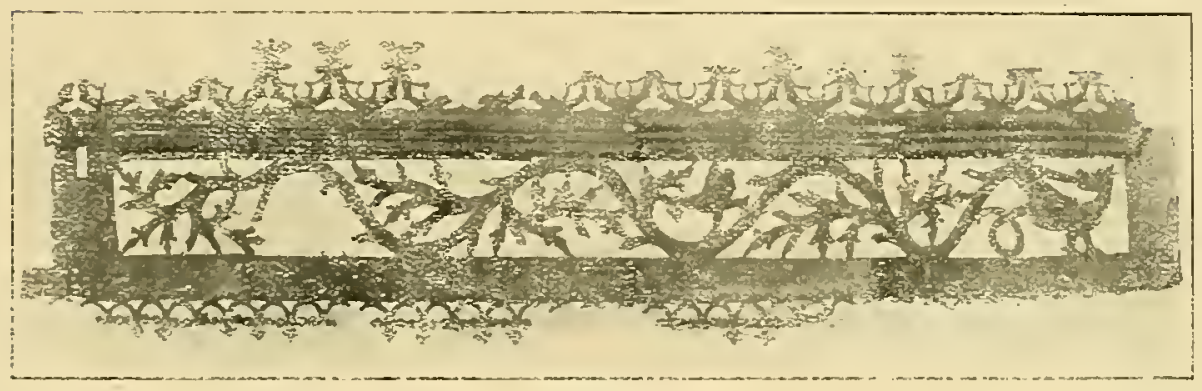

Nüm. 332.

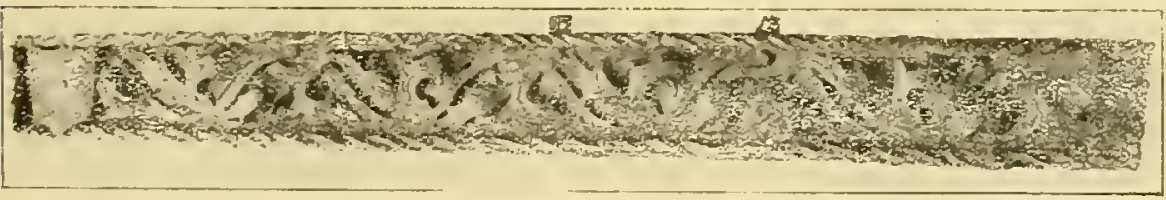

Núm. 333.

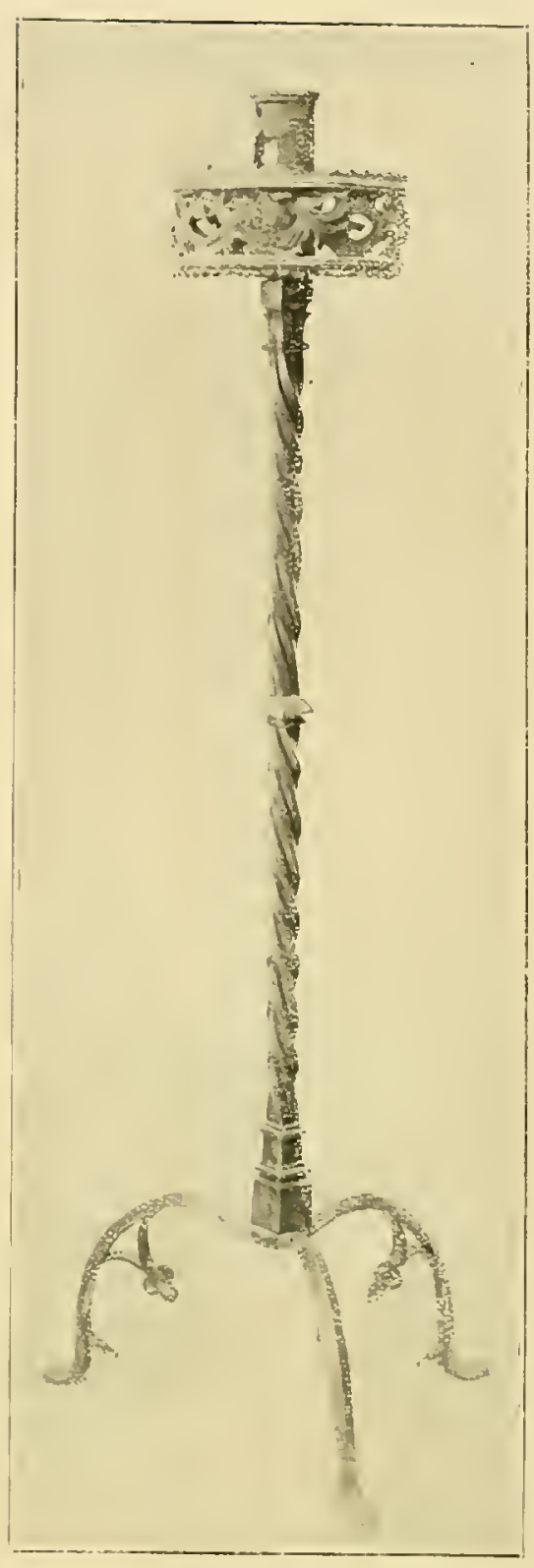

Núm. 336,

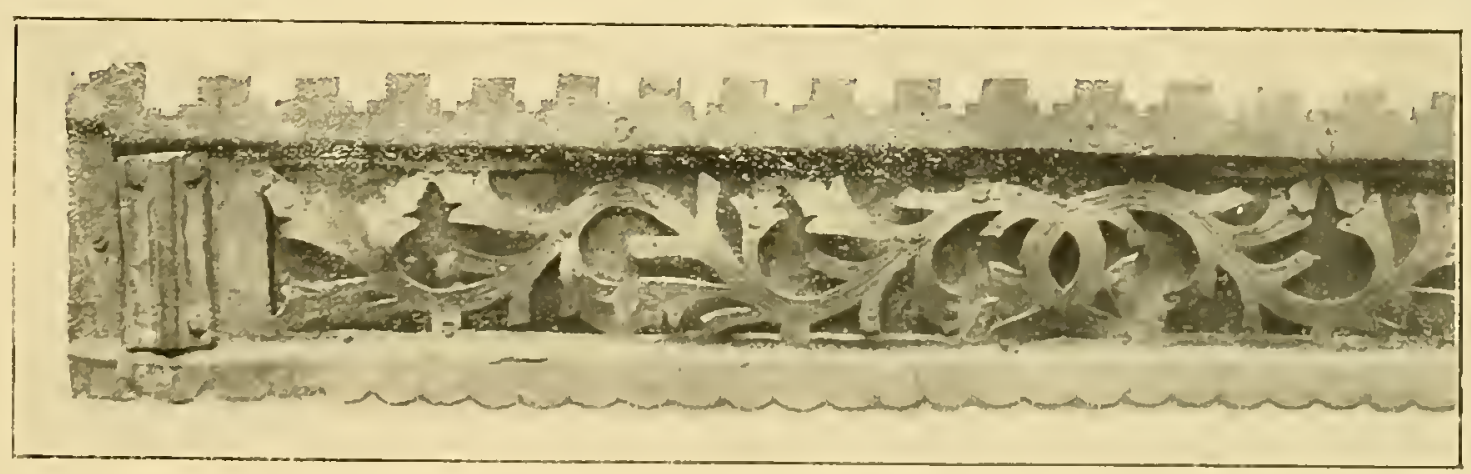

Núm. 334. 
Núm. 335.--Cerradura gótica cuadrada de cuyos vértices arrancan cuatro círculos en plancha calada con decoración floral. Trabajo tal vez italiano, pero de origen español, pues este molde fué adoptado en el Norte de Italia tomándolo de los alemanes, que se inspiraron en nuestras cerraduras de cuatro conchas. La labor de los círculos es de plancha calada y realzada y en el cerrojo aparece una arquería gótica que recuerda las nuestras árabes. Principios del siglo xvI.

Procede del Cau Ferrat.

\section{Expositor: D. Santiago Rusiñol.}

Núm. 336.-Dos candelabros góticos de varilla retorcida, pie triangular, con detalles góticos, arandela circular con una barandilla de plancha recortada y realzada, decorada con incisión lineal. Epoca de los Reyes Católicos.

Mide: 1,38 de altura.

Expositor: D. Domingo Guerrero, de San Sebastián.

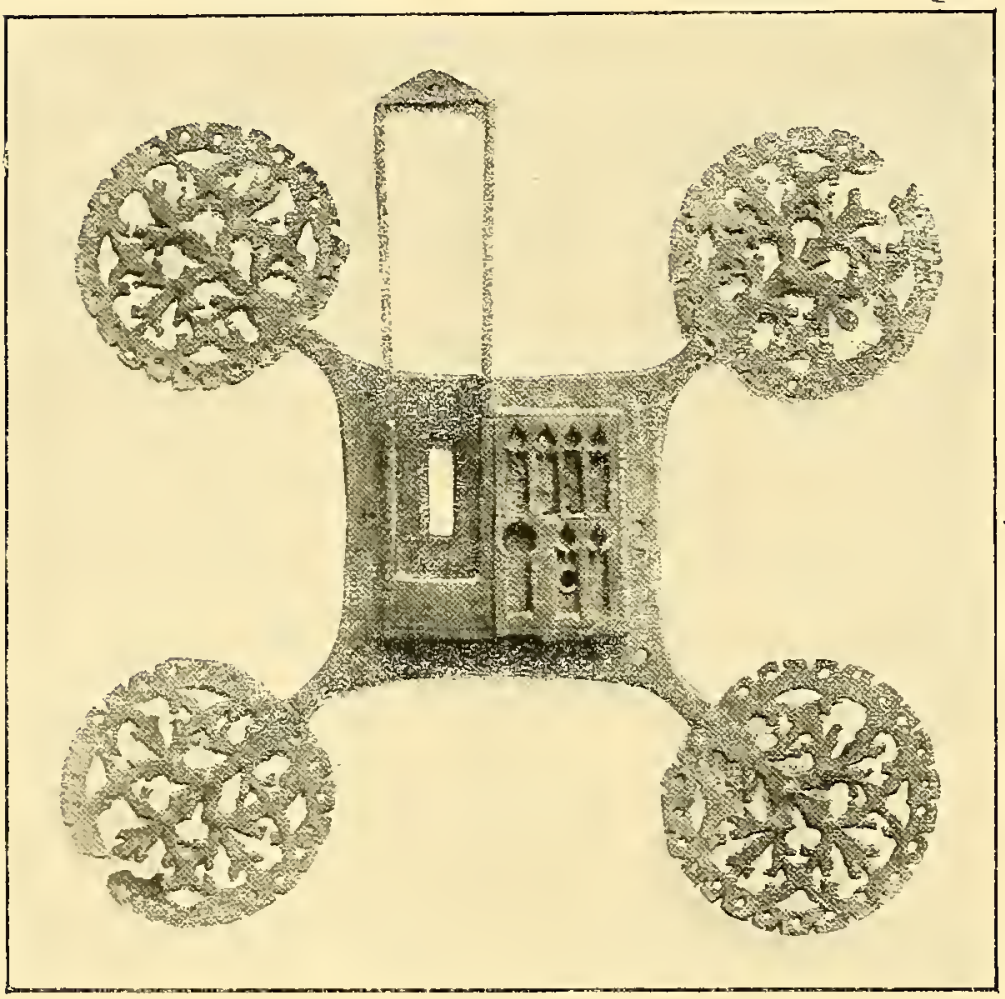

Nưm. 335.

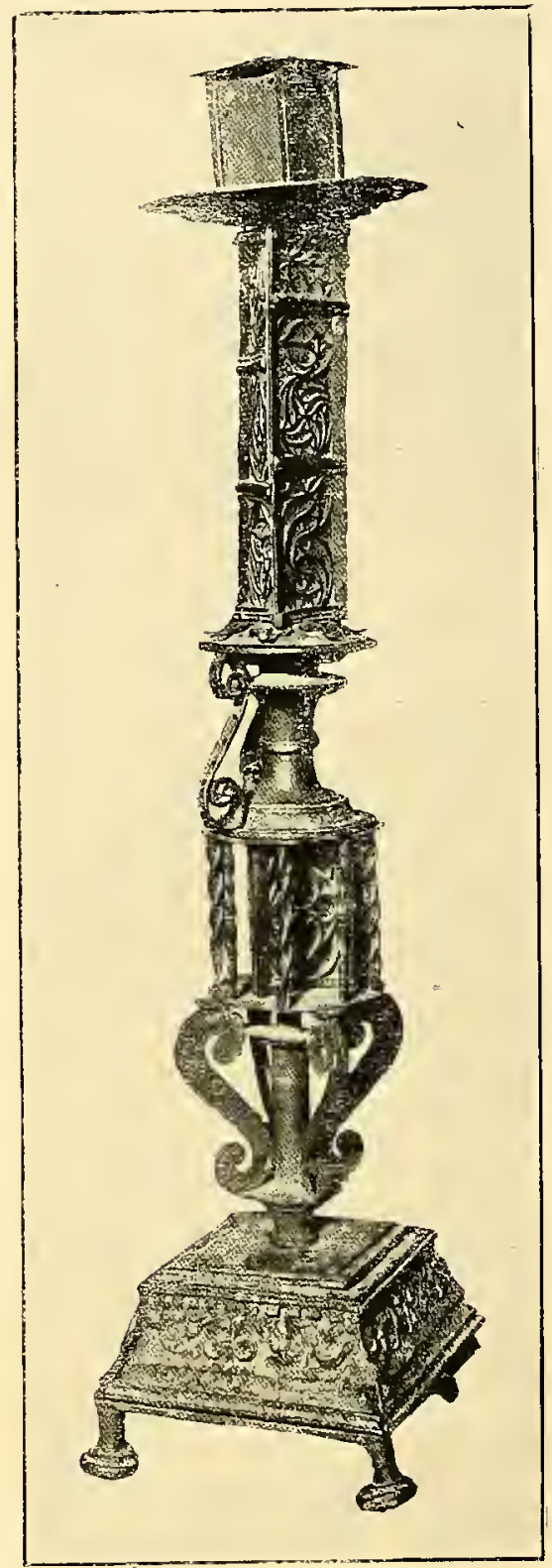

Nüm. 337.

Núm. 337.-Gran candelabro en hierro dulce. Estilo de transición del gótico al Renacimiento. Epoca de los Reyes Católicos.

Procede de la Catedral de León y son donación del Cabildo Catedral.-Mide: 1,40 metro de altura.

Expositor: Museo Arqueológico Nacional. 
Núm. 338.-Fragmento de plancha de fondo de chimenea, con las armas y la corona usadas por Doña Juana la Loca.

Principios del siglo xvi.

Expositor: Excmo. Sr. D. José Moreno Carbonero.

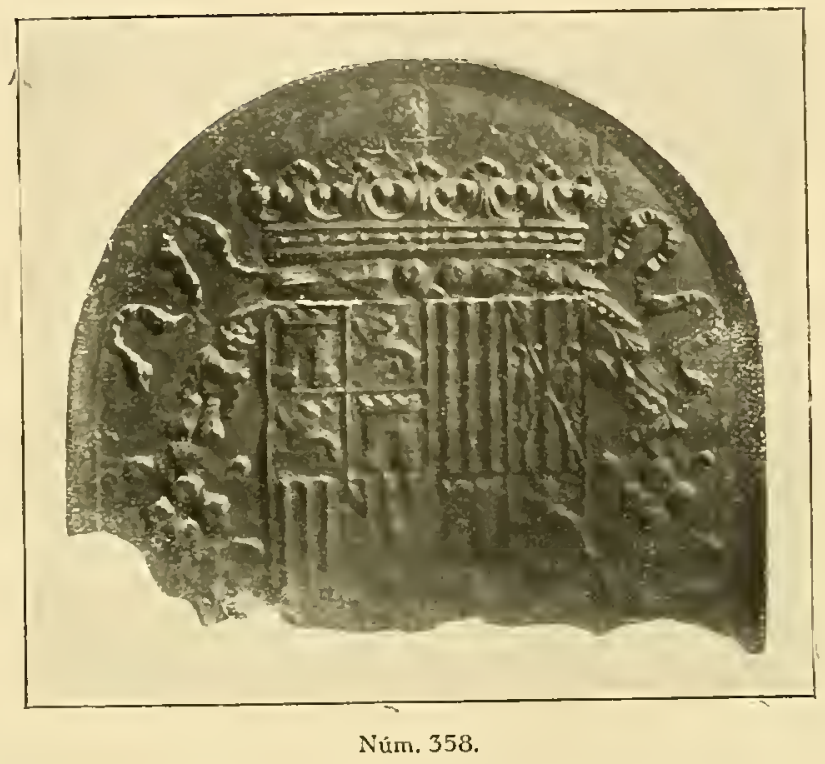




\section{Edad Moderna}

Núm. 339. - Una placa de chimenea, de hierro fundido, reproducción antigua de un ejemplar existente en el Patio de los Leones de la Alhambra de Granada.

Procede de Cau Ferrat.

Expositor: D. Santiago Rusiñol.

Núm. 340.--Plancha de chimenea, idéntica al ejemplar que precede.

Expositor: D. José Lázaro.

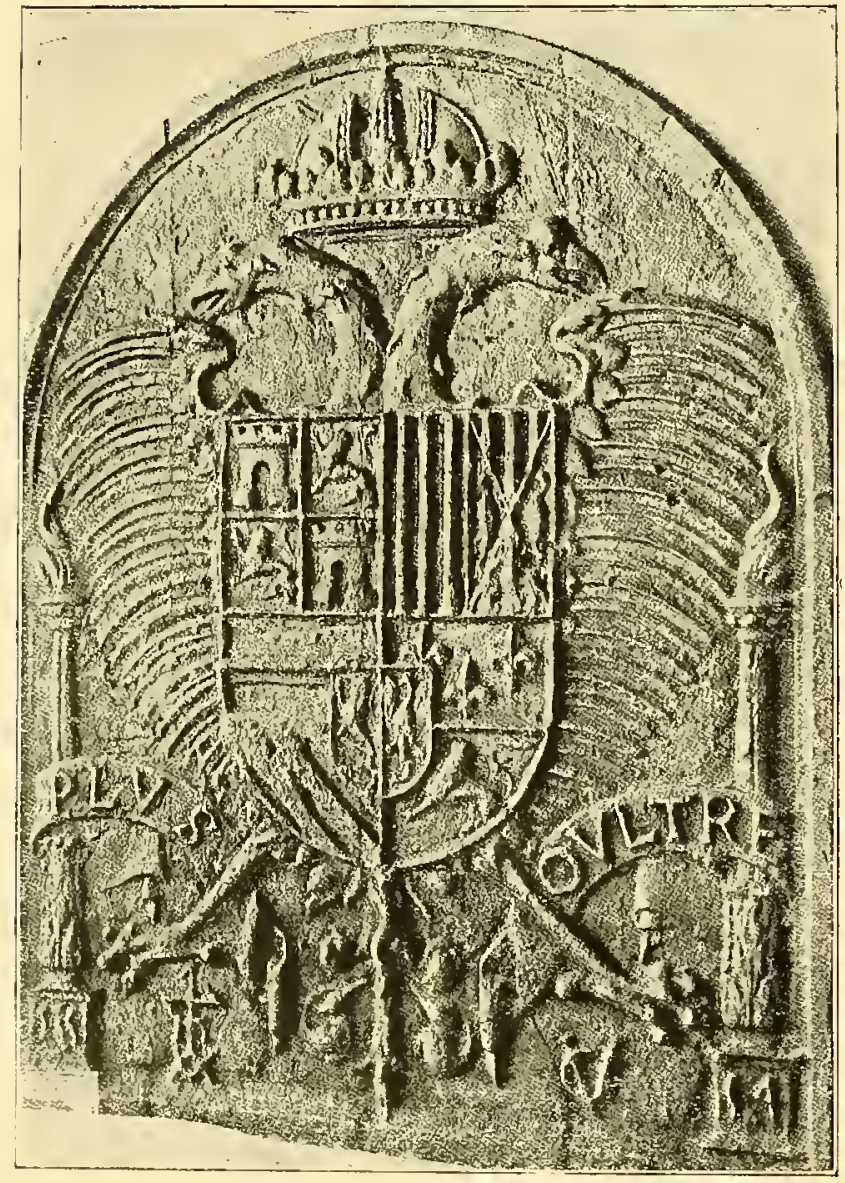

Nüm. 339.
Núm. 341.-Candelabro de tallo, cilíndrico, repujado y pie triangular. Trabajo perfectísimo en plancha repujada, que puede ser considerado como el más adecuado ejemplar

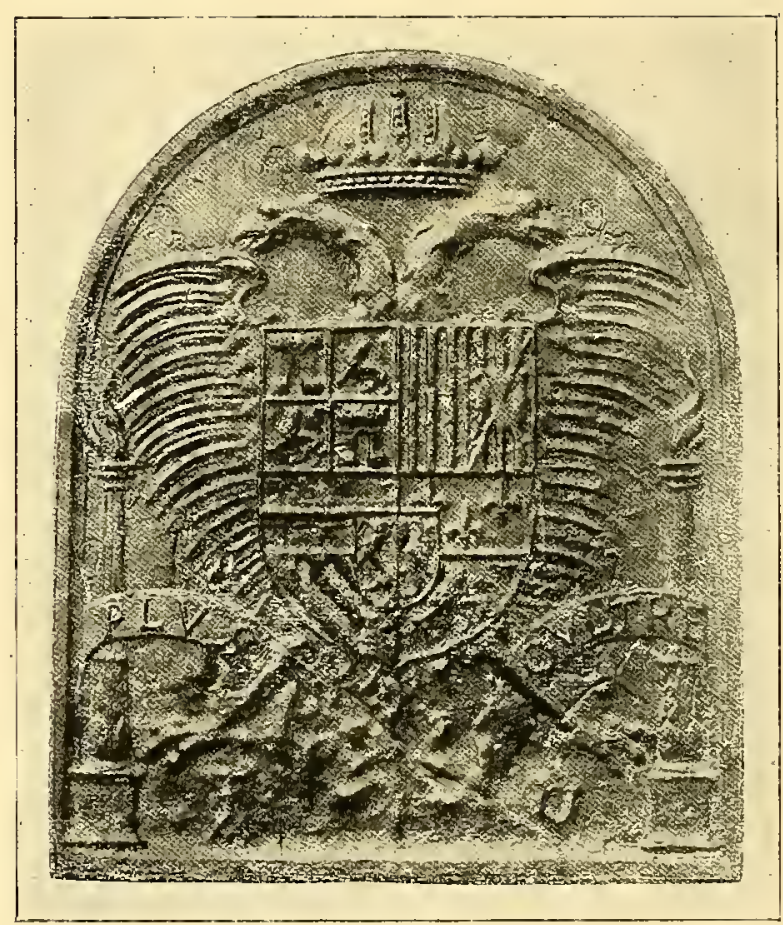

Ním. 340.

que en el trabajo del hierro define el estilo plateresco. Siglo xvi. Procede de la Catedral de León.

Mide 1,43 m. de alto.

Expositor: Museo Arqueológico Nacional. 


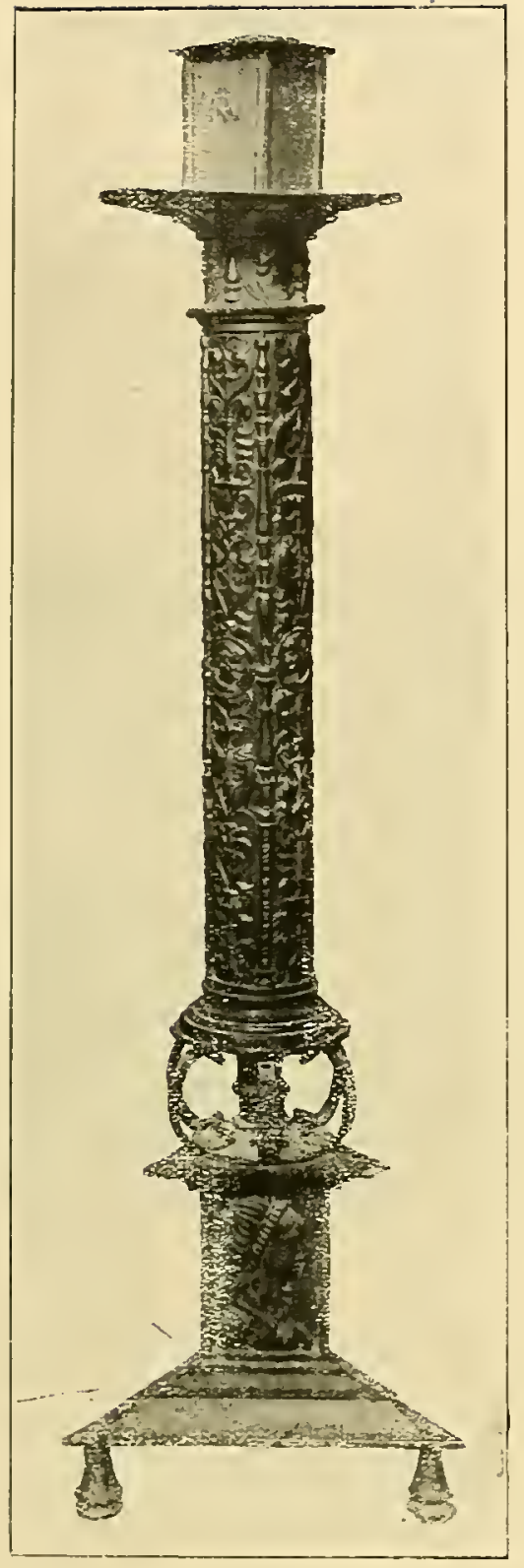

Núm. 3.17.

Núm. 342.-Crestería y friso de verja, de plancha recortada y realzada. Tallo en sinusoide con hojas de cardo. Cenefa superior de tallos y flores de lis combinadas, de motivo constantemente repetido. Dos escudos con castillo, en plancha repujada. Principios del siglo xvı.

Mide 1,50 por $20 \mathrm{~cm}$.

Expositor: D. Domingo Guerrero, de San Sebastián.

Núm. 343.-Friso de verja repujado formando hojas y ramos estilizados.

Siglo xvı.

Expositor: D. Domingo Guerrero, de San Sebastián.

Núm. 344.-Friso de verja de plancha calada, repujada y dorada, con motivos vegetales y ángeles adorantes.

Siglo xvı.

Expositor: D. Domingo Gnerrero, de Sain Sebastián.

Núm. 345. Friso de verja repujado y calado con medallones con figuras y otros elementos fantástico..

Siglo xv:

Exyostrer: D. Domingo Guertero, de San Sebastián.

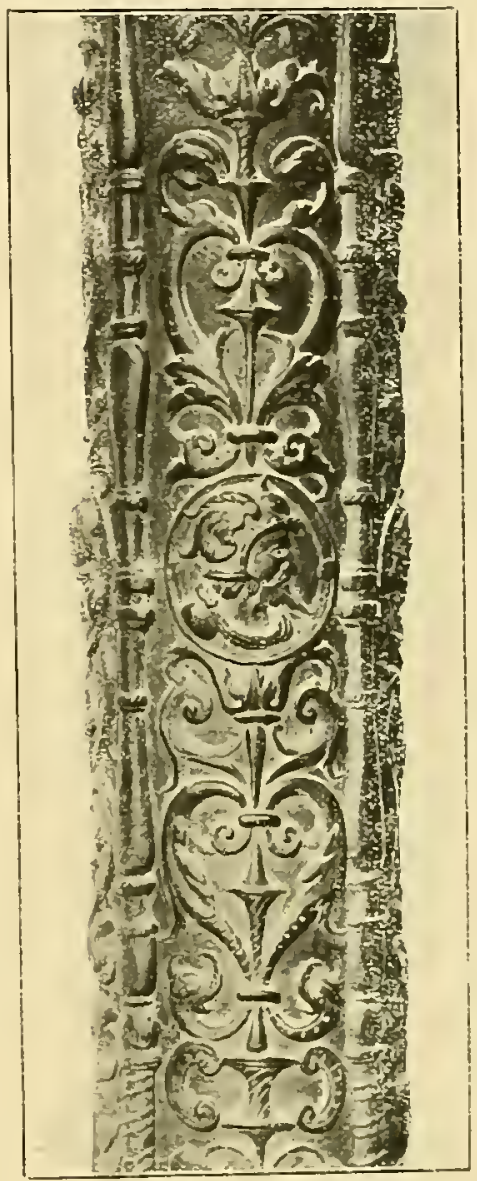

Nixm. 341.

Núm. 346. - Crestería y friso de verja con un escudo representando a un cazador y su escudero, y en lo restante del friso motivos y grifos u otros animales quiméricos. Siglo xvı.

Expositor: D. Domingo Guerrero, de San Sebastión.

Núm. j47. Dos frisos de reja en hierro repujado de $1 \mathrm{~m}$. de longitud por 18 centímetros de altura, con gru-

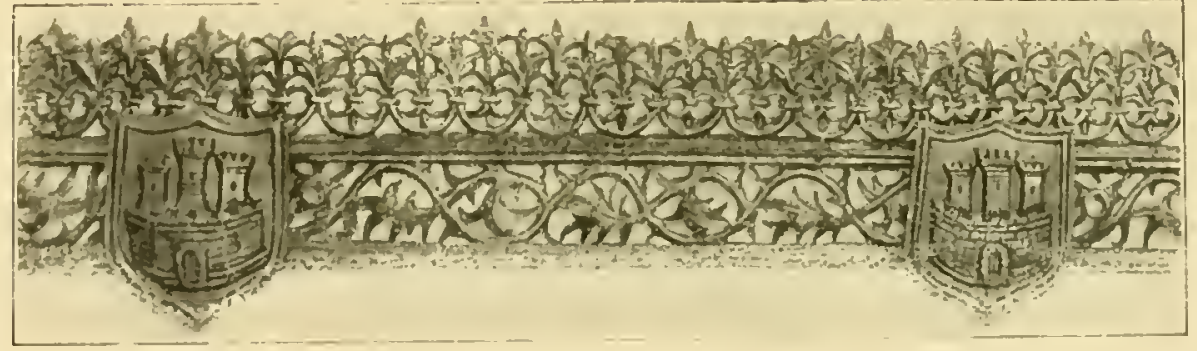

Nưir. 312. 


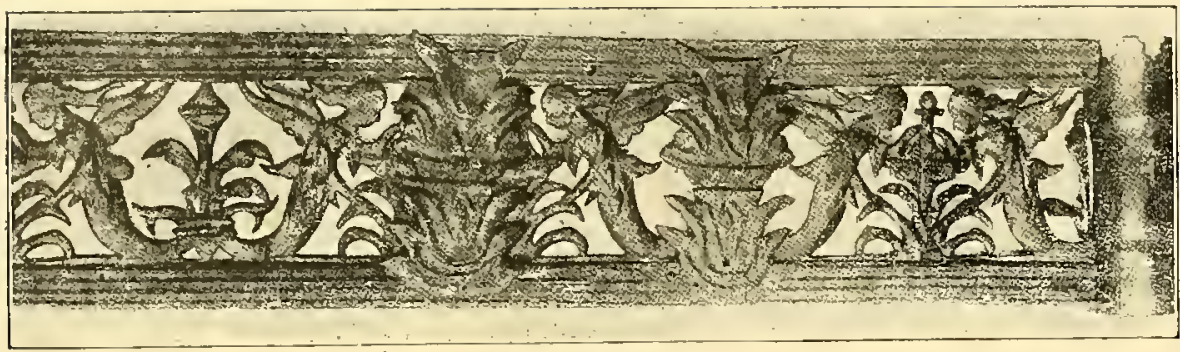

Nủm. 344. tescos del Renacimiento. Finales del siglo xvi.

Expositor: $D . D^{-}$ mingo Guerrero, de San Sebastián.

Núm. 348. - Plancha repujada de $44 \mathrm{~cm}$. de largo por 13 de alto, figurando

una cabeza en un medallón y dos grutescos laterales. Estilo del siglo xvı.

Expositor: D. José Lázaro.

Núm. 349. - Plancha de hierro repujado de 62 centímetros de largo por 14 de alto. Representa un jarrón con dos grutescos a los lados. Siglo xvi.

Procede de la Catedral de León.

Expositora: Excelentísima Señora D. ${ }^{a}$ Águeda, viuda de Lázaro.

Núm. 3500. - Dos pilastras de $1,02 \mathrm{~m}$. de altura por $16 \mathrm{~cm}$. de ancho, en hierro repujado con grutes-
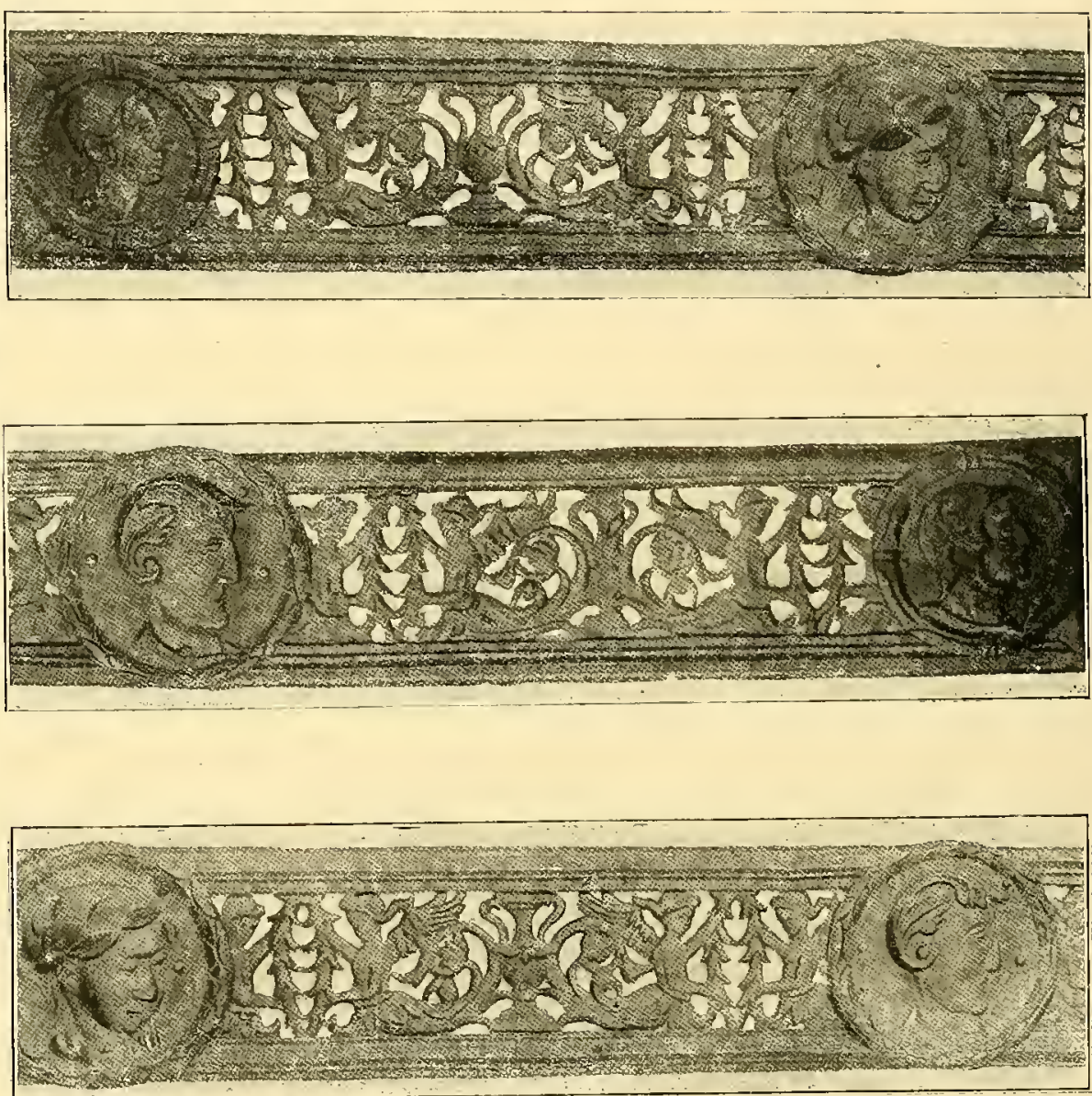

Núm. 345.

cos y cabezas policronadas. Mediados del siglo xvi.

Expositor: D. José Lázaro.

Núm. 351.-Friso de reja policromada en hierro repujado con grutescos y cabezas de $\mathrm{I}, 10 \mathrm{~m}$. de longitud por $22 \mathrm{~cm}$. de alto. Mediados del siglo xvi.

Expositor: D. José Lázaro. 
Núm. 352.-Dos tiras de friso de verja en plancha de hierro repujado, con dos cabezas en los centros y a los lados figuras y animales quiméricos. Siglo xvi.

Expositor: D. Domingo Guerrero, de San Sebastián.

Núm. 353.-Dos tiras repujadas de pilastra de verja, constituídas por jarrones, de los que parte un tallo

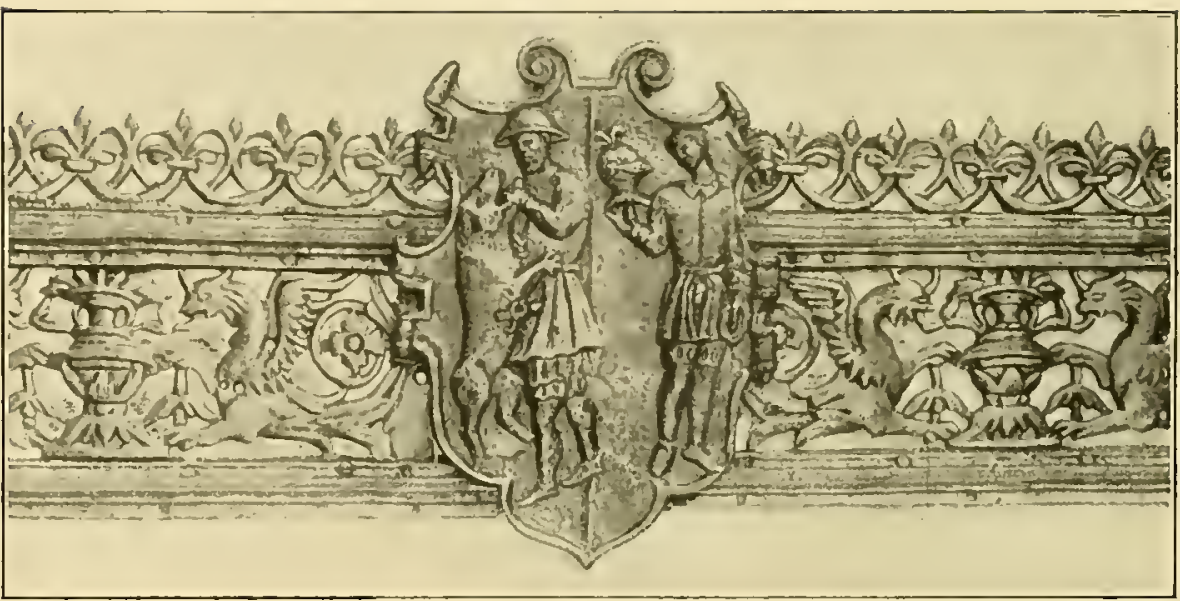

Nủm. 346.

que se resuelve en estilizaciones vegetales, con cabezas intercaladas. Son de plancha de hierro repujada. Fines del siglo xvi.
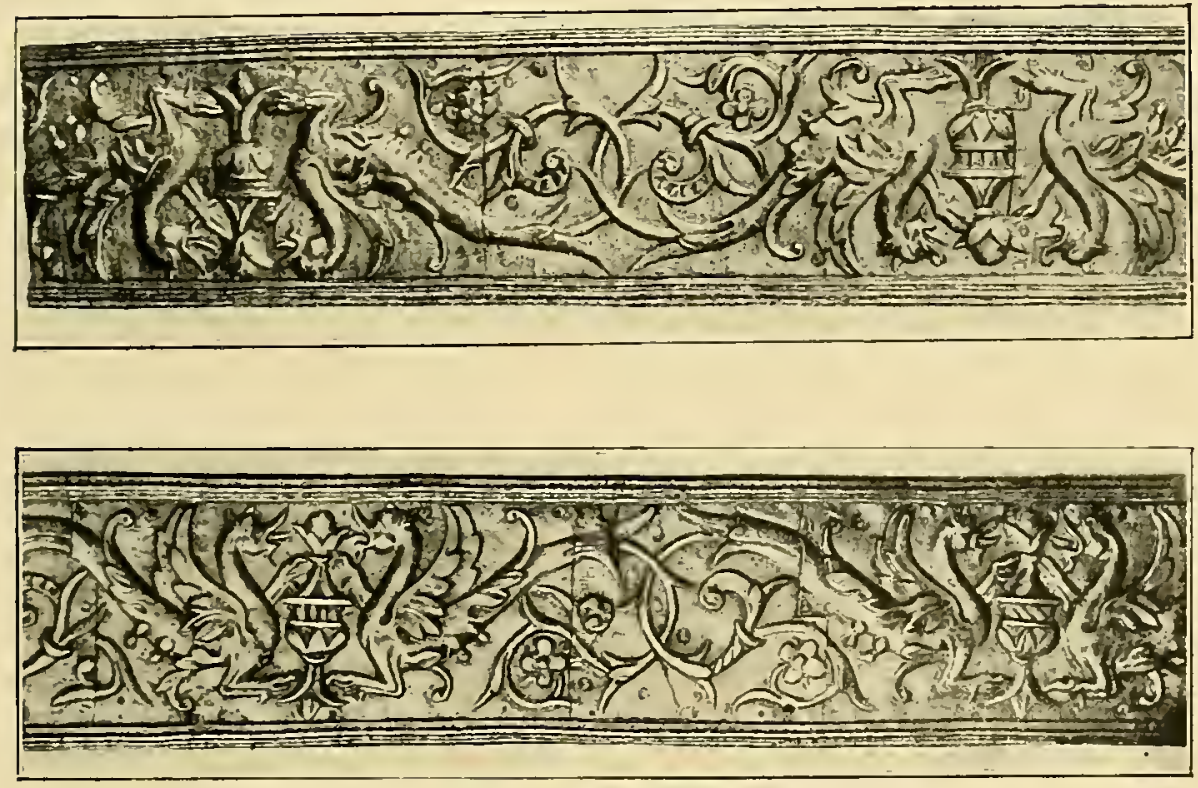

Núm. 347.
Expositor: $D$. Domingo Guerrero, de San Sebastián.

Núm. 354. - Dos tiras de friso de reja de hierro repujado y dorado, con grutescos y figuras.

Proceden de Cáceres. Miden $92 \mathrm{~cm}$. por 14 .

Siglo xvı.

Exposiror: D. Domingo Guerrero, de San Sebastián.

Núm. 355.-Cuatro hacheros de tres huecos y $1,51 \mathrm{~m}$. de alto por $86 \mathrm{cen}-$ tímetros de ancho. El vástago corresponde a modelos del Renacimiento. La decoración superior es gótica. Apoyan sobre cuatro pies, en varilla cuadrada, en arista y lobulada. Perte-

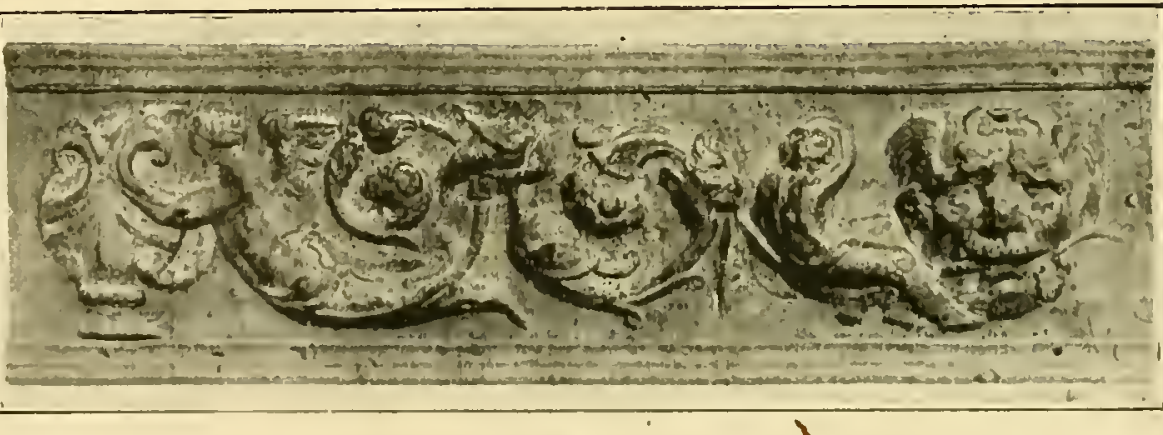

Nim. 348 


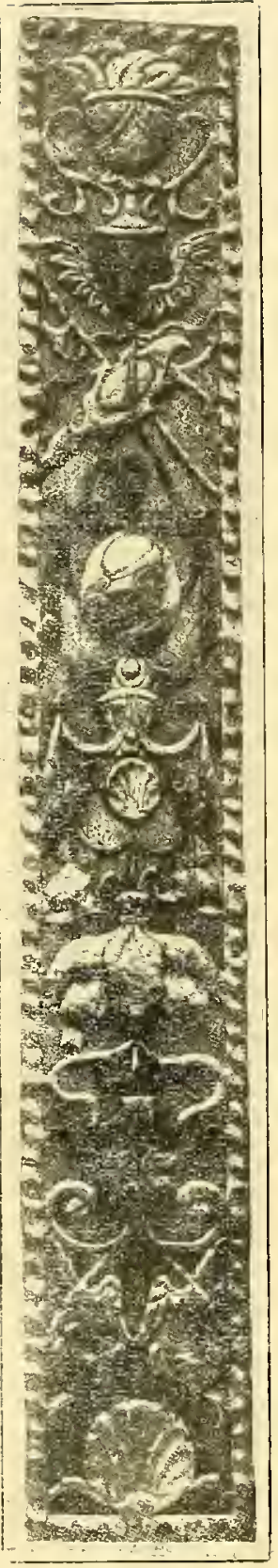

Núm. 350

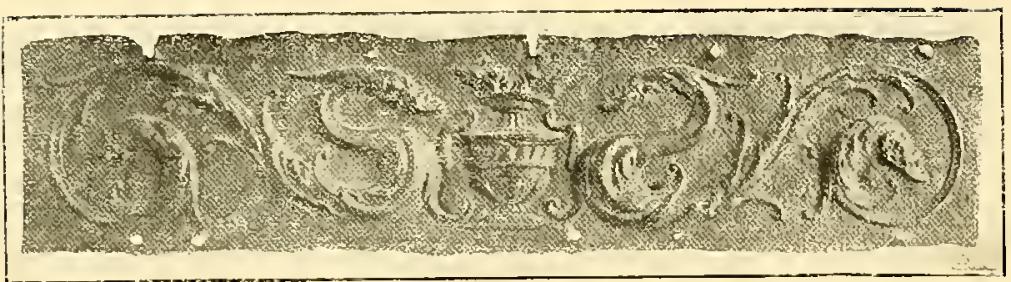

Nüm. 349.

necieron a la colección Miró. Primer tercio del sigilo xvı.

\section{Expositor: Museo Arqueológico Nacional.}

Núm. 3\$6.-Adorno o elemento decorativo de una verja, constituído por un escudo con el castillo sostenido por dos ángeles. Todo ello de plancha de hierro recortada, repujada y pintada. Siglo xvi.

Expositor: D. Domingo Guerrero, de San Sebastián.

Núm. 357.-Elemento decorativo de una verja, constituído por un escudo sostenido por dos ángeles. Es de plancha recortada, repujada y policromada. Siglo xvi.

Expositor: D. Domingo Guerrero, de San Sebastián.

Núm. 358.-Elemento decorativo de una verja constituído por dos quimeras y un escudo en plancha recurtada y repujada. Procede de la Catedral de Cuenca. Siglo xvı.

Expositor: D. Domingo Guemero, de San Sebastián.

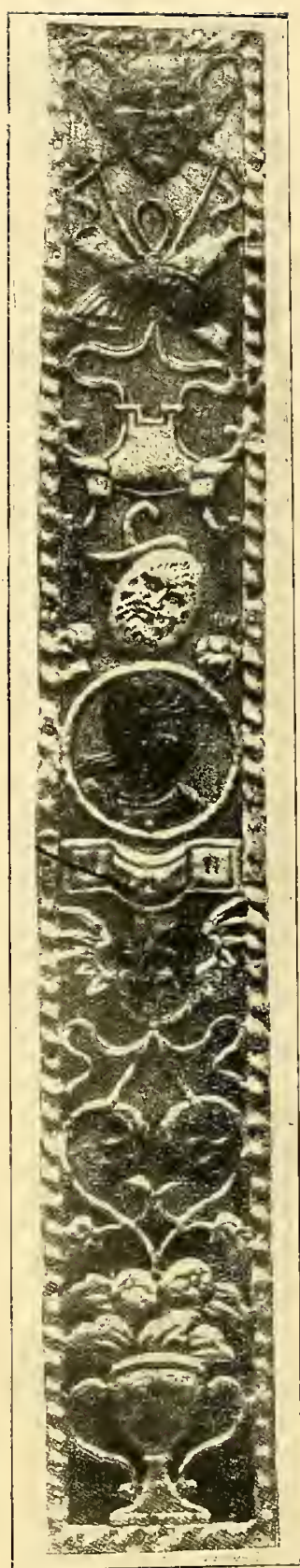

Nüm. 350.

Núm. 359. - Copete de reja con grutescos y decoraciones del Renacimiento. Escudo heráldico de cartela polilobulada.

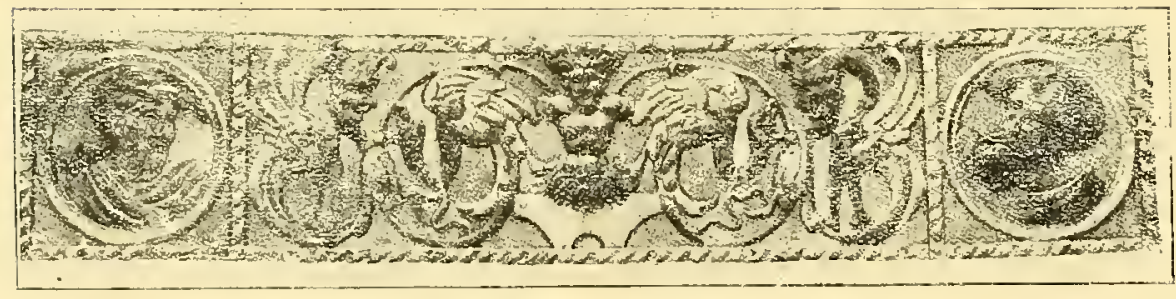

Núm. 351.
Primera mitad del siglo xvı.

Expositor: D. Jliall Lafora.

Núm. 360. - Copete de reja, procedente de la Magis- 
tral de Alcalá de Henares. Primera mitad del siglo xvi.

Expositor: Iglesia Magistral de Alcalá.

Núm. 361. - Figura de santo con orantes en varias planchas remachadas y repujadas formando un conjunto. Debió constituir el coronamiento de una reja. Mediados del siglo xvi.

Expositor: D. José Lázaro.
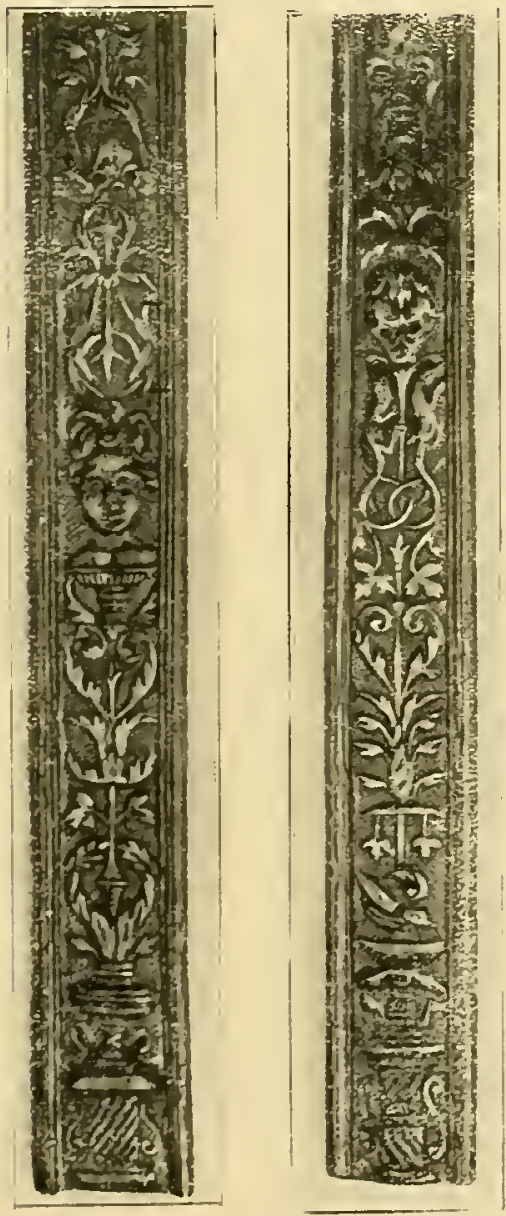

Nủm. 353,
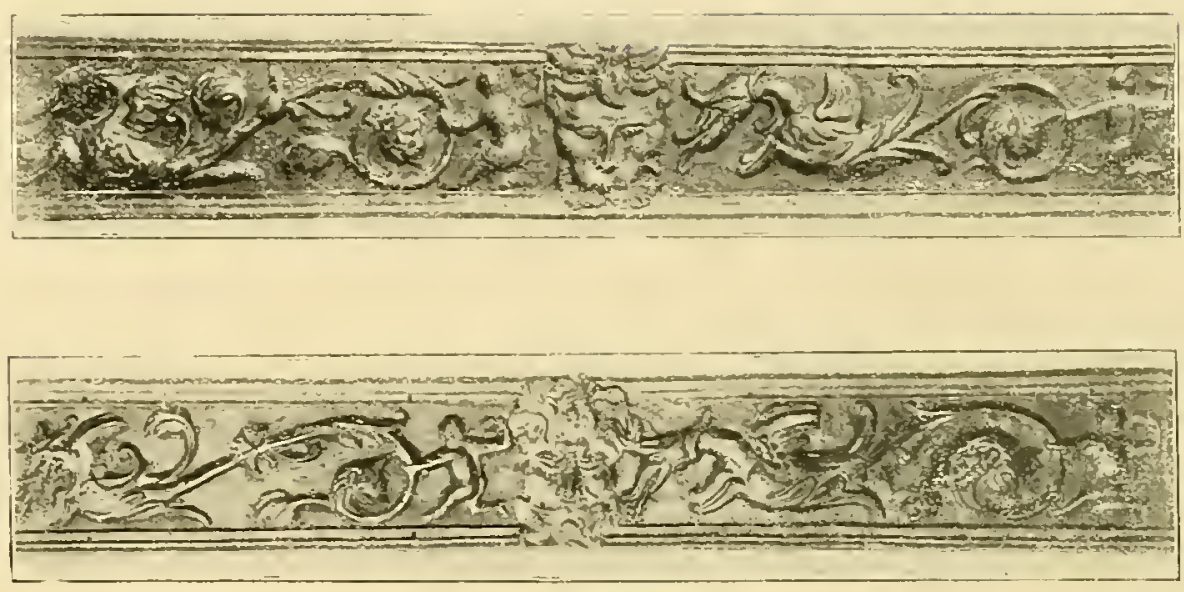

Nủm. 352.
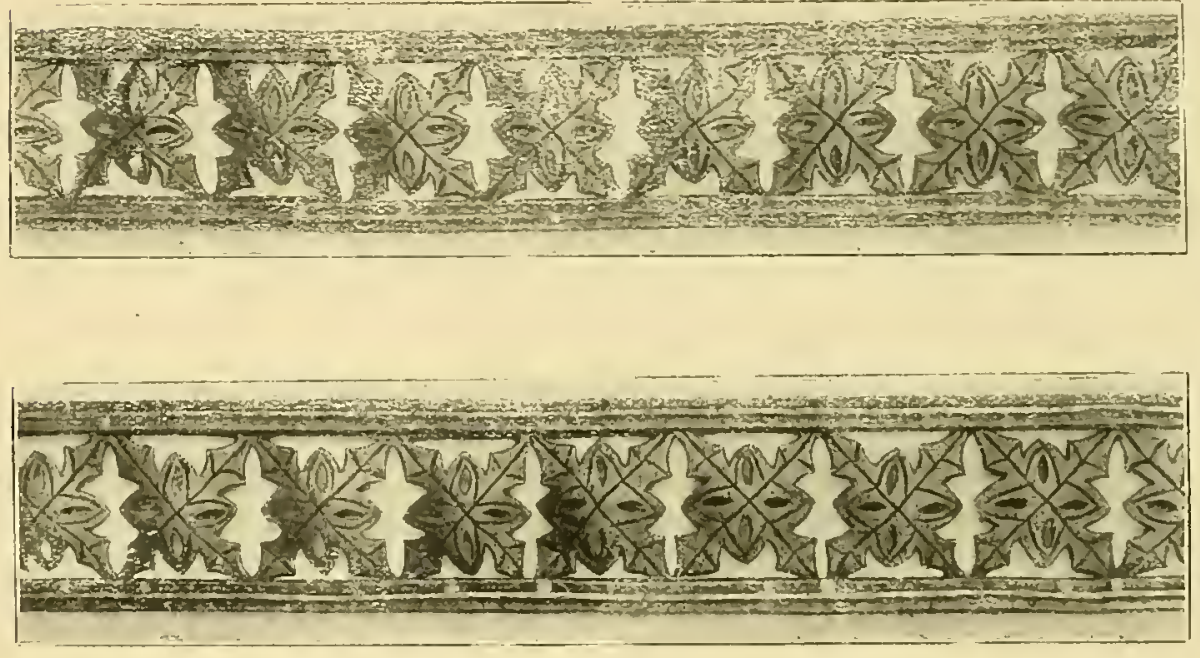

N'ủm. 354.

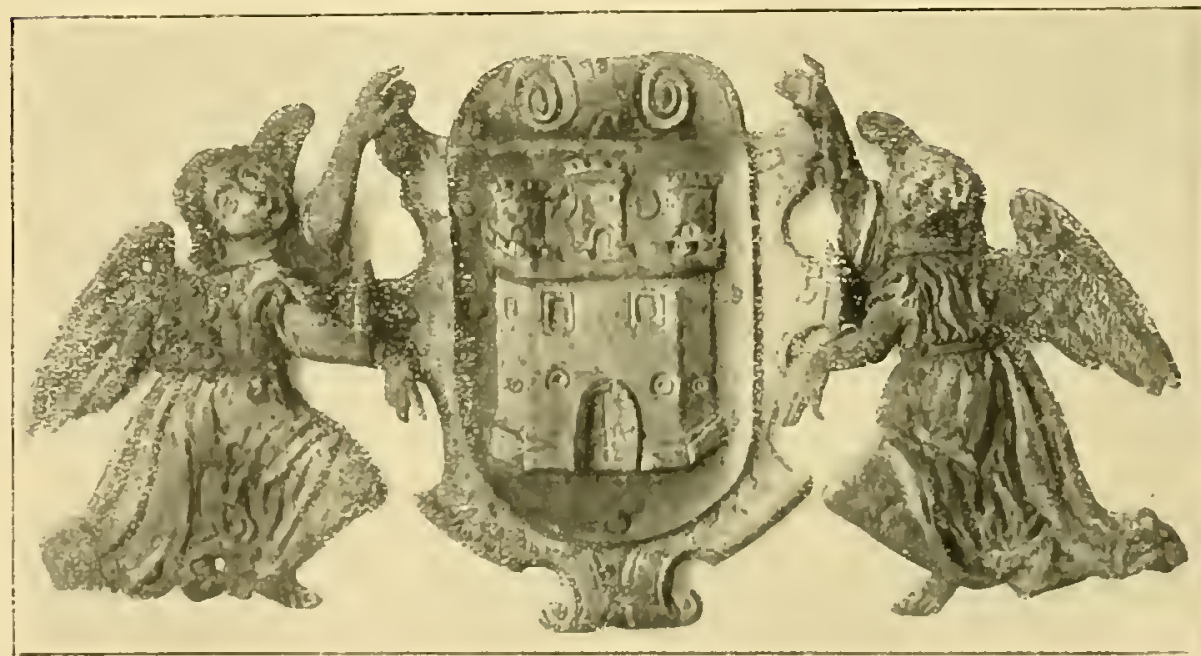

Núm. 350. 


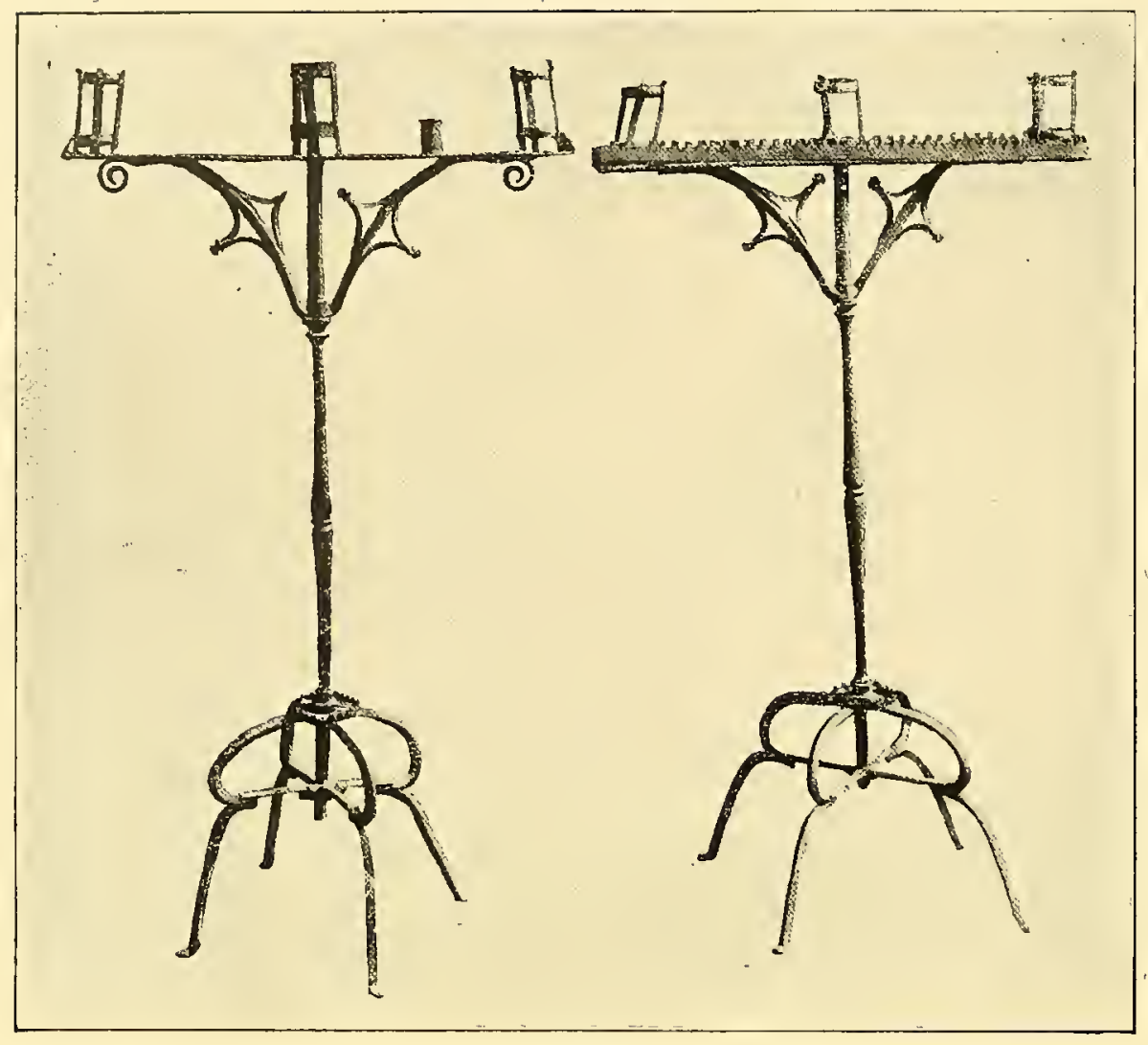

Nủm. 355.
Núm. 362.-Dos soportes de flameros de reja, en hierro torneado de 17 centímetros de altura por 15 de diámetro, decorado con clavos curvados según sus generatrices. Siglo xvi.

Expositor: D. José Lázaro.

Núm. 363.--Dos círculos de 15 y $16 \mathrm{~cm}$. de diámetro, representando cabezas policromadas. Sirvieron de decoración en trabajos de rejería.

Siglo xvı.

Expositora: Excelentísima Señora Marquesa de Bermejillo del Rey.

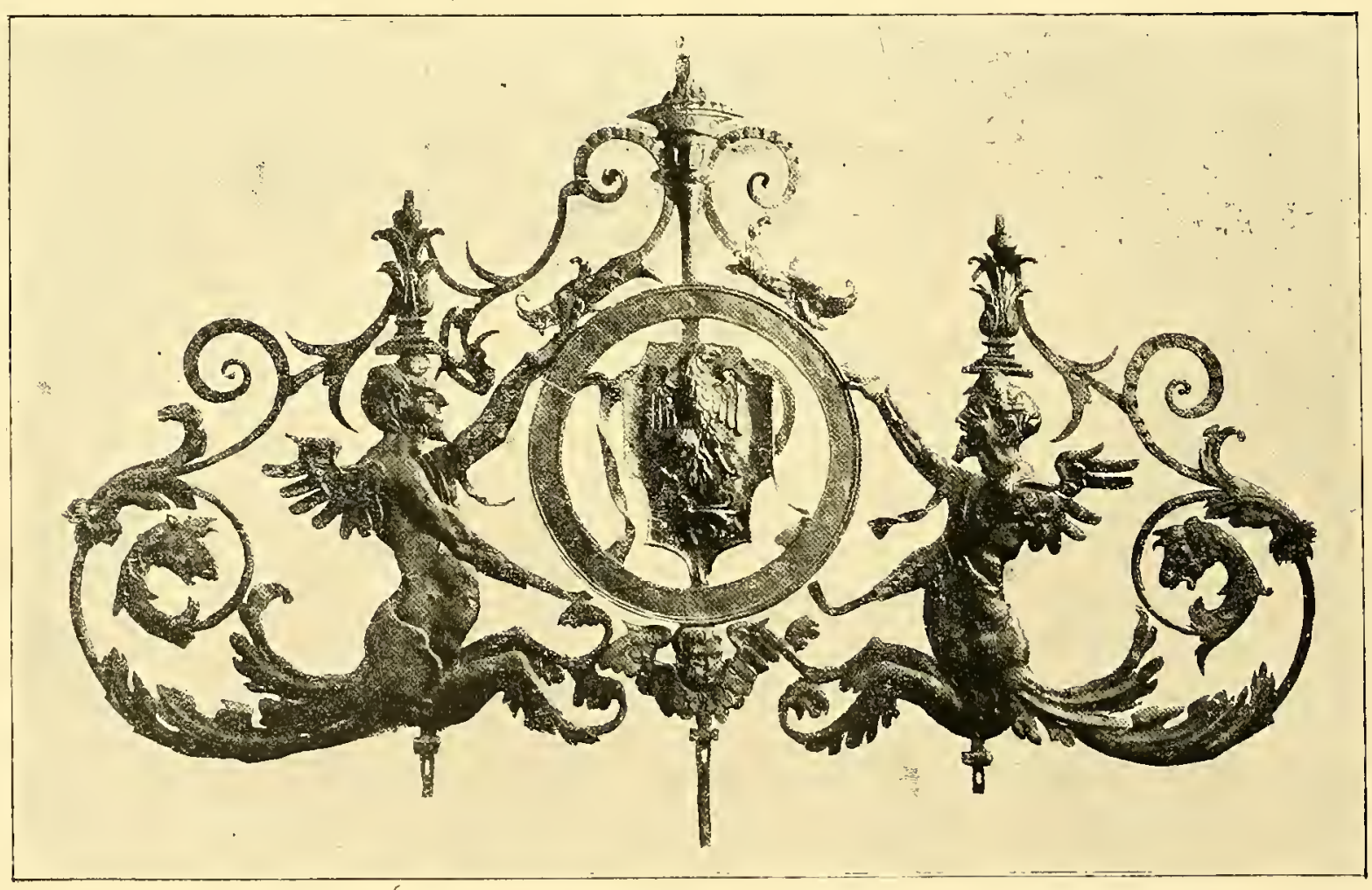

Nüm. 359. 
Núm. 364. - Dos medallones policromados de plancha repujada de 19 centímetros de diámetro, representando dos bustos cercados por una corona de laurel. Debieron servir de decoración en rejas.

Siglo xvI.

Expositora: Excelentisima Señora Marquesa de Bermejillo del Rey.

Núm. 365.-Tres elementos decorativos de rejería, constituídos por escudos heráldicos cercados por elementos decorativos del Renacimiento.

Siglo xvI.

Expositor: D. Juan Lafora.

Núm. 366.-Dos flameros de plancha repujada, simétricos, que debieron constituir de las dos caras

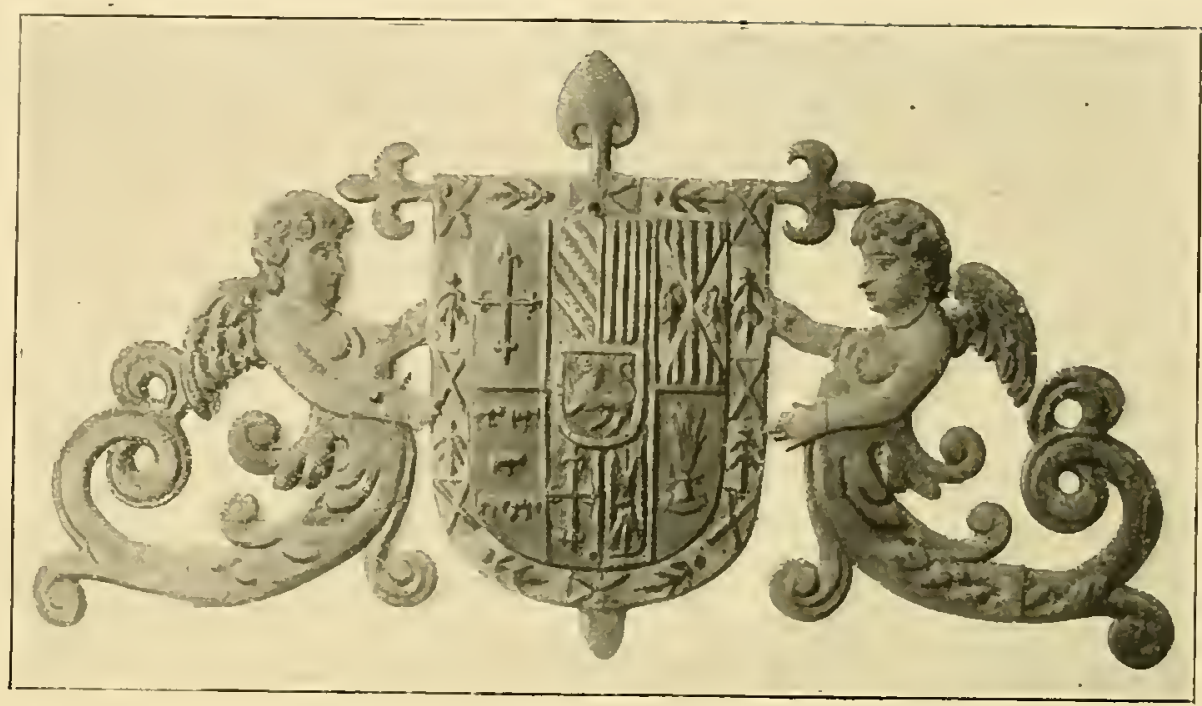

Nim. 357.

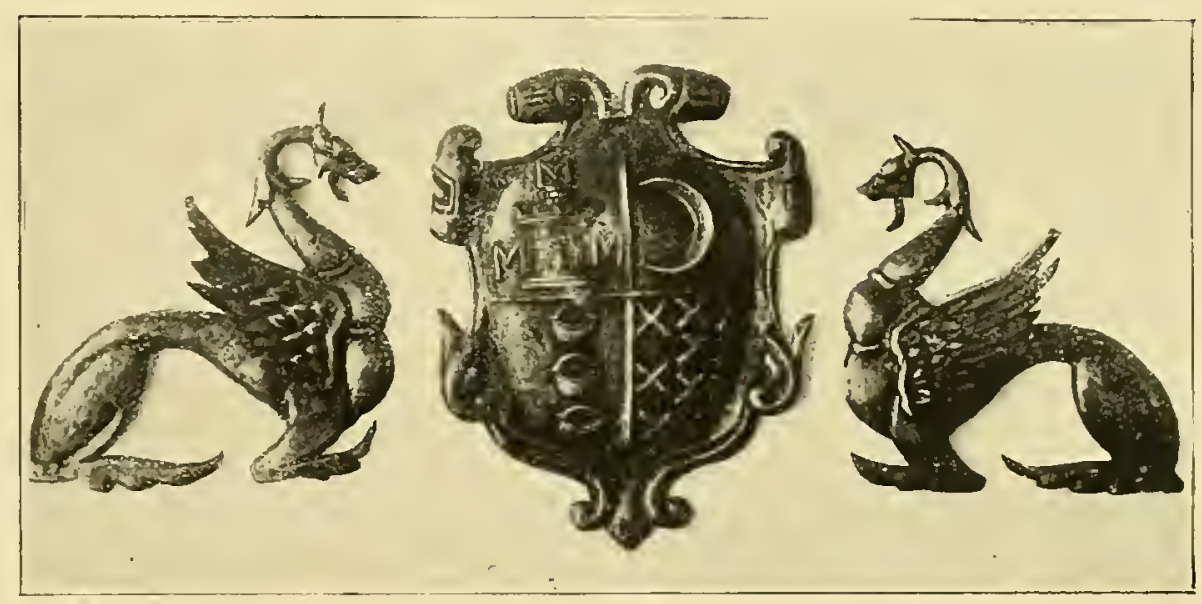

Ňúm. 358.

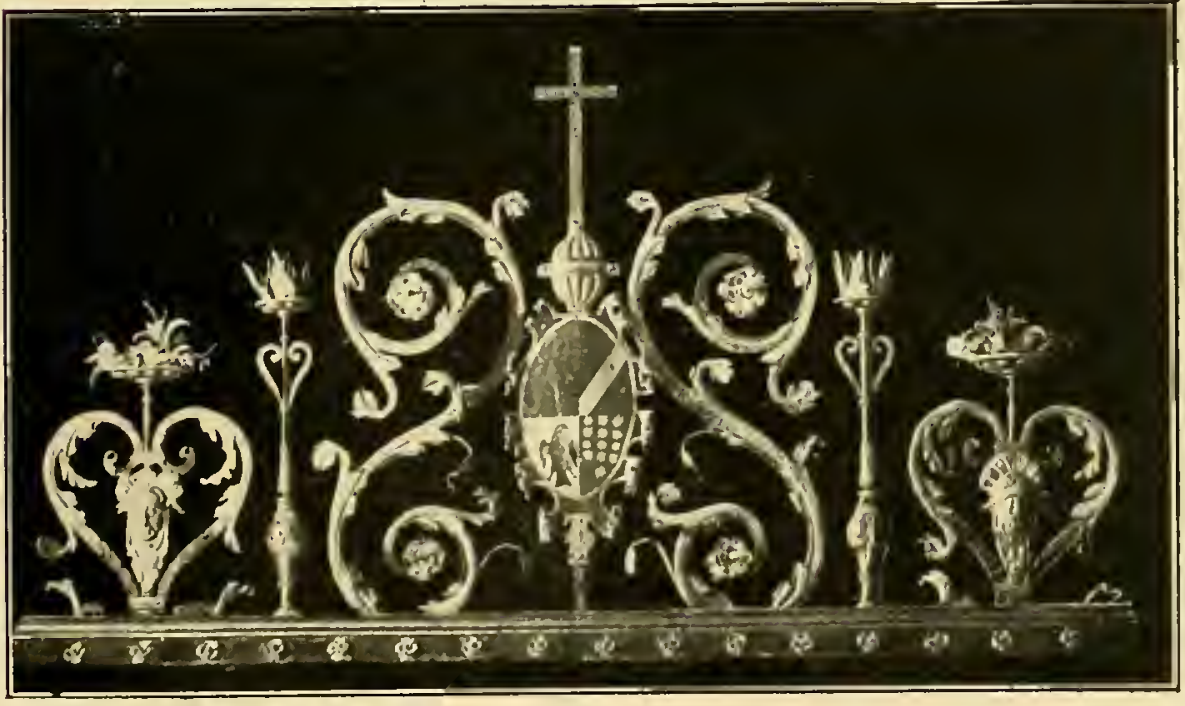

un solo candelabro de crestería de reja.

Siglo xvı.

Expositor: Excmo. Señor Marqués de la Torrecilla.

Núm. 367.-Una figura de guerrero en plancha repujada. Tamaño: dos tercios del natural. Siglo xvı.

Expositor: D. José A. Weissherger. 


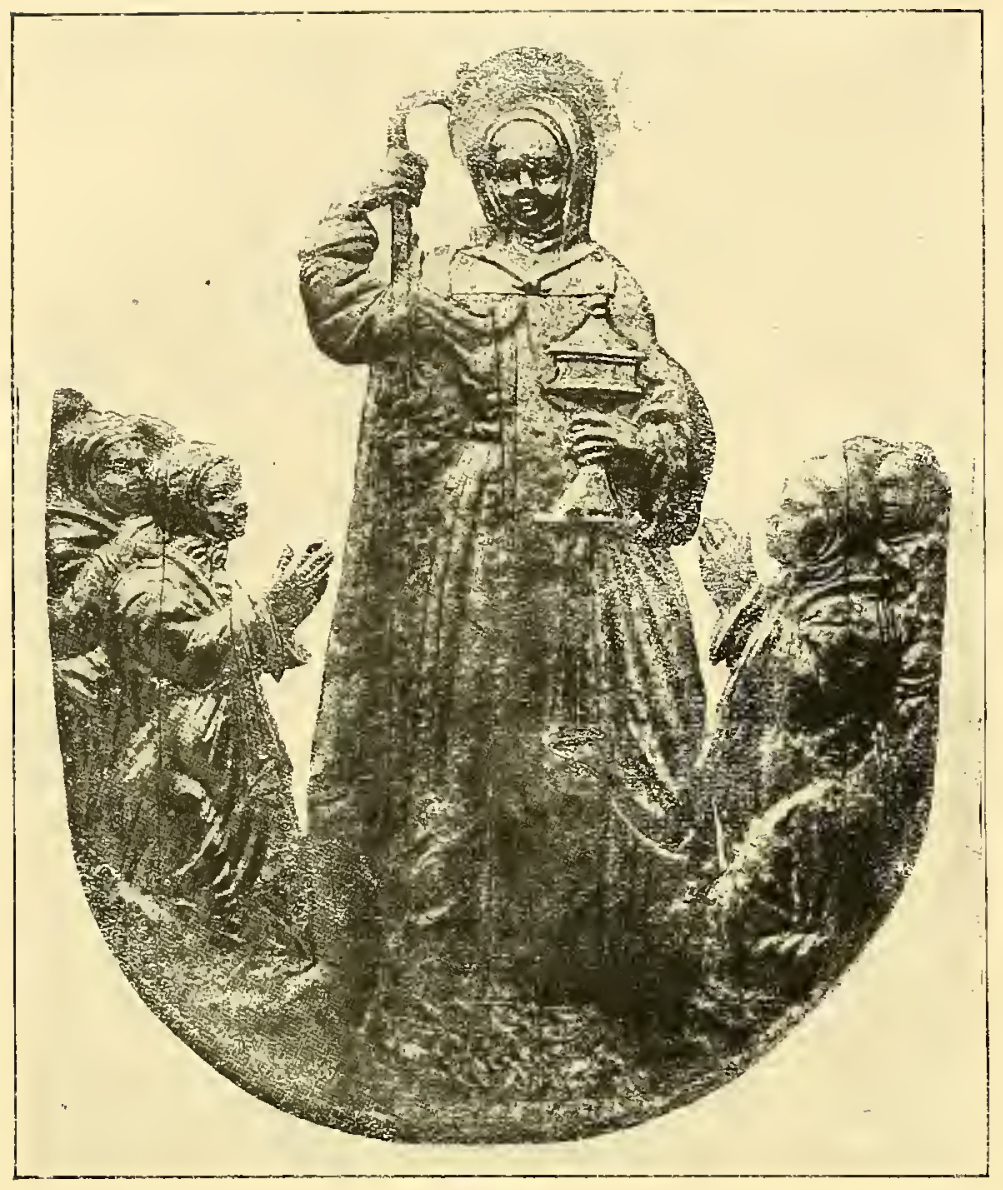

Nüm. 361.
Núm. 368.-Cabeza de apóstol en plancha repujada. Debió servir de ornamentación en los buenos trabajos de rejería del siglo xvi.

Expositor: D. José Lázaro.

Núm. 369.-Cuatro grandes medallones con bustos en plancha repujada, que estuvieron colocados en las lámpa-

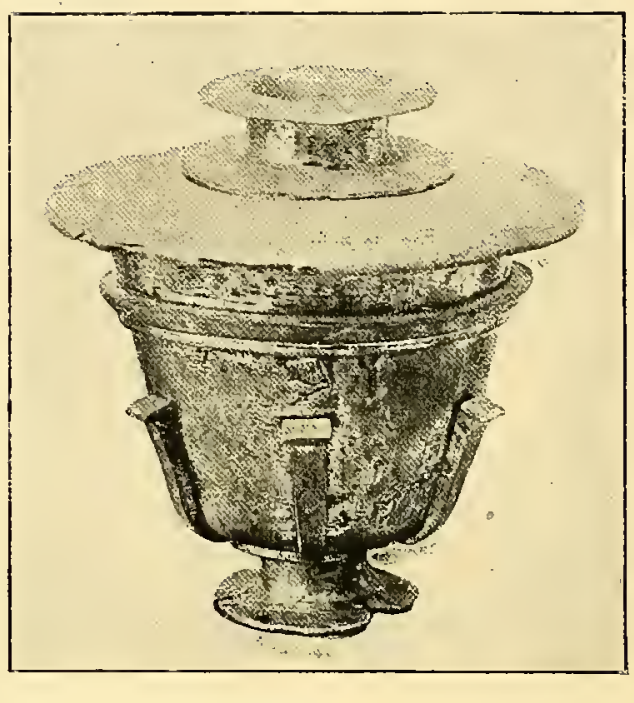

Nंúm 302.

ras ante el apóstol en la Capilla Mayor de la Catedral de Santiago. Obra de los maestros cerrajeros Guillén o Baltasar Ruiz, de 1557 a 1560.

Expositor: D. T. Blanco Cicerón, de Santiago.
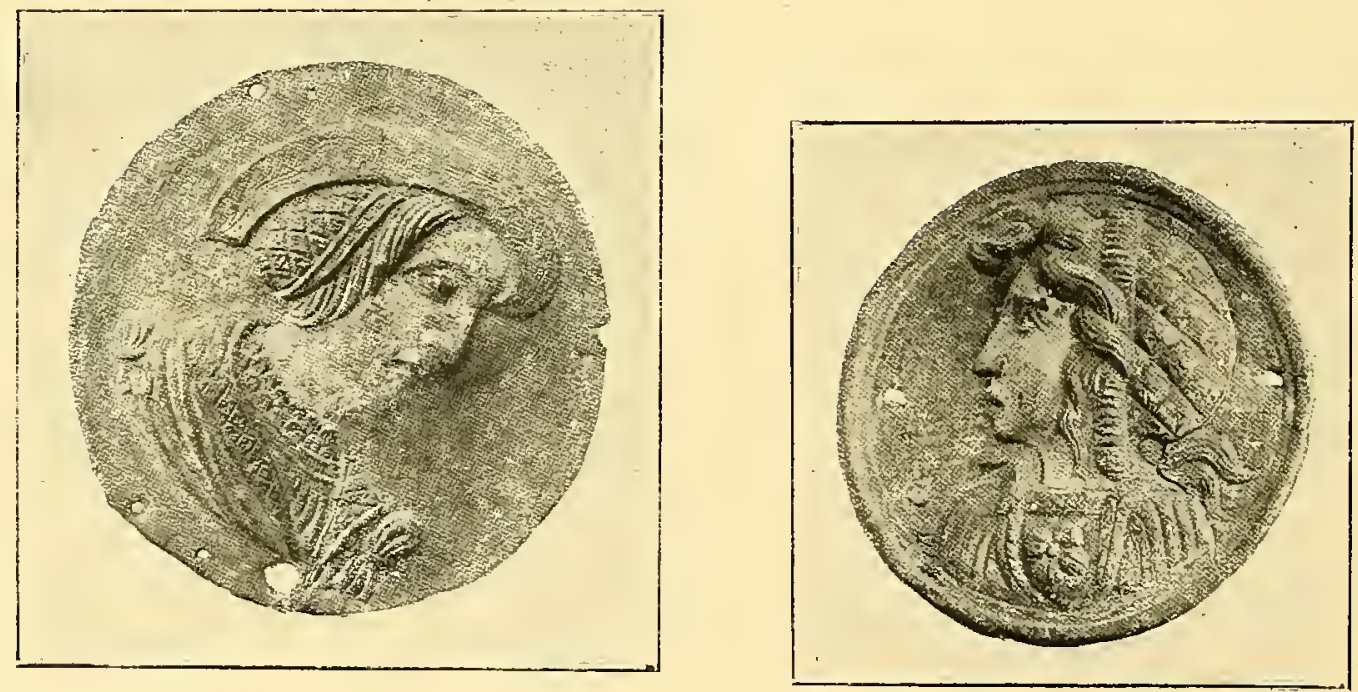

Núm. 363 
Núm. 370.-Pelícano con sus pequeñuelos. Trabajo en plancha de hierro repuja da para decoración de un copete de reja. Principios del siglo xvi.

Expositor: Excmo. Sr. Marqués de Bay.
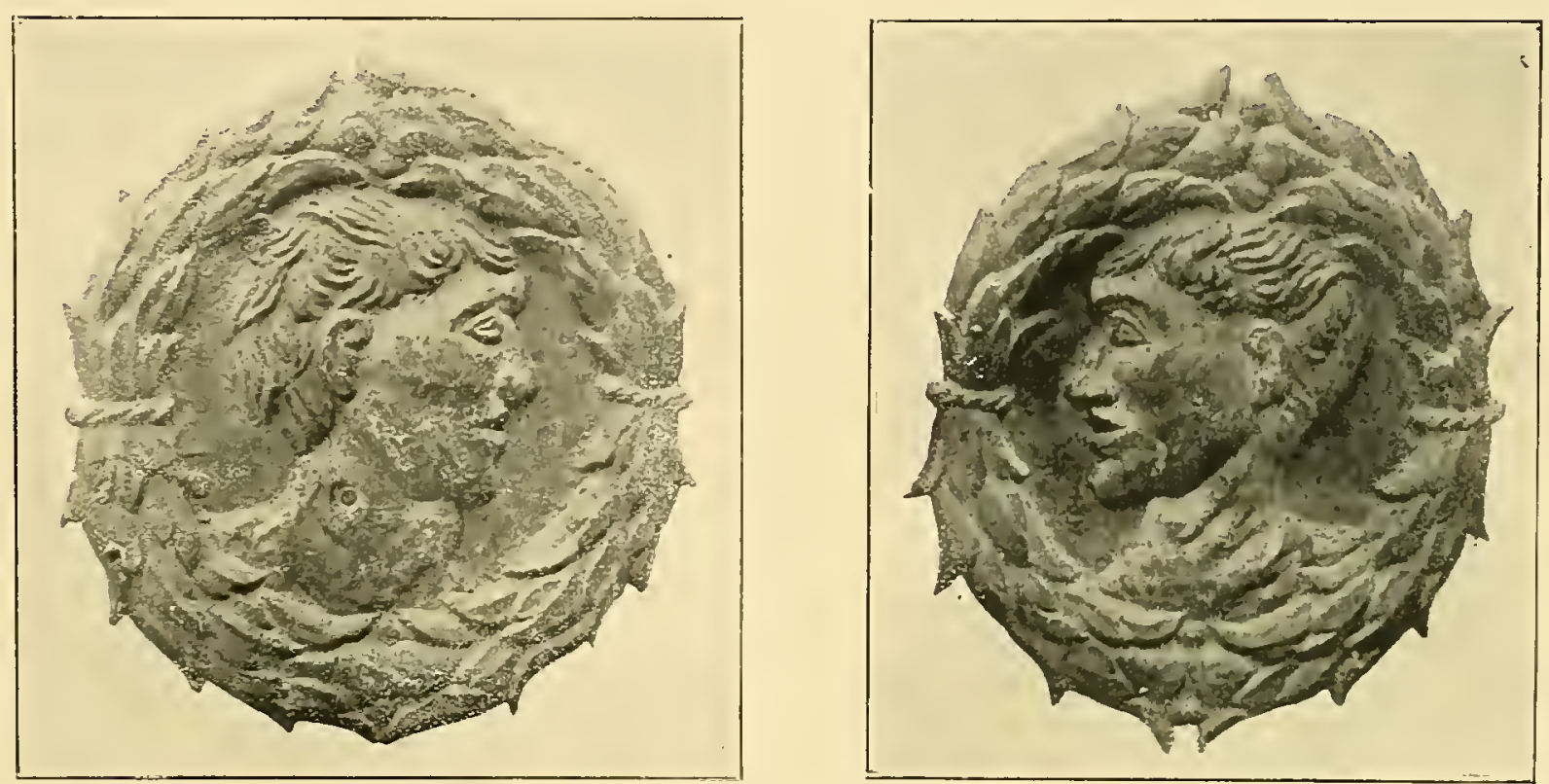

Nưm. 304.
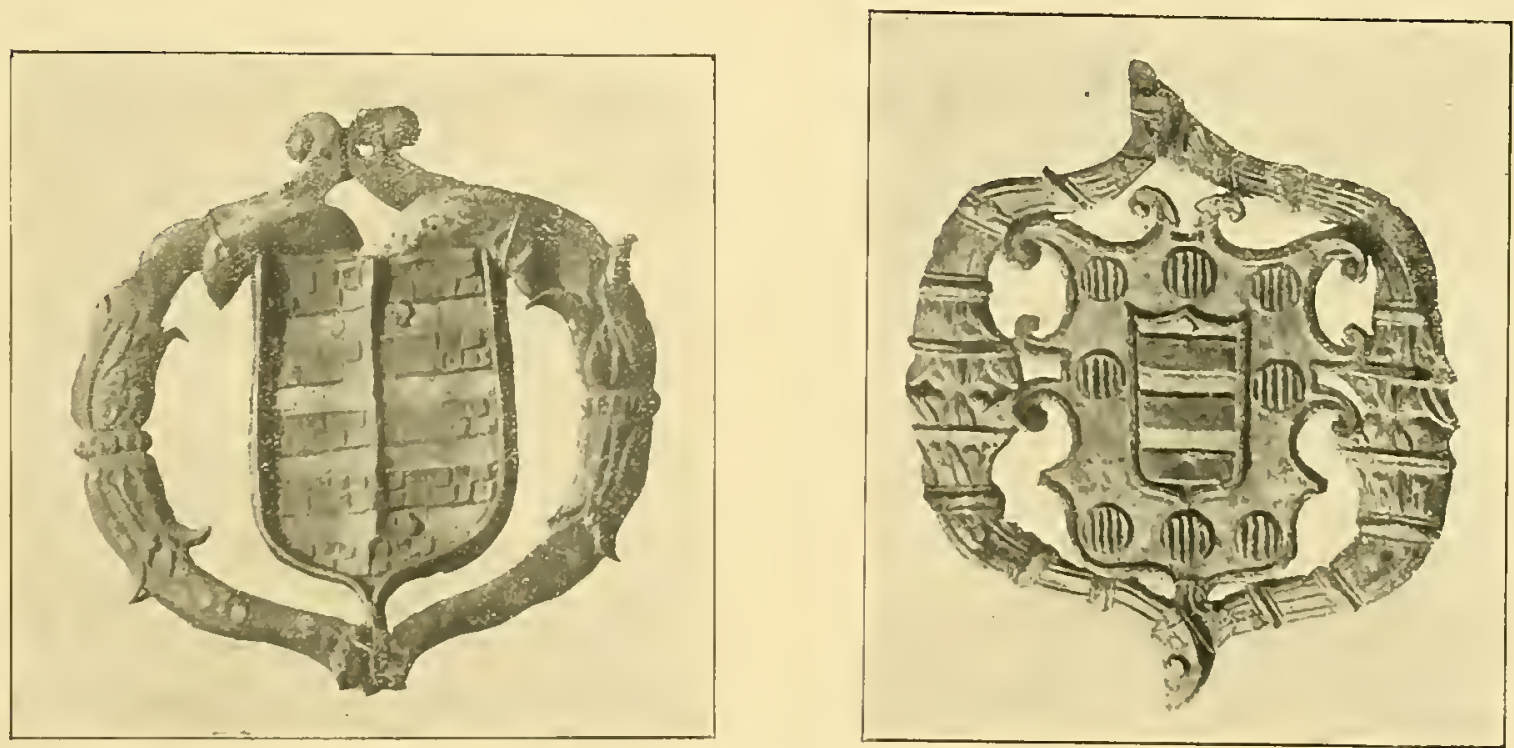

Núm. 365.

Núm. 371.-Atril de pie. Aguila sobre esfera completa, hecha en plancha repujada cosida. Presenta la particularidad de tener nimbo en la cabeza, lo cual haría suponer que pertenece a la época de los Reyes Católicos. Estilo de los Reyes Católicos.

Expositor: D. José Lázaro. 
Núm. 372.-Atril de pie. Aguila de plancha recortada cọn las alas explayadas apoyada sobre media esfera. Trabajo en varios órdenes de planchas festoneadas, superpuestas. El pie no corresponde a la época del ejemplar. El águila es obra del siglo xvi.

Expositor: D. José Lázaro.

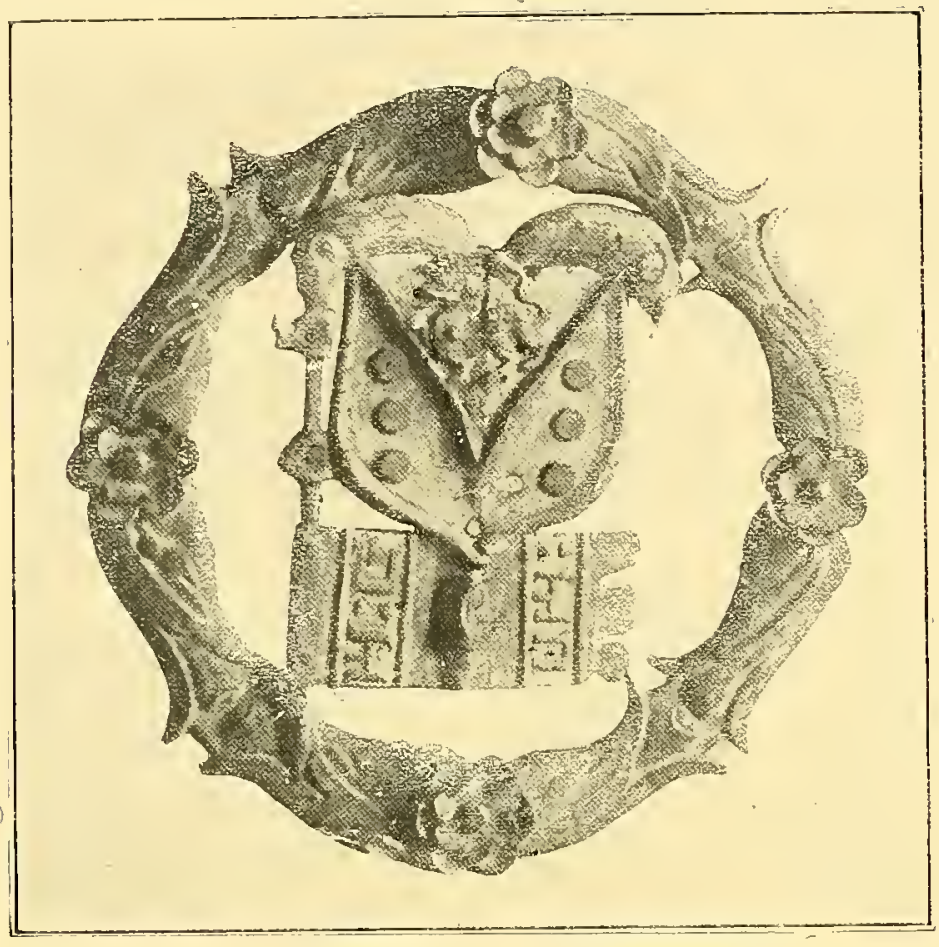

Núm. 365.

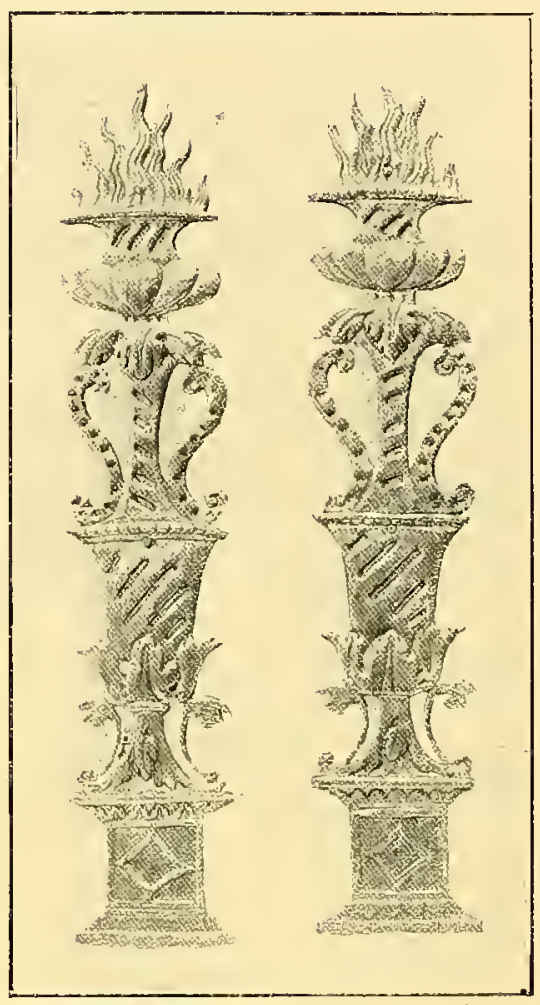

Núm. 366.

Núm. 373.-Atril de pie. Aguila de plancha recortada con decoración incisa en hojas superpuestas simulando

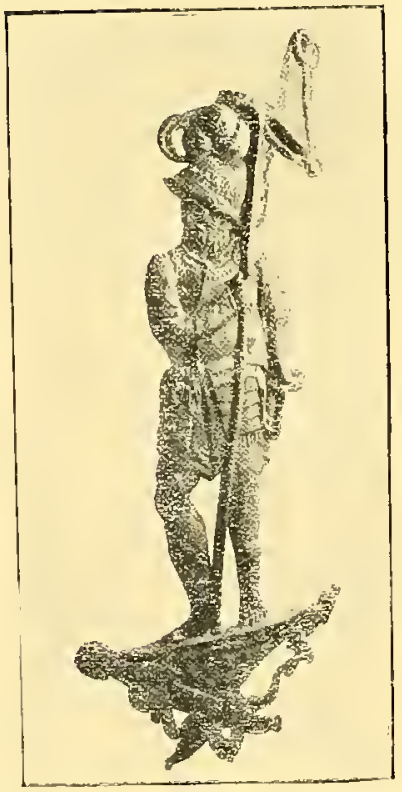

Núm. 367. cada unidad una pluma. Sobre cada una de las patas una esfera, apoyando sobre una varilla circular. El pie fué hecho con posterioridad.

Siglo xvr.

ExPOSITORA: Excelentísima Señora Marquesa de Bermejillo del Rey.

Núm. 374.-Figura de pájaro con las alas reco-

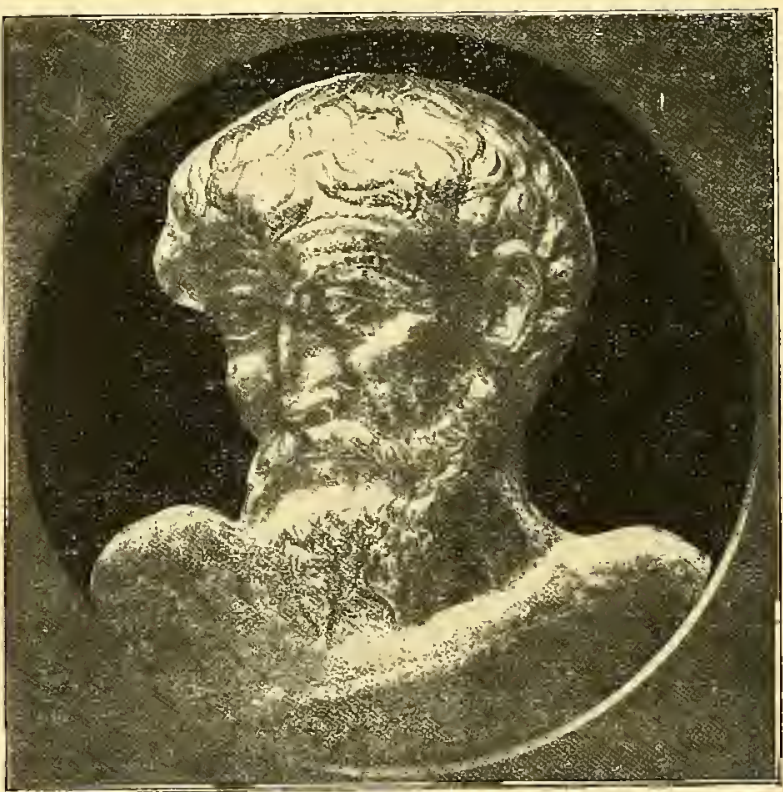

Núm. 368. 

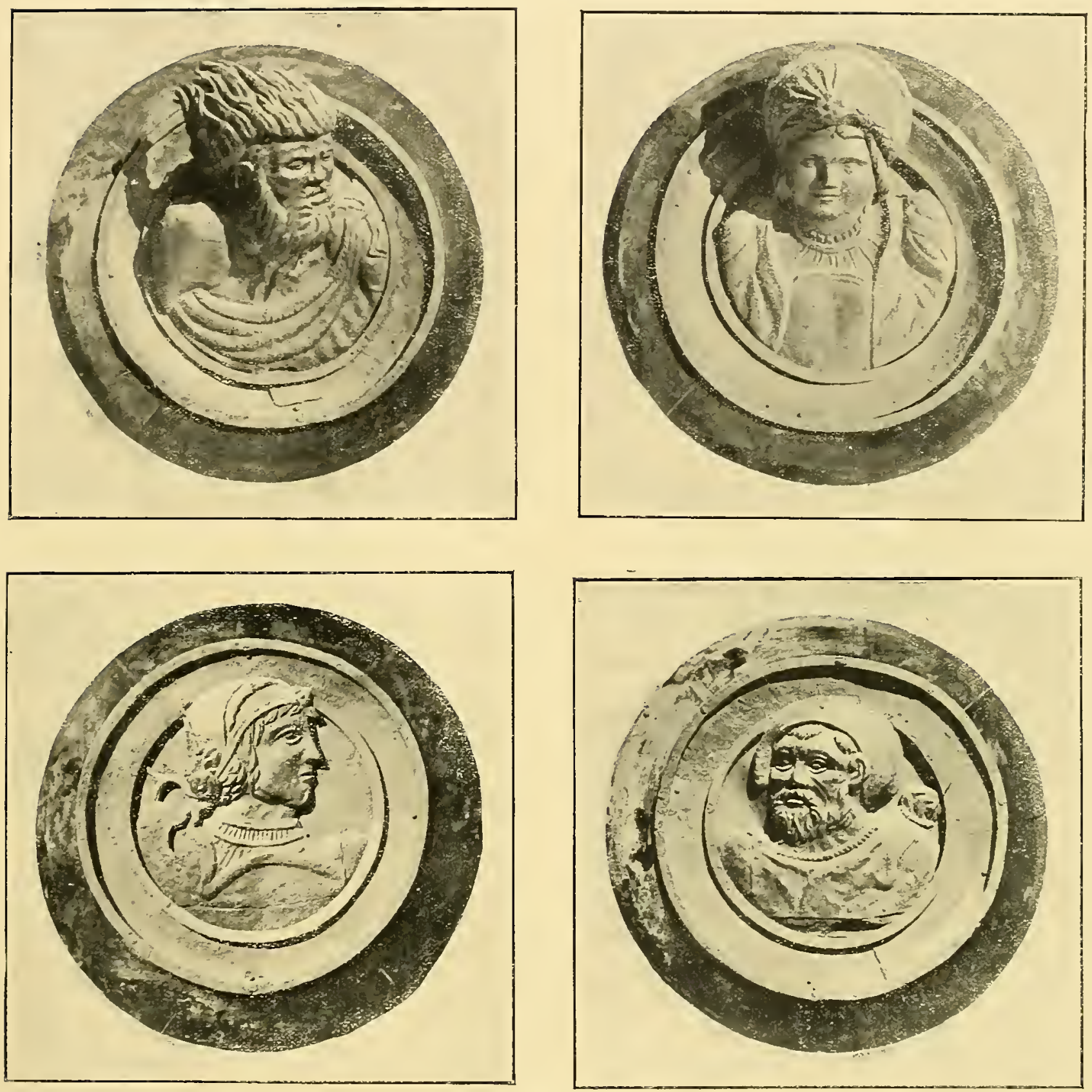

Ním. 369.

gidas de plancha recortada y repujada, de unos $25 \mathrm{~cm}$. de dimensión máxima. Siglo xvı. Expositor: D. Benito Mur.

Núm. 375. - Atril, cuyo plano de apoyo está formado por barras torneadas, recordando los balaustres de la época. Mediados del siglo xvı.

Expositor: D. José Lázaro.

Núm. 376.-Atril, cuya superficie de apoyo la forman cuatro medias varillas (una sus- 
tituída), siguiendo el perfil de diminutos balaustres, y un círculo en el centro formando una cruz. Siglo xvi.

\section{Expositor: Cabildo de la Catedral de Lérida.}

Núm. i377.-Atril cuya superficie de apoyo está formada por una cruz de varilla cuadrada y cuyo frente y costados son de plancha calada siguiendo motivos del Renacimiento. Siglo xv1.

Expositora: Excma. Sra. Marquesa de Bermejillo del Rey.

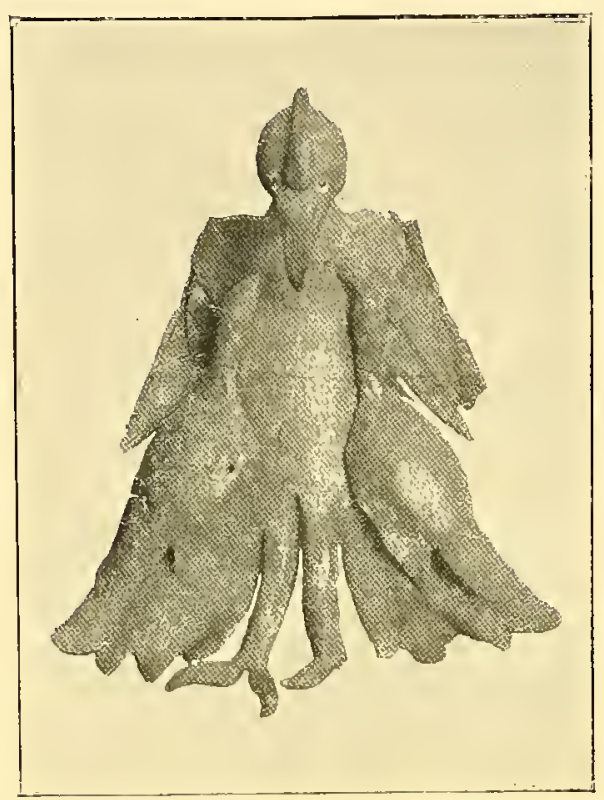

Nứm. 370.

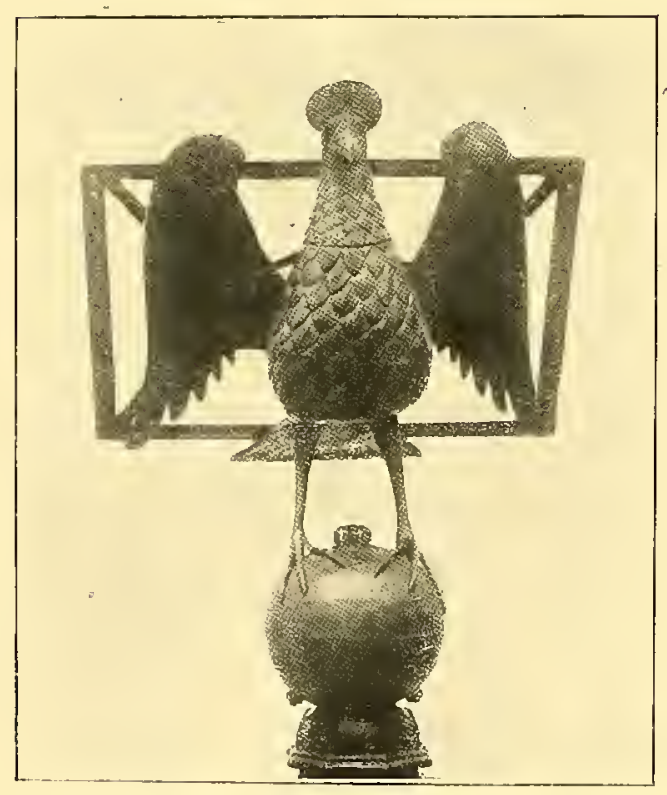

Núm. 371.

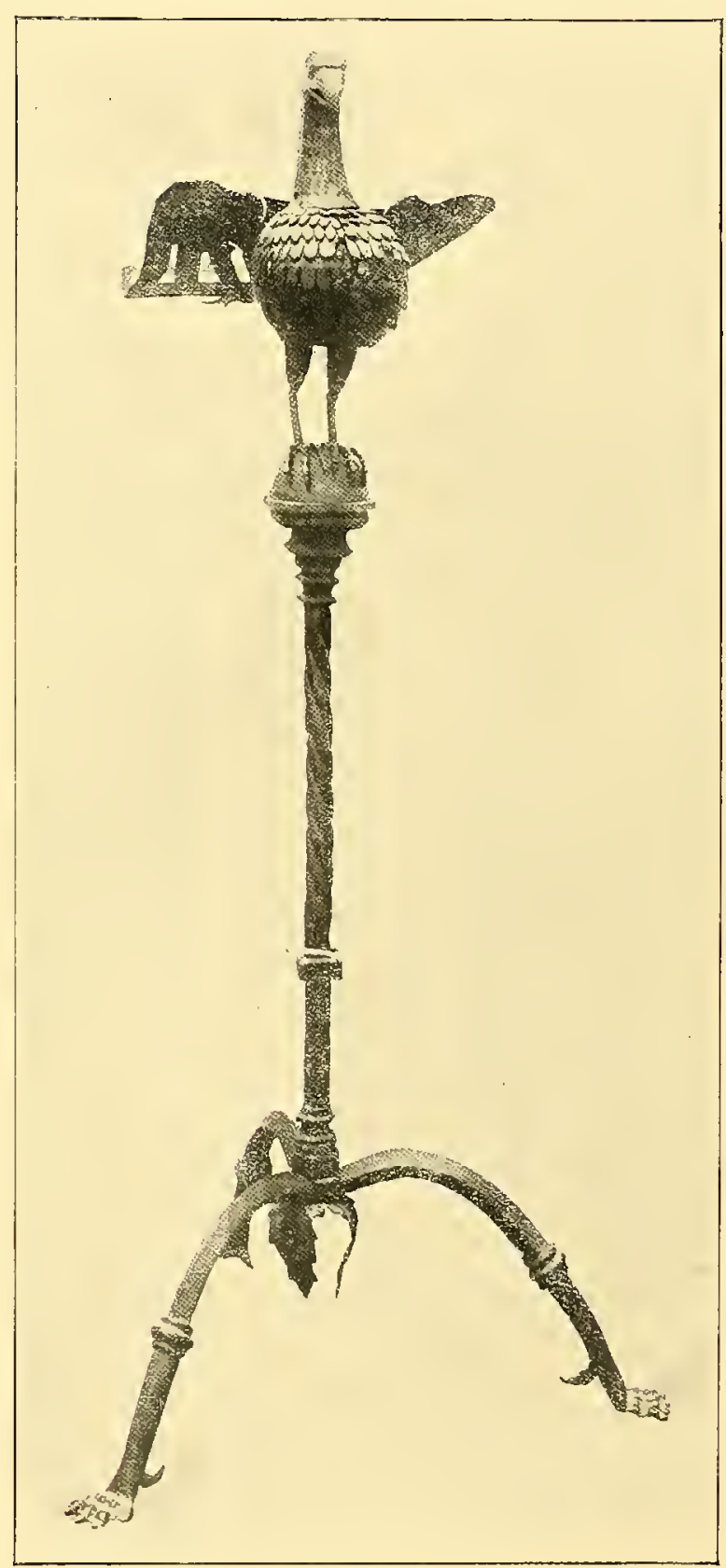

Nủm. 372. 


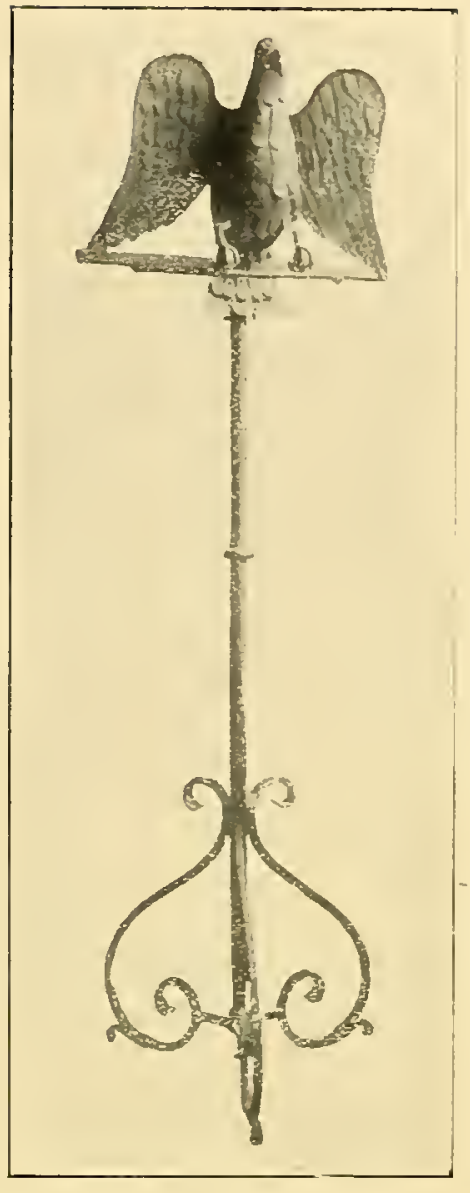

Núm. 373.

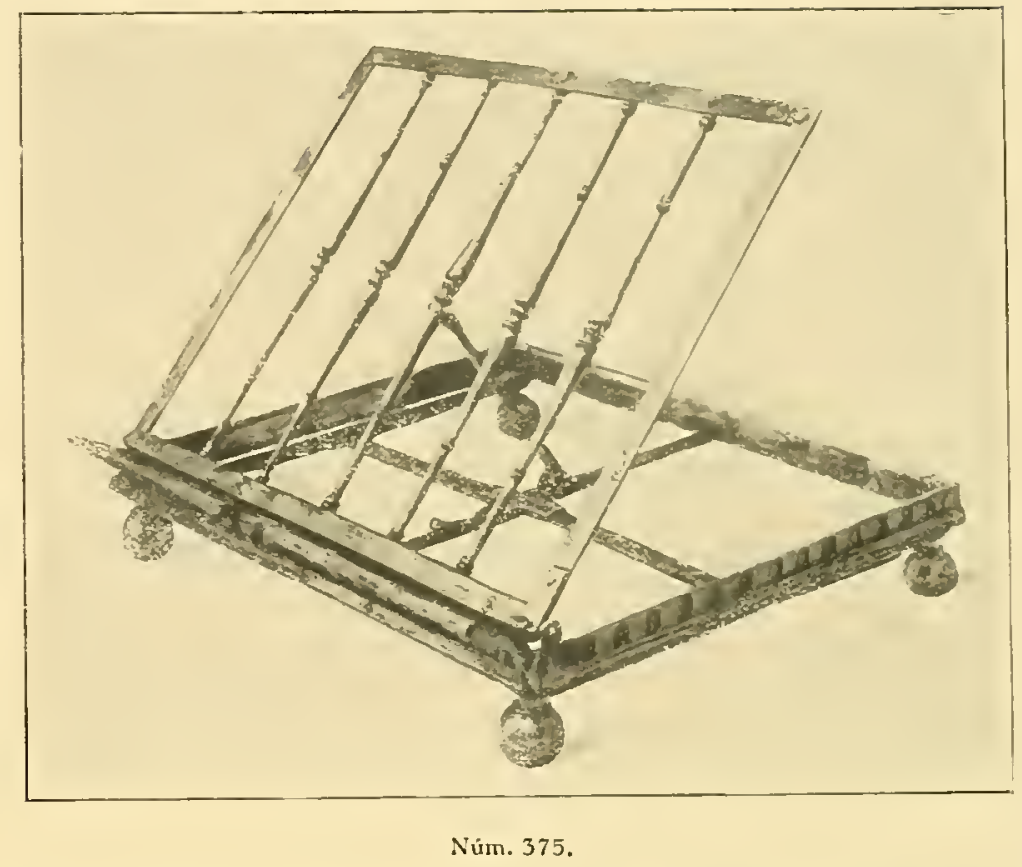

Núm. 378.-Atril, cuyo plano de apoyo está cubierto por una cruz de plancha recortada, siluetada siguiendo el perfil de gruesos balaustres, y cuya intersección ocupa un doble círculo con un corazón atravesado por dos flechas, escudo de la Orden de San Agustín. El frente, de plancha recortada, y el apoyo o tornapuntas también en plancha recortada. Siglo xvı.

Exiositora: Excma. Sra. Duquesa de Parcent.

Núm. 379.-Atril en hierro y bronce, cuyo plano de apoyo está constituído por un medallón en bronce que sostienen y circundan motivos del Renacimiento en plancha calada; dos columnas en bronce fueron añadidas con posterioridad. Una pequeña cor-

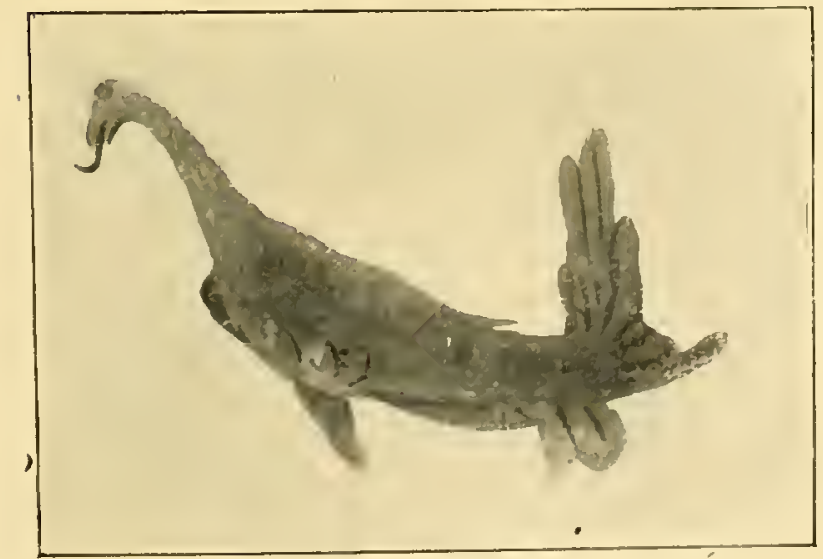

Niúm. 374.

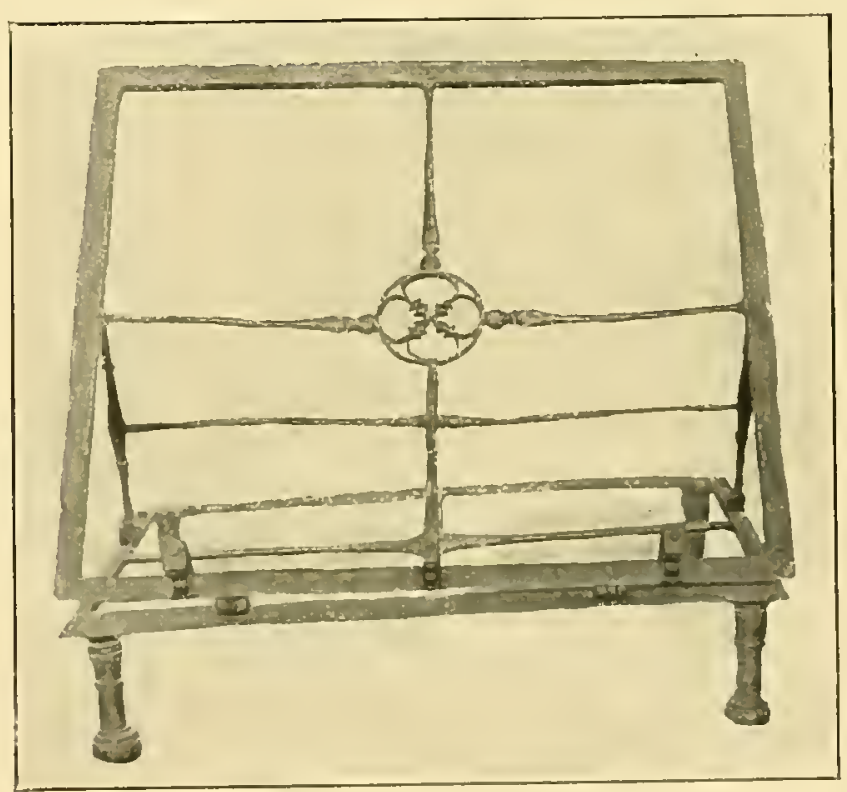

Nưm. 370. 


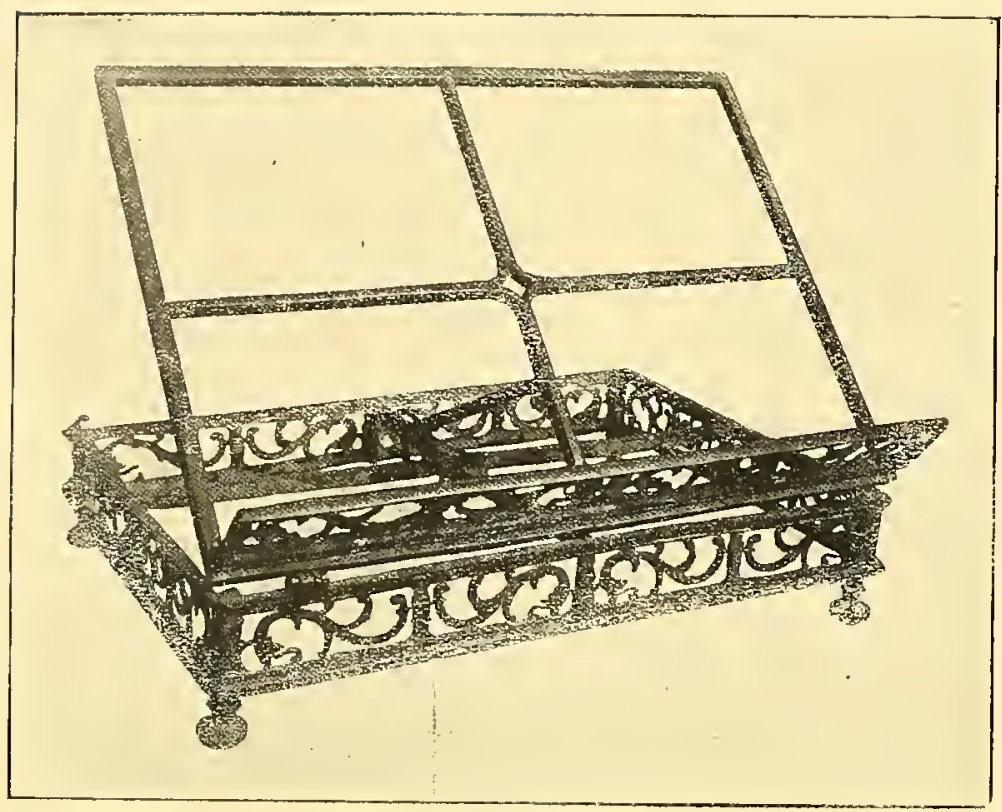

Núm. 377.

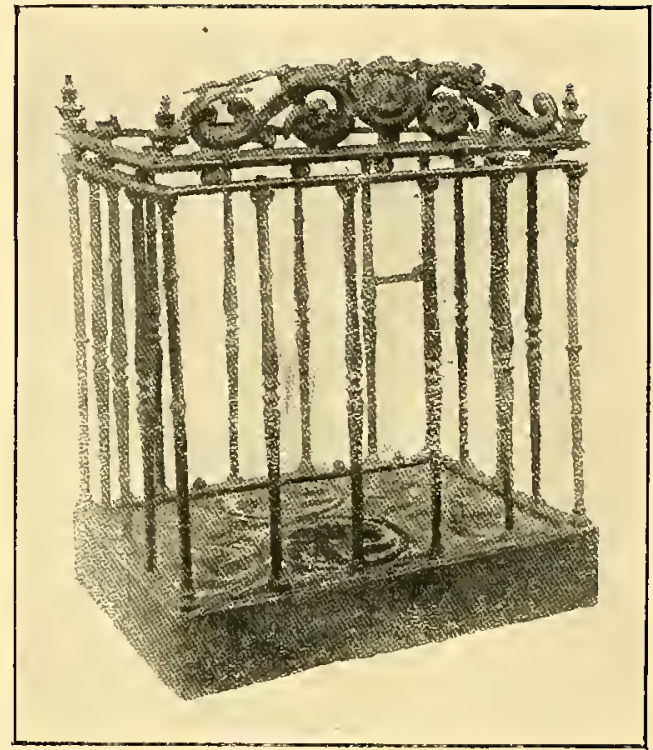

Nủm. 381.

nisa completa la superficie del apoyo. Balaustrada en el frente y costados y finos balaustres

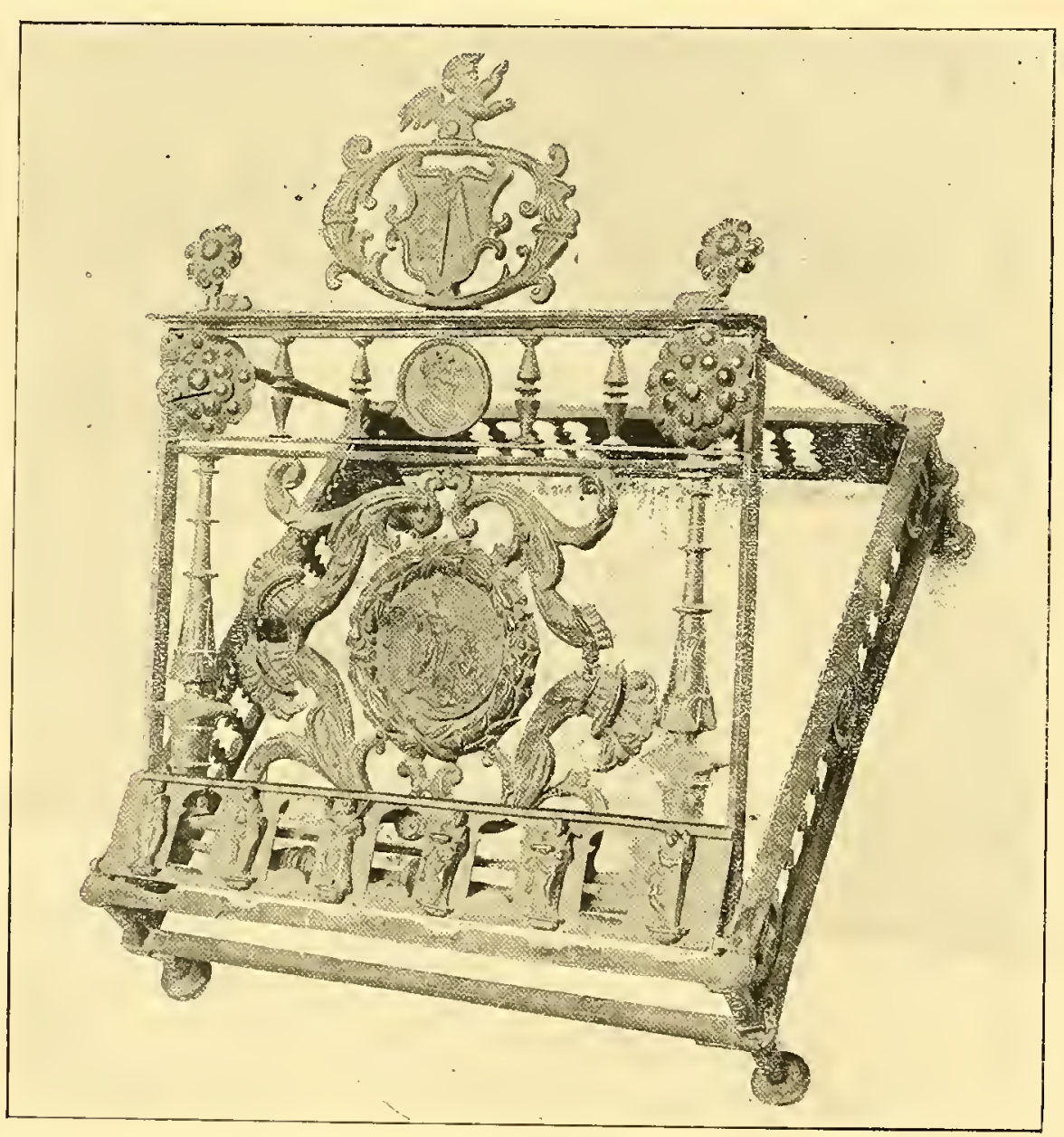

Núm, 379. como tornapuntas. Cornisa con imágenes de bronce en la faja de apoyo.

Procede de la Catedral de Burgo de Osma. Siglo xvı.

Expositor: Cabildo de la Catedral de Burgo de Osma.

Núm. 380.- Un punzón de señales para misal, con

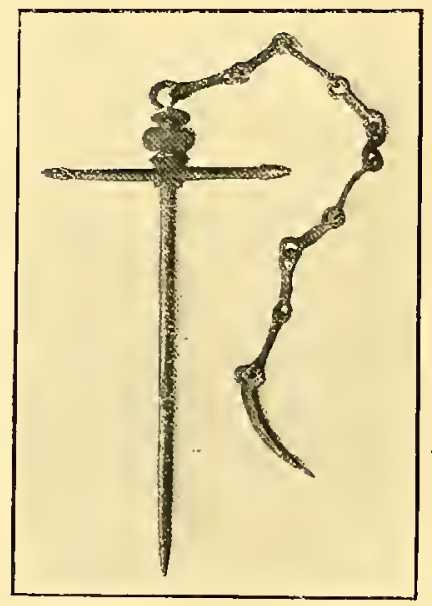

Núm. 380. 


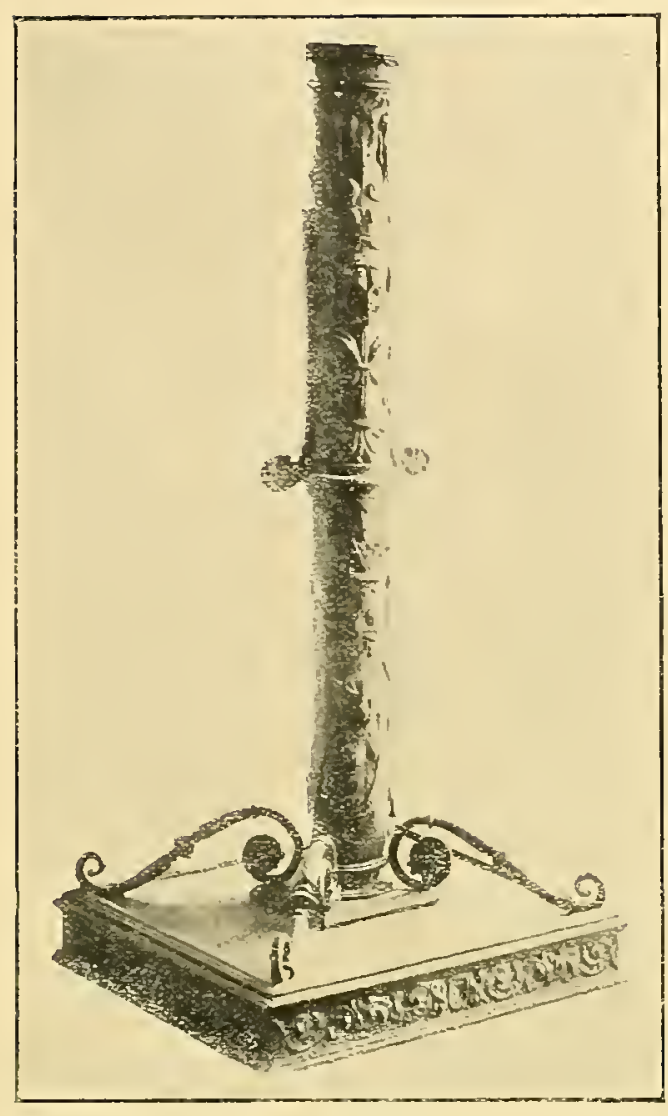

Nủm. 382. cadena de eslabones alargados.

Siglo xvi.

Expositor: EXXcelentísino Sr. Duque de Santa Lucía.

Núm. 381.--Una pequeña reja formando caja o jaula rectangular. La componen pequeños balaustres análogos a los empleados para la composición de atriles, un pequeño copete en plancha recortada. Debió estar, toda ella, cubierta,

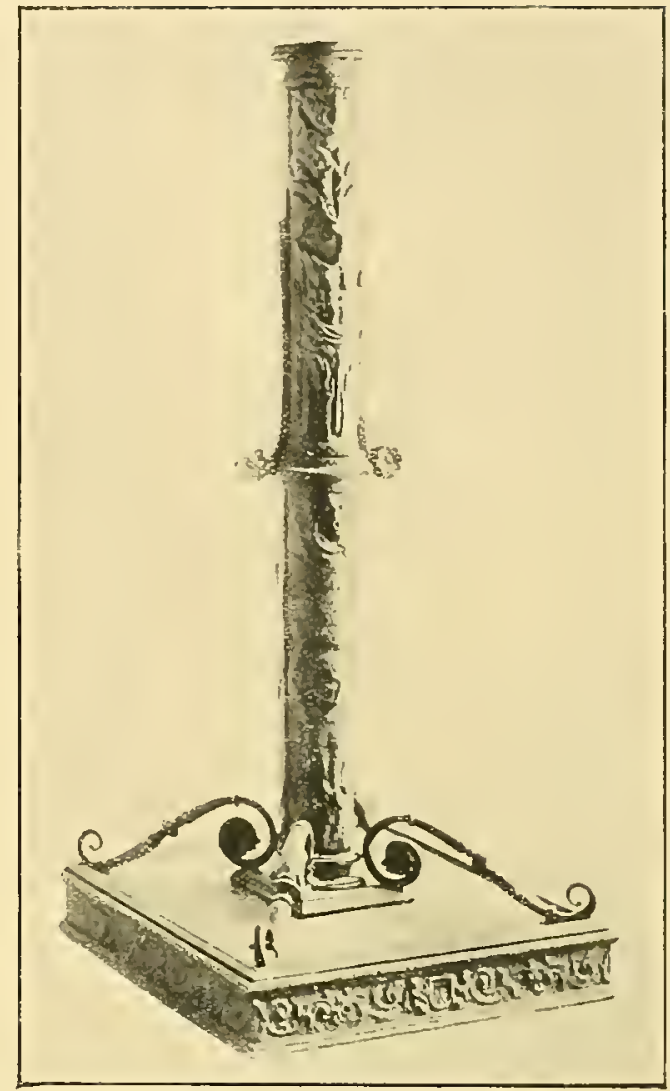

Núm. 382.

por elemento repetido, de plancha recortada, de los que aun se conserva un ejemplar. Siglo xvr.

Expositor: D. Benito Mur.

Núm. 382. - Columna de candelabro de plancha repujada con figuras y motivos del Renacimiento. Apoya sobre basamento cuadrado que se une a la columna por cuatro tornapuntas de varilla terminada en volutas. Siglo xvi. Mide $80 \mathrm{~cm}$. de alto.

Expositor: D. José A. Weissberger.

Núm. 383. - Candelabro de tallo cilíndrico-cónico, sobre basamento cuadrado y con decoración, de plancha superpuesta, recortada y ligeramente repujada. Siglo xvı.

Procede de la Catedral de León.-Mide 1,31 m. de alto.

Expositor: Museo Arqueológico Nacional.

Núm. 384.-Candelabro de tipo similar al precedente. Siglo xvı.

Procede de la Catedral de León. Mide 1,46 m. de altura.

Expositor: Museo Arqueológico Nacional. 
Núm. 385. - Magnífico candelabro del cirio pascual, de $1,56 \mathrm{~m}$. de altura, de tallo cilíndrico, basamento cuadrado en plancha repujada su parte cilíndrica inferior recortada y ligeramente repujada la superficie, con una galería de balaustres y tornapuntas en volutas invertidas en su parte central. Siglo xvI.

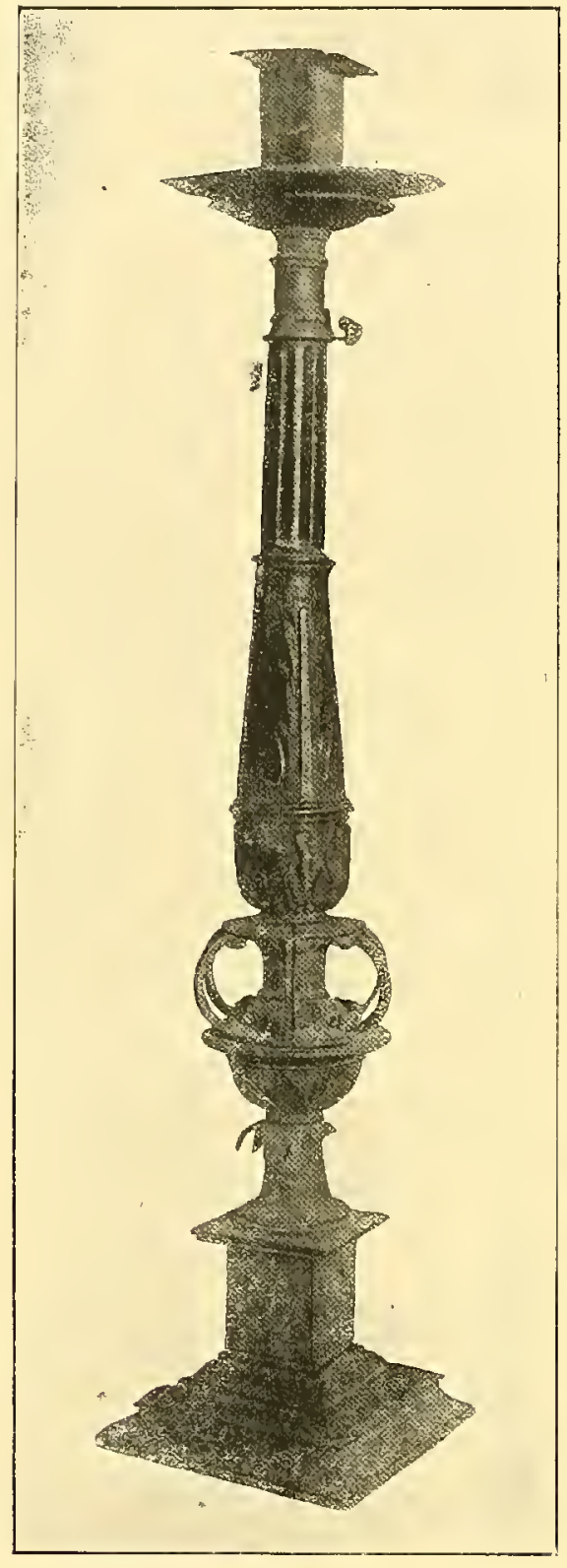

Nüm. 383.
Expositor: Cabildo de la Catedral de León.

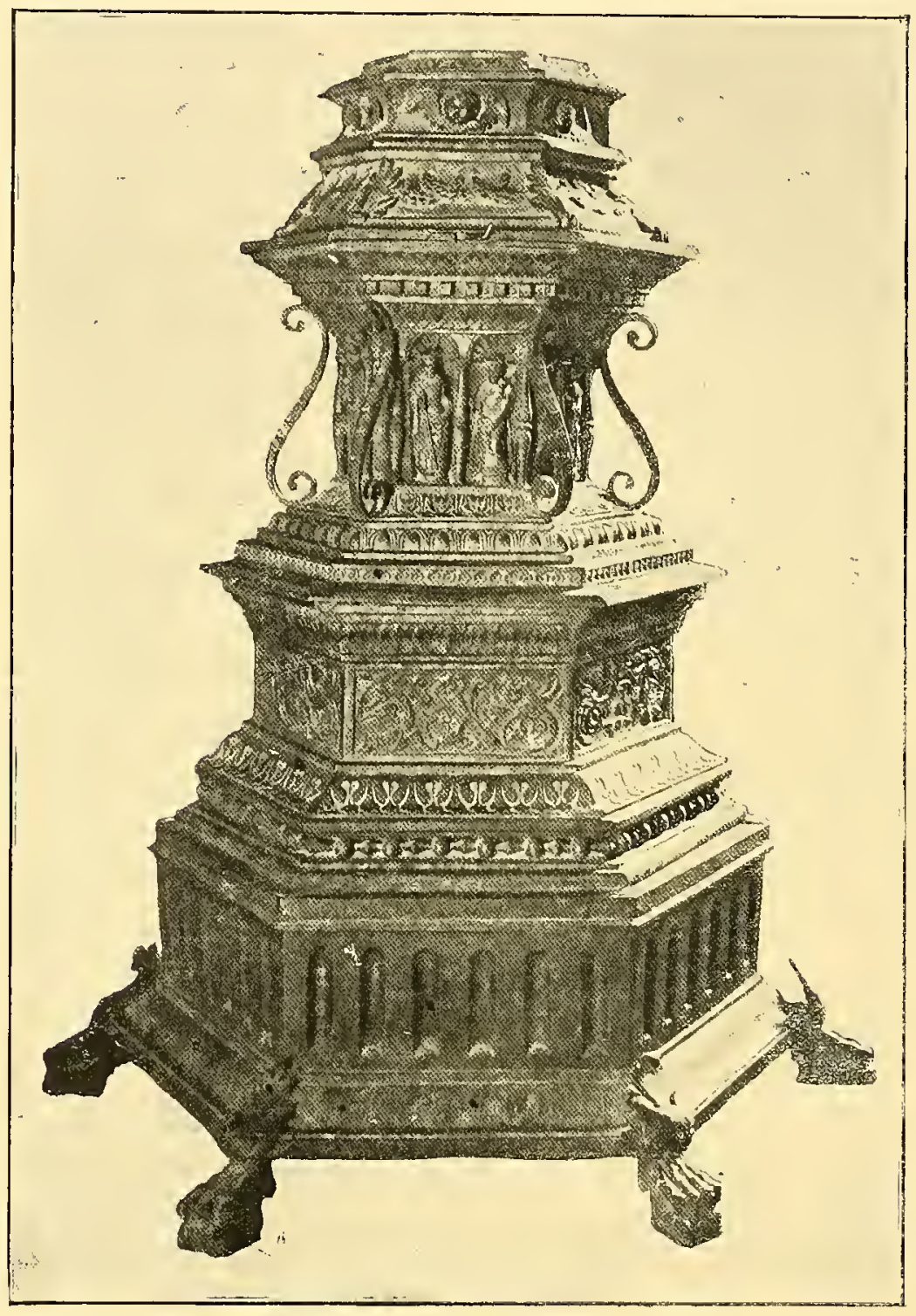

Nüm. 386.

Núm. 386. - Pie de facistol de sección exagonal y múltiples órdenes de pisos y cornisas, todo él de plancha repujada, ostentando, cerca de la terminación, los doce apóstoles. Obra de Hernando de Arenas.

Primer tercio del siglo xvı. Pertenece a la Catedral de Cuenca.

Expositor: Cabildo de la Catedral de Cuenca. 
Núm. 387.--Gran candelabro de $2 \mathrm{~m}$. de altura. Basamento triangular en dos pisos, vástago circular en distintos diámetros, las superficies del basamento ligeramente cóncavas, presentan un busto de frente, en plancha repujada sobre una corona circular de laurel. Cuatro clavos en dos tamaños decorados en doble orden de plancha recortada y repujada formando cada una tres hojas, completan la decoración simulando la fijación de una cartela. Los ángulos, en plancha superpuesta y recortada, representan una especie de monstruo que por un lado se prolonga en garra y por la parte superior en voluta. Una múltiple cornisa separa los dos pisos triangulares donde las superficies vienen decoradas por cabezas de apóstoles colocadas de perfil. El cuerpo superior, todo él ornamentado con motivos del Renacimiento, presenta en su centro tres óvalos, uno de ellos con las armas imperiales de España, un jarrón con azucenas, símbolo de la Anunciación, y las armas de un Mendoza, en cuya época fué trabajado el ejemplar. Sobre el reverso de la arandela un letrero que dice: OPERA FABRICE ECCLESIE. El fondo plateado y las decoraciones en realce doradas.

La opinión general es que fué trabajado en tiempos de D. Francisco de Mendoza y Bobadilla, Obispo que fué de Coria, nombrado Cardenal en 4 de Diciembre de 1545,

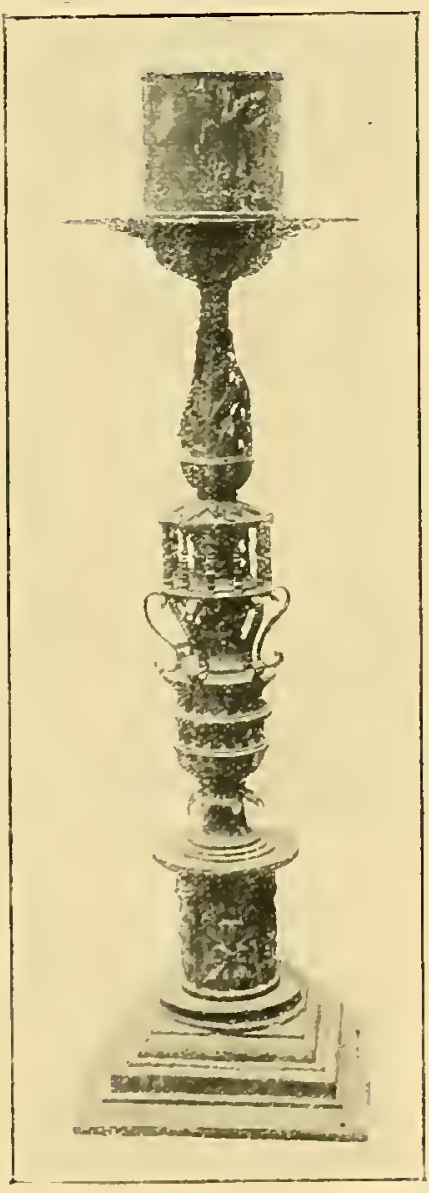

Núm. 385. modificando su título (de S. Maria in Ara Coeli, a S. Juan ante Portan Latinan) rigiendo ya el Arzobispado de Burgos en 1550 .

No obstante el estilo y la técnica parecen muy anteriores, quizá de la época de Andino, y hacen pensar en Don Iñigo López de Mendoza y Zúñiga, que rigió el Obispado de Burgos desde el 2 de Marzo de 1529 al 15 de Enero de 1537. Una consideración puede ser que, poco fundada, apoya esta hipótesis; en el caso de ser hecho en el

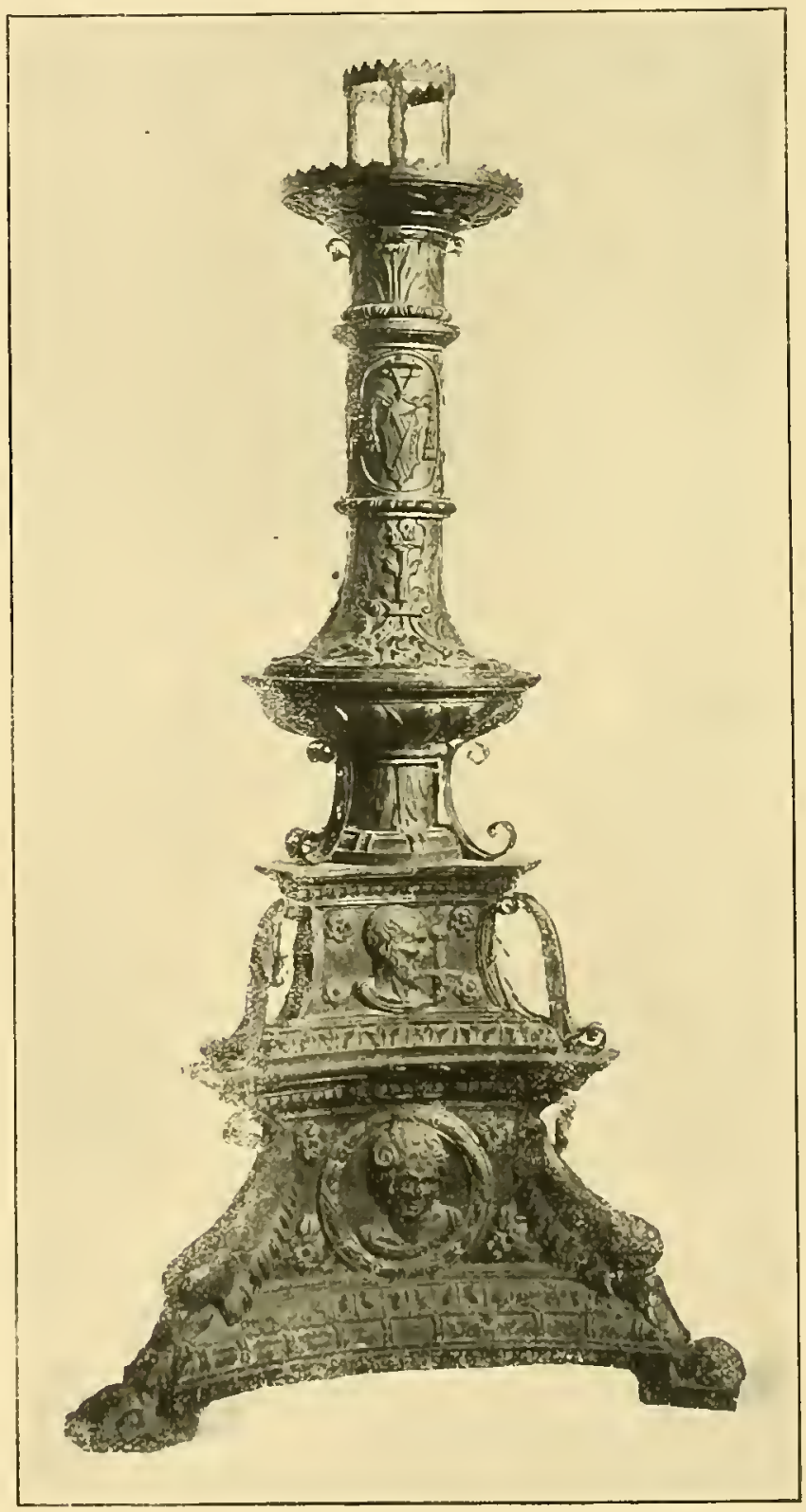

Núm. 387. 


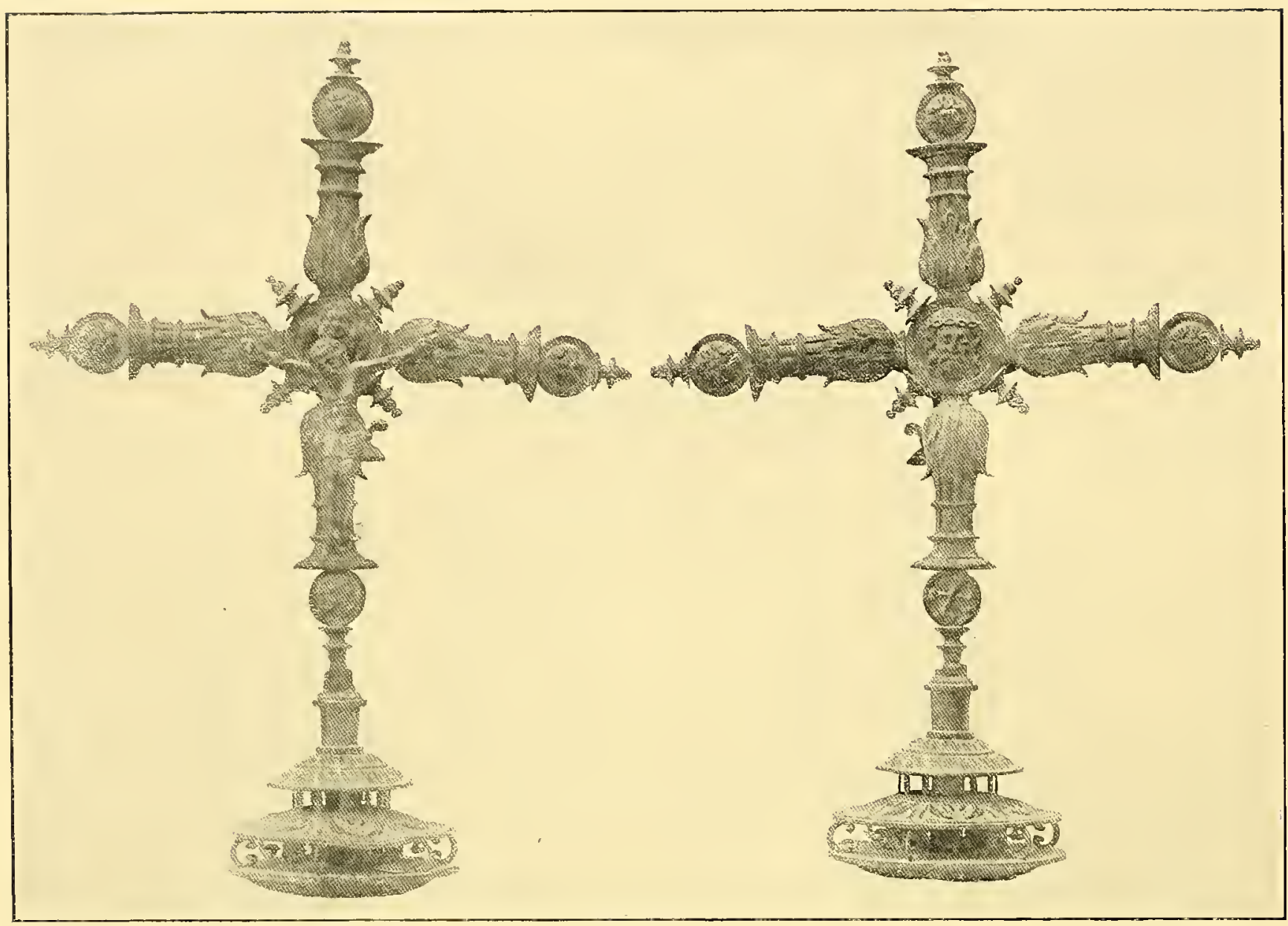

Núm. 388.

tiempo del segundo Mendoza, éste hubiera mandado acuartelar su segundo apellido Bobadilla para diferenciarse de su predecesor.

\section{Expositor: Cabildo de la Catedral de Burgos.}

Núm. 388.-Cruz procesional de hierro de brazos iguales en doble plancha repujada; en el centro un cuadrado de cuyos vértices arrancan, como bisectrices, motivos ornamentales en volutas invertidas. Cada uno de los brazos es una ornamentación floral de la que arranca una columna cónica estriada. Medallones en los extremos. El soporte lo constituye un cilindro decorado con cabezas de ángeles unido al eje por tornapuntas curvilíneos formando pisos. Altura: $1 \mathrm{~m}$. Siglo xvı.

\section{Expositor: Museo Arqueológico Nacional.}

Núm. 389.-Cruz procesional, análoga en un todo a la precedente, y policromada con la figura de Cristo también en plancha repujada. Altura: $57 \mathrm{~cm}$. Siglo xvı.

Expositor: D. Plátón Páraino. 
Núm. 390.-Cruz procesional de plancha ligeramente repujada, figurando cada brazo una doble cenefa que se abre en los cuatro extremos, dejando en hueco rombos y arrollando en volutas los extremos de la cenefa. Una fina cruz de línea en plancha recortada llena los espacios romboidales. Como soporte de la cruz, un pie cilíndrico en plancha repujada con una galería de plancha calada.

Siglo xvı.

Expositor: D. José Lázaro.

Núm. 391.-Cruz de gruesa plancha de hierro de brazos simétricos lobulados, un círculo central con el monograma JHS, toda ella dorada y cubierta con una ligera decora-

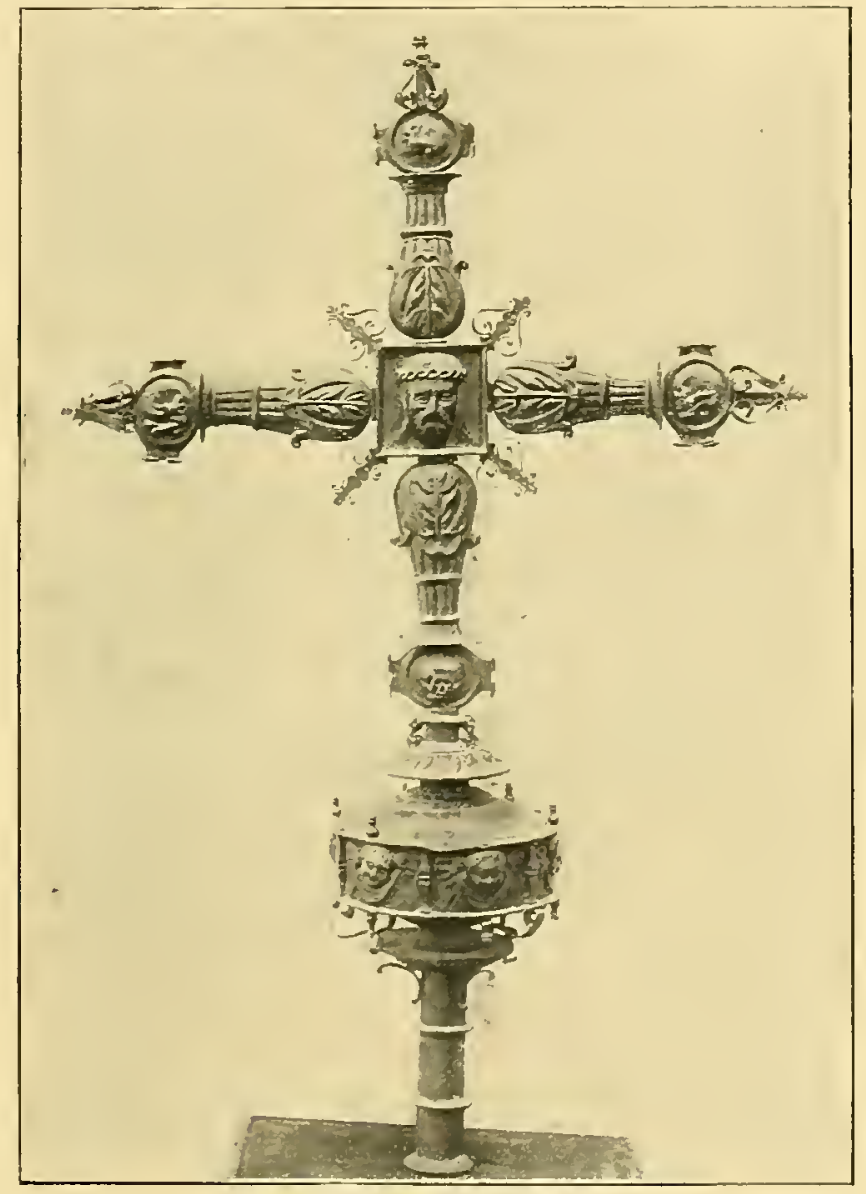

Núm. 389.

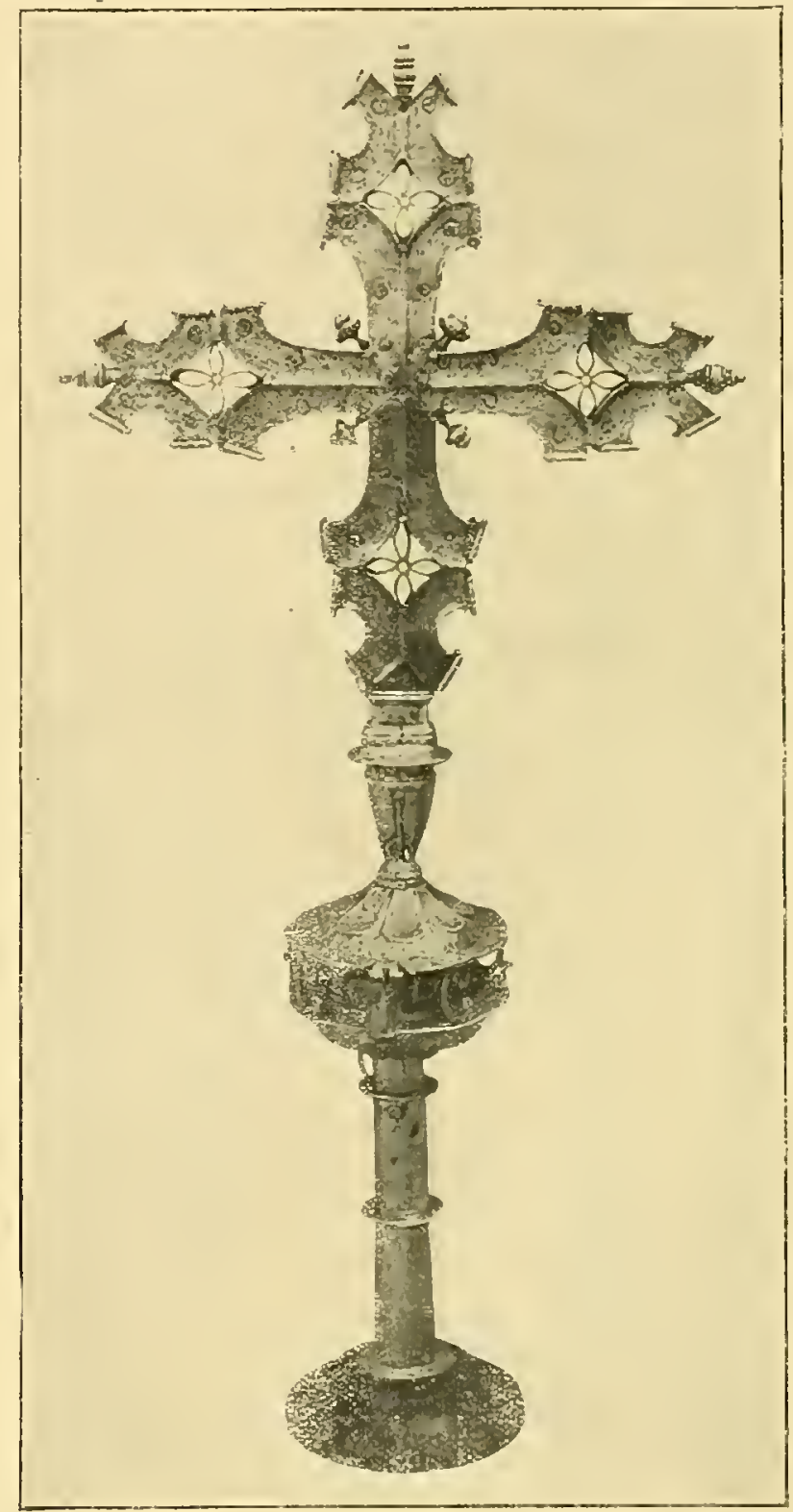

Nim. 390

ción incisa cruzada. Cuatro pequeñas varillas cuadradas con copete como bisectrices de los ángulos. Siglo xvi

\section{Expositor: D. José Lázaro.}

Núm. 392.- Reja de hierro, de $1,80 \mathrm{~m}$. de alto por $90 \mathrm{~cm}$. de ancho, dorada, con dos órdenes de balaustres; el superior, con una figura que representa la Resurrección del 


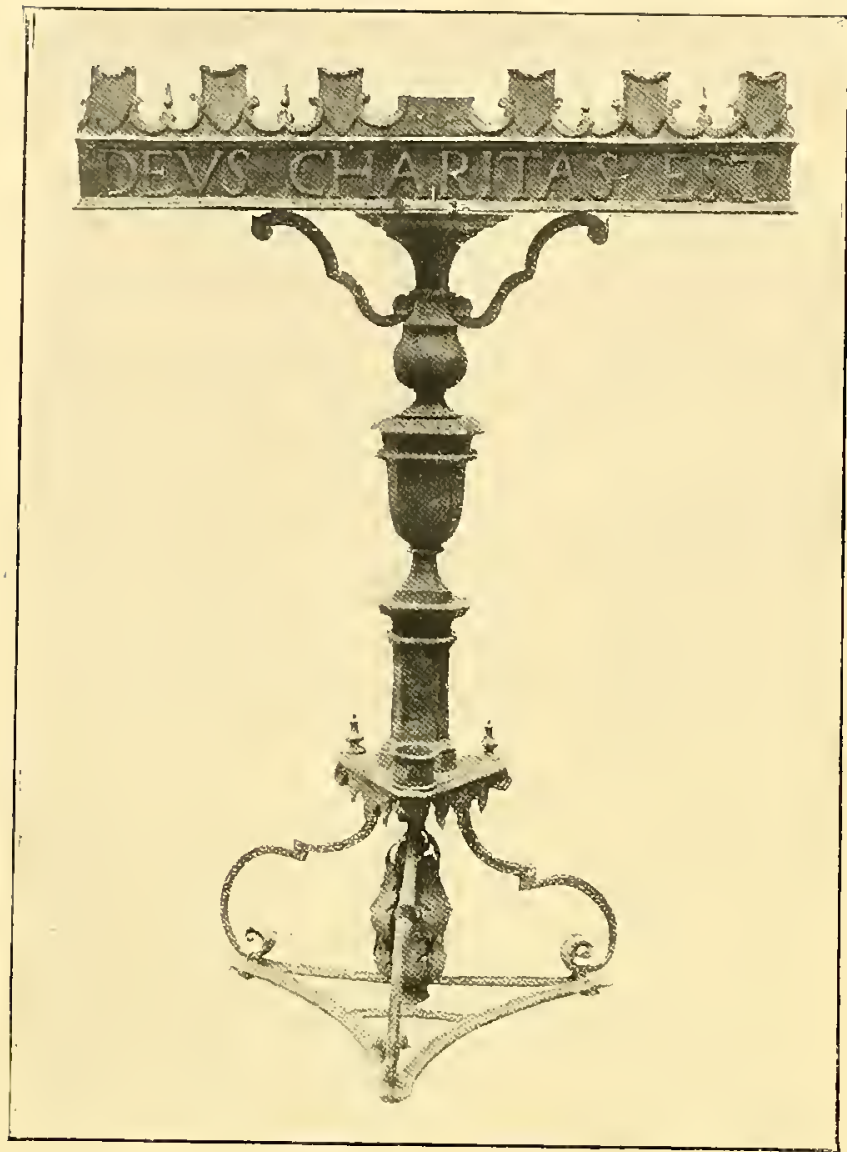

Nüm. 394.

Señor; dos frisos externos en grutescos, y uno central, que dice: SACERDOS ET HOSTIA.

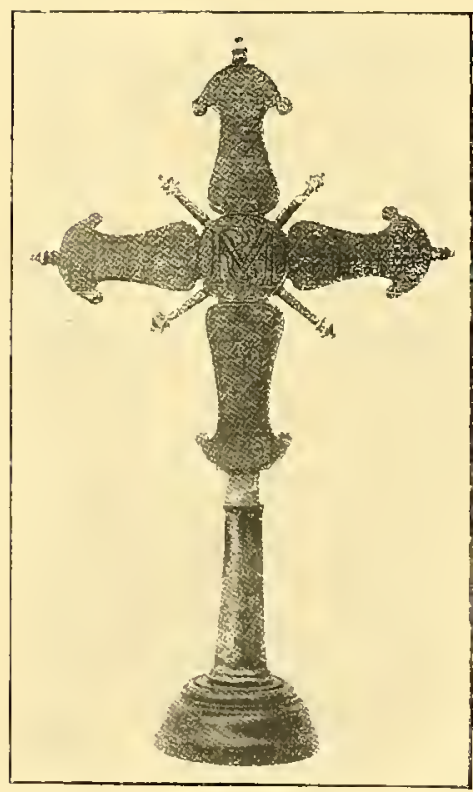

Núm. 391.
Copete con las armas del Arzobispo D. Bernardo Sandoval de Rojas.

Parece ser que, en su tiempo, y en

un escudo sobre círculo de laurel, que existe en la parte inferior, tuvo las armas del Cardenal Silíceo, hoy sustituídas, por otras acuarteladas, apenas visibles.

Fué construída por el rejero Juan López, para la capilla del Santísimo Sacramento, el año 1554, y la tasaron los maestros Domingo y Villalpando en 280 ducados que le fueron pagados el año 1555.

Expositor: Cabildo de la Catedral de Toledo.

Núm. 393.-Reja de 1,95 de alto por 1,90 de ancho, formada por barras verticales torneadas, formando anillo cen- 
tral en cada uno de los motivos que constituyen la decoración. Viene ésta formada por una primera serie de circunferencias, de barra cuadrada, colocada en arista, tangentes entre sí y paralelas, cortadas por una segunda serie, desplazada, lateral y verticalmente a la distancia de un radio. Los puntos de tangencia de la primera serie se decoran por rosetones de plancha recortada. Primera mitad del siglo xvi. Procede de una iglesia de Cuenca. Existen ejemplares idénticos en capillas de la Catedral.

Expositor: D. Juan Jiménez Aguilar, de Cuenca.

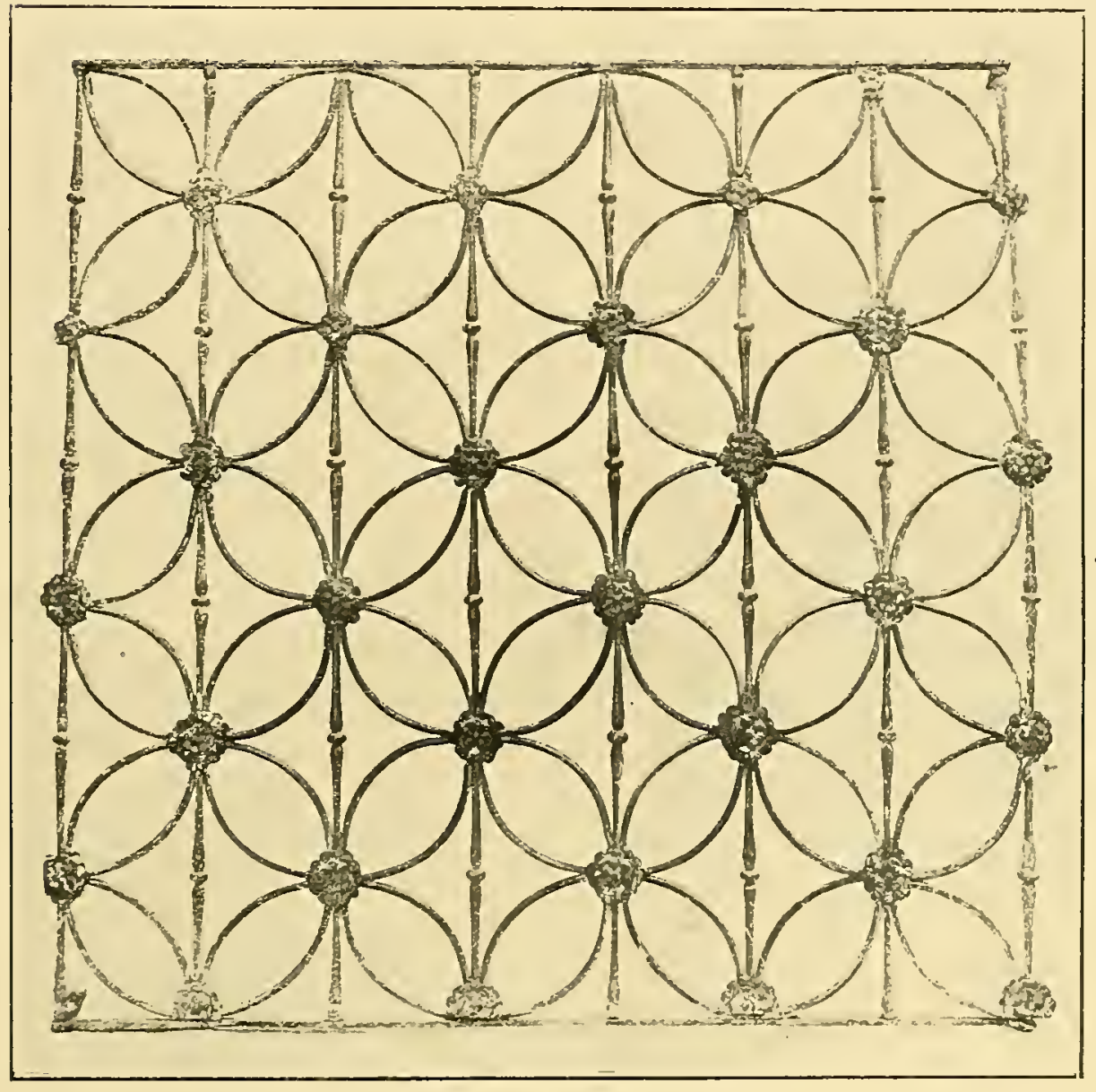

Nủm. 393.

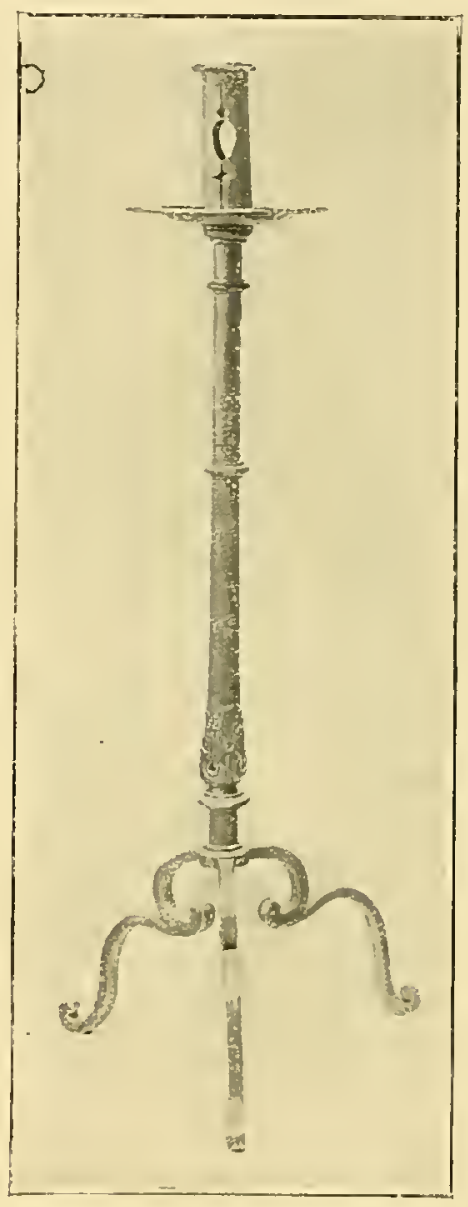

Nủm. 396.

Núm. 394.-Candelabro múltiple, de 1,52 m. de alto por 1,08 de ancho, de pie triangular: en su parte superior tiene una inscripción en plancha que dice: DEUS CHARITAS EST. La construcción es de líneas arquitecturales, sin decoración en las superficies.

Segunda mitad del siglo xvi.

Expositor: Hermandad de la Caridad de Toledo.

Núm. 395.-Candelabro de 1,19 m. de alto, de pie torneado, con un doble escudo, ostentando el monograma de María y la Cruz de Jerusalén. Triple pie de barra lobulada.

Siglo xvı.

Exposiron: Excmo. Sr. Cardenal Arzobispo de Toledo. 


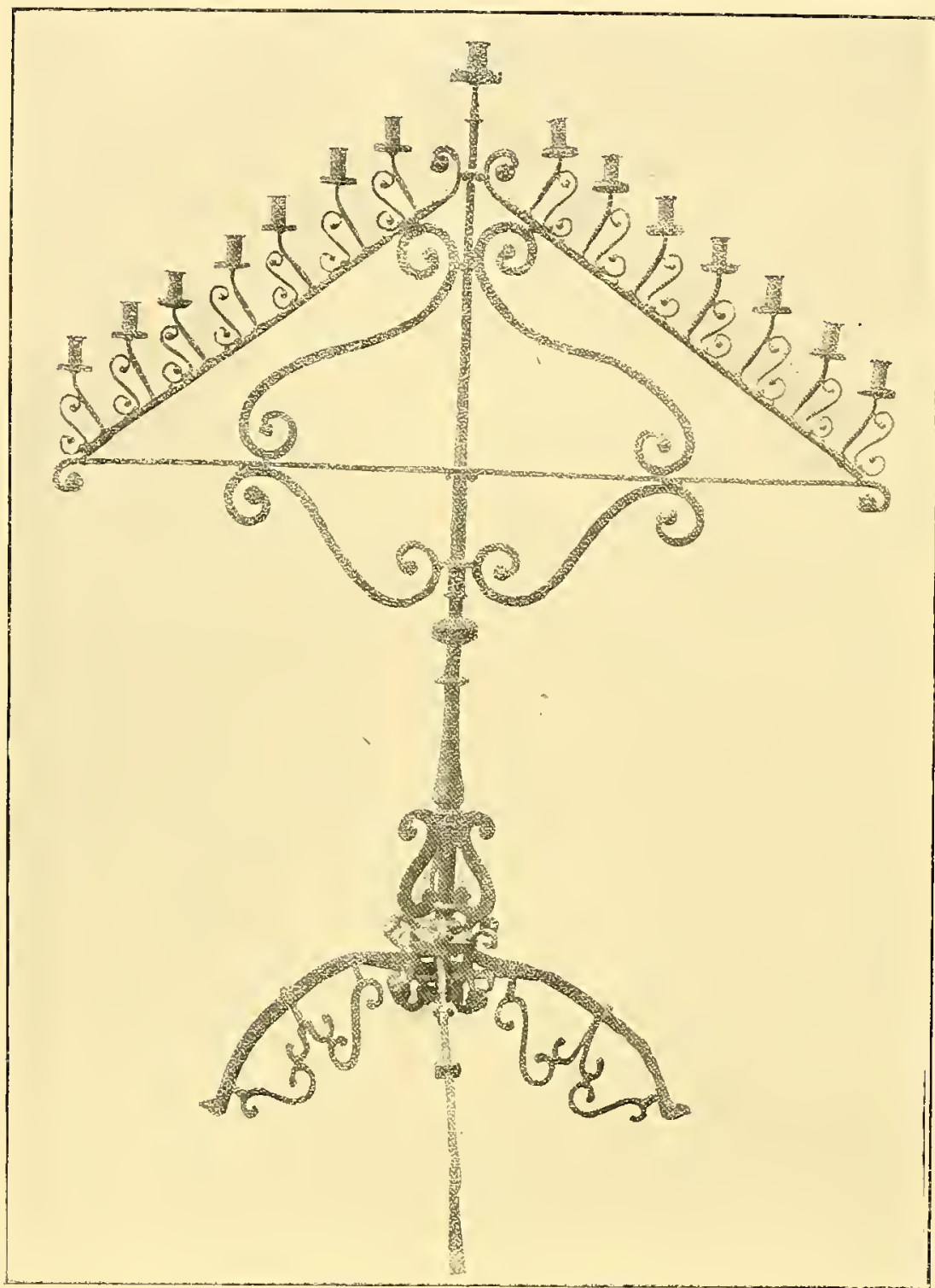

Núm. 307.

napuntas de volutas invertidas. Clásico tipo del estilo geometrizante y siluetado que dominó en tiempos de Felipe II. Finales del siglo xvı.

\section{Expositor: Cabildo de la Catedral de León.}

Núm. 398.-Ũn brasero de pie de $90 \mathrm{~cm}$. de altura y $75 \mathrm{~cm}$. de diámetro; formado por un eje torneado sosteniendo una balaustrada de planta poligonal y que cada dos barrotes sustituye el tercero por dos pirámides simétricas terminadas en bola; cuatro tornapuntas dobles de volutas invertidas en varilla ligeramente cónica forman el apoyo y el pie, descansando sobre un basamento circular
Núm. 396.-Candelabro de $1,33 \mathrm{~m}$. de altura, de vástago ligeramente cónico con ornamentación floral en su pie, recordando los balaustres de la rejería de su tiempo. Pie de varilla cuadrada lobulada.

Siglo xvı.

EXPOSITOR:

D. José

Lázaro.

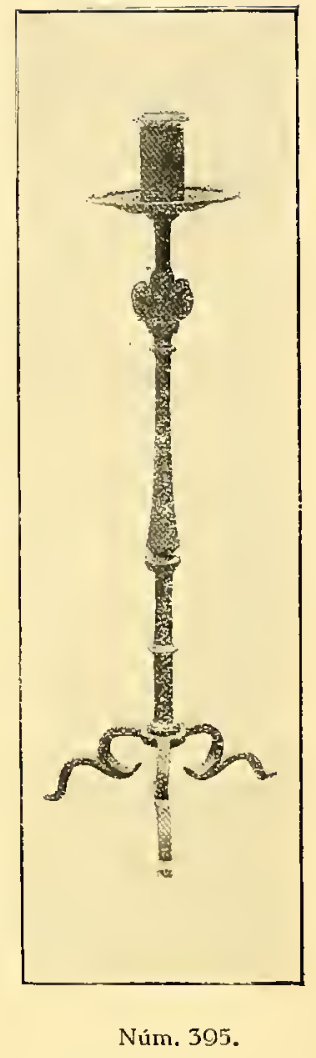

Núm. 397.-Candelabro múlt:ple, tenebrario de $2,35 \mathrm{~m}$. de alto por 1,78 de ancho, decorado por varilla y plancha recortada en tor-

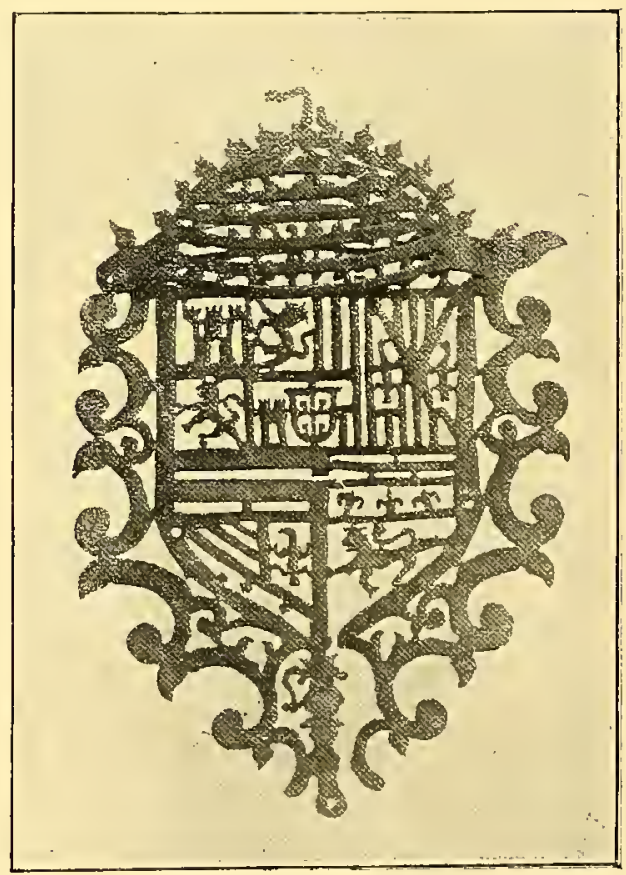

Núm. 399. 
con cuatro radios y ocho apoyos de barra rectangular, curvada en medio punto y prolongada. (Ejemplar de una extraordinaria belleza dentro del estilo geometrizante de los días de Felipe II, del que puede considerarse como el modelo más perfecto.

Siglo xvı. Pertenece a la Catedral de León.

Expositor: Cabildo de la Catedral de León.

Núm. 399.-Escudo de España en plancha de hierro calada y dorada, con doselete en forma de corona, también de plancha calada en líneas horizontales. Ejemplar clásico del estilo que decora por silueta en tiempos de Felipe II.

Finales del siglo xvi.

Expositora: Excma. Sra. Marquesa de Bermejillo del Rey.

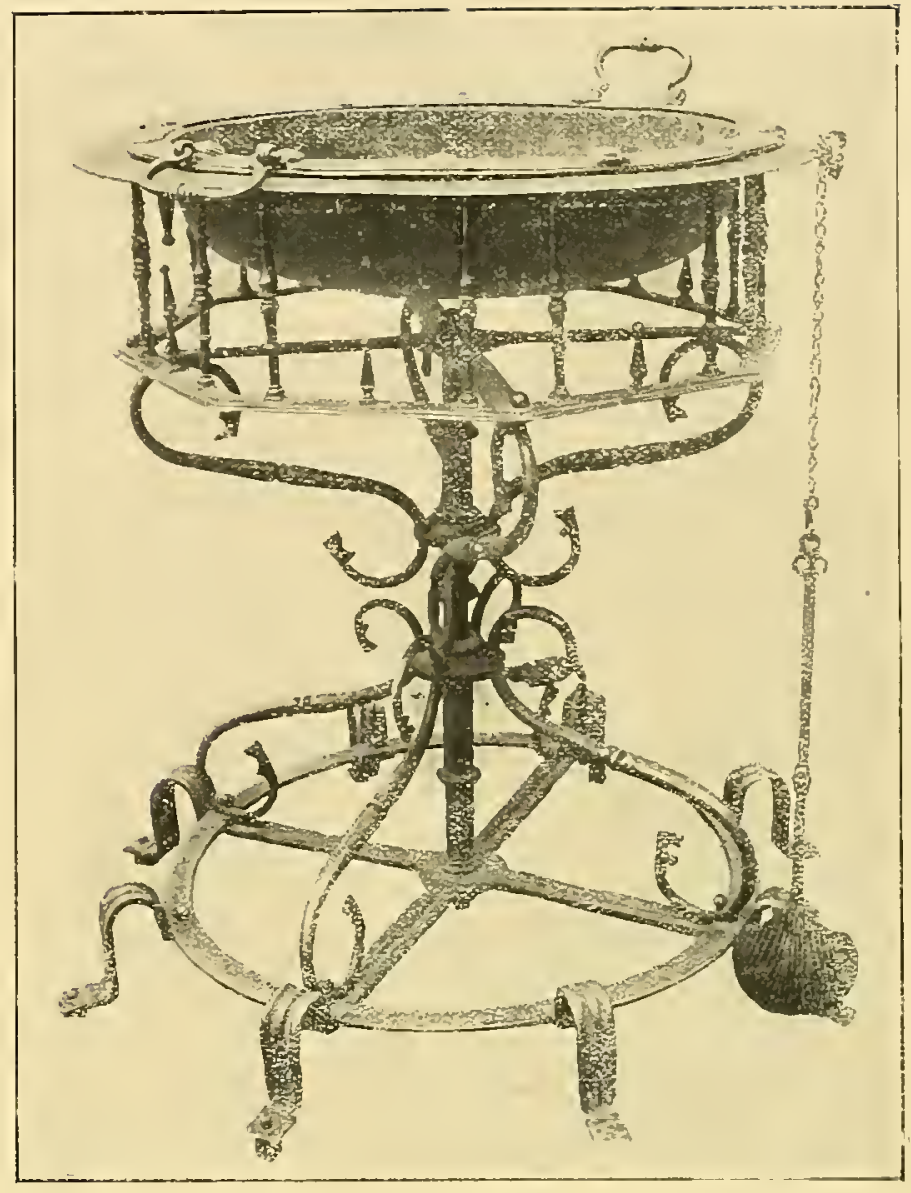

Núm. 398

Núm. 400.-Brasero análogo al anterior, de $68 \mathrm{~cm}$. de diámetro, con las láminas doblemente curvadas que sostienen el brasero, caladas en anchas estrías y un círculo superior con una cruz.

Estilo del siglo xvi.

Expositor: D. José Lázaro.

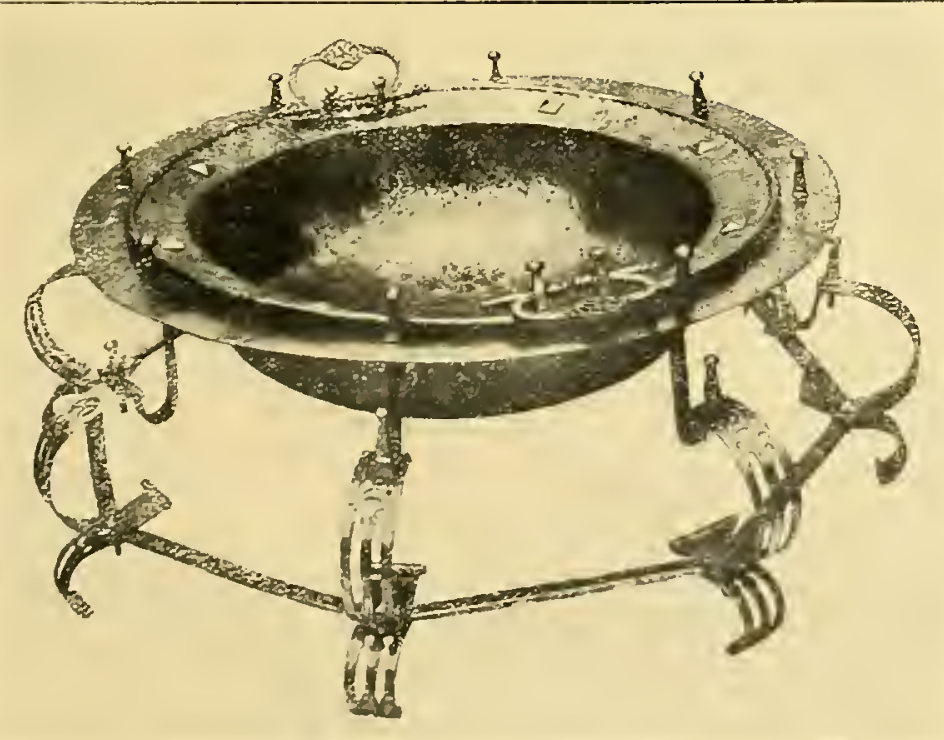

Nưrn. 400 ,
Núm. 401. - Brasero de anillo de $66 \mathrm{~cm}$. de diámetro con soporte de sección poligonal sobre planchas de doble curvatura, decorado todo él con pequeñas pirámides terminadas en bola.

Siglo xvı.

Expositor: D. Juan Lafora.

Núm. 402. - Veleta en forma de flecha y banderola, con un pájaro en plancha recortada. El eje de varilla retorcida. Siglo xvi.

Expositor: D. Jnan Jiménez Agurilar, de Cuenca. 


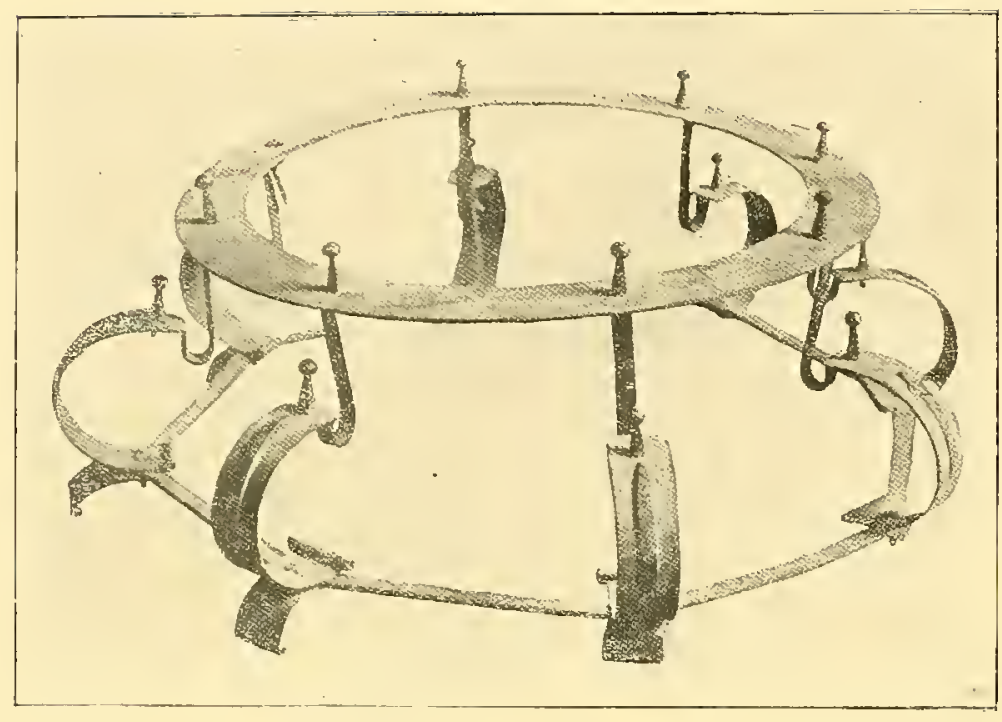

Núm. 401

Núm. 403. - Una veleta, constituída por una cruz, debajo de la cual puede girar, equilibrada, la veleta, sobre la que, en plancha calada, aparecen los cuarteles de Cisneros, Mendoza, Sabater y Zúñiga. Siglo xvı.

Procede de la Casa de Cisneros.

Expositor: Excmo. Ayuntamiento de Madrid.

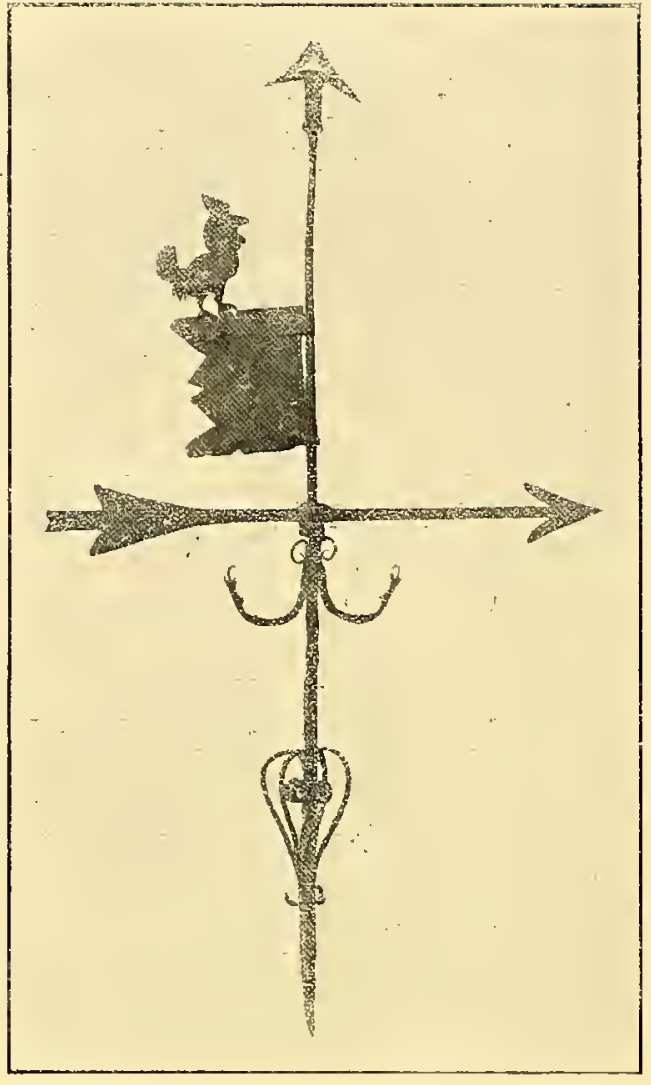

Nủm. 402.

Núm. 404.- Veleta terminada en cruz, análoga a

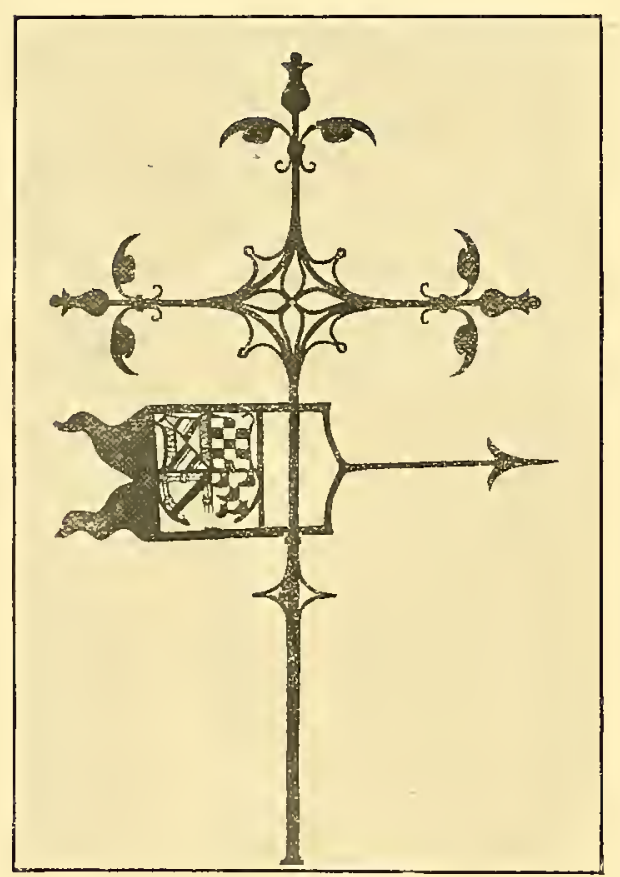

Nium. 403. las confeccionadas en la mitad del siglo xvi, de influencia italiana. La disposición giratoria, seguramente incompleta (falta la flecha), parece representar el cuartel de la Casa de Velasco.

Mediados del siglo xvi.

\section{Expositor: Sr. D. Pascual Fabriciano.}

Núm. 405.-Falleba circular, con cerrojo y pestillo; éstos y las argollas sobre plancha calada. La que sustenta el cerrojo figura la doble águila con corona imperial, prolongada en la parte inferior por el escudo de Madrid.

Mediados del siglo xvı.

Procede de la Casa de la Panadería.

Expositor: Excmo. Ayuntaniento de Madrid. 


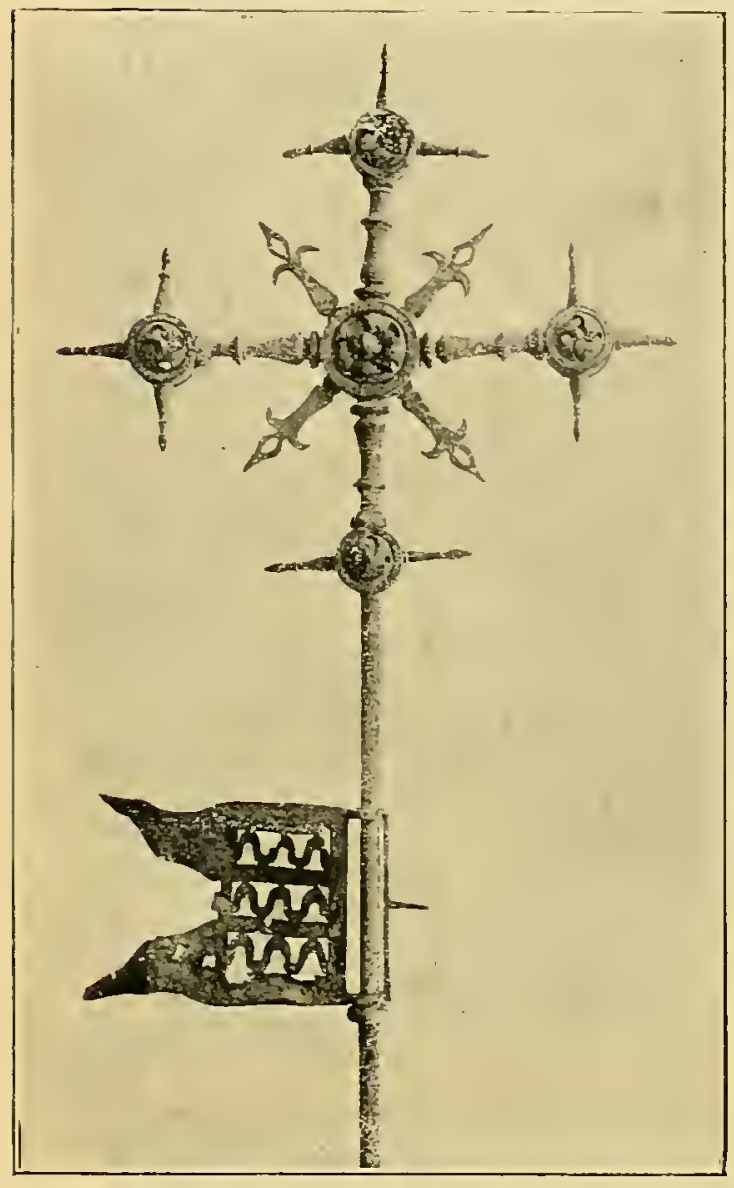

Nüm. 404.
Núm. 406. - Cerradura representando un patio del Renacimiento clásico fechada en 1558.

Procede del Monasterio de El Escorial.

Expositor: Su Majestad el Rey.

Núm. 407. - Cinco cerraduras múltiples decoradas con planchas recortadas y grabadas. Ejemplares de un interés extraordinario, tanto desde el punto de vista cinemático como por su trabajo de ajuste y de ornamentación. Segundo tercio del siglo xvı.

Proceden del Monasterio de El Escorial.

Expositor: SuMajestad el Rey.

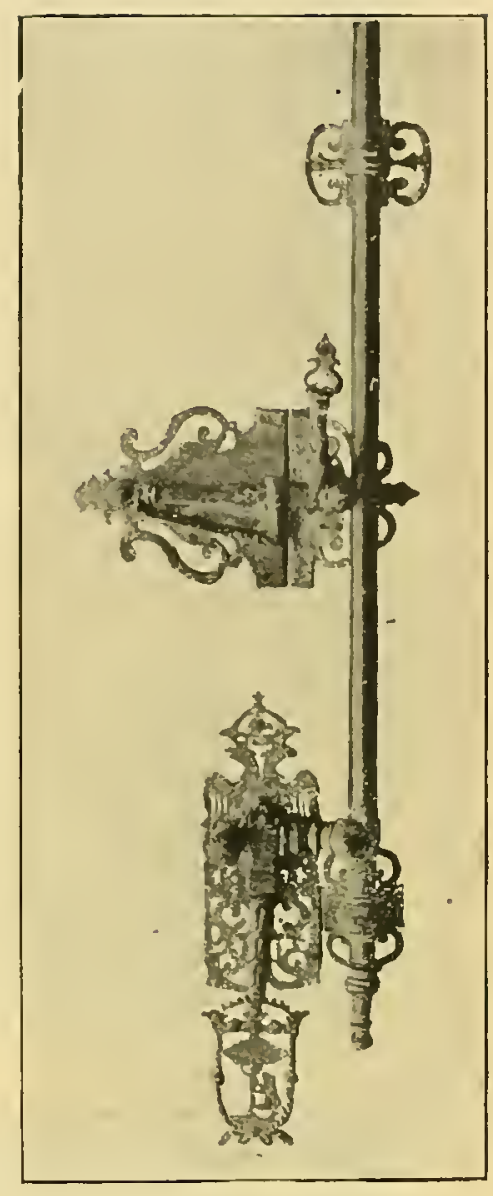

Núm. 405.

Núm. 408.--Soporte de polea de pozo en barra de sección cuadrada, estriada, decorado en la parte superior con pinchos en forma de pirámides. Segunda mitad del siglo xvı. Expositor: D. Rafael García Palencia.

Núm. 409.-Cruz de plancha gruesa recortada, simulando los brazos dos manos y el superior un sol o disco.

Trabajo popular de época indeterminada.

Expositor: Junta de Museos de Barcelona.

Núm. 410.- Sobre una esfera hueca de hierro con un anillo central calado, una cruz procesional de doble plancha con medallones en los extremos de los brazos y pirámides con bolas por remate; rayos ondulados en las bisectrices. Siglo xvı.

Expositor: Excmo. Sr. Marqués de la Torrecilla.

Núm. 411.-Cruz procesional en varilla cilíndrica de brazos terminados en lises y un doble medallón circular central. Apoya por cuatro tornapuntas de varilla rectangular en volutas invertidas. Siglo xvı.

Expositor: Excmo. Sr. Marqués de la Torrecilla. 

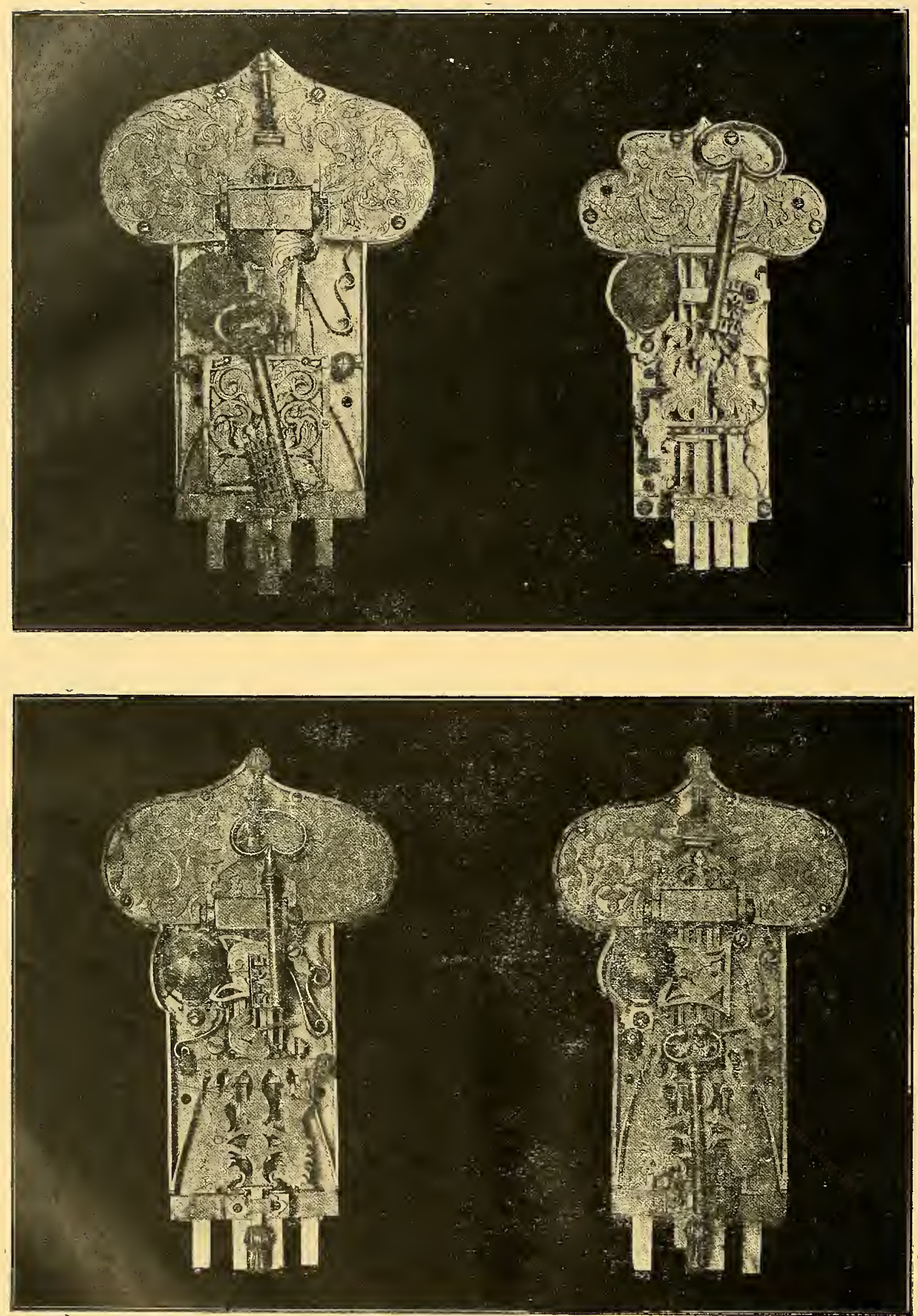

Nửm. 407. 


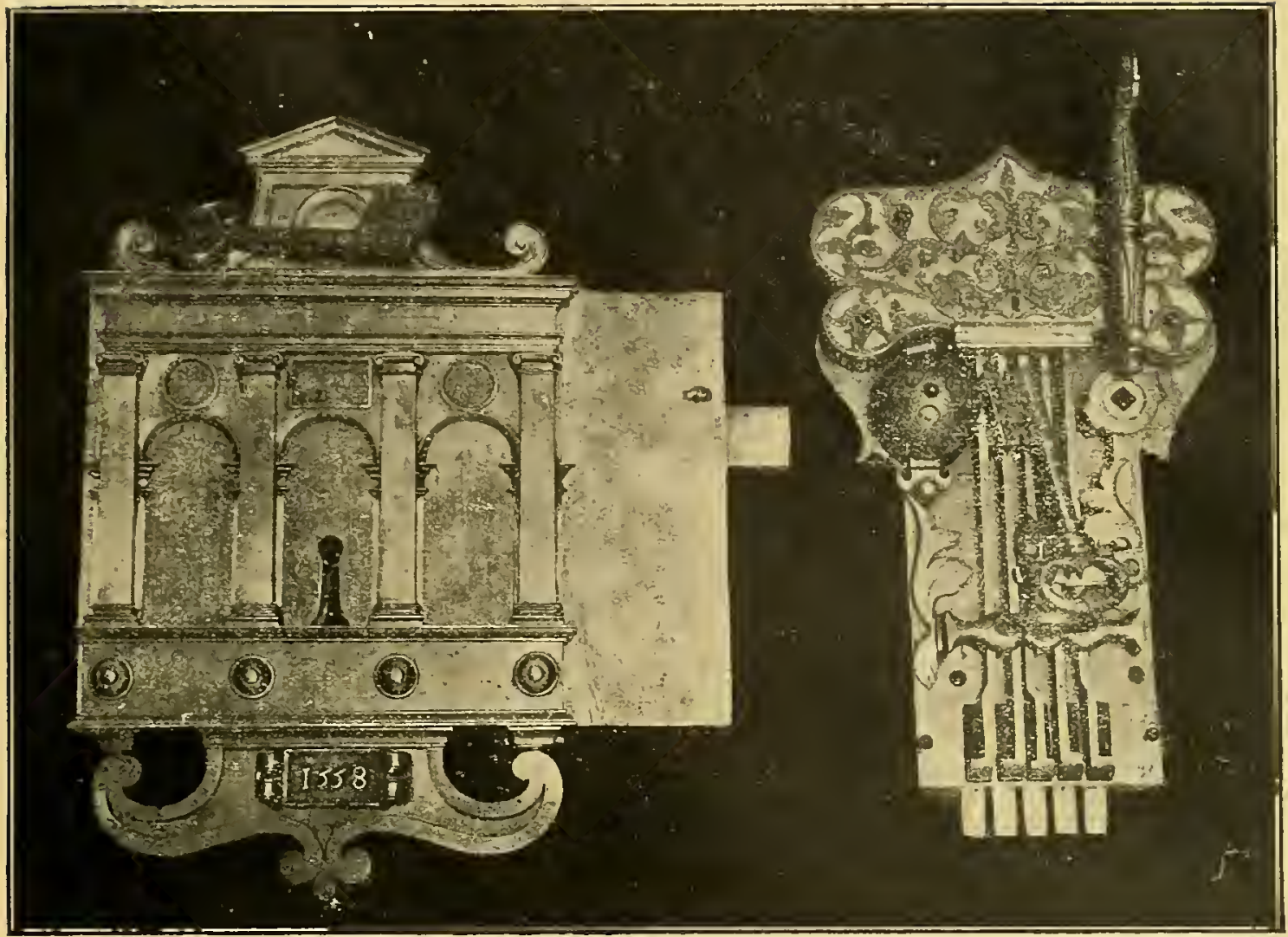

I"ủ n. 400.

Nั่ง. 407.

Núm. 412.-Pequeña cruz de $14 \mathrm{~cm}$. de alta por $13 \mathrm{~cm}$. de ancha, formada por cuatro varillas cónicas, sobre un anillo circular en su centro.

Escuela idéntica a la que precede. Siglo xvı.

Expositor: Excmo. Sr. Marqués de la Torrecilla.

Núm. 413.-Dos arcones de planchas de hierros reforzadas con anchas fajas de plancha formando cuadrícula. Cerradura múltiple de la escuela de las que preceden. Segundo tercio del s!glo xvi. Donación de la Duquesa de Vistahermosa al Museo Arqueológico Nacional.

Expositor : Museo Arqueológico Nacional.

Núm. 414.- Arca análoga a la precedente, con cerradura múltiple, del mismo tipo anterior. Segundo tercio del siglo xvı.

Expositor: Excmo. Sr. Marqués de la Torrecilla.

Núm. 415. - Cofre de hierro de $24 \mathrm{~cm}$. de largo por $14 \mathrm{~cm}$. de ancho y por $13 \mathrm{~cm}$. de alto, decorado por cinchos también de hierro con clavos simulados de cabeza cuadrada.

Fabricación española inspirada en las obras francesas de su tiempo. Siglo xvı.

Expositor: D. José Lázaro. 


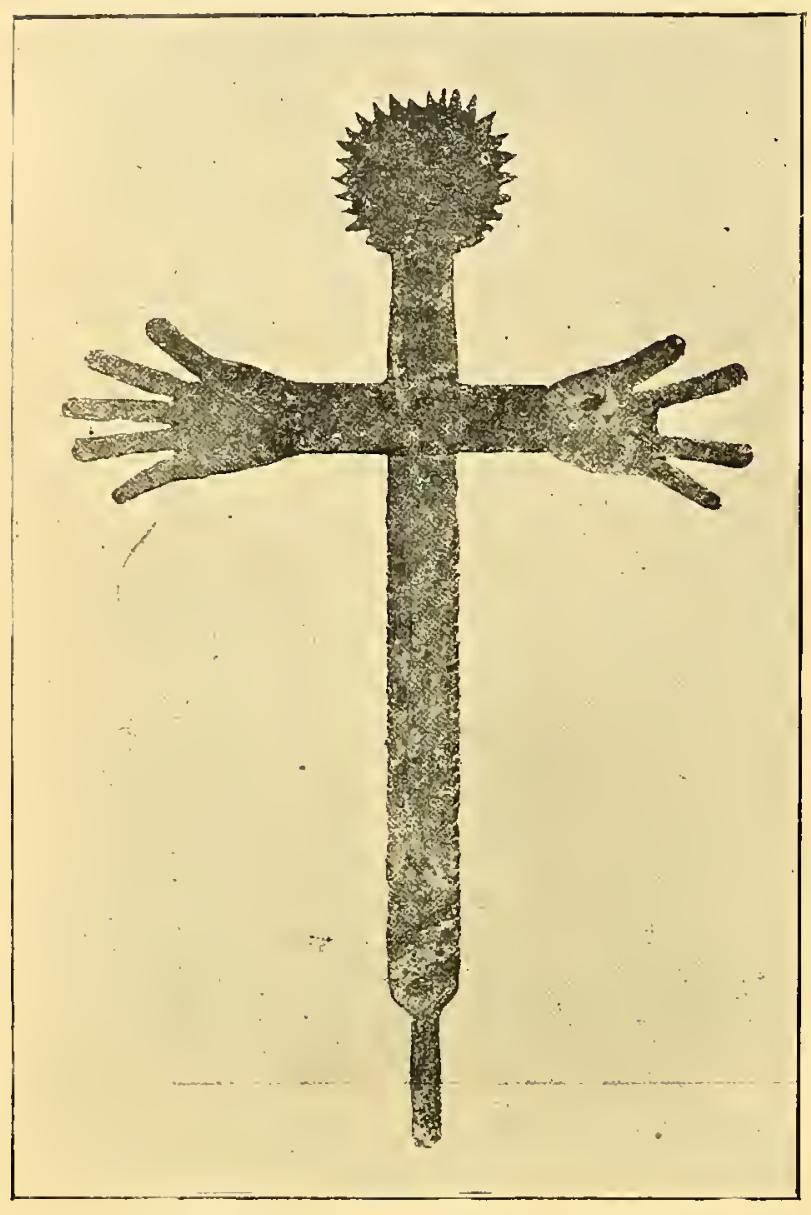

Ním:-409.
Núm. 416.-Arca de hierro policromada, tipo análogo al que precede, con las asas y cerrojos dorados; cerradura múltiple del mismo tipo de las precedentes del Monasterio de El Escorial. Decoración en la cerradura de pájaros, flores y figuras. Segundo tercio del siglo xvı.

\section{Expositor: $E X-$ celentísimo Sr. Marqués de la Torre- cilla.}

Núm. 417.-- Arca de hierro 'policromado, tipo análogo al anterior; cerradura múltiple, del mismo tipo de las del Monasterio de El Escorial.

Segundo tercio del siglo xvı.

Expositor: Escuela de Artes y Oficios de Córdoba.

Núm. 418.--Caja de hierro rectangular de $26 \mathrm{~cm}$. por 17 y 17 de a'tura, decorada en línea con columna en los ángulos y en la cara central.

Expositor: D. José Lázaro.

Núm. 419. - Arca de cuero negro, de sección trapezoidal y de $55 \mathrm{~cm}$. de

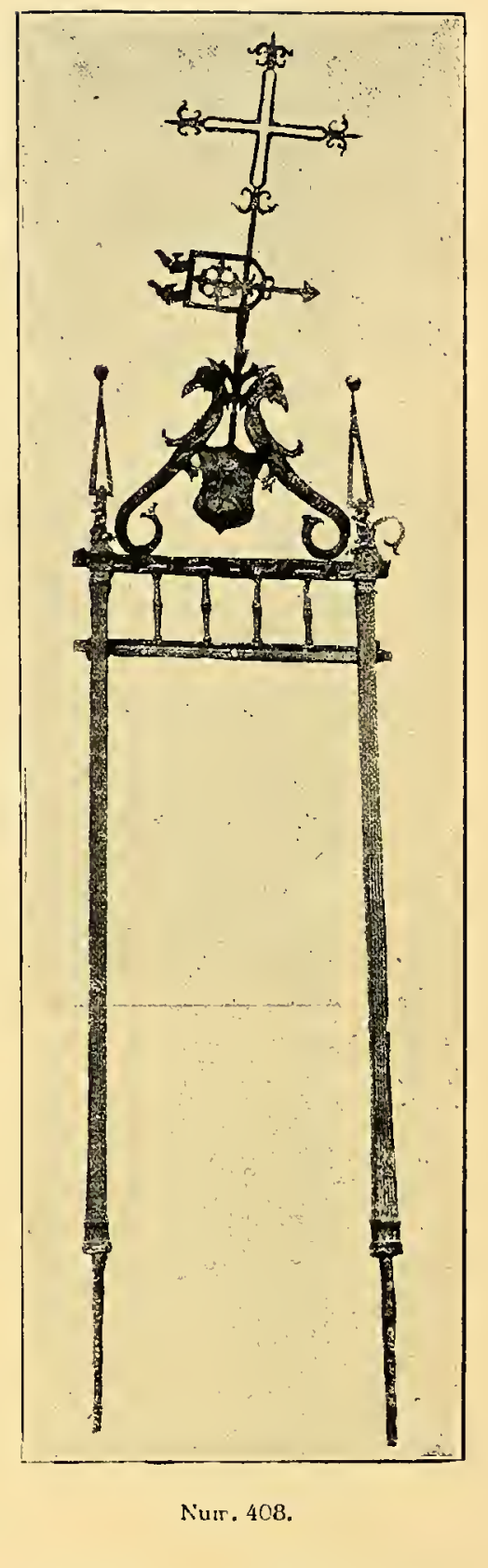


profundidad. Grandes herrajes en los ángulos.

Siglo xvı.

Expositora: $E X^{-}$ celentísima Sra. Duquesa de Parcent.

Núm. 420.-Dos figuras representando forjadores, que abandonadas en el interior de una mina, donde sufrieron la acción de aguas, conteniendo sales cúpricas, quedaron revestidas de una película de cobre que en parte ha sustituído al hierro.

Los ejemplares

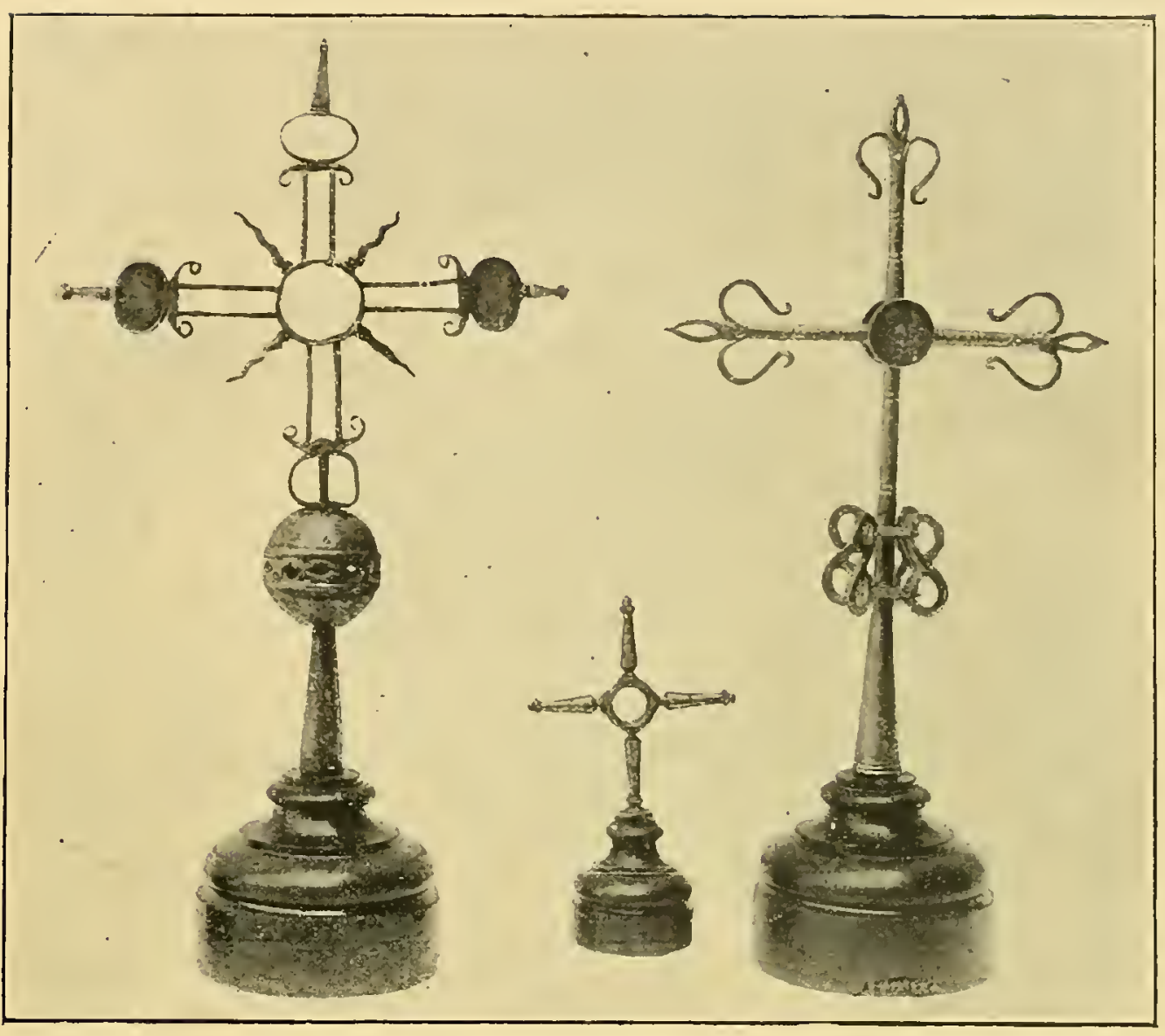

Núm. 410.

Nưm. 412.

Num. 411.

primitivos parecen del siglo xvı.

Expositor: Excelentisimo Sr. Duque de Santa Lucía.

Núm. 421.-Un perro de hierro forjado que perteneció a un llamador. Siglo xvi.

Expositor: D. José A. Weissberger:

Núm. 422.-Llamador de barra lanceolada, colocado sobre plancha rectangular repujada, con motivo del Renacimiento. El martillo 


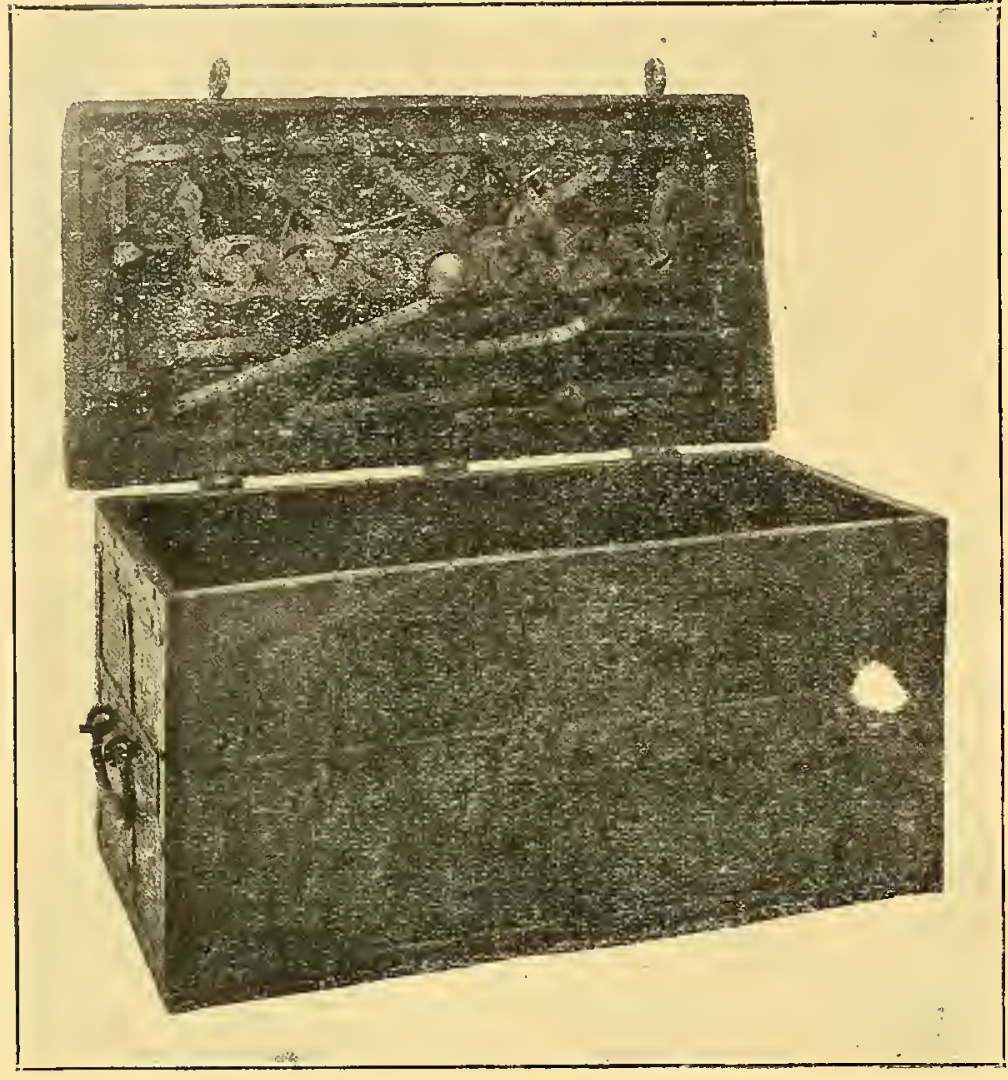

Nưm. $=4$ I4.

golpea sobre una figura de chapa repujada. Siglo xvı.

\section{Expositor: D. Domingo Gue- rrero, de San Sebastián.}

Núm. 423.-Llamador en forma de paloma con las alas explayadas y labor incisa curvilínea. Trabajo del siglo $\mathrm{xvI}$.

Expositor: Excmo. Sr. Marqués de la Torrecilla.

Núm. 424.-Llamador figurando una paloma o ave con las alas recogidas, decorada por trabajo lineal inciso. Siglo xvı.

\section{Expositora: Excma. Sra. Du- quesa de Parcent.}

[Núm. 425. - Llamador figurando un aguila o pájaro de frente con las alas explayadas; el eje y clavo sobre plancha recortada y dos barras festoneadas. El águila con labor incisa punteada. Siglo xvı.

\section{Expositor: D. Rafael} García Palencia.

Núm. 426. - Llamador formado por un dragón sosteniendo un escudo que oculta el martillo. Labor del siglo xv1.

Expositor: D. José Lázaro.

Núm. 427. - Llamador formado por una figura toscamente labrada, colocada sobre una plancha rectan-

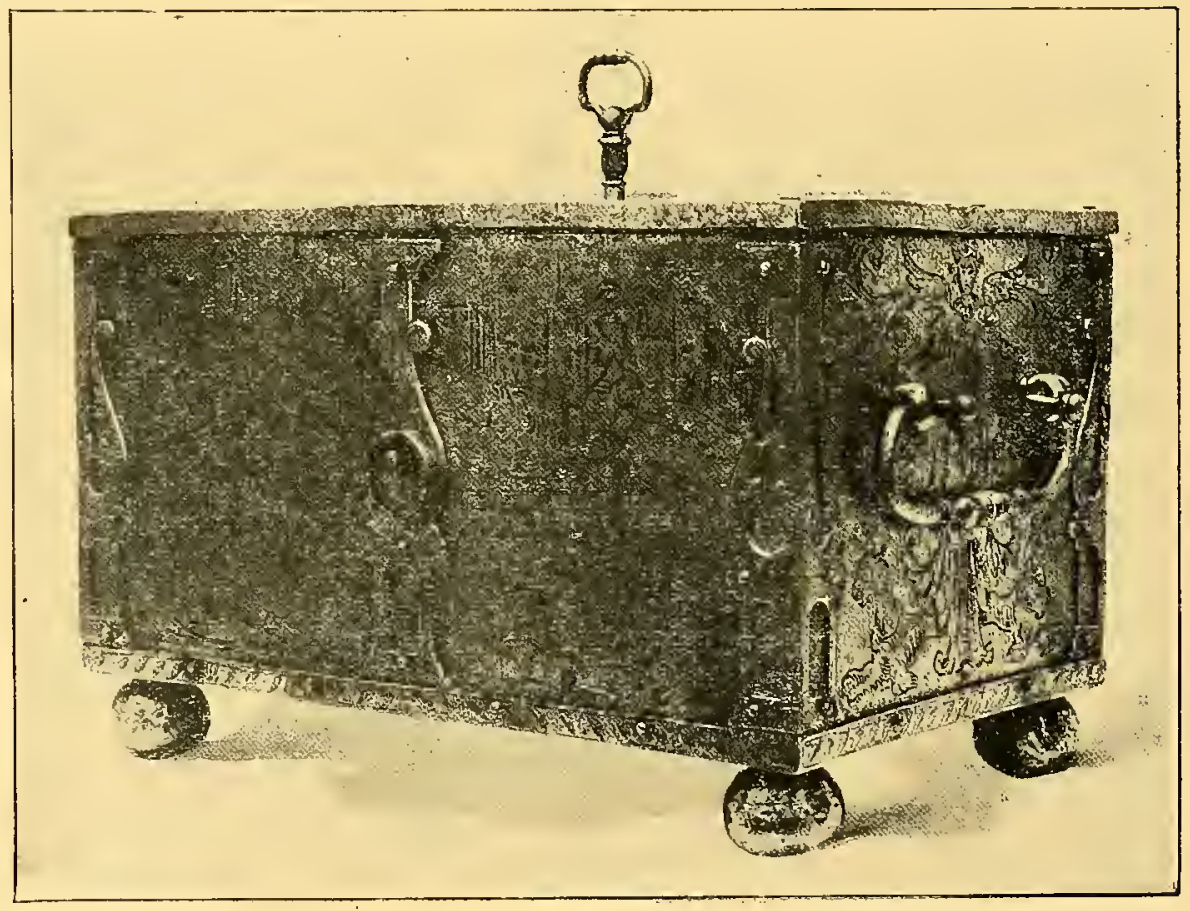

Núm. 418 , 
gular con fina labor incisa. Esta última es trabajo del siglo xvı.

\section{Expositor: Excmo. Sr. Du- que de Santa Lucía.}

Núm. 428.--Llamador en forma de perro sosteniendo una bola. Siglo xvi

\section{Expositor: Excmo. Sr. Du- que de Santa Lucía.}

Núm. 429.-Llamador análogo al que precede, pero sin alas explayadas. Siglo xvI.

Expositor: D. José Lázaro.

Núm. 430.-Llamador de barra cilíndrica que recuerda los balaustres de su tiempo; en ángulo recto, una cabeza toscamente trabajada, forma el martillo, terminando por

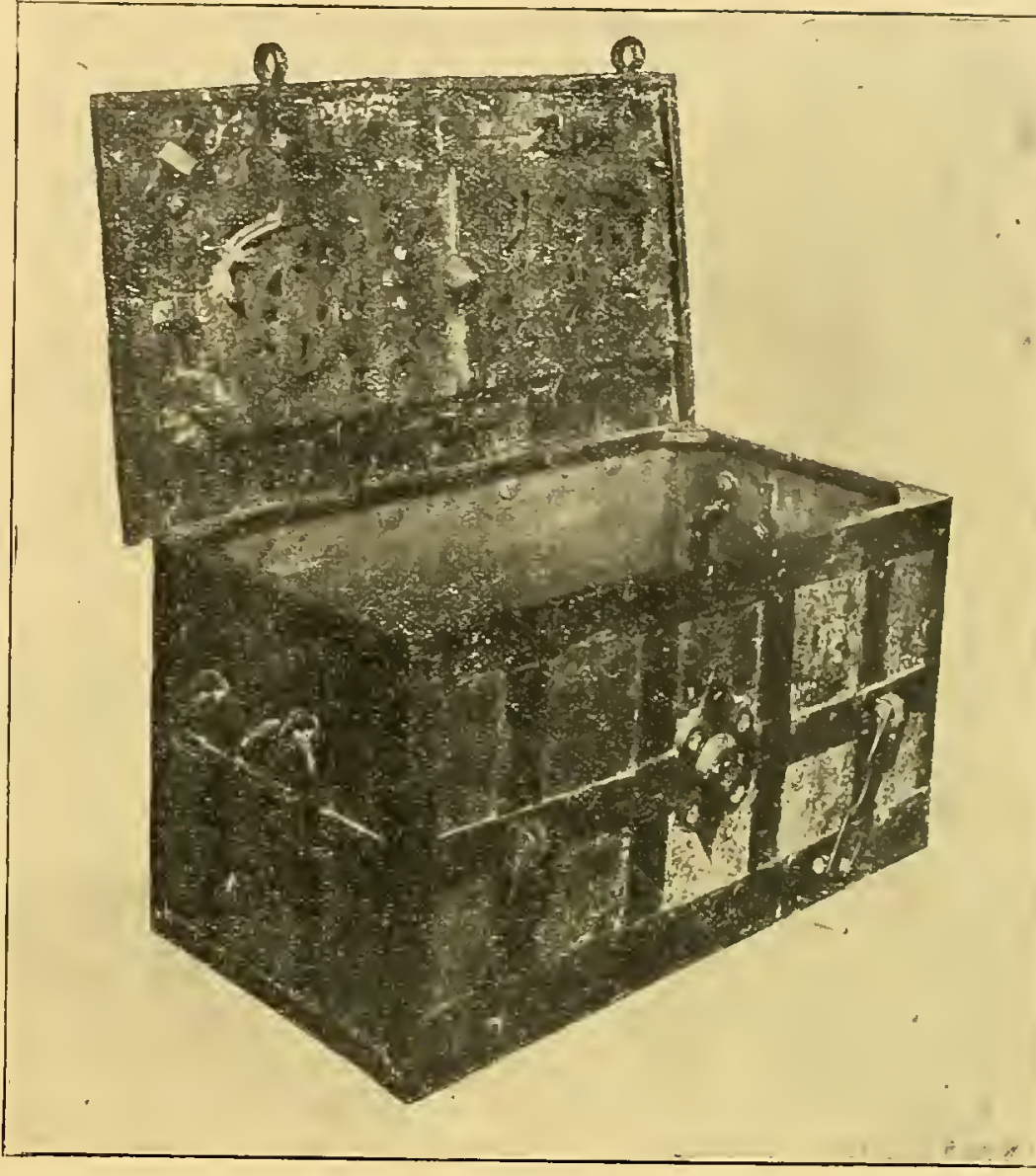

Nứn. 417. el otro extremo en voluta ensanchada. Clavo y argolla sobre plancha calada. Trabajo del siglo xvir.

Expositor: D. Domingo Guerrero, de San Sebastián.

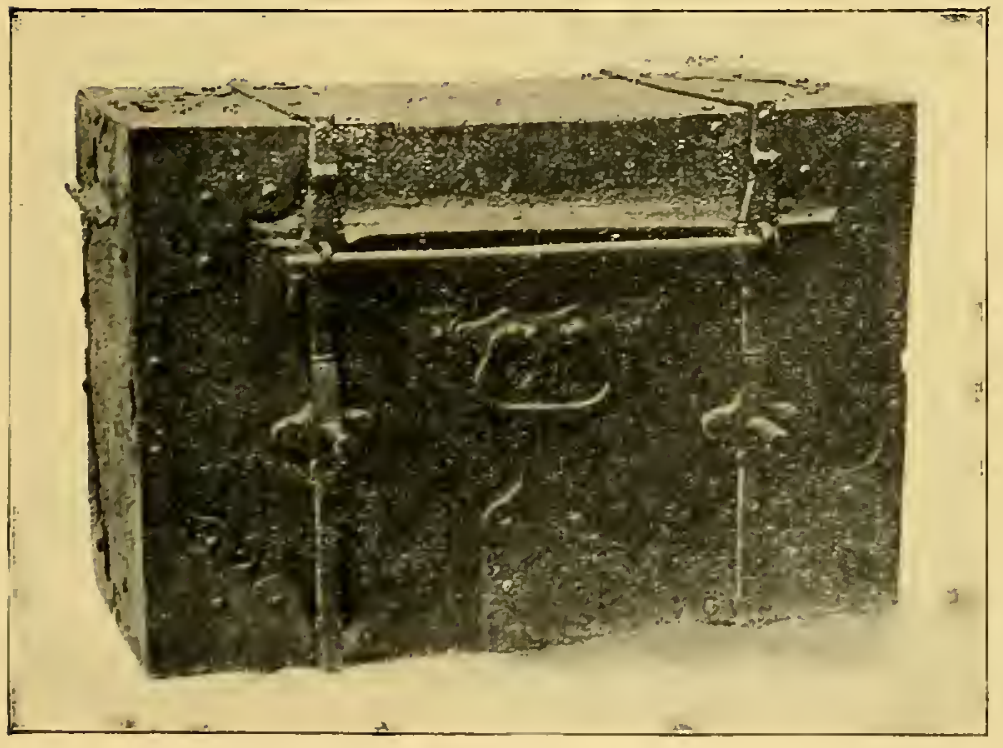

Nủm. 419.
Núm. 431. - Aldabón de barra cuadrada curvada golpeando sobre una pequeña figura de paloma. La barra aparece decorada por molduras incipientes y punteado. Siglo xvı.

Expositor: Excmo. Sr. Marqués de la Torrecilla.

Núm 432. - Llamador de cabeza de dragón toscamente trabajado. La prolongación de la mandíbula interior constituye el martillo en ángulo recto. Siglo xviI.

Expositor: Museo de Artes Industriales. 


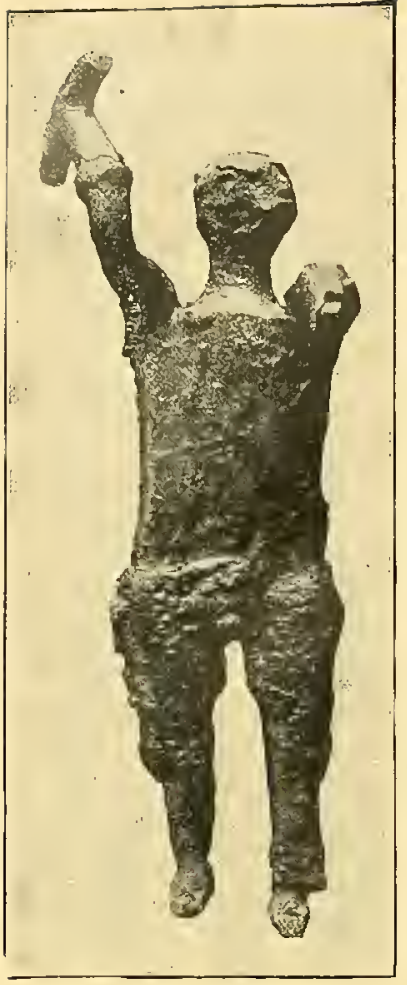

Núm. 420.
Núm. 433.-Aldabón sobre barra poligonal análogo al precedente. Decoración en círculos. El clavo sobre un elemento de visagra de época anterior. Siglo xvı.

Expositor: Excmo. Sr. Marqués de la Torrecilla.

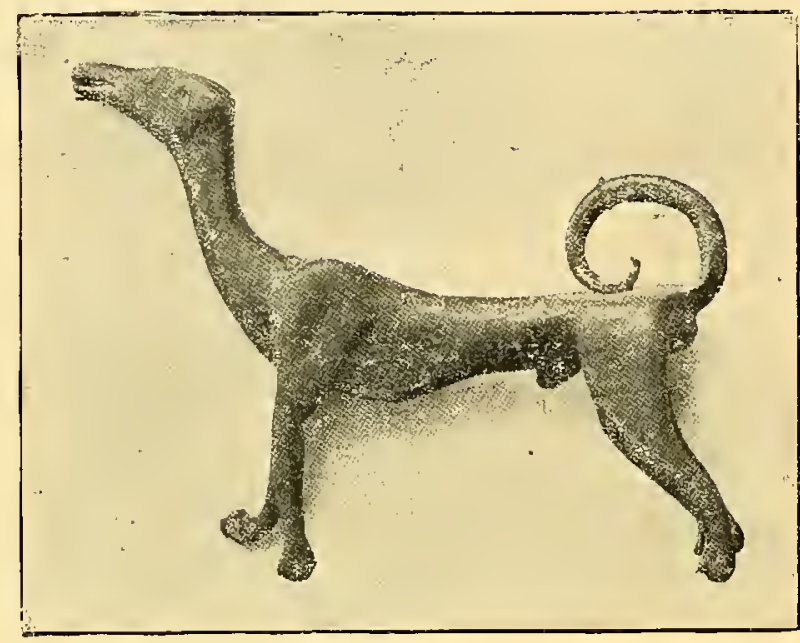

Nủm. 421.

Nüm. 422.

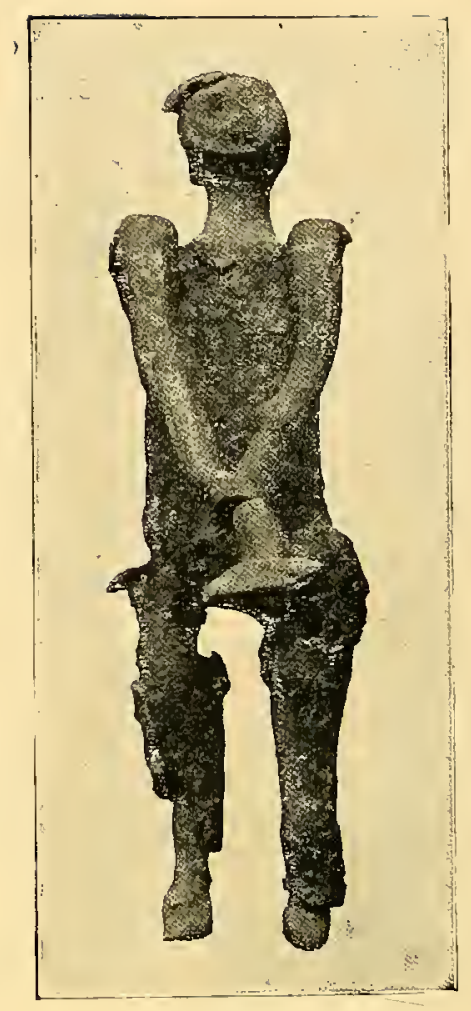

Núm. 420.

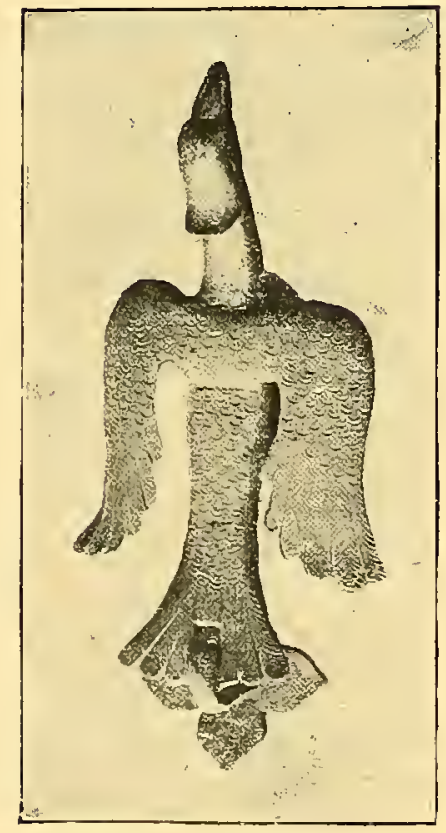

Num. 423,
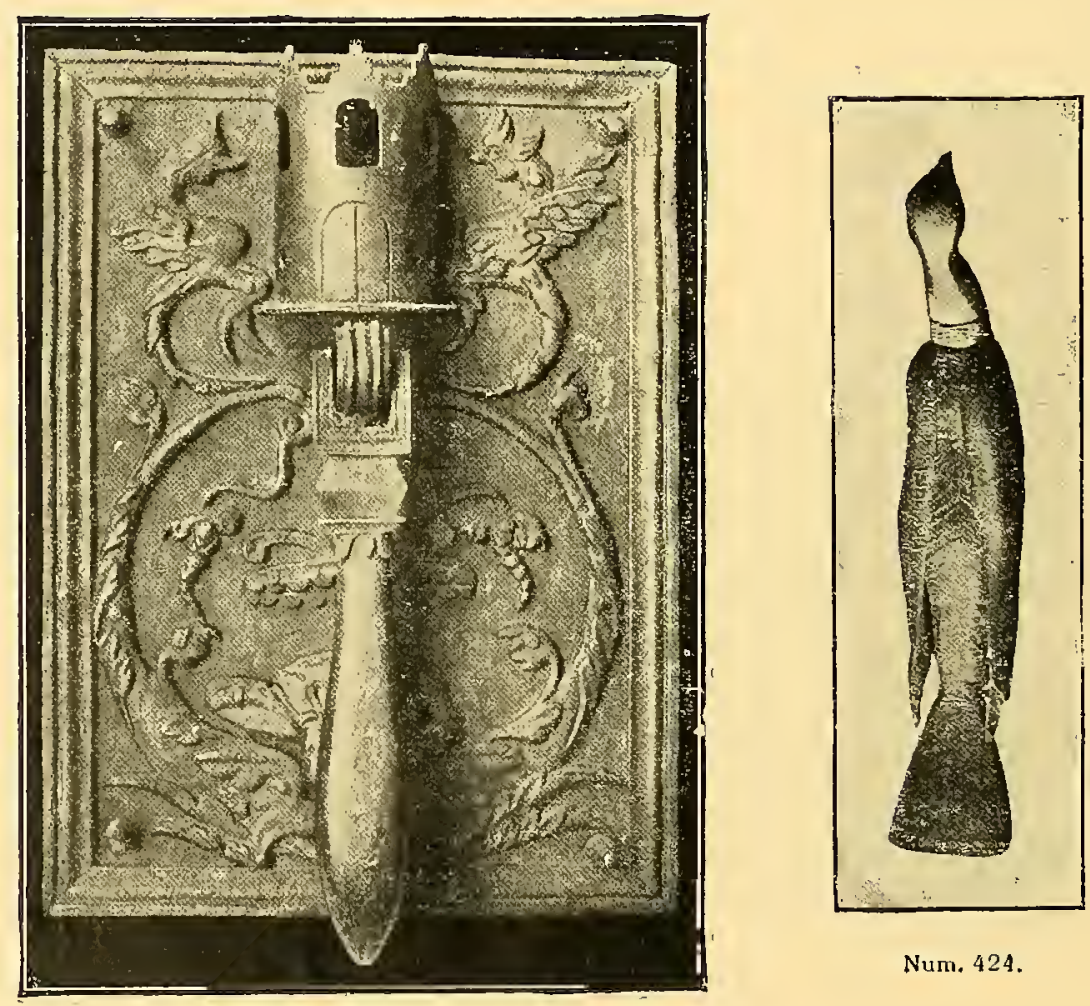

Num. 424 


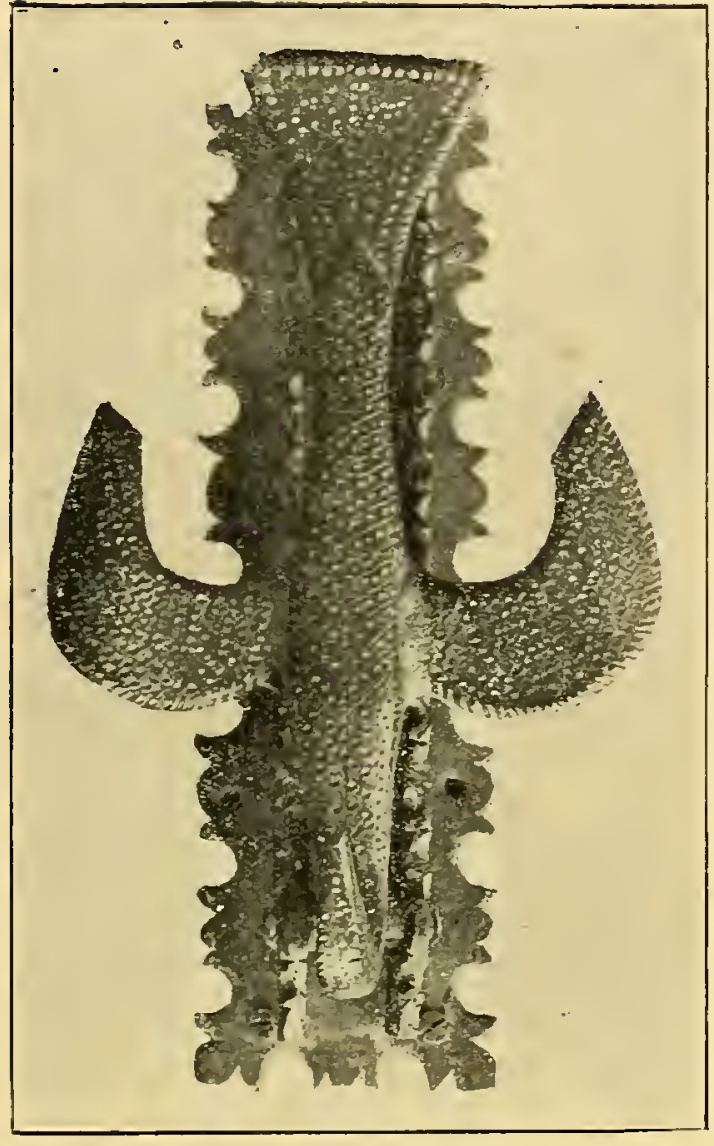

N'น̉m, 425.

Núm. 4304.-Aldabón de varilla sensiblemente cónica, terminada en lámina que inicia una voluta. Argolla y clavo sobre plancha recortada. Principios del siglo xvir.

Exposiror: Excelentísimo Señor Marqués de la Torrecilla.

Núm. 435.--Aldabón de gruesa barra ligeramente cónica, con ligero trabajo de cincelado, representando hojas que recuerdan las labores de los balaustres de su tiempo. Mitad del siglo xvir.

Expositor: D. JOsé Lázaro.

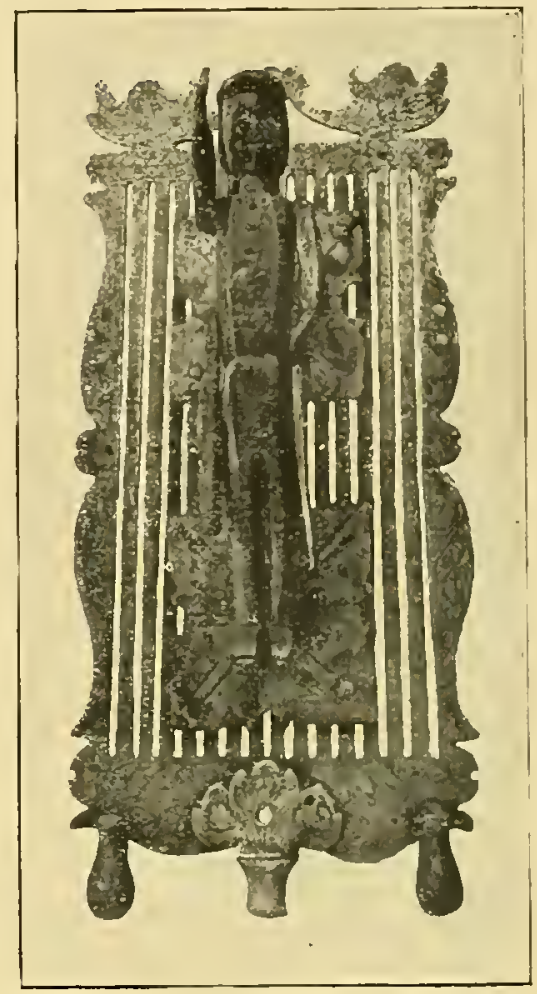

Nưm. 427.

Núm. 436.--Llamador-tirador de puerta. La argolla y el clavo sobre tres órdenes de

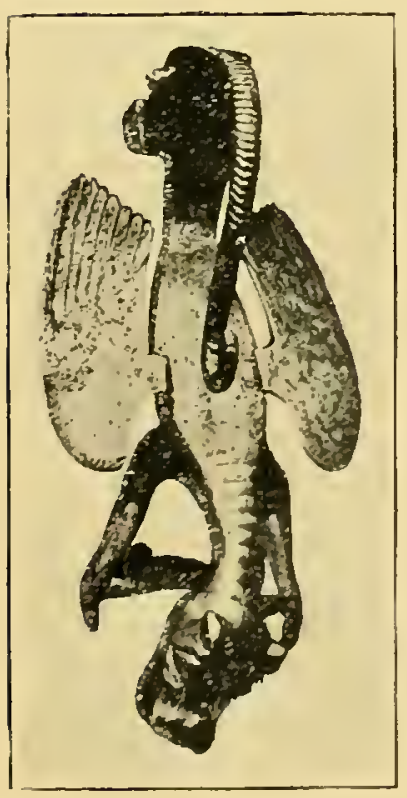

N่u๋t. 426.

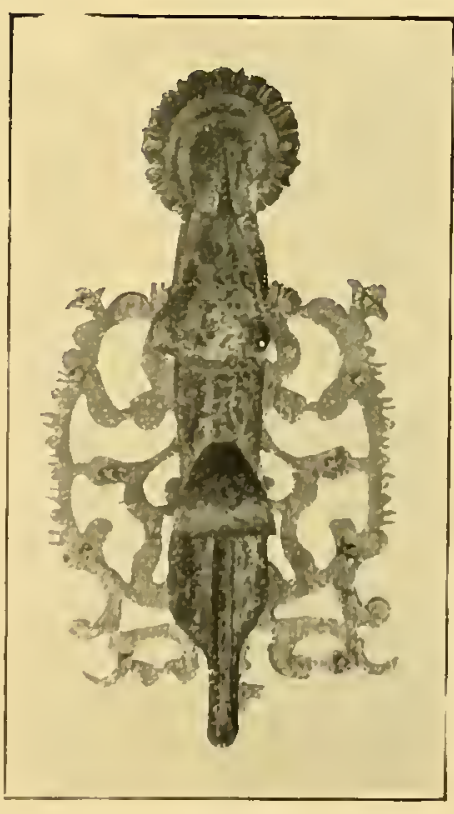

Nium. 428.

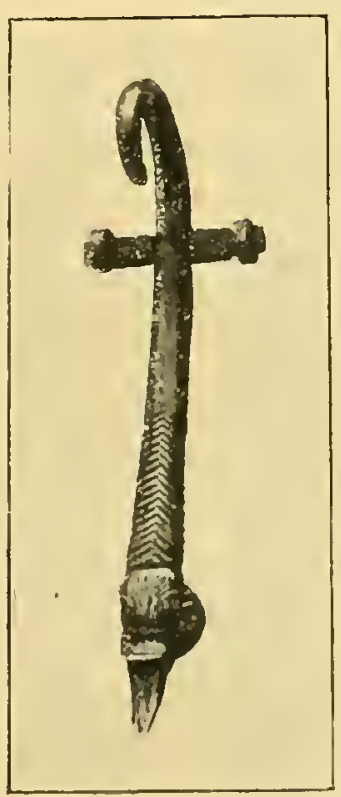

N่un. 420.

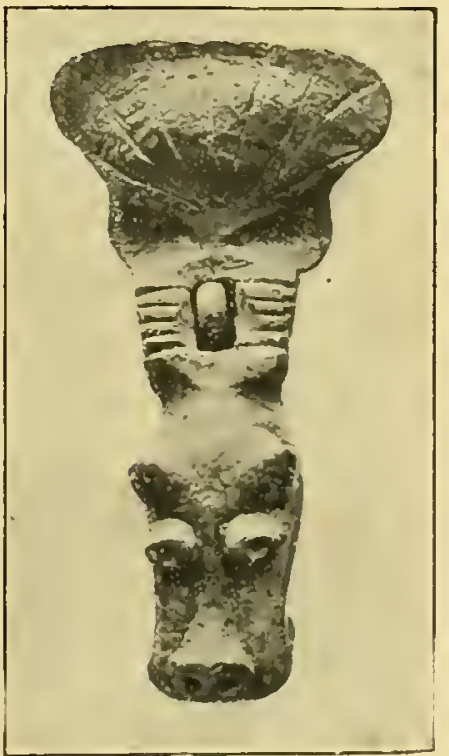

Num. 432. 


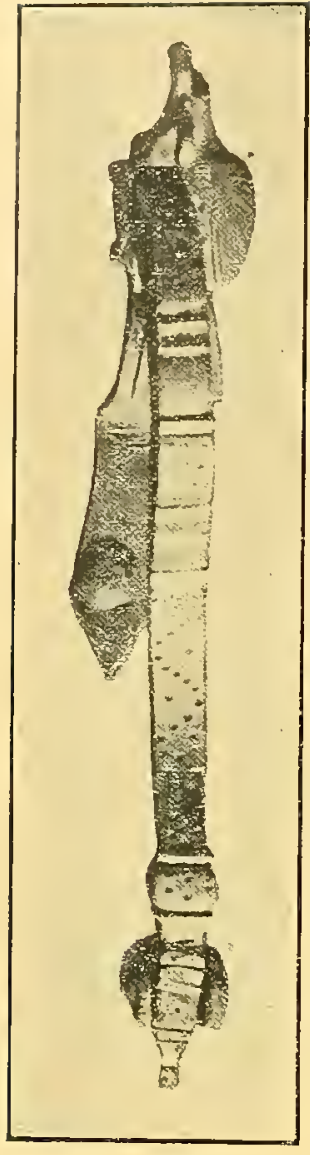

Núm. 431. planchas pentalobuladas y realzadas formando rosetones. Trabajo del siglo xviı.

Expositor: D. Domingo Guerrero, de San Sebastián.

Núm. 437.-Aldabón de barra cilíndrica curvada terminada en cabeza de dragón, sobre plancha calada. Principios del xvil siglo.

Expositor: D. Rafael García Palencia.

Núm. 438. - Llamador formado, en su mitad principal, por una barra cilíndrica que se prolonga en cono arrollado en espiral y termina en labor que figura una cabeza y con dos alas simétricas explayadas en el centro. Labor del siglo xvi.

\section{Expositor: Excmo. Sr. Marqués de la Torrecilla.}

Núm. 439.--Llamador de barra cuadrada colocada en arista y los dos extremos ensanchados en hojas formando volutas encontradas, sobre plancha recortada. Principios del siglo xvir.

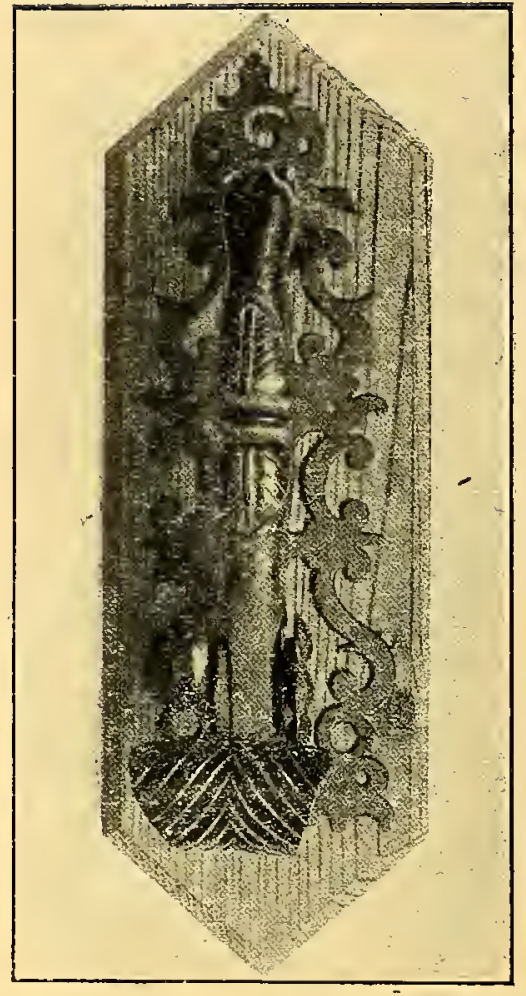

Núm. 430.

\section{Expositor: D. Rafael García Palencia.}

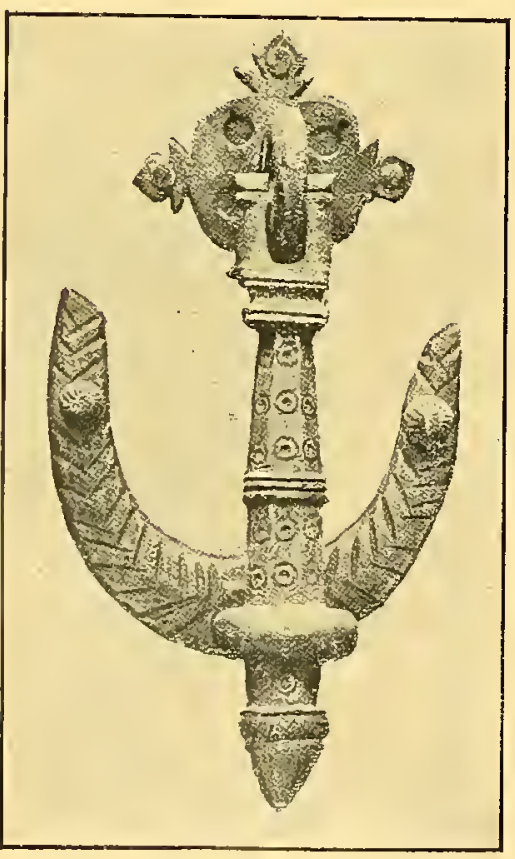

Núm, 433.

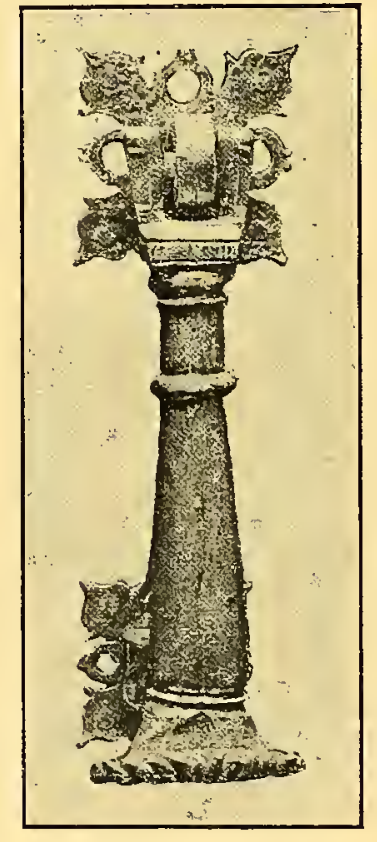

Nủm. 434 ,

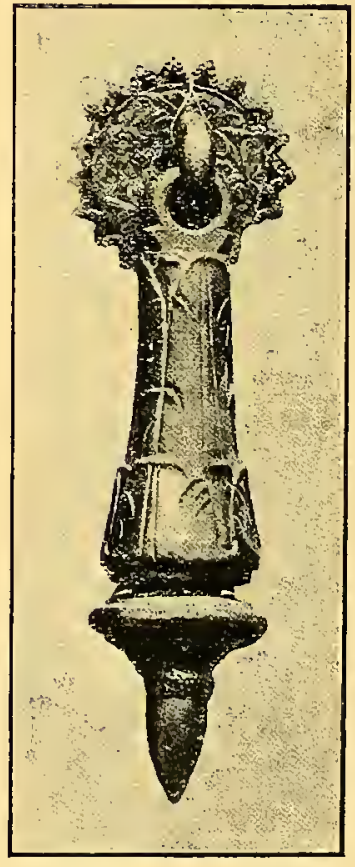

Núm. 435 . 
Núm. 440.- Animal fantástico de hierro forjado de factura grosera. Tiene 30 centímetros de longitud.

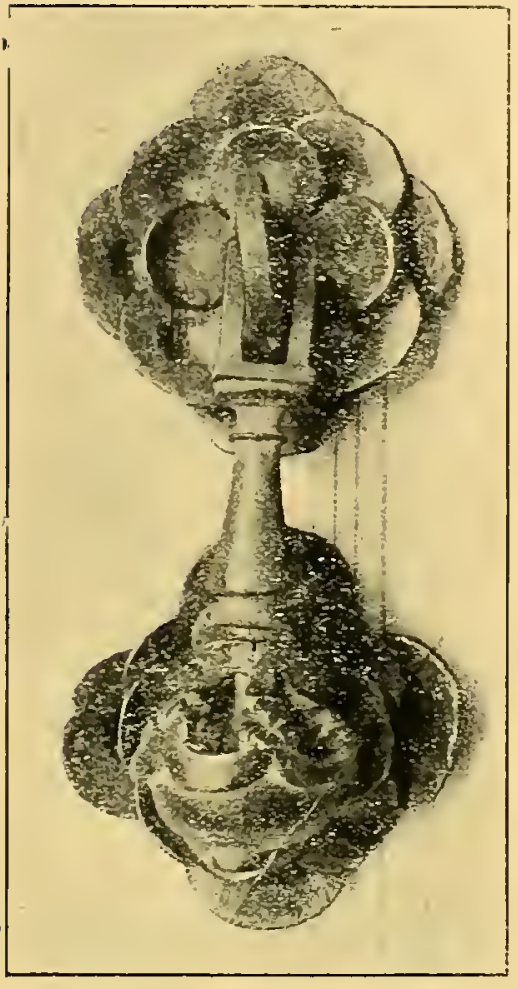

Nứm. 436.

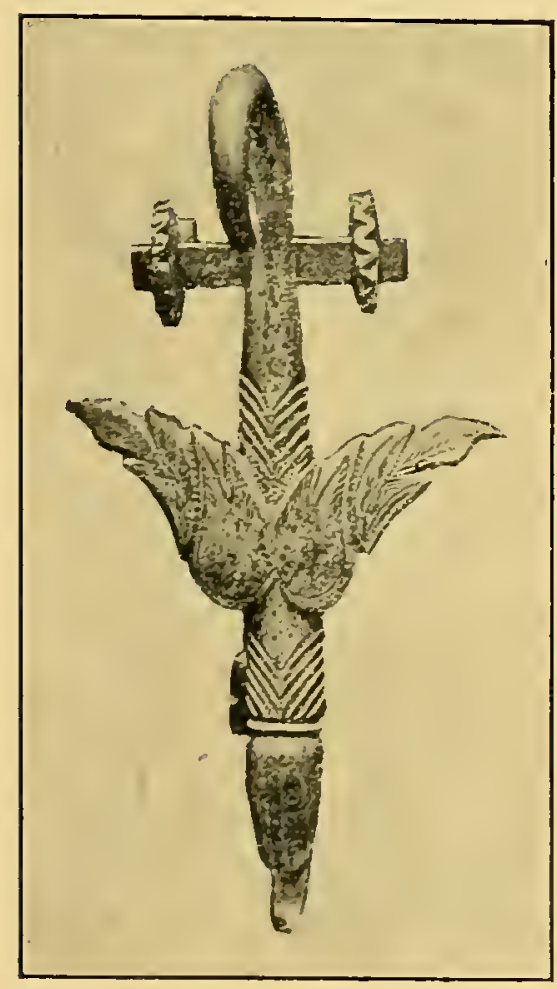

Nứm. 438.

Siglo xvi.

Expositor: Junta de Museos de Barcelona.

Núm. 441.- Llamador en forma de asa, recordando los tipos de doble voluta del siglo xv. Trabajo de fines del siglo xvı y principios del xvir.

Expositor: Excmo. Señor Marqués de la Torrecilla.

Núm. 442. - Llamador de barra cuadrada prolongada y doblada sobre sí misma en forma de cabeza de dragón. Siglo xvıl.

Expositor: D. José $A$. Weissberger.

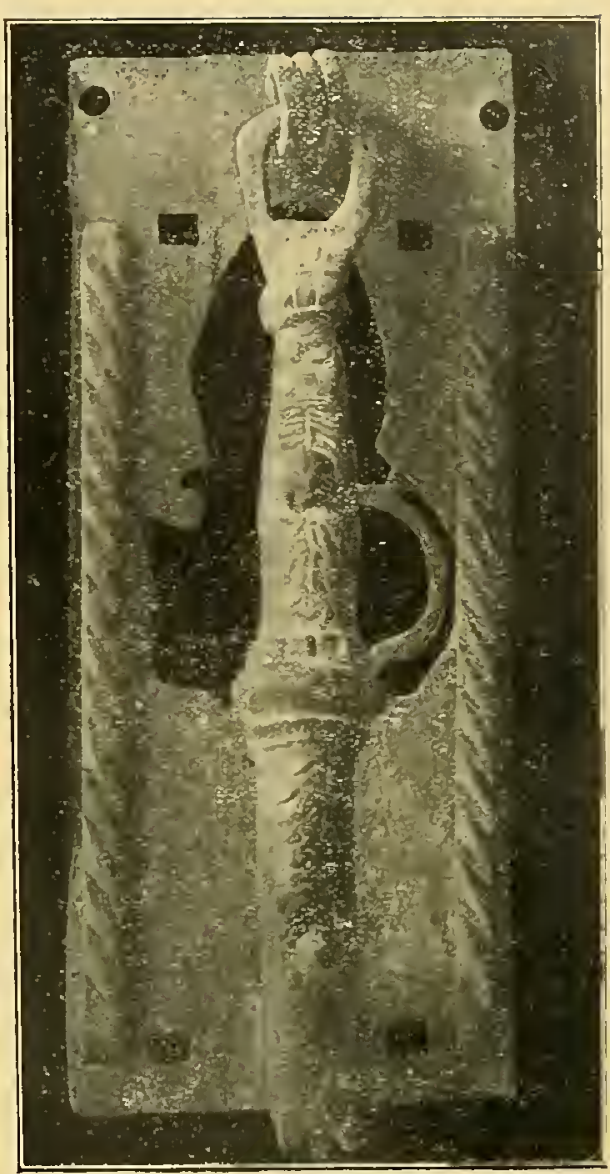

Núm. 437.

Núm. 443.- Un pequeño tirador, recordando las disposiciones de los llamadores góticos en doble voluta. Siglo xvil.

Expositor: D. José A. Weissberger.

Núm. 444. - Llamador en forma de pierna, colocado sobre un clavo de la época. Finales del siglo xvi al xvi.

Expositor: Excmo. Sr. Marqués de la Torrecilla.

Núm. 445.-Llamador de barra cuadrada terminado en la parte del martillo por cabeza de pez; y la barra, en su terminación superior, ha sido ensanchada y adelgazada para do-

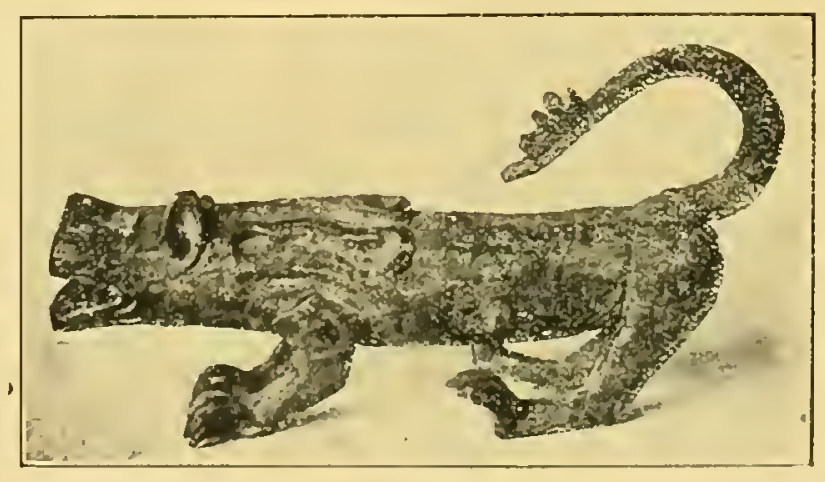

Num, 440. 


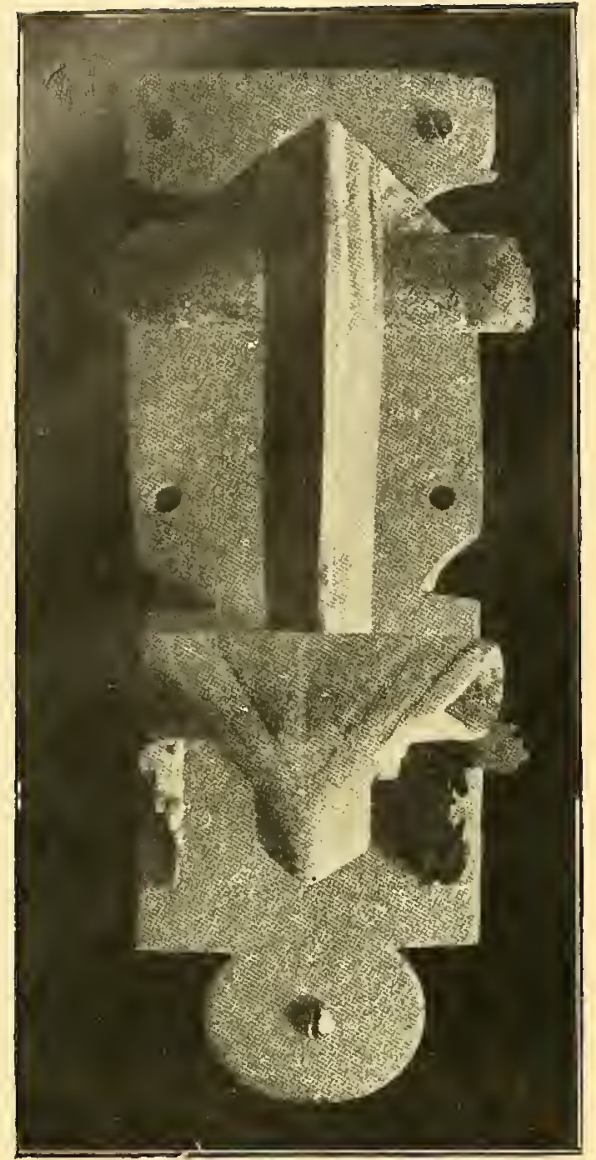

Num. 439.

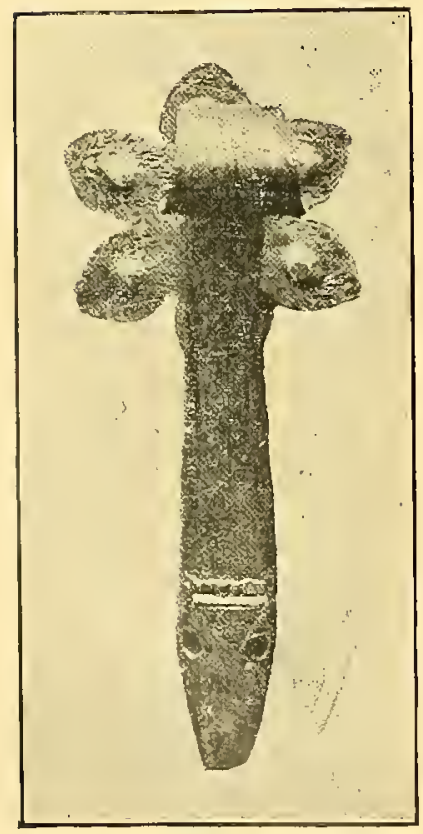

Núm. 445.

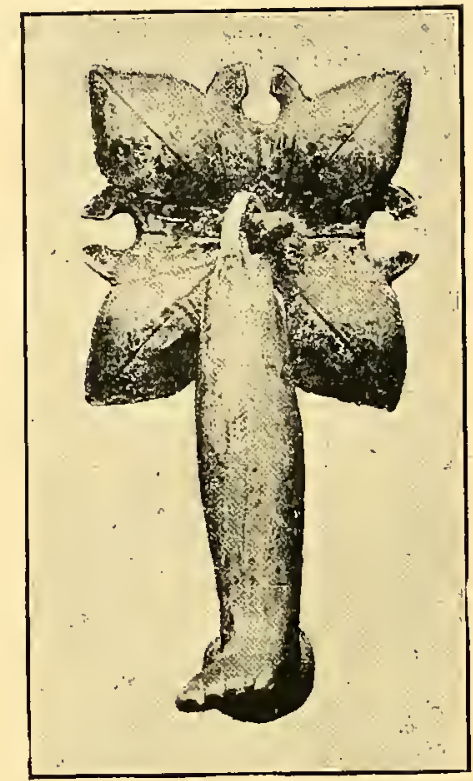

Nủn. 44 \%.

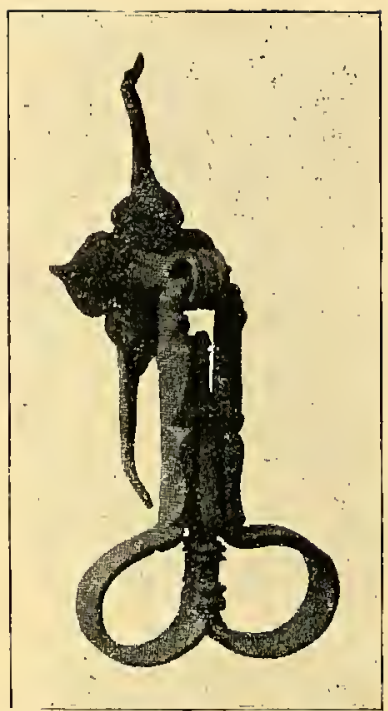

Nừn. 433.

blarla en volutas sobre sı misma. Finales del siglo xvı al xviI.

Expositor: $E x-$ celentísimo Sr. Marqués de la Torrecilla.

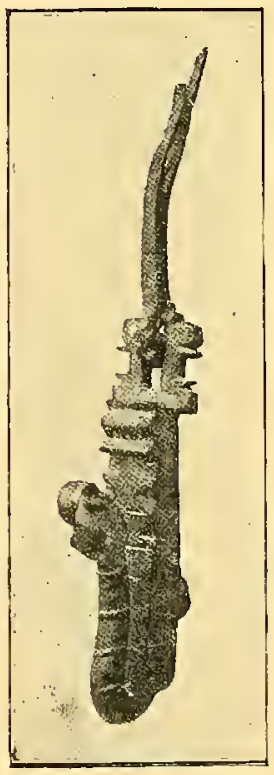

Nưm. 442.

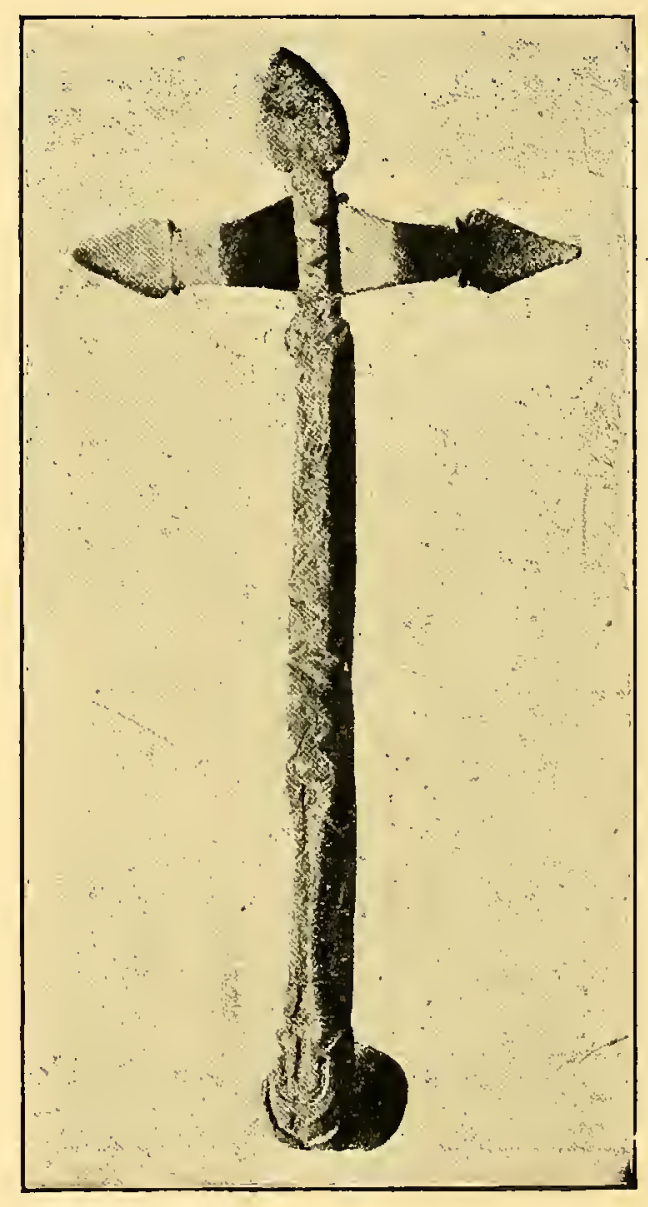

Nüm, 446. 


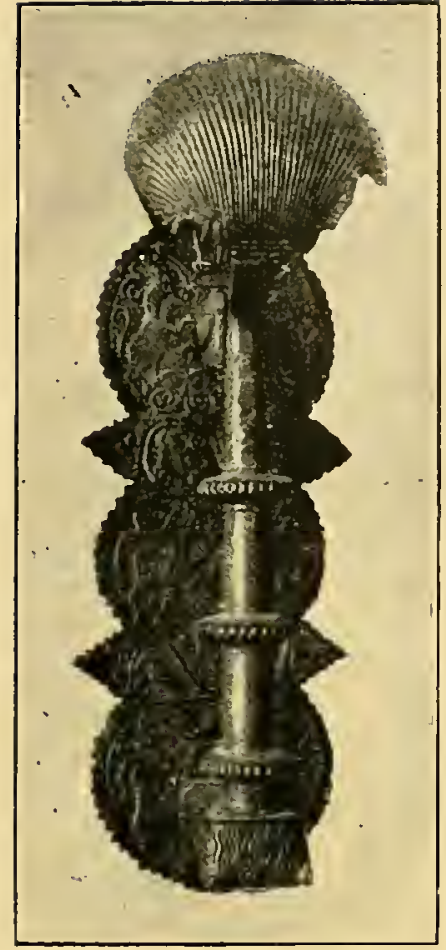

Nủm. 418.

Núm. 446.-Llamador de barra cuadrada, martillo en ángulo recto sin volutas pero con tres hojas en su eje. Trabajo inciso tosco. Ejemplar del siglo_xviı.

Expositor: D. Benito Mur.

Núm. 447.--Llamador de barra cilíndrica, martillo en ángulo recto y voluta con la barra ensanchada. Tipo análogo al precedente. Siglo xvir.

Expositor: Excmo. Sr. Marqués de la Torrecilla.

Núm. 448. - Llamador, en ángulo recto, decorado en la parte superior por una concha. La plancha que sostiene el eje y el clavo, sensiblemente rectangular, de perímetro lobulado, está decorada por zonas, con motivos de arte popular de la época, leones, caballeros, pájaros, etc. En

las espadas de cazoleta de la época se encuentran hoy, aunque no con mucha frecuencia, motivos ornamentales parecidos.

Procederá del Norte de España. Siglo xvı.

Expositor: D. Domingo Guerrero, de San Sebastián.

Núm. 449.-Candelabro arquitectural con decoración de plancha recortada y realzada. Siglo xvil.

Expositor: Cabildo de la Catedral de Toledo.

Núm. 450.- Una sencilla crestería de reja, formada por un óvalo con escudo partido de águila y cinco flores de lis, y dos tornapuntas simétricas en doble voluta y de plancha rectangular, completan la decoración y sirvieron en su tiempo para colocar planchas recortadas que completasen el conjunto. Finales del siglo xvir.

Exposiror: D. Virgilio Martín.

Núm. 451. - Copete de brocal de pozo decorado con volutas.

Expositor: D. Daniel Zuloaga.

Núm. 452.-Reja de balaustres iguales y simétricos, sensiblemente cónicos, con anillos y decoración floral. Finales del siglo xvi a mediados del siglo xvil.

Expositor: D. José Lázaro.

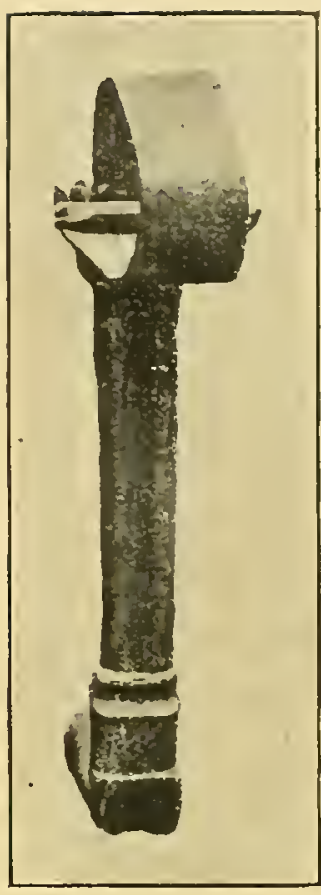

Nử ๆ. 447.

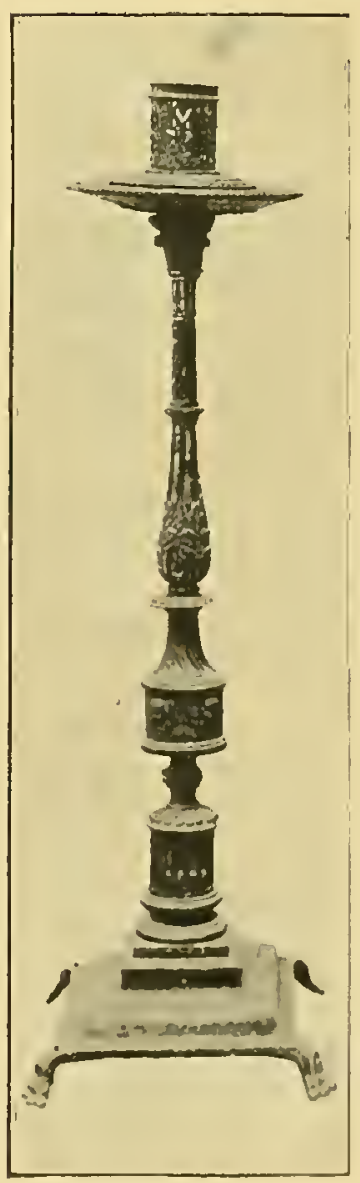

N่บน. 449. 


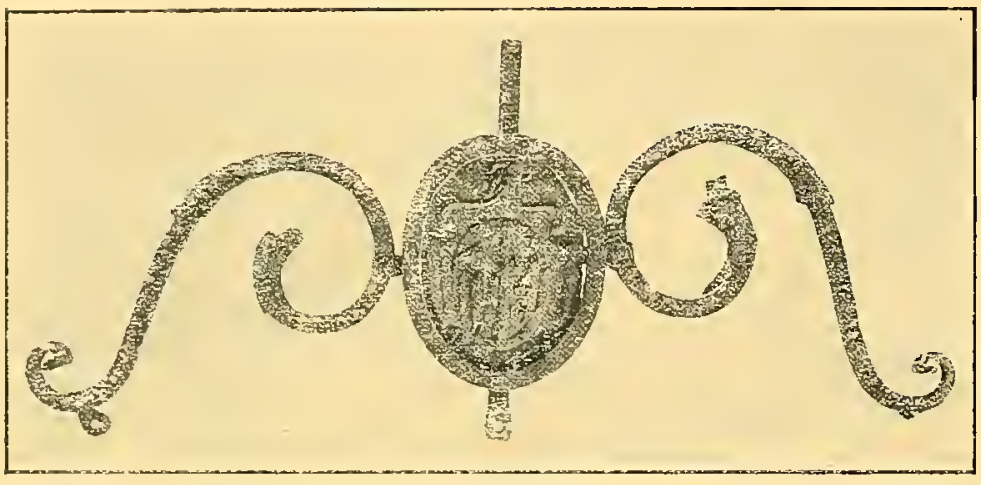

Nủm. 450.

Núm. 453.-Chafeta o braserillo de uso litúrgico. Alto $\mathrm{O}, 2 \mathrm{O}$, diámetro 0,195.

Siglo xvil.

Expositor: Junta de Museos de Barcelona.

Núm. 454.-Figura de ángel de plancha de hierro repujada y dorada; tamaño natural. D. Agustín Durán y Sampere, Director de la sección histórica del Archivo Municipal de Barcelona, ha podido hallar, referente a este ejemplar, la documentación siguiente:

Registre de Deliberacions, 1618 , f.-125 i se refiere al día 14 de agosto del mismo año: «Item, los magnifichs concellers tots sinch ajustats, etc. delliberaren que han pagades a Phelip Ros, argenter, dos centes sinquanta llinres, les quals se li paguen per lo pren, mans y bestretas y manufacturas de la figura del angel ha fet y fabricat per la agulla o pirámida de la plassa del Blat vella en honor de la gloriosa santa Eulalia, compres lo modello y totas altres despreses fetas, y perço, etc.

CCL. Mlinres."

La traza de la pirámide era debida al maestro albañil Rafael Plansó (1616).

Son dos los plateros de nombre Felipe Ros que encontramos citados por esos años; uno de ellos ingresó de maestro en el gremio en 1567 y el otro en 1597, según el Llibred Passantis, que se conserva en la Biblioteca del Museo del Parque.

A un Felipe Ros se le atribuye en los

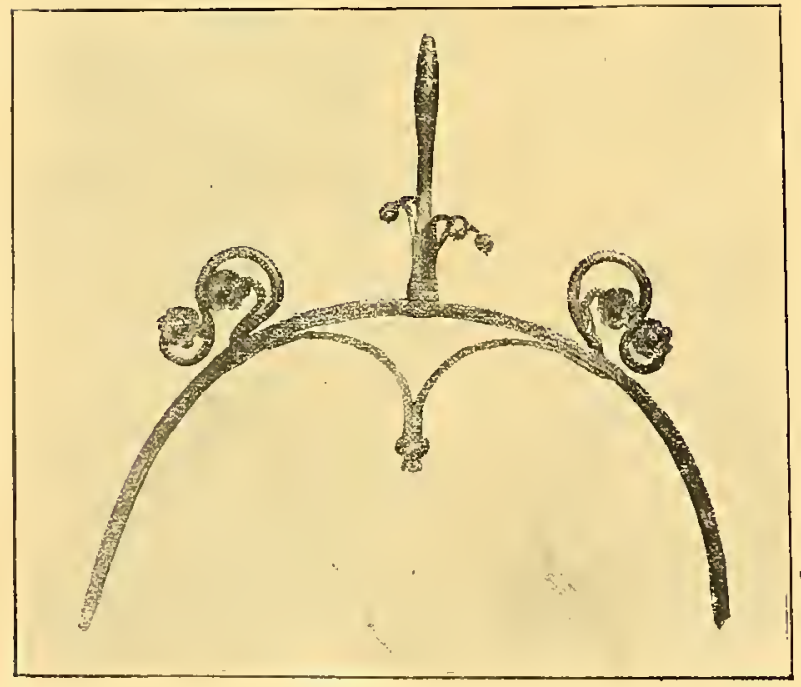

Núm. 451

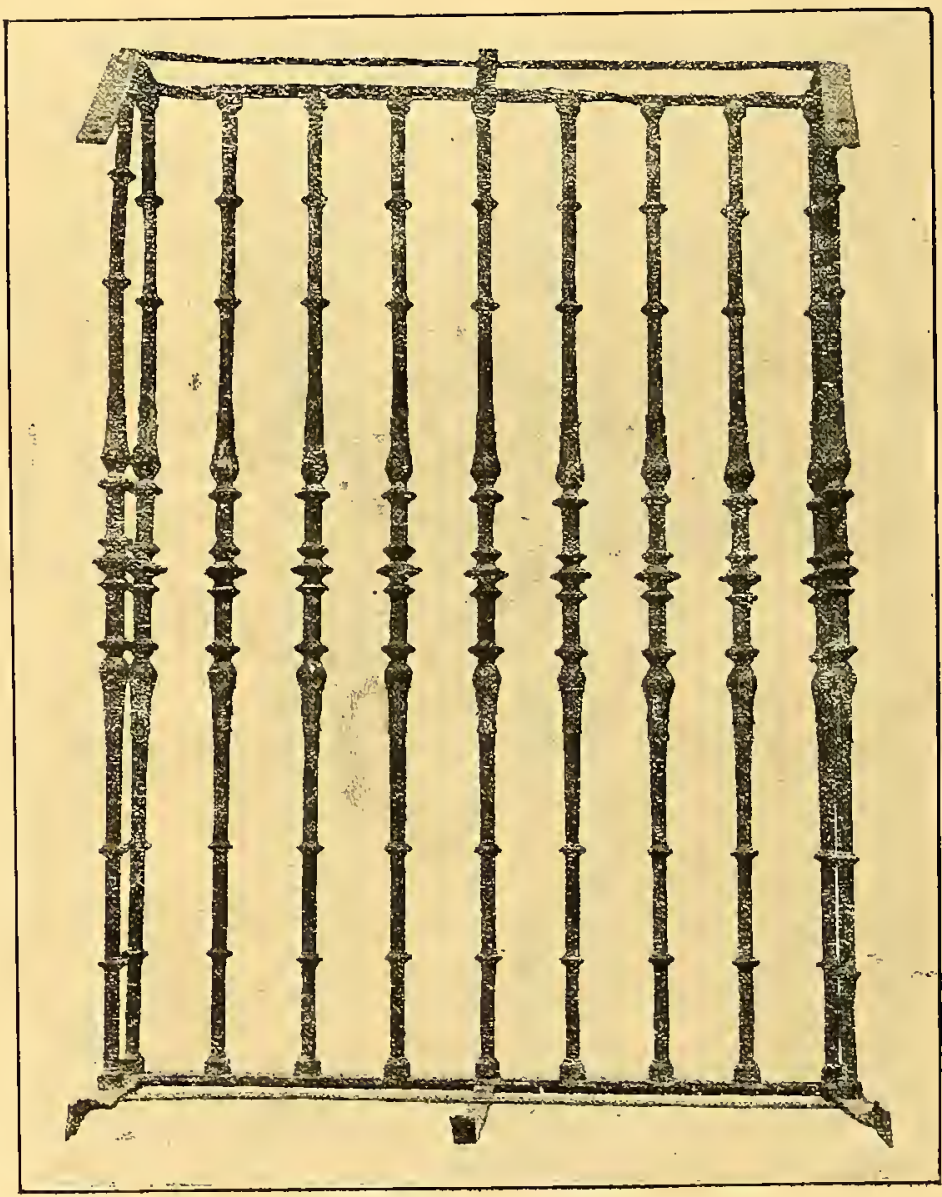

Núm, 452 


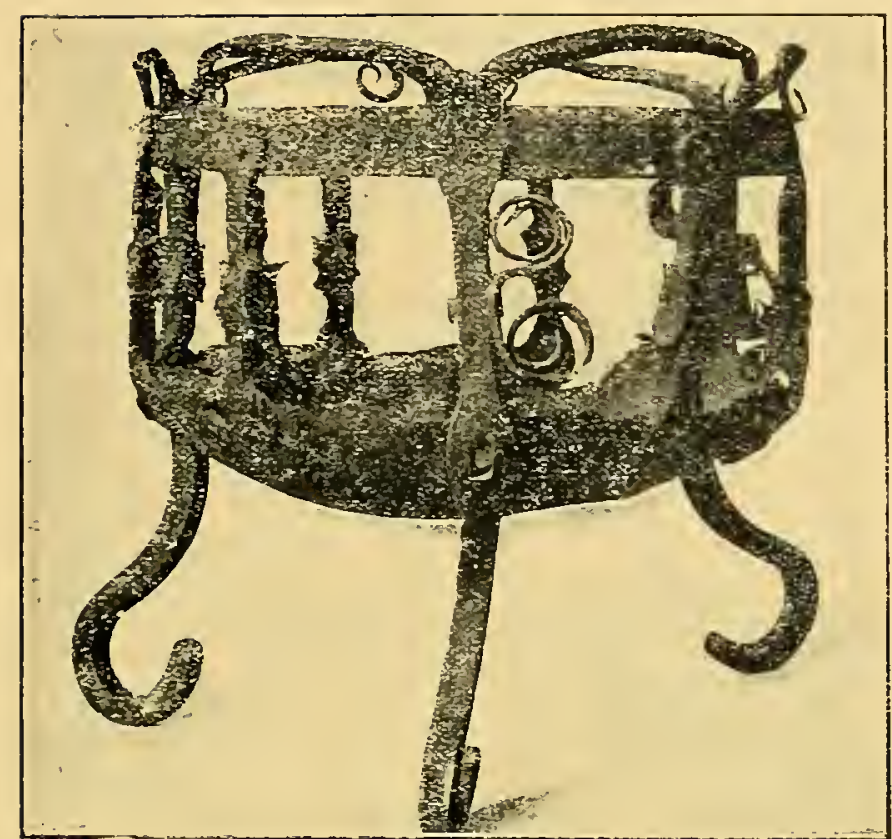

N่ủm. 453.

papeles inéditos de Ramóm N. Comas († en 1918), guardados en este Archivo, el relicario de San Jorge de la Genvalida, obra de 1626, y el relicario de San Fabián y San Sebastián que se labró por encaró municipal en 1611. Este, fabricado por Ros indiscutiblemente, puede verse en la obra de González Sugrañes Contribució a la histoira dels antichs gremis dels Arts y Ofices de Ia ciutat de Barcelona. V. I (1915), p. 188.

Expositor: Junta de Museos de Barcelona.

Núm. 455.-Cerradura sobre plancha circular calada y decorada por línea. El cerrojo se dobla dos veces en ángulo recto sobre su mismo plano, que es el de la cerradura. Todo él análogamente ćecorado. Ejemplar que guarda estrecha relación con los prei e lentes, aunque el hecho de no estar la cerradura sobre caja cuadrada realzada, sino a la inversa, embutida sobre el espesor de la madera, da un aspecto distinto al ejemplar. Procede del Cau Ferrat.

Expositor: D. Santiago Rusiñol.

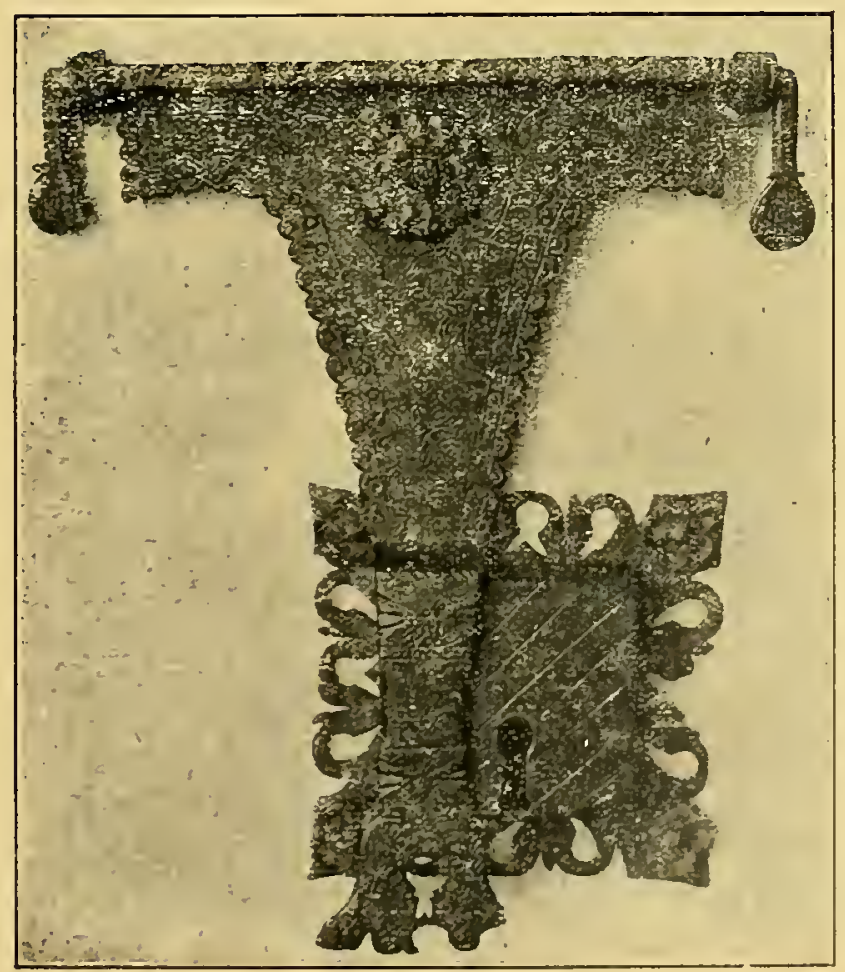

Nủm. 455.

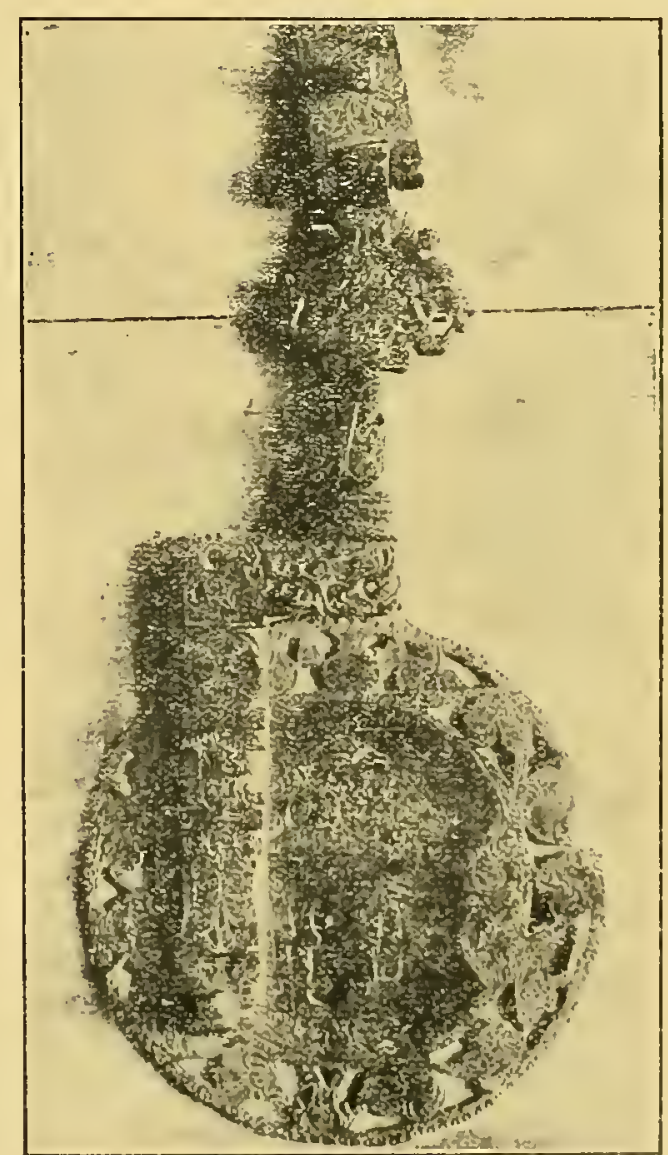

Núm. 456. 
Núm. 456.-Cerradura en caja cuadrada realzada; el cerrojo formando un triángulo de dos lados simétricos curvilíneos, girando sobre la base del triángulo, formado por una varita doblada en ángulo recto, sujeta en sus extremos por dos argollas. La parte prolongada del cerrojo se dobla dos veces en ángulo recto para ajustarse a la caja de la cerradura. Es característica de este tipo la decoración incisa de línea y un rosetón o figura, colocado sobre la superficie del triángulo del cerrojo, bajo el eje de la base. Fueron usados para muebles durante el siglo xviI.

Expositor: D. Domingo Guerrero, de San Sebastián.

Núm. 457.-Cerradura análoga a la precedente, con un águila bicéfala sobre la superficie del triángulo, sustituyendo al rosetón, y un lagarto sobre la terminación del cerrojo. Siglo xvil.

Expositor: D. Iosé Lázaro.

Núm. 458.-Cerradura análoga a las precedentes, con rosetón en el cerrojo. La de asiento de la cerradura no es en plancha calada. Siglo xvil.

Expositor: D. Iuan Lafora.

Núm. 459 -Ejemplar análogo a los que preceden, rosetón en múltiple plancha cortada y curvada. Siglo xvir.

Expositor: D. José Lázaro.

Núm. 460. - Ejemplar análogo a los precedentes, rosetón en plancha calada, sujeto como

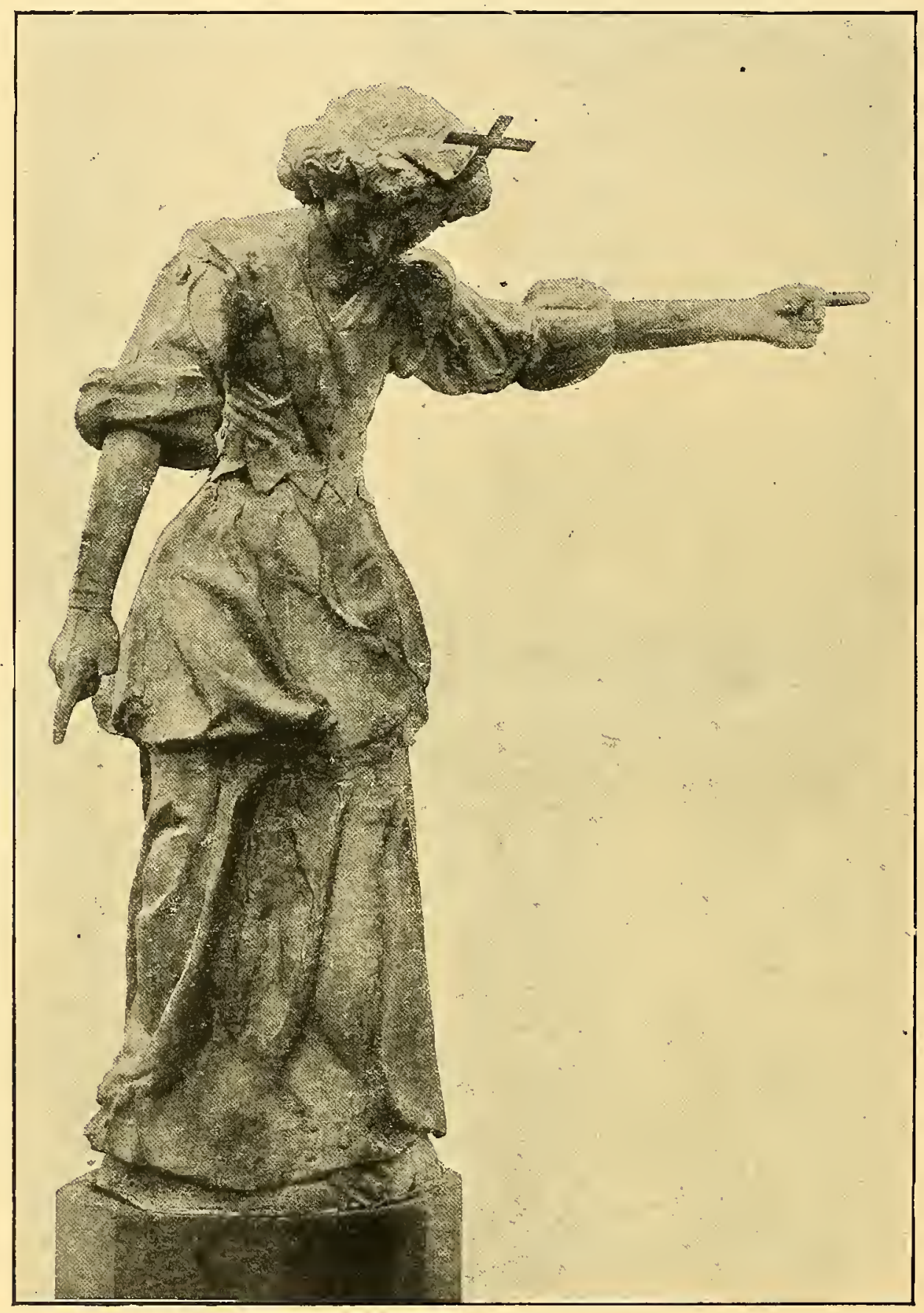

Núm. 454. 
el cerrojo por clavos cincelados representando un capullo. Siglo xvir.

Expositor: D. José Lázaro.

Núm. 461.- Ejemplar análogo a los que preceden, el cerrojo en plancha calada, los clavos son grandes capullos cincelados. Estilo de los ejemplares anteriores.

Expositor: D. José Lázaro.

Núm. 462.-Cerradura análoga a las precedentes, con el cerrojo en plancha calada simulando una lacería árabe. Siglo xvII.

Expositor: D. Juan Lafora.

Núm. 463.-Cerradura cuadrada sobre plancha recortada, terminada en triángulos, con cerrojo en doble ángulo recto. La plancha presenta una inscrip-

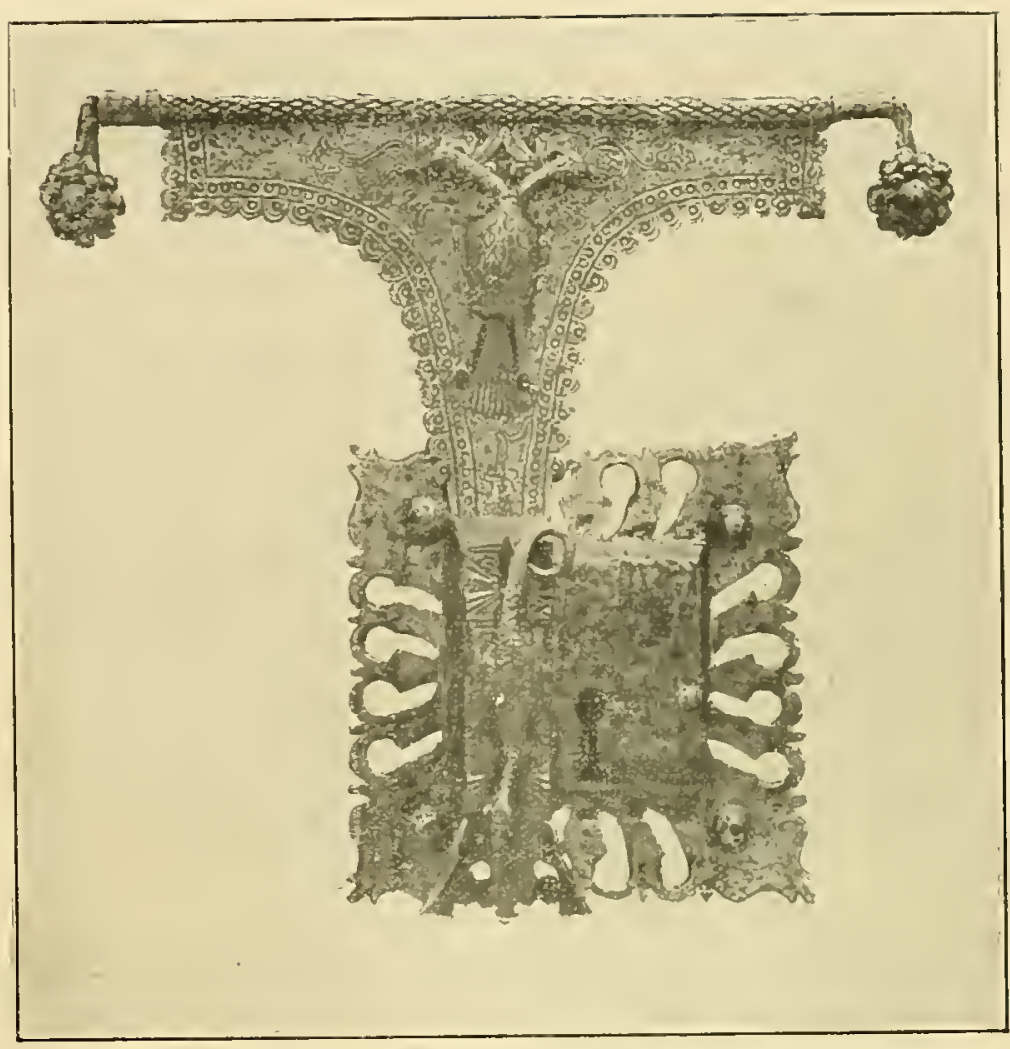

Nỉin. 457. ción que dice «Bosmedano» y debajo «Artiaga». Obra de Bosmediano. Siglo xvir.

Expositor: D. Manuel de Cossío y Gómez-Acebo.
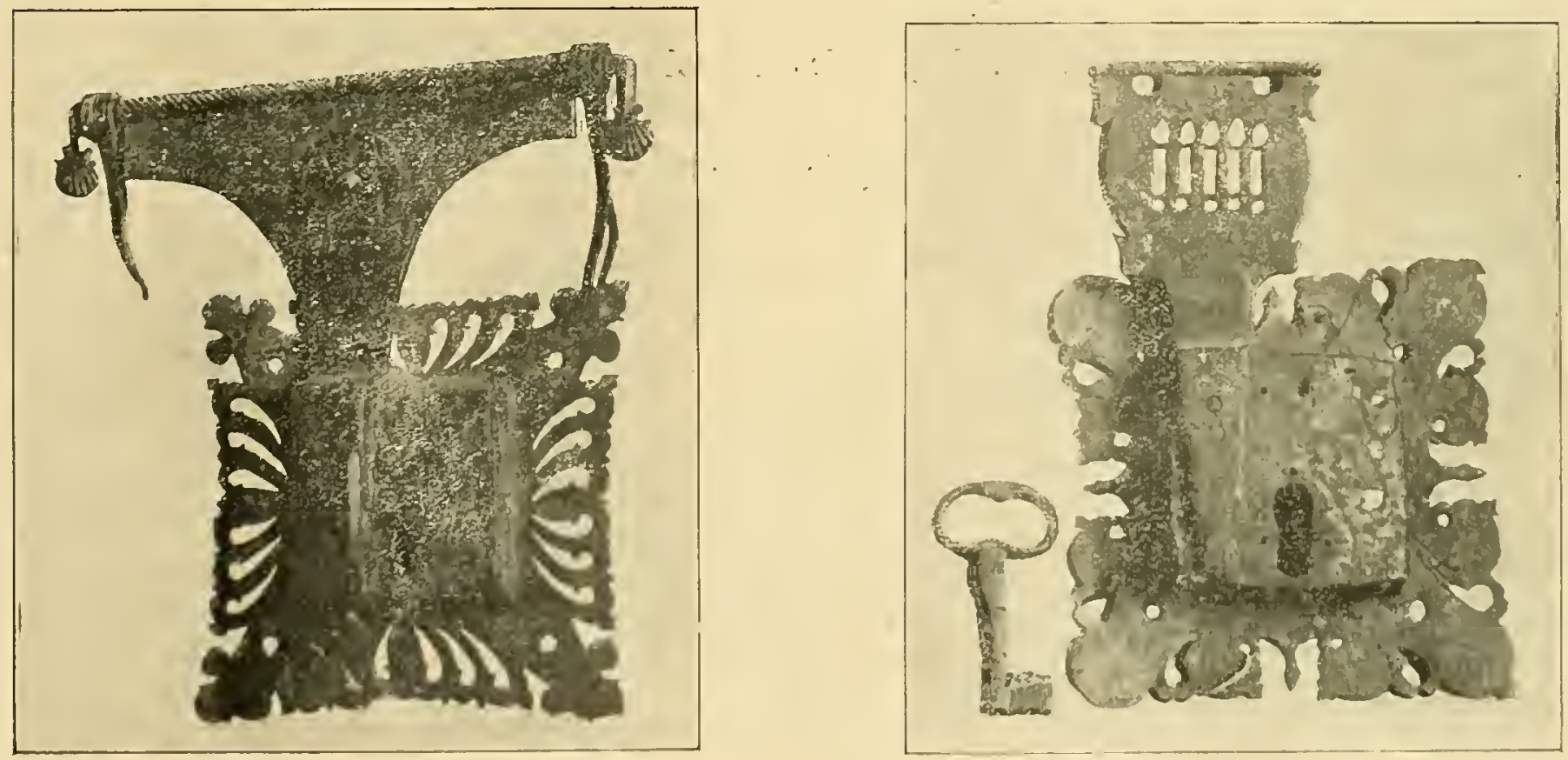


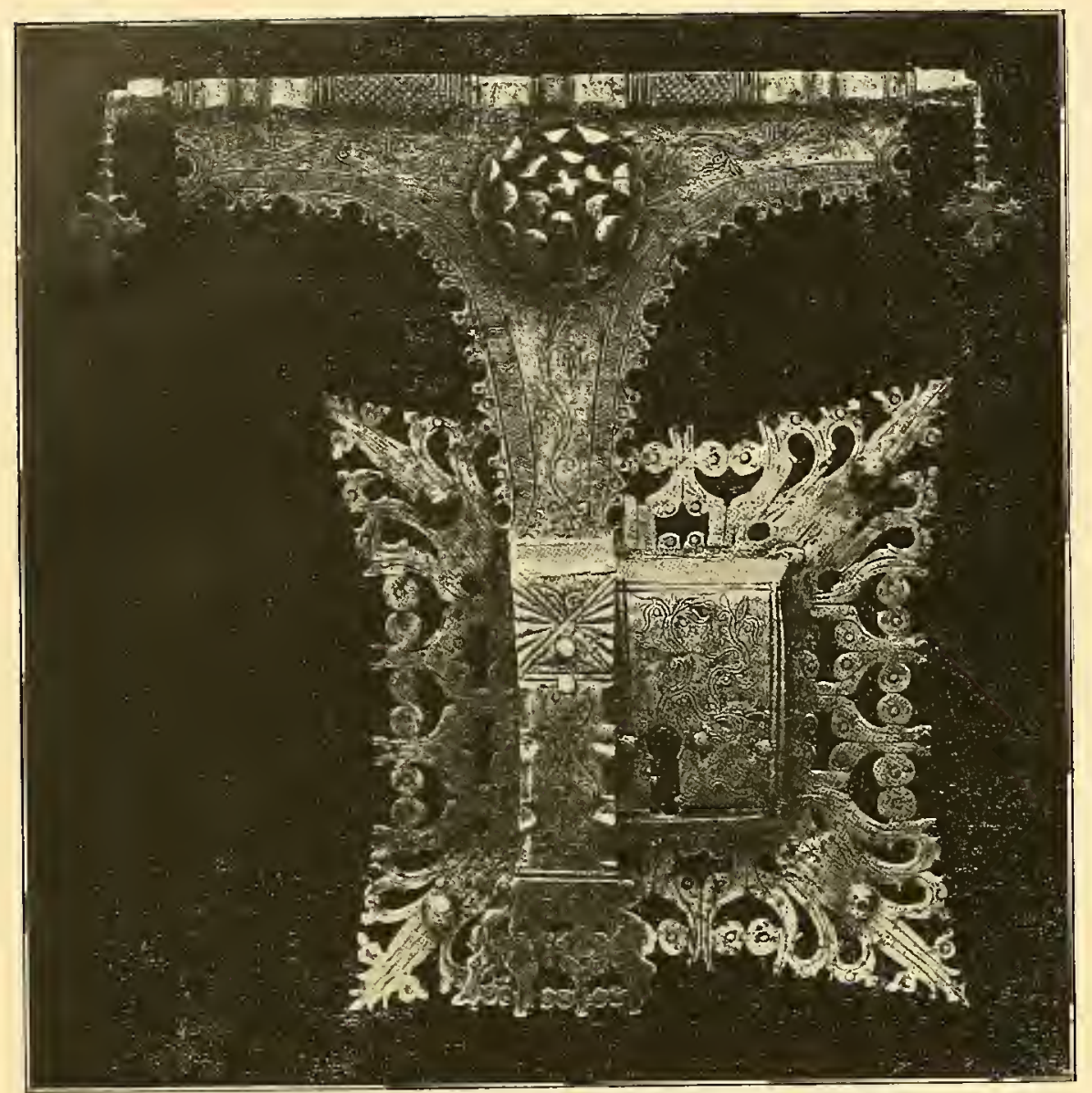

Núm. 459.
Núm. 464. - Cerradura en plancha calada y decorada, perímetro lobulado. Trabajo del siglo xvir.

Procede del Cau Ferrat.

Expositor: D. Santiago Rusiñol.

Núm. 465.- Un tirador de asa, de cajón, sobre plancha circular recortada,

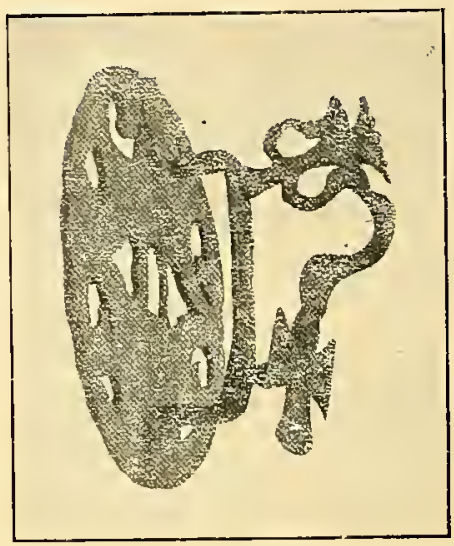

Núm. 465.

con ‘una pequeña paloma que termina en cruz, decorada por líneas incisas, sirviendo para apoyar el pulgar. Siglo xvi al xvir.

Expositor: Excmo. Sr. Duque de Santa Lucía.

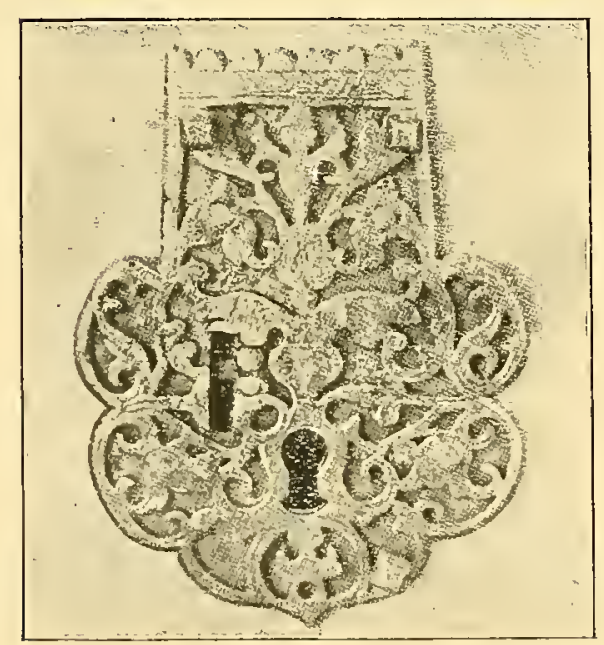

Nưm. 464.
Núm. 466.-Collar de perro formado por tres series de eslabones macizos unidos por plancha recortada y doblada en forma de pinchos. Finales del siglo xvil.

Procede de Capdella, provincia de Lérida, y se usaba

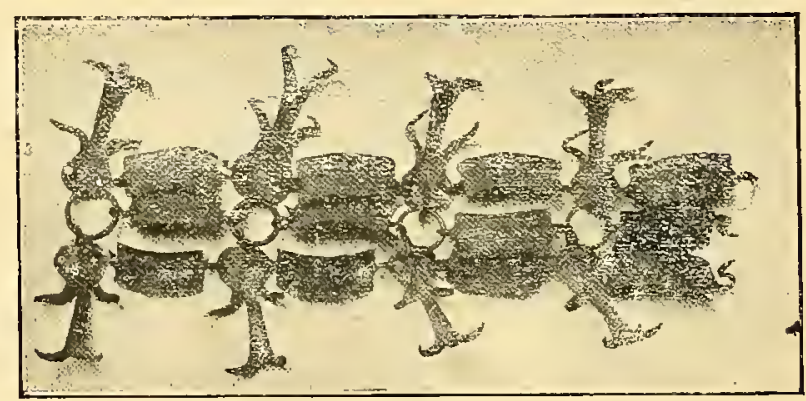

Nưm. 466. 
para defensa de los perros de ganado contra los ataques del lobo.

\section{Expositor: Junta de Museos de Barcelona.}

Núm. 467.-- Visagras de plancha de hierro recortada, de $23 \mathrm{~cm}$. de alto por $35 \mathrm{~cm}$. de ancho; se desarrollan verticalmente según hojas simétricas terminadas en voluta de sección decreciente. Finales del siglo xviı.

\section{Expositor: D. Domingo Gue- rrero, de San Sebastián.}

Núm. 468.-Dos escudos de plancha repujada, representando emblemas heráldicos, con corona ducal. Siglo xvil.

Expositor: D. Platón Páramo.

Núm. 469.-Escudo de armas par-

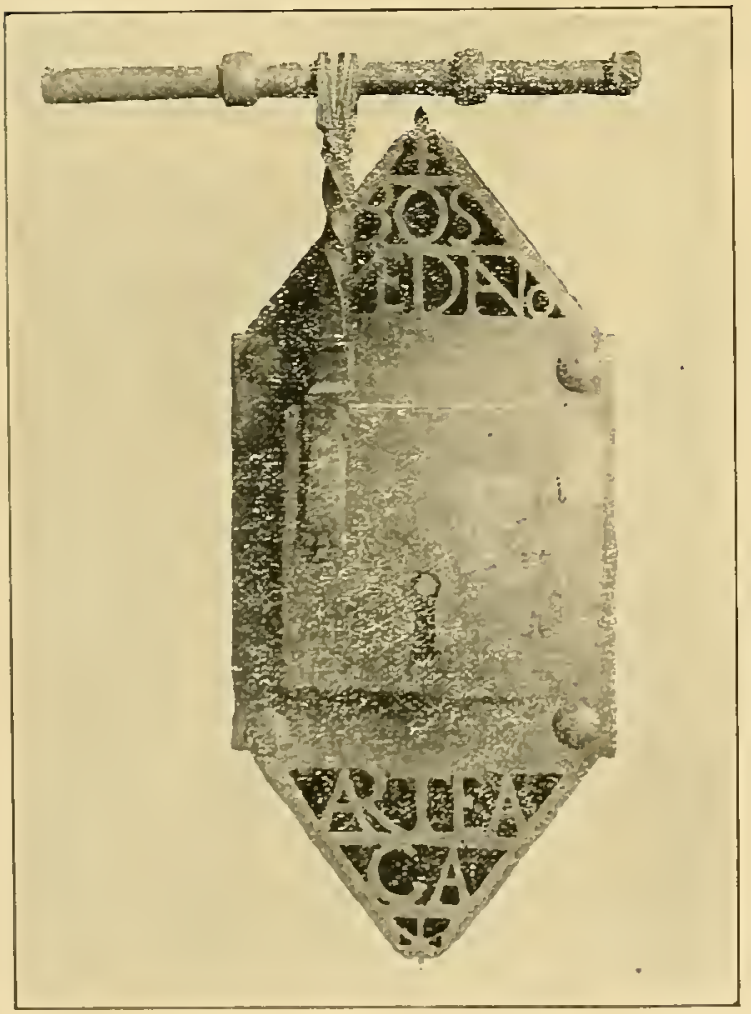

Núm. 463.

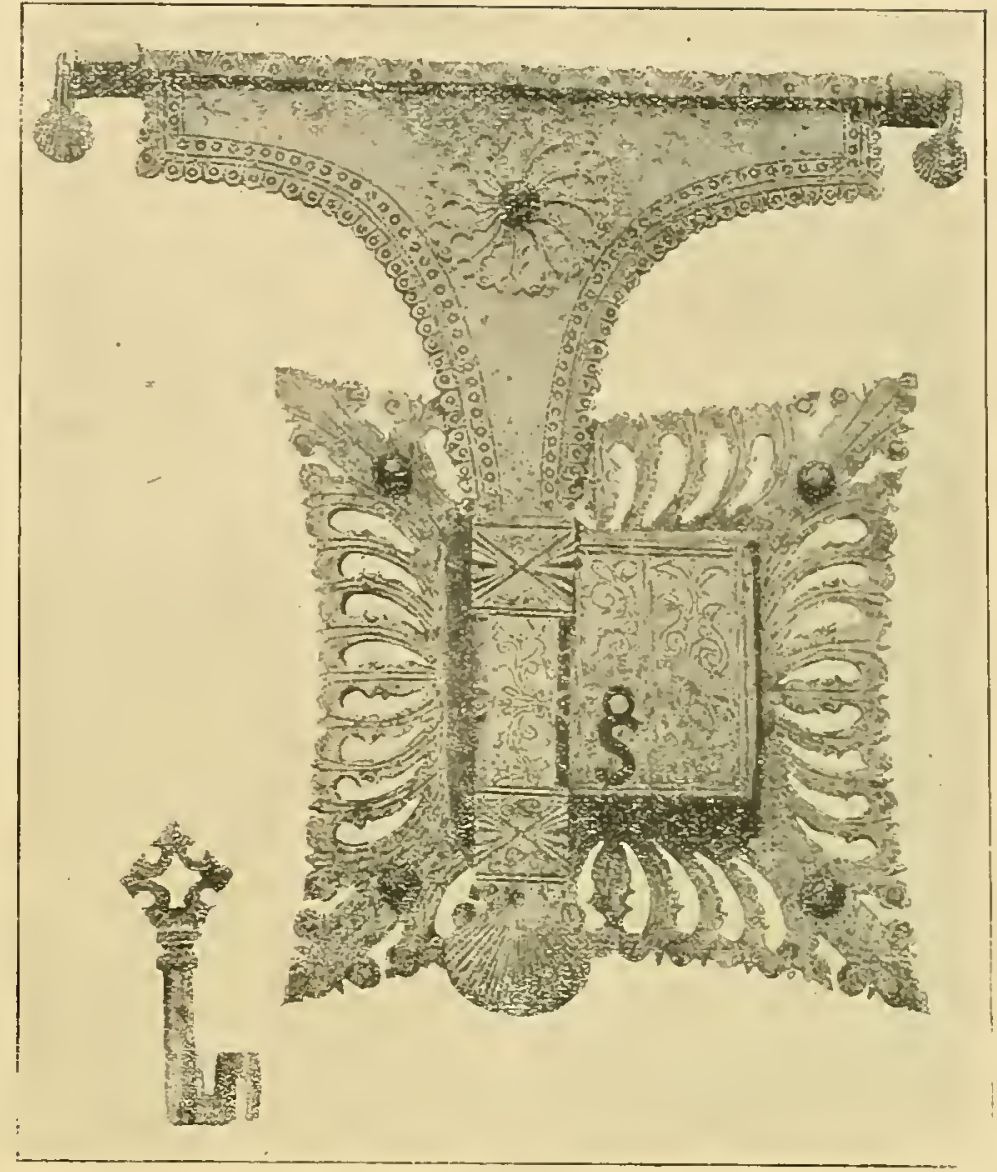

Nưm. 460

tido en plancha recortada y repujada, de 42 centímetros de alto por 31 de ancho. Siglo xvir.

Expositor: D. Domingo Guerrero, de San Sebastián.

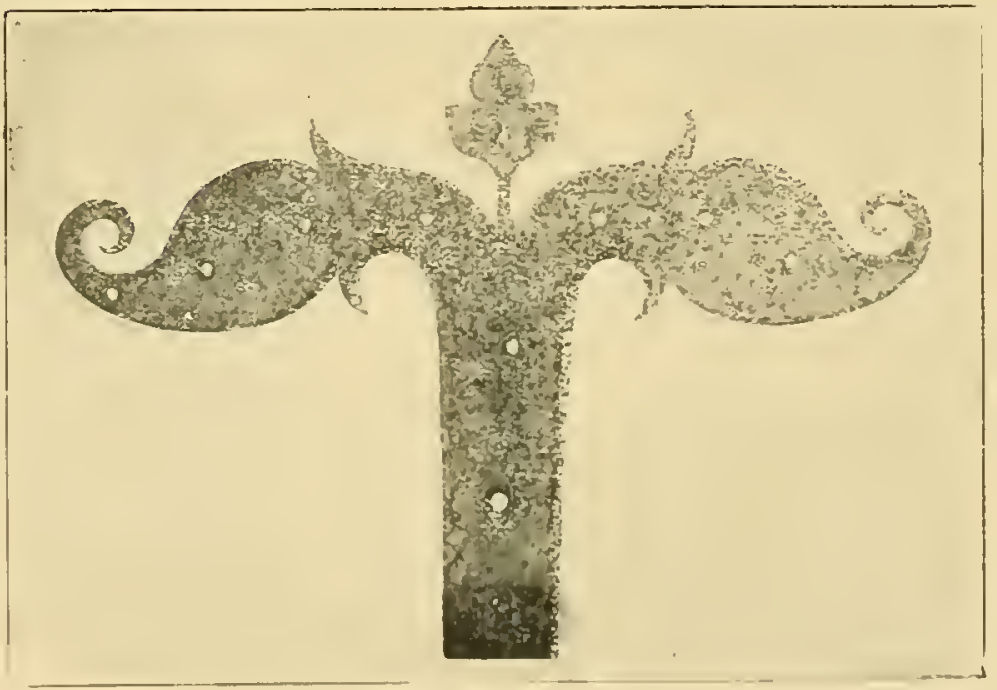

Nüm. 467 


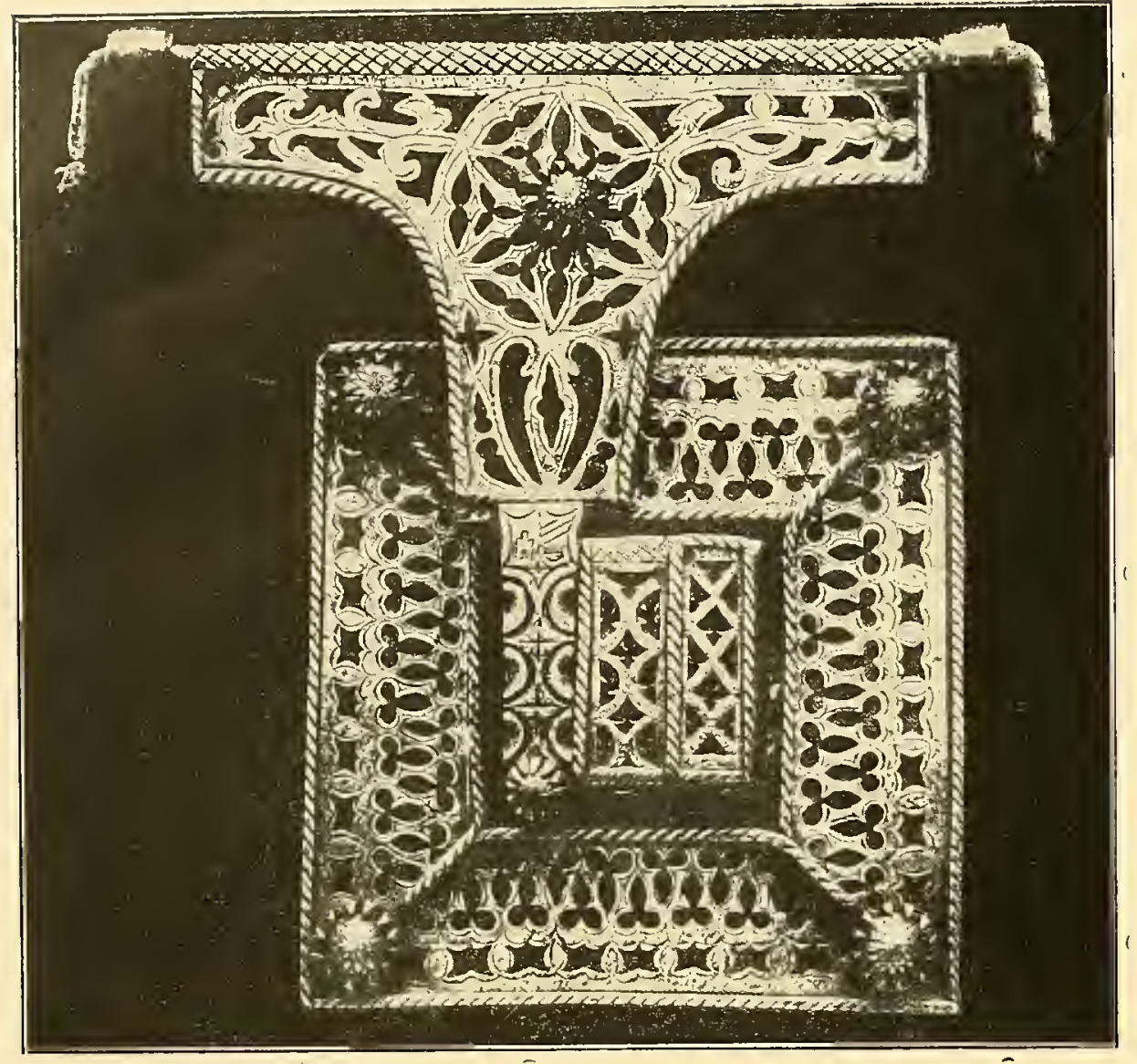

Núm. 461.
Núm. 470.-Escudo de armas acuartelado en plancha repujada y policromada de $35 \mathrm{~cm}$. de alto por 27 de ancho. Siglo xvil.

\section{Expositor: D. Do- mingo Guerrero, de San Sebastián.}

Núm. 471.-Escudo de armas de $35 \mathrm{~cm}$. de alto por 25 de ancho, en plancha recortada sobre otra plancha de hierro. Procede de la provincia de Salamanca. Siglo xvıI.

\section{Expositor: $D . D^{-}$ mingo Guerrero, de San Sebastián.}

Núm. 472. - Escudo acuartelado con figuras de cisne recortadas y superpuestas y varillas limitando las barras. Trabajo del siglo xvir. Expositor: D. José A. Weissberger.

Núm. 473. - Balcón con barrotes simétricos, ligeramente cónicos, decorados por un anillo central y motivos florales, basamento en plancha recortada en escalonamiento. Un doble medio punto en plancha igualmente recortada, se decora por flechas y rayos ondulados. El tipo pertenece a la arquitectura vascongada del siglo xvil, y se repite constantemente como decoración del bal-

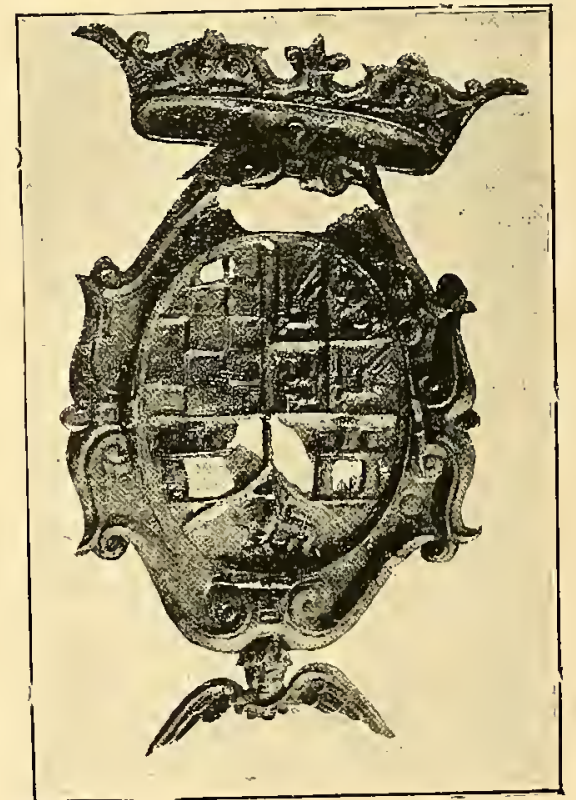


cón principal en las casas solariegas de aquella región durante la mencionada época. Siglo xvil. Alava.

Procede del pueblo de Salvatierra, en

Expositor: D. Daniel Zuloaga.

Núm. 474.-UÚn frontal de altar en plancha de hierro repujada, con un óvalo en el centro, friso y varillas en bronce. El conjunto queda dividido en casetones, decorados por un gran rosetón central y cuatro en los ángulos, llenando por completo toda la superficie.

Trabajo muy interesante de la segunda mitad del siglo xvir.

\section{Expositor: D. Mauricio López Roberts.}

Núm. 475.-Dos faroles de plancha perforada, de sección cuadrada, de 25 centímetros de lado y 57 de altura. Fue-

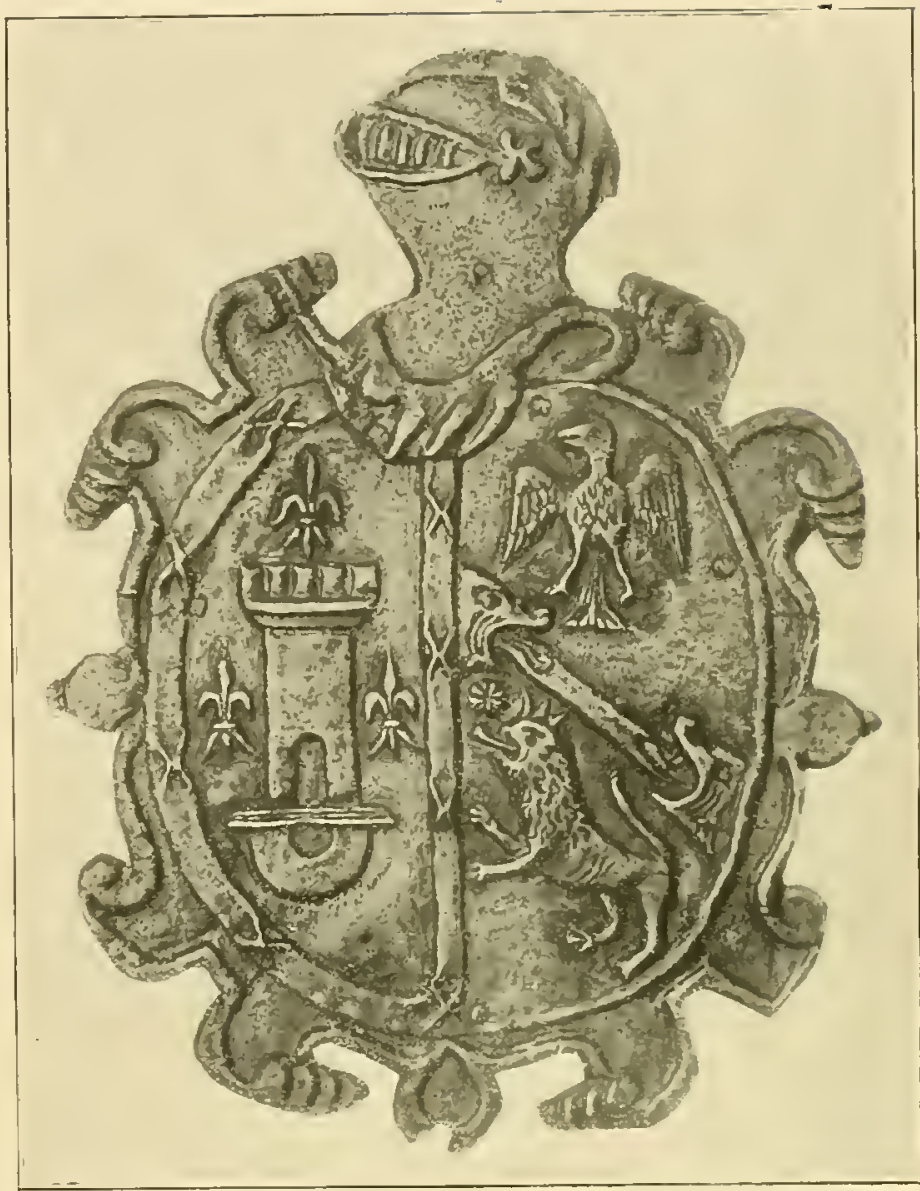

Nüm. 469. ron utilizados para servicios eclesiásticos. Ejemplares muy interesantes de la segunda mitad del siglo xvir.

\section{Expositor: D. Manuel Ruiz Balaguer.}

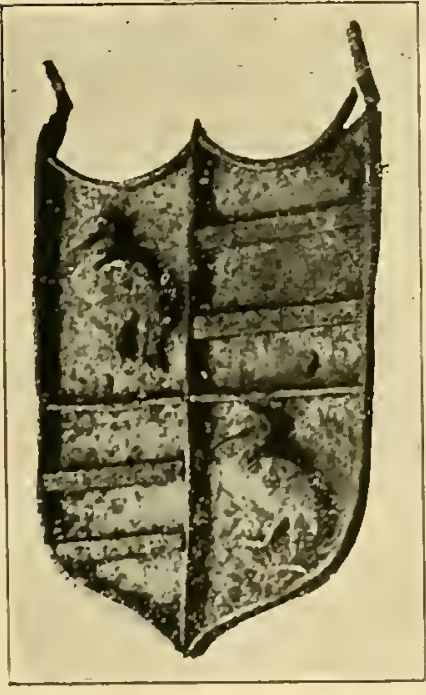

Nủm. 472.

Núm. 476.--Pequeña plancha de cocina, con el asa decorada por líneas incisas.

Epoca indeterminada.

Expositor: Excmo. Sr. Marqués de Bay.

Núm. 477.--Sencillo coronamiento de reja de mediados del siglo xviı.

Expositor: Museo Provincial de Bellas Artes de Avila.

Núm. 478.--Pequeña cruz de hierro, de varilla cuadrada en arista, adornada por cubos con caras paralelas al eje de la cruz.

Finales del siglo xvi.

Expositor: D. Frutos Barbero y Delgado. 


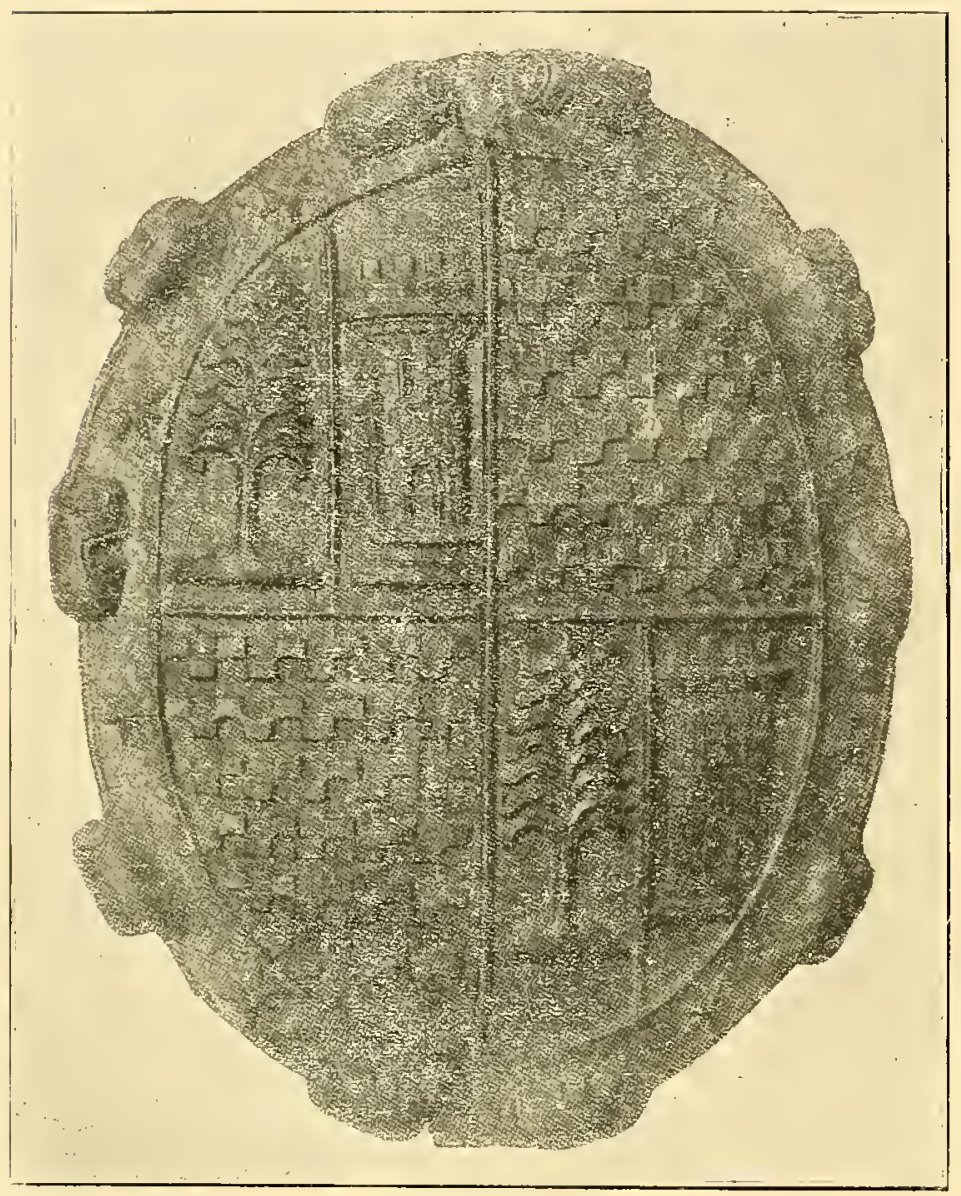

Núm._470.
Núm. 479.-Escudo de armas de $30 \mathrm{~cm}$. de alto por 25 de ancho, procedente de la provincia de Salamanca. Es de plancha de hierro recortada, bordeada y dividida por una varilla con adornos de plancha recortada. Siglo xvir.

Expositor: D. Domingo Guerrero, de San Sebastián.

Núm. 480.-Tirador de puerta en forma de columna, con incrustaciones de bronce. Una concha para el pestillo. Todo ello sobre plancha recortada y siluetada, representando la doble águila, sobre la que dos leones soportan la corona real. Siglo xvı.

Expositor: Sr. Rodríguez Rojas.

Núm. 481.-Cruz de barra rectangular con una figura en su pie y dos barras curvadas como basamento. Siglo xvir.

Procede del Cau Ferrat.

Expositor: D. Santiago Rusiñol.

Núm. 482.- Gran palomilla de grueso balaustre terminado en volutas. Siglo xvıı. Expositor: Hospital de la Caridad de Illescas,

Núm. 483. - Cruz de barra de sección rectangular con decoración de plancha en volutas siguiendo la escuela extremeña y plancha recortada. En su

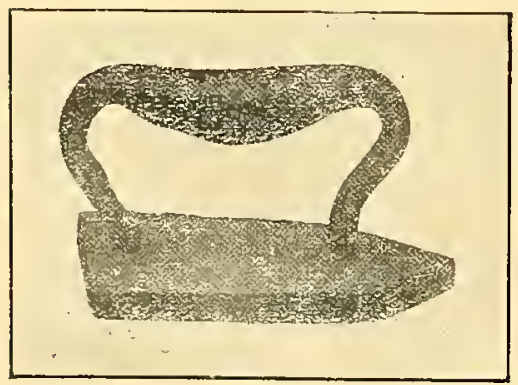

Nủm. 476.

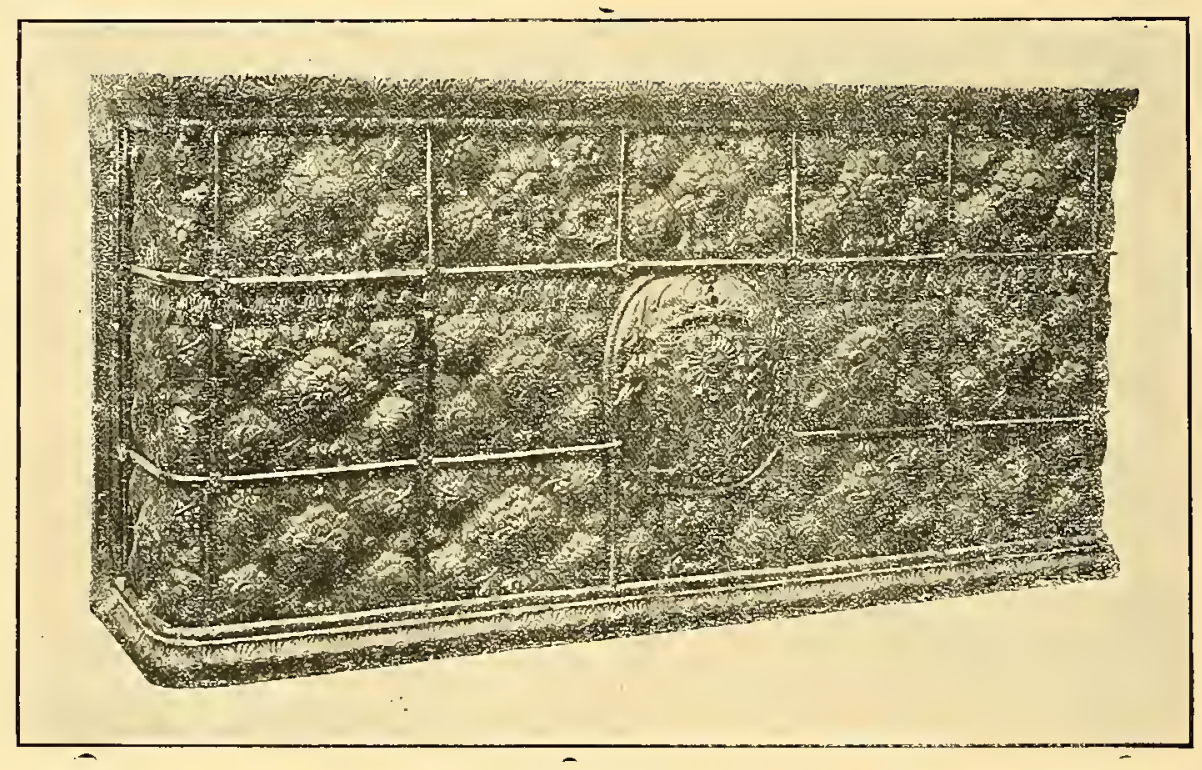

Nưm. 474. 
base lleva una doble estrella de ocho puntas en plancha recortada y ligeramente repujada. Finales del siglo xvir.

Procede del Cau Ferrat.

Expositor: D. Santiago Rusiñol.

Núm. 484. Cadena de chimenea para suspender de ella marmitas, etc., que solía colocarse en el cañón de la chimenea. Siglo xvıı.

Expositor: Junta de $\mathrm{Mu}$ seos de Barcelona.

Núm. 485. - Dos candelabros de madera dorada y policromada,

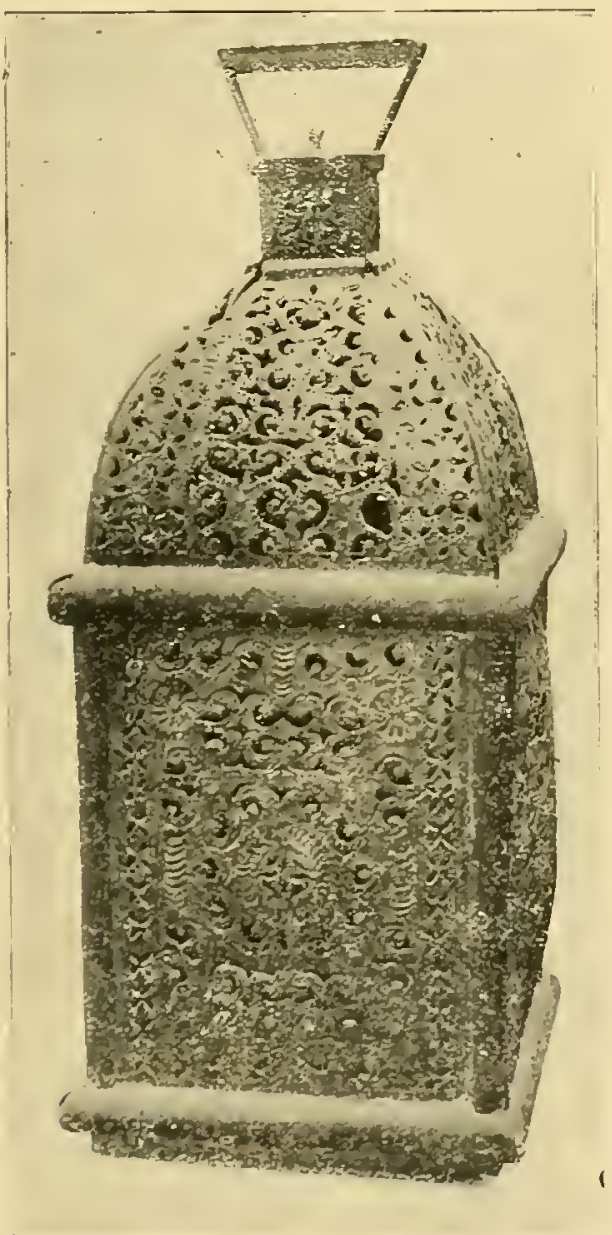

Nưn: 475.

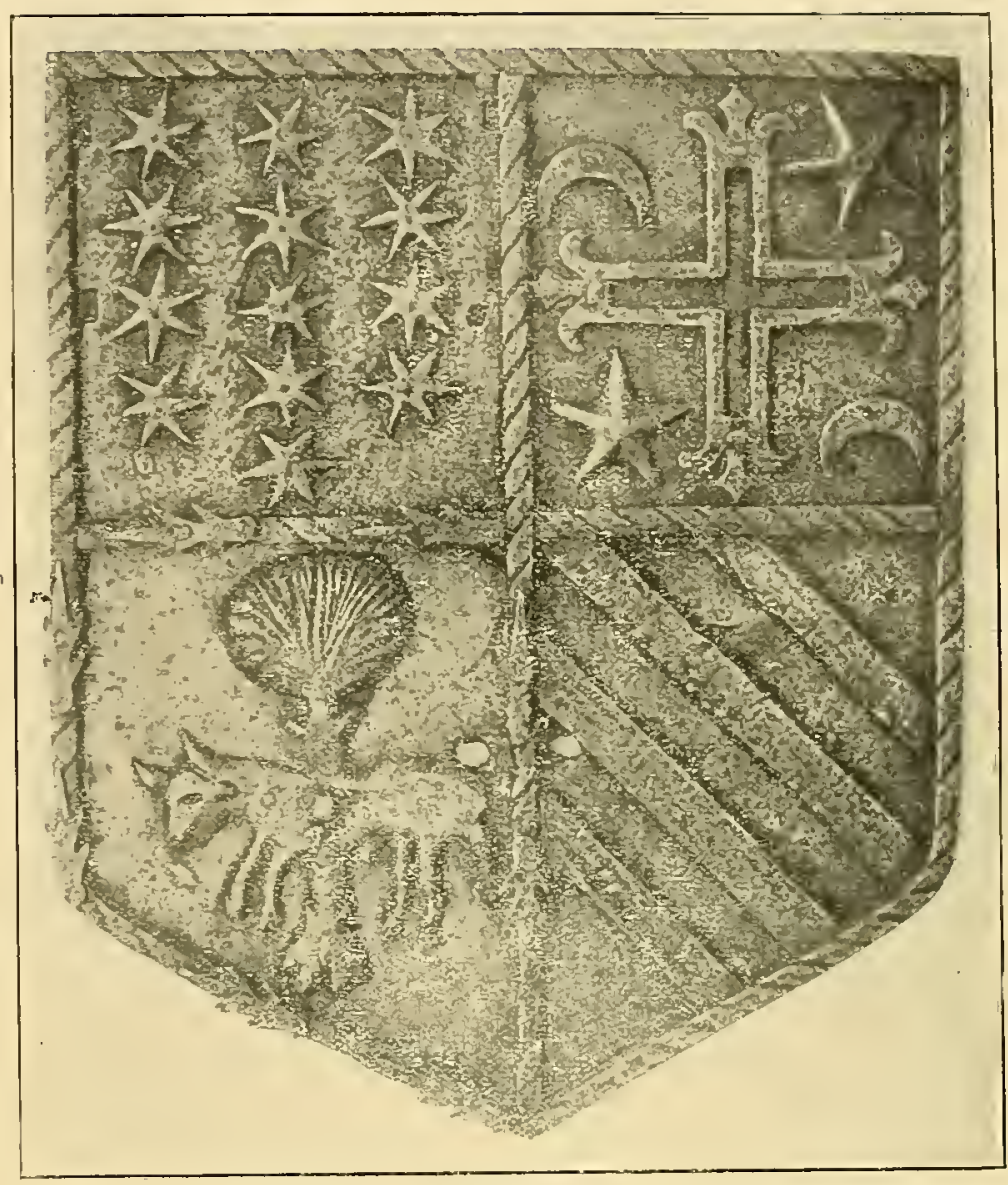

Nưm. 471.:

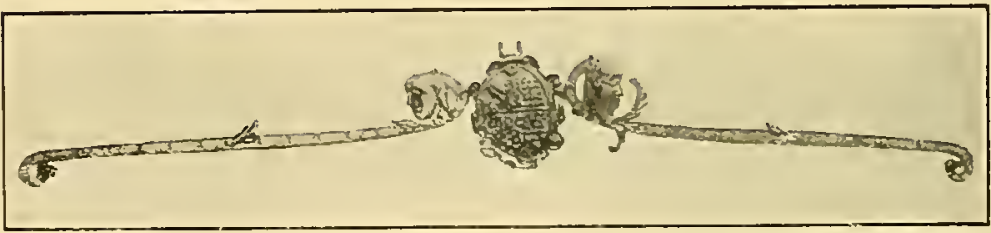

Nùm. 477.

aтandela circular de plancha perforada, representando leones y castillos. Tubo en plancha ligeramente repujada, formando las aristas columnas salomónicas.

Siglo xvII.

Expositor: D. Rafael García Palencia.

Núm. 486. - Hachero con

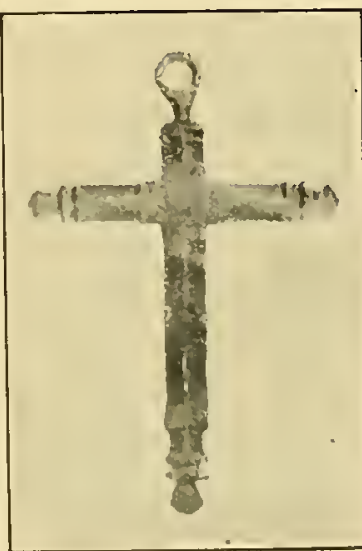

Nim, 478 


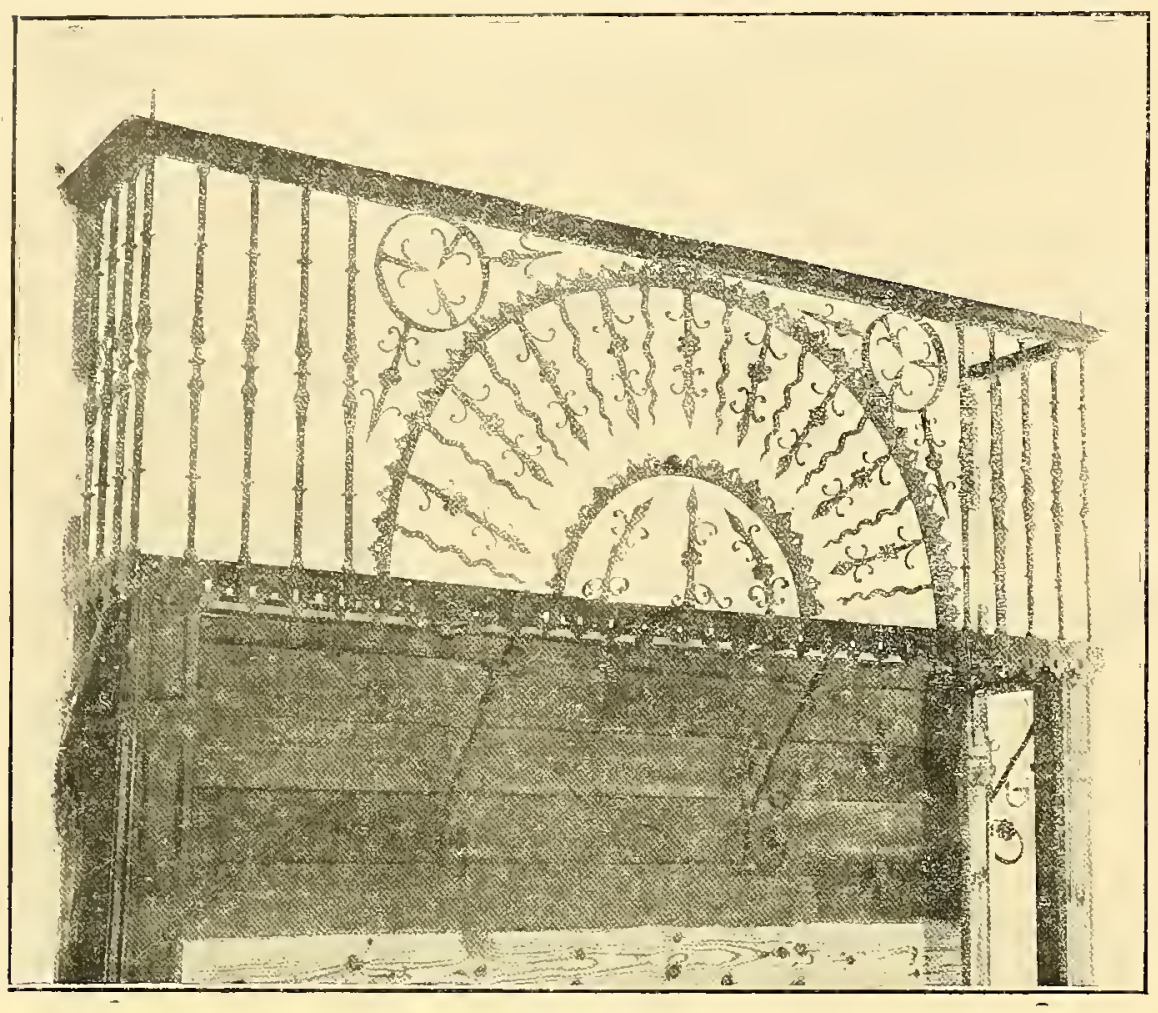

Ndm. 473. eje de madera y coronamiento en plancha dorada recortada.

Trabajo del siglo xvII.

Expositor: D. Juan Lafora.

Núm. 487.-Caja de hierro rectangular con tapa en forma de pirámide truncada y decoraciones en los ángulos y en el centro; es de plancha calada siluetada.

Siglo xvil.

Expositor: D. José Lázaro.

Núm. 488. - Dos morrillos de barra vertical cónica con planchas intermedias soldadas, terminadas en cabezas quiméricas. Ejemplares del arte popular del siglo xvı. Procede del Cau Ferrat. Expositor: D. Santiago Rusiñol.

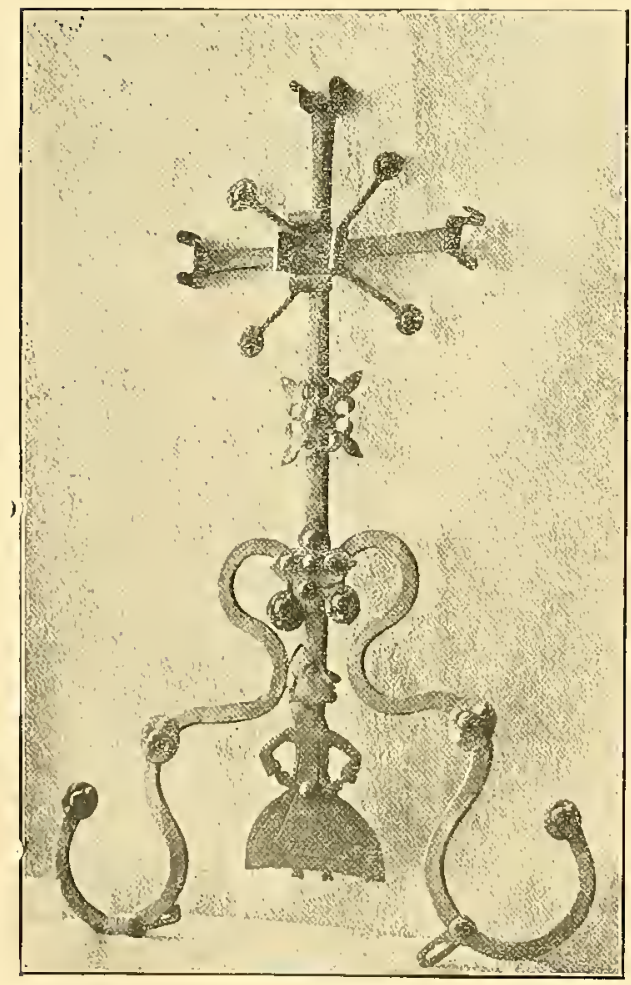

Num. 481.

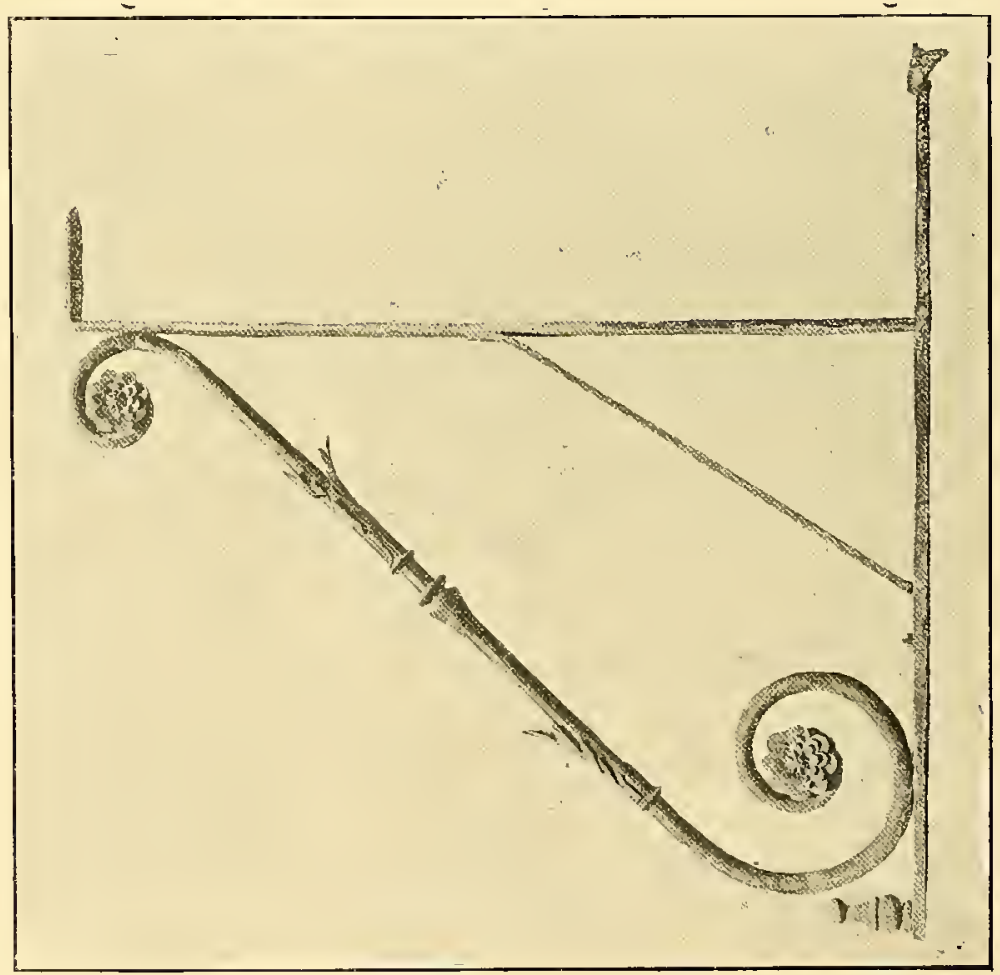

Nủm. 482. 


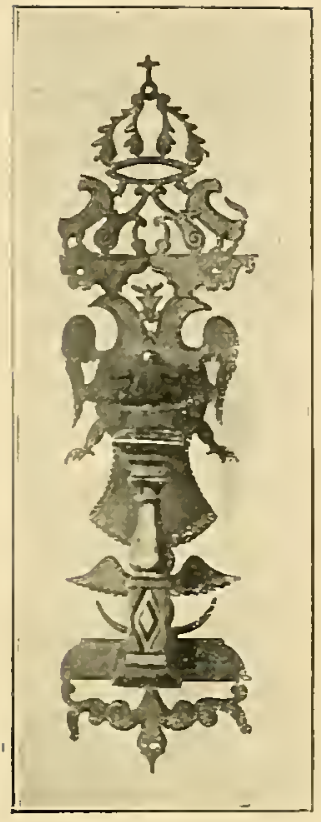

Nủm. 480.

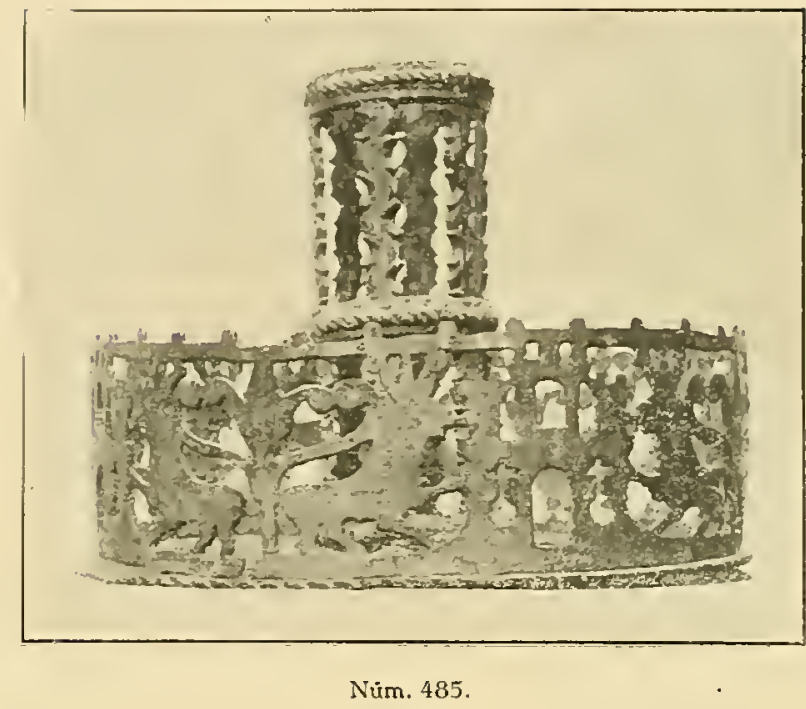

Núm. 489. -Ejemplar del mismo tipo que los anteriores. Siglo xviI. Procede del Cau Ferrat.

Expositor: D. Santiago Rusin̄ol.

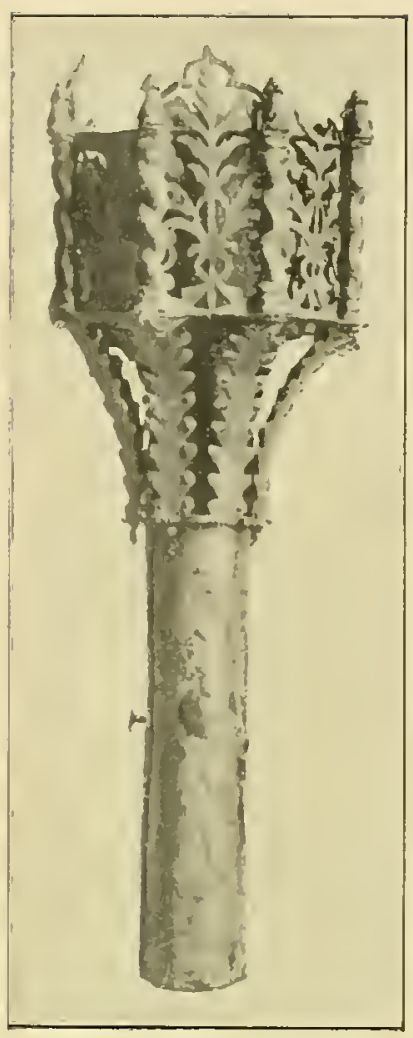

Nưm. 486.

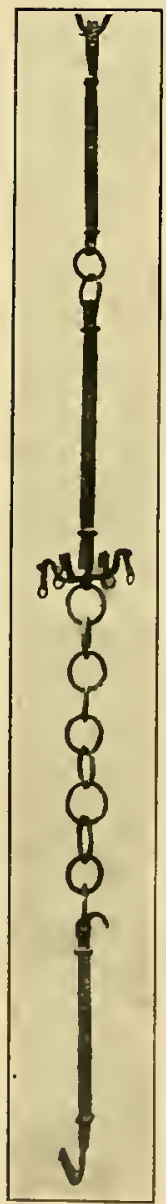

Nür. 484.

Núm. 490. - Morillo en barra de sección cuadrada, festoneada. El eje horizontal, formado por cuatro varillas retorcidas. Estilo del siglo xvir. Procede del Cau Ferrat. Expositor: D. Santiago Rusiñol.

Núm. 491.-Dos arrimadores de olla. Siglo xviı.

Expositor: D. José Albelda, de Huelva.

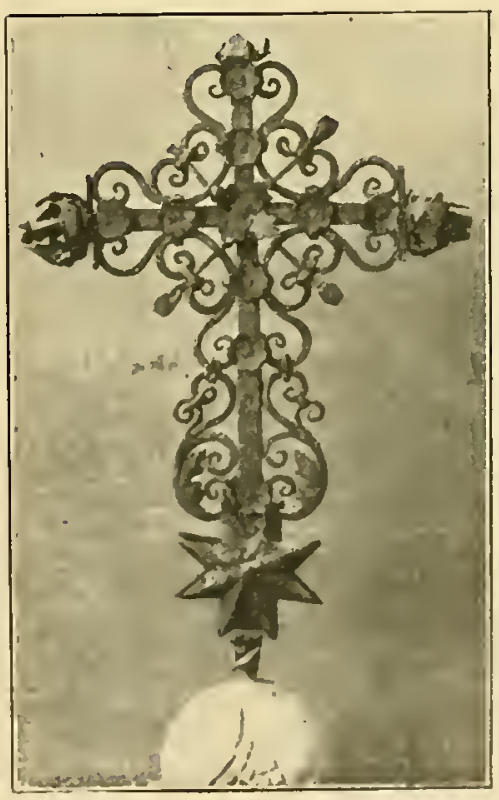

ưm. 483.

Núm. 492.-Dos grandes morillos de chimenea formados por varras verticales torneadas, terminadas en bola, conchas para la colocación de las herramientas. Siglo xvir.

Expositor: Junta de Museos de Barcelona.

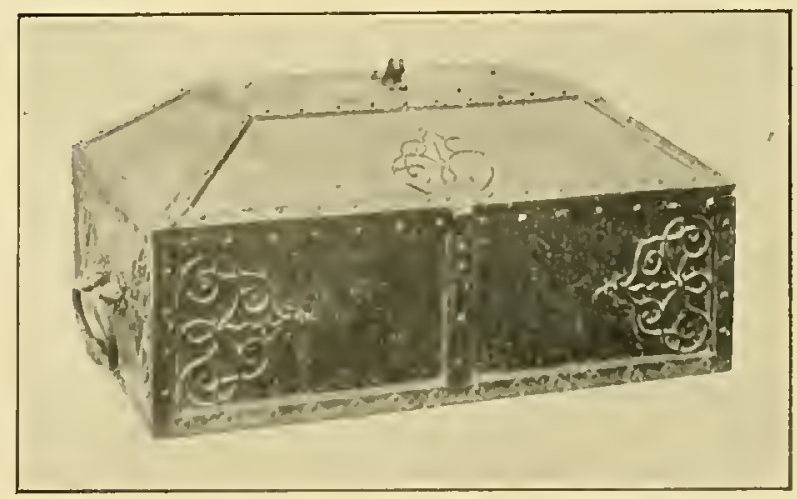

N้งแก. 487. 


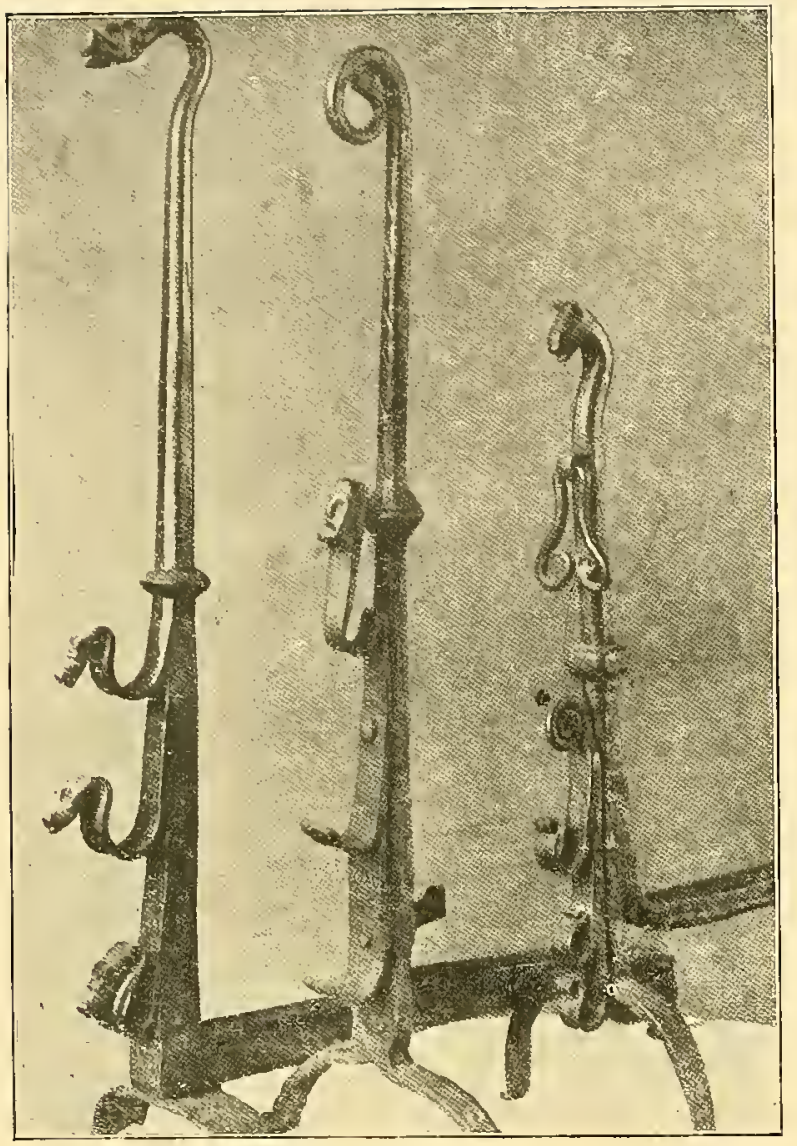

Nüms. 488-489.

Núm. 493.- - Tres caballitos para sostener hierros de cocina, en gruesa plancha recortada con decoración en varilla retorcida. Arte popular del siglo xvil.

Expositor: D. José Aibelda, de Huelva.

Núm. 494.-Morillos formados por barra vertical de sección cuadrada, terminada por un ensanchamiento figurando cabezas, dos planchas soldadas simulando trazos. Arte popular del siglo xviı.

Expositora: Excma. Sra. Marquesa de Bermejillo del Rey.

Núm. 495.-Balanza ricamente decorada con delfines en los extremos de la barra de la cruz y castillete sobre el punto del fiel. Trabajo muy interesante del siglo xvıl.

\section{Expositor: D. José Lázaro.}

Núm. 496.--Gran balanza de hierro forjado y doble piel, colgada sobre ejes que giran perpendicularmente, permitiéndoles todo género de movimientos, ornamentación de figuras, dragones y volutas. Se supone fué construída por el autor de la cruz llamada de la Cerrajería en Sevilla. Finales del siglo xvı o principios del xvilı. Pertenece a la Maestranza de Artillería de Sevilla.

Expositor: Maestranza de Artillería de Sevilla.

Núm. 497.--Romana. Trabajo en hierro y bronce, forjada y cincelada por el Maestro Salinas, de Madrid. Segundo tercio del siglo xvir.

Expositor: Museo $\mathrm{Ar}$ queológico Nacional.

Núm. 498. - Balanza de

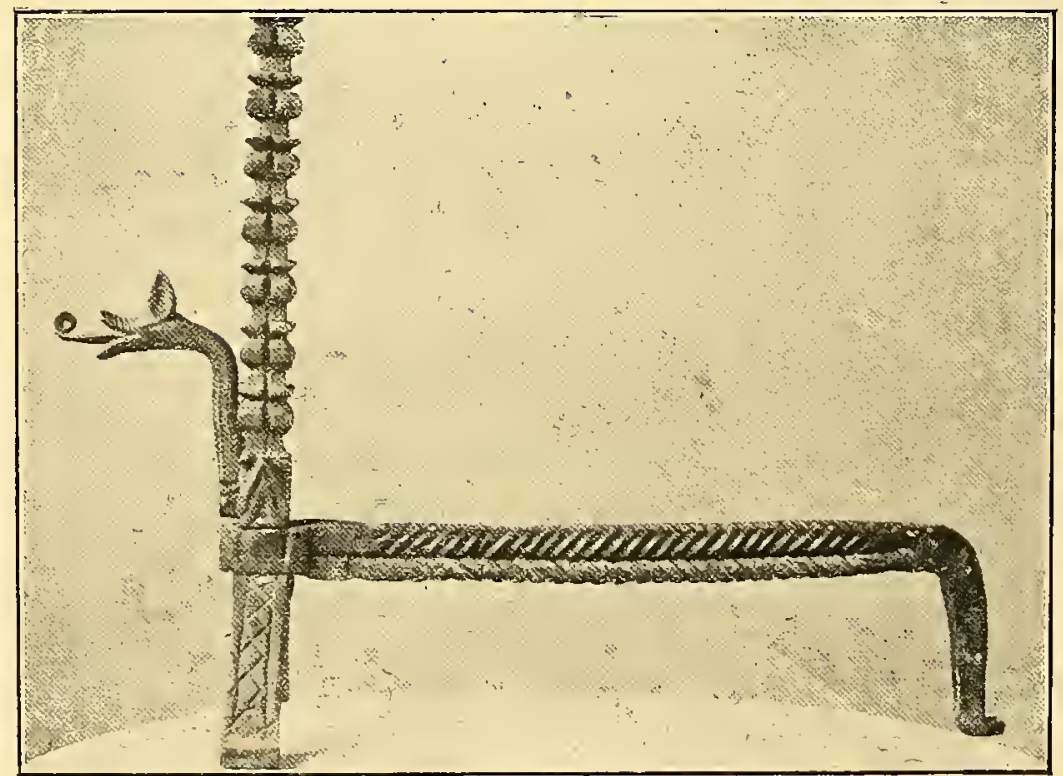

Nưm. 490 , 


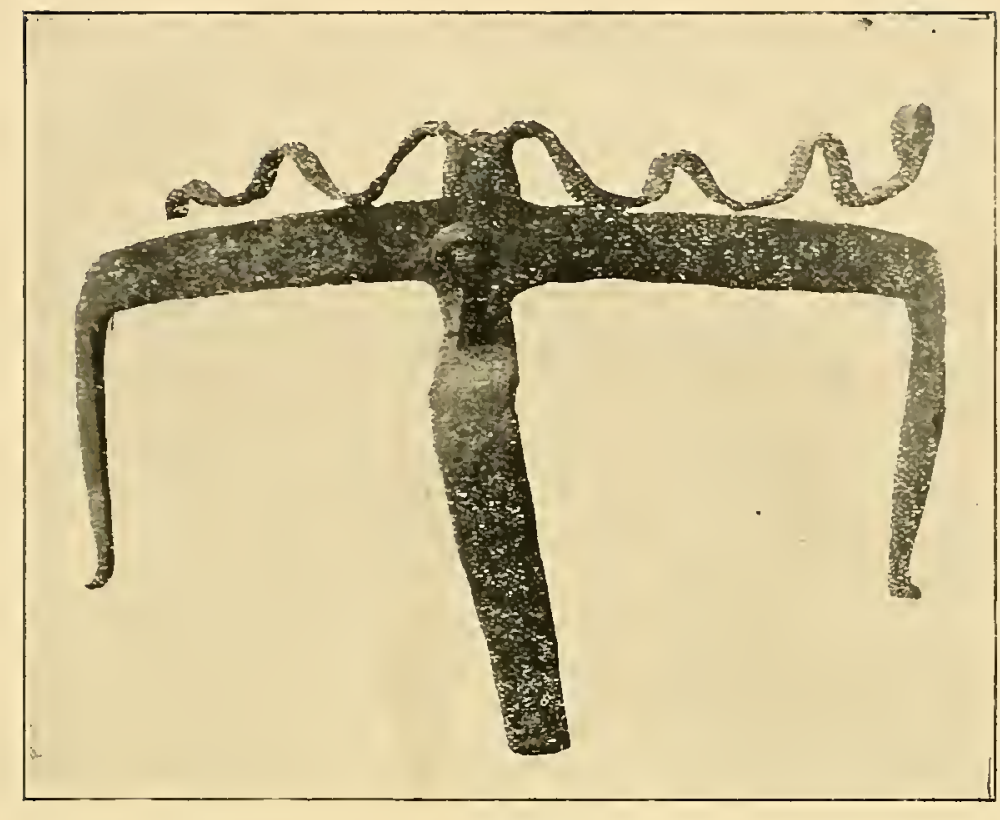

Núm. 491.

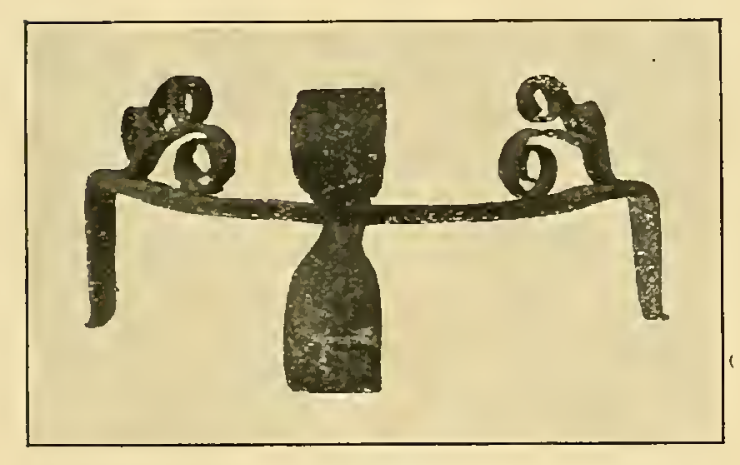

Nủm. 491.

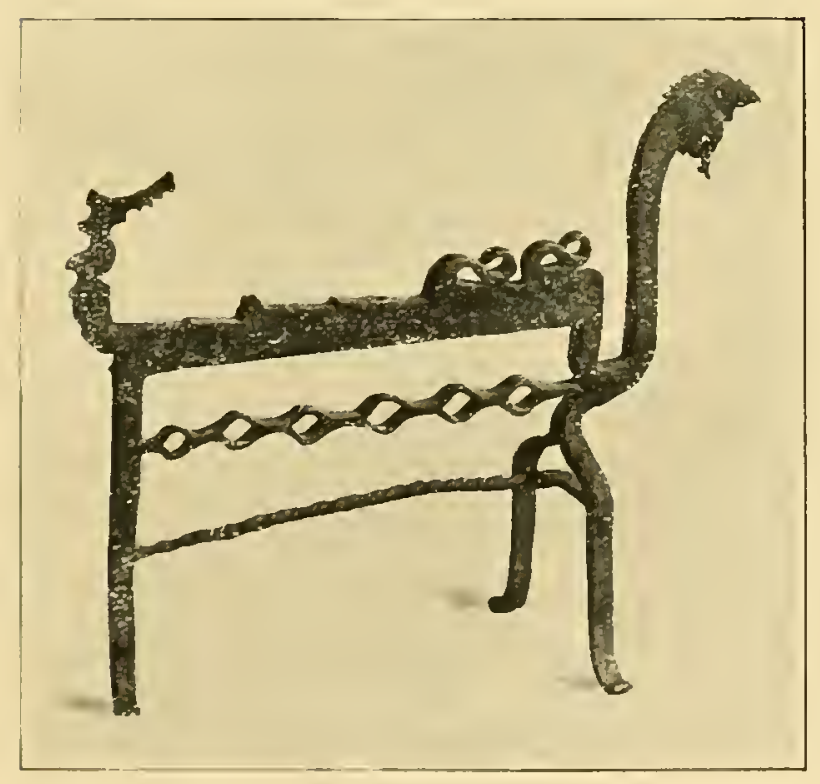

Nủm. 493.

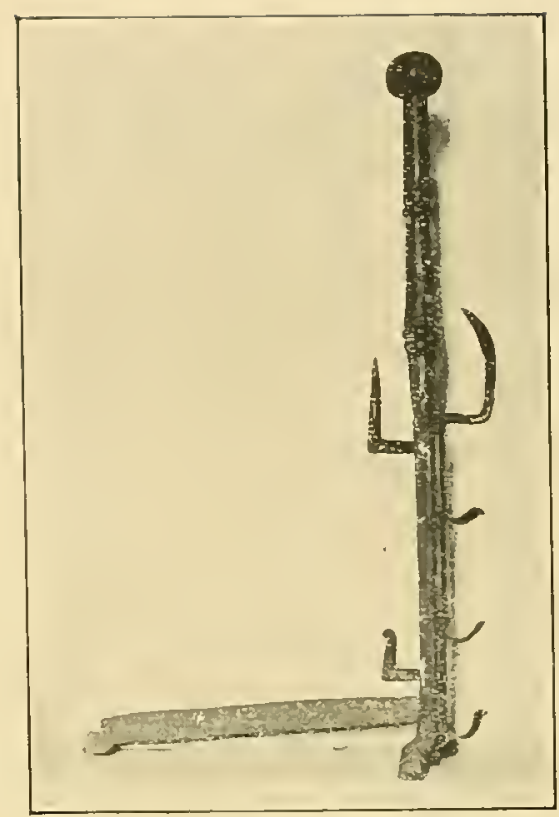

Nủm, 492.

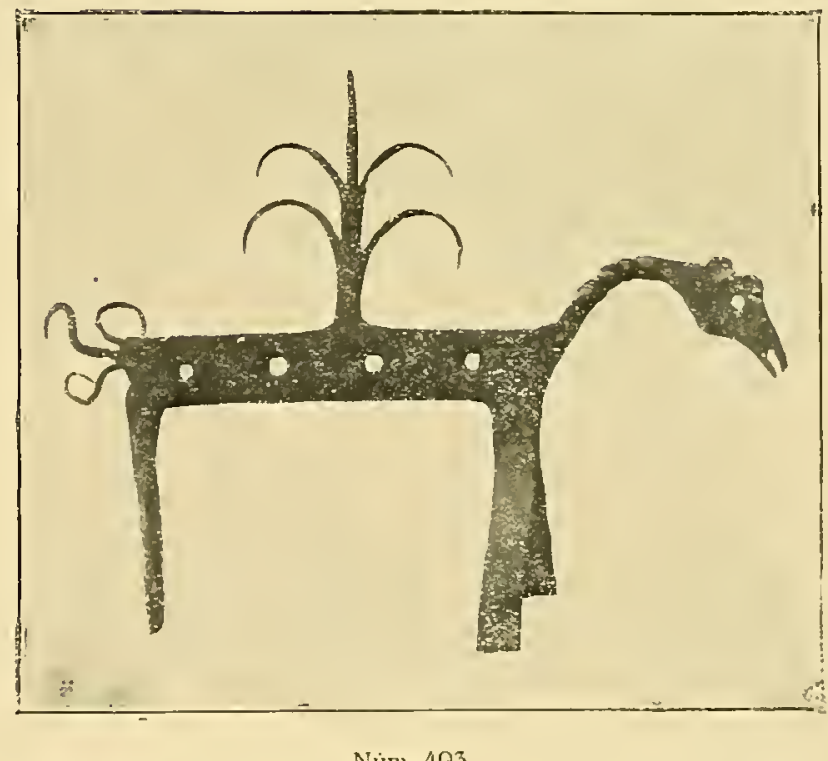

Nüm. 493.

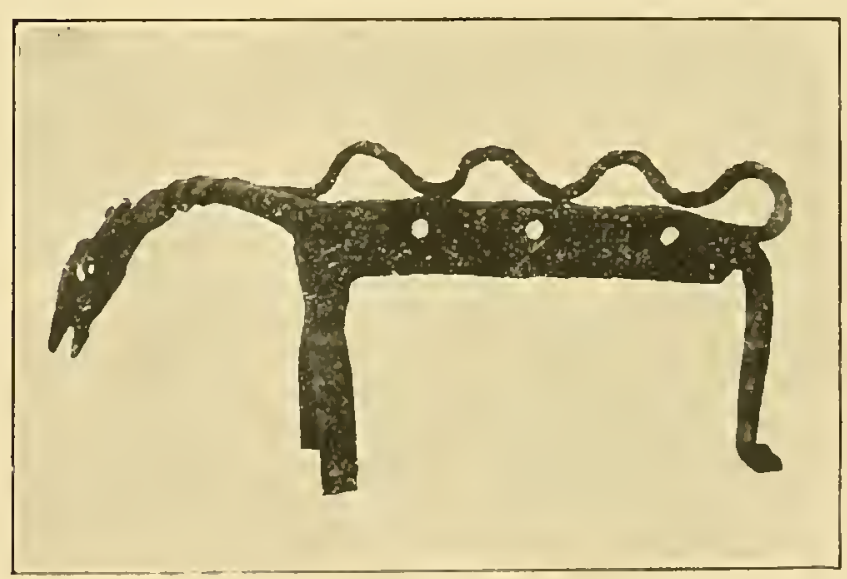

Nun. 493. 


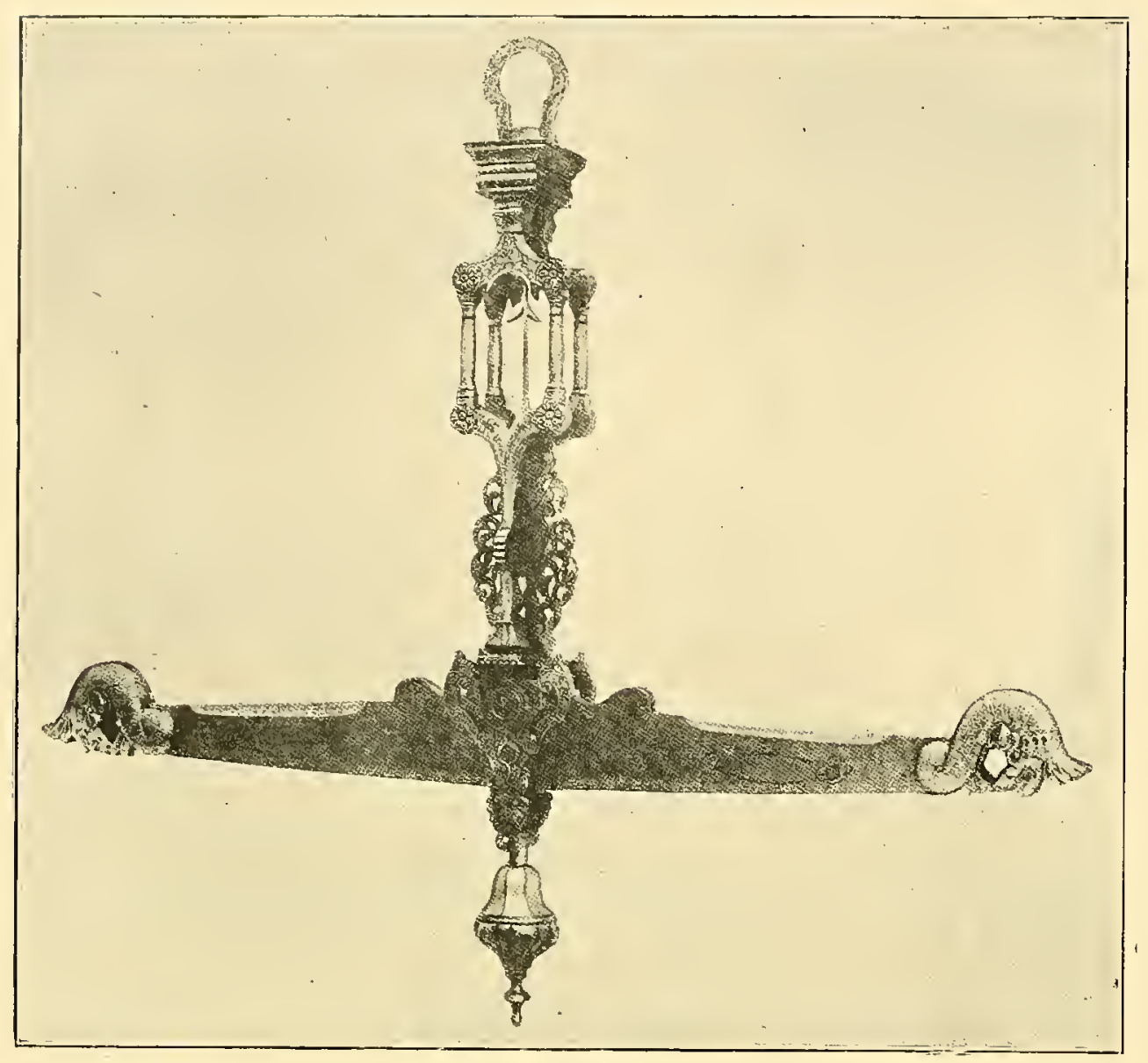

Núm. 495. hierro con decoraciones doradas. Trabajo del siglo xvil.

Expositor: Junta de Museos de Barcelona.

Núm. 499.- Un relicario en forma poligonal alargada, formando una doble caja con cinco cristales biselados. Finales del siglo xvıl.

Expositor : Don Rafael García Palencia.

Núm. 500.-Un relicario doble, de sección anular elíptica. Siglo xvir.

Expositor: Excelentísimo Señor Marqués de la Torrecilla.

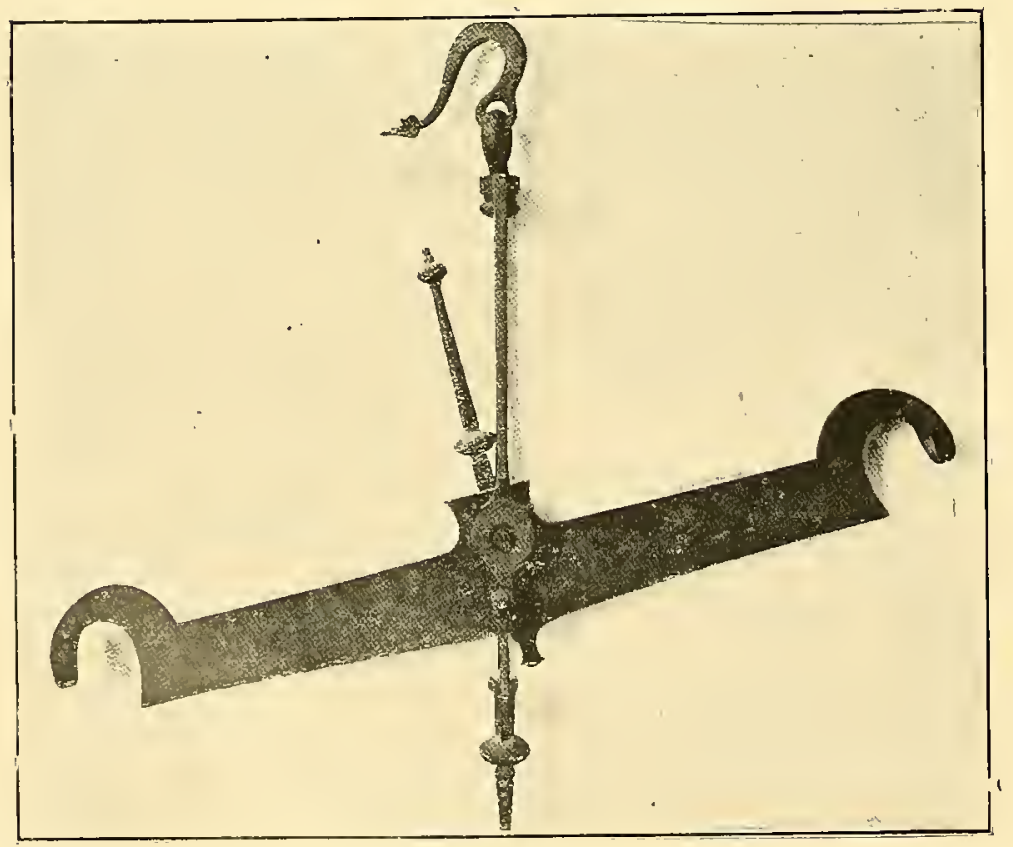

Núm. 498

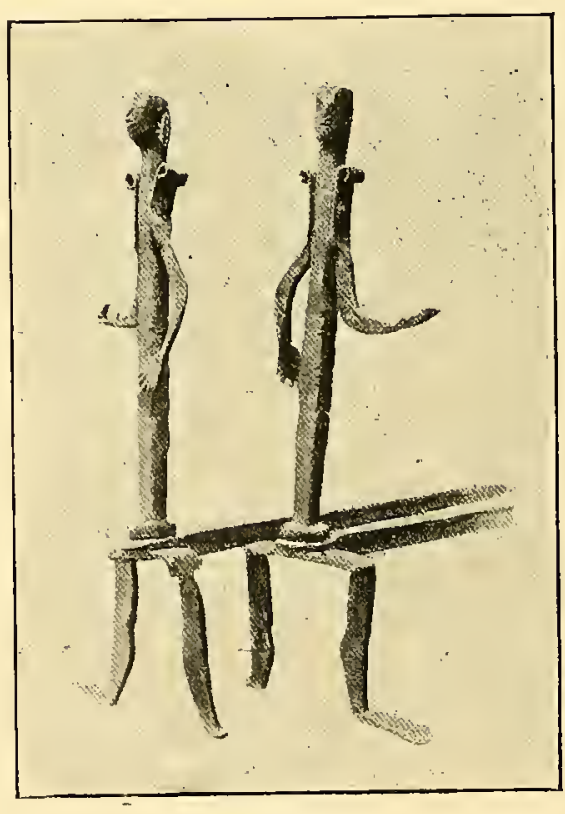

Núm. 494. 


$$
\Delta
$$




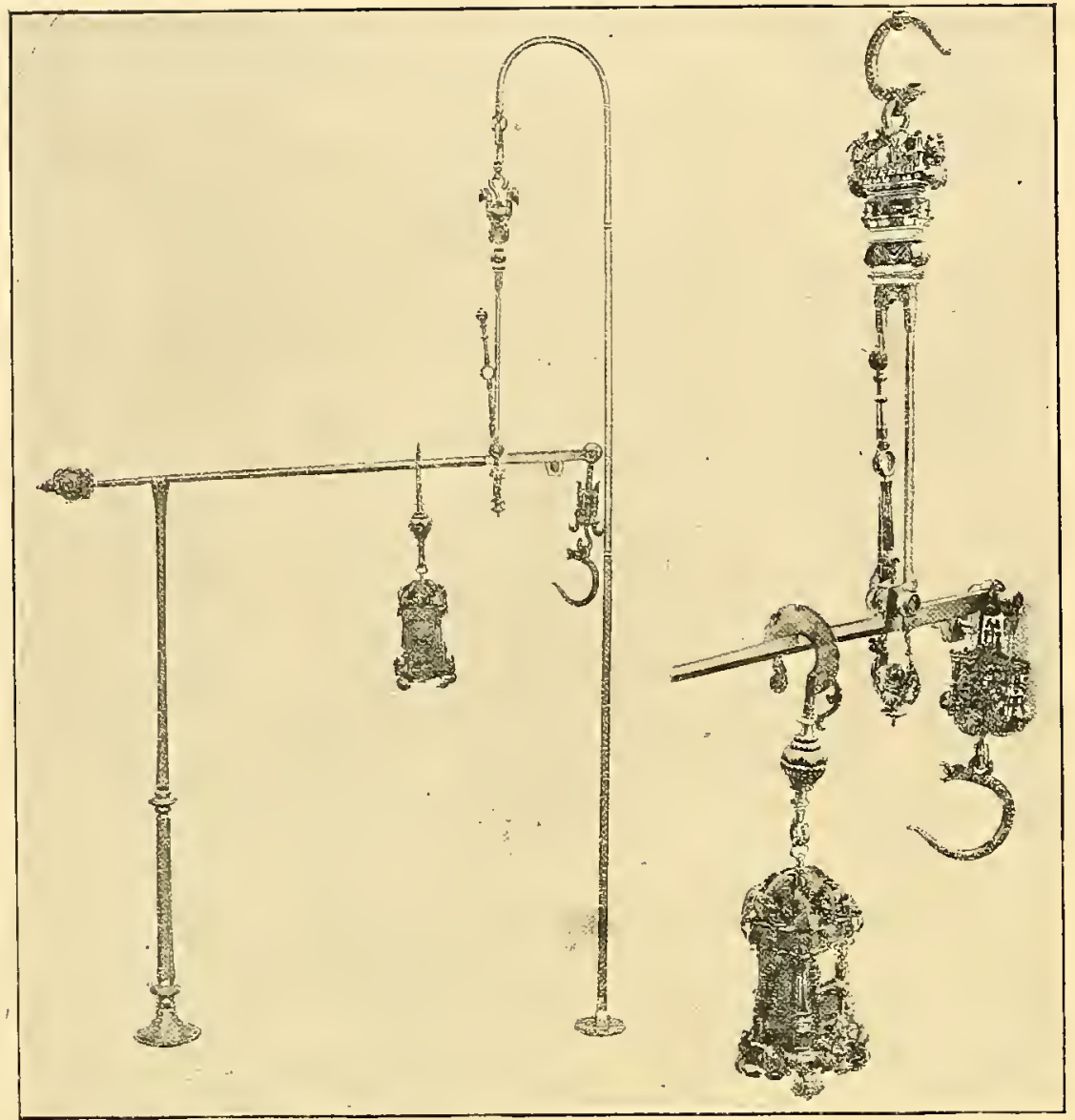

Núm. 497.

Núm. 504.-Estuche de hierro para tijera de bordar. Trabajo característico del siglo xvir.

Expositor: Junta de Mulseos de Barcelona.

Núm. 505. - Peineta de plancha de hierro recortada con incrustaciones de azófar y un letrero que dice: «Solo soy».

Siglo xvII.

Expositor: Excmo. Señor Marqués del Rey.

Núm. 506.--Un llavero con decoración incisa lineal.

Siglo xvII.

Expositor: Excmo. Señor Marqués de la Torrecilla.

Núm. 507. - Cruz de penitencia con los brazos articulados; gruesas puntas que rellenan la superficie. Siglo xviI.

Expositor: D. José Lázaro.

Núm. 508.-Candil colocado sobre un escudete de platillo petitorio. Siglo xvir. Expositor: Excmo. Sr. Marqués de Bay.

Núm. 509. - Terminación de coronamiento de reja; trabajo decadente representando el Santísimo Sacramento sostenido por dos ángeles; ejecutado en plancha recortada poligonal en el siglo xvil.

Expositor: Sr. Rodríguez Rojas.

Núm. 510.-Tornapuntas en barrilla de hierro, decorada con plancha recortada.

Finales del siglo xviI.

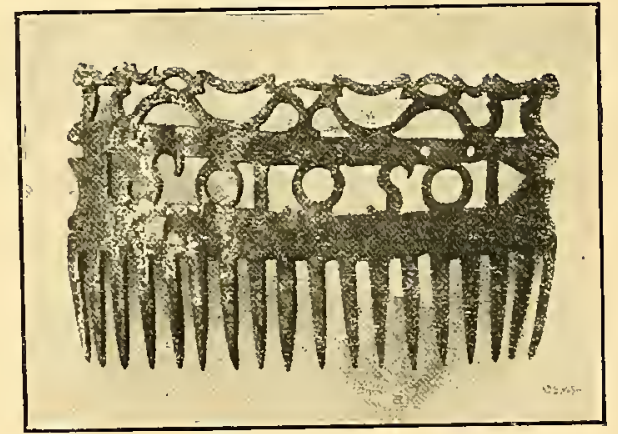

Núm. 504.

Expositor: D. Juan Lafora.

Núm. 505. 
Núm. 511.-Soporte de lámpara de varilla circular con decoración floral de plancha recortada.

Siglo xvir.

Expositor: $\mathrm{Ig} / \mathrm{le}-$ sia Magistral de Alcalá.

Núm. 512. - Palomilla de hierro, decorada con plancha recortada. Finales del siglo xvir.

Expositor: Don Rafael García Palencia.

Núm. 513. - Dos aparatos de hierro forjado para instalar utensilios de cocina, con tres piezas auxiliares y tres utensilios. Corresponden a la

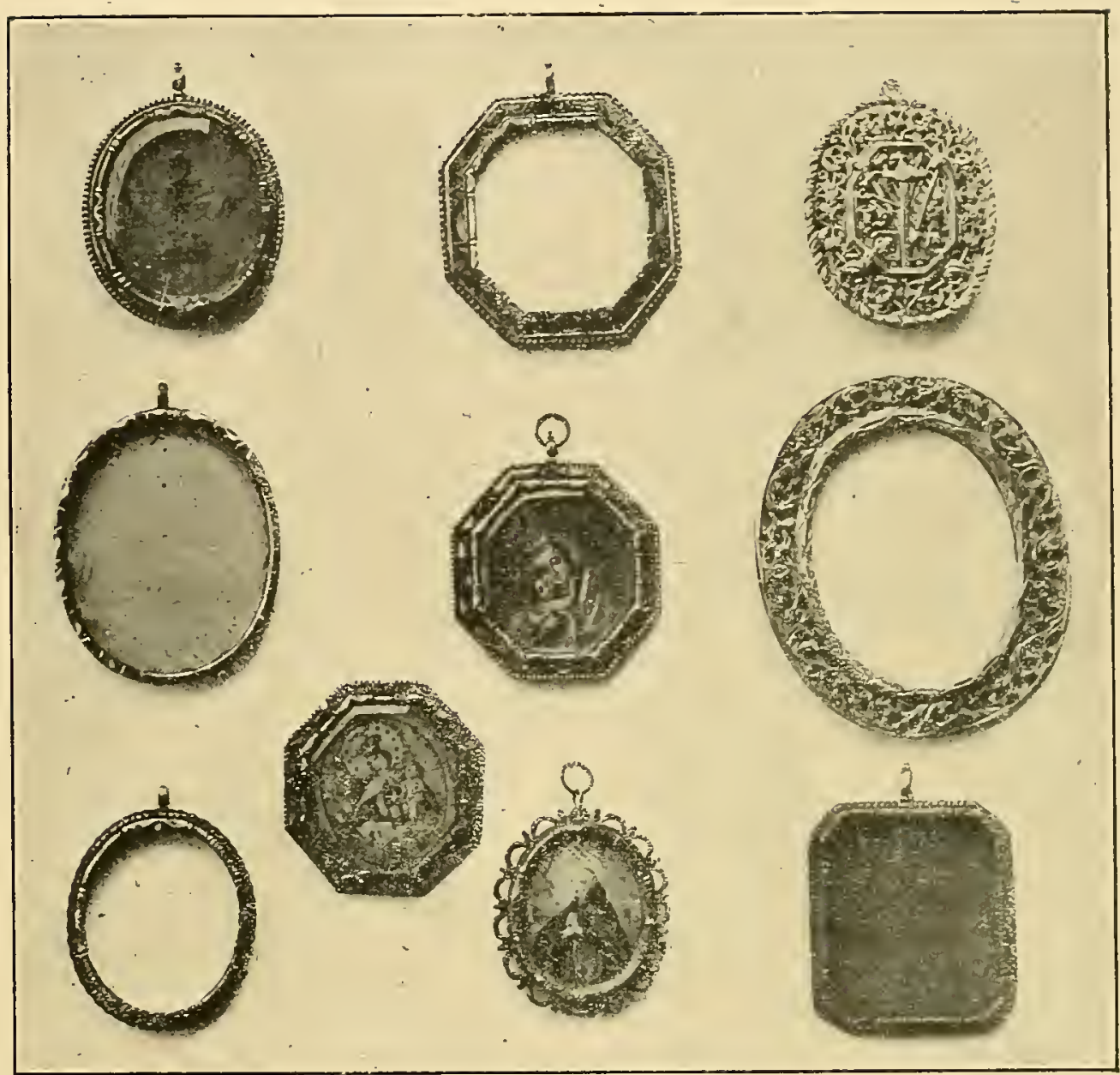

Nims. 500.501-502

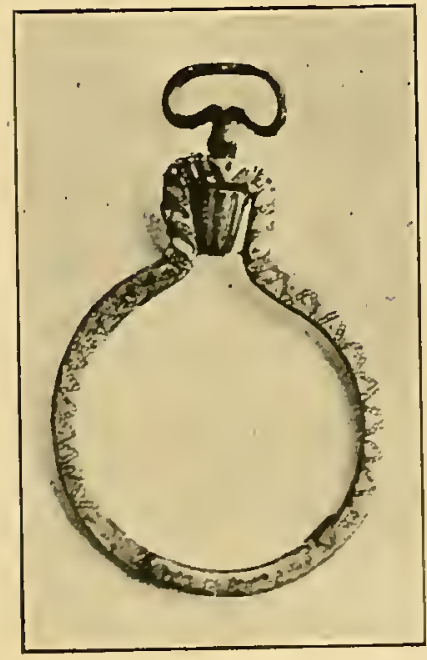

Nim. 506

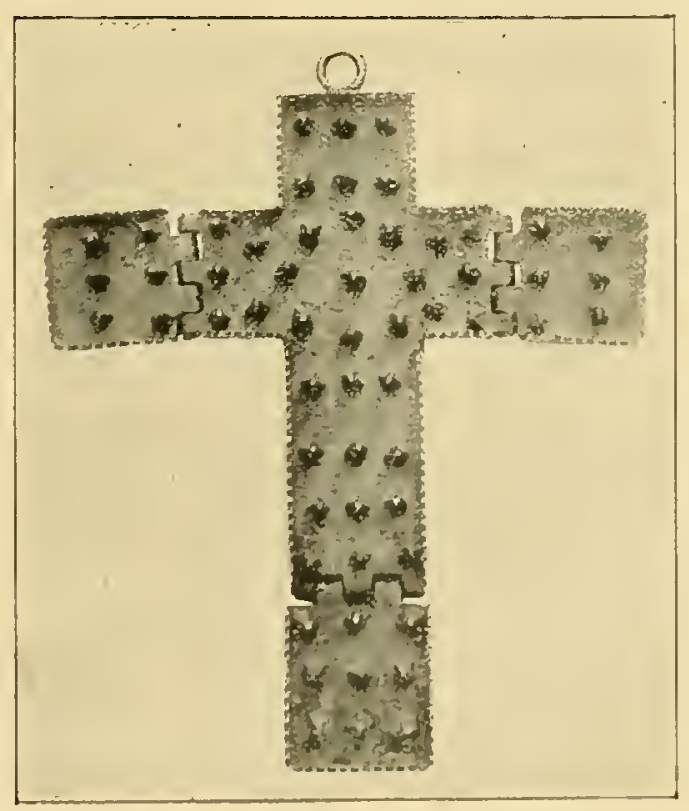

Nủm. 507.

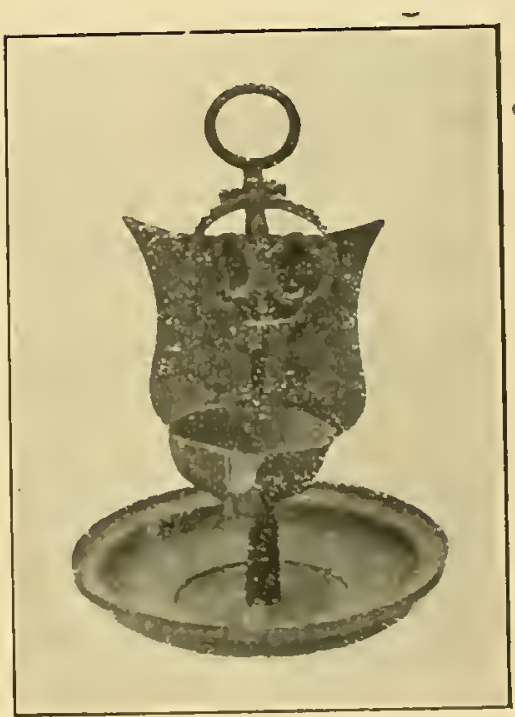

Nim. 508. 
escuela extremeña iniciada en los finales del siglo xviI, que se extiende más tarde por todo el oeste de Castilla y Andalucía. Finales del siglo xvı o principios del xviı.

Proceden de una cocina de Salamanca.

\section{Expositor: Junta de Museos de Barcelona.}

Núm. 514.-Aparato de hierro forjado para instalar utensilios de cocina, del que prenden nueve piezas de aplicación varia. Igual escuela que el precedente. Finales del siglo xvir o principios del xvill.

Procede de una cocina de Salamanca.

Expositor: Junta de Museos de Barcelona.

Núm. 515. - Llaveros de chimenea,

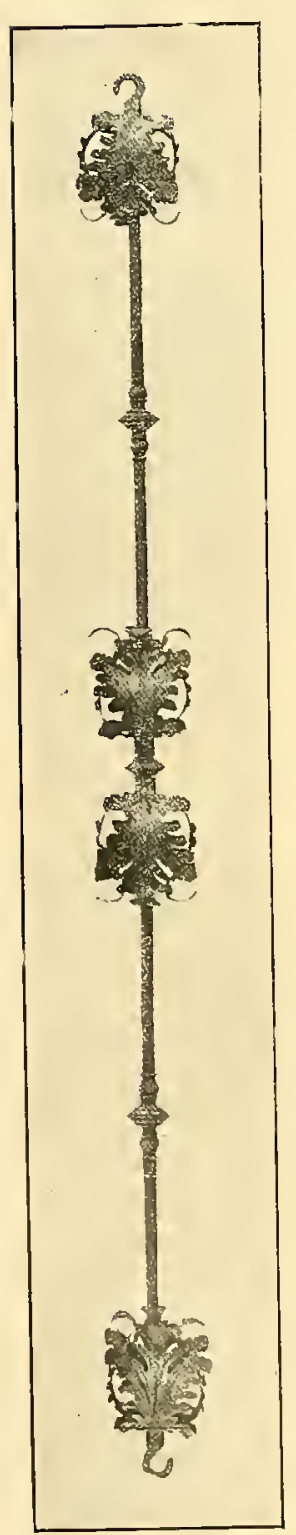

Núm. 517. de forma rectangular, terminadas en arco, de cuya parte inferior penden tres cadenas, rellenando la superficie hierros en forma de voluta y discos festoneados representando flores. Las líneas generales se adornan con plancha ondulada. Escuela extremeña de finales del siglo xvil.

Expositor: Junta de Museos de Barcelona.

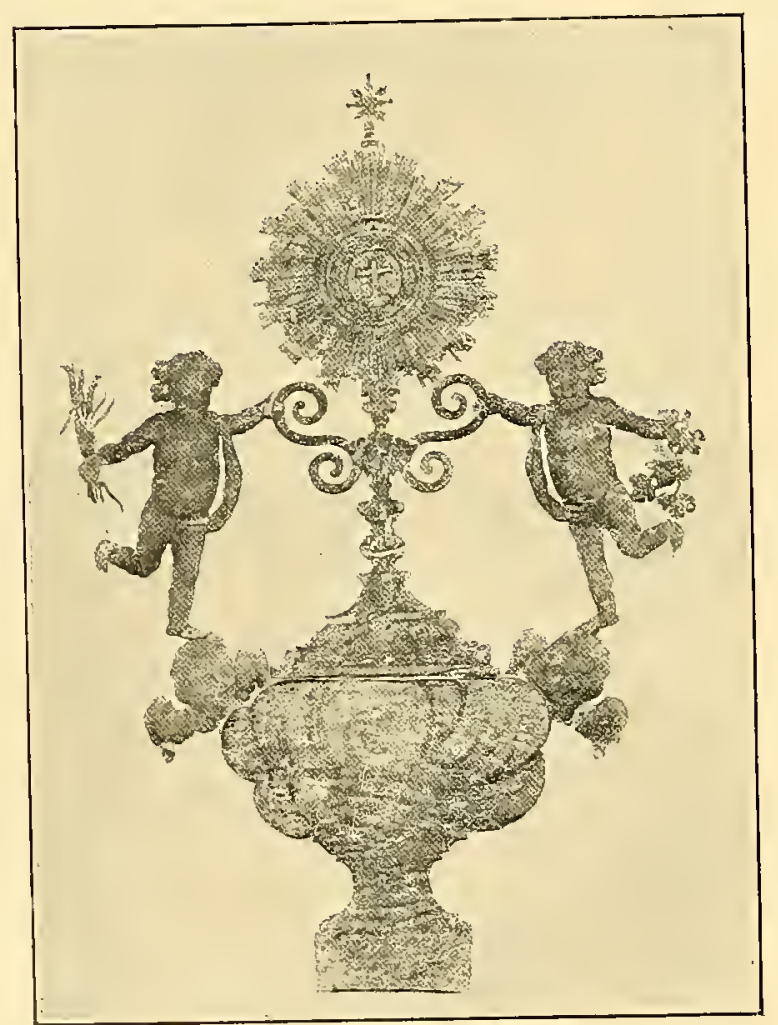

Ќ̛m. 509.

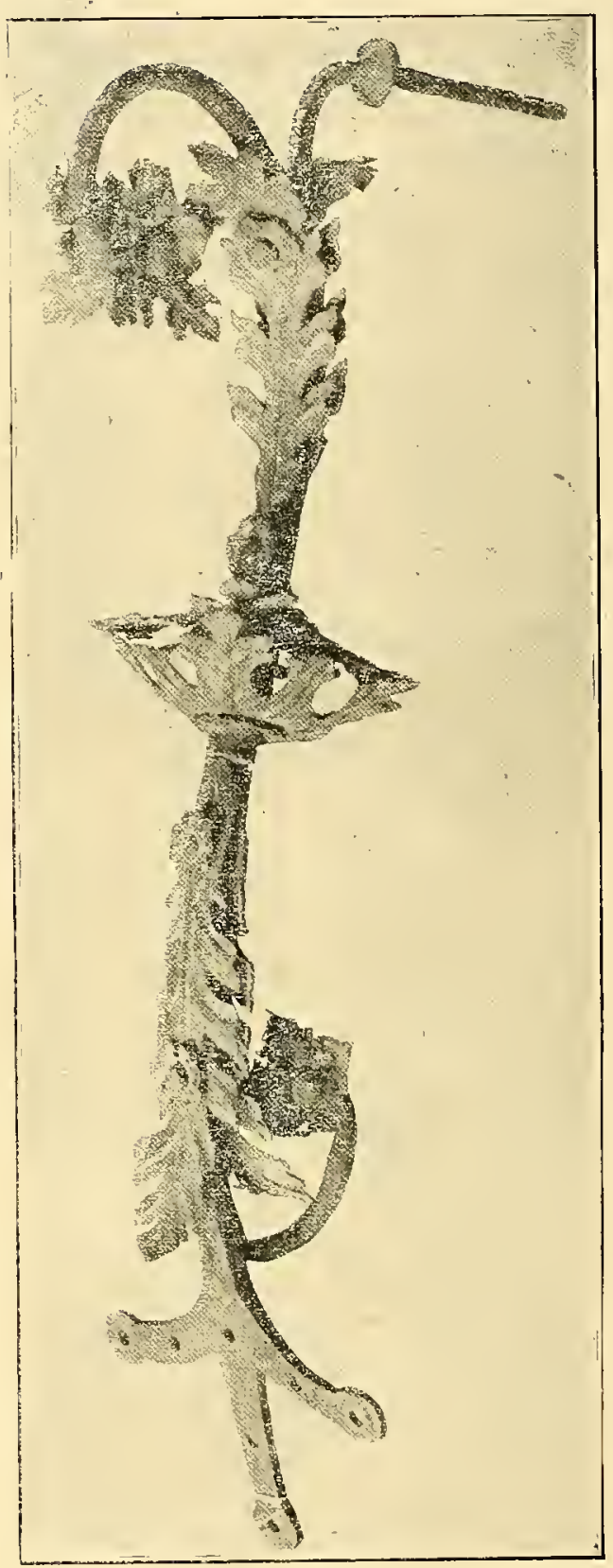

Nưm. 510. 


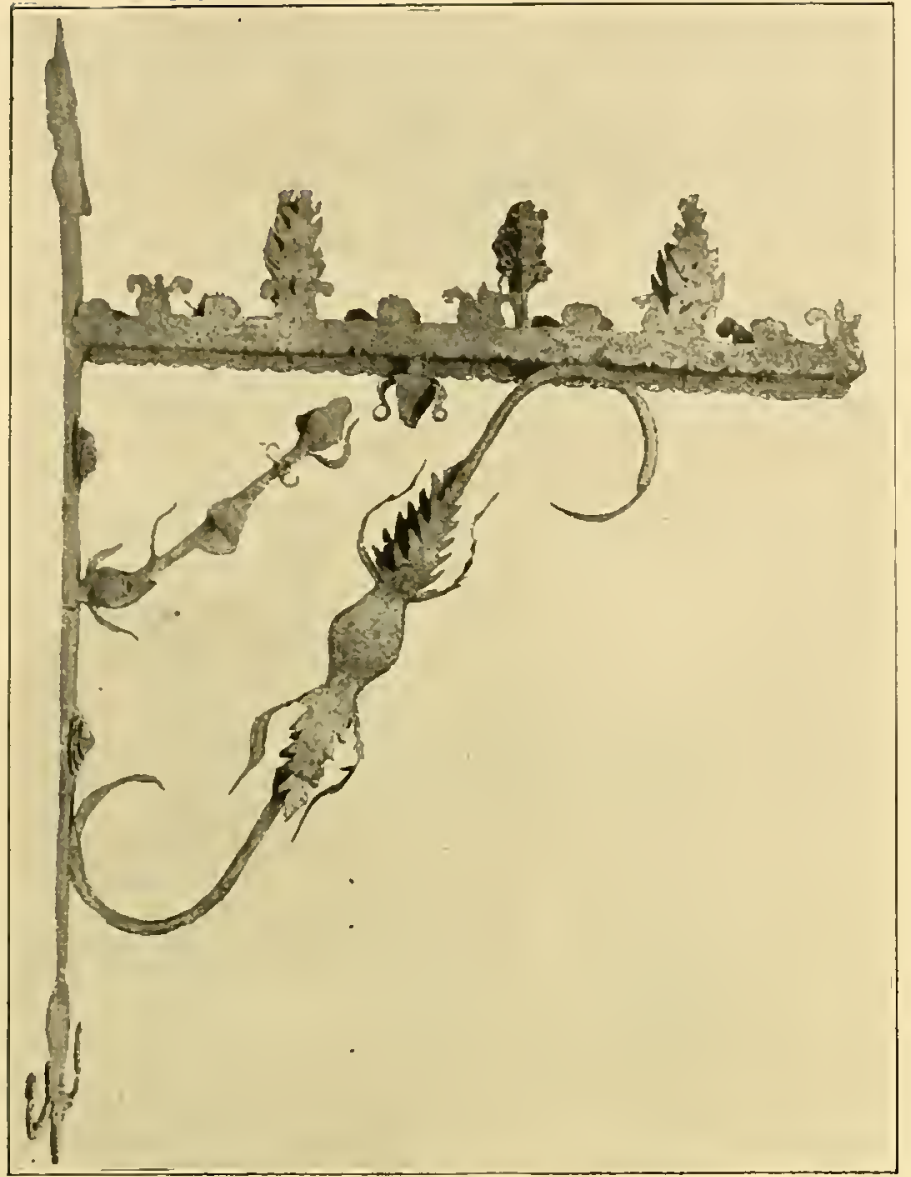

Núm. 512.

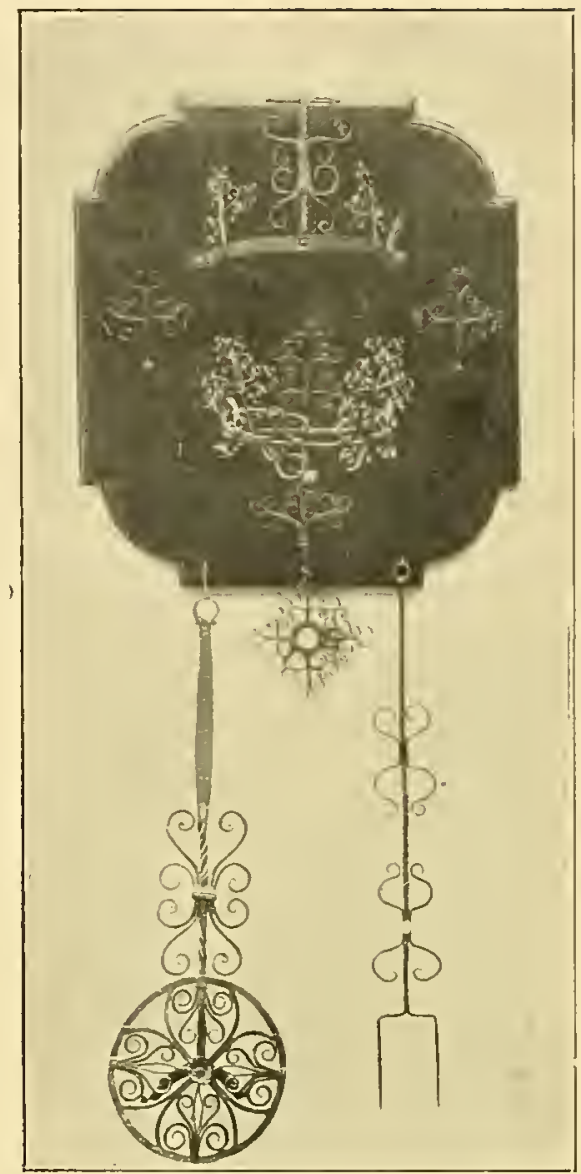

Nứm. 513.

Núm. 516. - Soporte giratorio para cocina, decorado en flores de lis, de plancha recortada. Finales del siglo xvilı.

\section{Expositor: D. Félix Rodríguez Rojas.}

Núm. 517.-Aparato de cocina giratorio, decorado con volutas y plancha recortada, de $29 \mathrm{~cm}$. de diámetro. Decoración, asimismo, de planchas recortadas y volutas.

Finales del siglo xvı.

Expositor: D. Juan Lafora.

Núm. 518.-Dos asadores de parrilla con mango de varilla retorcida. Siglos xvil a xvill.

Expositor: D. Fernando Márquez de la Plata y Echenique.

Núm. 519.-Ejemplar análogo al precedente, de $19 \mathrm{~cm}$. de diámetro, mango de varilla retorcida. Arte popular extremeño de principios del siglo xviII.

Expositor: D. Félix Rodriguez Rojas.

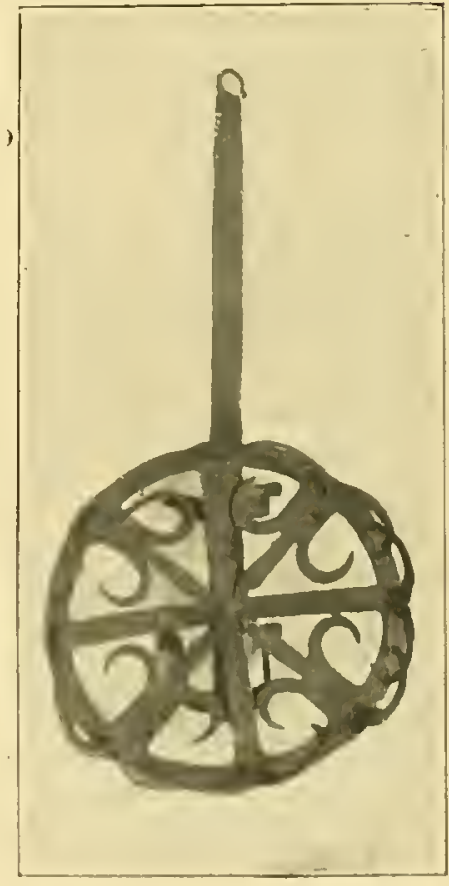

Nitu. $5 ! 3$. 


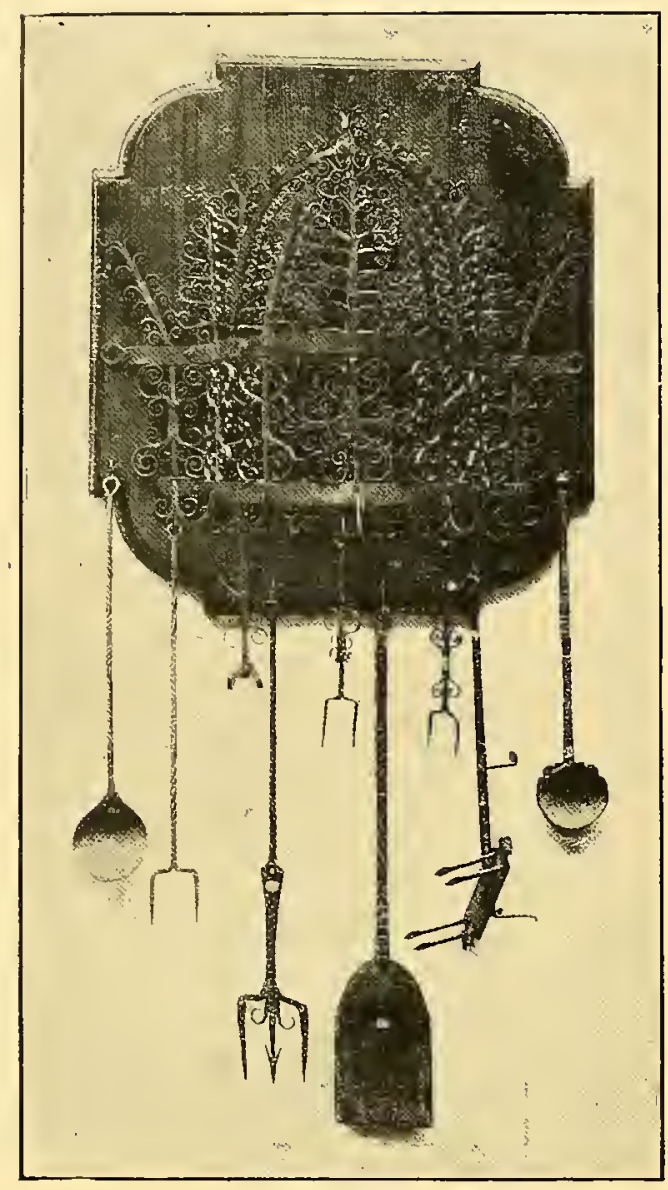

Núm. 514.

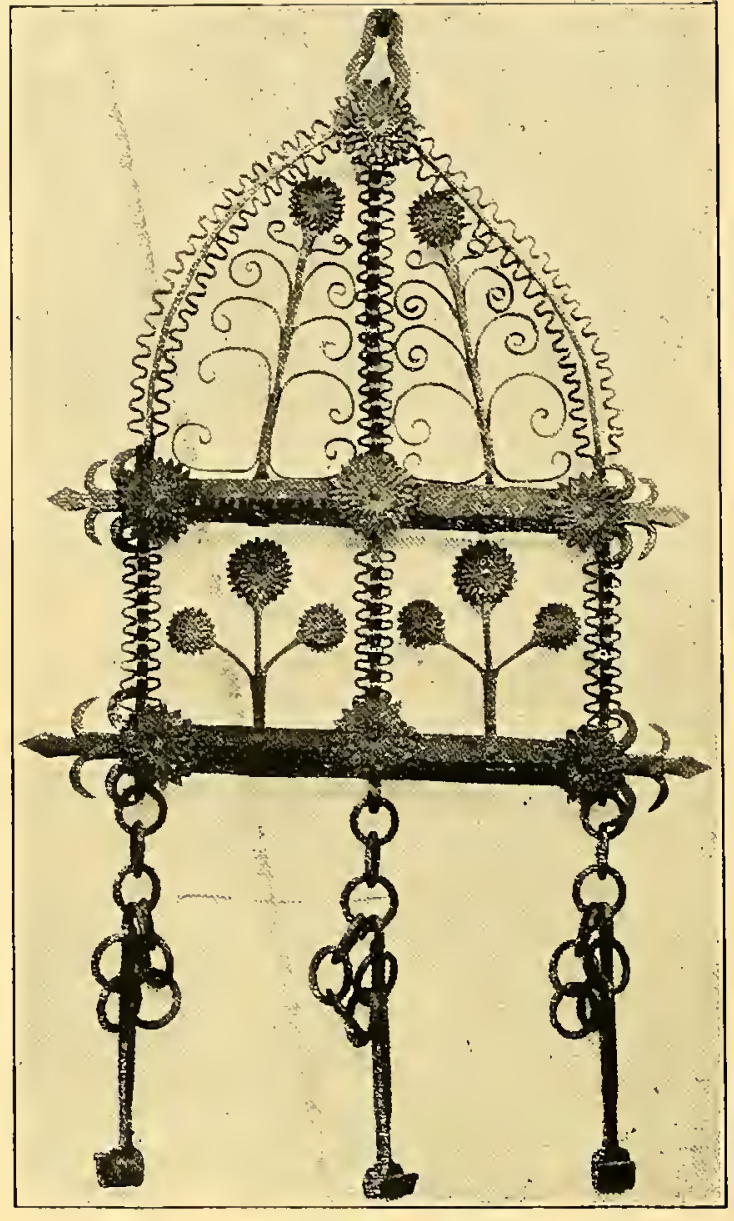

Nüm. 515.

Núm. 520. - Aparato de cocina decorado en el gusto popular de la escuela extremeña de su tiempo, ejemplar fijo de $40 \mathrm{~cm}$. de diámetro. Principios del siglo xviı.

Expositor: Cabildo de la Catedral de Burgo de Osma.

Núm. 521.-Aparato giratorio para cocina. Decoración en láminas de plancha recortada y arrolladas en volutas. Ejemplar popular del tipo anterior. Principios del iglo xvil.

Expositor: Excmo. Sr. D. José Moreno Carbonero.

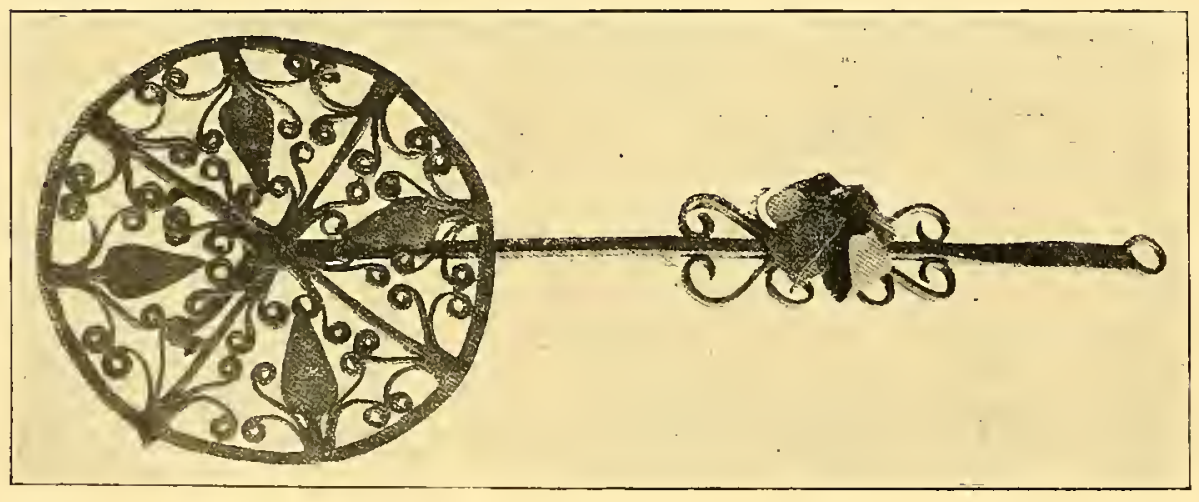

Nūm. 517.
Núm. 522. - Candil doble, cuyo eje prolongado se decora en varilla recortada en voluta. Escuela extremeña de principios del siglo xviII.

Expositor: Excelentísimo Señor Marqués de Bay. 


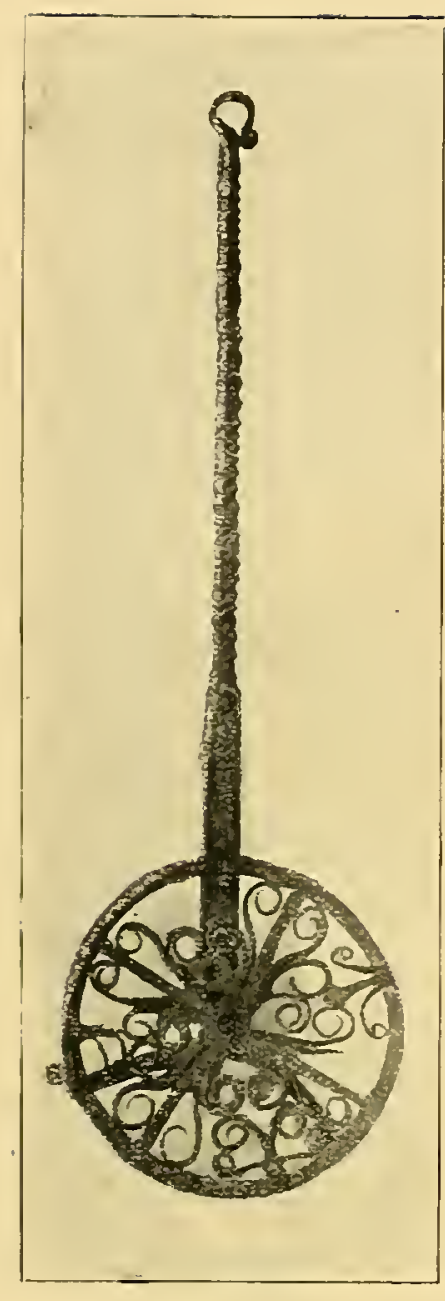

Núm. 518.

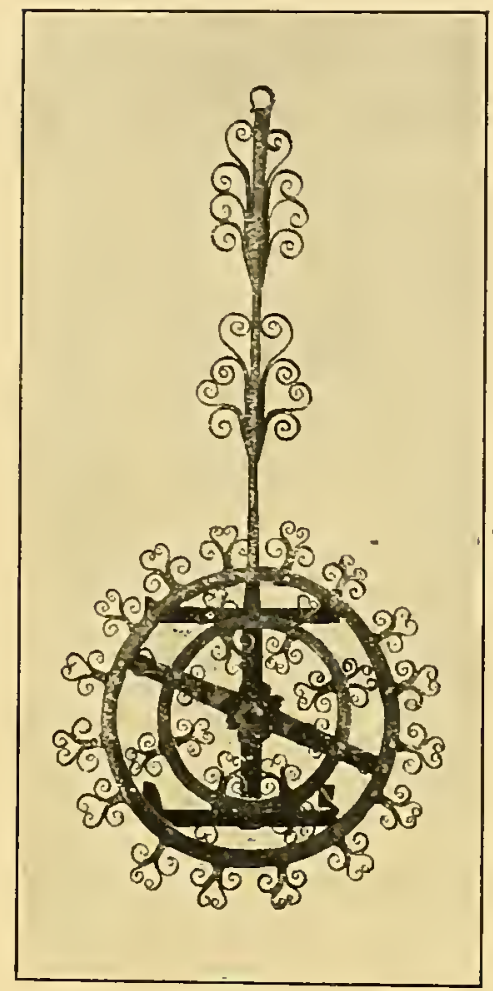

Nüm. 52I.

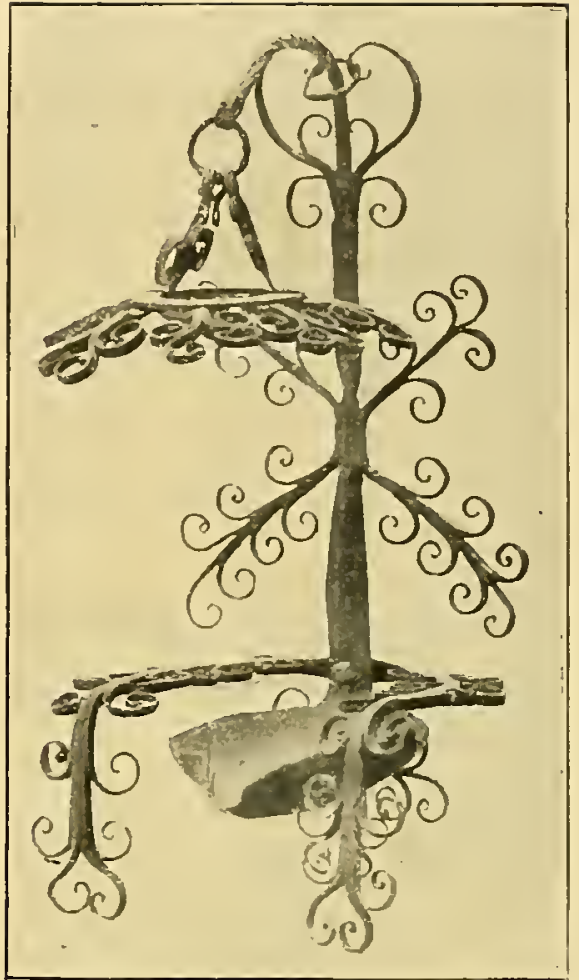

Nưm. 523.

Núm. 523. - Reloj de hierro con crestería de plancha recortada, obra del siglo xvil policromada en el xvill. Expositor: D. Anastasio Páramo.

Núm. 524.-Aparato rectangular para colgar utensilios de cocina, coronado por toros y pájaros, decorado en volutas. Ejemplar del siglo xvill. Expositor: D. Rafael García Palencia.

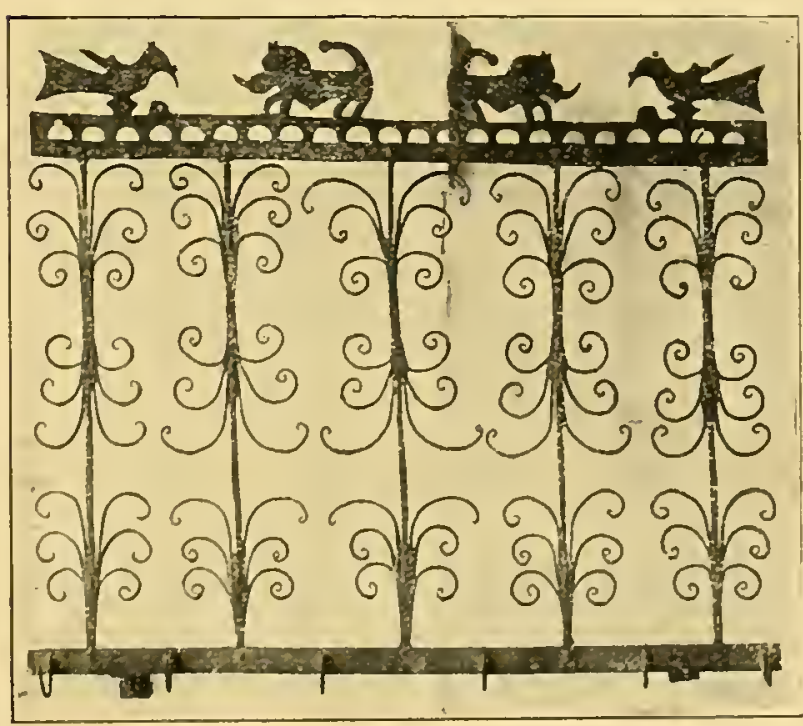

Nim. 524.

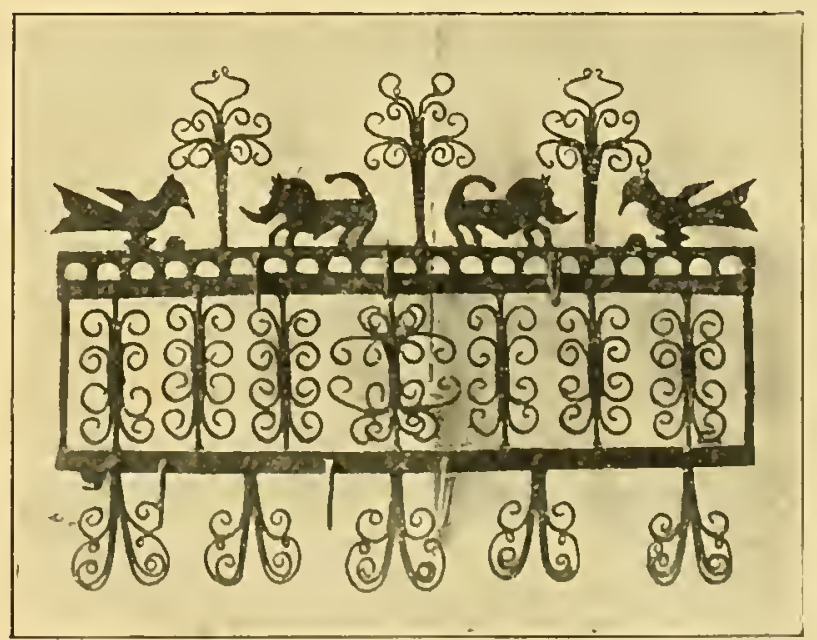

Nimi. 525. 


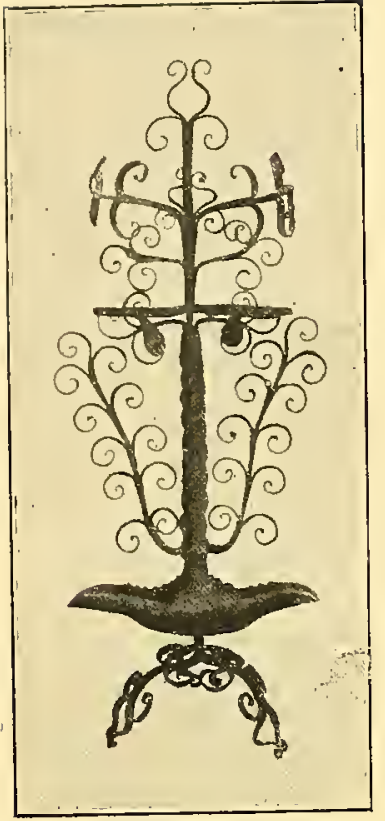

Núm. 522.

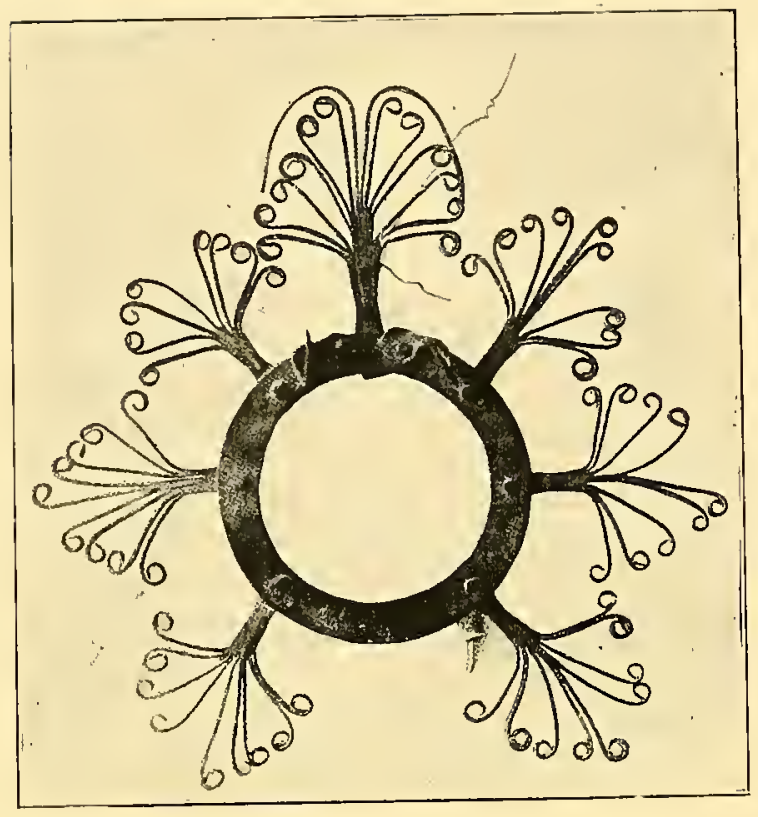

Núm. 526.

Núm. 525. - Soporte de utensilios de cocina, en plancha rectangular recortada, con figuras de toros y pájaros, decorado todo él, con tiras de varillas soliadas, terminadas en volutas. Ejemplar popular de la escuela antes mencionada. Principios del siglo xvilı.

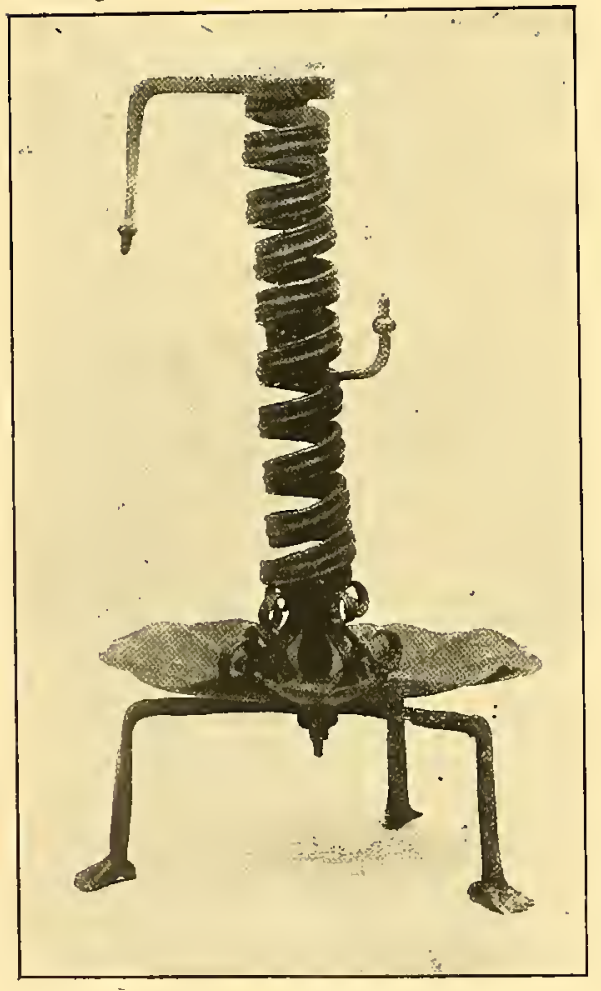

Núm. 532.
Expositor: D. Rafael García Palencia.

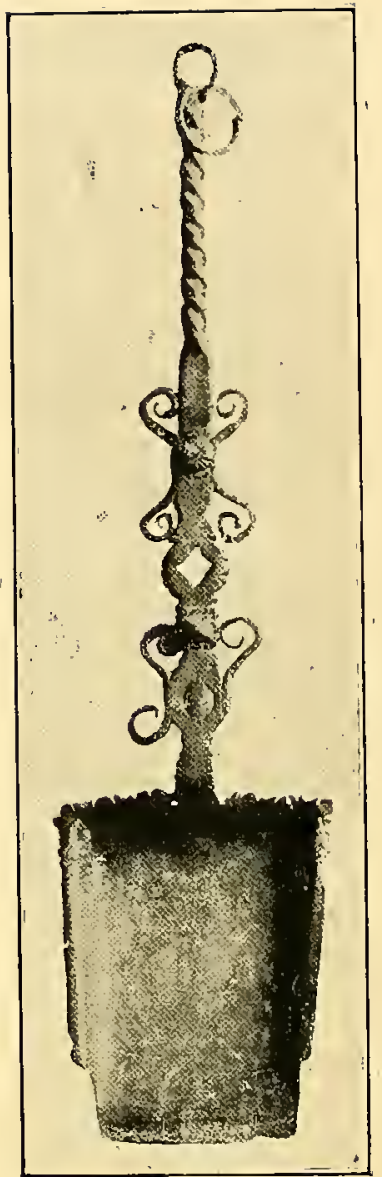

Núm. 527.

Núm. 526:- Un soporte para ollas, decorado con láminas de planchas onduladas, terminadas en voluta, dando la impresión de flores. Arte popular de la escuela extremeña. Principios del siglo xvill.

\section{Expositor: D. Rafael García Palencia.}

Núm. 527.-Pala de chimenea con vástago de varilla retorcida y volutas. Siglo xviII.

\section{Expositor: D. Juan Lafora.}

Núm. 528. - Aparato para colgar utensilios de cocina, con tres tenedores y un cucharón. Tipo análogo a los anteriores. Ejemplar popular de finales del siglo xvi y principios del xviu.

Expositor: D. José Domínguez. 


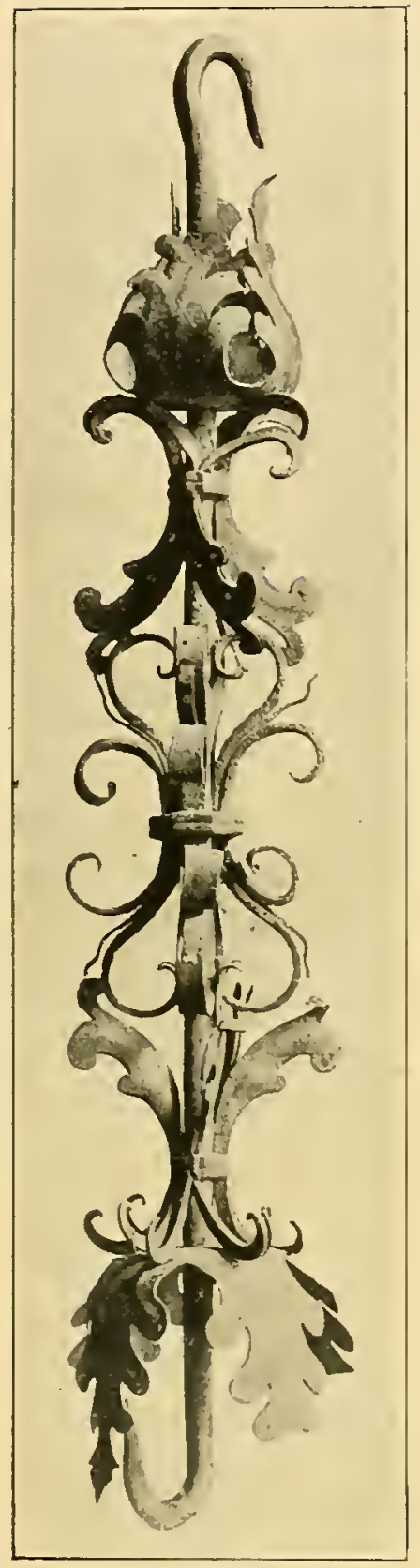

Nưm. 529

Núm. 529. - Sostén de lámpara formado por un eje que se decora con plancha recortada y curvada, y barras desarrolladas en volutas. Elemento muy ornamental. Siglo xviı.

\section{Expositor: Museo Arqueológico Nacional.}

Núm. 530.-Aparato para colgar útiles de cocina, con tres tenedores y cuatro cucharones. Ejemplar de arte popular de principios del siglo xvill.

\section{Expositor: D. José Dominguez.}

Núm. 531.-Un candelero de pie con soporte en espiral. Principios del siglo xviII.

Expositor: Don José Lázaro.

Núm. 532.-Candelero de varilla torneada con decoración en volutas. Principios del siglo xviII.

Expositor: Don José Lázaro.

Núm. 533. - Palomilla de barra horizontal, terminada en cabeza de dragón, cuya lengua forma la argolla; un tiesto siluetado sostiene un tallo con hojas y flores de plancha recortada.

Siglo xvil.

Expositora: Excma. Sra. Marquesa de Belvis de las Navas.

Núm. 534.- Balanza trabajada en barra del-

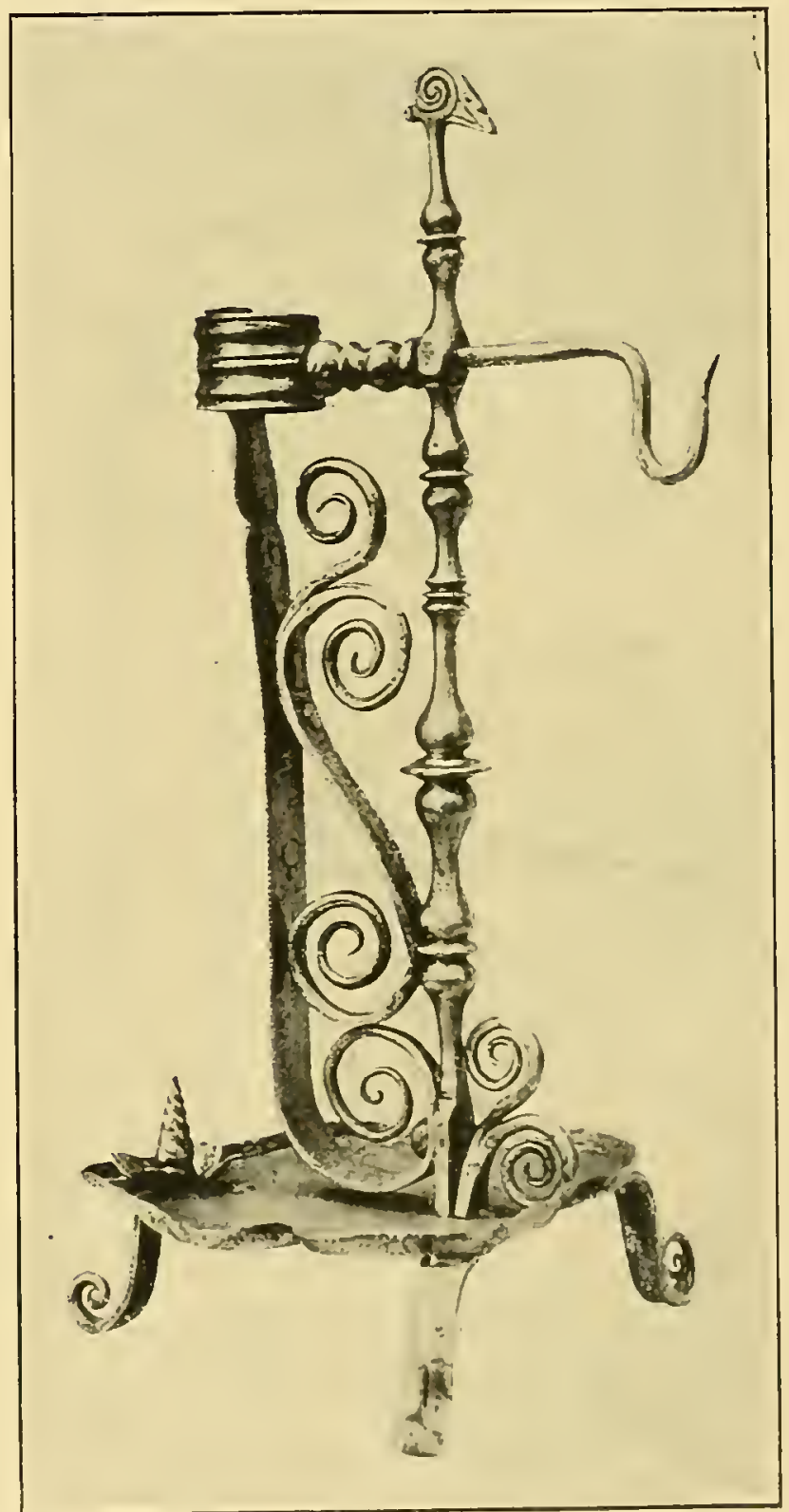

Núm. 532 


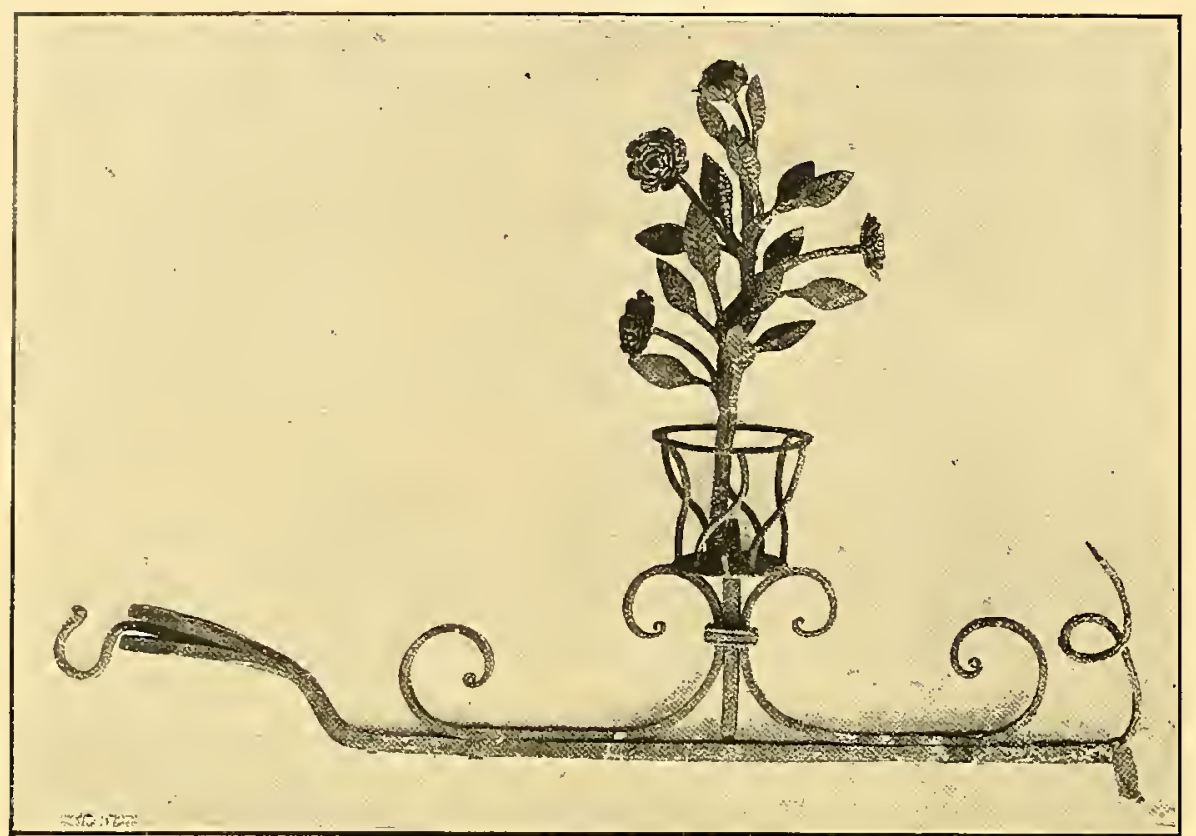

Núm. 533.

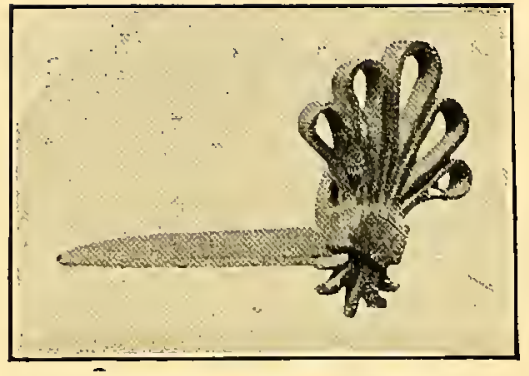

Núm. 535.

gada con doble castillete para el fiel y argolla de suspensión. Siglo xviII.

Expositor: D. Pedro Mg. de Artíñano.

Núm. 535. - Una grapa para cortinas, decorada en cinco órdenes de varilla curvada, formando una flor de cinco lóbulos. Siglo xvil. Expositor: D. Francisco"de Leguina.

Núm. 536. - Candado en perímetro lobulado. Siglo xvill.

Expositor: D. Juan Lafora.

Núm. 537. - Dos soportes de polea de pozo en varilla retorcida; la parte superior tra-

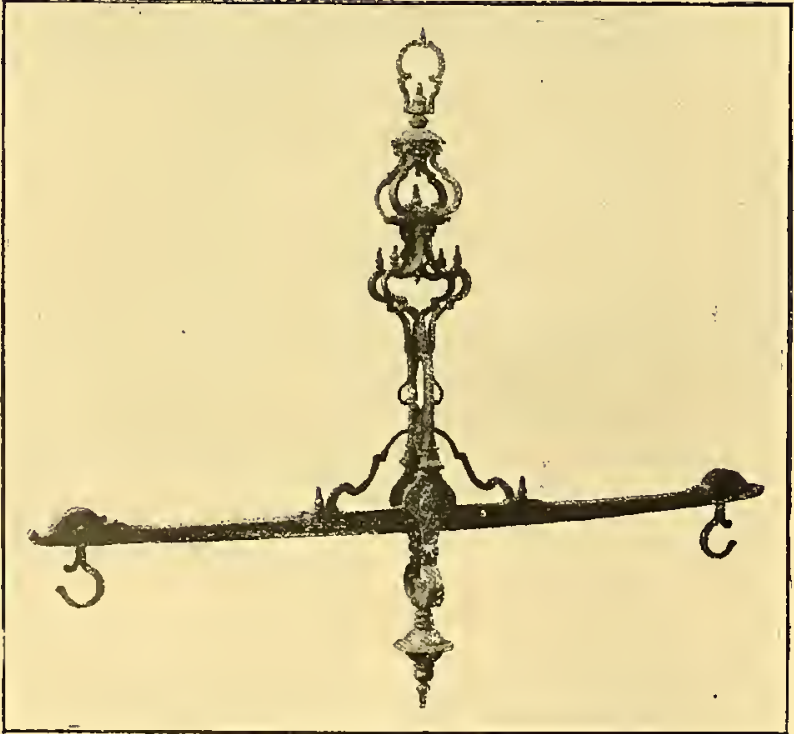

Núm. 534.

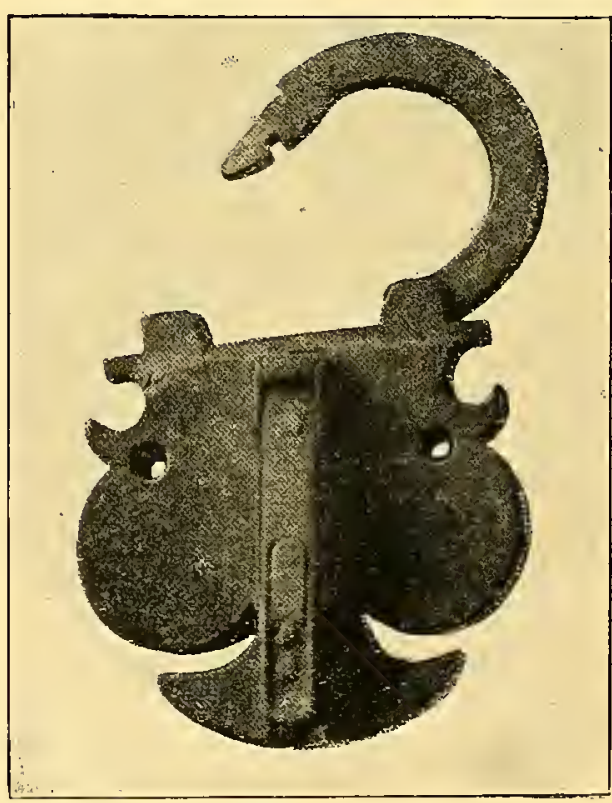

Nứm. 536. 


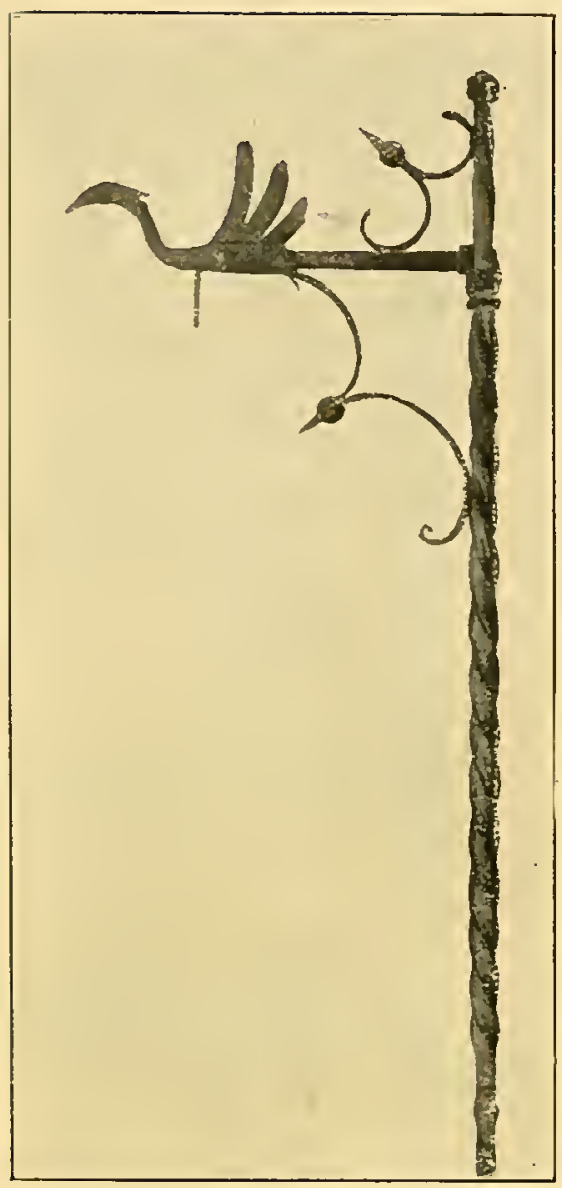

Núm. 537.

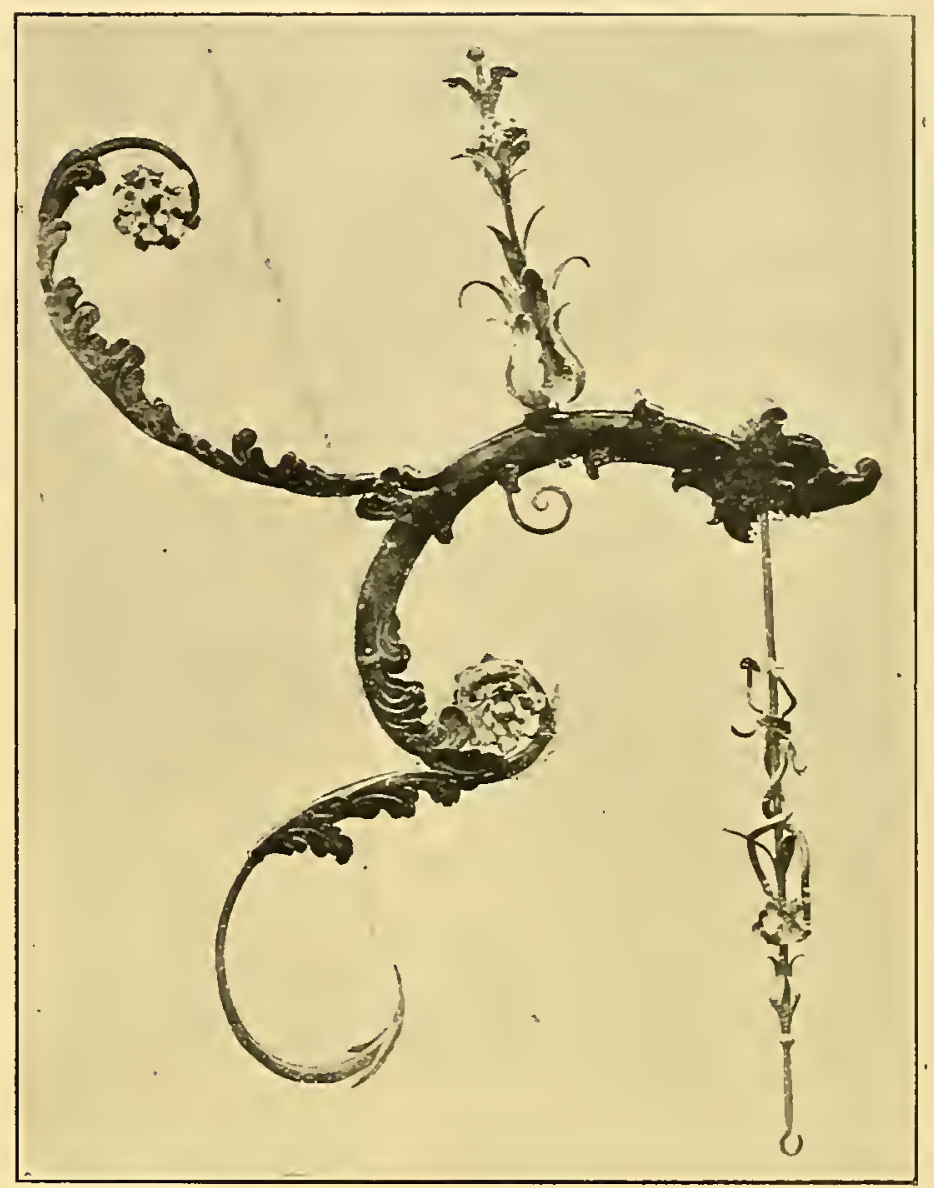

Núm. 539.

bajada recordando el estilo del siglo xvII. Siglo xviII.

Expositor: D. Rafael García Palencia.

Núm. 538.-Palomilla cuyo tornapuntas en forma de balaustre, termina en decoración floral de plancha recortada.

Expositor: Museo de Bellas Artes de Segovia.

Núm. 539.-Gran palomilla en barra cuadrangular, decorada en plancha recortada formando decoraciones florales; termina el gancho en cabeza de dragón. Una varilla se decora igualmente por barras cilíndricas terminadas en cabeza de dragón. Siglo xviII.

Expositor: Cabildo Catedral de Segovia.

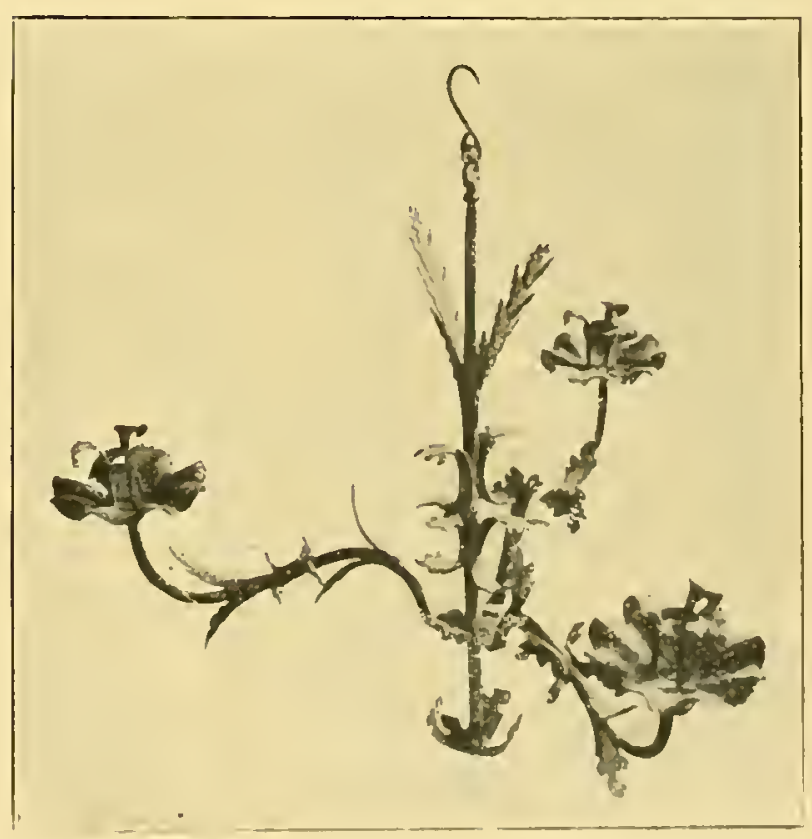

Nün. 540. 


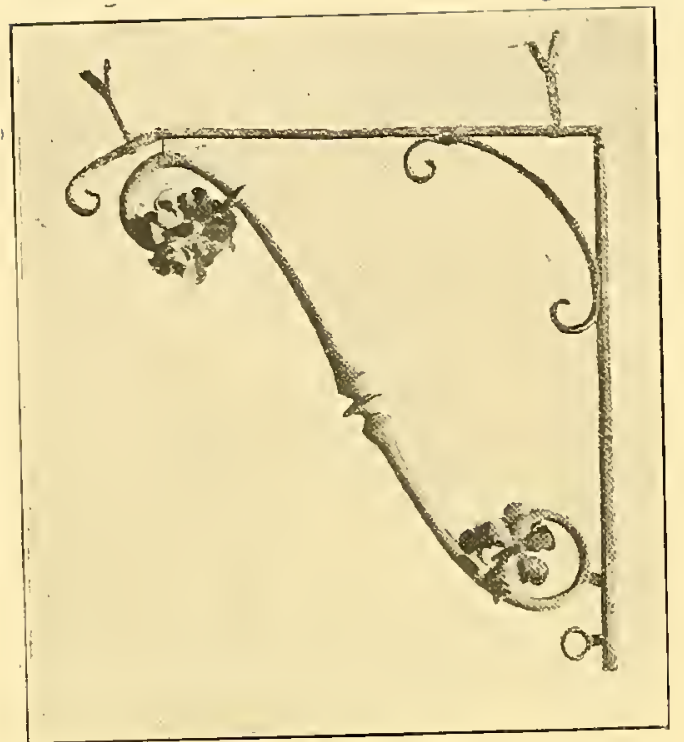

Núm. 538.
Núm. 540. - Araña de tres luces, de varilla redonda, decorada en plancha recortada.

Siglo xviII.

Expositor: D. José A. Weissberger.

Núm. 541. - Dos arañas de cuatro luces decoradas en plancha dorada recortada y repujada. Siglo xviII.

Expositor: D. Rafael García Palencia.

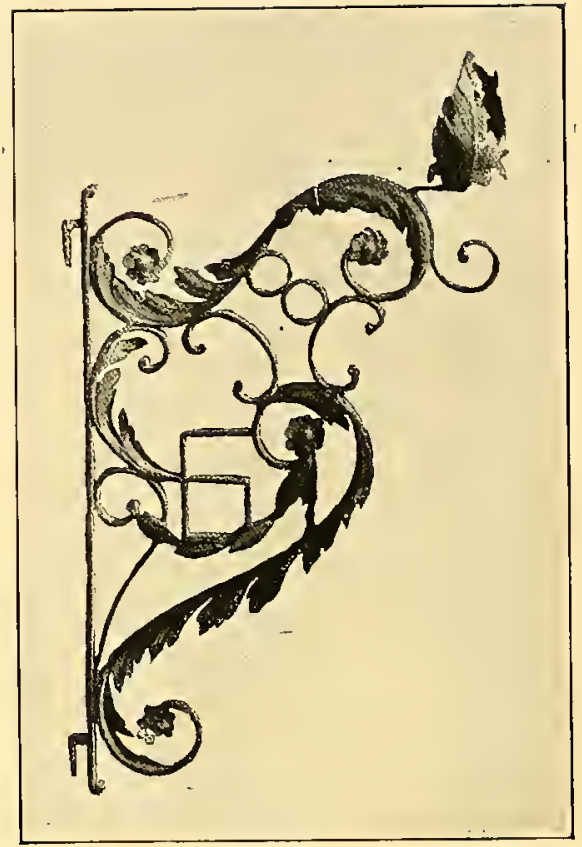

Núm. 542.

Núm. 542. - Palomilla de varilla de hierro, decorada con plancha recortada, siguiendo el gusto francés de mediados del siglo xviII.

Expositor: D. Juan Lafora.

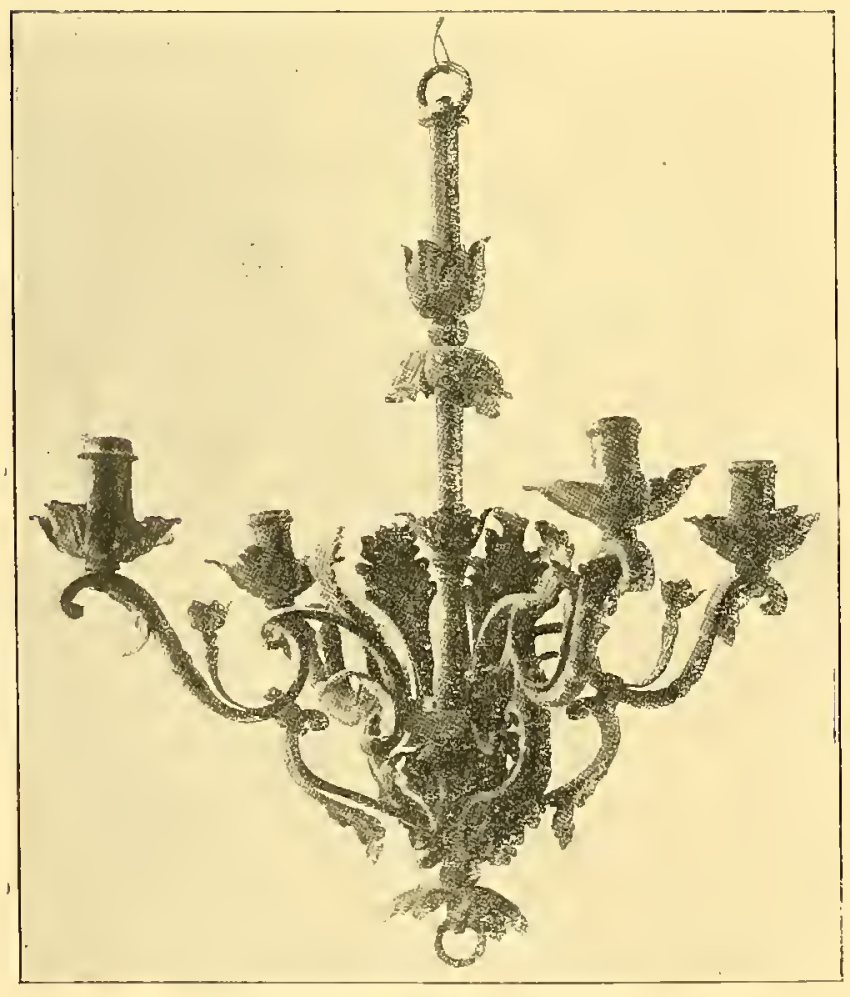

Núm. 541.
Núm. 543.-Cristo en hierro fundido, seguramente a la cera perdida.

Finales del siglo xviII.

Expositor: D. José A. Weissberger.

Núm. 544.-Cristo análogo al que precede, de brazos más cortos y labor más esmerada. Trabajo a la cera perdida.

Principios del siglo xviII.

Expositor: D. Frutos Barhero.

Núm. 545. - Fragmento de plancha de fondo de chimenea, con el escudo real de los Borbones y los collares del Toisón de Oro y de la Orden del Espíritu Santo.

Mediados del siglo xviII.

Expositor: D. Melitón Asenjo.

Núm. 546. - Escudo en plancha policromada. Mediados del siglo xviII.

Expositor: D. José Lázaro. 


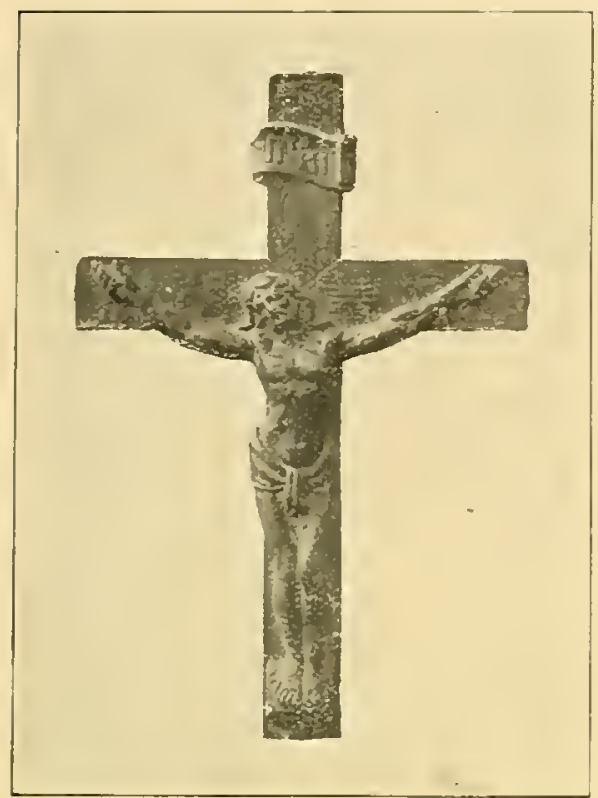

Nưm. 543.
Núm. 547. - Gran compás de puntas hecho por el P. Fray Vicente de Sevilla, en Uclés, el año 1754.

Expositor: Junta de Museos de Barcelona.

Núm. 548. - Cerradura fabricada por un presidiario en Orán, con cerrojo sobre plancha corrediza, plancha calada y múltiples disposiciones de cierre.

\section{Expositor: Armería Real.}

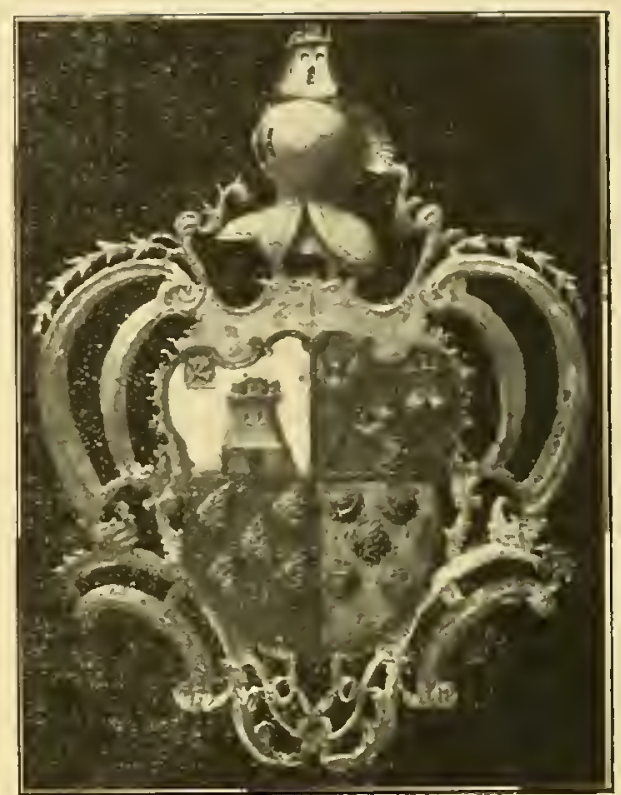

Núm. 546 .

Núm. 549. - Martillo de lujo hecho en Madrid, el año de 1787, por Lorenzo Ferré. Expositor: D. José Lázaro.

Núm. 550. - Cajita de hierro rectangular pintada, de $10 \mathrm{~cm}$. de largo por $13 \mathrm{~cm}$. de ancho y por $6 \mathrm{~cm}$. de alto. Siglo xvill.

Expositora: Excma. Sra. Marquesa de Belvis de las Navas.

Núm. 551.-Armazón de serreta. Ejemplar de lujo, en varilla de sección poligonal. Trabajo del siglo xvilı. Longitud de la herramienta, 27 cen-

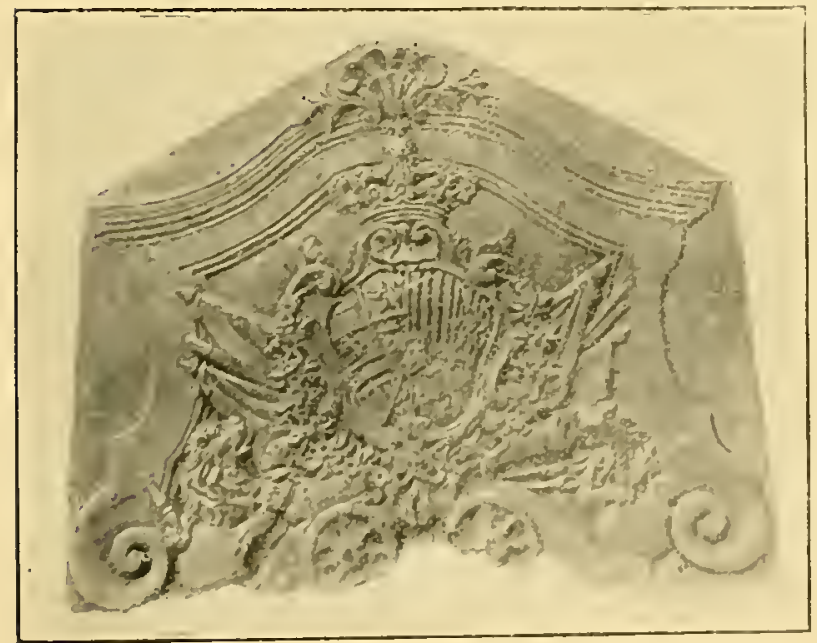

Nín 545. timetros.

Expositor: D. Juan Lafora.

Núm. 552.-Pico y azada. Herramienta decorada por incrustaciones en oro casi totalmente perdidas.

Trabajo a cincel. Ejemplar de todo lu-

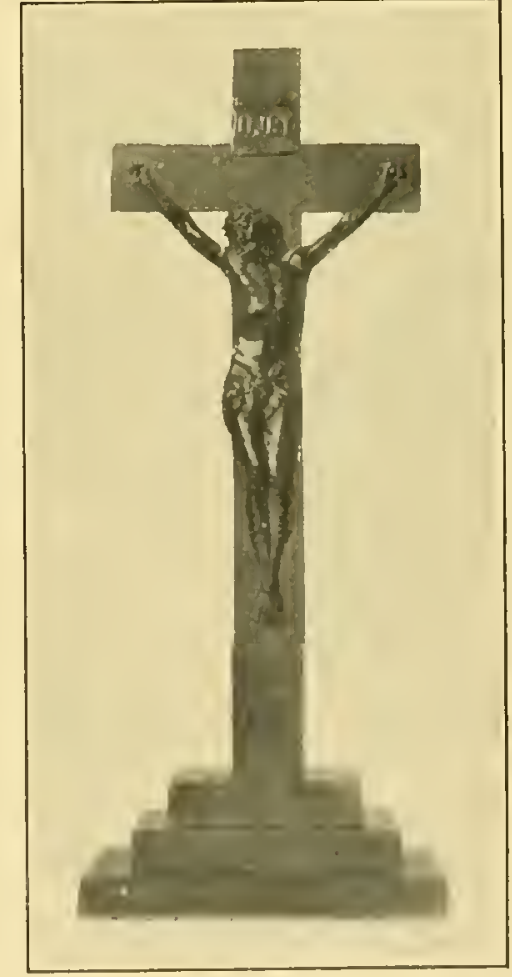

N่งก. 541. 


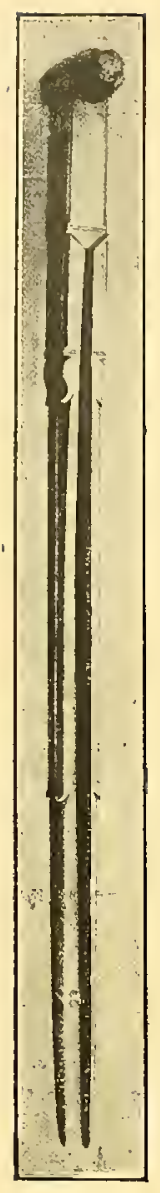

Núm. 547.

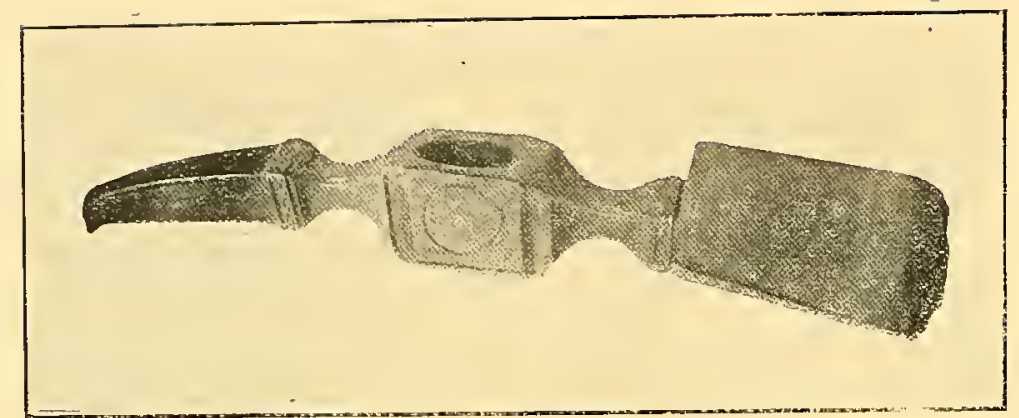

Núm. 552.

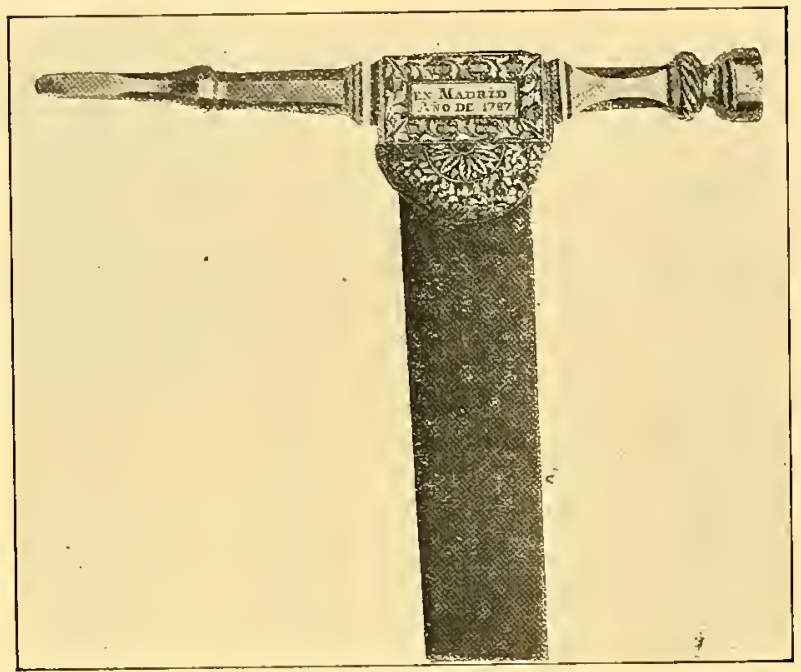

Núm. 549

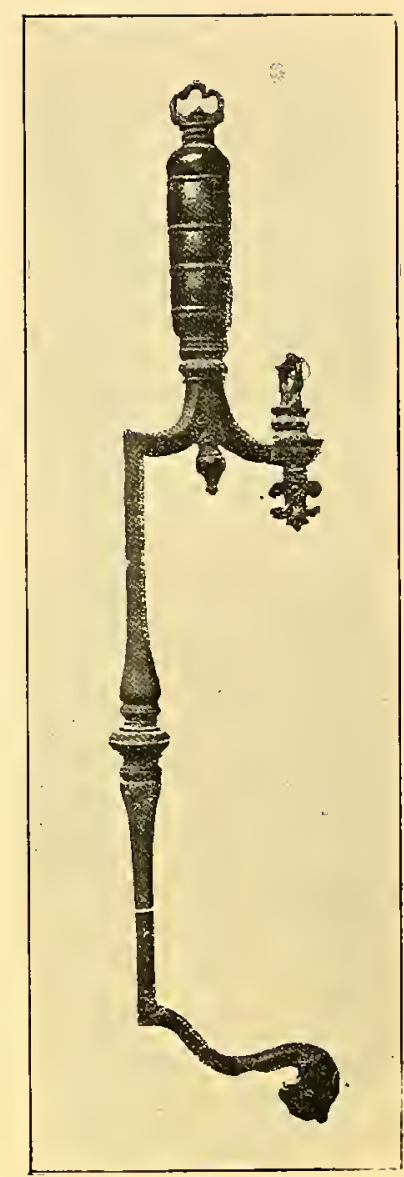

Nủm. 551.

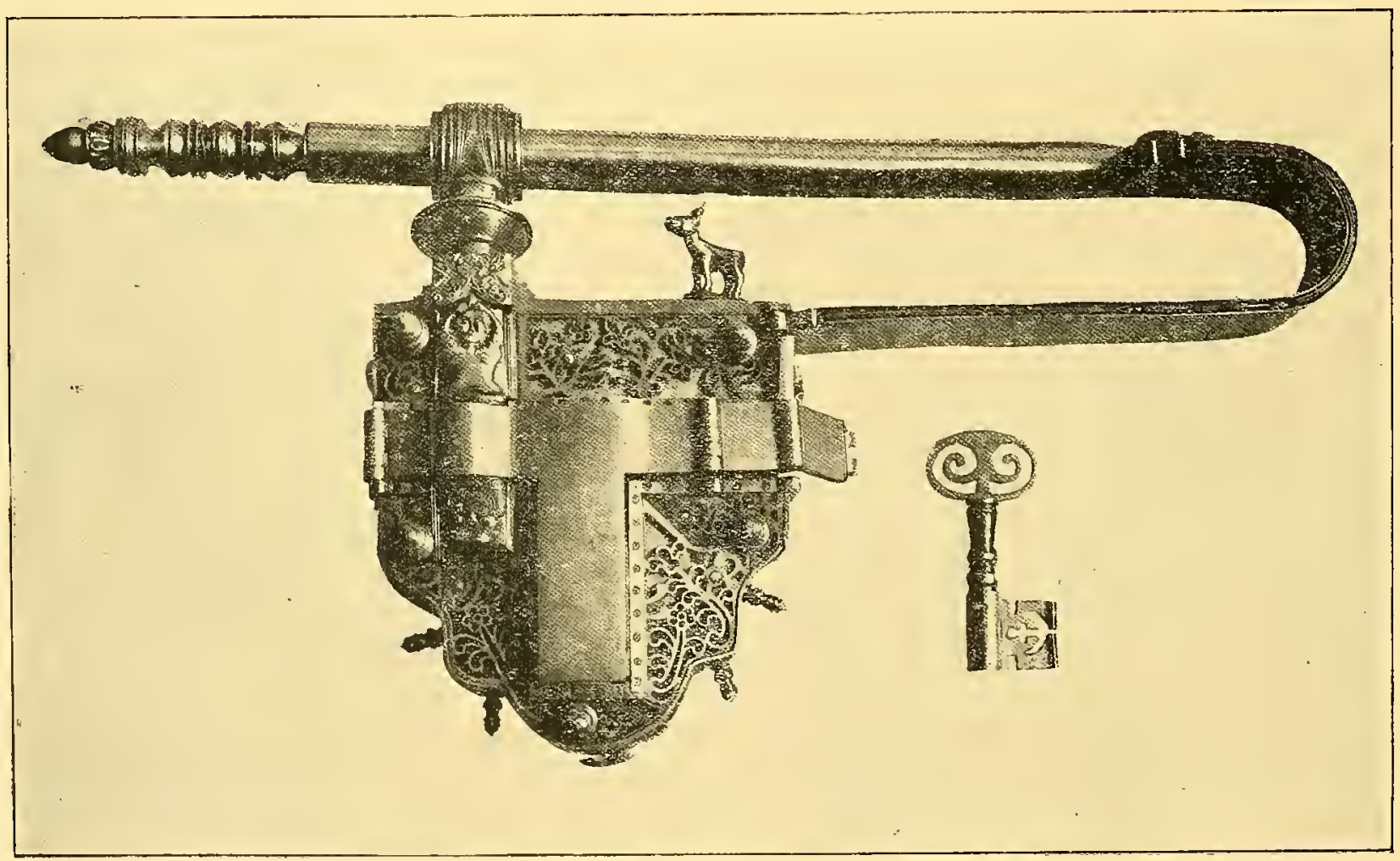

Núm, 548. 
jo que ha sido utilizado. Siglo xvil.

Expositor: D. Félix Sirabegne.

Núm. 553.-Dos asas con anillio central, flores de lis para los clavos; el anillo central con varilla en espiral triple, prolongada sobre el arco en sección circular maciza. Siglo xvir.

Expositor: D. José Lázaro.

Núm. 554. - Tijeras de hierro damasquinado, sección de media caña. Finales del siglo xvil1.

Expositora: Doña María Leguina.

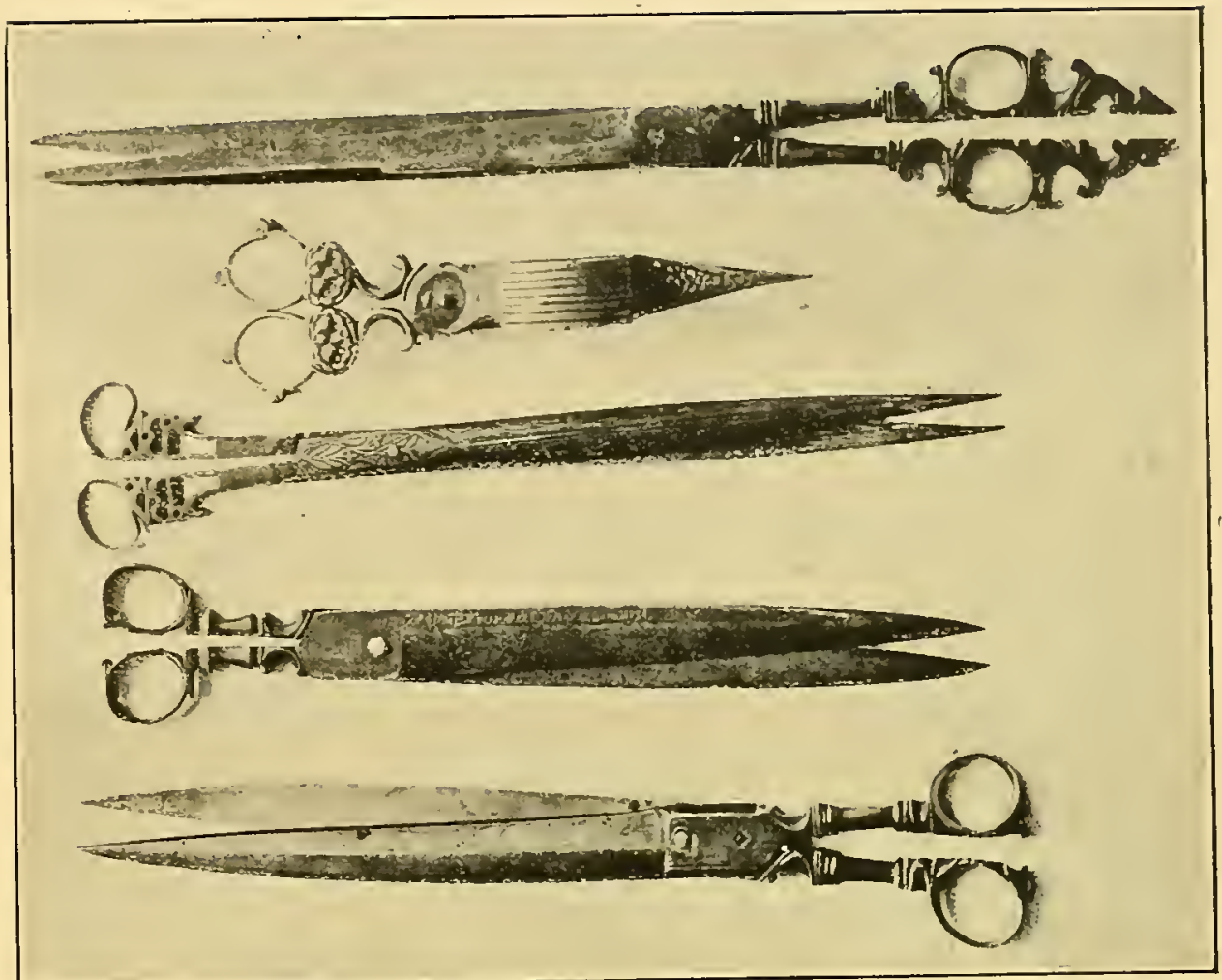

Núms. 554-555-556-557

Núm. 555.-Tijeras decoradas al agua fuerte, con inscripción. Siglo xviıl. Longitud, 27 centímetros.

\section{Exposiror: D. Angel Vegue.}

Núm. 556.-Tijeras de tipo análogo a la anterior. Mide 29 centímetros de largo. Siglo xvil.

Expositor: D. Angel Vegue.
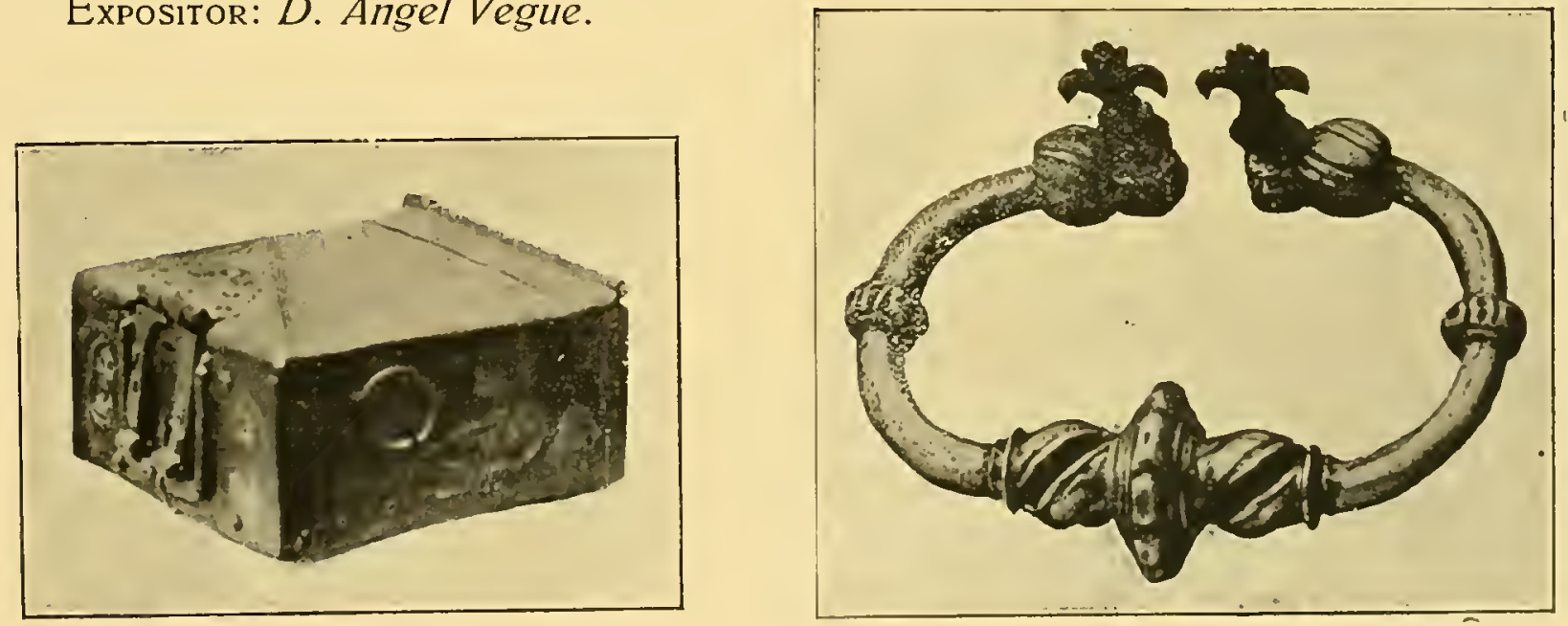


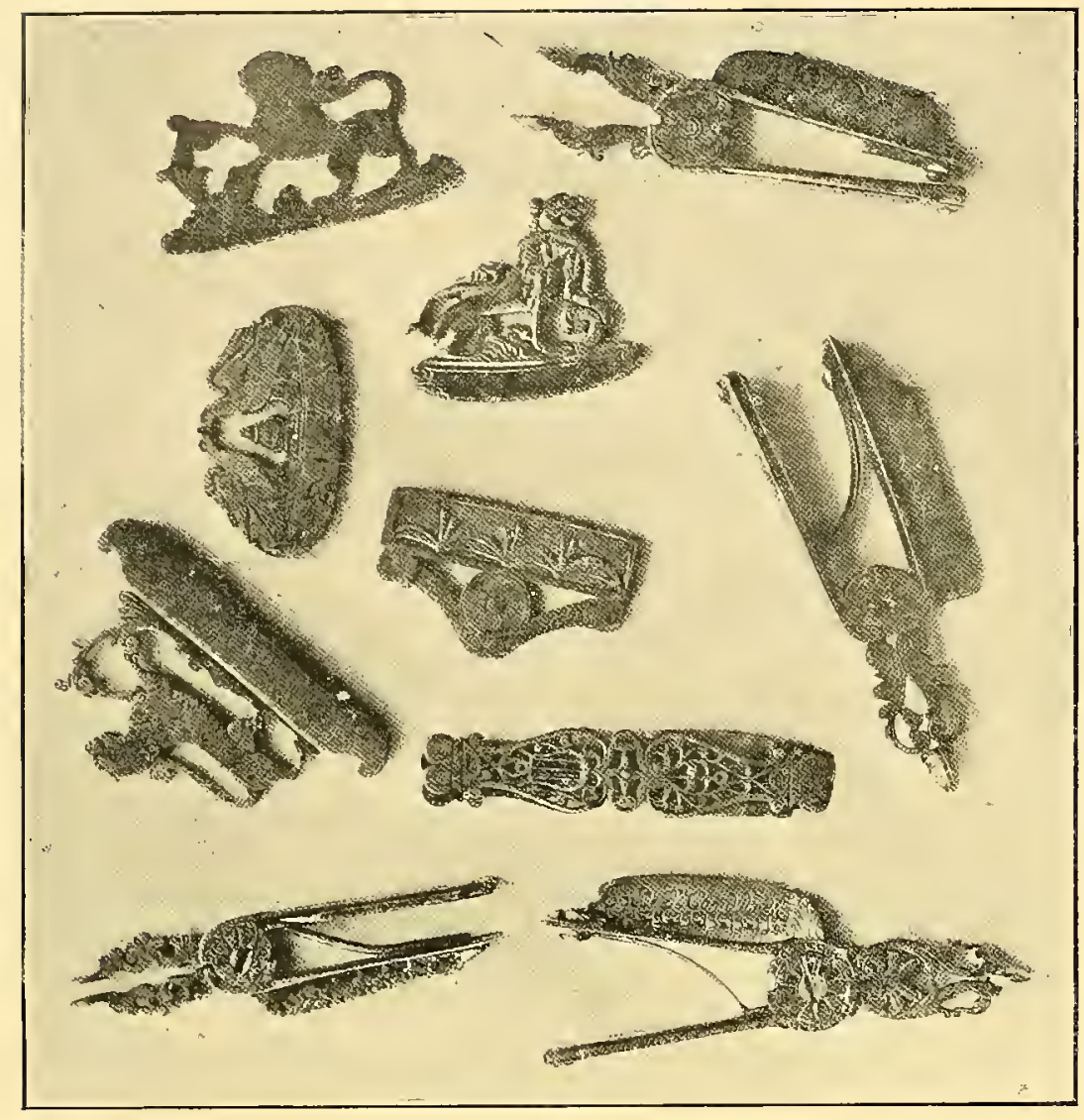

Nủms. 558-559-560.

Núm. 557.- Tijeras análogas a las precedentes, con los ojos prolongados en decoración de la época. Longitud, $35 \mathrm{~cm}$.

Siglo xvill.

Exposiror: D. Buenaventura Sánchez Comendador.

Núm. 558. - Cinco eslabones de hierro, con figuras de leones, pájaros y decoraciones cinceladas. Trabajo madrileño de finales del siglo xvir o principios del xix.

Expositora: Sra. de Herrera.

Núm. 559. - Cinco pinzas con

cuchillo, para diferentes usos. Trabajo análogo al precedente. Finales del siglo vxiII o principios del xix.

Expositora: Sra. de Herreta.

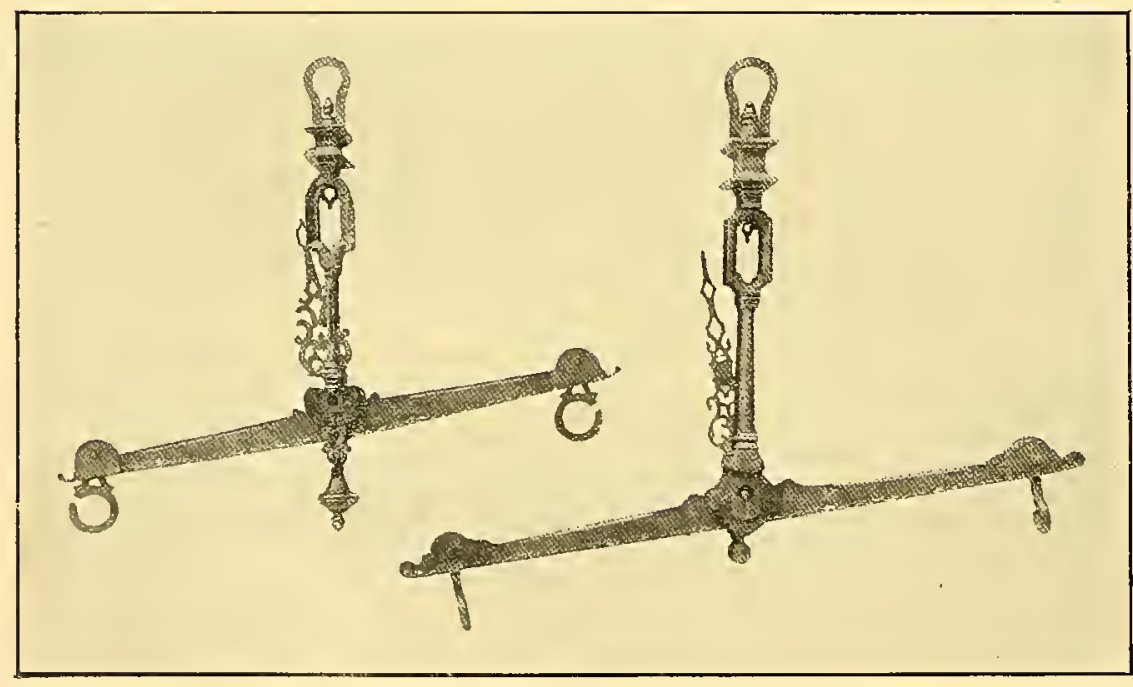

Nưm. 561,

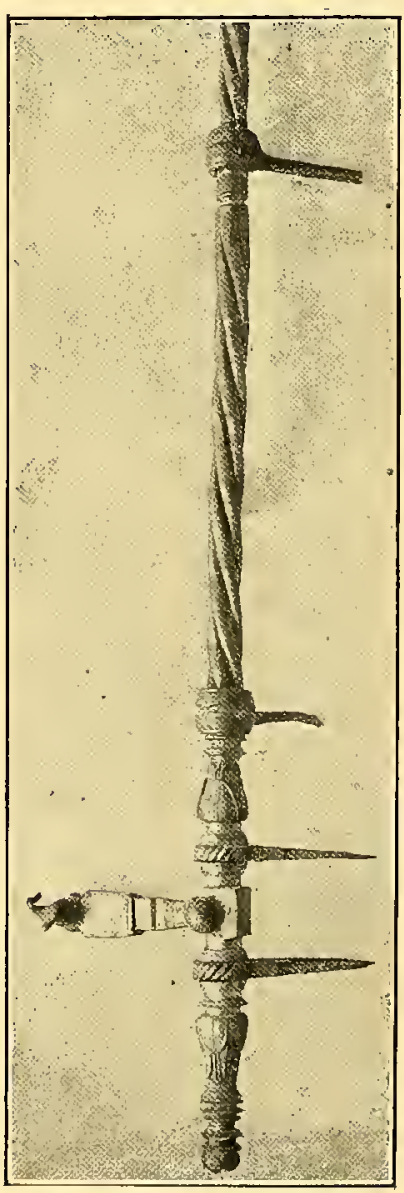

Núm. 563. 


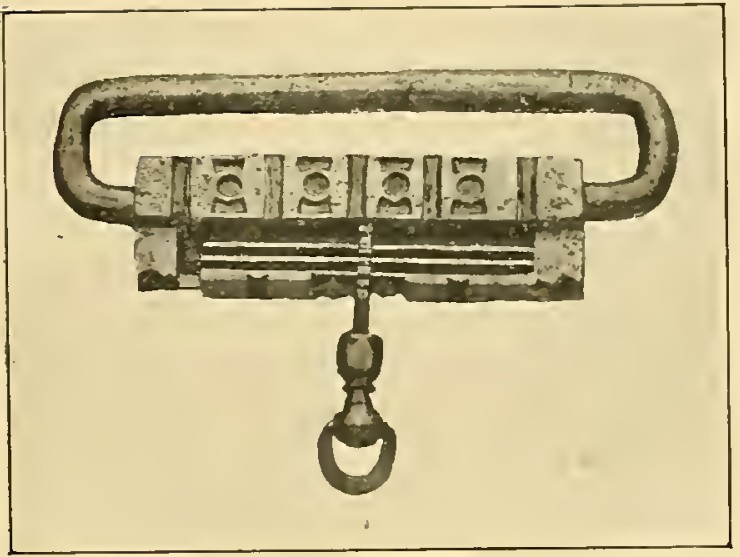

Núm. 562.

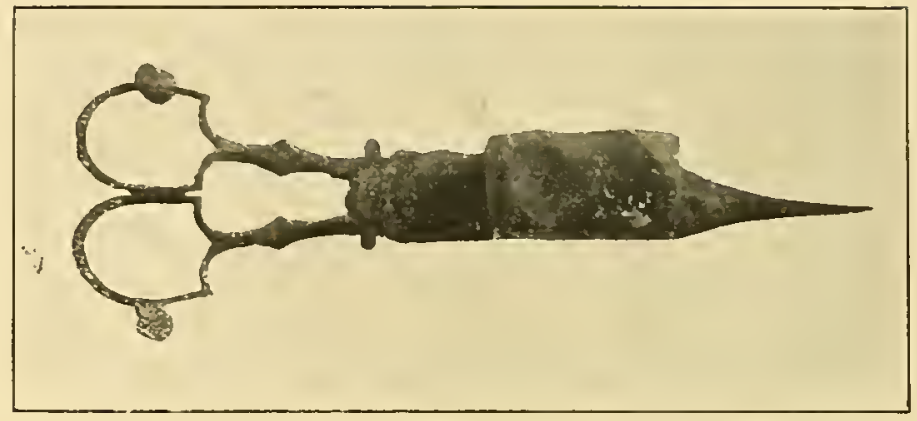

Nüm, 501.

Núm. 560.-Ejemplar análogo a los que preceden.

Trabajo ejecutado a finales del siglo xviI o principios del xix.

Expositor: D. Frutos Barbero.

Núm. 561.-Cinco balanzas, inspiradas en los tipos que preceden, muchas de ellas tuvieron carácter oficial. Finales del siglo xviır al xix.

Expositor: Excmo. Ayuntamiento de Madrid.

Núm. 562.-Candado con cerrojo corredizo. La cerradura sobre caja rectangular. Siglo xvill.

\section{Expositor: D. José Lázaro.}

Núm. 563.-Falleba de varilla retorcida y trabajo primoroso de cincel en la cerradura, cara'cterístico de la

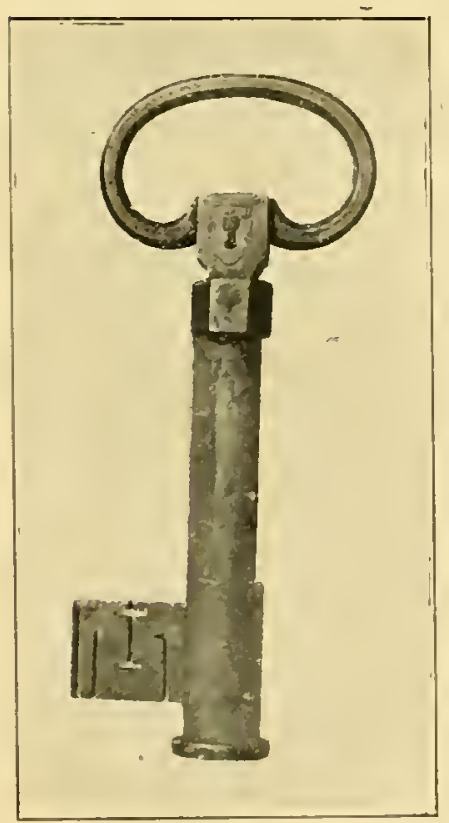

Noúm. 565. segunda mitad del siglo xvill.

Expositor: Don Anastasio Páramo.

Núm. 564. - Espabiladeras de hierro con decoración realzada.

Siglo xvIII.

Expositor: Don Francisco de Leguina.

Núm. 565. - Llave

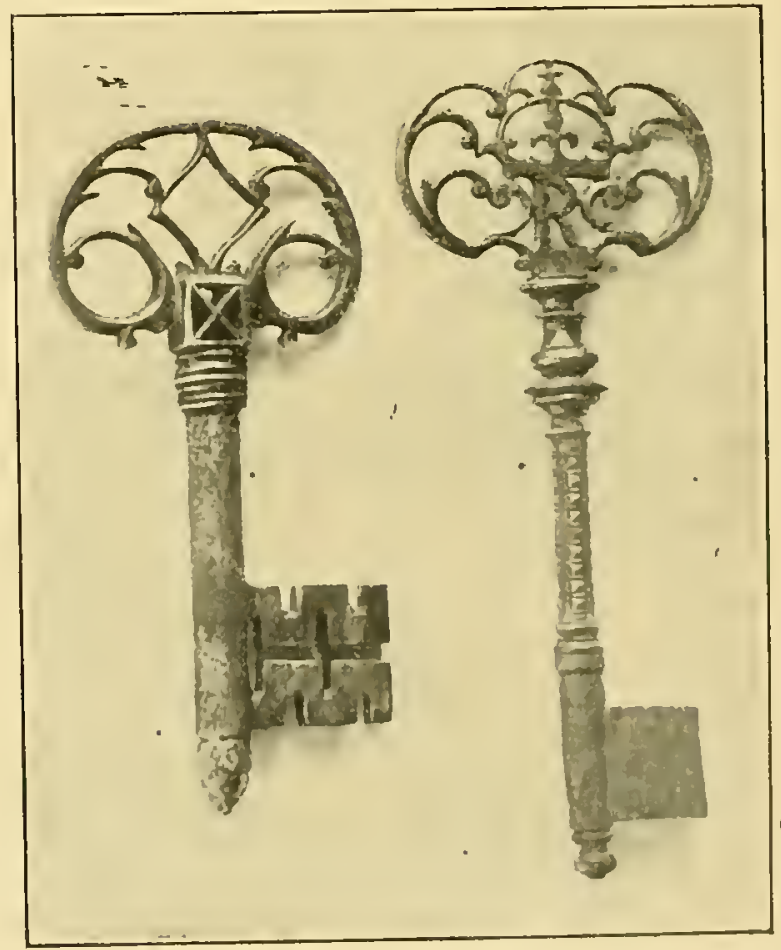

Nim. $5(x)$. 


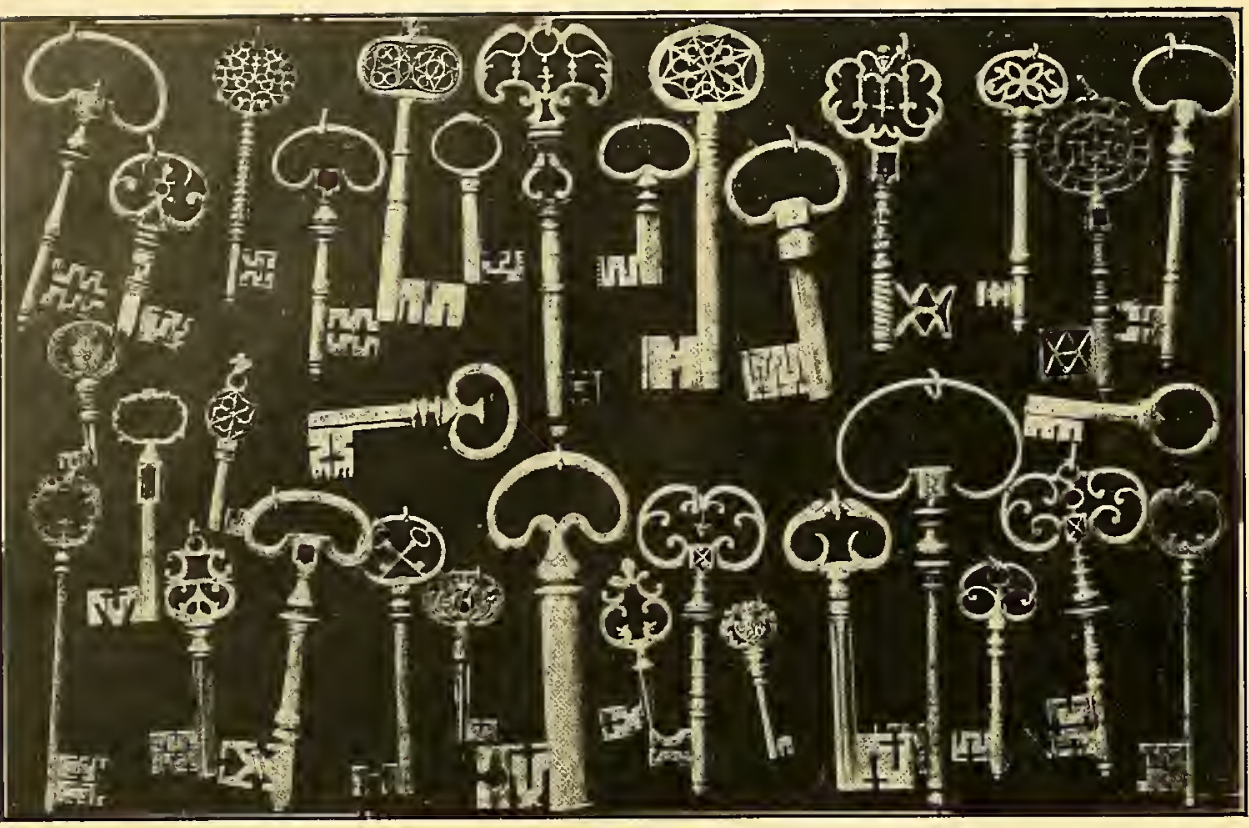

Núm. 567. denominada de "pasantia». Trabajo de examen de maestro cerrajero en el siglo xvIII.

Expositora: Excelentísima Sra. Duquesa de Parcent.

Núm. 566. Dos llaves, trabajo del xviII siglo.

Expositor: D. Manuel García Gómez Aleas.

Núm. 567.-Dos cartelas rectangulares que contienen en su mayoría llaves de los siglos xvil y xviı. Cuatro ejemplares de la Edad Media y tres del siglo xvi.

Alguno de los ejemplares, principalmente los que presentan el vástago en sección triangular o estriada, corresponden a trabajos de pasantia ejecutados por los oficiales cerrajeros para adquirir la categoría de maestros.

Un número no pequeño de ejemplares, presenta el vástago torneado, formando decoraciones caprichosas. Las guardas aparecen con frecuencia con calados que suponen un mecanismo de cierre, análogo a'l de los tipos antes mencionados que se conservan en el Monasterio de El Escorial, y que suponen para su funcionamiento una vuelta incompleta.

Los aros corresponden en general a dos tipos muy marcados; los que conservan una tradición mudéjar y como tal francamente española, y los que resultan inspirados en los dibujos franceses de la época.

Los primeros, sobre un anillo circular helíctico tienen una composición de lacería curvilínea

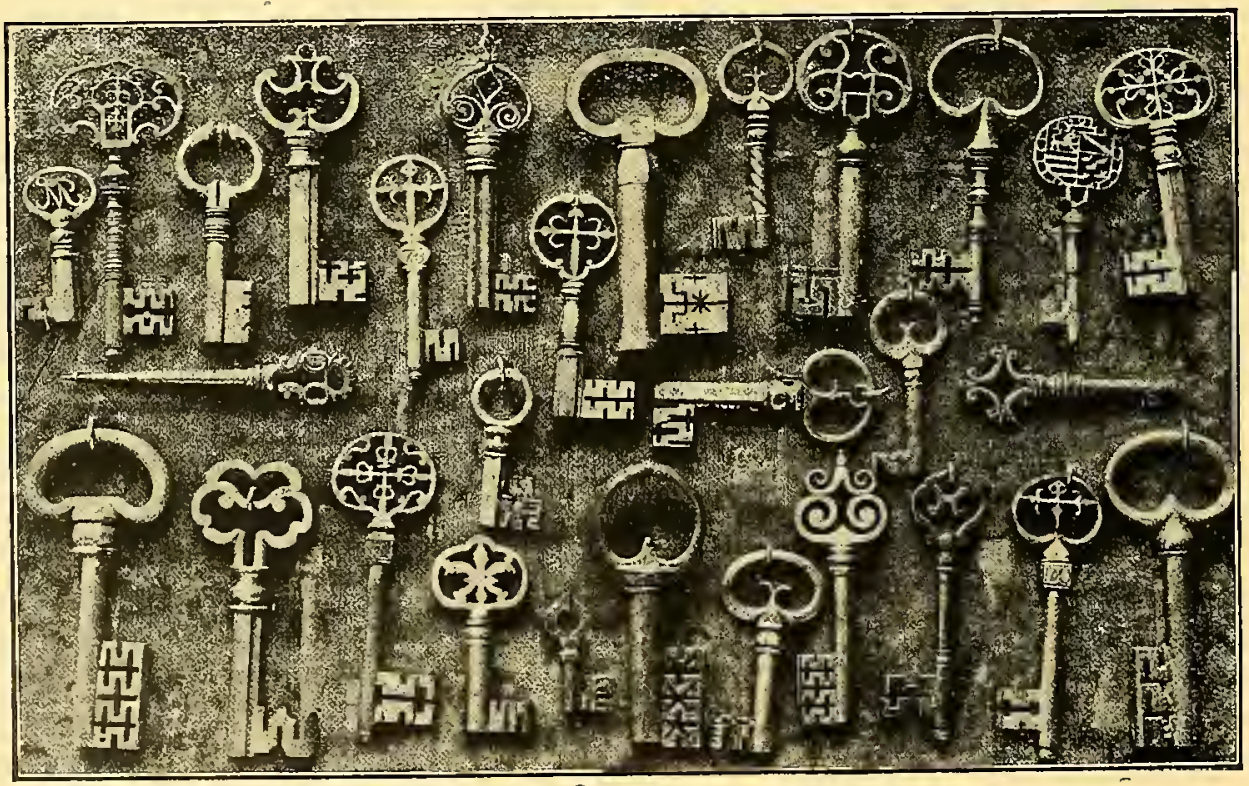

Núm. 567. 


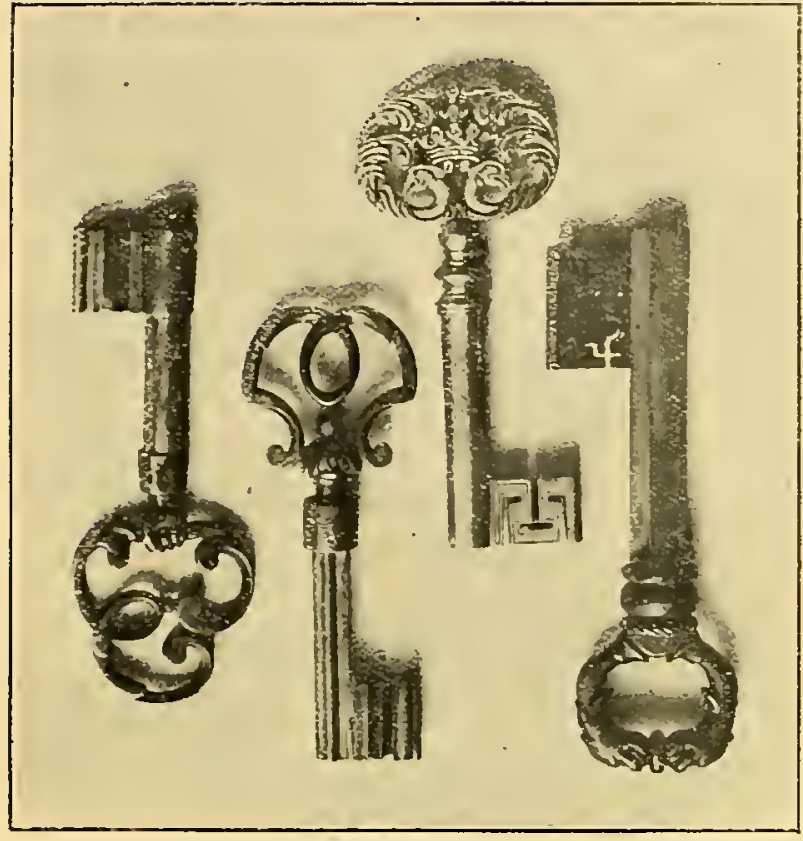

Núm. 568.

que recuerda los tipos góticos; y los de tipo francés invierten la curvatura del aro para unirse al vástago, presentando muchos de

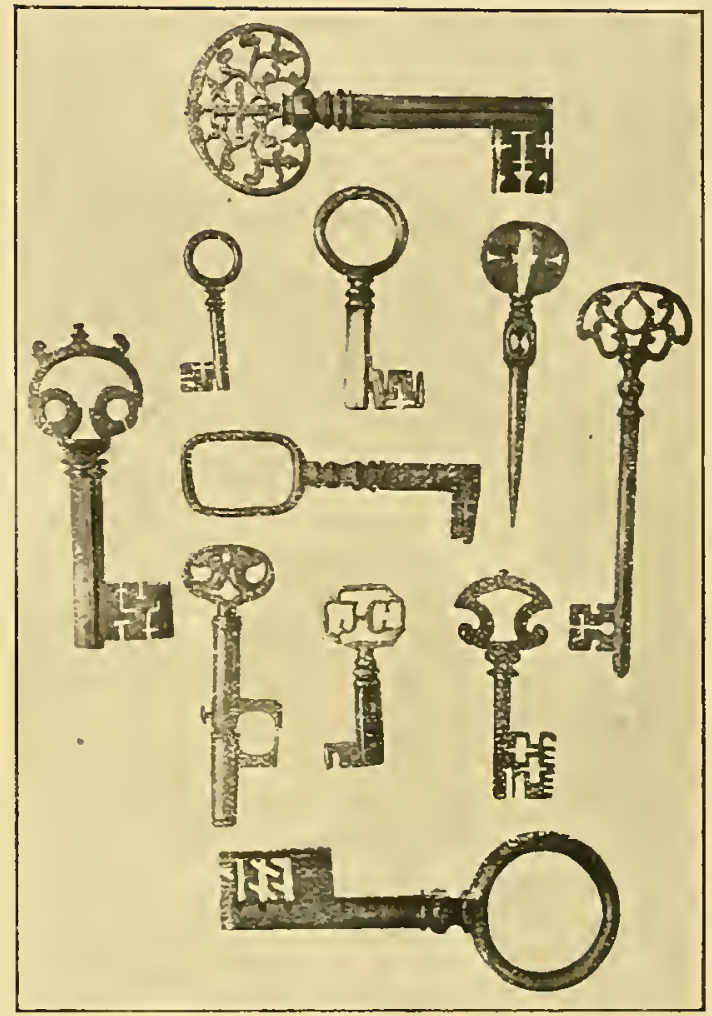

Núm 570.

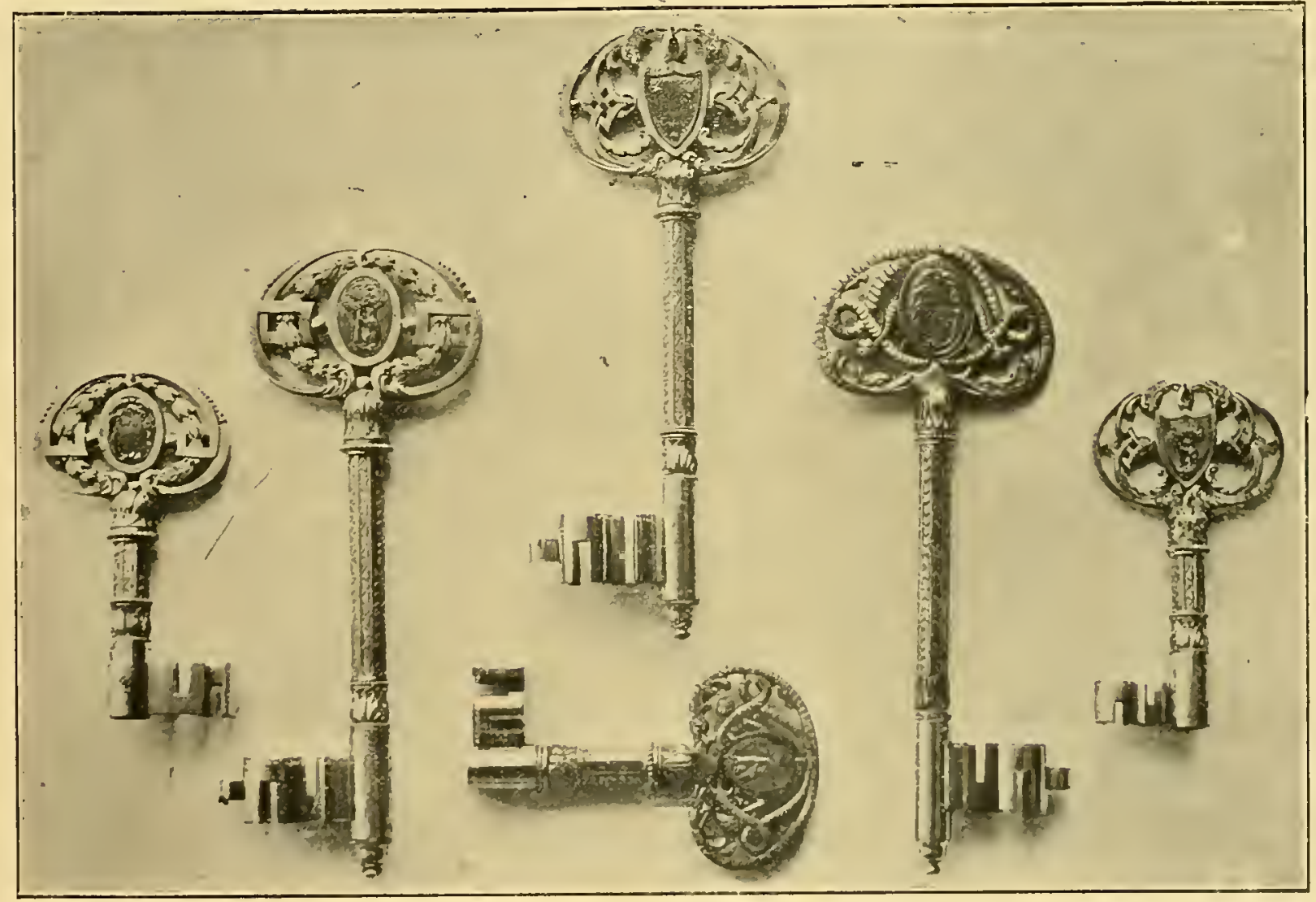

Nim, 500. 

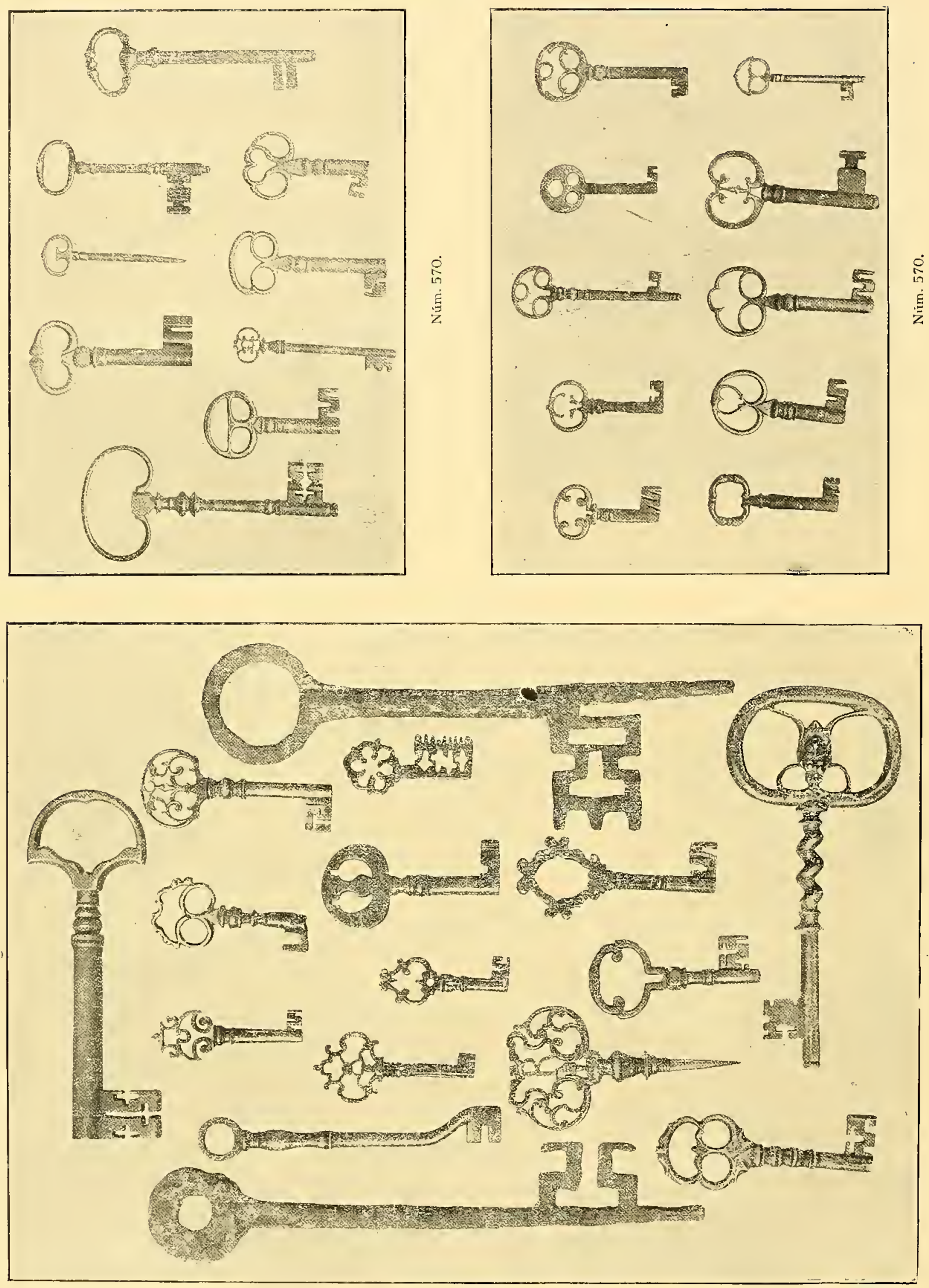

Núm. 570. 

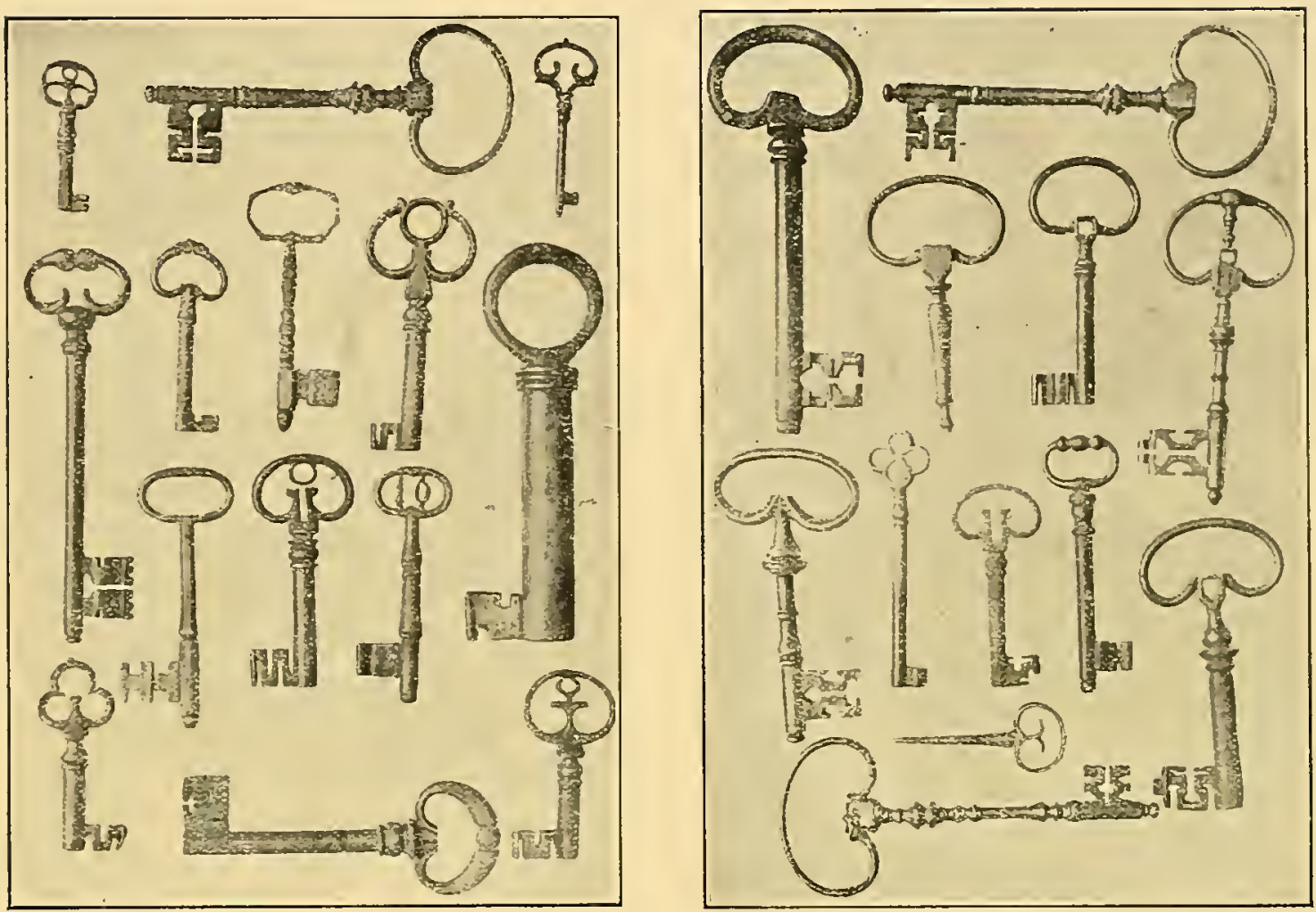

Núm. 570.

ellos en este punto un perqueño espacio, donde ha podido existir o existe una figura microscópica.

En el aro de los ejemplares del primer tipo, aparecen frecuentemente monogramas, emblemas heráldicos y cruces de las órdenes militares; todo indiscutiblemente español.

Expositor: Excmo. Sr. Marqués de la Torrecilla.

Núm 568.-Cuatro llaves, modelo de trabajo de cerrajería del siglo xvili, recordando una de ellas en sus guardas, los ejemplares góticos.

Expositora: Sra. de Lázaro.

Núm. 569. - Colección de llaves pertenecientes en su casi totalidad a los antiguos viajes de Madrid, esmeradísima labor de cerrajería madrileña en los finales del siglo xvm y principios del XIX.

Es curioso que estos trabajos en su mayor par-

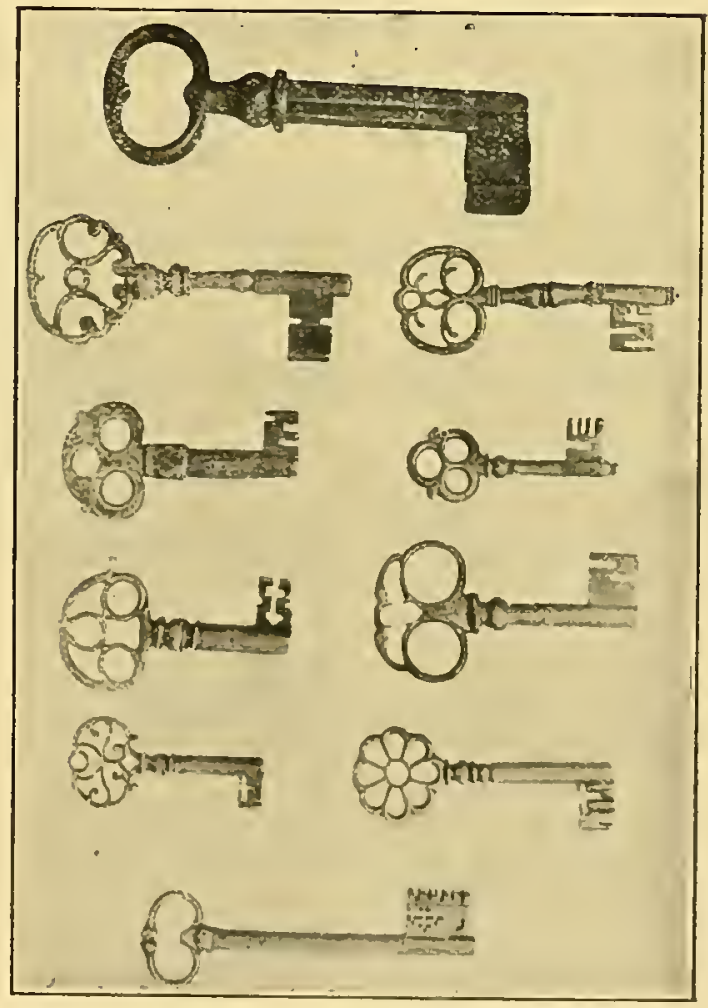

Nưm. 570. 
te, y precisamente algunos de los que suponen una mayor labor personal, tiempo y delicadeza, llevan la fecha de 1910 , habiendo sido por lo tanto ejecutados en los días de la guerra de la Independencia.

\section{Expositor: Excmo. Ayuntamiento de Madrid.}

Núm. 570. - Colección de llaves que corresponde a los tipos en uso desde el siglo xvı a finales del xvill.

La mayor parte de los ejemplares parecen inspirados en los dibujos franceses de su época, si bien en general las guardas hacen suponer cerraduras de vuelta entera en casi todas ellas.

El conjunto corresponde a una completa evolución de la cerrajería española, análogamente a lo dicho en los ejemplares del núm. 567.

Expositor: Excmo. Sr. D. Enrique de Montero.

Núm. 571.-Candado circular en cabeza de león, admirablemente cincelado. Principios del siglo xix.

Expositor: Excmo. Sr. Marqués de la Torrecilla.

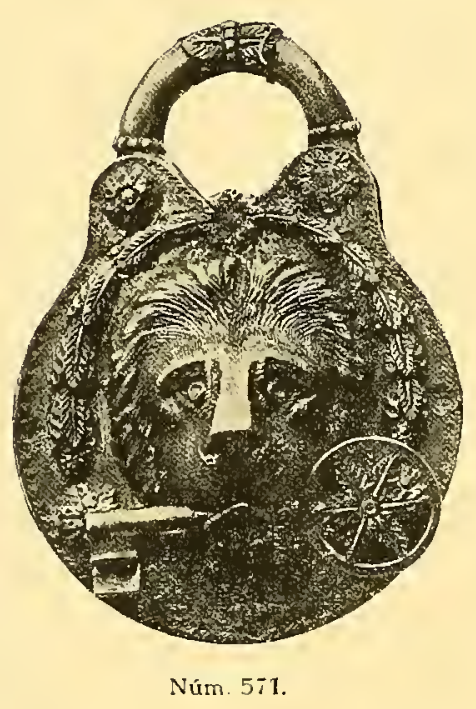




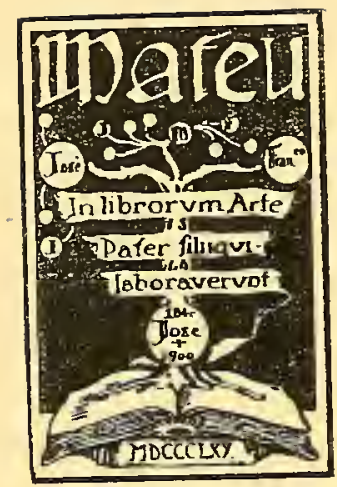

ESTA OBRA, COMPUESTA POR PEDRO M. DE ARTIÑANO

FUÉ IMPRESA EN MADRID EN LOS

TALLERES DE ARTES GRAFICAS «MATEU» POR ACUERDO DE LA SOCIEDAD ESPAÑOLA DE AMIGOS DEL ARTE EN 1919 





